\title{
Atualização da Diretriz de Ressuscitação Cardiopulmonar e Cuidados Cardiovasculares de Emergência da Sociedade Brasileira de Cardiologia - 2019
}

\author{
Realização: Sociedade Brasileira de Cardiologia
}

Conselho de Normatizações e Diretrizes: Fernando Bacal, Leandro loschpe Zimerman, Paulo Ricardo Avancini Caramori e Pedro A. Lemos

Coordenador de Normatizações e Diretrizes: Ludhmila Abrahão Hajjar

Coordenadores da Atualização: Sergio Timerman, Claudia Bernoche, Raul Dias dos Santos Filho e Marcus Vinícius Bolívar Malachias

Comissão de Redação e Planejamento: Thatiane Facholi Polastri e Claudia Bernoche

Capítulo 1 - Epidemiologia da Parada Cardiorrespiratória e Apresentação da Diretriz

Roberto Kalil Filho, Marcus Vinícius Bolívar Malachias, Otávio Berwanger, José Antônio Franchini Ramires, Maria Margarita Gonzalez, Claudia Bernoche, Raul Dias dos Santos Filho

Capítulo 2 - Suporte Básico de Vida no Adulto

Coordenadores: Thatiane Facholi Polastri, Patrícia Ana Paiva Corrêa Pinheiro

Autores: Ana Paula Quilici, Bruno Timerman, Elaine Peixoto, Maria Margarita Gonzalez, Renan Gianotto-Oliveira

Capítulo 3 - Terapias Elétricas: Desfibrilação, Cardioversão e Marca-Passo Transcutâneo

Coordenadores: Antonio Pazin-Filho, Cristiano Faria Pisani

Autores: Cantidio Soares Lemos Martins, Leonardo Nicolau Geisler Daud Lopes

Capítulo 4 - Dispositivos Auxiliares Durante as Manobras de Ressuscitação Cardiopulmonar

Coordenadores: Luiz Francisco Cardoso, Flavio Tarasoutchi

Autores: Caio de Assis Moura Tavares, Sergio Timerman, Tarso Duenhas Accorsi

Capítulo 5 - Suporte Avançado de Vida em Cardiologia no Adulto

Coordenadores: Sergio Timerman, Maria Helena Sampaio Favarato, Alexandre de Matos Soeiro, Natali Schiavo Gianetti

Autores: Andrei Hilário Catarino, Maria Margarita Gonzalez, Luís Augusto Palma Dallan, Edison Ferreira de Paiva, João Batista de Moura Xavier Moraes Junior, Manoel Fernandes Canesin, Thatiane Facholi Polastri

Capítulo 6 - Cuidados Pós-Ressuscitação

Coordenadores: Claudia Bernoche, Luis Augusto Palma Dallan

Autores: Liliane Kopel, Silvia Helena Gelas Lages, Sergio Timerman

Capítulo 7 - Síndrome Coronária Aguda

Coordenadores: Carlos Vicente Serrano Junior, Eduardo Gomes Lima

Autores: Felipe Gallego Lima, Eduardo Leal Adam, Marcia Maria Noya Rabelo, Roberto Kalil Filho, Leopoldo Soares Piegas, Gilson Soares Feitosa-Filho, Oscar Pereira Dutra, Ari Timerman, Tatiana de Carvalho Andreucci Leal, José Francisco Kerr Saraiva 
Capítulo 8 - Abordagem e Tratamento da Fase Aguda do Acidente Vascular Cerebral

Coordenadores: Eli Faria Evaristo, Maria Julia Machline Carrion

Autor: Lecio Figueira Pinto

Capítulo 9 - Ressuscitação Cardiopulmonar em Situações Especiais

Coordenadores: Fernando Ganem, David Szpilman

Autores: João Luiz de Alencar Araripe Falcão, Hélio Penna Guimarães, Ivanhoé Stuart Lima Leite, Jaime Paula Pessoa Linhares Filho

Capítulo 10 - Emergências Cardiológicas em Gestantes

Coordenadores: Walkiria Samuel Ávila, Maria Rita de Figueiredo Lemos Bortolotto

Autores: Claudia Bernoche, Lucas Colombo Godoy, Isabela Cristina Kirnew Abud, Fabio Bruno da Silva, Ana Maria Thomaz

Capítulo 11 - Suporte Básico de Vida em Pediatria

Coordenadores: Tania Miyuki Shimoda-Sakano, Yara Kimiko Sako

Autores: Nana Miura Ikari, Gustavo Foronda, Ana Cristina Sayuri Tanaka

Capítulo 12 - Suporte Avançado de Vida em Pediatria

Coordenadores: Amélia Gorete Afonso da Costa Reis, Ana Cristina Sayuri Tanaka

Autores: Mônica Satsuki Shimoda, Anna Christina de Lima Ribeiro, Adailson Wagner da Silva Siqueira, Estela Azeka, Filomena Regina Barbosa Gomes Galas, José Fernando Cavalini, Ludhmila Abrahão Hajjar, Sonia Meiken

Franchi, Vanessa Guimarães, Nana Miura Ikari

\section{Capítulo 13 - Ressuscitação Neonatal}

Coordenadoras: Ruth Guinsburg e Maria Fernanda Branco de Almeida

Capítulo 14 - Suporte Avançado de Vida em Insuficiência Cardíaca

Coordenadores: Sandrigo Mangini, Mucio Tavares de Oliveira Junior

Autores: Manoel Fernandes Canesin, Germano Emilio Conceição Souza, So Pei Yeu, Oscar Pereira Dutra, Antonio Carlos Pereira Barreto

Capítulo 15 - Suporte de Vida Extracorpóreo Neonatal, Pediátrico e Adulto

Coordenadores: Filomena Regina Barbosa Gomes Galas, Felipe Lourenço Fernandes

Autores: Ludhmila A. Hajjar, Luiz Fernando Caneo, Maria Aparecida Batistão Gonçalves, Claudia Bernoche, Marcelo Park

Capítulo 16 - Simulação no Ensino das Emergências

Coordenadora: Thatiane Facholi Polastri

Autores: Daniel Valente Batista, Ana Paula Quilici, Karen Cristine Abrão, Sergio Timerman, Bruna Romanelli Scarpa

Capítulo 17 - Time de Resposta Rápida, Código Azul, Registro de Ressuscitação Intra-Hospitalar e Padronização do Carro de Emergência

Coordenadores: Fatima Gil Ferreira, Felipe Gallego Lima

Autores: Maria Francilene Silva Souza, Vanessa Santos Sallai, Natali Schiavo Gianetti

Capítulo 18 - Atendimento Pré-Hospitalar, Regulação e Transporte

Coordenador: Agnaldo Piscopo

Autor: Leonardo Luis Torres Bianchi 


\section{Atualização}

\section{Capítulo 19 - Primeiros Socorros e Emergências Ambientais}

Coordenadores: Thatiane Facholi Polastri, Ceila Maria Sant'Ana Malaque, Patrícia Ana Paiva Corrêa Pinheiro Autores: Fan Hui Wen, Daniela Luana Fernandes Leandro, Antônio Fernando Barros de Azevedo Filho, Diego Manoel Gonçalves, Patricia Feitosa Frota dos Reis, Lucia Tobase

\section{Capítulo 20 - Princípios Éticos e Legais da Ressuscitação Cardiopulmonar Coordenadores: Eduardo Atsushi Osawa, Milena Frota Macatrão-Costa Autor: Pedro Henrique Moraes Cellia}

Autores da Atualização: Claudia Bernoche, ${ }^{1,2}$ Sergio Timerman, ${ }^{1}$ Thatiane Facholi Polastri, ${ }^{1}$ Natali Schiavo Giannetti, ${ }^{3}$ Adailson Wagner da Silva Siqueira, ${ }^{1}$ Agnaldo Piscopo, ${ }^{4}$ Alexandre de Matos Soeiro, ${ }^{1,5}$ Amélia Gorete Afonso da Costa Reis, ${ }^{6}$ Ana Cristina Sayuri Tanaka, ${ }^{1}$ Ana Maria Thomaz, ${ }^{1}$ Ana Paula Quilici, ${ }^{7}$ Andrei Hilário Catarino, ${ }^{1}$ Anna Christina de Lima Ribeiro, ${ }^{1}$ Antonio Carlos Pereira Barreto, ${ }^{1}$ Antonio Fernando Barros de Azevedo Filho, ${ }^{7}$ Antonio Pazin Filho, ${ }^{8}$ Ari Timerman, ${ }^{9}$ Bruna Romanelli Scarpa, ${ }^{1}$ Bruno Timerman, ${ }^{1}$ Caio de Assis Moura Tavares, ${ }^{10}$ Cantidio Soares Lemos Martins, ${ }^{1}$ Carlos Vicente Serrano Junior, ${ }^{1}$ Ceila Maria Sant'Ana Malaque, ${ }^{11}$ Cristiano Faria Pisani, ${ }^{1}$ Daniel Valente Batista, ${ }^{1}$ Daniela Luana Fernandes Leandro, ${ }^{1}$ David Szpilman, ${ }^{12}$ Diego Manoel Gonçalves, ${ }^{1}$ Edison Ferreira de Paiva, ${ }^{13}$ Eduardo Atsushi Osawa, ${ }^{1}$ Eduardo Gomes Lima,,${ }^{1,2}$ Eduardo Leal Adam, ${ }^{14}$ Elaine Peixoto, ${ }^{7}$ Eli Faria Evaristo, ${ }^{15}$ Estela Azeka, ${ }^{1}$ Fabio Bruno da Silva, ${ }^{9}$ Fan Hui Wen, ${ }^{11}$ Fatima Gil Ferreira, ${ }^{1}$ Felipe Gallego Lima, ${ }^{1}$ Felipe Lourenço Fernandes, ${ }^{1}$ Fernando Ganem, ${ }^{1}$ Filomena Regina Barbosa Gomes Galas, ${ }^{1}$ Flavio Tarasoutchi, ${ }^{1}$ Germano Emilio Conceição Souza, ${ }^{1}$ Gilson Soares Feitosa Filho, ${ }^{16,17}$ Gustavo Foronda, ${ }^{1,18,19}$ Helio Penna Guimarães, ${ }^{20,21}$ Isabela Cristina Kirnew Abud, ${ }^{18}$ Ivanhoé Stuart Lima Leite, ${ }^{1}$ Jaime Paula Pessoa Linhares Filho, ${ }^{1}$ João Batista de Moura Xavier Moraes Junior, ${ }^{22}$ João Luiz Alencar de Araripe Falcão, ${ }^{23}$ Jose Antônio Franchini Ramires, ${ }^{1}$ José Fernando Cavalini, ${ }^{1}$ José Francisco Kerr Saraiva, ${ }^{24}$ Karen Cristine Abrão, ${ }^{1}$ Lecio Figueira Pinto, ${ }^{1}$ Leonardo Luís Torres Bianchi, ${ }^{1}$ Leonardo Nícolau Geisler Daud Lopes, ${ }^{18}$ Leopoldo Soares Piegas, ${ }^{20}$ Liliane Kopel, ${ }^{1}$ Lucas Colombo Godoy, ${ }^{1}$ Lucia Tobase, ${ }^{25}$ Ludhmila Abrahão Hajjar, ${ }^{1}$ Luís Augusto Palma Dallan, ${ }^{1}$ Luiz Fernando Caneo, ${ }^{1}$ Luiz Francisco Cardoso, ${ }^{15}$ Manoel Fernandes Canesin, ${ }^{26}$ Marcelo Park, ${ }^{1}$ Marcia Maria Noya Rabelo, ${ }^{27}$ Marcus Vinícius Bolívar Malachias, ${ }^{28}$ Maria Aparecida Batistão Gonçalves, ${ }^{1}$ Maria Fernanda Branco de Almeida, ${ }^{21}$ Maria Francilene Silva Souza, ${ }^{1}$ Maria Helena Sampaio Favarato, ${ }^{1,15}$ Maria Julia Machline Carrion, ${ }^{18}$ Maria Margarita Gonzalez, ${ }^{1}$ Maria Rita de Figueiredo Lemos Bortolotto, ${ }^{1}$ Milena Frota Macatrão-Costa, ${ }^{1}$ Mônica Satsuki Shimoda, ${ }^{1}$ Mucio Tavares de Oliveira-Junior, ${ }^{1}$ Nana Miura Ikari, ${ }^{1}$ Oscar Pereira Dutra, ${ }^{29}$ Otávio Berwanger, ${ }^{1}$ Patricia Ana Paiva Corrêa Pinheiro, ${ }^{23}$ Patrícia Feitosa Frota dos Reis, ${ }^{1}$ Pedro Henrique Moraes Cellia, ${ }^{1}$ Raul Dias dos Santos Filho, ${ }^{1}$ Renan Gianotto-Oliveira, ${ }^{30}$ Roberto Kalil Filho, ${ }^{1}$ Ruth Guinsburg, ${ }^{21}$ Sandrigo Managini, ${ }^{1}$ Silvia Helena Gelas Lage, ${ }^{1}$ So Pei Yeu, ${ }^{1}$ Sonia Meiken Franchi, ${ }^{31}$ Tania Shimoda-Sakano, ${ }^{6}$ Tarso Duenhas Accorsi, ${ }^{18}$ Tatiana de Carvalho Andreucci Leal, ${ }^{1}$ Vanessa Guimarães, ${ }^{1}$ Vanessa Santos Sallai, ${ }^{1}$ Walkiria Samuel Ávila, ${ }^{6}$ Yara Kimiko Sako ${ }^{32}$

Instituto do Coração (Incor) do Hospital das Clínicas da Faculdade de Medicina da Universidade de São Paulo (FMUSP), ${ }^{1}$ São Paulo, SP - Brasil Hospital Nove de Julho, ${ }^{2}$ São Paulo, SP - Brasil

Clínica Cardiológica e Medicina Preventiva, ${ }^{3}$ São Paulo, SP - Brasil

Conselho Regional de Medicina de São Paulo (CREMESP), ${ }^{4}$ São Paulo, SP - Brasil

Hospital BP Mirante, ${ }^{5}$ São Paulo, SP - Brasil

Instituto da Criança do Hospital das Clínicas da Faculdade de Medicina da Universidade de São Paulo (FMUSP), ${ }^{6}$ São Paulo, SP - Brasil

Universidade Anhembi Morumbi, ${ }^{7}$ São Paulo, SP - Brasil

Faculdade de Medicina de Ribeirão Preto da Universidade de São Paulo (FMRP-USP), ${ }^{8}$ São Paulo, SP - Brasil

Instituto Dante Pazzanese de Cardiologia, ${ }^{9}$ São Paulo, SP - Brasil

Fundação Zerbini, ${ }^{10}$ São Paulo, SP - Brasil

Instituto Butantan, Secretaria de Estado da Saúde de São Paulo e do Ministério da Saúde, ${ }^{11}$ São Paulo, SP - Brasil

Hospital Municipal Miguel Couto, Secretaria Municipal de Saúde, ${ }^{12}$ Rio de Janeiro, RJ - Brasil

Serviço de Clínica Geral do Hospital das Clínicas da Faculdade de Medicina da Universidade de São Paulo (FMUSP), ${ }^{13}$ São Paulo, SP - Brasil

Hospital São Camilo, ${ }^{14}$ São Paulo, SP - Brasil

Hospital Sírio Libanês, ${ }^{15}$ São Paulo, SP - Brasil

Escola Bahiana de Medicina, ${ }^{16}$ Salvador, BA - Brasil

Rede FTC, ${ }^{17}$ Salvador, BA - Brasil

Hospital Israelita Albert Einstein, ${ }^{18}$ São Paulo, SP - Brasil

Hospital Sepaco, ${ }^{19}$ São Paulo, SP - Brasil

Hospital do Coração (HCor), ${ }^{20}$ São Paulo, SP - Brasil

Universidade Federal de São Paulo (UNIFESP), ${ }^{21}$ São Paulo, SP - Brasil

Hospital Agamenon Magalhães, ${ }^{22}$ Recife, PE - Brasil

Universidade de Fortaleza (UNIFOR), ${ }^{23}$ Fortaleza, CE - Brasil 
Saraiva \& Berlinger LTDA., ${ }^{24}$ São Paulo, SP - Brasil

Secretaria Municipal da Saúde da Prefeitura Municipal de São Paulo, ${ }^{25}$ São Paulo, SP - Brasil

Universidade Estadual de Londrina, ${ }^{26}$ Londrina, $P R$ - Brasil

Hospital São Rafael, ${ }^{27}$ Salvador, BA - Brasil

Faculdade Ciências Médicas de Minas Gerais (FCM-MG), ${ }^{28}$ Belo Horizonte, MG - Brasil

Instituto de Cardiologia do Rio Grande do Sul, ${ }^{29}$ Porto Alegre, RS - Brasil

Universidade Estadual de Campinas (UNICAMP), ${ }^{30}$ Campinas, SP - Brasil

Beneficência Portuguesa de São Paulo, ${ }^{31}$ São Paulo, SP - Brasil

Sociedade Brasileira de Cardiologia (SBC), ${ }^{32}$ Rio de Janeiro, RJ - Brasil

\section{Esta atualização deverá ser citada como:}

Bernoche C, Timerman S, Polastri TF, Giannetti NS, Siqueira AWS, Piscopo A et al. Atualização da Diretriz de Ressuscitação Cardiopulmonar e Cuidados de Emergência da Sociedade Brasileira de Cardiologia - 2019. Arq Bras Cardiol. 2019; 113(3):449-663

Nota: estas Diretrizes se prestam a informar e não a substituir o julgamento clínico do médico que, em última análise, deve determinar o tratamento apropriado para seus pacientes.

Correspondência: Sociedade Brasileira de Cardiologia - Av. Marechal Câmara, 360/330 - Centro - Rio de Janeiro - CEP: $20020-907$. E-mail: diretrizes@cardiol.br; diretriz.emergencia@gmail.com. 


\section{Atualização}

Declaração de potencial conflito de interesses dos autores/colaboradores da Atualização da Diretriz de Ressuscitação Cardiopulmonar e Cuidados Cardiovasculares de Emergência da Sociedade Brasileira de Cardiologia - 2019 Se nos últimos 3 anos o autor/colaborador das Diretrizes:

\begin{tabular}{|c|c|c|c|c|c|c|c|}
\hline $\begin{array}{l}\text { Nomes Integrantes da } \\
\text { Atualização }\end{array}$ & $\begin{array}{l}\text { Participou de estudos } \\
\text { clínicos e/ou experimentais } \\
\text { subvencionados pela } \\
\text { indústria farmacêutica ou de } \\
\text { equipamentos relacionados } \\
\text { à diretriz em questão }\end{array}$ & $\begin{array}{c}\text { Foi palestrante } \\
\text { em eventos } \\
\text { ou atividades } \\
\text { patrocinadas } \\
\text { pela indústria } \\
\text { relacionados à } \\
\text { diretriz em questão }\end{array}$ & $\begin{array}{l}\text { Foi (é) membro } \\
\text { do conselho } \\
\text { consultivo } \\
\text { ou diretivo } \\
\text { da indústria } \\
\text { farmacêutica ou } \\
\text { de equipamentos }\end{array}$ & $\begin{array}{l}\text { Participou } \\
\text { de comitês } \\
\text { normativos } \\
\text { de estudos } \\
\text { científicos } \\
\text { patrocinados } \\
\text { pela indústria }\end{array}$ & $\begin{array}{l}\text { Recebeu auxílio } \\
\text { pessoal ou } \\
\text { institucional da } \\
\text { indústria }\end{array}$ & $\begin{array}{l}\text { Elaborou textos } \\
\text { científicos em } \\
\text { periódicos } \\
\text { patrocinados } \\
\text { pela indústria }\end{array}$ & $\begin{array}{c}\text { Tem } \\
\text { ações da } \\
\text { indústria }\end{array}$ \\
\hline $\begin{array}{l}\text { Adailson Wagner da Silva } \\
\text { Siqueira }\end{array}$ & Não & Não & Não & Não & Não & Não & Não \\
\hline Agnaldo Piscopo & Não & Não & Não & Não & Não & Não & Não \\
\hline Alexandre de Matos Soeiro & Não & Não & Não & Não & Não & Não & Não \\
\hline $\begin{array}{l}\text { Amélia Gorete Afonso da } \\
\text { Costa Reis }\end{array}$ & Não & Não & Não & Não & Não & Não & Não \\
\hline Ana Cristina Sayuri Tanaka & Não & Não & Não & Não & Não & Não & Não \\
\hline Ana Paula Quilici & Não & Não & Não & Não & Não & Não & Não \\
\hline Andrei Hilário Catarino & Não & Não & Não & Não & Não & Não & Não \\
\hline $\begin{array}{l}\text { Anna Christina de Lima } \\
\text { Ribeiro }\end{array}$ & Não & Não & Não & Não & Não & Não & Não \\
\hline $\begin{array}{l}\text { Antonio Carlos Pereira } \\
\text { Barreto }\end{array}$ & Não & Não & Não & Não & Não & Não & Não \\
\hline $\begin{array}{l}\text { Antonio Fernando Barros de } \\
\text { Azevedo Filho }\end{array}$ & Não & Não & Não & Não & Não & Não & Não \\
\hline Antonio Pazin Filho & Não & Não & Não & Não & Não & Não & Não \\
\hline Ari Timerman & Não & Não & $\begin{array}{l}\text { Sanofi, Daiichi } \\
\text { Sankyo }\end{array}$ & Não & $\begin{array}{l}\text { Sanofi, Daiichi } \\
\text { Sankyo }\end{array}$ & Não & Não \\
\hline Bruna Romanelli Scarpa & Não & Não & Não & Não & Não & Não & Não \\
\hline Caio de Assis Moura Tavares & Não & Não & Não & Não & Não & Não & Não \\
\hline $\begin{array}{l}\text { Cantidio Soares Lemos } \\
\text { Martins }\end{array}$ & Não & Não & Não & Não & Não & Não & Não \\
\hline Carlos Vicente Serrano Junior & Não & Não & Não & Não & Não & Não & Não \\
\hline $\begin{array}{l}\text { Ceila Maria Sant'Ana } \\
\text { Malaque }\end{array}$ & Não & Não & Não & Não & Não & Não & Não \\
\hline Claudia Bernoche & Não & Não & Não & Não & Não & Não & Não \\
\hline Cristiano Faria Pisani & Não & Não & Não & Não & Não & Não & Não \\
\hline Daniel Valente Batista & Não & Não & Não & Não & Não & Não & Não \\
\hline $\begin{array}{l}\text { Daniela Luana Fernandes } \\
\text { Leandro }\end{array}$ & Não & Não & Não & Não & Não & Não & Não \\
\hline David Szpilman & Não & Não & Não & Não & Não & Não & Não \\
\hline Diego Manoel Gonçalves & Não & Não & Não & Não & Não & Não & Não \\
\hline Edison Ferreira de Paiva & Não & Não & Não & Não & Não & Não & Não \\
\hline Eduardo Gomes Lima & Bayer & Bayer & Não & Não & Bayer & Não & Não \\
\hline Eduardo Leal Adam & Não & Não & Não & Não & Bayer & Não & Não \\
\hline Eduardo Atsushi Osawa & Não & Não & Não & Não & Não & Não & Não \\
\hline Elaine Peixoto & Não & Sanofi & Não & Não & Não & Não & Não \\
\hline Eli Faria Evaristo & Não & Não & Não & Não & Não & Não & Não \\
\hline Estela Azeka & Não & Não & Não & Não & Não & Não & Não \\
\hline Fabio Bruno da Silva & Não & Não & Não & Não & Não & Não & Não \\
\hline
\end{tabular}




\begin{tabular}{|c|c|c|c|c|c|c|c|}
\hline Fan Hui Wen & Não & Não & Não & Não & Não & Não & Não \\
\hline Fatima Gil Ferreira & Não & Não & Não & Não & Não & Não & Não \\
\hline Felipe Gallego Lima & Não & Não & Não & Não & Não & Não & Não \\
\hline Felipe Lourenço Fernandes & Não & Não & Não & Não & Não & Não & Não \\
\hline Fernando Ganem & Não & Não & Não & Não & Não & Não & Não \\
\hline $\begin{array}{l}\text { Filomena Regina Barbosa } \\
\text { Gomes Galas }\end{array}$ & Não & Não & Não & Não & Não & Não & Não \\
\hline Flavio Tarasoutchi & Não & Não & Não & Não & Não & Não & Não \\
\hline $\begin{array}{l}\text { Germano Emilio Conceição } \\
\text { Souza }\end{array}$ & Não & Não & Não & Não & Não & Não & Não \\
\hline Gilson Soares Feitosa Filho & Não & Não & Não & Não & Não & Não & Não \\
\hline Gustavo Foronda & Não & Não & Não & Não & Não & Não & Não \\
\hline Helio Penna Guimarães & Não & Não & Não & Não & Não & Não & Não \\
\hline Isabela Cristina Kirnew Abud & Não & Não & Não & Não & Não & Não & Não \\
\hline Ivanhoé Stuart Lima Leite & Não & Não & Não & Não & Não & Não & Não \\
\hline $\begin{array}{l}\text { Jaime Paula Pessoa Linhares } \\
\text { Filho }\end{array}$ & Não & Não & Não & Não & Não & Não & Não \\
\hline $\begin{array}{l}\text { João Batista de Moura Xavier } \\
\text { Moraes Junior }\end{array}$ & Não & Não & Não & Não & Não & Não & Não \\
\hline $\begin{array}{l}\text { João Luiz Alencar de Araripe } \\
\text { Falcão }\end{array}$ & Não & Não & Não & Não & Não & Não & Não \\
\hline $\begin{array}{l}\text { Jose Antônio Franchini } \\
\text { Ramires }\end{array}$ & Não & Não & Não & Não & Não & Não & Não \\
\hline José Fernando Cavalini & Não & Não & Não & Não & Não & Não & Não \\
\hline José Francisco Kerr Saraiva & Não & Não & Não & Não & Não & Não & Não \\
\hline Karen Cristine Abrão & UCB Biopharma & Não & Não & Não & Não & Não & Não \\
\hline Lecio Figueira Pinto & UCB Biopharma & Não & Não & Não & $\begin{array}{l}\text { Genom } \\
\text { Química }\end{array}$ & $\begin{array}{c}\text { Genom } \\
\text { Quimica, } \\
\text { Zodiac, United } \\
\text { Medical }\end{array}$ & Não \\
\hline Leonardo Luís Torres Bianchi & Não & Não & Não & Não & Não & Não & Não \\
\hline $\begin{array}{l}\text { Leonardo Nícolau Geisler } \\
\text { Daud Lopes }\end{array}$ & Não & Não & Não & Não & Não & Não & Não \\
\hline Leopoldo Soares Piegas & Não & Não & Não & Não & Não & Não & Não \\
\hline Liliane Kopel & Não & Não & Não & Não & Não & Não & Não \\
\hline Lucas Colombo Godoy & Não & Não & Não & Não & Não & Não & Não \\
\hline Lucia Tobase & Não & Não & Não & Não & Não & Não & Não \\
\hline Ludhmila Abrahão Hajjar & Não & Não & Não & Não & Não & Não & Não \\
\hline Luís Augusto Palma Dallan & Não & Não & Não & Não & Não & Não & Não \\
\hline Luiz Fernando Caneo & Não & Não & Não & Não & Não & Não & Não \\
\hline Luiz Francisco Cardoso & Não & Não & Não & Não & Não & Não & Não \\
\hline Manoel Fernandes Canesin & Não & Não & Não & Não & Não & SEM, Novartis & Não \\
\hline Marcelo Park & Não & Não & Não & Não & Não & Não & Não \\
\hline Marcia Maria Noya Rabelo & Não & Não & Não & Não & Não & Não & Não \\
\hline $\begin{array}{l}\text { Marcus Vinícius } \\
\text { Bolívar Malachias }\end{array}$ & Não & Não & Não & Não & Não & Não & Não \\
\hline $\begin{array}{l}\text { Maria Aparecida Batistão } \\
\text { Gonçalves }\end{array}$ & Não & Não & Não & Não & Não & Não & Não \\
\hline $\begin{array}{l}\text { Maria Fernanda Branco de } \\
\text { Almeida }\end{array}$ & Não & Não & Não & Não & Não & Não & Não \\
\hline
\end{tabular}




\begin{tabular}{|c|c|c|c|c|c|c|c|}
\hline Maria Francilene Silva Souza & Não & Não & Não & Não & Não & Não & Não \\
\hline $\begin{array}{l}\text { Maria Helena Sampaio } \\
\text { Favarato }\end{array}$ & Não & Não & Não & Não & Não & Não & Não \\
\hline Maria Julia Machline Carrion & Não & Não & Boehringer & Não & Não & Não & Não \\
\hline Maria Margarita Gonzalez & Não & Não & Não & Não & Não & Não & Não \\
\hline $\begin{array}{l}\text { Maria Rita de Figueiredo } \\
\text { Lemos Bortolotto }\end{array}$ & Não & Não & Não & Não & Não & Não & Não \\
\hline Milena Frota Macatrão-Costa & Não & Não & Não & Não & Não & Não & Não \\
\hline Mônica Satsuki Shimoda & Não & Não & Não & Não & Não & Não & Não \\
\hline $\begin{array}{l}\text { Mucio Tavares de Oliveira } \\
\text { Junior }\end{array}$ & Não & Não & $\begin{array}{c}\text { Roche } \\
\text { Diagnóstica, } \\
\text { Torrent Pharma, } \\
\text { Sanofi Pasteur, } \\
\text { Boehringer } \\
\text { Ingelheim, } \\
\text { Biolab }\end{array}$ & $\begin{array}{c}\text { Torrent } \\
\text { Pharma, } \\
\text { Sanofi Pasteur }\end{array}$ & Não & $\begin{array}{c}\text { Torrent } \\
\text { Pharma, } \\
\text { Merck, SEM, } \\
\text { Biolab }\end{array}$ & Não \\
\hline Nana Miura Ikari & Não & Não & Não & Não & Não & Não & Não \\
\hline Natali Schiavo Giannetti & Não & Não & Não & Não & Não & Não & Não \\
\hline Oscar Pereira Dutra & Não & Não & Não & Não & Não & Não & Não \\
\hline Otávio Berwanger & Não & Não & Não & Não & Não & Não & Não \\
\hline $\begin{array}{l}\text { Patrícia Feitosa Frota dos } \\
\text { Reis }\end{array}$ & Não & Não & Não & Não & Não & Não & Não \\
\hline $\begin{array}{l}\text { Patricia Ana Paiva Corrêa } \\
\text { Pinheiro }\end{array}$ & Não & Não & Não & Não & Não & Não & Não \\
\hline Pedro Henrique Moraes Cellia & Não & Não & Não & Não & Não & Não & Não \\
\hline Raul Dias dos Santos Filho & Não & Não & Não & Não & Não & Não & Não \\
\hline Renan Gianotto-Oliveira & Não & Não & Não & Não & Não & Não & Não \\
\hline Roberto Kalil Filho & Não & Não & Não & Não & Não & Não & Não \\
\hline Ruth Guinsburg & Não & Não & Não & Não & Não & Não & Não \\
\hline Sandrigo Managini & Não & Não & Não & Não & Não & Não & Não \\
\hline Sergio Timerman & Não & Não & Não & Não & Não & Não & Não \\
\hline Silvia Helena Gelas Lages & Não & Não & Não & Não & Não & Não & Não \\
\hline So Pei Yeu & Não & Não & Não & Não & Não & Não & Não \\
\hline Sonia Meiken Franchi & Não & Não & Não & Não & Não & Não & Não \\
\hline Tania Shimoda-Sakano & Não & Não & Não & Não & Não & Não & Não \\
\hline Tarso Duenhas Accorsi & Não & Não & Não & Não & Não & Não & Não \\
\hline $\begin{array}{l}\text { Tatiana de Carvalho } \\
\text { Andreucci Leal }\end{array}$ & Não & Não & Não & Não & Não & Não & Não \\
\hline Thatiane Facholi Polastri & Não & Não & Não & Não & Não & Não & Não \\
\hline Vanessa Guimarães & Não & Não & Não & Não & Não & Não & Não \\
\hline Vanessa Santos Sallai & Não & Não & Não & Não & Não & Não & Não \\
\hline Walkiria Samuel Ávila & Não & Não & Não & Não & Não & Não & Não \\
\hline Yara Kimiko Sako & Não & Não & Não & Não & Não & Não & Não \\
\hline
\end{tabular}




\section{Sumário}

1. Epidemiologia da Parada Cardiorrespiratória e Apresentação da Diretriz

1.1. Apresentação da Atualização da Diretriz de Ressuscitação Cardiopulmonar e Cuidados Cardiovasculares de Emergência da Sociedade Brasileira de Cardiologia .......................................................................460

1.1.1. Epidemiologia da Parada Cardiorrespiratória ................................460

1.1.2. Êxito da Ressuscitação Cardiopulmonar .........................................460

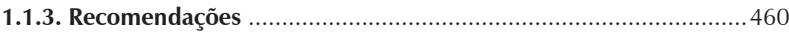

1.1.4. Evidência Científica

2. Suporte Básico de Vida no Adulto

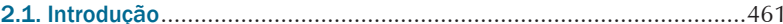

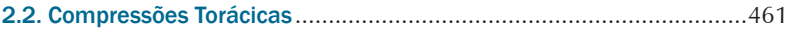

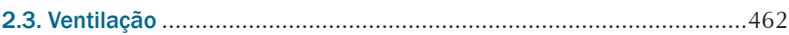

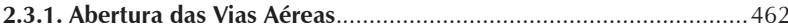

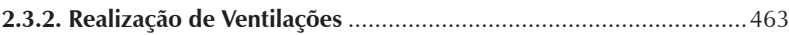

2.3.3 Ventilação com a Máscara de Bolso: a Pocket Mask .......................463

2.3.4. Ventilação com Bolsa-Válvula-Máscara ............................................463

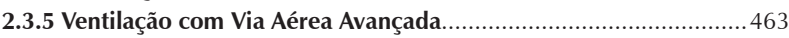

2.3.6. Ventilação em Vítima em Parada................................................ 464

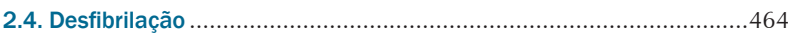

2.4.1. Uso do Desfibriladores Externos Automáticos em Situações

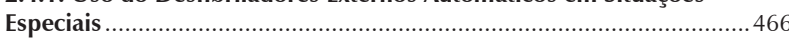

2.5. Sequência do Suporte Básico de Vida do Adulto para Profissionais da

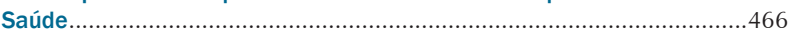

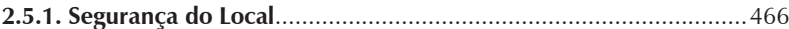

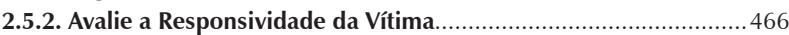

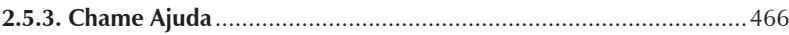

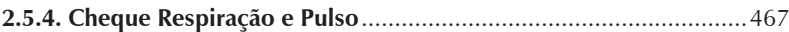

2.5.5. Inicie Ciclos de 30 Compressões e Duas Ventilações................... 467

2.6. Sequência do Suporte Básico de Vida do Adulto Realizada por Leigos .

3. Terapias Elétricas: Desfibrilação, Cardioversão e Marca-Passo

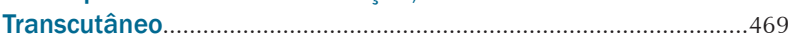

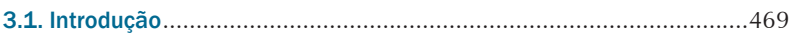

3.2. Características do Desfibrilador/Cardioversor ..................................469

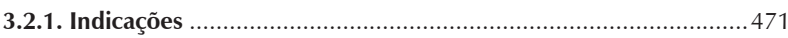

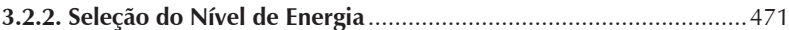

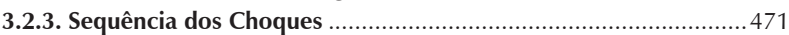

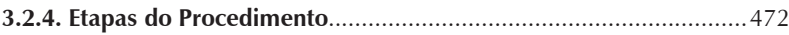

3.3. Marca-Passo Transcutâneo .............................................................. 472

3.3.1. Como Utilizar o Marca-Passo Transcutâneo …………………….... 473

4. Dispositivos Auxiliares Durante as Manobras de Ressuscitação

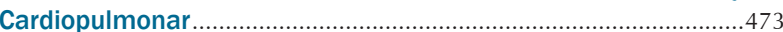

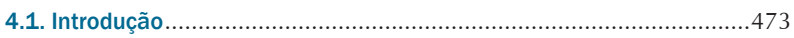

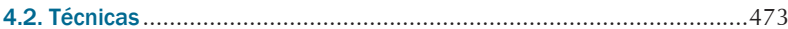

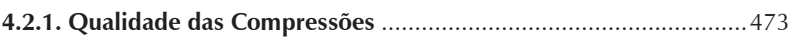

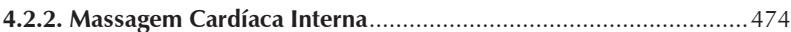

4.2.3. Compressão Torácica e Abdominal Intercalada .............................4 474

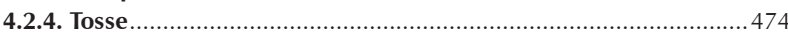

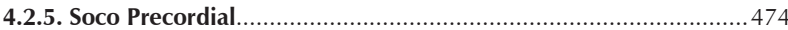

4.2.6. Reanimação Cardiopulmonar em Posição Prona ............................. 474

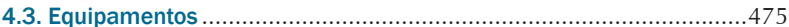

4.3.1. Ressuscitação Cardiopulmonar com Compressão-Descompressão

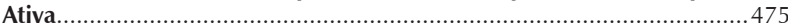

4.3.2. Válvula de Impedância Respiratória …………………………..... 475

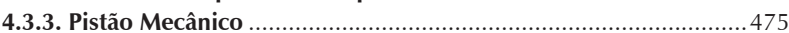

4.3.4. Colete Pneumático …….................................. 475

4.3.5. Assistência Circulatória ............................................................... 475

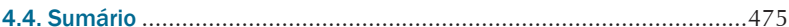

5. Suporte Avançado de Vida em Cardiologia no Adulto ...............475

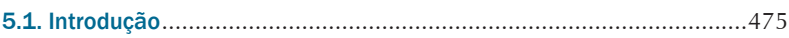

5.2. Suporte Ventilatório e Manejo da Via Aérea.......................................475
5.2.1. Administração de Oxigênio com Concentração de 100\% .............476 5.2.2. Ventilação com Dispositivo Bolsa-Válvula-Máscara.......................476 5.2.3. Dispositivos Auxiliares para Manejo da Via Aérea durante a Ressuscitação Cardiopulmonar ............................................................476

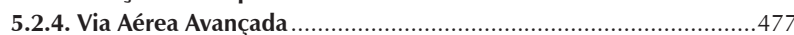
5.3. Monitorização durante a Parada Cardiorrespiratória .........................478 5.3.1. Parâmetros Mecânicos .............................................................. 478

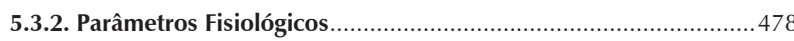
5.4. Manejo da Parada Cardíaca ...........................................................479 5.5. Tratamento da Parada Cardiorrespiratória Conforme o Ritmo..........479 5.5.1. Fibrilação Ventricular/Taquicardia Ventricular sem Pulso............. 479

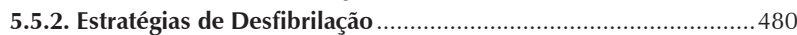
5.5.3. Medicações para a Fibrilação Ventricular ou Taquicardia Ventricular sem Pulso................................................................ 481

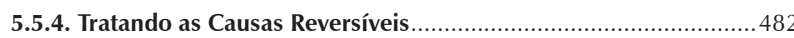
5.6. Assistolia e Atividade Elétrica sem Pulso.........................................482 5.6.1. Medicações para Assistolia e Atividade Elétrica sem Pulso .......... 482 5.6.2. Tratando as Causas Reversíveis............................................... 482

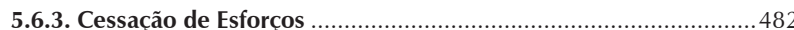
5.7. Intervenções Medicamentosas na Ressuscitação Cardiopulmonar ...482

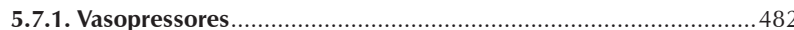

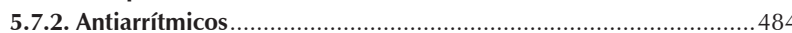
5.7.3. Intervenções Não Recomendadas Rotineiramente durante a Parada

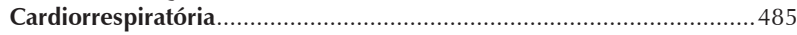

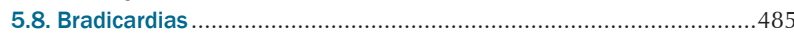

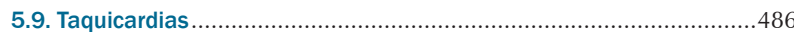
5.9.1. Taquicardias com QRS Estreito (QRS $<120$ Milissegundos).......488

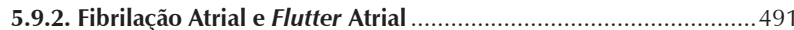
5.9.3. Taquicardia com QRS largo (QRS $\geq 120$ Milissegundos) ........... 492 5.9.4. Abordagem Inicial na Sala de Emergência .................................... 492

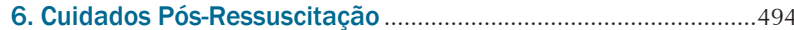

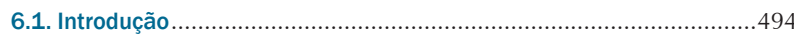

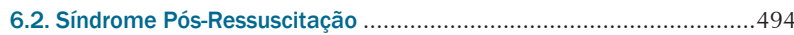

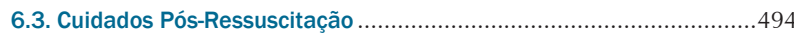

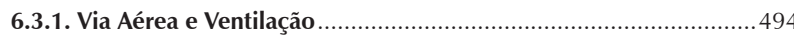

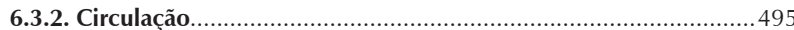

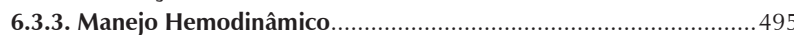

6.4. Modulação Terapêutica da Temperatura ……………………….......496

6.4.1. Quando e como Realizar a Modulação Terapêutica da

Temperatura ................................................................................ 496

6.4.2. Fases da Modulação Terapêutica da Temperatura: Indução,

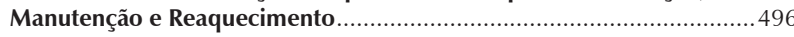

6.4.3. Contraindicações para a Modulação Terapêutica da

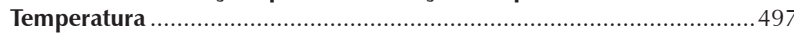

6.5. Estado Atual da Modulação Terapêutica da Temperatura..................497

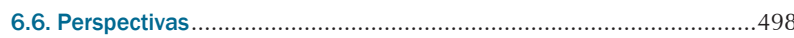

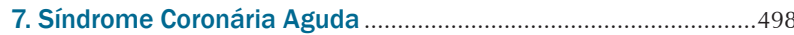

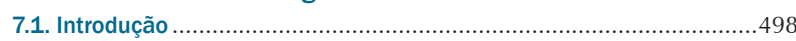

7.2. Epidemiologia da Doença Arterial Coronariana................................498

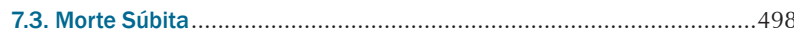

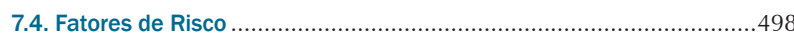

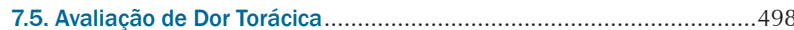

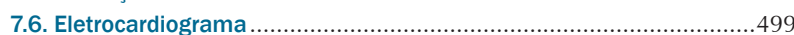

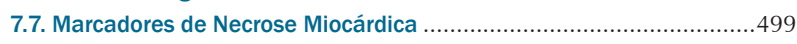

7.7.1. Isoenzima MB da Creatinoquinase ………….............................499

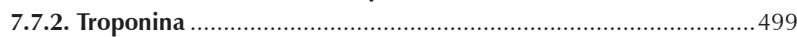

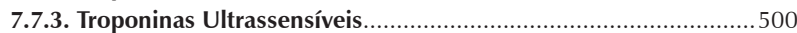

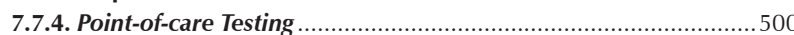

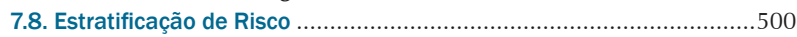

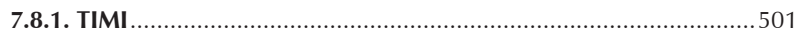

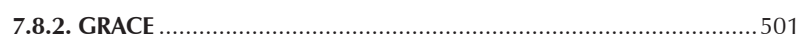

7.9. Tratamento da Síndrome Coronariana Aguda na Emergência.............502

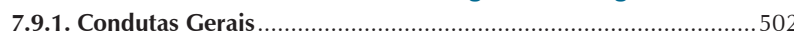

7.9.2. Antiagregantes Plaquetários...................................................... 502

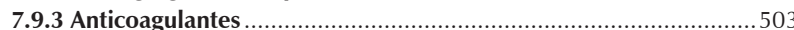




\section{Atualização}

7.9.4. Inibidores do Sistema Renina-Angiotensina-Aldosterona .............50 50

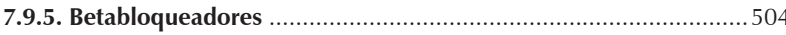

7.9.6. Estatinas e Hipolipemiantes .................................................... 504

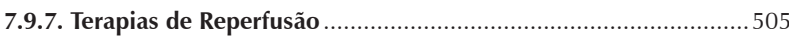

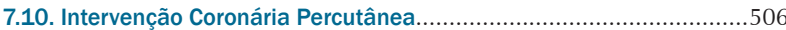

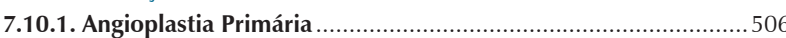

7.10.2. Escolhendo a Estratégia de Reperfusão.....................................506

7.10.3. Hospitais com Serviço de Hemodinâmica ……………................506

7.10.4. Hospitais sem Serviço de Hemodinâmica.....................................506

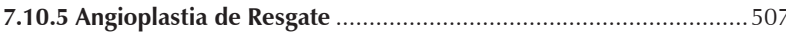

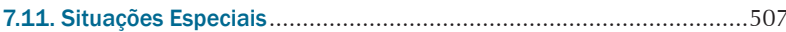

7.11.1. Choque Cardiogênico..............................................................507

7.11.2. Infarto do Ventrículo Direito .....................................................508

7.11.3. Complicações Mecânicas do Infarto Agudo do Miocárdio .........508

8. Abordagem e Tratamento da Fase Aguda do Acidente Vascular

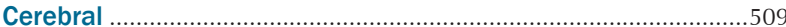

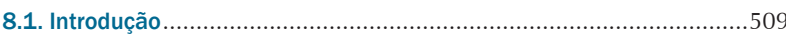

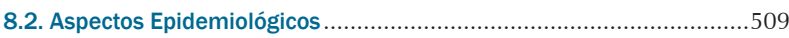

8.3. Acidente Vascular Cerebral: uma Emergência Neurológica.................509

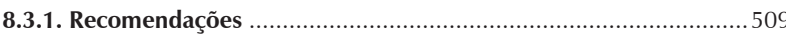

8.4. Atendimento Pré-Hospitalar e Transporte ……………….................509

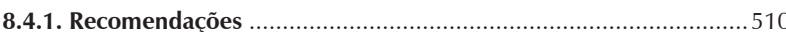

8.5. Exames de Imagem na Fase Aguda do Acidente Vascular Cerebral ....510

8.5.1. Tomografia Computadorizada de Crânio .....................................510

8.5.2. Ressonância Magnética de Crânio .................................................510

8.5.3. Angiotomografia ou Angiorressonância ........................................ 510

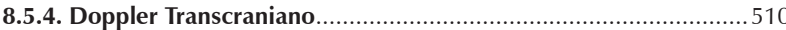

8.5.5. Outros Exames na Fase Aguda do Acidente Vascular Cerebral .......511

8.6. Atendimento Emergencial do Acidente Vascular Cerebral

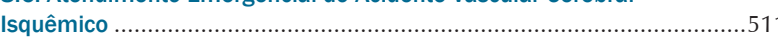

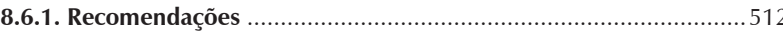

8.7. Anticoagulantes, Antiagregantes Plaquetários e Estatinas no Acidente

Vascular Cerebral Isquêmico Agudo ....................................................512

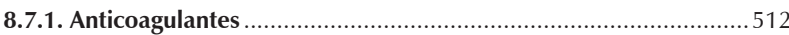

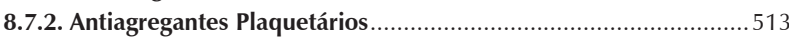

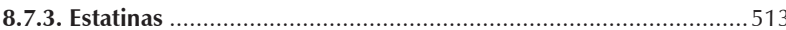

8.7.4. Protocolo de Trombólise Intravenosa …………………………..... 513

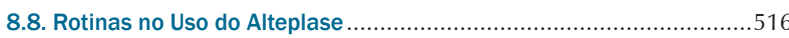

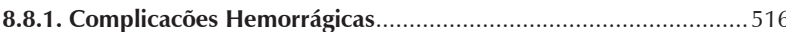

8.8.2. Angioedema Orolingual ...............................................................516

8.9. Tratamento Trombolítico Intra-Arterial, Combinado e Trombectomia

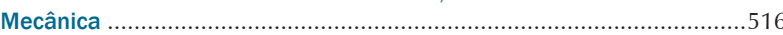

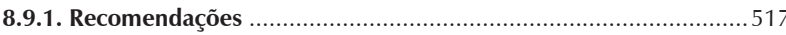

8.10. Classificação dos Centros de Referência para o Diagnóstico e

Tratamento do Acidente Vascular Cerebral Espontânea ............................517

8.11. Hemorragia Intraparenquimatosa Cerebral Espontânea ……….......518

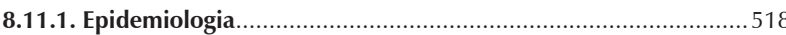

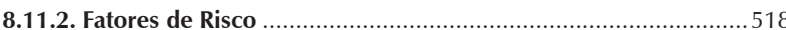

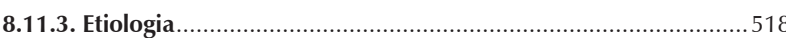

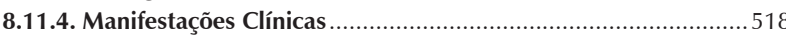

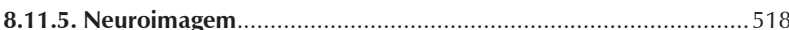

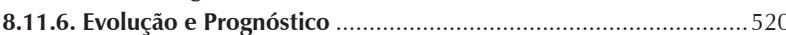

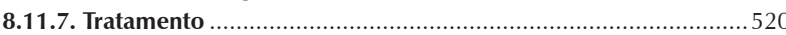

9. Ressuscitação Cardiopulmonar em Situações Especiais .........524

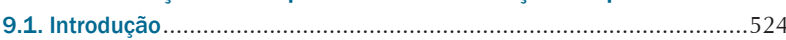

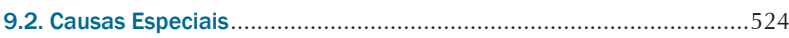

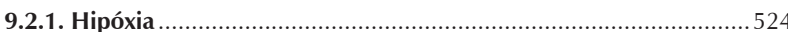

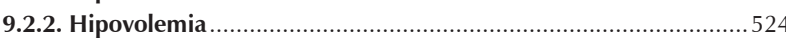

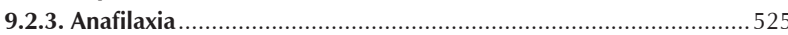

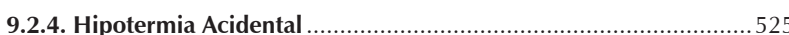

9.2.5. Tromboembolismo Pulmonar................................................... 526

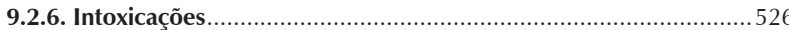

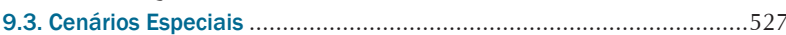

9.3.1. Parada Cardiorrespiratória no Pós-Operatório de Cirurgia

Cardíaca ...............527

9.3.2. Parada Cardiorrespiratória no Laboratório de Hemodinâmica.......527

9.3.3. Parada Cardiorrespiratória durante Atividades Desportivas ........528

9.3.4. Parada Cardiorrespiratória por Eletrocussão por Raios e

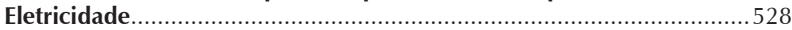

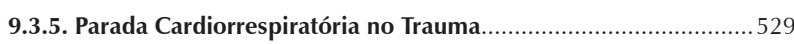

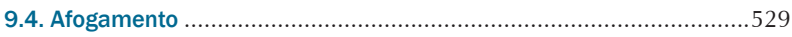

9.4.1. Particularidades dos Suportes Básico e Avançado no

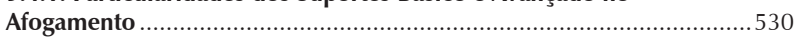

9.5. Pacientes Especiais: Obesos e Asmáticos .......................................531

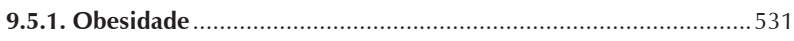

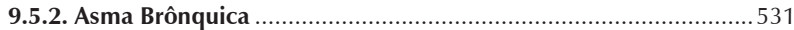

10. Emergências Cardiológicas em Gestantes................................532

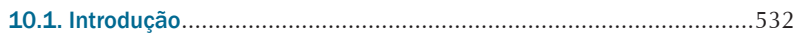

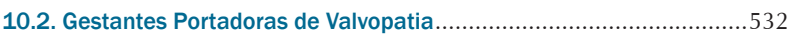

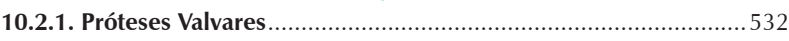

10.2.2. Diagnóstico e Conduta perante Trombose de Prótese Valvar .......533

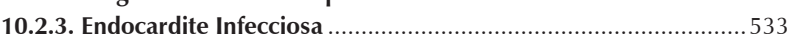

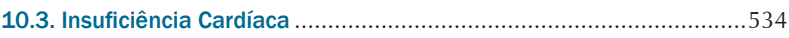

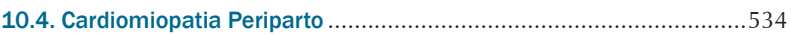

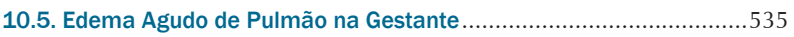

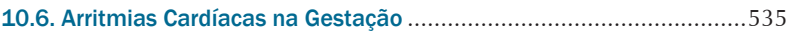

10.6.1. Taquiarritmias Supraventriculares ............................................5 535

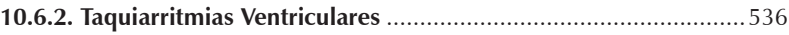

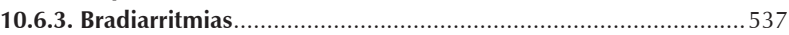

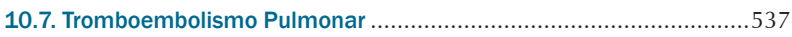

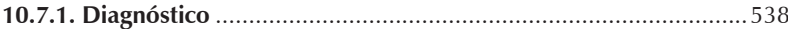

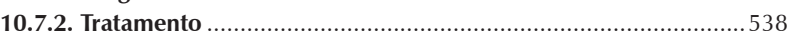

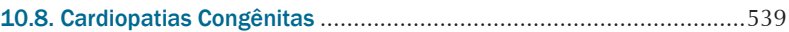

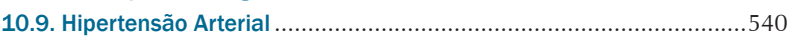

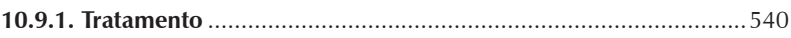

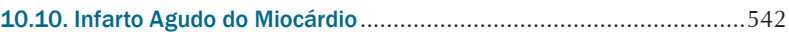

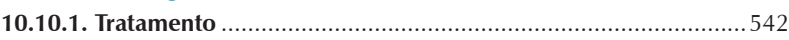

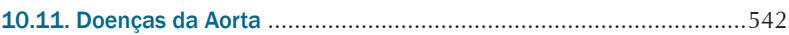

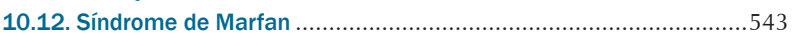

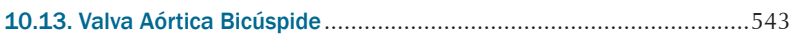

10.14. Parada Cardiorrespiratória .........................................................543

10.15. Considerações sobre Exposição à Radiação Durante a Gestação.......544

10.16. Considerações sobre Uso de Meios de Contraste na Gestação .....545

10.17. Considerações sobre Procedimentos Invasivos Durante a

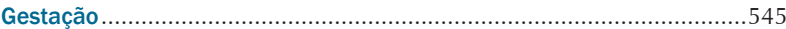

10.17.1. Intervenção Coronária Percutânea..............................................545

10.17.2. Valvoplastia Mitral Percutânea por Cateter Balão..................... 545

10.17.3. Outros Procedimentos Intervencionistas Valvares

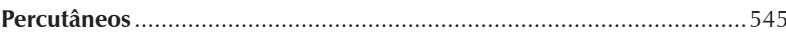

10.17.4. Cirurgia Cardíaca com Circulação Extracorpórea .....................545

10.17.5. Implante de Marca-Passo e Cardiodesfibrilador Implantável .......545

10.17.6. Ablação Percutânea de Arritmias por Radiofrequência .............545

10.18. Cuidados Gerais e Uso de Agentes Farmacológicos na Gestação e no

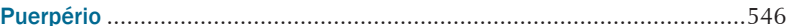

11. Suporte Básico de Vida em Pediatria ........................................550

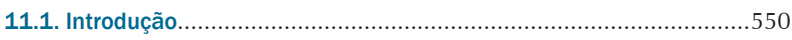

11.2. Suporte Básico de Vida em Pediatria ............................................551

11.2.1. Evidências de Aspectos Relacionados ao Período Pré-PCR .........551

11.2.2. Time de Resposta Rápida ou Time de Emergência Médica

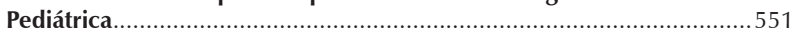

11.2.3. Sistemas de Classificação de Risco: o PEWS ................................. 551

11.2.4. Cardiomiopatia Dilatada Pediátrica ou Miocardite ........................551

11.3. Definição das Faixas Etárias para o Atendimento nas Emergências

Pediátricas .....................................................................................551

11.4. Sequência Compressão Torácica e Ventilação: C-A-B vs. A-B-C........551

11.5. Profundidade de Compressão Torácica ............................................551

11.6. Ressuscitação Cardiopulmonar Convencional vs. Só

Compressão . 551 
11.7. Características do Suporte Básico de Vida de alta qualidade...........552 11.8. Sequência do Suporte Básico de Vida em Lactentes e Crianças para um ou mais Profissionais de Saúde..........................................................552 11.9. Atendimento da Parada Cardiorrespiratória por Público Leigo ........555 11.10. Obstrução de Vias Aéreas Superiores por Corpo Estranho..............555 11.10.1. Reconhecimento da Obstrução de Vias Aéreas Superiores ......555

12. Suporte Avançado de Vida em Pediatria...................................557

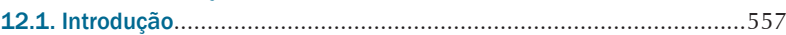

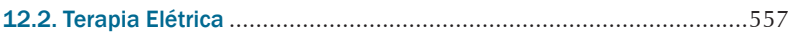

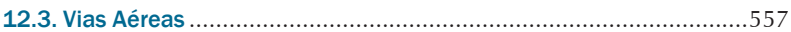

12.4. Medicações Administradas durante a Ressuscitação

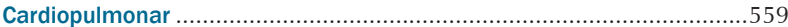

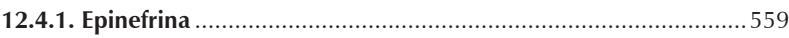

12.4.2. Cálcio

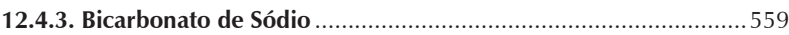

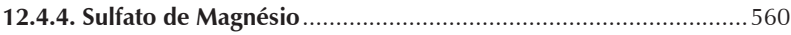

12.4.5. Glicose

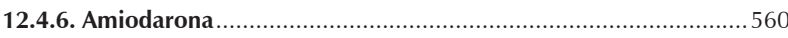

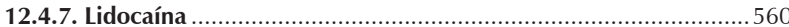

12.5. Medicamentos para a Manutenção do Débito ................................561

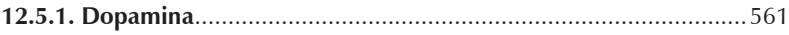

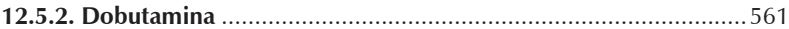

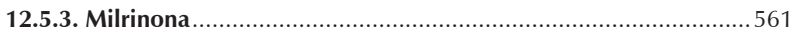

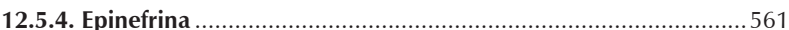

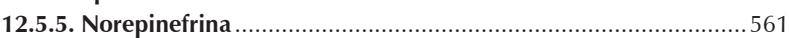

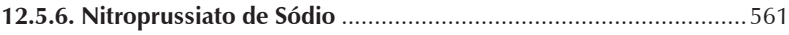

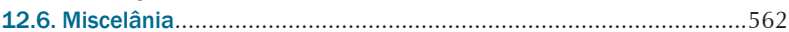

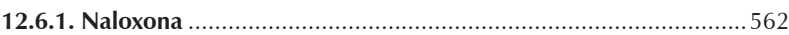

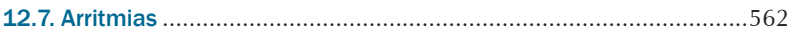

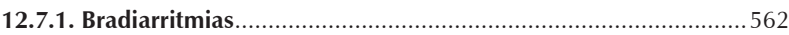

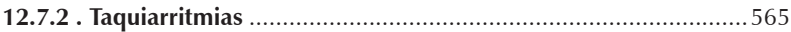

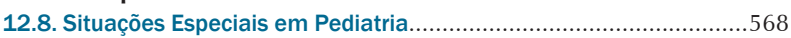

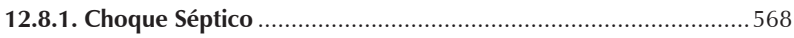

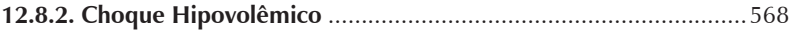

12.8.3. Trauma

12.8.4. Parada Cardiorrespiratória por Afogamento ..............................569

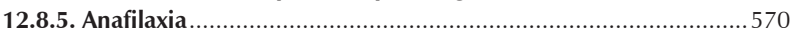

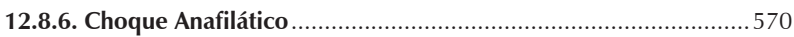

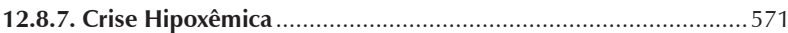

12.9. Cardiopatia Congênita - Ventrículo Único......................................571

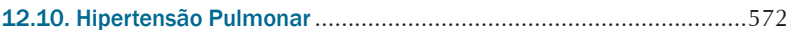

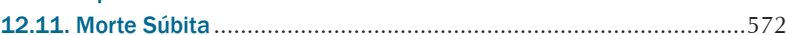

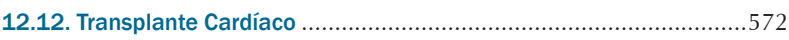

12.13. Disfunção Miocárdica Aguda em Pós-Operatório .........................572

12.13.1. Oxigenação por Membrana Extracorpórea ...............................572

12.13.2. Populações de Pacientes Tratados com Oxigenação por

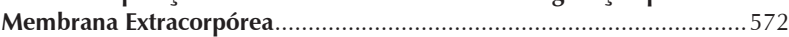

12.13.3. Fisiologia da Oxigenação por Membrana Extracorpórea ..........573

12.13.4. Tipos de Suporte com Oxigenação por Membrana

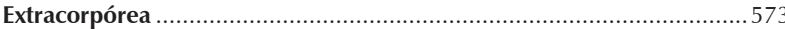

12.14. Dispositivos de Assistência Ventricular.......................................574

12.15. Manejo do Paciente em Extracorporeal Life Support.....................574

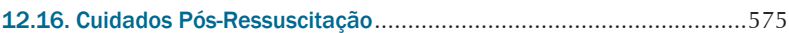

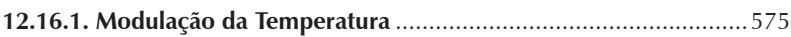

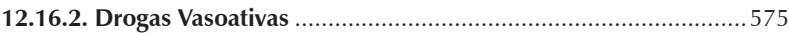

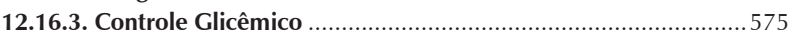

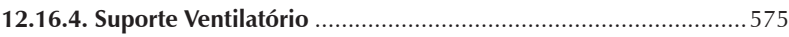

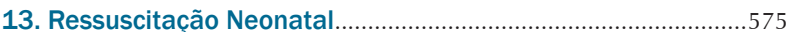

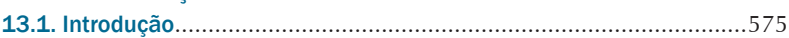

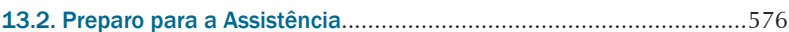

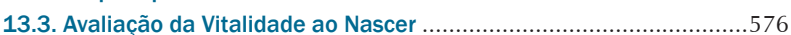

13.4. Clampeamento do Cordão Umbilical ............................................577

13.5. Passos Iniciais da Estabilização/Reanimação................................577

13.6. Assistência ao Recém-Nascido com Líquido Amniótico Meconial .....578
13.7. Ventilação com Pressão Positiva ....................................................578

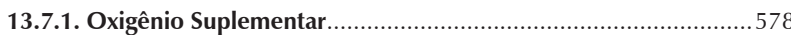

13.7.2. Ventilação com Balão Autoinflável e Máscara Facial....................578

13.7.3. Ventilação com Balão Autoinflável e Cânula Traqueal ................ 579

13.7.4. Uso do Ventilador Mecânico Manual em T................................5 579

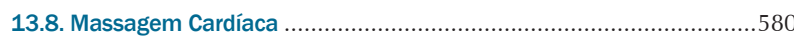

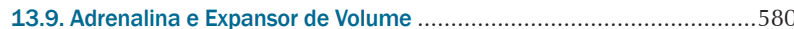

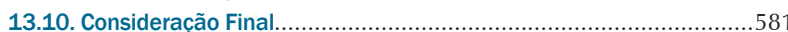

14. Suporte Avançado de Vida em Insuficiência Cardíaca............581

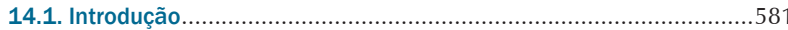

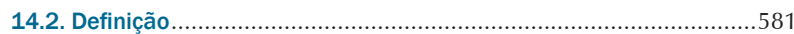

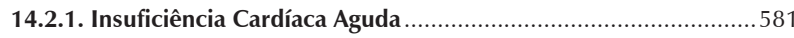

14.2.2. Exacerbação Aguda da Insuficiência Cardíaca Crônica................583

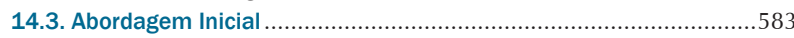

14.4. Padrão de Abordagem e Drogas Vasoativas ....................................586

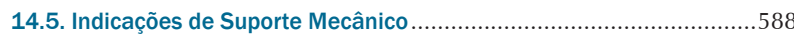

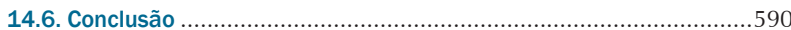

15. Suporte de Vida Extracorpóreo Neonatal, Pediátrico e

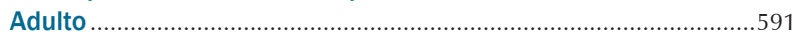

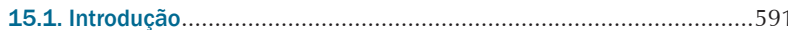

15.2. Resumo das Situações Clínicas com Indicação de Oxigenação

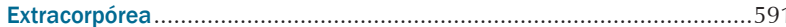

15.3. Centros Especializados em Oxigenação Extracorpórea .....................591

15.4. Extracorporeal Life Support no Choque Cardiogênico .......................593

15.4.1. Balão Intra-Aórtico de Contrapulsação .......................................593

15.4.2. Membrana de Oxigenação Extracorpórea....................................594

15.4.3. Dispositivos de Assistência Circulatória de Curta Duração........595

15.4.4. Dispositivos de Assistência Circulatória de Longa Duração...... 595

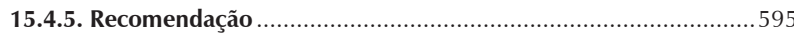

15.5. Extracorporeal Life Support na Insuficiência Respiratória Aguda ...595 15.5.1. Considerações da Oxigenação Extracorpórea Venovenosa.........596

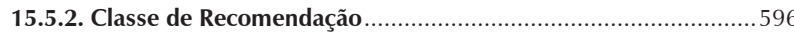
15.6. Extracorporeal Life Support em Neonatos ......................................596 15.7. Extracorporeal Life Support em Pediatria ......................................597 15.7.1. Dispositivos de Assistência Circulatória Mecânica em

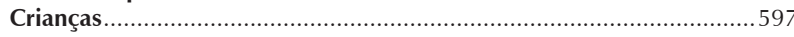

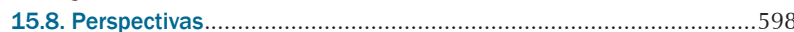

16. Simulação no Ensino das Emergências.....................................598

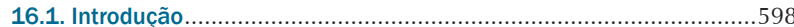

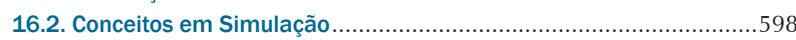
16.3. Treinamento de Habilidades (Part Task Trainer) .............................598

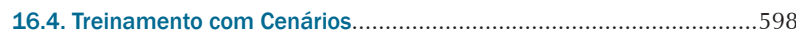
16.5. Treinamento em Ressuscitação Utilizando a Simulação....................598 16.6. Treinamento em Suporte Básico de Vida: Ênfase na Ressuscitação Cardiopulmonar de Qualidade ..................................................................599

17. Time de Resposta Rápida, Código Azul, Registro de Ressuscitação Intra-Hospitalar e Padronização do Carro de Emergência

17.1. Time de Resposta Rápida

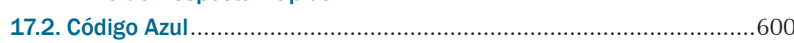

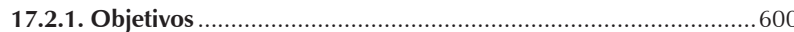

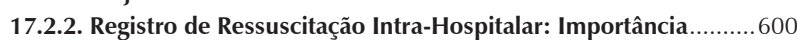
17.3. Padronização do Carro de Emergência ...........................................600

18. Atendimento Pré-Hospitalar, Regulação e Transporte .............600

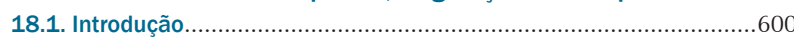
18.2. Regulação Médica das Urgências e Emergências.............................601

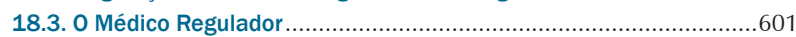
18.4. Classificação da Ambulância e Tripulação Necessária para Atendimento Pré-Hospitalar e Transporte de Pacientes .............................603 18.5. Etapas do Atendimento Pré-Hospitalar.............................................604

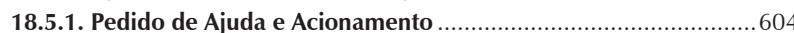
18.5.2. Regulação e Aconselhamento Médico............................................604 


\section{Atualização}

18.5.3. Reconhecimento e Ações do Médico Regulador em Casos de Vítimas com Dor Torácica

18.5.4. Reconhecimento e Ações do Médico Regulador em Casos de Vítimas com Parada Cardiorrespiratória................................................604

18.6. Ações ao se Deparar com um Acidente ou Atendimento Fora do Hospital.

18.7. Medicamentos Durante a Parada Cardiorrespiratória......................606

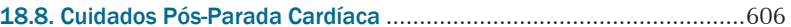

18.9. Quando Devemos Interromper os Esforços e Declarar Morte...........606

18.10. Atendimento de Vítimas de Trauma Fora do Hospital...................607

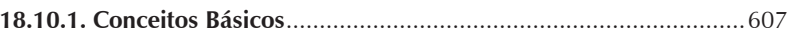

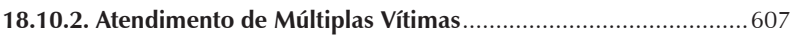

18.10.3. Critérios de Ressuscitação Cardiopulmonar no Trauma ...........607

19. Primeiros Socorros e Emergências Ambientais ........................607

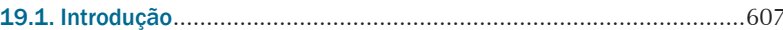

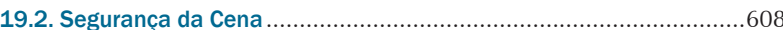

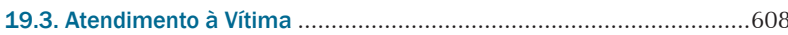

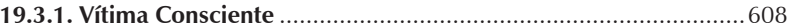

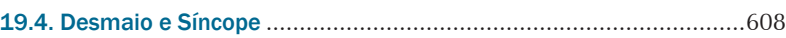

19.5. Obstrução de Vias Aéreas por Corpo Estranho.................................610

19.6. Dor Torácica Sugestiva de Isquemia Miocárdica..............................611

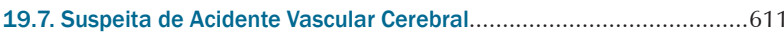

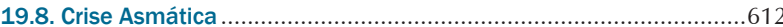

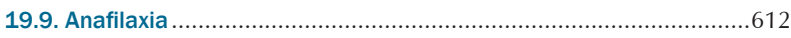

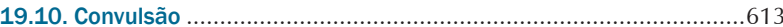

19.11. Atendimento Inicial à Vítima com Hipoglicemia ............................614

19.12. Intoxicação Exógena - Envenenamento ……………....................615

19.13. Abordagem à Vítima de Trauma..................................................615

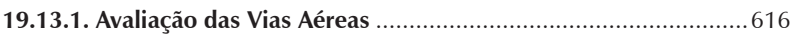

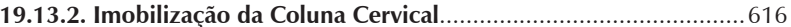

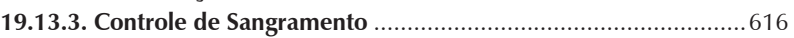

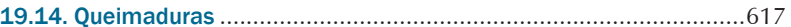

19.15. Acidentes por Animais Peçonhentos ...........................................618

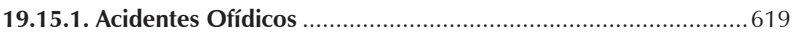

19.15.2. Acidentes por Serpentes não Peçonhentas ………………......620

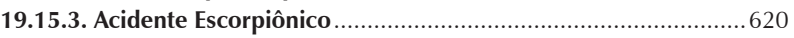

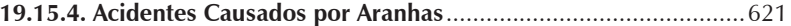

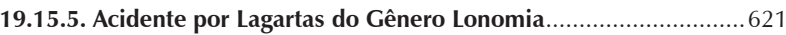

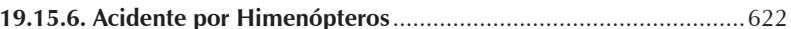

20. Princípios Éticos e Legais da Ressuscitação

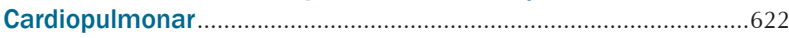

20.1. A Ética da Ressuscitação e Decisões de Fim de Vida .......................622

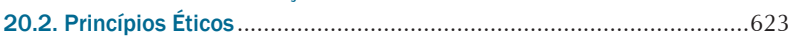

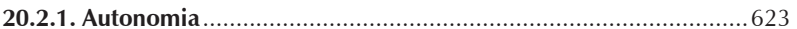

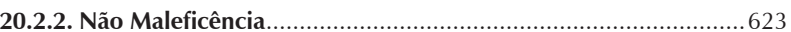

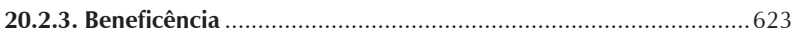

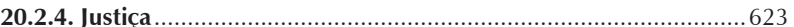

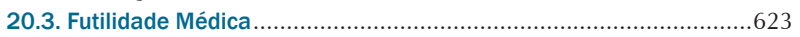

20.4. Os Desfechos da Ressuscitação Cardiopulmonar .............................623

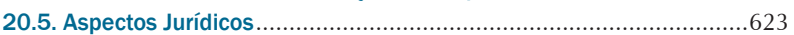

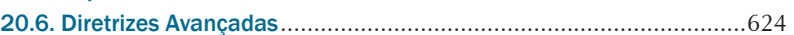

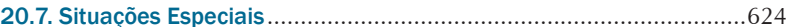

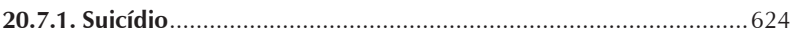

20.7.2. Ressuscitação Simbólica ...................................................624 


\section{Epidemiologia da Parada Cardiorrespiratória e Apresentação da Diretriz}

\subsection{Apresentação da Atualização da Diretriz de Ressuscitação Cardiopulmonar e Cuidados Cardiovasculares de Emergência da Sociedade Brasileira de Cardiologia}

O International Liaison Committee on Resuscitation (ILCOR) inclui representantes de diversos órgãos, como American Heart Association (AHA), European Resuscitation Council (ERC), Heart and Stroke Foundation of Canada (Heart \& Stroke), Australian and New Zealand Committee on Resuscitation (ANZCOR), Resuscitation Council of Southern Africa, InterAmerican Heart Foundation e Resuscitation Council of Asia (RCA). Este comitê se reúne regularmente, a cada cinco anos, desde 1999 em Dallas, para revisão de informações relevantes sobre Ressuscitação Cardiopulmonar (RCP) e Atendimento Cardiovascular de Emergência (ACE), com o objetivo de definir consensos e diretrizes sobre o assunto.

No Brasil, as disparidades de treinamento, registros de dados e resultados são significativas e, por vezes, conflitantes. O desenvolvimento e a atualização desta diretriz têm como finalidade contribuir para divulgação do conhecimento associado a uma homogeneidade de seus fundamentos.

\subsubsection{Epidemiologia da Parada Cardiorrespiratória}

A parada cardiorrespiratória (PCR) permanece como uma das emergências cardiovasculares de grande prevalência e com morbidade e mortalidade elevadas. A criação de protocolos e algoritmos internacionais permitiu a padronização e a organização da assistência médica.

O reconhecimento precoce das causas desencadeantes, orientando a intervenção para cada cenário clínico, com ênfase nos cuidados após o retorno à circulação espontânea, trouxe melhorias nos resultados, contribuído ao prognóstico dos pacientes.

Os dados na literatura quanto à incidência de PCR no Brasil são escassos. O principal ritmo de PCR em ambiente extra-hospitalar é a Fibrilação Ventricular (FV) e a Taquicardia Ventricular (TV), chegando a quase $80 \%$ dos eventos, com bom índice de sucesso na reversão, se prontamente tratados. Quando a desfibrilação é realizada precocemente, em até 3 a 5 minutos do início da PCR, a taxa de sobrevida é em torno de 50\% a 70\%. Em contrapartida, em ambiente intra-hospitalar, o ritmo de PCR mais frequente é Atividade Elétrica Sem Pulso (AESP) ou assistolia, com pior prognóstico e baixas taxas de sobrevida, inferiores a $17 \%$.

\subsection{2. Êxito da Ressuscitação Cardiopulmonar}

O protocolo no atendimento de uma PCR segue uma sequência lógica e fundamentada de condutas que melhoram as taxas de reversibilidade do processo inicial que desencadeou o evento. Neste contexto, o algoritmo é formado pela cadeia de elos de sobrevivência diferenciadas no contexto de uma PCR intra-hospitalar, que pode ser observada no quadro 1.1.

Quadro 1.1 - Cadeia de elos de sobrevivência diferenciadas no contexto de uma parada cardiorrespiratória (PCR) intra-hospitalar

Vigilância e prevenção

Reconhecimento e acionamento do serviço médico de emergência

RCP imediata de alta qualidade

Rápida desfibrilação, Suporte Avançado de Vida e cuidados pós-PCR, ou uma PCR extra-hospitalarReconhecimento e acionamento do serviço médico de emergência

RCP imediata de alta qualidade e rápida desfibrilação

Serviços médicos básicos e avançados de emergência

Suporte Avançado de Vida e cuidados pós-PCR

RCP: ressuscitação cardiopulmonar.

\subsubsection{Recomendações}

Deve-se atentar aos pontos essenciais para o sucesso do atendimento, que podem ser observados no quadro 1.2.

Quadro 1.2 - Pontos essenciais no sucesso do atendimento da parada cardiorrespiratória (PCR)

Reconhecimento de PCR: o sucesso depende do atendimento imediato e pronto reconhecimento, ressaltando o novo conceito de PCR como a ausência de pulso carotídeo ou presença de gasping. Ainda, deve-se sempre suspeitar de uma PCR em pacientes durante uma crise convulsiva

Treinamento e implementação: a capacitação e o exercício do algoritmo de RCP é fundamental para o êxito do retorno da circulação espontânea. $\mathrm{O}$ uso de manequins e materiais auxilia de forma satisfatória no aprendizado e na fixação do conteúdo, não se devendo esquecer da necessidade dos retreinamentos periódicos, com tempo recomendado de 1 a 2 anos. Não entanto pode ser insuficiente; assim, quanto mais precoce, melhores os resultados

Feedback durante a PCR: a interação entre os participantes é importante para melhorias no atendimento e fácil reconhecimento de erros na assistência

Ênfase na RCP: mais uma vez, as compressões cardíacas são o destaque, reforçando a necessidade de frequência cardíaca entre 100 e 120 compressões por minuto, com mínimo de interrupções e retorno completo do tórax

Criação de sistemas de times de resposta rápida e sistemas de times de emergência médica: grupos formados por profissionais de saúde convocados na suspeita de instabilidade clínica ou da deterioração do paciente, prevenindo ou intervindo precocemente na PCR

Melhoria nas estruturas e nos sistemas de saúde: criação de um sistema integrado com treinamento de pessoas, auxílio de materiais e transportes para um atendimento unificado, Além da disponibilidade de DEA em locais públicos com alta movimentação de pessoas

Cumprimento dos elos da cadeia de sobrevivência: ressaltando as diferenças entre uma PCR intra-hospitalar e extra-hospitalar, com foco na prevenção e na vigilância nos cuidados intra-hospitalares e pós-PCR nos dois âmbitos

Cuidados pós-PCR: ênfase na avaliação neurológica, cumprimento das metas hemodinâmicas e controle térmico, com menor variação de temperatura e prevenção de febre

$R C P$ : ressuscitação cardiopulmonar; DEA: desfibriladores externos automáticos. 


\subsubsection{Evidência Científica}

Os Graus de Recomendações e Níveis de Evidências de cada orientação desta diretriz podem ser observados no quadro 1.3.

\section{Quadro 1.3 - Graus de Recomendações e Níveis de Evidências}

\begin{tabular}{l} 
Classe de Recomendação \\
\hline Classe I: condições para as quais há evidências conclusivas; na sua falta, \\
consenso geral de que o procedimento é seguro e útil/eficaz \\
Classe II: condições para as quais há evidências conflitantes e/ou divergência \\
de opinião sobre segurança e utilidade/ eficácia do procedimento \\
Classe IIA: peso ou evidência/opinião a favor do procedimento. Aprovado pela \\
maioria dos profissionais \\
Classe IIB: segurança e utilidade/eficácia menos bem estabelecidas, não \\
havendo predomínio de opiniões a favor do procedimento \\
Classe III: condições para as quais há evidências e/ou consenso de que o \\
procedimento não é útil/eficaz e, em alguns casos, pode ser prejudicial \\
\hline Nível de Evidência \\
\hline Nível A: dados obtidos a partir de múltiplos estudos randomizados de bom porte, \\
concordantes e/ou de metanálise robusta de estudos clínicos randomizados \\
Nível B: dados obtidos a partir de metanálise menos robusta, por meio de um \\
único estudo randomizado ou de estudos não randomizados (observacionais) \\
Nível C: dados obtidos de opiniões consensuais de especialistas \\
\hline
\end{tabular}

\section{Suporte Básico de Vida no Adulto}

\subsection{Introdução}

A doença cardíaca isquêmica, principal determinante da PCR, continua liderando as causas de morte no mundo, e no Brasil não é diferente. ${ }^{1,2}$

Em 2013, nos Estados Unidos, a ocorrência de PCR ExtraHospitalar (PCREH) foi responsável por $63 \%$ desses eventos, com sobrevida de $9,5 \%$, o que reflete diretamente nos esforços do atendimento inicial realizados pelos presentes no local. Essas metas de melhoria estão sendo atingidas como consequência da ênfase na qualidade da RCP e nos cuidados pós-ressuscitação. ${ }^{3,4}$

Outro fator contribuinte é o acesso público à desfibrilação, pois cerca de 56 a $74 \%$ dos ritmos de PCREH ocorrem em FV, e a desfibrilação precoce é o tratamento de escolha. ${ }^{5,6}$

Sabe-se que, a cada minuto transcorrido do início do evento arrítmico súbito sem desfibrilação, a probabilidade de sobrevivência diminui em 7 a 10\%. Programas de RCP e com uso de Desfibrilador Externo Automático (DEA) precoce, realizados por leigos, têm proporcionado taxas de sobrevivência muito otimistas, alcançando até $85 \%$. . $^{6-8}$

No Brasil, estudo conduzido no Metrô de São Paulo evidenciou sobrevida de $43 \%$ sem défice neurológico, destacando o país sobre os demais da América Latina, por ser o primeiro a desenvolver um programa deste tipo. ${ }^{8}$
Os aspectos fundamentais do Suporte Básico de Vida (SBV) no adulto incluem: reconhecimento imediato da PCR, contato com o sistema de emergência, início da RCP de alta qualidade e uso do DEA, assim que disponível. ${ }^{9}$

Neste capítulo, abordaremos a RCP realizada pelo leigo e pelos profissionais de saúde, tendo em vista a grande prevalência de PCREH.

\subsection{Compressões Torácicas}

Os aspectos principais a serem observados nas compressões são frequência, profundidade, retorno do tórax a cada compressão e interrupção mínima.

Para a oxigenação adequada dos tecidos, é essencial minimizar as interrupções das compressões torácicas e maximizar a quantidade de tempo em que as compressões torácicas geram fluxo de sangue. A Fração das Compressões Torácicas (FCT) é a proporção de tempo em que as compressões são realizadas durante uma PCR. ${ }^{10}$

Para maximizar a perfusão, recomenda-se que as pausas das compressões torácicas sejam minimizadas, a fim de que a FCT seja de, pelo menos, $60 \%$ e, idealmente, de $80 \% .^{11}$

Para realização das compressões torácicas (Figura 2.1):

- Posicione-se ao lado da vítima e mantenha seus joelhos com certa distância um do outro, para que tenha melhor estabilidade.

- Afaste ou corte a roupa da vítima (se uma tesoura estiver disponível), para deixar o tórax desnudo.

- Coloque a região hipotenar de uma mão sobre a metade inferior do esterno da vítima e a outra mão sobre a primeira, entrelaçando-a. ${ }^{12,13}$

- Estenda os braços e os mantenha cerca de 90ํacima da vítima.

- Comprima na frequência de 100 a 120 compressões/ minuto. ${ }^{12,13}$

- Comprima com profundidade de, no mínimo, $5 \mathrm{~cm}$ (evitando compressões com profundidade maior que 6 $\mathrm{cm}) .{ }^{14,15}$

- Permita o retorno completo do tórax após cada compressão, evitando apoiar-se no tórax da vítima. ${ }^{16,17}$

- Minimize interrupções das compressões, pause no máximo 10 segundos para realização de duas ventilações. Considere obter uma fração de compressão torácica maior possível, tendo como objetivo um mínimo de $60 \%{ }^{18,19}$

- Reveze com outro socorrista a cada 2 minutos, para evitar o cansaço e compressões de má qualidade. ${ }^{20,21}$

No atendimento realizado por um leigo, estudos recomendam a realização de compressões torácicas contínuas, aumentando substancialmente a sobrevida de indivíduos que sofreram PCREH, ao se comparar com aqueles que não receberam nenhum atendimento de ressuscitação. ${ }^{22,23}$ Recomenda-se que o atendente do serviço de emergência oriente o leigo a realizar compressões torácicas contínuas. ${ }^{24}$

Embora alguns estudos não tenham evidenciado grande diferença com o uso de dispositivos de feedback, outros demonstraram que eles ajudam a evitar compressões torácicas 


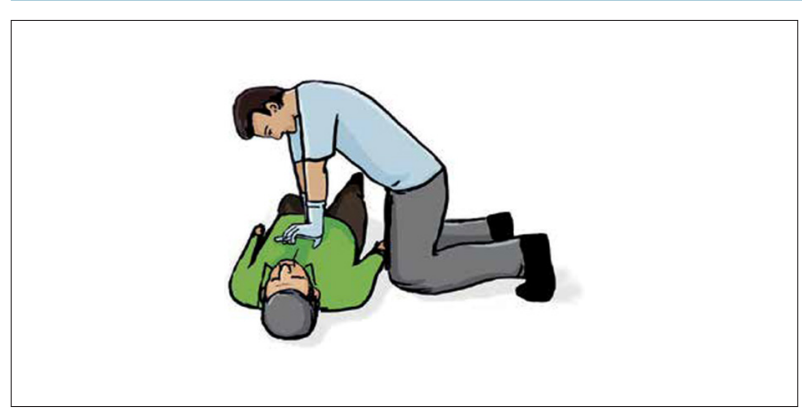

Figura 2.1 - Posicionamento adequado das mãos para realização das compressões torácicas.

inadequada. ${ }^{25-26}$ Portanto, é aceitável utilizar equipamentos de feedback audiovisuais, a fim de otimizar a qualidade das compressões (Quadro 2.1). ${ }^{27-29}$

As manobras de RCP devem ser ininterruptas, exceto quando: a vítima se movimentar; durante a fase de análise do ritmo cardíaco pelo desfibrilador; durante o posicionamento de via aérea avançada; e quando ocorrer exaustão do socorrista.

\subsection{Ventilação}

As ventilações são aplicadas após 30 compressões torácicas durante a RCP, seguindo a sequência C-A-B. A prioridade para as compressões torácicas deve-se ao fato da necessidade em gerar fluxo de sangue e também evitar os atrasos práticos inerentes às tentativas de ventilações adequadas. Além disso, se a vítima possui uma via aérea patente, ocorre a chamada ventilação passiva durante as compressões torácicas.

\subsubsection{Abertura das Vias Aéreas}

Independentemente da técnica utilizada para aplicar ventilações, é necessária a abertura de via aérea, que pode ser realizada com a manobra da inclinação da cabeça e elevação do queixo (Figura 2.2) e, se houver suspeita de trauma, a manobra de elevação do ângulo da mandíbula (Figura 2.3). ${ }^{30}$

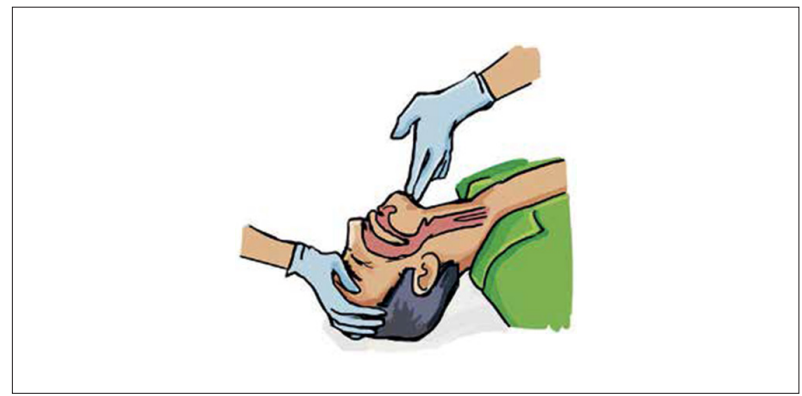

Figura 2.2 - Manobra da inclinação da cabeça e elevação do queixo.

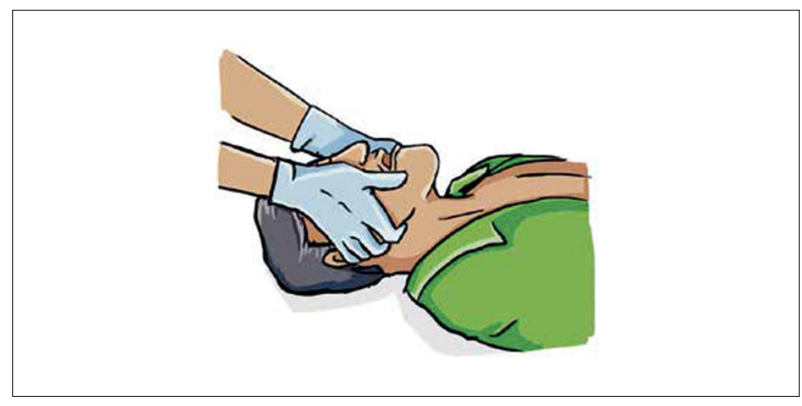

Figura 2.3 - Manobra de elevação do ângulo da mandíbula.

Quadro 2.1 - Recomendação e Nível de Evidência para realização das compressões torácicas em adultos

\begin{tabular}{|c|c|c|}
\hline Recomendação & Classe de Recomendação & Nível de Evidência \\
\hline $\begin{array}{l}\text { Posicionamento da região hipotênar de uma mão sobre a metade inferior do esterno e a outra mão } \\
\text { sobre a primeira, entrelaçando-a }\end{array}$ & Ila & C \\
\hline É aconselhável a realização de compressões na frequência de 100 a 120 compressões/minuto & Ila & C \\
\hline As compressões torácicas devem ter profundidade mínima de $5 \mathrm{~cm}$, sem exceder $6 \mathrm{~cm}$ & I & C \\
\hline Permitir o retorno completo do tórax, evitando se apoiar no tórax da vítima & Ila & C \\
\hline O intervalo das compressões entre a aplicação do choque deve ser o menor possível & I & C \\
\hline É aconselhável pausar as compressões por, no máximo, 10 segundos, a fim de aplicar 2 ventilações & Ila & C \\
\hline $\begin{array}{l}\text { Considere obter uma fração de compressão torácica maior possível, tendo como objetivo um mínimo } \\
\text { de } 60 \%\end{array}$ & $\| l b$ & C \\
\hline $\begin{array}{l}\text { Para profissionais da saúde que possuem dispositivo de barreira para aplicar ventilações, é } \\
\text { aconselhável realizar } 30 \text { compressões e } 2 \text { ventilações durante a RCP }\end{array}$ & Ila & C \\
\hline $\begin{array}{l}\text { Retomar as compressões torácicas imediatamente após o choque para adultos em parada } \\
\text { cardiorrespiratória }\end{array}$ & Ilb & C \\
\hline $\begin{array}{l}\text { O profissional atendente do serviço de emergência deve orientar a realização de compressões } \\
\text { torácicas contínuas para os chamados com suspeita de PCREH }\end{array}$ & I & C \\
\hline
\end{tabular}

RCP: ressuscitação cardiopulmonar; PCREH: parada cardiorrespiratória extra-hospitalar. 


\section{Atualização}

Quando o socorrista não conseguir realizar a manobra de elevação do ângulo da mandíbula e suspeitar de trauma cervical, sem evidência de lesão na cabeça, devem-se utilizar as manobras de inclinação da cabeça e elevação do queixo, pois apenas 0,12 a 3,7\% das vítimas apresentam lesão espinhal, sendo o risco elevado quando há lesão craniofacial ou Glasgow $<8 .{ }^{31-32}$

Socorristas leigos podem realizar a manobra de inclinação da cabeça e elevação do queixo (Figura 2.2) para vítimas sem suspeita de lesão medular e que se sintam confiantes em realizar ventilações. ${ }^{33}$ Caso haja suspeita de trauma, indica-se a imobilização manual da coluna cervical. ${ }^{34,35}$

\subsubsection{Realização de Ventilações}

Devem ser realizadas em uma proporção de 30 compressões para duas ventilações, com duração de apenas 1 segundo cada, fornecendo quantidade de ar suficiente para promover a elevação do tórax. ${ }^{36} \mathrm{~A}$ hiperventilação é contraindicada, pois pode aumentar a pressão intra-torácica, diminuindo a pré-carga e o Débito Cardíaco (DC), e comprometendo a sobrevida. ${ }^{37,38}$ Há ainda o risco de hiperinsuflação gástrica, podendo desencadear vômitos, broncoaspiração e limitação da mobilidade do diafragma. ${ }^{39,40}$ Evidências de contaminação com a realização de ventilação boca a boca são mínimas, mas é indicado que o socorrista utilize mecanismos de barreira - por exemplo, máscara de bolso (pocket mask) ou BolsaVálvula-Máscara (BVM).

Existe a preocupação de que a realização por períodos prolongados de compressões torácicas contínuas (sem ventilação) poderia ser menos eficaz do que a RCP convencional (compressões e ventilações), uma vez que o conteúdo arterial de oxigênio reduz, à medida que a PCR se prolonga. ${ }^{41}$ Evidencias apontam que pacientes em PCREH que receberam RCP por de compressões contínuas durante um período curto (zero a 15 minutos após o colapso) tiveram maior taxa de sobrevivência, com evolução neurológica favorável, em relação a nehuma manobra de ressuscitação. Para a PCR prolongada ( $>15$ minuto), a realização de RCP convencional (compressões e ventilações) apresentou taxa significativamente mais alta de sobrevivência com resultado neurológico favorável, quando comparado à RCP com compressões contínuas e não realização de RCP. Assim, em PCR prolongadas de origem cardíaca, a RCP convencional mostrou benefício adicional, em comparação à RCP somente com as compressões. ${ }^{42}$

\subsubsection{Ventilação com a Máscara de Bolso: a Pocket Mask}

Profissionais de saúde e socorristas leigos podem hesitar em realizar ventilações boca a boca. ${ }^{43-44}$ Assim, é indicada a utilização de uma máscara de bolso (pocket mask) para realização das ventilações (Figura 2.4).

\subsubsection{Ventilação com Bolsa-Válvula-Máscara}

O uso da BVM requer considerável prática e deve ser feito na presença de dois socorristas: um responsável pelas compressões e outro por aplicar as ventilações com o dispositivo (Figuras 2.5 e 2.6). ${ }^{33}$ Se disponível oxigênio complementar, conecte-o na BVM, assim que possível, de modo a oferecer maior porcentagem de oxigênio para a vítima.

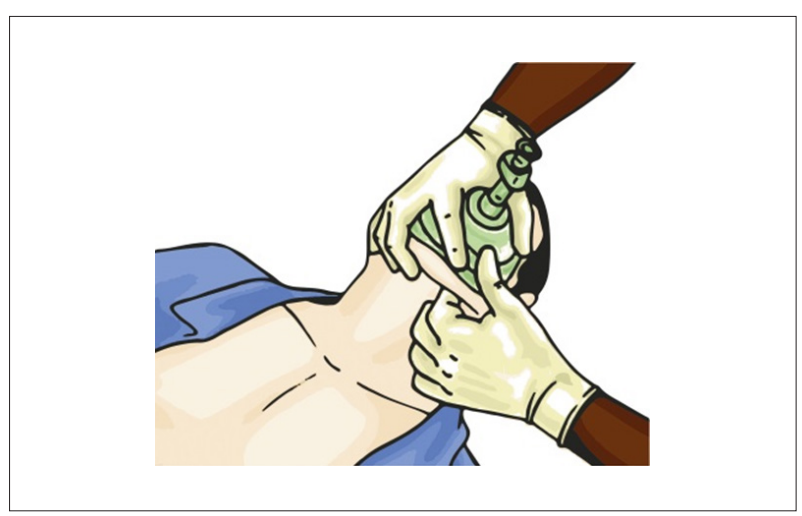

Figura 2.4 - Posicionamento utilizando máscara de bolso com hiperextensão da cabeça.

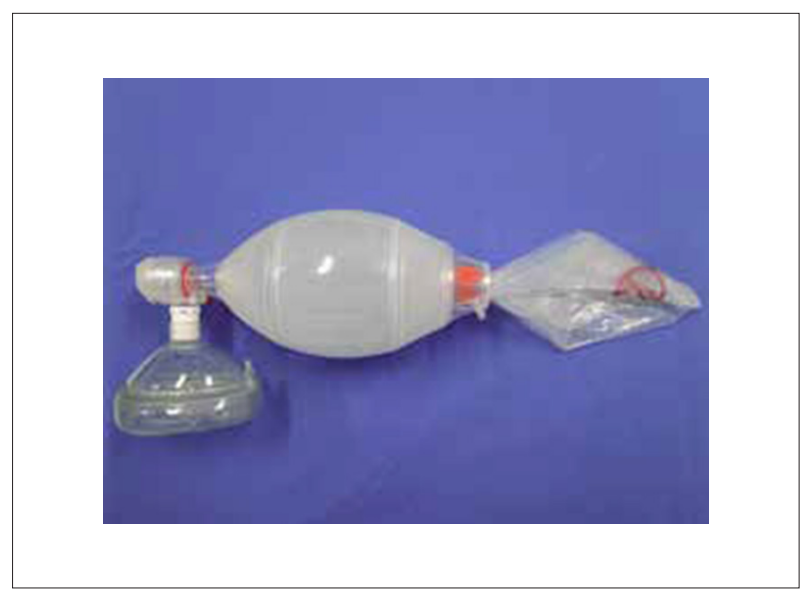

Figura 2.5 - Exemplos de bolsa-válvula-máscara.

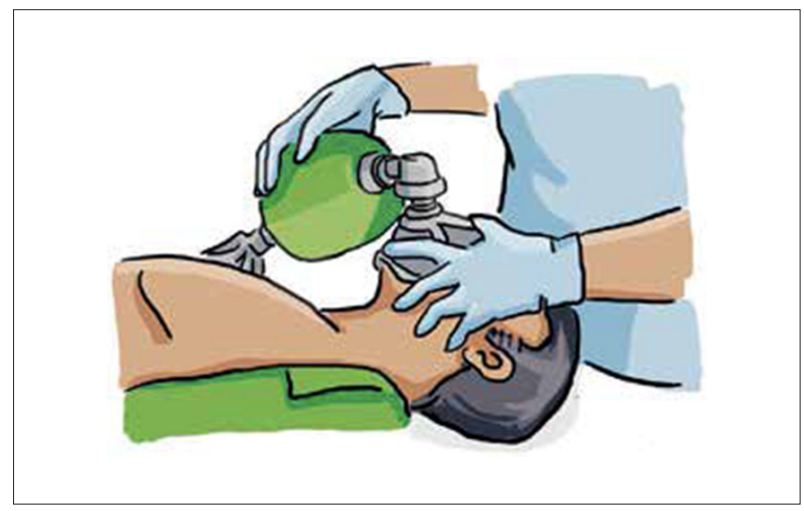

Figura 2.6 - Demonstração da ventilação utilizando bolsa-válvula-máscara.

\subsubsection{Ventilação com Via Aérea Avançada}

Quando uma via aérea avançada (por exemplo, intubação endotraqueal, Combitube ${ }^{\circledR}$, Máscara Laríngea) estiver instalada, o primeiro socorrista deve administrar compressões torácicas contínuas e o segundo socorrista, 
aplicar uma ventilação a cada 6 segundos - cerca de 10 ventilações por minuto (Figura 2.7). Não se devem pausar as compressões para aplicar as ventilações, em caso de via aérea avançada instalada. ${ }^{33}$

\subsubsection{Ventilação em Vítima em Parada Respiratória}

Vítima que não respira ou respira de forma ineficaz (gasping), porém apresenta pulso palpável, encontra-se em parada respiratória. Nesses casos, realize uma ventilação a cada 5 a 6 segundos (aproximadamente 10 a 12 ventilações por minuto) para vítimas adultas. ${ }^{33} \mathrm{O}$ pulso deve ser checado a cada 2 minutos, com a finalidade de verificar se a parada

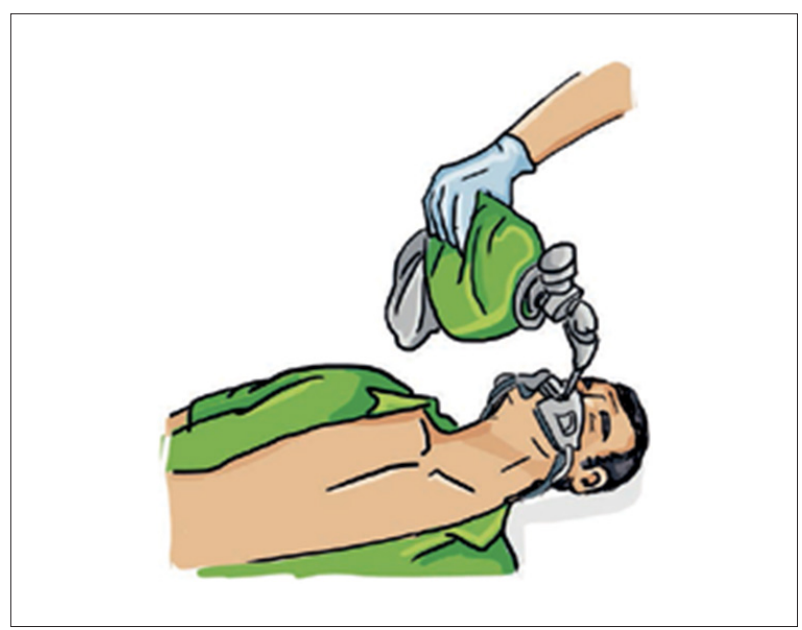

Figura 2.7 - Demonstração da ventilação com via aérea avançada. respiratória progrediu para uma $\mathrm{PCR}$, necessitando de $\mathrm{RCP}$ (Quadro 2.2).

\subsection{Desfibrilação}

Desfibrilação precoce é o tratamento para vítimas em FV e TV sem pulso (TVSP) de curta duração, que apresentaram colapso súbito em ambiente extra-hospitalar (Figura 2.8), sendo este o principal ritmo de PCR nesses locais. ${ }^{45,46}$ A Desfibrilação pode ser realizada com um equipamento manual ou o DEA. Este último pode ser utilizado por qualquer pessoa, assim que possível.

Nos primeiros 3 a 5 minutos de uma PCR em FV (Figura 2.8), o coração se encontra altamente propício ao choque. ${ }^{47}$ Após 5 minutos de PCR, a amplitude da FV diminui devido à depleção do substrato energético miocárdico. Assim, o tempo ideal para a aplicação do primeiro choque compreende os primeiros 3 a 5 minutos da PCR. ${ }^{48-51}$

O DEA é um equipamento portátil, capaz de interpretar o ritmo cardíaco, selecionar o nível de energia e carregar automaticamente, cabendo ao operador apenas pressionar o botão de choque, quando indicado (Figura 2.9).

O DEA deve ser utilizado assim que disponível. Recomendase que a RCP seja fornecida enquanto as pás do DEA são aplicadas e até que o DEA esteja pronto para analisar o ritmo..$^{51-54}$

Assim que o DEA estiver disponível, o socorrista, se estiver sozinho, deve parar a RCP para conectar o aparelho à vítima. Porém, se houver mais de um socorrista, o segundo socorrista manuseia o DEA e, nesse caso, a RCP só é interrompida quando o DEA emitir um alerta verbal como: "analisando o ritmo cardíaco", "não toque o paciente" e/ou "choque recomendado, carregando, afaste-se do paciente".

\section{Quadro 2.2 - Recomendação e Nível de Evidência na realização das ventilações}

\begin{tabular}{|c|c|c|}
\hline Recomendação & Classe de Recomendação & Nível de Evidência \\
\hline $\begin{array}{l}\text { Aplicação de ventilações com fornecimento da quantidade de ar suficiente para promover a elevação do } \\
\text { tórax }\end{array}$ & Ila & C \\
\hline $\begin{array}{l}\text { Evitar hiperventilação, pois aumenta o risco de insuflação gástrica, podendo causar regurgitação e } \\
\text { aspiração }\end{array}$ & III & B \\
\hline Abertura da via aérea com a inclinação da cabeça/elevação do queixo ou elevação do ângulo da mandíbula & $\| l b$ & C \\
\hline $\begin{array}{l}\text { Inclinação da cabeça quando o socorrista não conseguir realizar a manobra de elevação do ângulo da } \\
\text { mandíbula e a vítima apresenta apenas suspeita de trauma cervical, sem evidência de lesão na cabeça }\end{array}$ & Ila & B \\
\hline $\begin{array}{l}\text { Ao ventilar com bolsa-válvula-máscara, pressionar a bolsa durante aproximadamente } 1 \text { segundo para } \\
\text { cada ventilação, que é geralmente o suficiente para produzir elevação do tórax e manter oxigenação em } \\
\text { pacientes sem respiração }\end{array}$ & Ila & C \\
\hline Aplicar ventilação a cada 6 segundos na via aérea avançada & $\mathrm{Ilb}$ & C \\
\hline Não se devem pausar as compressões para aplicar ventilações quando via aérea avançada instalada & III & $\mathrm{B}$ \\
\hline $\begin{array}{l}\text { Para vítimas com suspeita de lesão medular, socorristas leigos devem utilizar a imobilização manual, } \\
\text { posicionando uma mão em cada lado da cabeça da vítima, a fim de mantê-la imóvel. A utilização de } \\
\text { aparelhos para imobilização por leigos tem o risco de prejudicar o estado da vítima }\end{array}$ & III & C \\
\hline Não se recomenda o uso rotineiro de técnicas de ventilação passiva durante a RCP em adultos & Ilb & C \\
\hline $\begin{array}{l}\text { Para equipes de emergência que atendem com base na prioridade, utilizando compressões torácicas } \\
\text { contínuas e cuja resposta é dividida em diversos níveis, a ventilação passiva pode ser considerada }\end{array}$ & Ilb & C \\
\hline
\end{tabular}

$R C P$ : ressuscitação cardiopulmonar 


\section{Atualização}

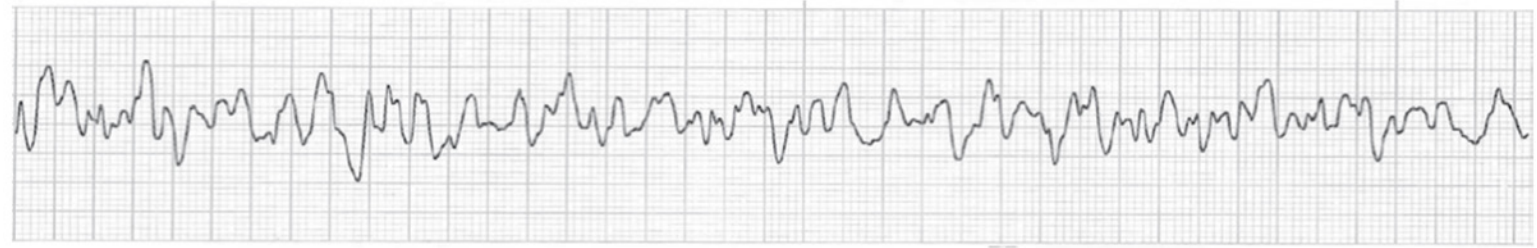

Figura 2.8 - Fibrilação ventricular

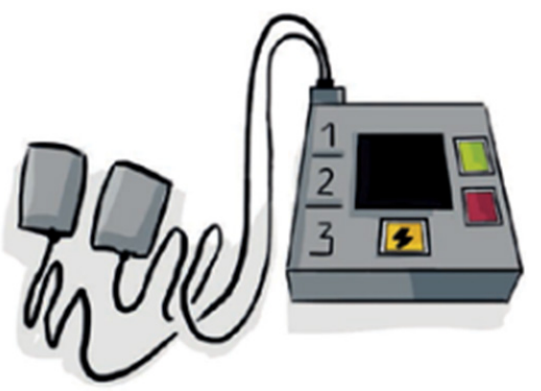

Figura 2.9 - Desfibrilador externo automático.

Os passos para utilização do DEA são descritos a seguir:

1. Ligue o DEA, apertando o botão on-off (alguns dispositivos ligam automaticamente ao abrir a tampa). Isso ativa os alertas verbais que orientam todas as etapas subsequentes.

2. Conecte as pás (eletrodos) ao tórax desnudo da vítima, observando o desenho contido nas próprias pás do posicionamento correto (selecionar pás do tamanho correto, adulto ou pediátrico, para o tamanho/idade do paciente. Remover o papel adesivo protetor das pás).

3. Encaixe o conector das pás (eletrodos) ao aparelho.

4. Quando o DEA indicar "analisando o ritmo cardíaco, não toque no paciente", solicitar para que todos se afastem efetivamente.

5. Se o choque for indicado, o DEA emitirá a frase: "choque recomendado, afaste-se do paciente". O socorrista que estiver manuseando o DEA deve solicitar para que todos se afastem.

6. Pressionar o botão indicado pelo aparelho para aplicar o choque, o qual produz uma contração repentina dos músculos do paciente.

7. A RCP deve ser iniciada pelas compressões torácicas, imediatamente após o choque. A cada 2 minutos, o DEA analisa o ritmo novamente e pode indicar novo choque, se necessário. Se não indicar choque, deve-se reiniciar a RCP imediatamente, caso a vítima não retome a consciência.

8. Mesmo se a vítima retomar a consciência, o aparelho não deve ser desligado e as pás não devem ser removidas ou desconectadas até que o serviço médico de emergência assuma o caso.

9. Se não houver suspeita de trauma, e a vítima já apresentar respiração normal e pulso, o socorrista pode lateralizar a vítima (Figura 2.10), porém deve permanecer no local até que o serviço médico de emergência chegue.

Posicionamento anterolateral: remova as roupas e descubra a vítima, coloque uma pá imediatamente abaixo da clavícula direita. Coloque a outra pá ao lado do mamilo esquerdo, com a borda superior da pá alguns centímetros abaixo da axila (Figura 2.11).

Posicionamento anteroposterior: deixe o tórax desnudo. Aplique uma pá do DEA no lado esquerdo do tórax, entre

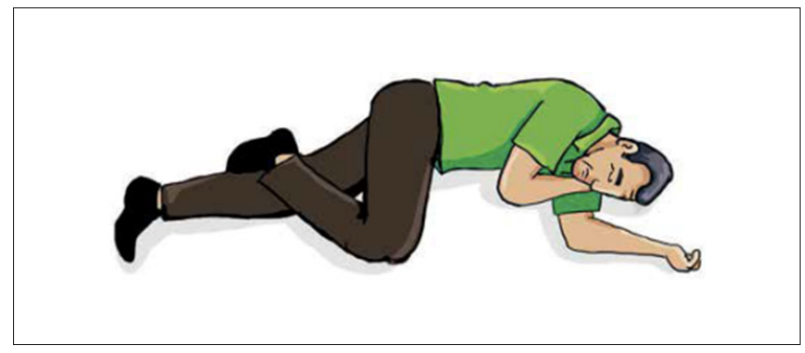

Figura 2.10 - Posição de recuperação.

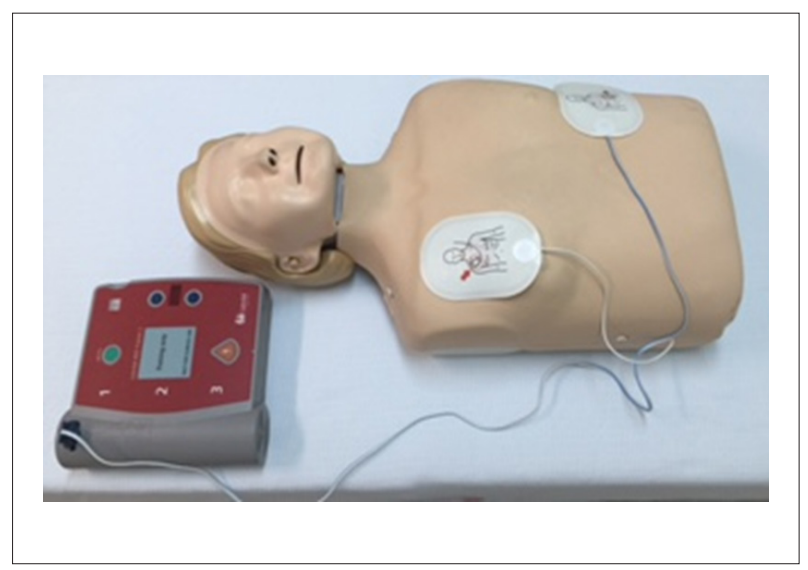

Figura 2.11 - Posicionamento das pás anterolateral. 
o lado esquerdo do esterno e o mamilo esquerdo, e a outra no lado esquerdo das costas, próximo à coluna (Figura 2.12).

\subsubsection{Uso do Desfibriladores Externos Automáticos em Situações Especiais}

As situações especiais a seguir podem exigir que o socorrista tenha cautela na colocação das pás ao usar um DEA (Quadro 2.3):

- Excesso de pelos no tórax: remover o excesso de pelos, somente da região onde são posicionadas as pás..$^{55}$

- Tórax molhado: se o tórax da vítima estiver molhado, secar por completo; se ela estiver sobre uma poça d'água não há problema, porém se essa poça também envolver o socorrista, remover a vítima para outro local, o mais rápido possível..$^{55}$

- Marca-passo ou Cardioversor Desfibrilador Implantável (CDI): se estiver na região onde é indicado o local para aplicação das pás, afaste-as ou opte por outro posicionamento das pás (anteroposterior, por exemplo). ${ }^{56,57}$

- Adesivos de medicamentos: remover o adesivo se estiver no local onde são aplicadas as pás do DEA; enxugue, se necessário. ${ }^{58}$

- Crianças com até $25 \mathrm{~kg}$ : utilizar o DEA com pás pediátricas e/ou atenuador de carga. Se o kit DEA possuir somente pás de adulto, está autorizada a utilização delas, porém se o tórax for estreito, pode ser necessária a aplicação de uma pá na região anterior do tórax (sobre o esterno) e outra na região posterior do tórax (entre as escápulas), para que não se sobreponham. ${ }^{59,60}$ As pás infantis não devem ser utilizadas em adultos, pois o choque aplicado é insuficiente. ${ }^{61,62}$

- Lactentes (zero a 1 ano): um desfibrilador manual é preferível, porém, se não estiver disponível, utilize o DEA com pás pediátricas e/ou atenuador de carga. Se este também não estiver disponível, utilize as pás de adulto, uma posicionada anteriormente (sobre o esterno) e a outra posteriormente (entre as escápulas). O prejuízo para o miocárdio é mínimo e há bons benefícios neurológicos. ${ }^{63,64}$

\subsection{Sequência do Suporte Básico de Vida do Adulto para Profissionais da Saúde}

Em uma situação de PCR, um mnemônico pode ser utilizado para descrever os passos simplificados do atendimento em SBV: O "C-A-B-D". ${ }^{65-68} \mathrm{O}$ "C" corresponde a compressões (30 compressões), "A" é a abertura das vias aéreas, "B" remete à boa ventilação (duas ventilações) e " $\mathrm{D}$ " à desfibrilação. Este mnemônico deve ser utilizado para o atendimento, após detecção da PCR. A seguir, a sequência completa de um atendimento, por um profissional de saúde, a uma vítima que se encontra em colapso súbito.

\subsubsection{Segurança do Local}

Certifique se o local é seguro para você e para a vítima, para não se tornar uma próxima vítima. Se o local estiver seguro prossiga o atendimento. ${ }^{65-66,68,69}$

\subsubsection{Avalie a Responsividade da Vítima}

Avalie a responsividade da vítima, chamando-a e tocando-a pelos ombros. Se a vítima responder, se apresente e converse com ela perguntando se precisa de ajuda. Se a vítima não responder, chame ajuda imediatamente..$^{66-68}$

\subsubsection{Chame Ajuda}

A Atualização da Diretriz de Ressuscitação Cardiopulmonar e Cuidados Cardiovasculares de Emergência da Sociedade Brasileira de Cardiologia 2019 considera o uso benéfico dos telefones celulares no acionamento do serviço médico de emergência, pois não

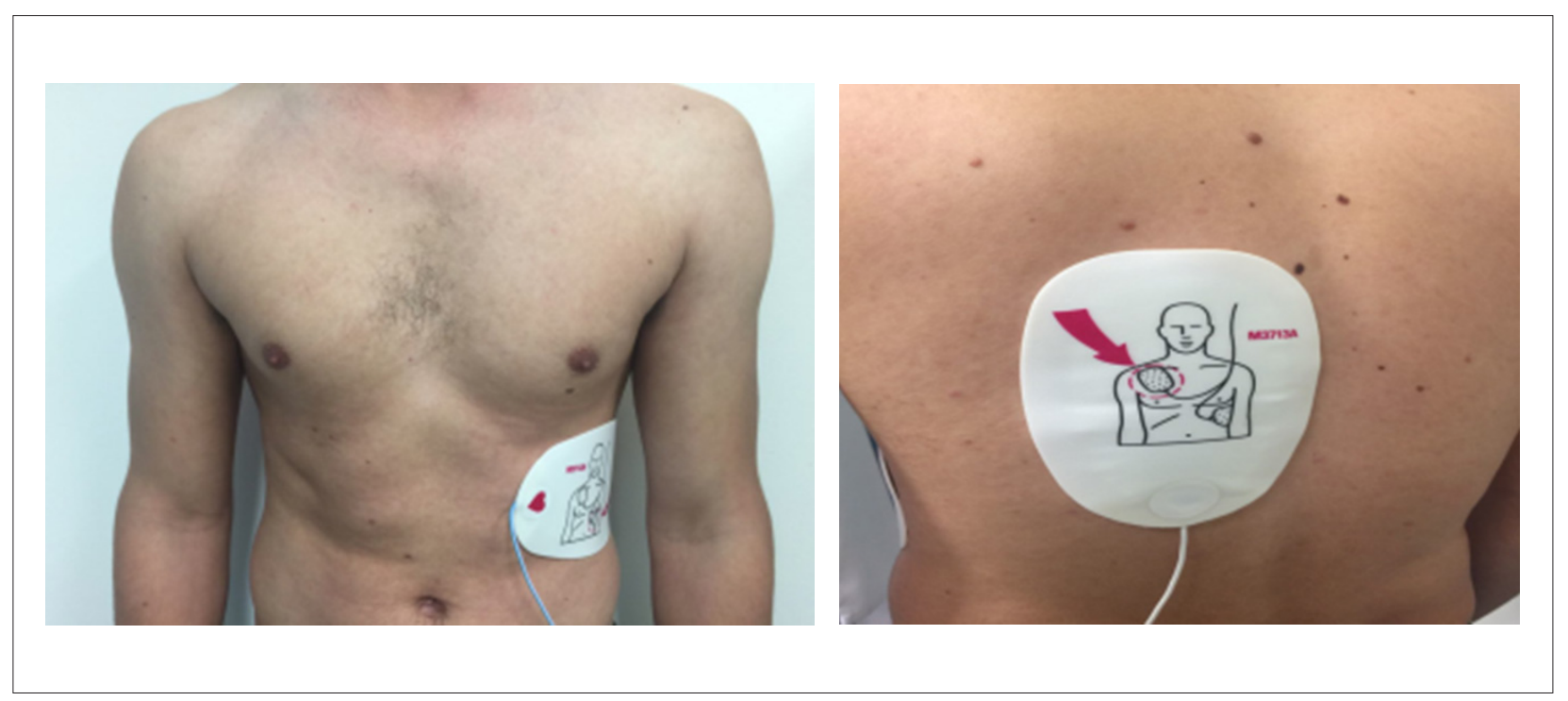

Figura 2.12 - Posicionamento das pás anteroposterior: aplique uma pá entre o lado esquerdo esterno e o mamilo esquerdo e a outra lado esquerdo das costas próximo a coluna. 


\section{Atualização}

\section{Quadro 2.3 - Classe de Recomendação e Nível de Evidência nas orientações quanto ao uso do desfibriladores externos automáticos}

\begin{tabular}{|c|c|c|}
\hline Recomendação & Classe de Recomendação & Nível de Evidência \\
\hline Desfibrilação é o tratamento de escolha para FV de curta duração & 1 & A \\
\hline Se possivel, a RCP deve ser realizada enquanto o desfibrilador é preparado & । & B \\
\hline Para facilitar a memorização e a educação, considerar a posição das pás anterolateral um padrão aceitável & Ila & B \\
\hline Para crianças de 1 a 8 anos, recomenda-se utilizar atenuador de carga, se disponível & Ila & C \\
\hline $\begin{array}{l}\text { Para crianças < } 1 \text { ano de idade, um desfibrilador manual é preferivel; se não estiver disponivel, um DEA com } \\
\text { atenuador de carga pode ser usado; se nenhuma dessas opções estiverdisponivel, pode ser utilizado o DEA } \\
\text { com pás para adultos }\end{array}$ & $\mathrm{llb}$ & C \\
\hline $\begin{array}{l}\text { Em pacientes com excesso de pelos no tórax, é necessário remover o excesso somente no local onde são } \\
\text { aplicadas as pás do DEA }\end{array}$ & $1 \mathrm{lb}$ & C \\
\hline Se a vítima estiver com o tórax molhado, antes de aplicar as pás do DEA, deve secá-lo & $1 \mathrm{lb}$ & C \\
\hline Remover adesivos medicamentosos/ hormonais, caso estiverem no local onde são posicionadas as pás do DEA & $\mathrm{llb}$ & C \\
\hline $\begin{array}{l}\text { Recomenda-se que programas de acesso público à desfibrilação para pacientes em parada cardíaca } \\
\text { extra-hospitalar sejam implementado em locais onde existem mais chances de ocorrer parada cardíaca } \\
\text { testemunhada }\end{array}$ & I & C \\
\hline $\begin{array}{l}\text { Para adultos em PCR testemunhada quando um DEA estiver disponível de imediato, é aceitável de que } 0 \\
\text { desfibrilador seja utilizado o mais cedo possível }\end{array}$ & Ila & C \\
\hline $\begin{array}{l}\text { Para adultos com parada cardíaca não monitorizada ou para quem um DEA não estiver imediatamente } \\
\text { disponível, é aceitável que a RCP seja iniciada enquanto o desfibrilador está sendo checado e aplicado, e que a } \\
\text { desfibrilação, se indicada, seja realizada logo que o dispositivo estiver pronto para uso }\end{array}$ & $\mathrm{Ila}$ & B \\
\hline
\end{tabular}

FV: fibrilação ventricular; RCP: ressuscitação cardiopulmonar DEA: desfibrilador externo automático; PCR: parada cardiorrespiratória.

é necessário deixar a vítima, a fim de acionar o socorro, o que permite iniciar a RCP prontamente.

Em ambiente extra-hospitalar, ligue para o número local de emergência (por exemplo, Sistema de Atendimento Móvel de Urgência - SAMU, telefone 192) e, se um DEA estiver disponível no local, vá buscá-lo. Se não estiver sozinho, peça para uma pessoa ligar e conseguir um DEA, enquanto continua o atendimento à vítima. ${ }^{68-70}$ É importante designar pessoas para que sejam responsáveis em realizar essas funções. ${ }^{68}$

\subsubsection{Cheque Respiração e Pulso}

Cheque o pulso carotídeo e a respiração simultaneamente, observando se há elevação do tórax da vítima e se há pulso, em não mais que 10 segundos. Se a vítima não respirar, ou apresentar gasping e o pulso estiver ausente, inicie RCP.

Os socorristas treinados são encorajados a executar simultaneamente alguns passos. O objetivo é reduzir o tempo do início das compressões.

Estudos mostraram que tanto profissionais da saúde quanto socorristas leigos têm dificuldade em detectar pulso, e que leigos podem levar muito tempo para realizá-lo. Caso o profissional tenha dificuldades na detecção do pulso, deve iniciar imediatamente as compressões torácicas. ${ }^{71,72}$

Se a vítima não apresentar respiração e pulso, o profissional deve sinalizar que é uma PCR e acionar o Código Azul (se a instituição possuir um Time de Resposta Rápida - TRR) ou solicitar a presença de profissionais necessários para o atendimento.

Caso a vítima tenha respiração e pulso, fique ao seu lado e aguarde para ver sua evolução e a chegada de outros profissionais necessários para o atendimento (ou do serviço médico de emergência em ambiente extra-hospitalar).

Se a vítima não estiver respirando ou apresentar somente gasping e pulso, aplique uma ventilação a cada 5 a 6 segundos, mantendo frequência de 10 a 12 ventilações por minuto. Cheque o pulso a cada 2 minutos. Se não detectar pulso na vítima ou estiver em dúvida, inicie os ciclos de compressões e ventilações. ${ }^{68,73,74}$

\subsubsection{Inicie Ciclos de 30 Compressões e Duas Ventilações}

Inicie ciclos de 30 compressões e duas ventilações (Figura 2.13), considerando que existe um dispositivo de barreira (por exemplo, máscara de bolso para aplicar as ventilações).

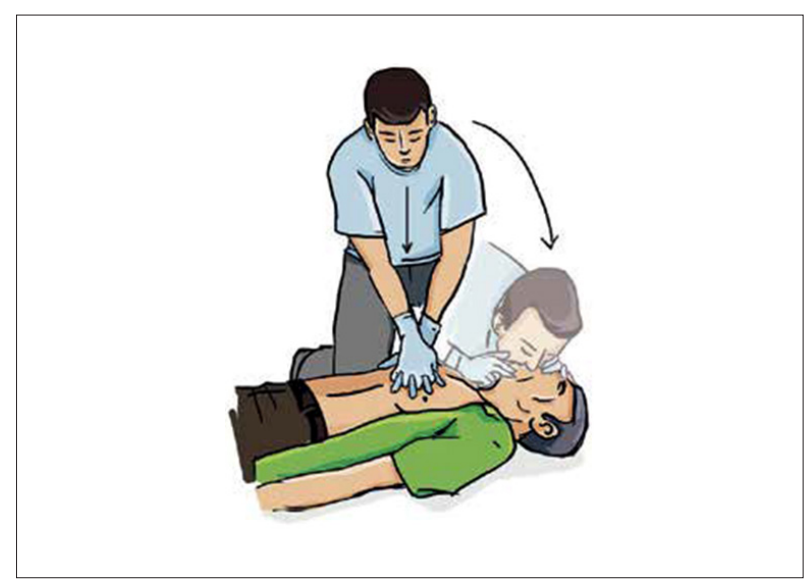

Figura 2.13 - Realização de compressões e ventilações. 
Se o profissional não possuir máscara de bolso ou não se sentir preparado para aplicar as ventilações, ele pode realizar as compressões contínuas de 100 a 120 por minuto. ${ }^{68,69,75,76}$

Compressões torácicas efetivas são essenciais para promover o fluxo de sangue, devendo ser realizadas em todos pacientes em parada cardíaca. ${ }^{68-77}$
Se houver mais de um socorrista, alterne as funções de compressão e ventilação a cada 2 minutos, a fim de manter a qualidade da RCP (Figura 2.14). ${ }^{68,78,79}$ No quadro 2.4, estão as Classes de Recomendação e Níveis de Evidência para a sequência de atendimento a uma vítima inconsciente pelo profissional de saúde.

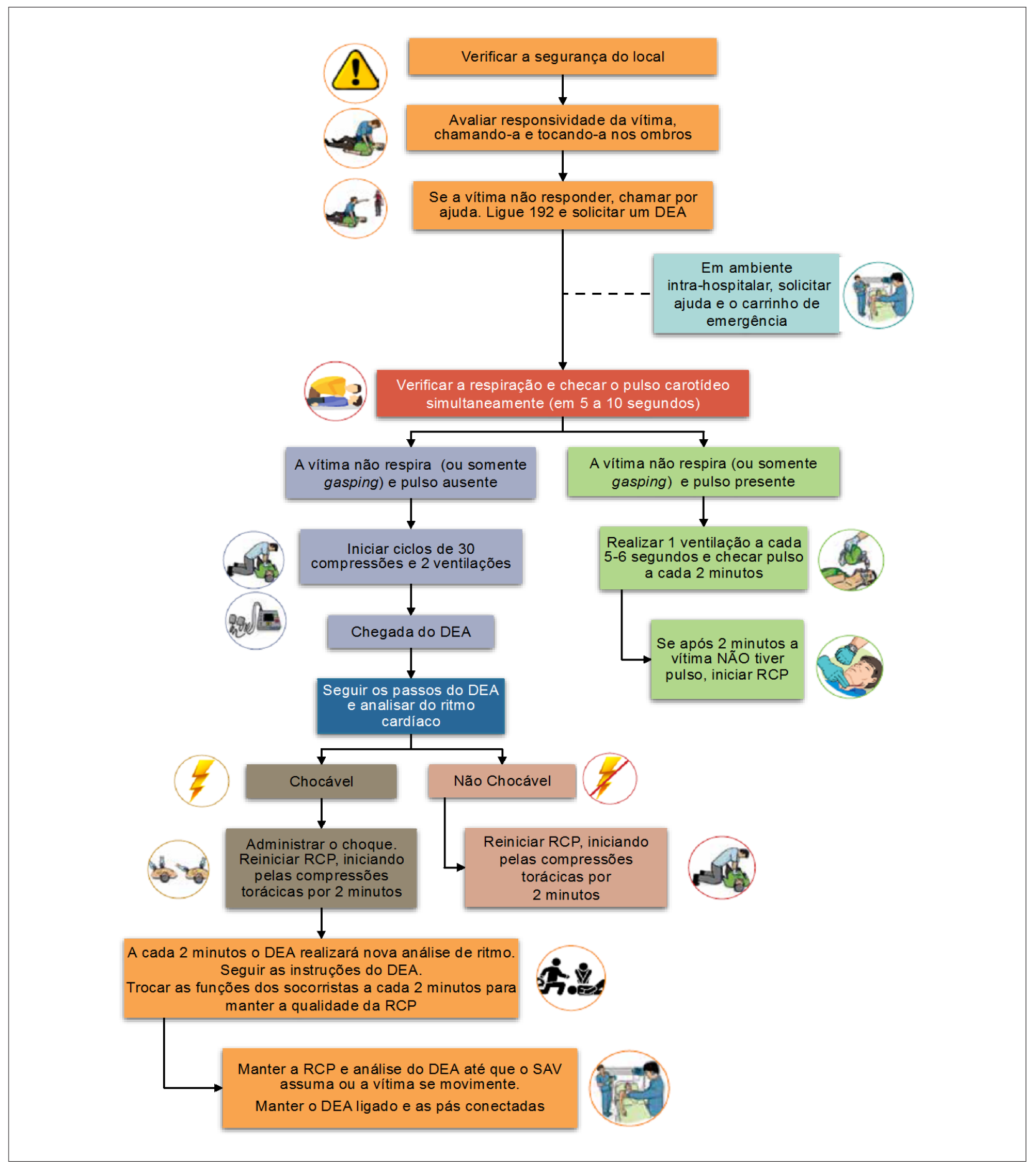

Figura 2.14 - Suporte Básico de Vida para profissionais de saúde. DEA: desfibrilador externo automático; RCP: ressuscitaçãoo cardiopulmonar; SAV: Suporte Avançado de Vida. 


\section{Atualização}

Quadro 2.4 - Orientação para a abordagem de vítima inconsciente pelo profissional de saúde

\begin{tabular}{|c|c|c|}
\hline Recomendação & Classe de Recomendação & Nível de Evidência \\
\hline Avaliação da responsividade e respiração da vítima & 1 & C \\
\hline Acionamento de ajuda & I & $\mathrm{C}$ \\
\hline Checagem de pulso e início da RCP se pulso ausente ou se estiver em dúvida & Ila & $\mathrm{C}$ \\
\hline $\begin{array}{l}\text { Realização de } 3 \text { ciclos de compressões contínuas (200) com ventilação passiva de oxigênio, em casos de PCR } \\
\text { presenciada com ritmo em FV/TV }\end{array}$ & Ilb & C \\
\hline Realização de 30 compressões e 2 ventilações, para os adultos em PCR & Ila & C \\
\hline
\end{tabular}

RCP: ressuscitação cardiopulmonar; PCR: parada cardiorrespiratória; FV: fibrilação ventricular; TV: taquicardia ventricular.

\subsection{Sequência do Suporte Básico de Vida do Adulto Realizada por Leigos}

Leigos devem imediatamente ligar para o serviço médico de emergência, caso encontre uma vítima que, após avaliação da responsividade, não responde.

A orientação do atendente do sistema de emergência pode aumentar o desempenho do leigo no atendimento à PCR, orientando-o na identificação da respiração da vítima e em como realizar as compressões torácicas. ${ }^{80-82}$ Caso o socorrista esteja sozinho, ele pode acionar o serviço de emergência por meio do celular, colocando-o no viva-voz para seguir as orientações do atendente do serviço médico de emergência.

Nos primeiros minutos de uma PCR em FV, as ventilações não são importantes como são as compressões. A realização de compressões torácicas contínuas aumenta substancialmente a sobrevida de indivíduos que sofreram PCREH, ao se comparar com aqueles que não receberam RCP. ${ }^{83}$

Se o socorrista leigo for treinado e puder realizar compressões torácicas e ventilações, na relação 30 compressões e duas ventilações, realize-as. Estudos demonstraram que, em PCR prolongada extra-hospitalar, independente da causa, a realização de compressões e ventilações mostrou benefício adicional em relação às taxas de sobrevivência, quando comparado ao atendimento somente com compressões (Quadro 2.5 e Figura 2.15). ${ }^{83-85}$

\section{Terapias Elétricas: Desfibrilação, Cardioversão e Marca-Passo Transcutâneo}

\subsection{Introdução}

A desfibrilação e a Cardioversão Elétrica (CVE) consistem na aplicação de corrente elétrica de alta energia para reversão de arritmias cardíacas geradas pelo mecanismo de reentrada. Na desfibrilação, esta corrente elétrica é aplicada em qualquer momento do ciclo cardíaco; enquanto na CVE esta é sempre sincronizada com os complexos QRS, para que não seja administrada durante o período vulnerável da repolarização ventricular (onda T), quando pode desencadear uma FV. ${ }^{86}$

\subsection{Características do Desfibrilador/Cardioversor}

Os desfibriladores/cardioversores podem ser classificados em:

A) Manuais, cujo reconhecimento do ritmo cardíaco e administração do choque dependem do operador:

- Semiautomáticos, também conhecidos como DEA, cujo reconhecimento do ritmo é realizado pelo dispositivo que informa se há recomendação para o choque elétrico, sendo a decisão da aplicação dependente de um operador. Amplamente empregados no cenário pré-hospitalar e hospitalar, na tentativa de propiciar a desfibrilação precoce. ${ }^{86-89}$

\section{B) Externos e internos:}

- Externos, nos quais a corrente é aplicada pela superfície do tórax por meio de pás manuais, as quais o operador posiciona, exercendo pressão de aproximadamente $13 \mathrm{~kg}$, com o cuidado de colocar gel na interface, visando diminuir a resistência à passagem da corrente elétrica. $\mathrm{O}$ uso de pás adesivas dispensa a utilização do gel e da compressão. Parece não haver diferenças pertinentes às taxas de sucesso de reversão em relação a estes dois dispositivos.

- Internos, nos quais a corrente elétrica é aplicada por cabos eletrodos geralmente implantados através do sistema venoso.

Quadro 2.5 - Orientação do Suporte Básico de Vida realizado por leigos

\begin{tabular}{|c|c|c|}
\hline Recomendação & Classe de Recomendação & Nível de Evidência \\
\hline $\begin{array}{l}\text { Treinamento de indivíduos leigos em RCP e uso do DEA pode elevar substancialmente a probabilidade de um } \\
\text { espectador realizar a RCP e aumentar a sobrevida de uma vítima que sofreu parada cardíaca }\end{array}$ & I & $B$ \\
\hline $\begin{array}{l}\text { O serviço médico de emergência deve orientar a realização de compressões torácicas contínuas para leigos } \\
\text { que se depararem com vítima não responsiva sem respiração normal }\end{array}$ & I & B \\
\hline O leigo não treinado deve realizar compressões torácicas contínuas, ao invés de RCP convencional & I & C \\
\hline
\end{tabular}

$R C P$ : ressuscitação cardiopulmonar; DEA: desfibriladores externos automáticos. 


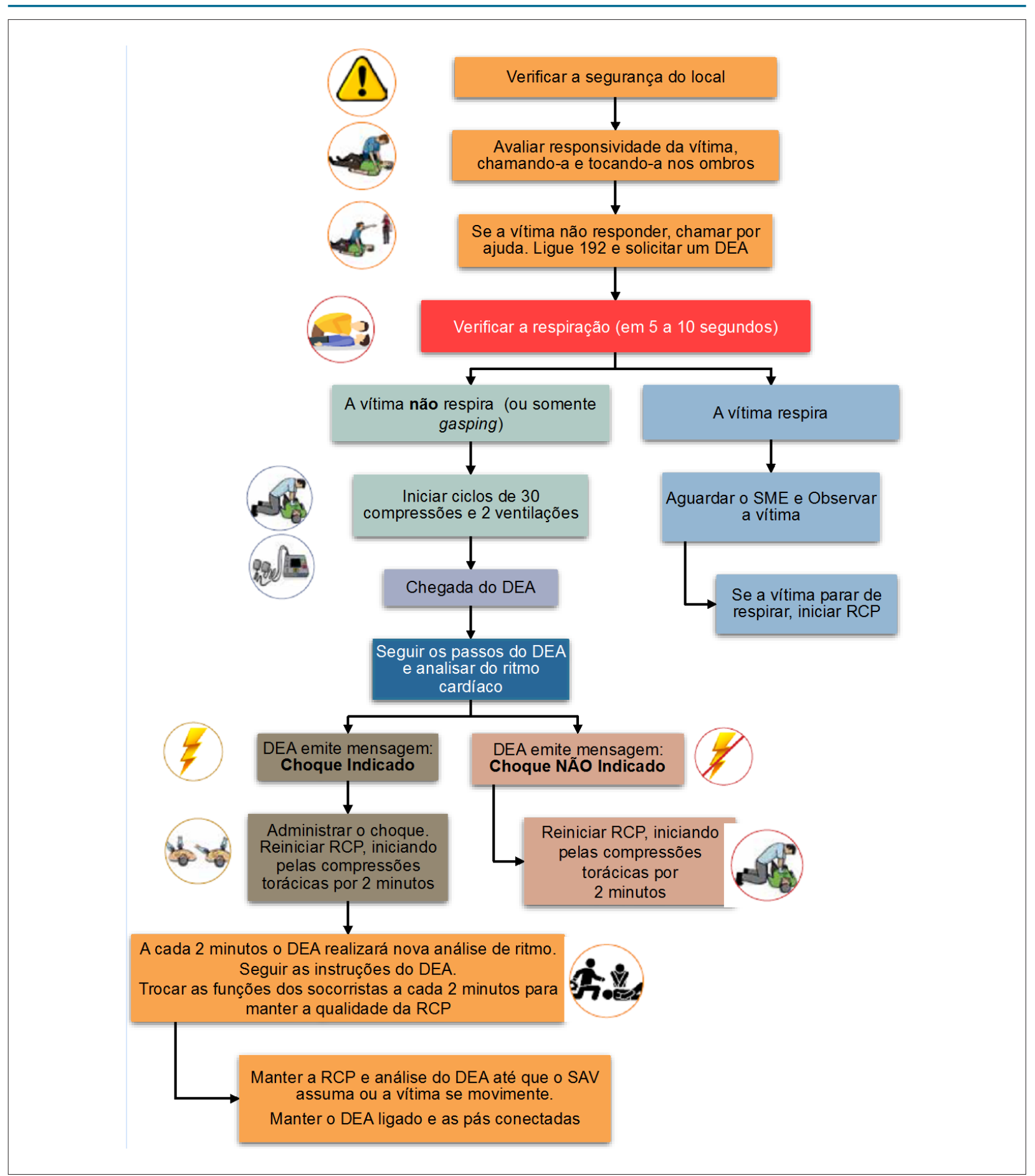

Figura 2.15 - Suporte básico de vida para leigos.

DEA: desfibrilador externo automático; RCP: ressuscitação cardiopulmonar; SAV: Suporte Avançado de Vida.

\section{C) Formato de onda:}

- Monofásicos, a energia selecionada é aplicada em um único sentido vetorial;

- Bifásicos, parte da corrente é administrada em um sentido, e a outra no sentido inverso (inversão de polaridade).
Embora seja preferível, o uso de desfibriladores bifásicos não é mandatório, já que esses não mostraram benefício na redução de mortalidade após PCR. ${ }^{90-100}$

O local mais adequado para instalação é a posição anterolateral, na qual uma das pás é colocada na região 
infraclavicular direita e a outra na região precordial. Posições alternativas, como anteroposterior e laterolateral, podem ser utilizadas em situações especiais, como presença de marca-passo, no qual as pás devem ser obrigatoriamente posicionadas pelo menos $8 \mathrm{~cm}$ de distância do gerador (Quadro 3.1). ${ }^{86,101-104}$

\subsubsection{Indicações}

A desfibrilação está indicada no tratamento da FV, na TVSP e na reversão de TV polimórfica sustentada devido à dificuldade de sincronização com os diferentes complexos QRS observados nesta arritmia.

A CVE está indicada para reversão das taquiarritmias com instabilidade hemodinâmica caracterizada pela presença de ao menos um destes quatro sinais: hipotensão e sinais de choque circulatório, dor torácica anginosa, dispneia associada à congestão pulmonar e rebaixamento do nível de consciência. Este procedimento também pode ser empregado para reversão de taquiarritmias estáveis após tentativa de controle farmacológico sem sucesso (Quadro 3.2). ${ }^{105}$

\subsubsection{Seleção do Nível de Energia}

Deve-se utilizar a máxima energia do aparelho - 360 J, no desfibrilador monofásico, e de 120 a 200 J, no desfibrilador bifásico, conforme orientação do fabricante. Se esta orientação é desconhecida, deve ser administrado choque de $200 \mathrm{~J}$.

Na CVE, os níveis de energias estão padronizados para o cardioversor monofásico, considerando-se a sequência crescente de energia: 100 J, 200 J, 300 J e 360 J (Quadro 3.3).

No cardioversor bifásico, os níveis de energia não estão bem padronizados. Geralmente, pode-se iniciar com energias menores que aquelas definidas anteriormente para o desfibrilador monofásico (Figura 3.1). ${ }^{95,105-109}$

\subsubsection{Sequência dos Choques}

Na situação de desfibrilação, recomenda-se um choque, intercalado por 2 minutos de $\mathrm{RCP}^{95,109,110}$ visto que, mesmo após a reversão da FV, geralmente ocorre breve período de assistolia ou de AESP, além de esta estratégia propiciar a não interrupção da RCP. ${ }^{111}$

\section{Quadro 3.1 - Recomendações para seleção do desfibrilador/cardioversor}

\begin{tabular}{|c|c|c|}
\hline Recomendações & Classe de Recomendação & Nível de Evidência \\
\hline Os DEA devem ser empregados no ambiente pré-hospitalar & I & B \\
\hline A posição anterolateral é a mais adequada para colocação das pás & I & $\mathrm{B}$ \\
\hline $\begin{array}{l}\text { Os DEA podem ser utilizados no ambiente hospitalar, principalmente em locais com pouca experiência na } \\
\text { identificação de graves arritmias }\end{array}$ & Ila & C \\
\hline Os desfibriladores monofásicos podem ser utilizados quando não estiver disponível um desfibrilador bifásico & Ila & C \\
\hline $\begin{array}{l}\text { Parece não haver diferenças entre a utilização das pás manuais e das pás adesivas nas taxas de sucesso de } \\
\text { reversão das arritmias }\end{array}$ & Ila & B \\
\hline $\begin{array}{l}\text { Posições alternativas podem ser utilizadas, principalmente em pacientes portadores de marca-passo ou } \\
\text { cardioversor desfibrilador implantável }\end{array}$ & Ila & $\mathrm{C}$ \\
\hline
\end{tabular}

DEA: desfibriladores externos automáticos.

Quadro 3.2 - Indicações para desfibrilação/cardioversão

\begin{tabular}{|c|c|c|}
\hline Recomendações & Classe de Recomendação & Nível de Evidência \\
\hline A desfibrilação deverá ser utilizada no tratamento da FV, TV sem pulso e TV polimórfica sustentada & I & $\mathrm{B}$ \\
\hline A desfibrilação em ritmos chocáveis deve ser priorizada e não retardada frente a outras manobras na PCR & I & $\mathrm{B}$ \\
\hline A CVE deverá ser utilizada no tratamento das taquiarritmias associadas a sinais de instabilidade & I & $\mathrm{B}$ \\
\hline Hipotensão associada a sinais de choque e na presença de instabilidade & I & $\mathrm{B}$ \\
\hline $\begin{array}{l}\text { A presença de dispneia, associada a congestão pulmonar, dor torácica anginosa ou rebaixamento do nível de } \\
\text { consciência, indica instabilidade }\end{array}$ & Ila & C \\
\hline A CVE pode ser empregada para reversão de taquiarritmias estáveis refratárias ao tratamento farmacológico & Ila & C \\
\hline $\begin{array}{l}\text { A CVE pode ser empregada para reversão de fibrilação atrial persistente quando for optado pela estratégia de } \\
\text { controle do ritmo }\end{array}$ & Ila & $B$ \\
\hline $\begin{array}{l}\text { Tentativa de CVE na vigência de taquicardia sinusal e outras arritmias, nas quais a reentrada não é o } \\
\text { mecanismo fisiopatológico }\end{array}$ & III & C \\
\hline
\end{tabular}

FV: fibrilação ventricular; TV: taquicardia ventricular; PCR: parada cardiorrespiratória; CVE: cardioversão elétrica. 


\section{Quadro 3.3 - Recomendações para seleção da energia do desfibrilador/ cardioversor}

\begin{tabular}{|c|c|c|}
\hline Recomendações & Classe de Recomendação & Nível de Evidência \\
\hline $\begin{array}{l}\text { Realizar desfibrilação com a dose máxima recomendada pelo fabricante (120 a } 200 \text { J bifásica ou } 360 \mathrm{~J} \\
\text { monofásica) }\end{array}$ & I & B \\
\hline Sempre realizar um ciclo de RCP (2 minutos) após cada procedimento de desfibrilação & I & B \\
\hline Sempre utilizar sedativos antes da CVE & I & C \\
\hline Sempre acionar o sincronismo antes da realização da CVE & I & B \\
\hline $\begin{array}{l}\text { Utilizar energia máxima ( } 200 \mathrm{~J} \text { no desfibrilador bifásico se a dose inicial recomendada pelo fabricante for } \\
\text { desconhecida e } 360 \mathrm{~J} \text { no desfibrilador monofásico) durante o procedimento de desfibrilação }\end{array}$ & Ila & C \\
\hline $\begin{array}{l}\text { Utilizar a sequência de energia de } 100 \text { J, } 200 \text { J, } 300 \text { J e } 360 \text { J durante a CVE, utilizando-se do cardioversor } \\
\text { monofásico }\end{array}$ & Ila & B \\
\hline $\begin{array}{l}\text { O nível de energia não está padronizado para os cardioversores bifásicos, devendo-se utilizar níveis de energia } \\
\text { inferiores (geralmente a metade) daqueles padronizados para o desfibrilador monofásico }\end{array}$ & Ila & C \\
\hline Realizar choques sucessivos se o paciente mantém o mesmo ritmo após a tentativa de CVE inicial & $\| l b$ & C \\
\hline A intubação orotraqueal é obrigatória antes da realização da desfibrilação ou CVE & III & C \\
\hline
\end{tabular}

RCP: ressuscitação cardiopulmonar; CVE: cardioversão elétrica.

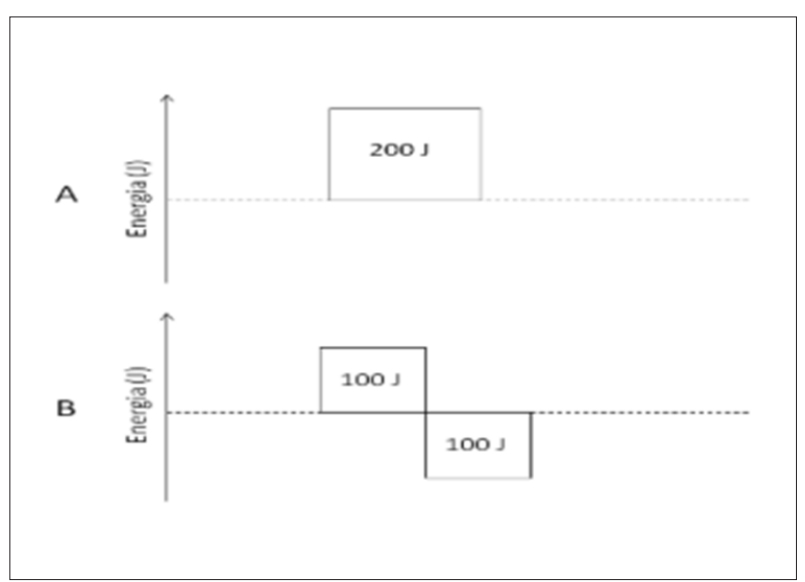

Figura 3.1 - Exemplo esquemático da liberação de energia nos desfibriladores/cardioversores monofásicos $(A)$ e bifásicos (B).

$\mathrm{Na} C V E$, pode-se realizar o choque sequencial com um nível crescente de energia, lembrando sempre de sincronizar o cardioversor antes de cada procedimento. ${ }^{105}$

\subsubsection{Etapas do Procedimento}

Na desfibrilação, não há necessidade de sedação, visto que o paciente está em PCR. Na CVE, deve-se administrar um sedativo antes da administração do choque para minimizar o desconforto e a dor do procedimento (por exemplos: midazolam, fentanil, etomidato e propofol).

Para a CVE eletiva, é necessário pelo menos 6 horas de jejum. Não há necessidade de Intubação Orotraqueal (IOT) preventiva, porém cuidado adicional deve ser dado na abertura das vias aéreas e na ventilação, geralmente utilizando-se BVM (Ambu).

Durante a CVE, deve-se:

- Acionar o botão de sincronização antes da administração de cada choque.
- Selecionar o nível adequado de energia de acordo com a arritmia.

- Aplicar gel nas pás, posicioná-las sobre o tórax do paciente aplicando uma pressão correspondente a $13 \mathrm{~kg}$. Carregar o desfibrilador/ cardioversor.

- Solicitar e verificar o afastamento do operador e socorristas, pois existe o risco de condução da corrente elétrica, podendo causar graves complicações.

- Verificar a ausência de oxigênio em alto fluxo próximo ao desfibrilador, devido ao risco de formação de faíscas.

- Aplicar o choque elétrico, mantendo as pás sobre o tórax por alguns segundos, principalmente durante a CVE, pois pode haver um pequeno atraso na administração do choque, devido à necessidade de adequada sincronização. ${ }^{86,105}$

\subsection{Marca-Passo Transcutâneo}

A estimulação cardíaca temporária, por meio do Marca-Passo Transcutâneo (MPTC), é um procedimento de emergência e tem a vantagem de ser uma técnica não invasiva e de instalação praticamente imediata, fornecendo corrente elétrica por eletrodos colados na pele, cuja despolarização leva à contração cardíaca.

A principal indicação é em pacientes com bradicardia sintomática (Quadro 3.4).

A desvantagem do MPTC é a necessidade de alta energia em razão da impedância transtorácica, que tem de ser vencida para chegar ao miocárdio.

Quadro 3.4 - Situações de indicação de marca-passo transcutâneo

\begin{tabular}{lc}
\hline Indicações & Não indicado \\
\hline $\begin{array}{l}\text { Bradicardia de alto grau (incluem bloqueios atrioventriculares } \\
\text { de segundo grau Mobitz ll e o de terceiro grau ou total) }\end{array}$ & \\
sintomática, com pulso & Assistolia \\
Falência do tratamento da bradicardia sintomática com atropina & \\
\hline
\end{tabular}




\section{Atualização}

Em bradicardia sintomática com pulso, dois trials randomizados compararam o MPTC com terapia medicamentosa e não revelaram diferença na sobrevida. Assim, a recomendação atual para bradicardia sintomática com pulso é: ${ }^{112}$

- Considere o uso de atropina 0,5 mg por via intravenosa, enquanto aguarda o marca-passo; pode ser repetida até um total de $3 \mathrm{mg}$. Se não eficaz, inicie o MPTC.

- Considere o uso de epinefrina (2 a $10 \mu \mathrm{g} /$ minuto) ou infusão de dopamina (2 a $10 \mu \mathrm{g} / \mathrm{kg} /$ minuto), enquanto aguarda a colocação do MPTC, ou se este não for eficaz.

\subsubsection{Como Utilizar o Marca-Passo Transcutâneo}

- Verifique se há a opção de MPTC em seu monitor/ desfibrilador/cardioversor.

- Monitorize o paciente.

- Considere analgesia e sedação, tendo o cuidado com a qualidade da ventilação.

- Fixe as pás autoadesivas no tórax colocando o eletrodo anterior à esquerda do esterno, centralizado e o mais próximo possível do ponto de máximo do impulso cardíaco. Colocar o eletrodo posterior nas costas, diretamente atrás do eletrodo anterior e à esquerda da coluna torácica. Uma alternativa é a colocação semelhante à do DEA: uma das pás sobre o ápice do coração e a outra na região paraesternal direita (Figuras 3.2 a 3.3).

- Ligue o MPTC na frequência desejada e procure a opção PACER OU MARCA-PASSO.

- Em seguida, ajuste a corrente elétrica aumentando gradualmente, até que se obtenha captura elétrica, caracteriza pelo alargamento do complexo QRS com uma onda T larga e oposta à polaridade do QRS (Figuras 3.4 e 3.5$)$

- Observe qual é o ponto de corte para que haja captura de praticamente todas as espículas do marca-passo, deixando o valor da corrente elétrica com margem de segurança de $10 \%$ acima desse limiar.

\section{Dispositivos Auxiliares Durante as Manobras de Ressuscitação Cardiopulmonar}

\subsection{Introdução}

No Brasil, os dados sobre mortalidade são imprecisos, mas as Doenças Cardiovasculares (DCV) ainda são a principal causa de mortalidade. Muitos esforços vem sendo realizados nas últimas três décadas para reduzir estas taxas, por meio da divulgação do conhecimento em massa, do desenvolvimento de algoritmos e do emprego de dispositivos de assistência à PCR de acesso rápido e de fácil manejo. ${ }^{113} \mathrm{~A}$ aplicação destas novas técnicas necessita de um número maior de pessoas capacitadas para atuar em diferentes cenários, além de investimentos em novos equipamentos. ${ }^{114}$

\subsection{Técnicas}

\subsubsection{Qualidade das Compressões}

Frequência e duração da compressão são variáveis que têm sido exaustivamente analisadas, para determinar sua influência

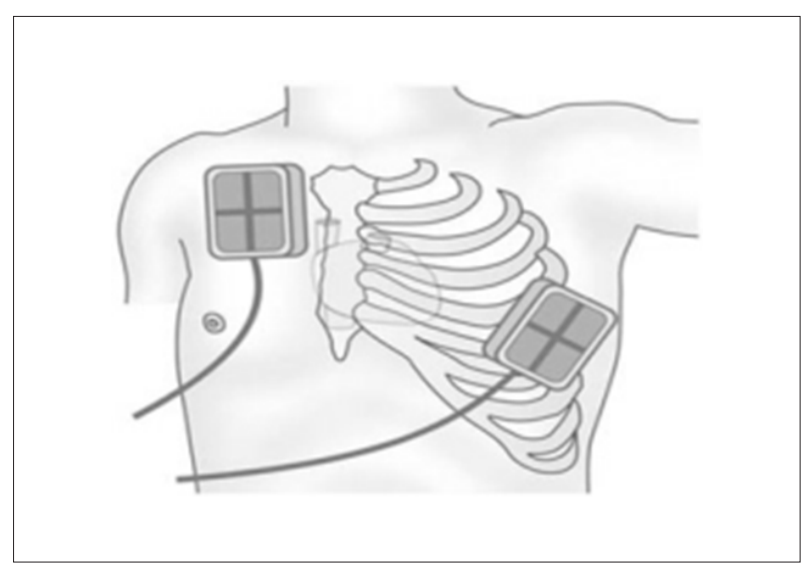

Figura 3.3 - Colocação anterolateral do marca-passo transcutâneo.
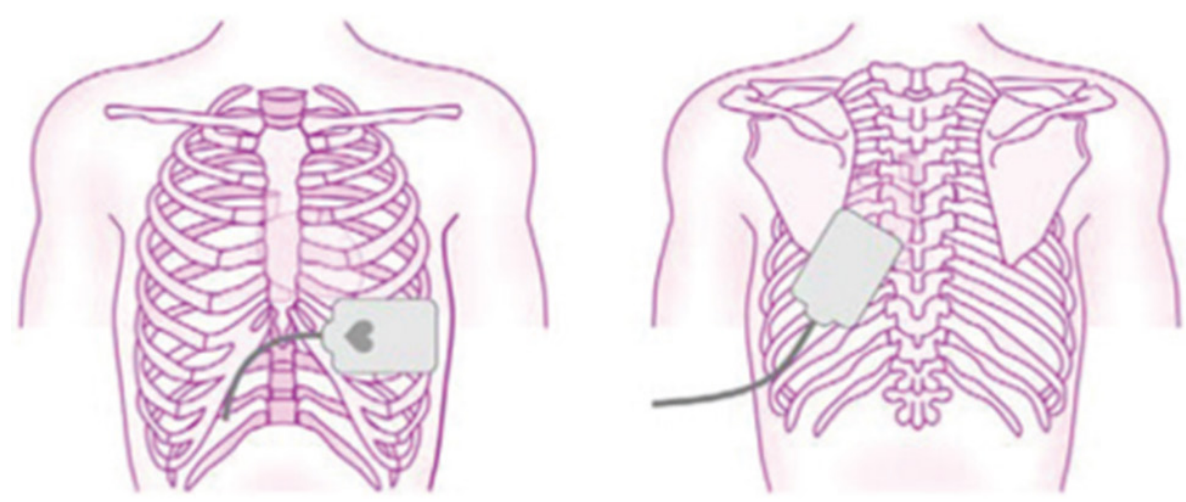

Figura 3.2 - Colocação anteroposterior do marca-passo transcutâneo. 


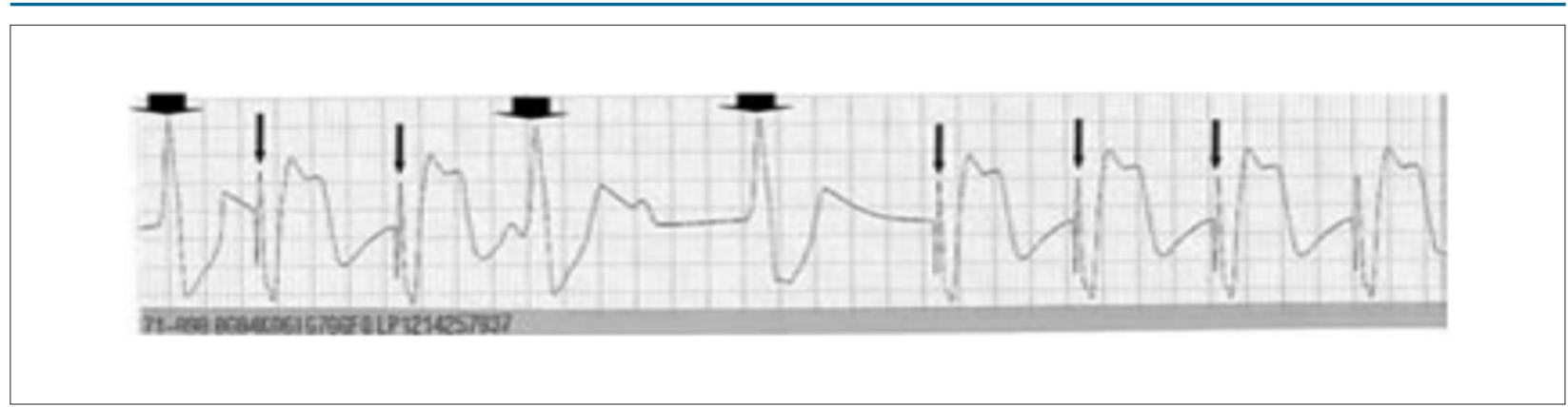

Figura 3.4 - Ritmo não comandado totalmente pelo marca-passo (setas largas e curtas). O comando do marca-passo pode ser visualizado pela espícula do marcapasso (setas finas e longas) seguida de complexo QRS alargado.

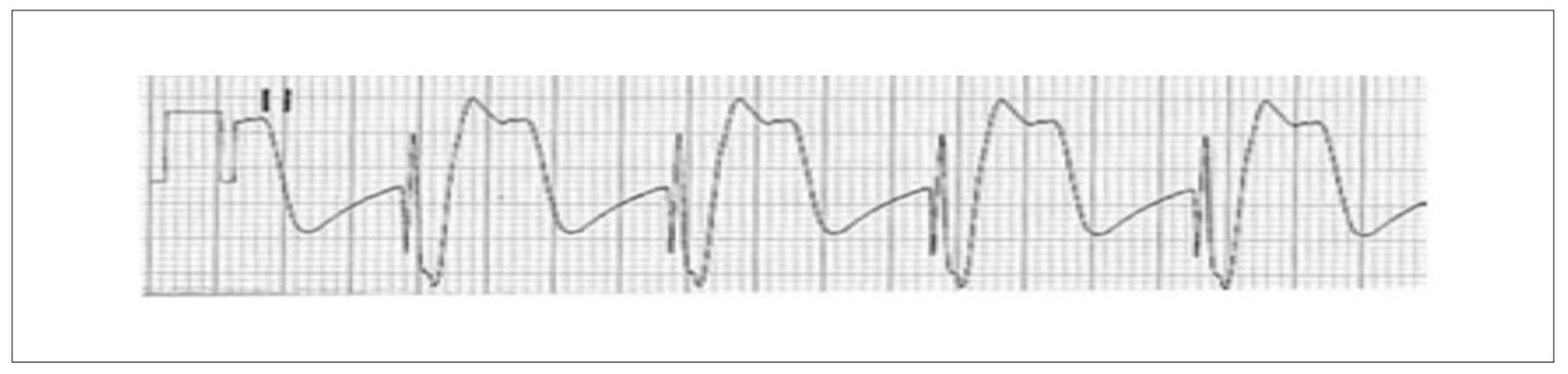

Figura 3.5 - Toda espícula do marca-passo conduz um complexo QRS alargado. Agora, o ritmo está totalmentecomandado pelo marca-passo.

sobre a força despendida para a circulação do sangue durante as compressões torácicas externas. Particularmente, RCP com alta frequência de compressões (> 120/minuto) foi estudada com o objetivo de otimizar seu resultado. ${ }^{115}$ Entretanto tais resultados são controversos. Desta forma, não há evidência suficiente para recomendar esta técnica como mais eficiente ${ }^{116,117}$ (Classe de Recomendação Ilb; Nível de Evidência C).

\subsubsection{Massagem Cardíaca Interna}

A Massagem Cardíaca Interna $(\mathrm{MCl})$ é superior à RCP padrão, pois promove maior pressão de perfusão coronariana. ${ }^{118-121}$ Muitos trabalhos referem-se a bons resultados da $\mathrm{MCl}$ após trauma fechado ou aberto (sobrevida e grau de déficit neurológico na alta), mas não há evidência para seu uso rotineiro.

Esta técnica pode ser utilizada durante cirurgia com tórax ou abdome abertos ${ }^{122-126}$ (Classe de Recomendação Ila; Nível de Evidência C), podendo ser indicada em situações de Atendimento Pré-Hospitalar (APH) de ferimento por trauma perfurante com tempo de transporte elevado até serviço avançado ${ }^{127,128}$ (Classe de Recomendação Ilb; Nível de Evidência C).

\subsubsection{Compressão Torácica e Abdominal Intercalada}

A Compressão Torácica e Abdominal Intercalada (CTAI) é uma técnica que envolve a participação de três socorristas (compressor torácico, abdominal e o responsável pelas ventilações), promovendo o aumento do retorno venoso. Dois estudos randomizados intra-hospitalares mostraram diferença em relação à sobrevida, ${ }^{129,130}$ mas seguimentos de outras cortes não reproduziram estes achados. ${ }^{131}$ Dessa forma, recomendase CTAI em ambiente hospitalar com equipe treinada (Classe de Recomendação Ilb; Nível de Evidência B).

\subsubsection{Tosse}

A solicitação para uma vítima ainda consciente tossir vigorosamente pode produzir pressões intratorácicas e sistêmicas superiores às produzidas pela RCP padrão, permitindo fique consciente por breves períodos. Esta técnica é frequentemente utilizada em laboratórios de hemodinâmica ${ }^{132-135}$ (Classe de Recomendação Ilb; Nível de Evidência C).

\subsubsection{Soco Precordial}

Existem relatos de que o soco precordial pode reverter TV com baixa taxa de sucesso, ${ }^{136-138}$ permanecendo inconclusivo em algumas publicações. ${ }^{139-143}$ Esta técnica não tem valor em PCR não presenciada e somente deve ser empregada em PCR presenciada em ritmo de TVSP/FV enquanto se aguarda a chegada do desfibrilador (Classe de Recomendação Ilb; Nível de Evidência C). ${ }^{144}$ Eventualmente, o soco precordial pode transformar um ritmo perfundido em um não perfundido. ${ }^{145}$

\subsubsection{Reanimação Cardiopulmonar em Posição Prona}

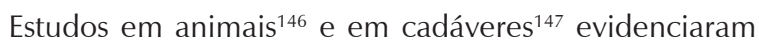
que a elevação da cabeça $\left(30^{\circ}\right)$ durante a realização da RCP aumenta a perfusão cerebral e coronariana. ${ }^{148-151}$ Pela 
ausência de estudos clínicos, ainda não há uma Classe de Recomendação, mas parece ser uma alternativa razoável em espaços pequenos (Classe de Recomendação Ilb; Nível de Evidência C).

\subsection{Equipamentos}

Recentemente, três grandes estudos clínicos compararam a RCP com compressão torácica mecânica vs. tratamento usual em ambiente extra-hospitalar, com total de 7.582 pacientes. Não houve vantagem clara para o uso dos dispositivos auxiliares de compressão mecânica. ${ }^{152-157}$

\subsubsection{Ressuscitação Cardiopulmonar com Compressão- Descompressão Ativa}

Nesta técnica de Compressão-Descompressão Ativa (CDA), utiliza-se um equipamento que aplica, além da compressão, um mecanismo de descompressão por sucção, e a queda da pressão intratorácica durante a fase de descompressão aumenta o retorno venoso. ${ }^{158-161}$ Uma das vantagens é que um único ressuscitador é capaz de prover as manobras. Os resultados são conflitantes (eficácia hemodinâmica e sobrevida) ${ }^{159,161-169}$ (Classe de Recomendação Ilb; Nível de Evidência C).

\subsubsection{Válvula de Impedância Respiratória}

Equipamento que é acoplado ao tubo endotraqueal que tem por função impedir a entrada de ar durante a fase de descompressão da RCP, o que provoca um aumento do retorno venoso para o coração. A válvula de impedância respiratória e o CDA podem agir sinergicamente, desde que ela esteja acoplada a um tubo traqueal com cuff insuflado ou com a máscara-facial adequadamente vedada. Resultados discordantes em relação à sobrevida foram observados com seu uso. ${ }^{170-176}$ Seu uso esta indicação apenas para manipulação por equipe treinada (Classe de Recomendação IIb; Nível de Evidência B para o uso de válvula de impedância respiratória isolada; e Classe de Recomendação IIb; Nível de Evidência C para o uso combinado de CDA/válvula de impedância respiratória).

\subsubsection{Pistão Mecânico}

Equipamento que produz a depressão do esterno por meio de um pistão acionado por gás ou eletricidade. Alguns trabalhos mostraram sua eficácia em melhorar o dióxido de carbono exalado e a pressão média arterial. Entretanto não houve diferença significativa em relação à sobrevida. ${ }^{177-182}$ Uso restrito a cenários específicos e com a equipe treinada (Classe de Recomendação IIb; Nível de Evidência C). ${ }^{183}$

\subsubsection{Colete Pneumático}

Dispositivo semelhante a um grande manguito de pressão formando por uma prancha e uma faixa, que é colocada ao redor do tórax do paciente, ligado a um compressor que ciclicamente gera uma pressão circunferencial. Estudos iniciais demonstraram melhora hemodinâmica do Retorno da Circulação Espontânea (RCE), ${ }^{184-186}$ e sobrevida na alta hospitalar. Entretanto, estudo multicêntrico demonstrou não ocorrer melhora na sobrevida em 4 horas e nem haver piora neurológica com o uso do colete pneumático. ${ }^{186}$ Recentemente, estudo clínico randomizado e controlado comparou o uso do colete pneumático (dispositivo AutoPulse, fabricado pela Zoll Circulation, Chelmsford, Massachusetts, EUA) randomizando em 4.753 para RCP padrão vs. colete pneumático. Houve equivalência entre os dois métodos. Assim recomenda-se sua utilização em cenários específicos com pessoal treinado (Classe de Recomendação IIB; Nível de Evidência B).

\subsubsection{Assistência Circulatória}

Composta por um oxigenador de membrana (Oxigenação por Membrana Extracorpórea - ECMO), a assistência circulatória envolve cenários em quem as medidas de Suporte Avançado de Vida falharam ou para facilitar intervenções específicas. ${ }^{187,188}$ Não existe ainda nenhum estudo randomizado comparando RCP extracorpórea vs. RCP padrão. ${ }^{189-194}$ Não há evidência para indicar seu uso rotineiro (Classe de Recomendação Ilb; Nível de Evidência C).

\subsection{Sumário}

Nenhuma nova técnica ou equipamento mostrou-se superior à RCP padrão em termos de resultado de sobrevida ou RCE. Estas técnicas podem promover uma demora no início da RCP em muitas situações. Sua aplicação deve ser considerada em cenários específicos, nos quais a equipe precisa estar altamente capacitada e constantemente treinada.

\section{Suporte Avançado de Vida em Cardiologia no Adulto}

\subsection{Introdução}

Em ambiente intra-hospitalar, a maioria dos pacientes em PCR apresenta ritmo inicial de AESP (37\%) e assistolia (39\%), ${ }^{195}$ sendo que os ritmos de FV e TVSP são responsáveis por $23 \%$ a $24 \%$ dos eventos, compreendendo a maior taxa de sobrevivência por todos os ritmos. ${ }^{195,196-199}$

Os principais aspectos no Suporte Avançado de Vida (SAV) em cardiologia no adulto discutidos na presente diretriz são: ênfase na realização das manobras de RCP de boa qualidade; administração precoce de adrenalina durante ritmos não chocáveis está associada ao aumento das taxas de sobrevida hospitalar, não existindo evidências robustas para administração de vasopressina durante as manobras de ressuscitação; caso uma via aérea avançada seja estabelecida, as compressões torácicas devem ser aplicadas continuamente (frequência 100 a 120 compressões/minuto) e as ventilações devem ser aplicadas com frequência de 10 por minuto, ou seja, uma ventilação a cada 6 segundos; o emprego de monitorização fisiológica pode otimizar a qualidade e serve como indicador de RCE.

\subsection{Suporte Ventilatório e Manejo da Via Aérea}

O objetivo das ventilações é manter oxigenação adequada, com eliminação suficiente de dióxido de carbono. No entanto, 
não há indicações precisas quanto a volume corrente, frequência respiratória e concentração de oxigênio. ${ }^{200}$

Durante os primeiros minutos de uma RCP, compressões torácicas sem interrupção podem manter troca gasosa adequada, assim, a inserção da via aérea avançada não deve retardar e nem prejudicar as compressões torácicas ou a desfibrilação. ${ }^{200-203}$

A prioridade deve ser manter as compressões torácicas e as ventilações com BVM, exceto se estas se mostrarem inadequadas. ${ }^{200}$ Para inserção de uma via aérea avançada, não deverá haver interrupção da RCP (Classe de Recomendação I; Nível de Evidência C), podendo ser indicada conforme treinamento do socorrista (Quadro 5.1). ${ }^{204-206}$

\subsubsection{Administração de Oxigênio com Concentração de $100 \%$}

O uso de oxigênio a 100\% é razoável durante as manobras de RCP (Classe de Recomendação Ila; Nível de Evidência C), com o objetivo de aumentar a oxi-hemoglobina arterial e a oferta de oxigênio. ${ }^{200}$ Embora a exposição prolongada a 100\% seja tóxica, não existem evidências definitivas sobre toxicidade com a exposição breve, como no cenário da RCP em adultos. ${ }^{207,208}$

\subsubsection{Ventilação com Dispositivo Bolsa-Válvula-Máscara}

O dispositivo deve ser conectado a uma fonte de oxigênio, de modo a possibilitar a oferta de oxigênio a 100\%, mantendo seu reservatório expandido.
Durante a RCP, as ventilações são administradas alternadamente às compressões torácicas, em uma frequência de 30 compressões torácicas para duas ventilações, com cada ventilação durando em torno de 1 segundo. ${ }^{209}$

A máscara deve cobrir a cavidade nasal e oral, de modo a evitar escape de oxigênio (Figura 5.1). Antes de cada ventilação, verifica-se a abertura da via aérea. ${ }^{200,210} \mathrm{~A}$ melhor maneira de realizar as ventilações com a BVM é com dois socorristas, um deles mantendo a vedação, realizando o " $\mathrm{C}$ " e "E" com as duas mãos, e o segundo comprimindo a bolsa apenas o suficiente para se obter expansão torácica (400 a $600 \mathrm{~mL}$ ), a fim de reduzir os riscos, como distensão gástrica e broncoaspiração. ${ }^{210-214}$ Não há evidência definitiva de diferença de prognóstico ou de sobrevivência da ventilação com BVM quando comparada com uso de via aérea avançada. ${ }^{200,201,205}$

\subsubsection{Dispositivos Auxiliares para Manejo da Via Aérea durante a Ressuscitação Cardiopulmonar}

A. Cânula orofaríngea: deve ser inserida na cavidade oral. Facilita a ventilação ao evitar a queda da língua, mantendo a abertura de via aérea, devendo-se realizar a medida antes de sua inserção 200,211 (Figura 5.2). Seu uso é reservado para pacientes não responsivos ou com reflexo de vômito ausente, podendo ser inserida por profissionais treinados ${ }^{200}$ (Classe de Recomendação Ila; Nível de Evidência C).

Quadro 5.1 - Orientações quanto ao manejo de via aérea durante a parada cardiorrespiratória

\begin{tabular}{|c|c|c|}
\hline Recomendações & Classe de Recomendação & Nível de Evidência \\
\hline $\begin{array}{l}\text { Em pacientes em PCR sem via aérea avançada, manter ventilações com bolsa-válvula-máscara na frequência } \\
\text { de } 30 \text { compressões para } 2 \text { ventilações }\end{array}$ & Ila & C, dados limitados \\
\hline Oxigênio a $100 \%$ durante as manobras de RCP & Ila & C \\
\hline Inserção de via aérea avançada não deve atrasar o início da RCP e a desfibrilação & I & C \\
\hline $\begin{array}{l}\text { Se a inserção da via aérea avançada for causar interrupção nas compressões torácicas, o socorrista pode optar } \\
\text { por atrasar esta inserção, até que haja falência de resposta às medidas de RCP e desfibrilação, ou até o RCE }\end{array}$ & $\| l b$ & C \\
\hline $\begin{array}{l}\text { Tanto ventilação com bolsa-válvula-máscara quanto com via aérea avançada podem ser utilizadas para } \\
\text { oxigenação e ventilação durante uma PCR }\end{array}$ & $\mathrm{Ilb}$ & C, dados limitados \\
\hline $\begin{array}{l}\text { Para profissionais de saúde treinados, tanto dispositivos supraglóticos quanto a intubação orotraqueal podem } \\
\text { ser indicados como via aérea avançada }\end{array}$ & Ilb & C, dados limitados \\
\hline Treinamento frequente é recomendado para socorristas que realizam intubação orotraqueal & I & B \\
\hline $\begin{array}{l}\text { Para facilitar a ventilação com bolsa-válvula-máscara, a cânula orofaríngea pode ser utilizada em pacientes } \\
\text { sem reflexo de tosse ou vômito, sendo inserida apenas por profissionais treinados em seu uso }\end{array}$ & Ila & C \\
\hline $\begin{array}{l}\text { Para facilitar a ventilação com bolsa-válvula-máscara em paciente com fratura de base de crânio confirmada ou } \\
\text { suspeita ou coagulopatia grave, preferir a cânula orofaríngea em detrimento da nasofaríngea }\end{array}$ & Ila & C \\
\hline O uso rotineiro da pressão cricoide durante a PCR não é recomendado & III & C \\
\hline $\begin{array}{l}\text { Capnografia contínua com forma de onda é recomendada após avaliação clínica para confirmação e } \\
\text { monitorização do posicionamento correto da intubação orotraqueal }\end{array}$ & I & C, dados limitados \\
\hline $\begin{array}{l}\text { Se a capnografia contínua com forma de onda não está disponível, alternativas possíveis são detector de } \\
\text { dióxido de carbono sem forma de onda, detector esofágico e ultrassonografia }\end{array}$ & Ila & C, dados limitados \\
\hline O tubo orotraqueal deve ser fixado com fita convencional, bandagem ou dispositivo comercial & I & C \\
\hline $\begin{array}{l}\text { Após a instalação de uma via aérea avançada, proceder a ventilações a cada } 6 \text { segundos (10 ventilações/ } \\
\text { minuto) enquanto compressões são realizadas de maneira contínua }\end{array}$ & $\| l b$ & C, dados limitados \\
\hline
\end{tabular}

$P C R$ : parada cardiorrespiratória; $R C P$ : ressuscitação cardiopulmonar; $R C E$ : retorno da circulação espontânea. 


\section{Atualização}

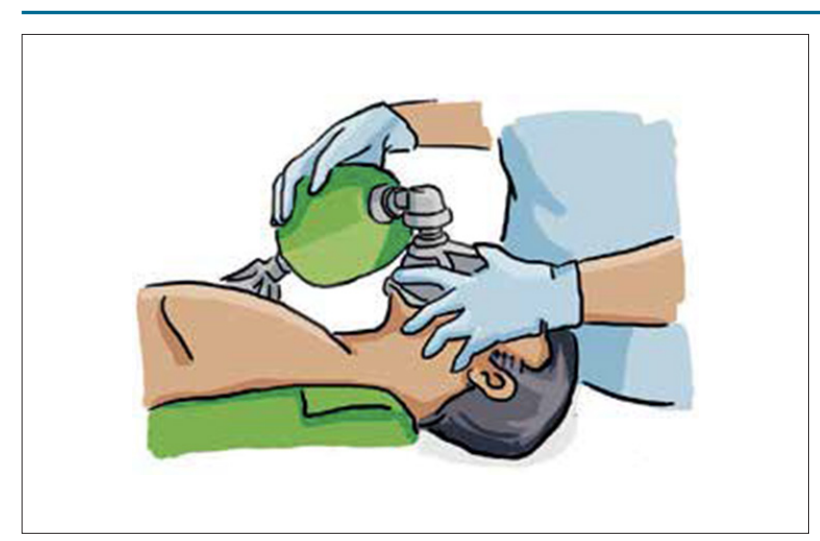

Figura 5.1 - Utilização da bolsa-válvula-máscara.

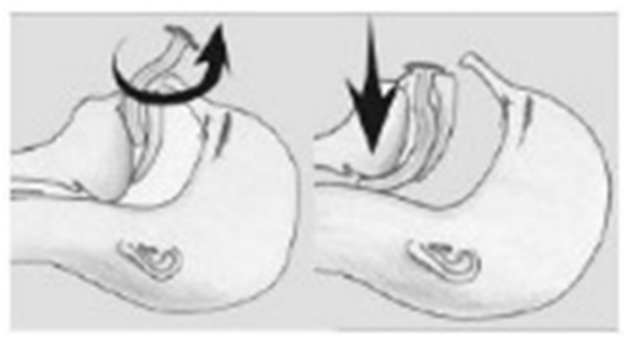

Figura 5.2 - Introdução da cânula orofaríngea.

B. Cânula nasofaríngea: pode ser indicada em pacientes despertos ou com reflexo de tosse presente. O tamanho adequado é obtido pela distância entre a parte distal da asa do nariz e a proximal no trago da orelha. Na suspeita de fratura de base de crânio ou uma coagulopatia severa, está contraindicada ${ }^{200}$ (Classe de Recomendação Ila; Nível de Evidência C).

C. Pressão cricoide: pode prevenir o refluxo gástrico durante a IOT, mas deve ser realizada com cautela, podendo dificultar o procedimento. $\mathrm{O}$ papel da pressão cricoide, durante a PCR, não foi estudado, e seu uso rotineiro, portanto, não é recomendado ${ }^{200,215}$ (Classe de Recomendação III; Nível de Evidência C).

\subsubsection{Via Aérea Avançada}

A. IOT: é a obtenção de via aérea avançada e que permite melhor oxigenação, além de diminuir as interrupções das compressões durante a RCP, pois estas passam a ser contínuas; permite, por meio da capnografia com forma de onda, a monitorização da qualidade da RCP. O momento mais adequado para sua inserção ainda não foi devidamente esclarecido (Classe de Recomendação Ilb; Nível de Evidência C). O profissional mais experiente presente deve se responsabilizar pela inserção do dispositivo. ${ }^{216-219}$ Não se interrompe a RCP para a laringoscopia, podendo-se interrompê-la, por menos de 10 segundos, para IOT e checagem do posicionamento do dispositivo.

- A checagem clínica inclui ausculta de cinco pontos: epigástrico (excluir intubação esofágica), base esquerda (excluir intubação seletiva à direita, mais provável), base esquerda e ápices. Esta checagem deve ser realizada em até 10 segundos.

- Além da checagem clínica com ausculta, está indicada uma checagem secundária com outros dispositivos: capnografia com forma de onda - método preferencial (Classe de Recomendação I; Nível de Evidência C) métodos colorimétricos, detectores esofágicos, ultrassom traqueal. ${ }^{200}$ Métodos como a observação de névoa na cânula não devem ser utilizados, pela baixa fidedignidade. .3,220-225 $^{2}$

- O tubo orotraqueal de ser fixado com fixador comercial, bandagens ou cadarço ${ }^{200}$ (Classe de Recomendação I; Nível de Evidência C). Em seguida, ventila-se o paciente com a BVM a cada 6 segundos, de maneira assíncrona às compressões torácicas, que devem ser contínuas. Cada ventilação deve ser suficiente para provocar a expansão do tórax. O socorrista deve evitar frequência e volume excessivos. ${ }^{43,220}$

- Capnografia com forma de onda também pode ser adjunto de monitorização da qualidade da RCP. Valor superior a $10 \mathrm{mmHg}$ é indicativo de manobras adequadase RCP; abaixo de $10 \mathrm{mmHg}$ por mais de 20 minutos, mesmo após aplicação de compressões adequadas, constitui informação que deve ser levada em consideração para a decisão de se manter ou não a RCP, porém não isoladamente (Classe de Recomendação IIb; Nível de Evidência C - dados limitados/LD).

- Os estudos com a capnografia com forma de onda não incluíram seu uso com dispositivos supraglóticos, mas sugerem-se observar a forma de onda e o valor obtido, pois acredita-se que a ventilação efetiva deve ser capaz de produzir curva capnográfica durante a RCP. ${ }^{209}$

Após a obtenção de uma via aérea avançada, de sua confirmação e fixação, a RCP deve prosseguir com compressões contínuas e uma ventilação a cada 6 segundos ${ }^{200}$ (Classe de Recomendação Ilb; Nível de Evidência C - dados limitados/LD).

$\mathrm{Na}$ tentativa de minimizar os erros associados, como atraso na indicação e obtenção da via aérea avançada, os profissionais que atendem a PCR devem ser treinados para este procedimento (Classe de Recomendação I; Nível de Evidência B).

B. Dispositivos supraglóticos: são exemplos a máscara laríngea, o tubo esofágico traqueal e o tubo laríngeo. Possuem inserção mais fácil que o tubo orotraqueal, além de poderem ser inseridos por enfermeiros treinados. ${ }^{226,227}$

- Tubo esofágico traqueal (combitube): consiste em tubo com duas luzes e dois cuffs devidamente identificados (Figura 5.3). Projetado para ser introduzido sem visualização direta, permitindo a ventilação adequada, caso ele penetre o esôfago (ocorrência em mais de 90\% das inserções) ou caso penetre a traqueia. 228,229 


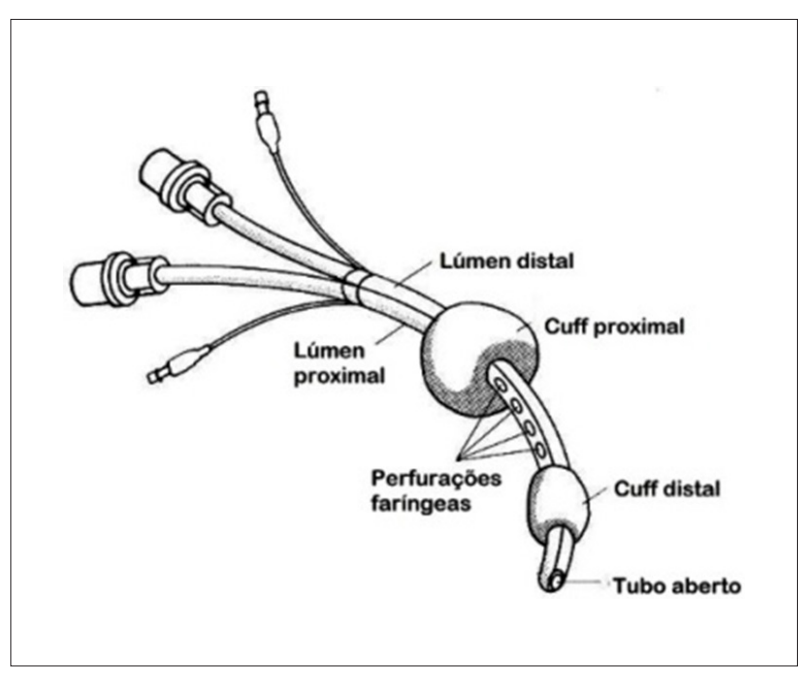

Figura 5.3 - Tubo esofágico traqueal.

- Máscara laríngea: de fácil inserção, uma vez que não necessita de visualização direta. Seu tamanhho é indicado conforme o peso do paciente (Figura 5.4). Após insuflar o cuff, checar a ausculta pulmonar, para confirmar posicionamento e funcionamento correto da máscara, afastando possibilidade de complicações, como dobras na máscara. ${ }^{230,231}$

- Tubo laríngeo: projetado para ventilar pelas frestas laterais do tubo (Figura 5.5), uma vez que possui lúmen único. ${ }^{232-235}$

\subsection{Monitorização durante a Parada Cardiorrespiratória}

\subsubsection{Parâmetros Mecânicos}

Dispositivos como metrônomos visuais ou auditivos, ou até mais sofisticados, como monitores desfibriladores, que fornecem retorno da frequência, profundidade e pausa das compressões torácicas (em tempo real), favorecem a realização de correlação da qualidade da RCP com a sobrevida dos pacientes (Classe de Recomendação lla; Nível de Evidência B). ${ }^{236}$ De modo similar, mecanismos didáticos e mnemônicos podem produzir impacto positivo, imediato e sustentado na boa execução das compressões torácicas. ${ }^{237}$

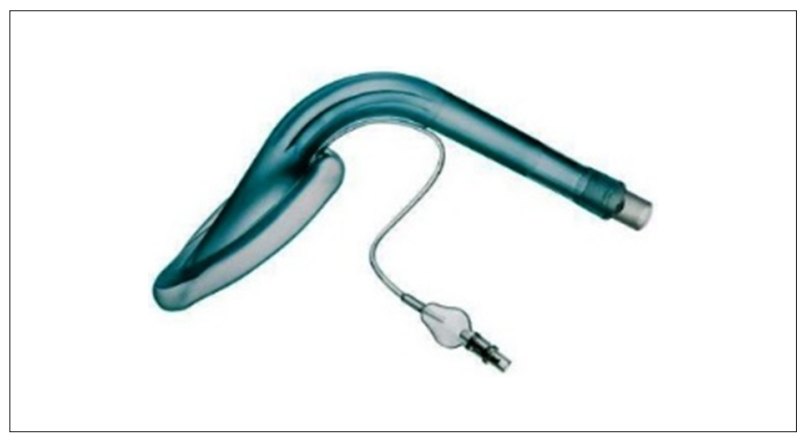

Figura 5.4 - Máscara laríngea.

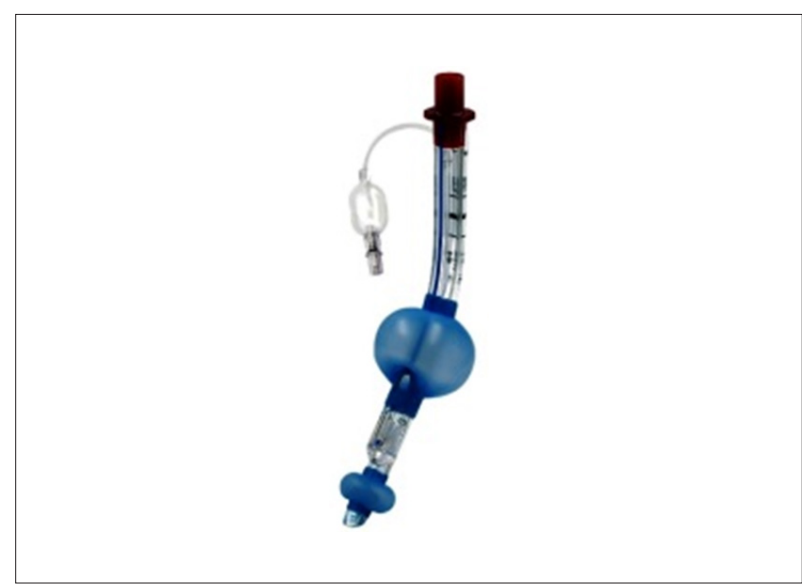

Figura 5.5 - Tubo laríngeo.

\subsubsection{Parâmetros Fisiológicos}

Embora nenhum estudo clínico tenha avaliado se seguir parâmetros fisiológicos durante a RCP melhora prognóstico, quando disponíveis estes devem ser considerados para monitorar e otimizar a RCP, guiar a infusão de vasopressores e detectar o RCE (Classe de Recomendação Ilb; Nível de Evidência B)..$^{238,239}$

O dióxido de carbono exalado no final da expiração $\left(\mathrm{PETCO}_{2}\right.$ ), expresso em $\mathrm{mmHg}$, tem sido correlacionado com a qualidade da RCP e com o RCE. Valores $<10 \mathrm{mmHg}$ revelam pouca probabilidade de RCE, indicando a necessidade de melhora na qualidade da RCP (Classe de Recomendação Ila; Nível de Evidência B) (Figura 5.6). ${ }^{240-243}$

As mesmas evidências sugerem que, se o paciente mantiver valores baixos de $\mathrm{PETCO}_{2}$ por longos períodos, a despeito de condições ideais de RCP, dificilmente o RCE será atingido. Este valor pode ser levado em consideração por ocasião da definição de cessação de esforços. Quando o PETCO $_{2}$ se mantém abaixo de $10 \mathrm{mmHg}$ após 20 minutos de RCP, existe relação direta com mau prognóstico do paciente e baixa probabilidade de RCE (Classe de Recomendação Ilb; Nível de Evidência B). ${ }^{240,243-245} \mathrm{Em}$ pacientes não intubados, não existe cut-off definido para essa avaliação, e esse parâmetro não deve ser usado como auxiliar na cessação dos esforços (Classe de Recomendação III; Nível de Evidência C).

No entanto, se, durante as manobras de RCP, existe aumento abrupto do PETCO $_{2}$ (para 35 a $40 \mathrm{mmHg}$ ), é razoável considerar que houve RCE (Classe de Recomendação Ila; Nível de Evidência B) (Figura 5.7).245,246

Outro mecanismo muito útil para a monitorização da RCP é a medida da Pressão Arterial Diastólica (PAD) em pacientes com monitorização arterial invasiva no momento da PCR. Seu valor tem sido correlacionado com a pressão de perfusão coronária e com o RCE. ${ }^{202,222}$ Nas situações em que a pressão de diastólica é $<20 \mathrm{mmHg}$, é razoável considerar melhorar a qualidade da RCP (Classe de Recomendação Ilb; Nível de Evidência C). A presença de dispositivos arteriais também pode reduzir o tempo de interrupção da RCP na checagem de 


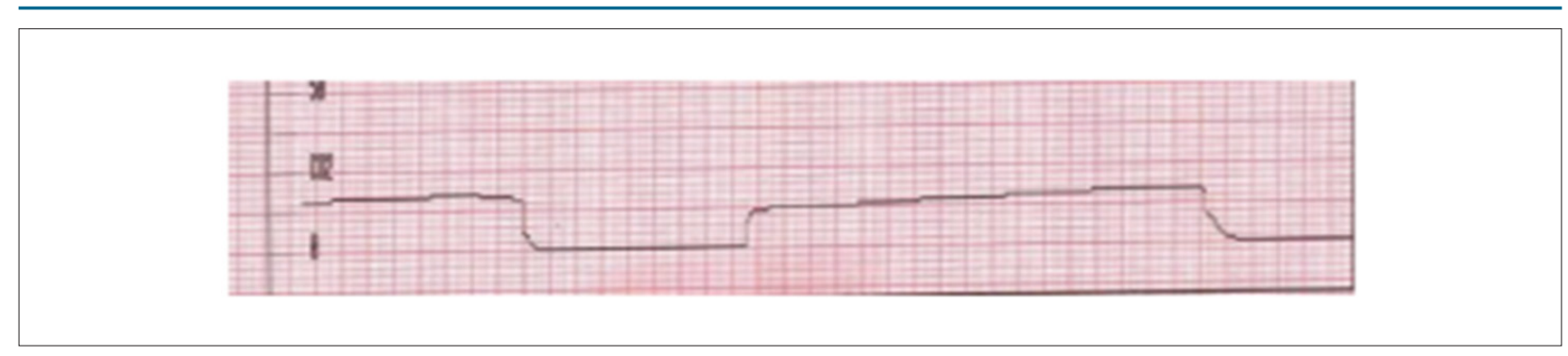

Figura 5.6 - Nível de dióxido de carbono exalado de $15 \mathrm{mmHg}$ - sugestivo de reanimação adequada.

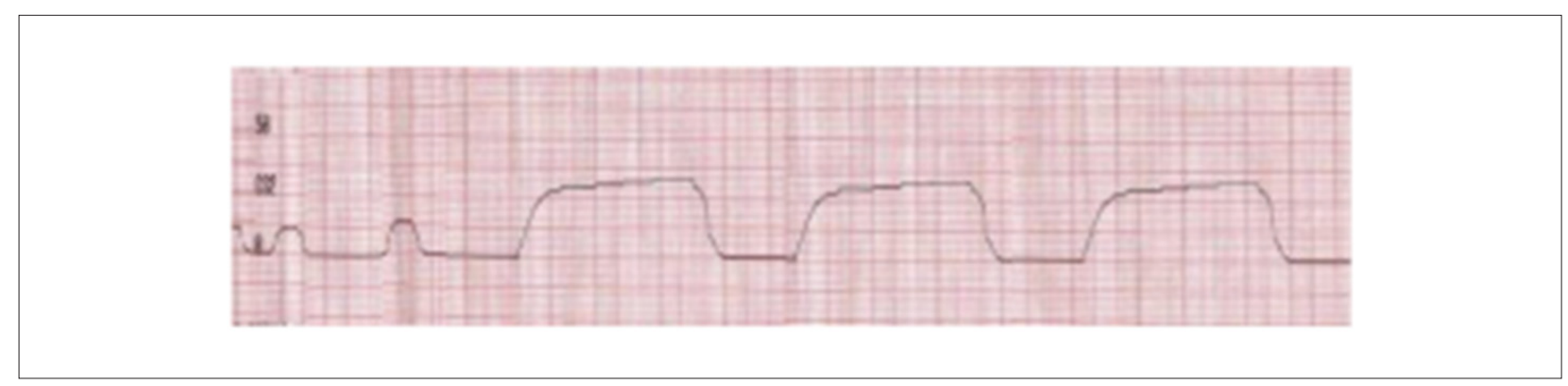

Figura 5.7 - Aumento abrupto de dióxido de carbono exalado sugerindo retorno da circulação espontânea.

pulso, em pacientes com atividade elétrica organizada (Classe de Recomendação Ilb; Nível de Evidência C).

Sugere-se que é necessário manter saturação venosa central maior que $30 \%$ durante a PCR, quando disponível, a fim de avaliar a qualidade da RCP (Classe de Recomendação Ilb; Nível de Evidência C). Coletar gasometria arterial de rotina durante a RCP tem valor incerto até o momento (Classe de Recomendação Ilb; Nível de Evidência C).

O uso da ecocardiografia transtorácica ou transesofágica pode ser considerado para o diagnóstico de causas específicas e tomada de decisão em situações como tamponamento cardíaco, dissecção de aorta e embolia pulmonar (Classe de Recomendação Ilb; Nível de Evidência C). ${ }^{221-228}$ Estudos mais recentes têm pontuado a avaliação ultrassonográfica, realizada por operador treinado, como o único método de ser utilizado sem comprometer a execução da RCP de qualidade e, eventualmente, agregando informações que possam aumentar a chance de sobrevida ${ }^{228}$ (Quadro 5.2).

\subsection{Manejo da Parada Cardíaca}

A PCR pode ser causada por quatro ritmos: FV, TVSP, AESP e assistolia. A sobrevida depende da integração do SBV, do Suporte Avançado de Vida em Cardiologia (SAVC) e dos cuidados pós-ressuscitação. Para vítimas de FV/TVSP, a realização de RCP e desfibrilação precoce tem demonstrado aumento significativo da sobrevida. ${ }^{247,248}$

O atraso no início da administração de vasopressores para além dos primeiros 5 minutos de PCR, bem como a demora em instalar via aérea avançada, pode estar associado a pior prognóstico. ${ }^{247}$ Assim, pode-se sugerir o início do uso de vasopressores no início do segundo ciclo, para pacientes em FV/TVSP. ${ }^{249,250}$

O socorrista deve tentar identificar a causa da PCR diagnóstico diferencial, obtendo dados, examinando o paciente ou conversando com os familiares. A maioria das causas de PCR pode ser resumida na memorização mnemônica "cinco Hs e cinco Ts" (Quadro 5.3). ${ }^{200,251-253}$

Após o RCE, os cuidados organizados dão ênfase na otimização neurológica, hemodinâmica, ventilatória e metabólica, com o objetivo de melhorar a sobrevida à alta hospitalar (Quadro 5.4). ${ }^{254} \mathrm{O}$ treinamento contínuo em equipe, a liderança, a comunicação efetiva em alça fechada e a retomada dos principais pontos ao término do atendimento são metas fortemente recomendadas (Quadro 5.4).255-257

\subsection{Tratamento da Parada Cardiorrespiratória Conforme o Ritmo}

\subsubsection{Fibrilação Ventricular/Taquicardia Ventricular sem Pulso}

Quando a monitorização com desfibrilador manual revela ritmo de FV/TVSP, a prioridade deve ser a desfibrilação precoce, uma vez que aumenta o sucesso do prognóstico.

Um socorrista carrega o desfibrilador, e outro reinicia as compressões torácicas, até o dispositivo estar pronto para desfibrilar. Realiza-se prévio aviso para todos se afastarem e, imediatamente após o choque, as compressões torácicas devem ser reiniciadas, sendo mantidas continuamente por 2 minutos, ao fim dos quais todos devem se afastar do paciente para que o ritmo seja reavaliado. Nesse momento de pausa 
Quadro 5.2 - Orientação para a monitorização de manobras de ressuscitação cardiopulmonar no Suporte Avançado de Vida em adultos

\begin{tabular}{|c|c|c|}
\hline Recomendações & Classe de Recomendação & Nível de Evidência \\
\hline $\begin{array}{l}\text { A utilização de dispositivos de feedback de RCP favorece a realização da RCP de alta qualidade e aumenta a } \\
\text { sobrevida dos pacientes }\end{array}$ & Ila & B \\
\hline Valores de $\mathrm{PETCO}_{2}<10 \mathrm{mmHg}$, indicam necessidade de melhora na qualidade da RCP & Ila & B \\
\hline Se houver aumento abrupto do $\mathrm{PETCO}_{2}$ (para 35 a $40 \mathrm{mmHg}$ ), é razoável considerar que houve RCE & Ila & B \\
\hline $\begin{array}{l}\text { Valores de } \mathrm{PETCO}_{2} \text { abaixo de } 10 \mathrm{mmHg} \text { após } 20 \text { minutos de RCP referem-se a mau prognóstico e uma baixa } \\
\text { probabilidade de RCE }\end{array}$ & $\| l b$ & B \\
\hline $\begin{array}{l}\text { Quando disponíveis, os parâmetros fisiológicos devem ser considerados para monitorar e otimizar a RCP e } \\
\text { detectar o RCE }\end{array}$ & $\| \mathrm{lb}$ & C \\
\hline Se valores de pressão arterial diastólica $<20 \mathrm{mmHg}$, é razoável considerar melhorar a qualidade da RCP & $\| l b$ & C \\
\hline $\begin{array}{l}\text { Checagem da pressão arterial invasiva pode reduzir o tempo de interrupção da RCP na checagem de pulso, em } \\
\text { pacientes com atividade elétrica organizada }\end{array}$ & $\| l b$ & C \\
\hline A aferição contínua de saturação venosa central < $30 \%$ tem sido relacionada à impossibilidade de RCE & $1 \mathrm{lb}$ & C \\
\hline $\begin{array}{l}\text { A saturação venosa central pode auxiliar na detecção de retorno à RCE e na qualidade das compressões } \\
\text { torácicas }\end{array}$ & $1 \mathrm{lb}$ & C \\
\hline Coletar gasometria arterial durante a RCP tem valor incerto até o momento & $\| \mathrm{lb}$ & C \\
\hline $\begin{array}{l}\text { A ecocardiografia transtorácica ou transesofágica pode ser considerada para o diagnóstico e a tomada de } \\
\text { decisão em situações como tamponamento cardíaco, dissecção de aorta e embolia pulmonar }\end{array}$ & $11 \mathrm{~b}$ & C \\
\hline
\end{tabular}

RCP: ressuscitação cardiopulmonar; PETCO: : dióxido de carbono exalado no final da expiração; RCE: retorno da circulação espontânea.

Quadro 5.3 - Possíveis causas em todas as modalidades de parada cardiorrespiratória

\begin{tabular}{lc}
\hline Hipóxia & Tóxicos \\
\hline Hipovolemia & Tamponamento cardíaco \\
Hidrogênio (acidose) & $\begin{array}{c}\text { Tensão no tórax (pneumotórax } \\
\text { hipertensivo) }\end{array}$ \\
Hiper/hipocalemia & Trombose coronária (infarto agudo do \\
miocárdio)
\end{tabular}

\section{Quadro 5.4 - Principais objetivos iniciais e subsequentes dos} cuidados pós-parada cardiorrespiratória

Otimizar a função cardiopulmonar e a perfusão de órgãos vitais após o RCE

Transportar/transferir para um hospital apropriado ou UTI com completo sistema de tratamento pós-PCR

Identificar e tratar síndromes coronárias agudas e outras causas reversíveis

Controlar a temperatura para otimizar a recuperação neurológica

Prever, tratar e prevenir a disfunção múltipla de órgãos. Isto inclui evitar ventilação excessiva e hiperóxia

RCE: retorno da circulação espontânea; UTI: unidade de terapia intensiva; PCR: parada cardiorrespiratória.

para análise do ritmo, que não deve exceder 10 segundos, os socorristas responsáveis pelas compressões devem se rodiziar, a fim de manter a boa qualidade da RCP. Durante a desfibrilação, as fontes de oxigênio devem ser desconectadas do paciente. ${ }^{258}$ Após a desfibirlação as compressões devem ser retomadas por mais um ciclo de 2 minutos. Durante a reanimação, devem se consideradas drogas vasopressoras e antiarrítmicas, bem como identificar e tratar causas potencialmente reversíveis (Figura 5.8; Quadro 5.3).

\subsubsection{Estratégias de Desfibrilação}

No desfibrilador bifásico, a energia do choque deve ser entre 120 e 200 J, conforme as orientações do fabricante (Classe de Recomendação I; Nível de Evidência B). Se o socorrista desconhece as orientações do fabricante, o choque deve ser administrado com a energia máxima disponível no aparelho (Classe de Recomendação IIb; Nível de Evidência C). Choques subsequentes devem ocorrer com energia equivalente ou superior (Classe de Recomendação IIb; Nível de Evidência B). ${ }^{200}$

Há duas possibilidades de posicionamento para as pás: anterolateral, em que as pás devem ser posicionadas na projeção do ápice cardíaco e abaixo da clavícula direita, ou anteroposterior. ${ }^{259}$ Não existe tamanho ideal, mas uma superfície maior gera menor resistência e maior corrente, associando-se à menor lesão miocárdica. ${ }^{260}$

Alguns estudos demonstram equivalência ou superioridade dos dispositivos de onda bifásica. ${ }^{260-264}$ Recomendam-se manter as compressões torácicas enquanto se prepara o desfibrilador para o choque (Classe de Recomendação I; Nível de Evidência B). ${ }^{265,266}$ Não há evidência suficiente para recomendar atrasar o primeiro choque para realização de RCP por 1,5 a 3 minutos (Classe de Recomendação Ilb; Nível de Evidência B), devendo-se realizar a desfibrilação, assim que possível (Quadro 5.5). ${ }^{266-268}$ 


\section{Atualização}

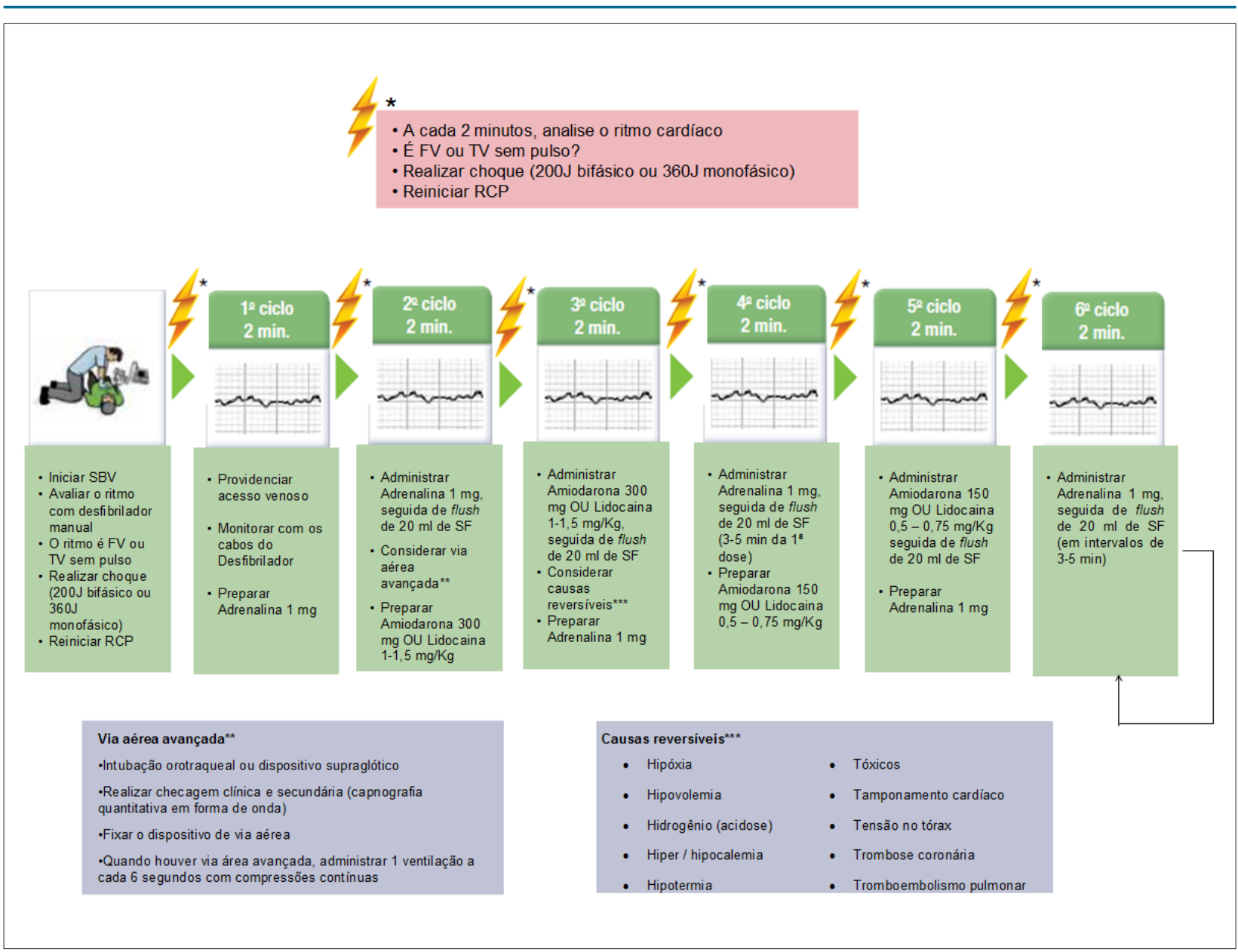

Figura 5.8 - Algoritmo do tratamento da parada cardiorrespiratória em fibrilação ventricular/taquicardia ventricular (FV/TV) sem pulso. * $A$ cada 2 minutos, analise 0 ritmo cardíaco; * ${ }^{*}$ Considerar via aérea avançada; ${ }^{* \star *}$ Causas reversiveis. FV: fibrilação ventricular; RCP: ressuscitação cardiopulmonar; SBV: Suporte Básico de Vida; SF: solução fisiológica; TV: taquicardia ventricular.

\section{Quadro 5.5 - Orientação para desfibrilação}

\begin{tabular}{lcc}
\hline Recomendação & Classe de Recomendação & Nivel de Evidência \\
\hline Choque bifásico seguindo as recomendações do fabricante & I & B \\
Choque bifásico com carga máxima, se desconhecidas as orientações do fabricante & Ilb & C \\
Realizar RCP enquanto se prepara a desfibrilação & I & B \\
Atrasar desfibrilação para realizar RCP por 2 minutos & Ilb & B \\
\hline
\end{tabular}

$R C P$ : ressuscitação cardiopulmonar.

\subsubsection{Medicações para a Fibrilação Ventricular ou Taquicardia Ventricular sem Pulso}

Após o primeiro choque, procede-se à RCP por 2 minutos, seguida de checagem de ritmo no monitor. Se a FV/TV persistir, procede-se a novo choque de alta energia, seguido por RCP durante 2 minutos.

O momento para administrar o vasopressor não tem sido estabelecido, devendo-se considerar seu início após o estabelecimento do acesso venoso. A administração precoce poderia otimizar o fluxo sanguíneo miocárdico antes do próximo choque.

Em qualquer ritmo de PCR, a primeira droga a ser utilizada deve ser a adrenalina. Embora o nível de evidência seja limitado, recomenda-se administração de adrenalina $1 \mathrm{mg}$ a cada 3 a 5 minutos. ${ }^{269}$

A vasopressina não é mais indicada como droga vasopressora na PCR. 270 
Caso haja persistência de FV ou TVSP, apesar da RCP, desfibrilação e vasopressor, indica-se um antiarrítmico, podendo este ser amiodarona ou lidocaína.

A amiodarona pode reduzir a recorrência de arritmias ventriculares em mais de $50 \%$ dos pacientes, devendo ser administrada por pelo menos 24 horas após o RCE, em bomba de infusão contínua. A dose é de 900 mg em 24 horas (360 mg nas primeiras seis horas e, então 540 mg por 18 horas). A manutenção da infusão além das 24 horas iniciais deve ser decidida pela equipe de especialistas, assim como seu uso nos que não receberem dose de amiodarona durante a PCR. ${ }^{273,274}$

O sulfato de magnésio não deve ser utilizado de maneira rotineira. Estudos demonstram benefício do uso para FV ou TVSP associada a prolongamento do intervalo QT por drogas ou TV polimórfica do tipo Torção das Pontas (TdP) (Quadro 5.6). ${ }^{275}$

\subsubsection{Tratando as Causas Reversíveis}

Diagnóstico e tratamento das causas reversíveis de PCR são fundamentais na abordagem de todos os ritmos de PCR, lembrando sempre dos "5Hs e 5Ts" (Quadro 5.3). ${ }^{249}$

No caso de FV/TVSP refratária, considerar como causa potencial a Síndrome Coronária Aguda (SCA). Estudos têm demonstrado benefícios com estratégias de reperfusão precoce. ${ }^{273}$ Terapêutica trombolítica durante a RCP não demonstrou melhora dos desfechos. ${ }^{276-278}$

\subsection{Assistolia e Atividade Elétrica sem Pulso}

São ritmos em que a desfibrilação não está indicada. Devese, então, promover RCP de alta qualidade, além de aplicar as drogas indicadas e procurar identificar e tratar as causas reversíveis (Figura 5.9 e Quadro 5.3). ${ }^{249}$

A assistolia como ritmo inicial de PCR está associada a prognóstico extremamente reservado (7\% de alta hospitalar). Na maioria das vezes é secundaria, sendo evolução tardia da FV/TV, ou via final de hipóxia prolongada, acidose ou necrose miocárdica. ${ }^{195}$

Uma vez que a amplitude do traçado da FV no monitor é dependente das reservas de ATP do miocárdio, a visualização de uma linha reta no monitor deve levantar duas hipóteses: assistolia ou FV fina. Deixar de desfibrilar uma FV é inadmissível, e desfibrilar assistolia piora o prognóstico. A assitolia deve ser confirmada em menos de 10 segundos, por meio das manobras checagem da correta conexão dos cabos, aumento do ganho máximo do aparelho e troca da derivação de monitorização. ${ }^{200}$
Após 2 minutos de RCP, se houver um ritmo organizado no monitor, procede-se à checagem do pulso carotídeo por 5 a 10 segundos. Caso não haja pulso palpável nesse período, identifica-se AESP.

\subsubsection{Medicações para Assistolia e Atividade Elétrica sem Pulso}

Para ritmo de assistolia ou AESP, um vasopressor, adrenalina (Classe de Recomendação Ilb; Nível de Evidência A) pode ser administrado com o objetivo de aumentar o fluxo sanguíneo cerebral e miocárdico. ${ }^{269}$ Recomenda-se em ritmos não chocáveis a administração precoce da adrenalina, de preferência no primeiro ciclo de RCP (Quadro 5.7). ${ }^{279}$

\subsubsection{Tratando as Causas Reversíveis}

AESP e assistolia podem ser causadas por condições reversíveis e tratadas com sucesso, se estas condições forem detectadas. Durante a RCP, os socorristas devem se lembrar dos "5Hs e 5Ts" (Quadro 5.3). Na AESP, quando existe a suspeita de um Tromboembolismo Pulmonar (TEP), a administração empírica de trombolíticos deve ser considerada (Classe de Recomendação Ila; Nível de Evidência B). ${ }^{249,276-280}$

\subsubsection{Cessação de Esforços}

Não existe recomendação clara sobre o momento de cessação dos esforços durante a RCP. A determinação de cessar esforços é difícil e deve se basear em consenso entre os membros da equipe. ${ }^{252,281}$ Alguns instrumentos de monitorização, como a ecografia durante a RCP e o valor da capnografia, podem vir a ser utilizados como parâmetros para auxiliar tal decisão. ${ }^{260}$

\subsection{Intervenções Medicamentosas na Ressuscitação Cardiopulmonar}

\subsubsection{Vasopressores}

O racional para o uso de vasopressores durante a RCP é aumentar a pressão de perfusão coronariana, definida como a diferença entre a pressão aórtica e a pressão no átrio direito, durante a fase de relaxamento (descompressão) torácico. Uma pressão de perfusão coronariana $\geq 15 \mathrm{mmHg}$ é preditiva do RCE. ${ }^{200,280}$

\section{A) Adrenalina}

A adrenalina tem sido utilizada devido a seus efeitos pressores alfadrenérgicos possibilitando, por

Quadro 5.6 - Orientação das medicações para fibrilação ventricular ou taquicardia ventricular sem pulso

\begin{tabular}{|c|c|c|}
\hline Recomendação & Classe de Recomendação & Nível de Evidência \\
\hline Vasopressor para PCR refratária à desfibrilação e RCP & Ilb & A \\
\hline Amiodarona ou lidocaína para PCR refratária a desfibrilação, $R C P$ e vasopressor & $\mathrm{Ilb}$ & A \\
\hline
\end{tabular}

PCR: parada cardiorrespiratória; $R C P$ : ressuscitação cardiopulmonar 


\section{Atualização}

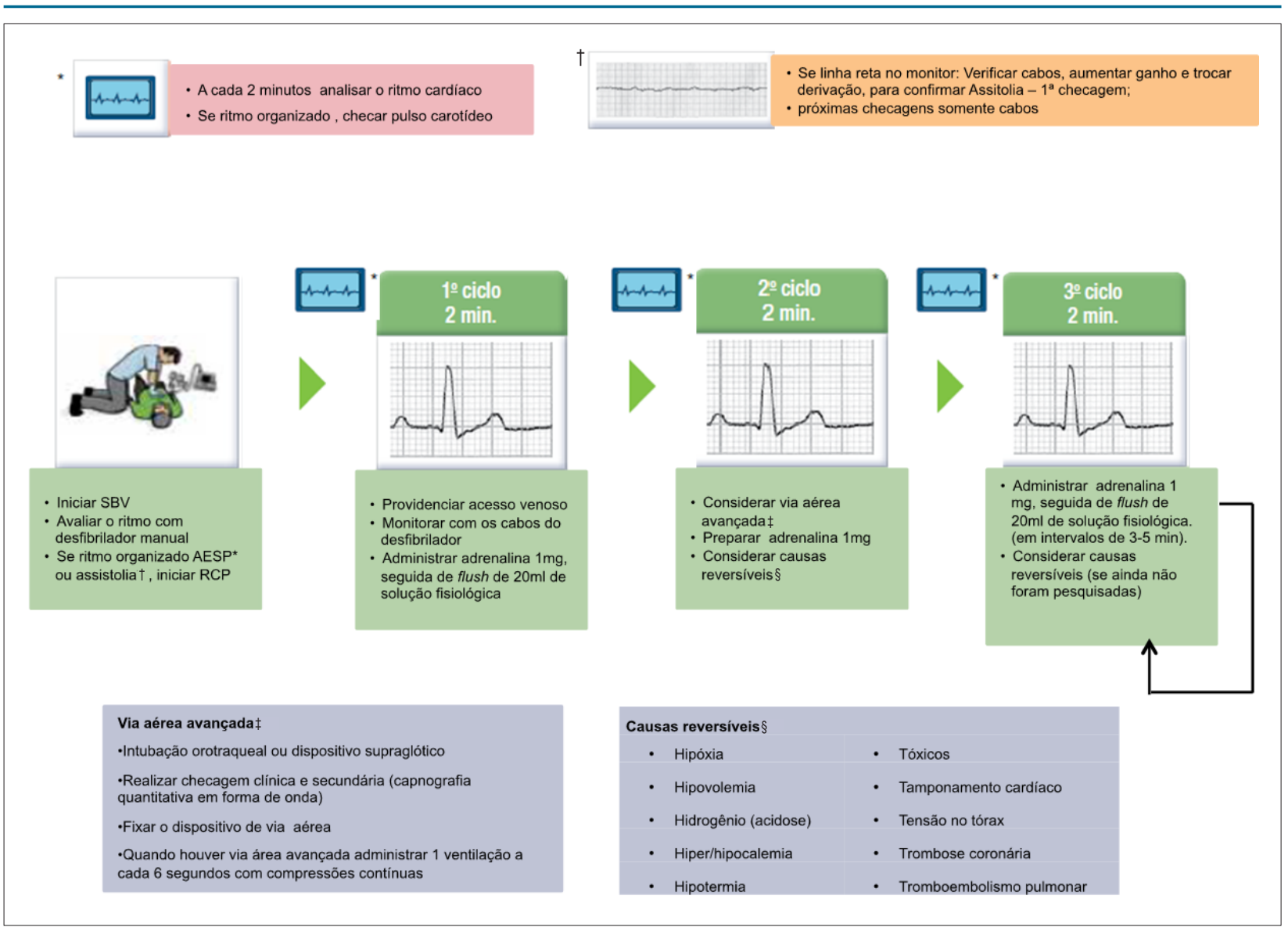

Figura 5.9 - Algoritmo do tratamento da parada cardiorrespiratória em atividade elétrica sem pulso (AESP) ou assistolia. * Monitor evidenciando ritmo cardíaco; † Monitor evidenciando traçado em linha reta; ‡ Considerar via aérea avançada para reversão de causas desencadeantes como hipoventilação, hipóxia e obstrução de via aérea; § Causas passiveis de tratamento para o retorno a circulação espontânea. SBV: Suporte Básico de Vida.

\section{Quadro 5.7 - Orientação de medicações para assistolia e atividade elétrica sem pulso ou assistolia}

\begin{tabular}{lcc}
\hline Recomendação & Classe de Recomendação & Nível de Evidência \\
\hline Iniciar adrenalina, droga vasopresora assim que disponivel para AESP/ assistolia & llb & A \\
\hline AESP: atividade elétrica sem pulso ou assistolia. & &
\end{tabular}

conseguinte, aumento das pressões de perfusão cerebral e coronariana. ${ }^{202,203,282,283}$ A dose ótima de adrenalina ainda não se encontra estabelecida. ${ }^{270,284-291}$

Em ritmos não chocáveis, três estudos mostraram melhora de sobrevida com a administração precoce de adrenalina. ${ }^{292-294}$ Dessa forma, a adrenalina deve ser utilizada da seguinte forma durante as manobras de RCP:

1. FV/TVSP: $1 \mathrm{mg}$ por via intravenosa, podendo ser repetida a cada 3 a 5 minutos, se necessário (Classe de Recomendação Ilb; Nível de Evidência C), a partir do segundo ciclo.

2. Assistolia e AESP: $1 \mathrm{mg}$ por via intravenosa tão logo se obtenha um acesso vascular, podendo ser repetida a cada 3 a 5 minutos, se necessário. As manobras de RCP não devem ser interrompidas para a administração de medicações ${ }^{269}$ (Classe de Recomendação Ilb; Nível de Evidência C).

\section{B) Vasopressina}

A vasopressina, um potente vasoconstritor não adrenérgico, mostrou-se bastante eficaz, superior à adrenalina, na RCP, em animais. No entanto, a vasopressina não oferece vantagem em relação à administração da adrenalina e não deve ser utilizada de rotina na PCR (Classe de Recomendação IIB; Nível de Evidência B). ${ }^{295}$

\section{C) Noradrenalina}

Teoricamente, a noradrenalina, por não apresentar efeitos beta-2-adrenérgicos importantes, promove maior aumento 
da PAD, causando menos taquicardia. A administração de noradrenalina não tem demonstrado benefícios adicionais durante a RCP, não sendo recomendada. ${ }^{288}$

\section{Recomendações atuais}

Apesar da ausência de dados conclusivos, parece ser razoável o emprego rotineiro de adrenalina na RCP na dose de $1 \mathrm{mg}$ IV/IO a cada 3 a 5 minutos (a cada dois ciclos), durante a continuidade das manobras de RCP. ${ }^{200}$ Em AESP/ assistolia, a adrenalina deve ser administrada precocemente após obtenção de acesso venoso. O uso de vasopressina não é mais indicado em pacientes em PCR. Não há dados suficientes para recomendar o uso de corticosteroides de rotina em PCR intra-hospitalar, sendo necessários novos estudos (Classe de Recomendação Ilb; Nível de Evidência C) (Quadro 5.8).

\subsubsection{Antiarrítmicos}

Os agentes antiarrítmicos têm sido empregados em PCR, em FV/TVSP, como medicações coadjuvantes, ou para prevenir suas recorrências. Não há evidências de que seu uso, durante as manobras de RCP, aumente as taxas de sobrevida na alta hospitalar.

\section{A) Amiodarona}

Em um ensaio clínico em adultos com FV/TVSP, observouse que a administração de amiodarona 300 mg ou 5 mg/ kg melhorou a sobrevida à admissão hospitalar, quando comparada com placebo ou administração de lidocaína. No entanto, não houve melhora do prognóstico neurológico. ${ }^{272,296}$

A amiodarona pode ser considerada para FV/TVSP que não responde à $\mathrm{RCP}$, desfibrilação e terapêutica vasopressora
(Classe de Recomendação Ilb; Nível de Evidência B). A dose inicial deve ser de 300 mg por via intravenosa ou intraóssea e pode ser administrada uma dose adicional de $150 \mathrm{mg}$, intercalada com vasopressor. ${ }^{272,296-298}$

\section{B) Lidocaína}

Evidências recentes mostraram que a lidocaína apresentou mesma taxa de sobrevida quando comparada à amiodarona em PCR extra-hospitalar. A dose inicial recomendada é de 1,0 a 1,5 mg/kg por via intravenosa. Se a FV/TVSP persistir, uma segunda dose de 0,5 a $0,75 \mathrm{mg} / \mathrm{kg}$ pode ser administrada. Seu uso pode ser considerado após a PCR em FV/TVSP em infusão continua (Classe de Recomendação Ilb; Nível de Evidência C). ${ }^{272,299-302}$

\section{C) Sulfato de magnésio}

Dois estudos observacionais mostraram que a administração de sulfato de magnésio por via intravenosa pode finalizar TV polimórfica do tipo TdP, porém não é efetiva para TV polimórfica em pacientes com intervalo QT normal.

Em três estudos clínicos randomizados, o magnésio não foi associado à maiores taxas de RCE, e nem à melhora no índice de alta hospitalar e no prognóstico neurológico, independente do ritmo inicial da PCR. ${ }^{303}$

A dose deve ser 1 a 2 g, diluída em $10 \mathrm{~mL}$ de soro glicosado 5\% (Classe de Recomendação Ilb; Nível de Evidência C). Suas indicações são: suspeita de hipomagnesemia; TV com padrão eletrocardiográfico de TdP. Não se recomenda seu uso rotineiro na RCP (Classe de Recomendação III; Nível de Evidência B). ${ }^{250,275,303}$

\section{Quadro 5.8 - Orientação uso de drogas e manobras no Suporte Avançado de Vida em adultos}

\begin{tabular}{|c|c|c|}
\hline Recomendações & Classe de Recomendação & Nível de Evidência \\
\hline É razoável que a adrenalina seja administrada assim que possível após o início da PCR em AESP/assistolia & Ilb & C \\
\hline É razoável que a adrenalina seja administrada após o primeiro ciclo de RCP em FVITVSP & $\mathrm{llb}$ & C \\
\hline Em PCR, o uso de corticosteroides não mostrou benefício & $\mathrm{llb}$ & C \\
\hline $\begin{array}{l}\text { Amiodarona ou lidocaína devem ser considerada como antiarrítmico de primeira escolha para FV/TVSP que } \\
\text { não responde a RCP, desfibrilação e vasopressor }\end{array}$ & $\mathrm{Ilb}$ & B \\
\hline O uso de lidocaína pode ser considerado alternativa na PCR em FV/TVSP & $\mathrm{llb}$ & B \\
\hline $\begin{array}{l}\text { O soco precordial pode ser considerado na TV instável em pacientes monitorizados, quando um desfibrilador } \\
\text { não está imediatamente pronto para uso }\end{array}$ & $\mathrm{Ilb}$ & B \\
\hline O uso precoce de betabloqueadores pode ser considerado em pacientes pós-RCE por ritmos de FV/TVSP & Ilb & $\mathrm{B}$ \\
\hline Atropina não é recomendada no tratamento da PCR & Ilb & C \\
\hline Não existem benefícios com a administração rotineira de bicarbonato de sódio durante a PCR & III & $\mathrm{B}$ \\
\hline Não se recomenda o uso rotineiro de sulfato de magnésio na RCP & III & $\mathrm{B}$ \\
\hline A administração rotineira de cálcio, durante a PCR, não é recomendada & III & $\mathrm{B}$ \\
\hline Fibrinolíticos não devem ser administrados rotineiramente na PCR & III & B \\
\hline A colocação de marca-passo, durante a PCR, não é recomendada & III & B \\
\hline
\end{tabular}

PCR: parada cardiorrespiratória; AESP: atividade elétrica sem pulso ou assistolia; RCP: ressuscitação cardiopulmonar; FV: fibrilação ventricular; TVSP: taquicardia ventricular sem pulso; TV: taquicardia ventricular; RCE: retorno da circulação espontânea. 


\section{D) Procainamida}

A procainamida foi recentemente estudada como agente antiarrítmico em PCR extra-hospitalar em FV/TVSP refratária à lidocaína. Não se observaram benefícios nas taxas de admissão hospitalar com seu uso nesta situação. ${ }^{200}$

\section{E) Betabloqueadores}

Estudo observacional com uso de betabloqueadores via oral ou intravenosa após a PCR por FV/TVSP mostrou reduzir mortalidade 72 horas após e em 6 meses. ${ }^{304}$ No entanto, podem levar à piora hemodinâmica, exacerbar sinais de Insuficiência Cardíaca (IC) e causar arritmias. ${ }^{305}$

Dessa forma, existe apenas fraca evidência de que o uso de betabloqueadores pós-PCR deva ser utilizado de rotina. Seu uso precoce pode ser considerado em pacientes recuperados de PCR em FV/TVSP (Classe de Recomendação Ilb; Nível de Evidência C).

\section{Recomendações atuais}

No cenário de FV ou FV/TVSP, refratárias ou recorrentes às manobras de RCP (incluindo desfibrilação e uso de vasopressores), amiodarona ou lidocaína intravenosas são indicadas como medicação de primeira escolha. O sulfato de magnésio, 1 a 2 g por via intravenosa, pode ser administrado em casos suspeitos de hipomagnesemia ou TdP. No entanto, seu uso rotineiro não está indicado (Classe de Recomendação III; Nível de Evidência B). O uso precoce de betabloqueadores pode ser considerado em pacientes recuperados de PCR em FV/TVSP (Classe de Recomendação Ilb; Nível de Evidência C).

\subsubsection{Intervenções Não Recomendadas Rotineiramente durante a Parada Cardiorrespiratória}

\section{A) Reposição volêmica}

Não há evidências definitivas quanto à administração rotineira de fluidos intravenosos durante a PCR. Considerar infusão quando houver suspeita de PCR por hipovolemia. ${ }^{306}$

\section{B) Atropina}

A atropina antagoniza a ação da acetilcolina, um neurotransmissor parassimpático, nos receptores muscarínicos. Dessa forma, ela bloqueia o efeito do nervo vago tanto no nó sinoatrial como no nó atrioventricular, aumentando a frequência de disparos do nó sinusal e facilitando a condução atrioventricular, o que, teoricamente, podia torná-la útil para uso em casos de assistolia ou AESP. No entanto, diversos estudos ${ }^{307}$ mostraram que ela não esteve associada com benefícios consistentes. Essa droga não é, assim, mais recomendada no tratamento da PCR (Classe de Recomendação IIb; Nível de Evidência B). ${ }^{200}$

\section{C) Bicarbonato de Sódio}

O melhor tratamento da acidose na PCR é a compressão torácica adequada. Além disso, há algum benefício com a ventilação. Durante a PCR/RCP, a gasometria arterial não se correlaciona com o estado metabólico tecidual. Ademais, o uso de bicarbonato pode ter alguns efeitos deletérios, como aumento na geração de dióxido de carbono, exacerbando a acidose intracelular e o desvio da curva de dissociação da hemoglobina para a esquerda (Classe de Recomendação III; Nível de Evidência B). Em situações especiais, como acidose metabólica prévia, hipercalemia e intoxicação por antidepressivos tricíclicos, sua administração pode ser benéfica. Quando for usado, a dose inicial é de $1 \mathrm{mEq} / \mathrm{kg} .{ }^{308}$

\section{D) Cálcio}

O cálcio apresenta papel no mecanismo celular de contração miocárdica e da musculatura lisa vascular. Não há evidências científicas que deem suporte ao uso rotineiro do cálcio na RCP (Classe de Recomendação III; Nível de Evidência B). Seu uso pode ser considerado, na dose de 0,5 a $1 \mathrm{~g}$ (gluconato de cálcio $10 \%$, de 15 a $30 \mathrm{~mL}$, ou cloreto de cálcio $10 \%$, de 5 a $10 \mathrm{~mL}$ ), nas seguintes condições de PCR: hiperpotassemia, hipocalcemia e intoxicação por agentes bloqueadores dos canais de cálcio. Não utilizar soluções de cálcio e bicarbonato de sódio simultaneamente na mesma via de administração. ${ }^{309,310}$

\section{E) Corticosteroides}

Em PCR, não há dados suficientes para recomendar o uso de corticosteroides de rotina (Classe de Recomendação IIb; Nível de Evidência C), sendo necessários novos estudos. ${ }^{311-313}$

\section{F) Fibrinolíticos}

Fibrinolíticos não devem ser administrados rotineiramente na PCR (Classe de Recomendação III; Nível de Evidência B). ${ }^{276,277,312} \mathrm{Na}$ suspeita de embolia pulmonar, ou se esta for a causa da PCR, seu uso empírico pode ser considerado (Classe de Recomendação Ila; Nível de Evidência B). ${ }^{280,313}$

\section{G) Marca-Passo na Parada Cardiorrespiratória}

Não existem estudos que indiquem benefícios na sobrevida com a colocação de marca-passo, durante a PCR (Classe de Recomendação III; Nível de Evidência B). ${ }^{314,315}$

\section{H) Soco Precordial}

O soco precordial pode ser considerado para finalização de TV instável em pacientes monitorizados, quando um desfibrilador não está imediatamente pronto para uso (Classe de Recomendação Ilb; Nível de Evidência B). Contudo não se deve retardar a CVE. ${ }^{316-318}$

\subsection{Bradicardias}

Correspondem à alteração do ritmo cardíaco com Frequência Cardíaca (FC) menor que 50 bpm. ${ }^{200,319,320}$ Este limite é individual, e frequências menores do que essas podem ser consideradas fisiológicas para alguns pacientes e inadequadas para outros. ${ }^{321,322}$

O tratamento está indicado somente nos casos em que a bradicardia, independente de seu tipo ou causa, provoca sinais clínicos de baixo DC. ${ }^{200,319,323}$ 
As causas podem ser não cardíacas (uso de drogas; causas metabólicas ou endócrinas, distúrbios eletrolíticos, fatores neurológicos entre outros) ou de origem cardíaca (isquemia miocárdica, cardiopatia valvar ou doença degenerativa primária elétrica, entre outras).

Após o RCE, durante a modulação terapêutica da temperatura, a presença de bradicardias associa-se a prognóstico favorável. ${ }^{324,325}$

Os pacientes devem ser monitorados e fornecer terapia imediata na presença de hipotensão, convulsões e outros sinais de choque relacionados à bradicardia (Figura $5.10 \mathrm{e}$ Quadro 5.9). ${ }^{319}$ Os Bloqueios Atrioventriculares (BAV) podem ser divididos de acordo com a gravidade, a saber:200,319,326 BAV de primeiro grau; BAV de segundo grau, que inclui tipo I ou Mobitz I ou fenômeno de Wenckebach, e tipo II ou Mobitz tipo I; BAV total ou de terceiro grau.

\section{A) Atropina}

Droga de escolha para bradicardia sintomática aguda na ausência de causas reversíveis (Classe de Recomendação Ila; Nível de Evidência B). ${ }^{327-329}$ O sulfato de atropina reverte as bradicardias mediadas por colinérgicos e deve ser considerada medida temporária, enquanto se aguarda a colocação de um MPTC, nos pacientes com BAV sintomático de alto grau. A atropina é útil para tratar a bradicardia sinusal sintomática e pode ser benéfica para qualquer tipo de BAV em nível nodal. ${ }^{200,319,329}$

A dose recomendada para a atropina na bradicardia é de 0,5 mg por via intravenosa a cada 3 a 5 minutos, com dose máxima total de $3 \mathrm{mg}$. As doses de sulfato de atropina menores que $0,5 \mathrm{mg}$ paradoxalmente podem causar lentificação do ritmo.

Deve utilizar-se atropina cautelosamente na presença de SCA. ${ }^{319}$

\section{B) Drogas alternativas}

A dopamina e a adrenalina são drogas alternativas, quando a bradicardia não responde à atropina e como medida transitória, para recuperação ou enquanto se aguarda a disponibilidade de um marca-passo. ${ }^{6,319}$

O cloridrato de dopamina tem ações alfa e betaadrenérgica (Classe de Recomendação Ilb; Nível de Evidência B). A infusão é de 2 a $20 \mathrm{mcg} / \mathrm{kg} /$ minuto e pode ser associada à adrenalina ou ser administrada isoladamente. A dose deve ser titulada de acordo com a resposta do paciente. .,138 $^{6,}$

A adrenalina pode ser usada em pacientes sintomáticos não responsivos à atropina, na indispinibilidade de marcapaaso ou caso este não ofereça debito adequado (Classe de Recomendação Ilb; Nível de Evidência B). Dose inicial recomendada 2 a $10 \mathrm{mcg} /$ minuto titulada de acordo com a resposta do paciente. ${ }^{200,328}$

\section{C) Marca-passo transcutâneo}

Intervenção para o tratamento da bradicardia sintomática, na qual sua instalação deve ser imediata (Classe de Recomendação Ila; Nível de Evidência B). ${ }^{330} \mathrm{O}$ acionamento pode ser doloroso e não produzir captura mecânica eficaz. Este dispositivo tem como finalidade oferecer condição hemodinâmica até a reversão do ritmo, tratamento da causa desencadeante ou implante de um Marca-Passo Transvenoso (MPTV). Recomenda-se solicitar a avaliação de um especialista. ${ }^{200,320}$

\subsection{Taquicardias}

Ritmo taquicárdico é aquele cuja frequência é superior a 100 bpm. O espectro de apresentação das taquicardias é amplo, de casos completamente assintomáticos, identificados durante investigação por outra queixa clínica, até eventos com instabilidade hemodinâmica significante, que podem ser fatais, caso nenhuma intervenção seja realizada. A menos que disfunção ventricular importante esteja presente, é consenso entre os especialistas que somente ritmos acima de 150 bpm causam sintomas de comprometimento hemodinâmico.

Em indivíduos assintomáticos, uma ampla gama de taquiarritmias pode ser identificada e não necessitar de qualquer tratamento específico imediato, já que não determinam alterações clínicas. Devem, contudo, ser documentadas de modo a permitir reavaliação posterior para definição diagnóstica e conduta terapêutica apropriada.

Nos pacientes sintomáticos, devem ser estabelecidos dois aspectos fundamentais. O primeiro diz respeito à intensidade dos sintomas. Pacientes sintomáticos podem apresentar sintomas desconfortáveis, como palpitações, tontura e/ou dispneia leve, mas não apresentar qualquer sinal clínico de comprometimento hemodinâmico. A consequência funcional de uma taquiarritmia é a redução do DC. Diversos sistemas manifestam sinais e sintomas como os listados a seguir, que são indicativos deste comprometimento hemodinâmico: alteração no nível de consciência; hipotensão arterial sistêmica (Pressão Arterial Sistólica - PAS $<90$ mmHg) ou choque circulatório com alteração da perfusão periférica; congestão pulmonar; e dor precordial anginosa.

O segundo aspecto fundamental é o estabelecimento de uma relação causal entre a presença da taquiarritmia e os sintomas. Em que pese o fato de existir comprometimento hemodinâmico que necessite tratamento imediato, nem sempre é possível estabelecer relação direta. Por exemplo, em situações de hipovolemia secundária a uma hemorragia interna ou a um estado de choque séptico, pode ocorrer taquicardia sinusal reacional, a qual pode ser sintomática, mas cujo tratamento deve ser da causa primária. Se tais eventos ocorrerem em indivíduos com bloqueios de ramo ou Fibrilação Atrial (FA), podem determinar registros eletrocardiográficos compatíveis com taquiarritmias potencialmente letais. Cabe, portanto, sempre tratar o indivíduo - e não o Eletrocardiograma (ECG). Em todas as situações, é mandatória uma história clínica breve, de modo a estabelecer a relação causa-efeito entre a taquiarritmia e os sintomas presentes.

Pode-se, de um ponto de vista prático, classificar inicialmente as taquicardias em dois grupos, independente do diagnóstico eletrocardiográfico: instáveis e estáveis. 


\section{Atualização}

\section{Algoritmo das Bradicardias}

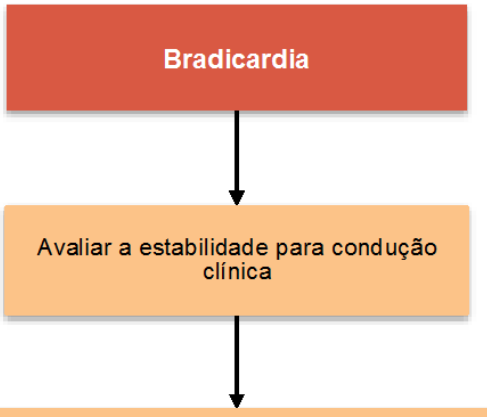

Identificar e tratar causa subjacente

Manter via aérea patente; auxiliar a respiração conforme necessidade

Oxigênio (oxigênio se SatO $2 \leq 94 \%$ )

Monitor cardíaco para identificar o ritmo, monitorar pressão arterial e oximetria

Acesso venoso

Realizar ECG de 12 derivações, se disponível, não retarde o tratamento

Dose Atropina IV:

$0,5 \mathrm{mg}$ em bolus

Repetir a cada $3-5 \mathrm{~min}$

Dose máxima: $3 \mathrm{mg}$

Dopamina IV

Velocidade de infusão: $2-20 \mathrm{mcg} / \mathrm{kg} / \mathrm{min}$

Epinefrina IV:

Velocidade de infusão: $2-10 \mathrm{mcg} / \mathrm{min}$

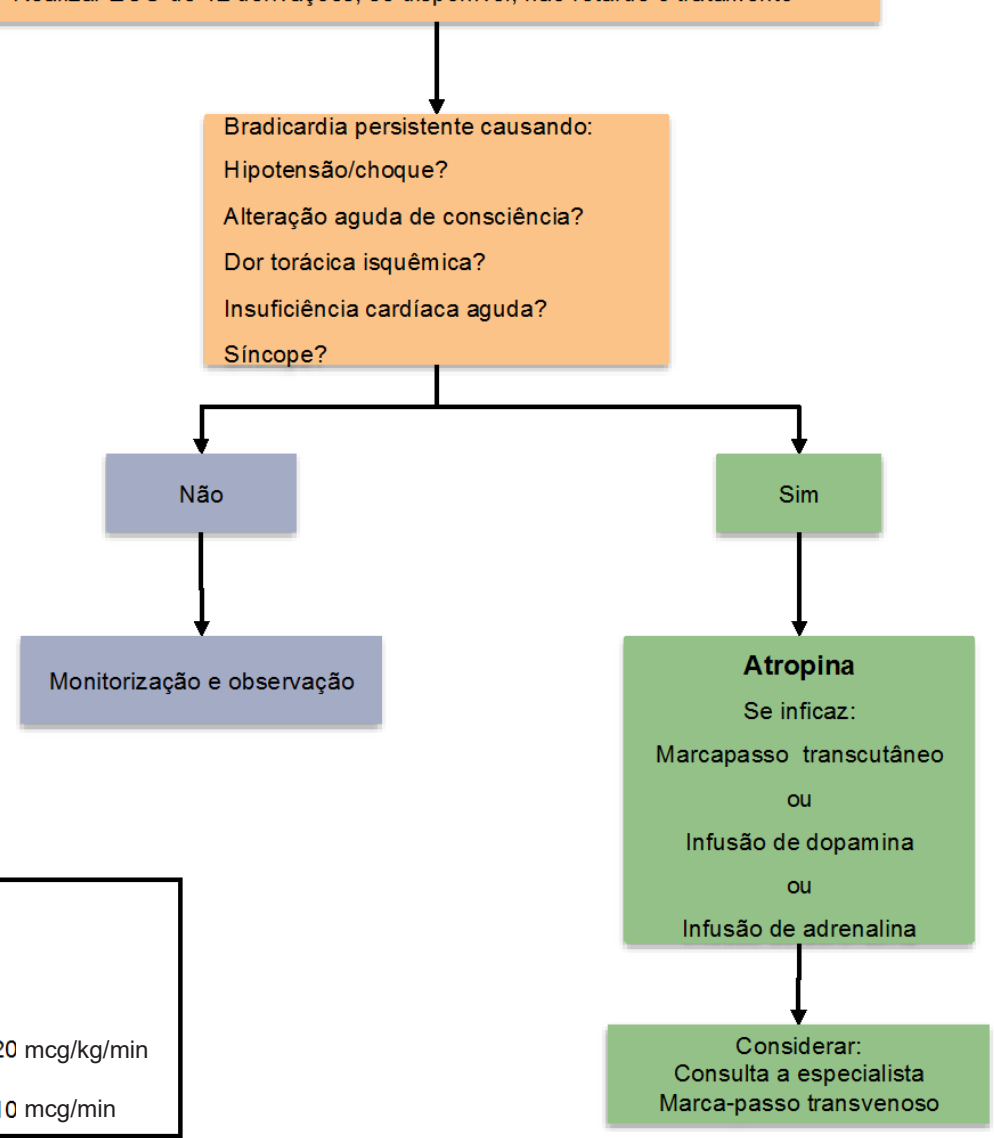

Figura 5.10 - Algoritmo para tratamento de bradicardias. SatO ${ }_{2}$ : saturação de oxigênio; ECG: eletrocardiograma; IV: intravascular.

As primeiras são aquelas que apresentam FC e são geralmente superiores a 150 bpm (caso não haja disfunção ventricular acentuada), com pelo menos um dos sinais ou sintomas de comprometimento hemodinâmico listados. Neste caso, independente do diagnóstico eletrocardiográfico, a CVE sincronizada deve ser prontamente instituída de modo a restaurar um ritmo cardíaco organizado e com frequência menor capaz de produzir DC mais efetivo. 
Quadro 5.9 - Orientação para o tratamento farmacológico das bradicardias

\begin{tabular}{lcc}
\hline Recomendação & $\begin{array}{c}\text { Classe de } \\
\text { Recomendação }\end{array}$ & $\begin{array}{c}\text { Nível de } \\
\text { Evidência }\end{array}$ \\
\hline Atropina & $\| l a$ & $\mathrm{~B}$ \\
Marca-passo transcutâneo & $\| l a$ & $\mathrm{~B}$ \\
Adrenalina e dopamina & $\mathrm{llb}$ & $\mathrm{B}$ \\
\hline
\end{tabular}

A seguir, descreveremos a abordagem das taquicardias estáveis. Do ponto de vista de atendimento emergencial, podemos dividi-las em dois tipos, de acordo com a duração do complexo QRS: QRS estreito ( $<120$ milissegundos) e QRS largo ( $\geq 120$ milissegundos). O quadro 5.10 traz um resumo dos principais antiarrítmicos, suas doses e efeitos adversos.

\subsubsection{Taquicardias com QRS Estreito (QRS $<120$ Milissegundos)}

\section{A) Tratamento inicial das taquicardias com QRS estreito}

As taquicardias de QRS estreito podem ser subdivididas, de acordo com o ILCOR, ${ }^{200,331} \mathrm{em}$ irregulares como FA, flutter atrial e Taquicardia Atrial (TA) multifocal, ou regulares como Taquicardia por Reentrada Nodal (TRN), Taquicardia por Reentrada Atrioventricular (TRAV), flutter atrial e TA.

Para melhor raciocínio terapêutico, também é possível dividi-las de acordo com a dependência do nó atrioventricular para seu início e manutenção. Assim, temos as taquicardias em que o circuito da arritmia utiliza o nó atrioventricular (TRN, TRAV e taquicardia juncional) e as que não o utilizam (taquicardia sinusal, TA, TA multifocal, FA e flutter).

Em pacientes estáveis, uma abordagem rápida e dirigida, visando ao diagnóstico genérico e à terapêutica é, na maioria das vezes, suficiente para o cenário da sala de emergência. ${ }^{331-335} \mathrm{O}$ algoritmo para as taquiarritmias de QRS estreito está sumarizado na figura 5.11.

\section{B) Manobras vagais (manobra de Valsalva e massagem do seio carotídeo)}

As manobras vagais são efetivas no tratamento das taquicardias supraventriculares. ${ }^{336,337}$ Elas induzem a uma diminuição temporária da atividade do nó sinusal e da condução do nó atrioventricular, por estimular barorreceptores da aorta que, por sua vez, deflagram reflexo de aumento de reposta vagal e diminuição de resposta simpática. Na Massagem do Seio Carotídeo (MSC), temos esse mesmo reflexo, deflagrado pela pressão externa no bulbo carotídeo, estimulando seus barorreceptores.

A manobra de Valsalva exige que o paciente force a expiração contra a glote fechada. Para tanto, deve-se colocar o dorso da mão do paciente na boca, de modo a evitar a saída de ar, ocluir o nariz, colocar a mão do profissional de saúde no abdome, para criar resistência, e, em seguida, solicitar que o paciente faça o movimento de expiração contra esta resistência. ${ }^{338}$ A efetividade da manobra de
Valsalva para cessação de Taquicardia Supraventricular (TSV) foi avaliada em revisão do grupo Cochrane em 2015, não sendo encontradas evidências definitivas a favor ou contra seu uso, com necessidade de mais estudos na área, bem como padronização de sua técnica. ${ }^{339}$

A MSC é realizada com o paciente em posição supina, com o pescoço hiperestendido. Antes do procedimento, deve-se observar a presença de sopro carotídeo, que é uma contraindicação formal, assim como Acidente Vascular Cerebral (AVC) ou acidente isquêmico transitório prévios (exceto se exame de imagem de carótidas sem doença aterosclerótica), Infarto Agudo do Miocárdio (IAM) nos últimos 6 meses e história de arritmia ventricular grave (TV/ FV). ${ }^{340}$ Realiza-se pressão estável em região inferior ao ângulo da mandíbula, na altura da cartilagem tireoidea, perto do pulso arterial, por 5 a 10 segundos. $^{337,341}$ Se não houver resposta positiva, pode-se repetir a manobra do outro lado, após 2 minutos.

A MSC é, em geral, segura e bem-tolerada. Porém podem ocorrer algumas complicações: hipotensão importante, bradicardia com BAV avançado e síncope, AVE, acidente isquêmico transitório e arritmias. Toda MSC deve ser realizada sob monitorização eletrocardiográfica e pressórica. Por se tratar de uma resposta fisiológica do tipo "tudo ou nada", a massagem deve ser interrompida assim houver redução na FC.

\section{C) Adenosina}

Adenosina é uma droga que diminui a condução pelo nó atrioventricular e promove vasodilatação coronária. Possui meia-vida de menos de 5 a 10 segundos, tendo efeito fugaz, porém efetivo no término da maioria das taquicardias de QRS estreito. ${ }^{335,341-343}$ Efeitos colaterais podem ocorrer em até $60 \%$ dos casos. Os principais efeitos colaterais da adenosina são: ${ }^{344}$

- Cardiovasculares: flush facial, palpitação, hipotensão e dor torácia.

- Bradicardias: bloqueio atrioventricular de qualquer grau.

- Taquicardias: extrassístoles ventriculares, TV não sustentada, TV monomórfica e polimórfica (TdP).

- Respiratórios: dispneia (12\%), hiperventilação e broncoespasmo.

- Sistema nervoso central: cefaleia (8 a 25\%), tonturas e vertigens (20\%), parestesias e turvação visual.

É importante orientar previamente o paciente que poderá apresentar pressão torácica importante, com sensação de "morte iminente", porém tais efeitos são transitórios.

As contraindicações absolutas à adenosina são: ${ }^{345,346}$ bloqueio atrioventricular de segundo ou terceiro graus, disfunção do nó sinusal e FA pré-excitada.

\section{D) Diagnóstico diferencial das taquicardias de $Q R S$ estreito}

A MSC e a adenosina podem produzir quatro resultados em pacientes com taquicardia de QRS estreito (Figura 5.12):

- Diminuição da atividade do nó sinusal, causando redução transitória da atividade atrial (pacientes com taquicardia 


\section{Atualização}

Quadro 5.10 - Indicações, doses e efeitos colaterais (EC) dos fármacos com ação nas arritmias

\begin{tabular}{|c|c|c|c|}
\hline Medicação & Quando & Como & EC \\
\hline Adenosina & $\begin{array}{l}\text { TSV estável (efeito } \\
\text { diagnósitco) }\end{array}$ & $\begin{array}{c}6 \mathrm{mg}, \mathrm{IV} \text {, em bólus rápido } \\
\text { Caso não haja resposta, repetir } 12 \mathrm{mg} \\
\text { Cada dose deve ser seguida de } 20 \mathrm{~mL} \text { de solução salina } \\
\text { EV rápido e elevado o membro por } 10-20 \text { segundos }\end{array}$ & $\begin{array}{c}\text { Rubor facial, tosse, dispneia, broncoespasmo } \\
\text { Evitar em pacientes com asma } \\
\text { Não é eficaz nos pacientes em uso de } \\
\text { metilxantinas } \\
\text { Se acesso central, realizar metade da dose }\end{array}$ \\
\hline $\begin{array}{l}\text { Bloqueadores de } \\
\text { canal de cálcio }\end{array}$ & $\begin{array}{l}\text { TSV estável com função } \\
\text { ventricular preservada, para } \\
\text { controle de frequência }\end{array}$ & $\begin{array}{l}\text { Verapamil - 2,5-5 mg IV lento. Podem-se repetir } 5-10 \mathrm{mg} \\
\text { após } 15 \text { a } 30 \text { minutos da primeira dose até total de } 20 \mathrm{mg} \\
\text { Diltiazem - 0,25 mg/kg IV em } 2 \text { minutos. Pode-se repetir } \\
\quad 0,35 \mathrm{mg} / \mathrm{kg} \text { após } 15 \text { minutos da primeira dose }\end{array}$ & $\begin{array}{c}\text { Bradicardia } \\
\text { Contraindicações: graus avançados de BAV, IC, } \\
\text { choque cardiogênico, hipotensão arterial }\end{array}$ \\
\hline Betabloqueadores & $\begin{array}{l}\text { TSV estável com função } \\
\text { ventricular preservada e } \\
\text { DPOC compensada, para } \\
\text { controle de frequência }\end{array}$ & $\begin{array}{l}\text { Metoprolol } 5 \mathrm{mg} \text { IV lento até } 15 \mathrm{mg} \\
\text { Propranolol } 1 \mathrm{mg} \text { IV a cada } 5 \mathrm{~min} \text { até } 5 \mathrm{mg}\end{array}$ & $\begin{array}{c}\text { Bradicardia } \\
\text { Contraindicações: graus avançados de BAV, IC, } \\
\text { choque cardiogênico, hipotensão arterial } \\
\text { Pode precipitar/agravar broncoespasmo }\end{array}$ \\
\hline Amiodarona & $\begin{array}{c}\text { TSV, FA/ flutter para } \\
\text { controle de frequência em } \\
\text { disfunção ventricular/IC } \\
\text { descompensada } \\
\text { TV monomórfica estável } \\
\text { FV/TVSP }\end{array}$ & $\begin{array}{c}\text { Dose de ataque (exceto PCR) } \\
150 \text { mg em } 100 \text { mL em } 10-20 \text { minutos, podendo ser } \\
\text { repetido a cada } 10-20 \text { minutos } \\
\text { Manutenção } 1 \text { mg/minuto nas primeiras } 6 \text { horas e } 0,5 \mathrm{mg} / \\
\text { minuto nas } 18 \text { horas consecutivas } \\
\text { Dose máxima diária: } 2,2 \mathrm{~g} \\
\text { Dose na PCR: primeira dose } 300 \mathrm{mg} \text { em bólus, segunda } \\
\text { dose } 150 \mathrm{mg} \text { em bólus }\end{array}$ & $\begin{array}{c}\text { Hipotensão arterial } \\
\text { Bradicardia } \\
\text { Diminui metabolismo da digoxina e da varfarina } \\
\text { Efeito aditivo com outras medicações que } \\
\text { prolongam QT }\end{array}$ \\
\hline Digital & $\begin{array}{l}\text { TSV, FA/flutter para controle } \\
\text { de frequência }\end{array}$ & Lanatosídeo C 0,8 a 1,6 mg em até 4 doses fracionadas & $\begin{array}{l}\text { Toxicidade: graus variados de BAV e bradicardia } \\
\text { Interações medicamentosas: quinidina, } \\
\text { antagonista do cálcio, amiodarona, } \\
\text { espironolactona, eritromicina, tetraciclina } \\
\text { Monitorar intervalo QT }\end{array}$ \\
\hline Procainamida & $\begin{array}{l}\quad \text { TSV estável } \\
\text { Reversão de FA e flutter } \\
\text { Controle de FC no WPW }\end{array}$ & $\begin{array}{c}\text { Ataque } 20 \mathrm{mg} / \text { minuto até resolução da arritmia, } \\
\text { hipotensão, alargamento do QRS > 50\% do basal ou } \\
\text { dose máxima de } 17 \mathrm{mg} / \mathrm{kg} \\
\text { Manutenção } 1 \text { a } 4 \mathrm{mg} / \text { minuto }\end{array}$ & $\begin{array}{c}\text { Contraindicações: lúpus eritematoso sistêmico, } \\
\text { QT longo e reação de hipersensibilidade a } \\
\text { procainas }\end{array}$ \\
\hline Proprafenona & $\begin{array}{l}\text { Reversão de FA flutter atrial } \\
\text { Controlar FC e reversão de } \\
\text { FA no WPW }\end{array}$ & $\begin{array}{l}\qquad 450 \text { a } 600 \text { mg VO } \\
\text { Primeiro uso sempre intra-hospitalar }\end{array}$ & $\begin{array}{c}\text { Contraindicações: IC, doença do nó sinusal, } \\
\text { bradicardia grave, BAV, DPOC, hipotensão, } \\
\text { choque cardiogênico }\end{array}$ \\
\hline Sotalol & $\begin{array}{l}\text { TSV estável } \\
\text { Controlar FC e reversão de } \\
\text { FA no WPW }\end{array}$ & 1 a $1,5 \mathrm{mg} / \mathrm{kg}$ EV lento a no máximo $10 \mathrm{mg} /$ minuto & $\begin{array}{c}\text { Contraindicações: asma, bradicardia, BAV de } \\
\text { grau avançado, síndrome do QT longo, choque } \\
\text { cardiogênico, ICC } \\
\text { Pacientes com hipocalemia ou hipomagnesemia } \\
\text {-predisposição à TV polimórfica }\end{array}$ \\
\hline Lidocaína & $\begin{array}{l}\text { TV monomórfica estável } \\
\text { FV/TVSP }\end{array}$ & $\begin{array}{c}1 \text { a } 1,5 \mathrm{mg} / \mathrm{kg} \text { em bólus. Manutenção de } 1-4 \mathrm{mg} / \text { minuto } \\
\text { Primeira dose 1-1,5 mg/kg em bólus } \\
\text { Segunda dose - 0,5-0,75 mg/kg em bólus. Dose máxima } \\
\text { de } 3 \mathrm{mg} / \mathrm{kg}\end{array}$ & Efeito pró-arrítmico descrito \\
\hline
\end{tabular}

TSV: taquicardia supraventricular; IV: via intravenosa; EV: via endovenosa; BAV: bloqueio atrioventricular; IC: insufuciência cardiaca; DPOC: doença pulmonar obstrutiva crônica; TSV: taquicardia supraventricular; FA: fibrilação atrial; TV: taquivardia ventricular; TVSP: taquicardia ventricular sem pulso; PCR: parada cardiorrespiratória; WPW: síndrome de Wolff-Parkinson-White; VO: via oral; ICC: insuficiência cardíaca congestiva.

sinusal). Nestes casos, a onda P fica evidente no traçado eletrocardiográfico, e o retorno da FC aos níveis basais sugere ser esta decorrente de resposta fisiológica.

- O atraso da condução pelo nó atrioventricular pode levar a um bloqueio atrioventricular, podendo revelar a atividade atrial (TA e flutter) não sinusal.

- Término da taquicardia por interrupção do circuito de reentrada, nas taquicardias dependentes do nó atrioventricular (TRN e TRAV).

- Ausência de resposta.
O diagnóstico diferencial das taquiarritmias de QRS estreito deve ser de forma mandatória e feito com registro de ECG de 12 derivações e tira de ritmo longa. Algoritmos que levam em consideração os dados eletrocardiográficos de regularidade do intervalo $R R$, presença ou ausência de onda P, frequência atrial, morfologia de atividade atrial, intervalo RP e relação atrioventrículo auxiliam no diagnóstico da taquiarritmia. Para o clínico emergencista, a conduta clínica independe do diagnóstico preciso, mas o registro eletrocardiográfico de 12 derivações obtido previamente 


\section{Algoritmo Taquicardias de Complexo Estreito}

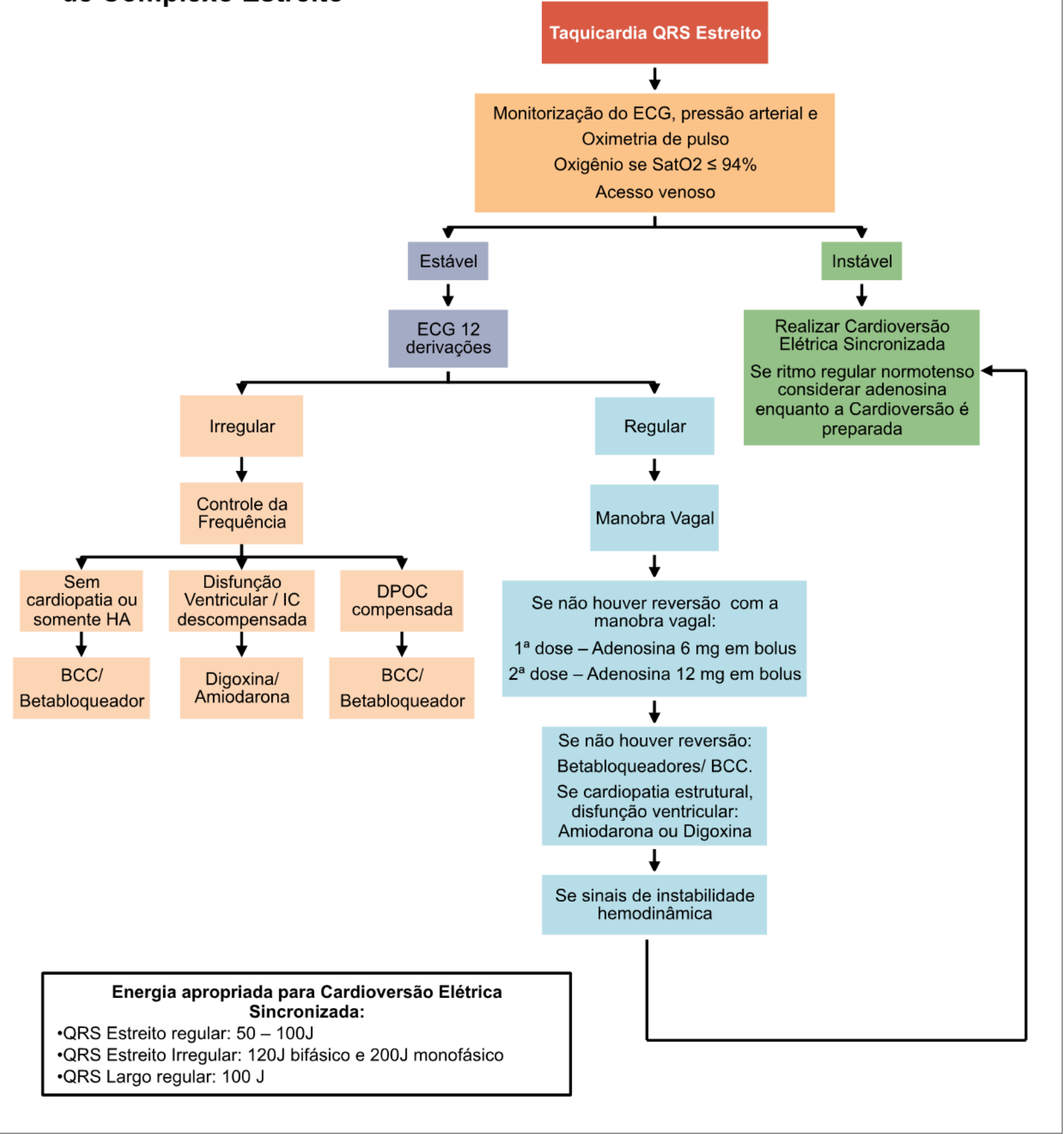

Figura 5.11 - Algoritmo para a abordagem das taquiarritmias supraventriculares regulares. ECG: eletrocardiograma; SatO2: saturaçãoo de oxigênio; HA: hipertensão arterial; BCC: bloqueador dos canias de cálcio; IC: insuficiência cardiaca; DPOC: doença pulmonar obstrutiva crônica.

pode auxiliar o cardiologista a programar as investigações e tratamento posterior.

A taquicardia de QRS estreito e regular mais frequente é a TRN, respondendo por mais de $50 \%$ dos casos. Após, temos a TRAV $^{347}$ e a TA. ${ }^{348}$
A FA e o flutter atrial situam-se em um grupo de maior risco para eventos cardioembólicos, tendo suas abordagens baseadas em horas do início da arritmia, tratamento antitrombótico prévio e decisão entre reversão do ritmo e controle de frequência. ${ }^{349}$ 


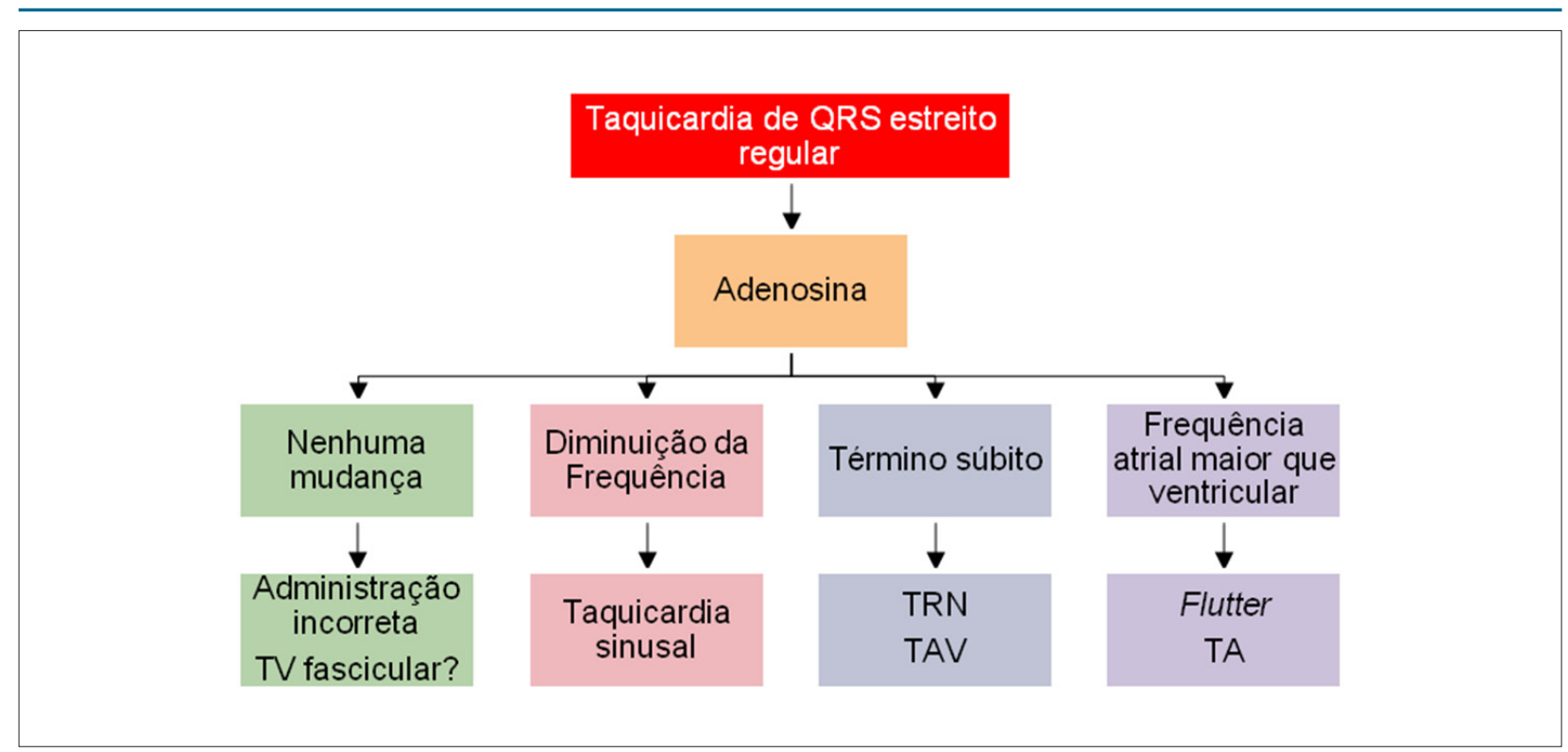

Figura 5.12 - Algoritmo para diagnóstico diferencial das taquicardias com QRS estreito, de acordo com a resposta à infusão de adenosina. TV: taquicardia ventricular; TRN: taquicardia por reentrada nodal; TA: taquicardia atrial.

\section{E) Drogas antiarrítmicas}

Caso após realização de manobras vagais e adenosina, não houver resolução da arritmia, procede-se à administração de outros bloqueadores do nó atrioventricular, como os bloqueadores de canal de cálcio não diidropiridínicos e betabloqueadores.

Verapamil e diltiazem mostraram-se efetivos em reversão para ritmo sinusal em diversos ensaios clínicos ${ }^{330}$ e permanecem como tratamento de primeira linha para o tratamento das taquicardias supraventriculares. Betabloqueadores, como nadolol, metoprolol ou esmolol, também, podem ser usados, porém poucos estudos clínicos randomizados embasam o efeito de reversão para ritmo sinusal. ${ }^{350-352}$ Recente estudo sugere probabilidade de reversão da TSV regular de 95\% com uso de diltiazem 0,25 $\mathrm{mg} / \mathrm{kg}$, enquanto esta foi de $59,6 \%$ e $64,91 \%$ após as doses de 6 e 12 mg de adenosina, respectivamente. ${ }^{353}$

É importante ressaltar que as DAA têm potencial próarrítmico e causam hipotensão arterial e bradicardias após reversão de uma arritmia, quando vários antiarrítmicos são utilizados em sequência. Desse modo, com exceção da adenosina, não se recomenda a administração sucessiva de várias DAA. Após a adequada utilização de uma droga até sua dose máxima, se não houver reversão da arritmia ou comprometimento hemodinâmico, o paciente deve ser considerado instável, e deve ser realizada a CVE sincronizada.

Para pacientes com disfunção ventricular sistólica, a amiodarona e a digoxina são as drogas mais utilizadas. Bloqueadores de canal de cálcio e betabloqueadores intravenosos devem ser evitados quando houver esta suspeita clínica (área cardíaca aumentada, edema de membros inferiores, hepatomegalia, turgência jugular a $45^{\circ}$ e história clínica de IC).
Não há evidências consistentes de benefício do uso de magnésio nas taquicardias de QRS estreito. ${ }^{353-355}$

\subsubsection{Fibrilação Atrial e Flutter Atrial}

$\mathrm{Na}$ abordagem da FA e do flutter atrial de alta resposta ventricular, alguns pontos devem ser definidos para a programação da terapêutica. Sinais de comprometimento hemodinâmico são indicação formal para CVE sincronizada. Em pacientes estáveis, dados como Fração de Ejeção de Ventrículo Esquerdo (FEVE), tempo de duração da arritmia (menor ou maior que 48 horas) e presença de préexcitação ventricular (síndrome de Wolf-Parkinson-White) são imprescindíveis para tomada de decisões acerca de indicação de anticoagulação, reversão do ritmo ou controle da resposta ventricular e avaliação da segurança para a reversão do ritmo.

\section{A) Início $<48$ horas}

A CVE é a terapia de escolha para se restaurar o ritmo sinusal, tendo em vista o baixo risco de embolismo neste período (atenção com pacientes com eventos tromboembólicos prévios, portadores de valvopatia e IC). ${ }^{356}$

A terapia farmacológica também pode ser recomendada, mas não é a primeira escolha (reservar para casos em que a CVE e seu preparo - sedação - impõem risco alto para o paciente). Vários estudos foram realizados para definir a eficácia de medicações na cardioversão química da FA. ${ }^{356-359}$

A flecainida (não disponível no Brasil) é muito efetiva na cardioversão da FA com menos de 24 horas, em apresentação intravenosa (reversão de 67 a 92\% em 6 horas), sendo mais efetiva que procainamida, sotalol, propafenona e amiodarona. A apresentação oral ("pílula de bolso") também mostrou-se tão eficaz quanto à apresentação intravenosa. ${ }^{360-364}$ 
A propafenona via oral ("pílula de bolso") mostrou-se muito efetiva na reversão do ritmo em FA em um estudo, com sucesso em 56 a 83\% dos pacientes. ${ }^{365-368}$

Ibutilida intravenosa, antiarrítmico da classe III, ainda não disponível no Brasil, também mostrou-se eficaz na reversão de FA em trials, porém nunca foi comparada com as drogas supracitadas. Possui a vantagem de poder ser utilizada em paciente com doença cardíaca estrutural, mas sem IC. ${ }^{365}$

A eficácia da amiodarona na cardioversão química da FA é controversa, estando seu uso reservado para controle de frequência e para pacientes com doença estrutural. Alguns estudos referiram a mesma eficácia que o placebo, e outros que a compararam com antiarrítmicos diversos demonstraram eficácia inferior. ${ }^{366}$ Outros estudos observaram eficácia, porém com reversão após mais de 8 horas. ${ }^{367}$

O vernakalant, nova droga bloqueadora de correntes de sódio e potássio, também não disponível no Brasil, mostrouse eficaz em alguns estudos clínicos na reversão da FA. ${ }^{368,369}$ O sotalol e a dronedarona não são recomendados para a cardioversão da FA. ${ }^{370} \mathrm{~A}$ digoxina está indicada apenas para o controle da resposta ventricular.

\section{B) Início > 48 horas ou duração desconhecida}

Aumenta-se o risco de formação de trombo em átrio esquerdo e de eventos cardioembólicos. Assim, devem-se iniciar anticoagulação e decidir posteriormente sobre a reversão do ritmo. Duas abordagens são possíveis: realizar anticoagulação efetiva (Razão Normalizada Internacional - RNI - terapêutica) por 3 semanas, e proceder à cardioversão e manter anticoagulação por mais 4 semanas; ou realizar ecocardiograma transesofágico para exclusão de trombo, iniciar anticoagulação e realizar cardioversão do ritmo no mesmo tempo, mantendo anticoagulação por mais 4 semanas.

Para controle de frequência em pacientes com disfunção ventricular, a droga recomendada é a digoxina. Betabloqueadores e amiodarona também podem ser usados. ${ }^{370}$

Estudo comparando uso de metoprolol 0,15 mg/kg com diltiazem $0,25 \mathrm{mg} / \mathrm{kg}$ para pacientes com FA/flutter de alta resposta ventricular mostrou maior probabilidade de controle da FC com diltiazem, com menor risco de eventos adversos. Pelas características metodológicas deste estudo, precisamos de mais evidências para fortalecer recomendações direcionadas. ${ }^{371}$

\section{C) Tratamento de fiblilção atrial/flutter em pacientes com síndrome de Wolf-Parkinson-White}

O tratamento de escolha é a CVE. Proprafenona, amiodarona, procainamida e ibutilida devem ser usadas para reversão farmacológica e controle de frequência nos pacientes estáveis com FA/flutter, com duração menor de 48 horas.

Adenosina, betabloqueadores, bloqueadores de canal de cálcio e digoxina estão contraindicados pela ação predominante no nó atrioventricular. ${ }^{370-374}$

Se FA/flutter com mais de 48 horas de duração e estabilidade hemodinâmica, o especialista deve ser consultado.

\subsubsection{Taquicardia com $Q R S$ largo ( $Q R S \geq 120$ Milissegundos)}

A taquicardia de QRS largo ( $\geq 120$ milissegundos) representa sempre desafio clínico na sala de emergência, até mesmo para equipes mais experientes (Figura 5.13).

Apesar de a maioria das taquicardias de QRS largo ser de origem ventricular (TV), uma série de arritmias pode se manifestar com este padrão morfológico (por exemplo: TSV com condução aberrante, taquicardia antidrômica via acessória, taquicardia mediada por marca-passo, TSV com hipercalemia). O diagnóstico diferencial por meio de algoritmos é complexo e, muitas vezes, imperfeito.

Terapia imediata frequentemente é necessária, tendo em vista que os pacientes se apresentam já hemodinamicamente instáveis e/ou a deterioração hemodinâmica pode ocorrer a qualquer momento do curso clínico. ${ }^{375-379}$

\subsubsection{Abordagem Inicial na Sala de Emergência}

No cenário da sala de emergência, as duas opções de tratamento das taquiarritmias de QRS largo são CVE ou química. A decisão terapêutica depende da estabilidade clínica e do ritmo (monomórfica vs. polimórfica).

Apesar da dificuldade em estabelecer o diagnóstico, é importante salientar que cerca de $80 \%$ das apresentações de taquicardia de QRS largo têm origem ventricular e, em pacientes com doença cardíaca estrutural, esse valor pode atingir $90 \%{ }^{380}$ É racional que a abordagem terapêutica seja direcionada para TV. A taquicardia de QRS largo deve ser interpretada como TV, se o diagnóstico ainda não estiver esclarecido (Classe de Recomendação I; Nível de Evidência C).

O comprometimento hemodinâmico pode estar presente em qualquer taquicardia de QRS largo. Digno de nota, a presença de instabilidade hemodinâmica não diferencia TSV de TV. Em pacientes com taquicardia de QRS largo, instáveis hemodinamicamente, a CVE é a terapia de escolha.

A CVE sincronizada deve ser realizada com choque de 100 a 200 J (monofásico) ou 100J (bifásico), com aumento gradativo da carga, conforme a necessidade. ${ }^{381,382}$

Em pacientes não responsivos ou com TVSP, o atendimento deve seguir o protocolo para PCR, de acordo com os algoritmos de PCR. Nesses casos, choque de alta energia não sincronizado, 360 J (monofásico) e 200 J (bifásico), deve ser aplicado. Além disso, condições associadas ou predisponentes devem ser tratadas (isquemia miocárdica, IC, distúrbios hidroeletrolíticos e intoxicações).

\section{A) Taquicardia ventricular monomórfica em paciente estável}

A TV é definida como sequência de três ou mais batimentos acima de $100 \mathrm{bpm}$, que se origina abaixo do feixe de His, podendo surgir no sistema especializado de condução, no músculo ventricular ou na combinação de ambos. Pode acometer indivíduos com coração normal ou com cardiopatia estrutural. Quanto à morfologia e à apresentação clínica, a TV poder ser dividida em monomórfica ou polimórfica, estável e instável hemodinamicamente. O conhecimento de tais 


\section{Atualização}

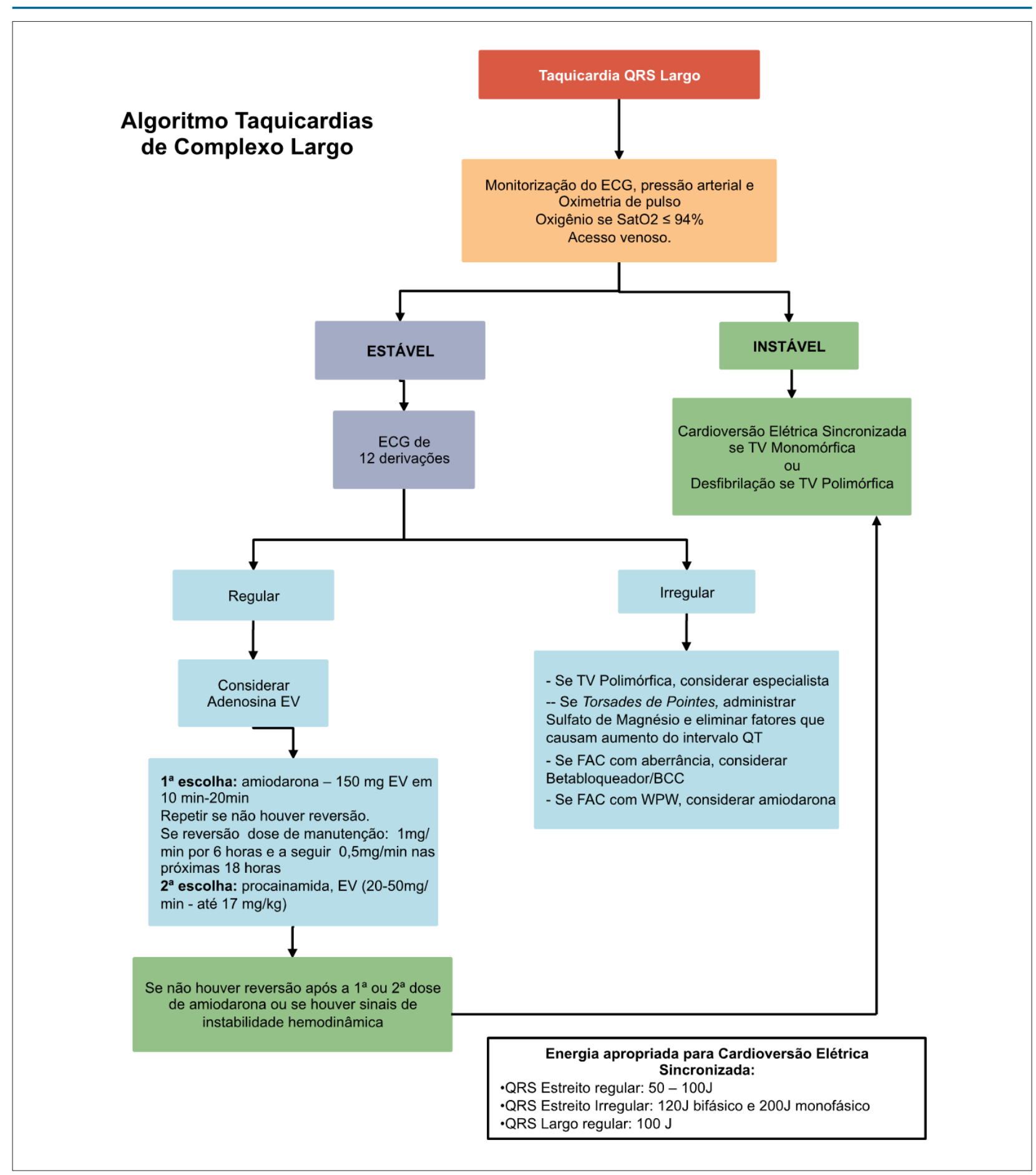

Figura 5.13 - Algoritmo do tratamento da taquicardia com QRS largo. ECG: eletrocardiograma; SatO ${ }_{2}$ : saturação de oxigênio; TV: taquicardia ventricular; EV: via endovenosa; FAC: fibrilaçãoo atrial crônica; BCC: bloqueador dos canias de cálcio; WPW: síndrome de Wolf-Parkinson-White.

características é essencial no manuseio adequado dos pacientes na sala de emergência.

A estabilidade hemodinâmica permite tempo adicional para o diagnóstico e, com isso, a terapia pode ser direcionada para taquiarritmia específica. Em pacientes com taquicardia de
QRS largo, estáveis hemodinamicamente, a CVE, sob sedação adequada, é a conduta usualmente apropriada.

As DAA são também utilizadas no manejo de pacientes estáveis. As DAA da classe I e III da classificação de Vaughan Williams podem ser úteis não só na reversão inicial, mas 
também nos casos refratários e na prevenção de recorrências. As DAA mais eficazes são procainamida, lidocaína, sotalol, amiodarona e ajmalina. ${ }^{382-385}$

Em pacientes com TV sustentada, estável hemodinamicamente, a amiodarona configura importante papel na reversão da arritmia. Podemos utilizar 150 mg endovenoso em 10 minutos, sempre atentos para hipotensão secundária à infusão. Alternativas terapêuticas são procainamida (até $17 \mathrm{mg} / \mathrm{kg}$ por via intravenosa) ou ajmalina (50 a $100 \mathrm{mg}$ por via intravenosa durante 5 minutos), pois ambas podem proporcionar altas taxas de reversão. ${ }^{386}$ Nos pacientes com TV e IAM, a lidocaína foi, por muito tempo, o tratamento de escolha, porém seu efeito pró-arrítmico e sua limitada eficácia, comparada a sotalol, procainamida, amiodarona e ajmalina, limitaram seu uso atual neste contexto. ${ }^{200,387,388}$ Em outras situações, ela ainda pode ser considerada entre as alternativas terapêuticas. É importante ressaltar que tanto a procainamida (Estados Unidos), como a ajmalina (Europa) não estão disponíveis comercialmente em nosso país, mas a importação direta por diversos serviços é realizada. Assim, em nosso meio, a amiodarona por via intravenosa passa ser a droga de primeira escolha para o tratamento das taquiarritmias de QRS largo.

A amiodarona é administrada por via intravenosa, na dose de ataque $150 \mathrm{mg}$ durante período de 10 minutos. Posteriormente, infusão de $1 \mathrm{mg} /$ minuto durante 6 horas e, então, dose de manutenção $0,5 \mathrm{mg} /$ minuto. A dose nas 24 horas não deve ultrapassar 2,2 g. A amiodarona por via intravenosa geralmente é bem-tolerada, inclusive em pacientes com disfunção ventricular esquerda. Entretanto, nos casos que apresentam disfunção ventricular sistólica acentuada, a infusão deve ser cautelosa pelo risco de hipotensão arterial. ${ }^{279,387,389,390}$

\section{B) Taquicardia ventricular polimórfica}

Neste caso, a TV deve ser sempre tratada como FV e, portanto ser submetida à desfibrilação imediata com 200J (bifásico) ou 360J (monofásico).

\section{C) Torção das pontas}

A "torção das pontas" ("torsades de pointes") é um subtipo de TV polimórfica marcada pela mudança cíclica, sinusoidal e progressiva do eixo e da morfologia do QRS. Geralmente, é autolimitada e recorrente. Tais características a diferenciam da FV. Ocorre em pacientes com intervalo de QT longo desenvolvido ou congênito e está associada a alguns fatores predisponentes e potencialmente tratáveis. ${ }^{391-393}$

Esses fatores predisponentes incluem drogas que prolongam intervalo QT, hipocalemia, hipomagnesemia e hipocalcemia. Eventos isquêmicos raramente causam TdP e ainda é controversa sua causa, tendo em vista que há casos de aumento de QT em vigência de isquemia. A bradicardia pelo aumento do QT também está envolvida no desenvolvimento de TdP. ${ }^{393-396}$

Assim, em pacientes que se apresentam com TdP hemodinamicamente instáveis, o tratamento de escolha é a desfibrilação elétrica, tendo em vista que a morfologia dos QRS na TdP dificulta a sincronização.
Em pacientes estáveis, a terapia envolve tratamento dos fatores predisponentes, MPTV provisório e algumas DAA.

O tratamento de primeira linha é o sulfato de magnésio por via intravenosa, mesmo em pacientes com magnésio sérico normal. ${ }^{326,392}$ A dose recomendada é de 1 a 2 g de sulfato magnésio 50\% em 5 a 20 minutos, seguida, se necessário, de mais 2 g após 15 minutos. ${ }^{340}$ Em alguns casos, pode-se administrar infusão contínua de 3 a 20 mg/minuto.

O MPTV deve ser utilizado para pacientes que não respondem ao magnésio, especialmente em pacientes bradicárdicos. Deve-se manter estimulação atrial ou ventricular de 100 a 120 bpm, que diminuij ${ }^{391,392}$ o QT e a predisposição para fenômenos R sobre T. ${ }^{397}$

O isoproterenol, droga que aumenta a FC, também, pode ser utilizado como medida ponte até o posicionamento adequado do MPTV.

DAA, como lidocaína e fenitoína, evidenciaram-se efetivas em algumas séries de casos. ${ }^{398}$

A reposição de potássio também deve ser realizada, mesmo em pacientes com seus níveis normais, objetivando valores no limite superior da normalidade, porém poucos estudos demonstraram sua eficácia ${ }^{398}$ (Quadro 5.11).

Pacientes com síndrome do QT longo congênito devem ser avaliados por especialista.

\section{Cuidados Pós-Ressuscitação}

\subsection{Introdução}

A lesão cerebral e a instabilidade cardiovascular são as principais determinantes de sobrevida após PCR. A Modulação Terapêutica da Temperatura (MTT) tem como finalidade conter a síndrome pós-PCR, diminuindo o consumo de oxigênio cerebral, e limitando a lesão ao miocárdio e os danos sistêmicos. Pelo fato de a MTT ser a única intervenção que demonstrou melhora da recuperação neurológica, ela deve ser considerada para qualquer paciente que seja incapaz de obedecer comandos verbais após o RCE. ${ }^{399-404}$ No entanto, lesões cerebrais podem se manifestar como convulsões, mioclonias, diferentes graus de défice cognitivo, estados de coma e morte cerebral.

\subsection{Síndrome Pós-Ressuscitação}

A síndrome pós-ressuscitação abrange o dano cerebral, a disfunção miocárdica, a isquemia sistêmica facilitada pelo mecanismo de isquemia-reperfusão e também as causas precipitantes do evento. A instalação e a gravidade da lesão causada pela síndrome pós-ressuscitação são consequências diretas das causas desencadeantes da PCR, do local do evento, do tempo de RCP e das condições de saúde pregressas do paciente. ${ }^{401}$

\subsection{Cuidados Pós-Ressuscitação}

\subsubsection{Via Aérea e Ventilação}

Alguns pacientes evoluem no RCE conscientes e com padrão respiratório adequado. Essas situações clínicas podem 


\section{Atualização}

\section{Quadro 5.11 - Resumo das indicações para abordagem terapêutica de bradicardias e taquiarritmias ${ }^{398}$}

\begin{tabular}{|c|c|c|}
\hline Recomendação & Classe de Recomendação & Nível de Evidência \\
\hline Atropina para bradicardia com sinais e sintomas de instabilidade & Ila & $\mathrm{B}$ \\
\hline Dopamina, epinefrina ou marca-passo transcutâneo para bradicardia sintomática refratária à atropina & Ila & $\mathrm{B}$ \\
\hline Cardioversão elétrica imediata para taquicardia com instabilidade. Sedação se paciente consciente & 1 & $\mathrm{~B}$ \\
\hline Adenosina para taquicardia supraventricular regular estável & Ilb & C \\
\hline A dose recomendada de energia bifásica para cardioversão de fibrilação atrial é 120 a $200 \mathrm{~J}$ & Ila & A \\
\hline $\begin{array}{l}\text { A dose mínima de energia monofásica recomendada para cardioversão de fibrilação atrial é } 200 \mathrm{~J} \text { e deve ser } \\
\text { aumentada caso não haja sucesso }\end{array}$ & Ila & B \\
\hline Repetir choque com carga maior de energia caso cardioversão sem sucesso & $\mathrm{Ilb}$ & C \\
\hline $\begin{array}{l}\text { Verapamil e diltiazem, para taquicardia supraventricular refratária à adenosina ou à manobra vagal, ou } \\
\text { recorrente, após administração de adenosina, ou quando administração de adenosina ou manobra vagal } \\
\text { revelam fibrilação atrial ou flutter }\end{array}$ & Ila & B \\
\hline $\begin{array}{l}\text { Betabloqueadores para taquicardia supraventricular refratária à adenosina ou manobra vagal, ou recorrente } \\
\text { após administração de adenosina, ou quando administração de adenosina ou manobra vagal revelam fibrilação } \\
\text { atrial ou flutter }\end{array}$ & Ila & $\mathrm{C}$ \\
\hline $\begin{array}{l}\text { Não usar agentes que bloqueiam o nó atrioventricular (adenosina, bloqueadores de cálcio, betabloqueadores e } \\
\text { digitálicos) em pacientes com pré-excitação em fibrilação atrial ou flutter }\end{array}$ & III & C \\
\hline Soco precordial para TV instável em pacientes monitorizados, mas com desfibrilador indisponível & $\mathrm{Ilb}$ & C \\
\hline $\begin{array}{l}\text { Para taquicardia com QRS largo monomórfica de etiologia indeterminada, o uso de adenosina é seguro, } \\
\text { podendo servir para diagnóstico e tratamento }\end{array}$ & $\mathrm{Ilb}$ & $\mathrm{B}$ \\
\hline Adenosina não deve ser utilizada para taquicardias de complexo largo irregulares ou polimórficas & III & C \\
\hline $\begin{array}{l}\text { Verapamil não deve ser usado para taquicardias de complexo largo, a menos que haja certeza de origem } \\
\text { supraventricular }\end{array}$ & III & $\mathrm{B}$ \\
\hline Amiodarona e sotalol para taquicardias de complexo largo monomórficas & $\| \mathrm{lb}$ & $\mathrm{B}$ \\
\hline Procainamida para taquicardias de complexo largo monomórficas & Ila & B \\
\hline $\begin{array}{l}\text { Sotalol e procainamida devem ser evitados em pacientes com QT longo. Se administrados, ponderar uso de } \\
\text { próximo antiarrítmico, fazendo-o somente com consulta a especialista }\end{array}$ & III & B \\
\hline Na falha de antiarrítmicos para taquicardica com complexo largo monomórfica, cardioversão elétrica & Ila & C \\
\hline $\begin{array}{l}\text { Betabloqueadores e bloqueadores do canal de cálcio não diidropiridínicos por via endovenosa para fibrilação } \\
\text { atrial de alta resposta ventricular }\end{array}$ & Ila & A \\
\hline $\begin{array}{l}\text { Na ausência de QT longo, isquemia é a principal causa de taquicardia ventricular polimórfica. Nessa suspeita, } \\
\text { amiodarona e betabloqueadores poderiam reduzir o risco de recorrência da arritmia }\end{array}$ & $\mathrm{llb}$ & C \\
\hline Magnésio não é efetivo na prevenção de taquicardia ventricular polimórfica sem QT longo, mas amiodarona o é & Ilb & C \\
\hline
\end{tabular}

ser observadas em sobreviventes de PCR de curta duração, mas parcela considerável necessita de suporte de oxigênio, que deve ser oferecido quando não houver saturação na oximetria de pulso de $94 \% .{ }^{405}$ Não entanto, aos pacientes com sinais clínicos de desconforto ou rebaixamento do nível de consciência, deve, sim, ser oferecido oxigênio suplementar e a via aérea segura deve ser ponderada. Durante a ventilação, a hipocarbia deve ser evitada, já que pode desencadear vasoconstrição cerebral. ${ }^{406}$ Sedação, nesta fase, é necessária, para viabilizar a ventilação e diminuir o consumo de oxigênio cerebral. Nos pacientes que serão submetidos a MTT, deve ser considerado o uso de bloqueadores neuromusculares. ${ }^{407,408}$

\subsubsection{Circulação}

A lesão coronária aguda atinge 59 a $71 \%$ dos pacientes que evoluem para PCR sem etiologia cardíaca evidente.
Desta forma, um ECG deve ser prontamente realizado e, se indicada, a terapia de reperfusão coronária deve ser iniciada.

Entre aqueles nos quais a presença de uma causa cardíaca como desencadeante não permanecer clara, ou na ausência de fatores de risco predisponentes, ou na falta de um diagnóstico determinante provável (exemplo de embolia pulmonar e acidentes vascular cerebral), e considerando a incidência de doença coronária em séries de óbitos, recomenda-se a obtenção de um cateterismo coronário diagnóstico nas 2 horas iniciais após o RCE. ${ }^{409}$ Medidas adicionais, como MTT, podem ser continuadas durante esta fase, não podendo retardar o diagnóstico e nem o tratamento do fator desencadeante.

\subsubsection{Manejo Hemodinâmico}

Frequentemente, após o RCE, há instabilidade hemodinâmica, distúrbios de ritmo consequência do baixo 
débito cardícao. Nos pacientes com instabilidade, há indicação para uso de drogas vasoativas. Usualmente, os resultados mais efetivos são obtidos associando-se reposição de fluidos e drogas vasoativas. Na persistência da instabilidade, podem ser considerados suportes circulatórios, como Balão Intra-Aórtico (BIA) e ECMO (Figura 6.1).

\subsection{Modulação Terapêutica da Temperatura}

Os estudos desenvolvidos em Hipotermia Terapêutica (HT) iniciados na década de 1980 e 1990 apresentaram limitações principalmente relacionadas a dificuldades no controle da temperatura, sangramentos e infecções. Este cenário apresentou mudanças com o surgimento de dispositivos e cuidados que permitem controlar a temperatura com segurança. ${ }^{410-412}$

Dois estudos multicêntricos desenvolvidos ganharam repercussão em publicações no início de 2002. ${ }^{399,400}$ Em 2010, o ILCOR estabeleceu a HT dentre os cuidados após o RCE de eventos extra-hospitalares e manteve a recomendação para o controle de temperatura ideal de $32 \mathrm{a} 34^{\circ} \mathrm{C}$. O método ganhou aceitação, e seu emprego se estendeu para outros ritmos de PCR e para o ambiente intra-hospitalar. ${ }^{406,407}$

Nielsen et al. publicam dados do estudo randomizado TTM Trial (Target Temperatura Manegement) com corte composta por 950 indivíduos que evoluíram comatosos após o RCE extra-hospitalar e foram submetidos à hipotermia com temperaturas-alvo de $33^{\circ} \mathrm{C}$ ou de $36^{\circ} \mathrm{C} . .^{408-410}$

Com isso, criou-se o conceito de "modulação terapêutica da temperatura", em que as evidências apontam que adultos que permanecerem comatosos no RCE após PCR no ritmo de TV/FV fora do ambiente hospitalar devem ser resfriados a $32^{\circ} \mathrm{C}$ a $36^{\circ} \mathrm{C}$ por 12 a 24 horas (Classe de Recomendação I; Nível de Evidência B). A MTT pode beneficiar sobreviventes de PCR fora do hospital a partir de outros ritmos, como assistolia ou AESP, ou PCR intrahospitalares (Classe de Recomendação IIb; Nível de Evidência B). ${ }^{402,404,413-418}$

O tempo ideal da fase de manutenção é, atualmente, de 24 horas. $^{414-422}$

\subsubsection{Quando e como Realizar a Modulação Terapêutica da Temperatura}

A MTT mostrou-se intervenção capaz de oferecer melhora na recuperação neurológica e deve ser considerada para os pacientes comatosos, ou seja, incapazes de atender ordem verbal após o RCE (Quadro 6.1).399-413

Pacientes que atingirem estabilidade hemodinâmica após o RCE, à custa de inotrópicos e vasoconstritores, podem iniciar o tratamento. ${ }^{401,410}$

\subsubsection{Fases da Modulação Terapêutica da Temperatura: Indução, Manutenção e Reaquecimento}

Indução: a temperatura central deve ser monitorada continuamente por termômetro esofágico, cateter vesical ou cateter de artéria pulmonar. O uso de termômetros convencionais (axilares, retais ou orais) não se mostrou adequado e seguro. ${ }^{399,400,423,424}$

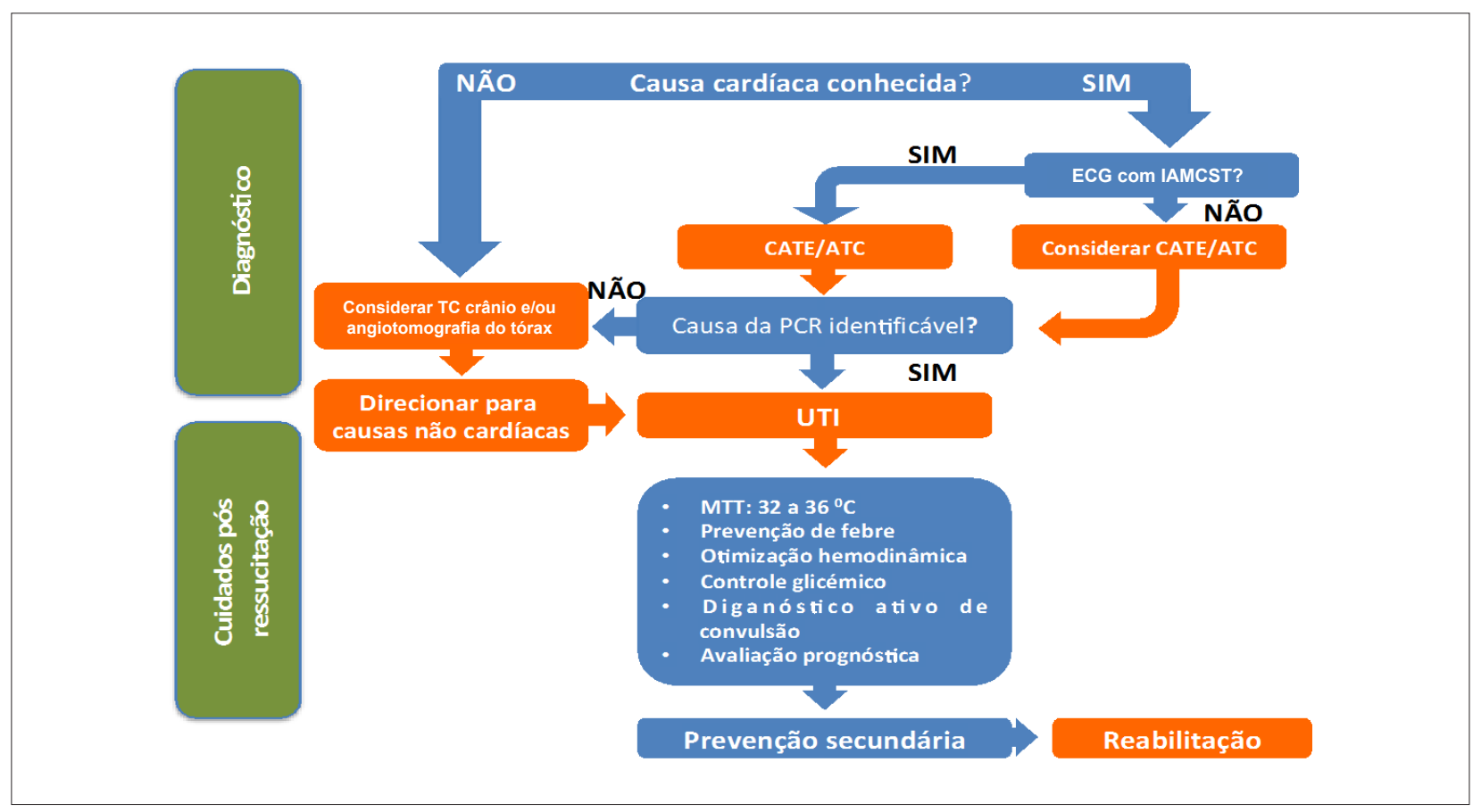

Figura 6.1 - Abordagem após o retorno a circulação espontânea. TC: tomografia computadorizada; CATE: cineangiocoronariografia; ATC: angioplastia coronária; UTI: unidade de terapia intensiva; ECG: eletrocardiograma; IAMCST: infarto agudo do miocárdio com supradenivelamento do segmento ST; PCR: parada cardiorrespiratória; MTT: modulação terapêutica da temperatura. 


\section{Quadro 6.1 - Critérios de seleção para modulação terapêutica da temperatura (MTT) ${ }^{399-413}$}

\begin{tabular}{lc}
\hline Critérios de inclusão & $\begin{array}{c}\text { Limitações para o início da MTT: } \\
\text { nritérios de exclusão }\end{array}$ \\
\hline Idade: 18 a 75 anos & $\begin{array}{c}\text { Portadores de coagulopatias - exceto } \\
\text { as induzidas }\end{array}$ \\
PCR presenciada & $\begin{array}{c}\text { Choque cardiogênico refratário à } \\
\text { terapêutica - uso crescente de doses } \\
\text { de drogas vasoativas }\end{array}$ \\
$\begin{array}{l}\text { Tempo de manobras de reanimação } \\
<45 \text { minutos }\end{array}$ & $\begin{array}{c}\text { Choque séptico } \\
\text { estímulos } \\
\begin{array}{l}\text { Acesso ao atendimento primário entre } \\
5 \text { e } 15 \text { minutos após o início da PCR } \\
\text { Intervalo de tempo pós-PCR de até } \\
12 \text { horas }\end{array} \\
\text { Recorrência de PCR prolongada após } \\
\text { admissão }\end{array}$ \\
\hline
\end{tabular}

PCR: parada cardiorrespiratória.

O resfriamento deve ser iniciado prontamente, preferencialmente no local do evento ou até 6 a 12 horas após o RCE. Objetivo é atingir a temperatura-alvo o mais rapidamente possível, recomendando-se associação de métodos. ${ }^{425-427}$

Frequentemente, após o RCE, há queda da temperatura corpórea $\left(35^{\circ} \mathrm{C}\right.$ e $\left.36^{\circ} \mathrm{C}\right)$. Se a temperatura-alvo de $36^{\circ} \mathrm{C}$ for escolhida, pode-se permitir reaquecimento passivo lento para $36^{\circ} \mathrm{C}$. Se o objetivo for temperatura-alvo de $33^{\circ} \mathrm{C}$, o resfriamento inicial pode ser facilitado por bloqueio neuromuscular e sedação, o que impede os tremores (Quadro 6.2).426-432

Manutenção: esta fase se inicia ao se atingir a temperaturaalvo e se estende por 12 a 24 horas. Os cuidados são direccionados a fim de se evitar o hiperresfriamento (temperatura $<32^{\circ} \mathrm{C}$ ). A infusão de soluções geladas deve ser interrompidas nesta fase. A queda nos níveis de temperatura pode induzir à bradicardia e à poliúria, contribuindo para deterioração do estado hemodinâmico, facilitando hipovolemia e distúrbios hidroeletrolíticos. ${ }^{431,432,434}$

Mioclonias e convulsões devem ser prontamente identificadas e tratadas. O diagnóstico diferencial deve ser feito com Eletroencefalograma (EEG), e não há evidência para sustentar o uso preventivo de anticonvulsivantes. ${ }^{399,400,401,420-423,427,432-439}$

Reaquecimento: as manobras que sinalizam o início desta fase não implicam na descontinuidade imediata dos dispositivos de resfriamento, já que o ganho de temperatura deve ser gradativo, idelamentemende de $0,25^{\circ} \mathrm{C}$ a $0,5^{\circ} \mathrm{C}$ a cada hora. Alterações hemodinâmicas, hidroeletrolíticas e nas taxas metabólicas são esperadas nesta fase, e atenção deve ser dada à conteção da hipertermia rebote, que está associada à pior evolução neurológica. ${ }^{440-443}$

Adicionalmente, o reaquecimento ativo deve ser evitado naqueles que, espontaneamente, desenvolvam um leve grau
Quadro 6.2 - Principais métodos de indução e manutenção de hipotermia ${ }^{432-435}$

\begin{tabular}{|c|c|c|}
\hline Método & & Cuidados \\
\hline \multirow{3}{*}{$\begin{array}{l}\text { Resfriamento } \\
\text { de superfície }\end{array}$} & Pacotes de gelo & $\begin{array}{l}\text { Rodiziar locais: axilar, virilha e } \\
\text { pescoço } \\
\text { Prevenir lesões de pele }\end{array}$ \\
\hline & Mantas térmicas & $\begin{array}{l}\text { Atender especificações do } \\
\text { fabricante }\end{array}$ \\
\hline & $\begin{array}{l}\text { Dispositivos de aplicação } \\
\text { cutânea: capacetes, } \\
\text { coletes e perneiras }\end{array}$ & $\begin{array}{l}\text { Atender especificações do } \\
\text { fabricante }\end{array}$ \\
\hline $\begin{array}{l}\text { Resfriamento } \\
\text { por sonda } \\
\text { gástrica }\end{array}$ & $\begin{array}{l}\text { Solução salina a } 4^{\circ} \mathrm{C} \text {, } \\
\text { em bólus de } 250 \mathrm{~mL} \text { por } \\
\text { sonda gástrica, volume } \\
\text { final } 30 \mathrm{~mL} / \mathrm{kg}\end{array}$ & $\begin{array}{l}\text { Verificar posição da sonda } \\
\text { gástrica } \\
\text { Aspirar conteúdo gástrico inicial }\end{array}$ \\
\hline \multirow{2}{*}{$\begin{array}{l}\text { Resfriamento } \\
\text { endovenoso }\end{array}$} & $\begin{array}{c}\text { Solução salina a } \\
4^{\circ} \mathrm{C} \text {, infusão por via } \\
\text { endovenosa, volume final } \\
\text { de } 30 \mathrm{~mL} / \mathrm{kg}\end{array}$ & $\begin{array}{l}\text { Empregar perfusor para otimizar } \\
\text { o tempo de infusão } \\
\text { Suspender infusão de volume se } \\
\text { oximetria de pulso }<94 \% \\
\text { Limitar uso em pacientes com } \\
\text { congestão pulmonar }\end{array}$ \\
\hline & $\begin{array}{l}\text { Cateter endovascular de } \\
\text { resfriamento contínuo }\end{array}$ & $\begin{array}{l}\text { Necessita de punção femoral } \\
\text { ou venosa central. Risco de } \\
\text { complicações: mecânica, } \\
\text { sangramento, infecção e } \\
\text { trombose }\end{array}$ \\
\hline
\end{tabular}

de hipotermia $\left(>32^{\circ} \mathrm{C}\right)$ após o RCE e durante as primeiras 48 horas (Classe de Recomendação III; Nível de Evidência C). ${ }^{444}$

O controle posterior da temperatura deve se estender ao menos por 72 horas para a prevenção ativa da ocorrência de febre. ${ }^{433,436}$

\subsubsection{Contraindicações para a Modulação Terapêutica da Temperatura}

Incluem infecção sistêmica grave e coagulopatia preexistente. Terapia fibrinolítica não é contraindicação à hipotermia induzida leve. ${ }^{445}$

\subsection{Estado Atual da Modulação Terapêutica da Temperatura}

O uso de hipotermia atua como supressor das vias facilitadoras da morte cerebral e da apoptose celular.

Há uma diminuição de $6 \%$ na taxa de metabolismo cerebral de oxigênio na redução da temperatura corpórea a cada $1{ }^{\circ} \mathrm{C}$.

Existe evidência de uma diminuição dos radicais livres durante o controle da temperatura.

Há um bloqueio à ação intracelular da exposição às excitotoxina (acionadas pelo aumento do cálcio e do glutamato), reduzindo a resposta inflamatória na síndrome pós-PCR.

O Advanced Life Support Task Force do ILCOR sustenta as seguintes orientações:

- O termo "modulação terapêutica da temperatura " passou a ser preferível ao termo "hipotermia terapêutica", anteriormente empregado. 
- Manter faixa de 32 a $36^{\circ} \mathrm{C}$ quando a MTT for indicada.

- Em algumas subpopulações, o benefício associado a baixas temperaturas com faixas de 32 a $34^{\circ} \mathrm{C}$, ou a temperaturas mais elevadas de $36^{\circ} \mathrm{C}$, permanece incerto, e novos estudos devem ser realizados.

- Recomenda-se MTT para adultos sobreviventes de PCR extra-hospitalar com ritmo inicial FV/TV e que permanecem em coma após o RCE.

- Sugere-se MTT para adultos sobreviventes de PCR extra-hospitalar com ritmo inicial não chocável e que permaneçam em coma após o RCE.

- Sugere-se MTT para adultos sobreviventes de PCR intrahospitalar em qualquer ritmo inicial e que permaneçam arresponsivos após o RCE.

- Bradicardia durante HT leve pode ser benéfica, presumivelmente porque a função autonômica é preservada. ${ }^{446}$

\subsection{Perspectivas}

A divulgação do conhecimento ao público, favorecendo o reconhecimento das situações de PCR e da necessidade do início das manobras de RCP, associada a estruturas que ofereçam atendimento rápido, trouxe melhora da sobrevida e da qualidade de vida aos pacientes que evoluíram com RCE. Apesar disto, na prática, a partir dos critérios de inclusão, fica evidente que o número de pacientes elegíveis para MTT é significativamente inferior ao total dos admitidos pós-PCR nos serviços de emergência.

A terapia da MTT certamente é um dos tópicos que deve ocupar mais espaço no tratamento de pacientes sobreviventes a PCR. A valorização de um parâmetro simples, a temperatura corpórea, deve ser incorporada nos cuidados médicos a pacientes críticos pós-PCR, em busca da redução da mortalidade e de qualidade de vida na alta hospitalar.

\section{Síndrome Coronária Aguda}

\subsection{Introdução}

A SCA pode ser dividida em dois grandes grupos: IAM com Elevação do Segmento ST (IAMCST) e a SCA sem Elevação de Segmento ST (SCASST), que, por sua vez, pode também ser subdividida em Angina Instável (AI) e IAM sem Elevação do Segmento ST (IAMSST).

Dessa forma, os critérios para diagnóstico de IAM são aumento e/ou queda de marcadores de necrose miocárdica, preferencialmente a troponina, com pelo menos um valor acima do percentil 99 do método, associado a pelo menos uma das seguintes alterações: sintomas sugestivos de isquemia, novas alterações do segmento ST, onda T ou Bloqueio de Ramo Esquerdo (BRE) novo, aparecimento de ondas Q patológicas no ECG, exame de imagem com perda de miocárdio viável ou nova alteração na contratilidade segmentar e identificação de trombo intracoronário na angiografia ou em autópsia. ${ }^{447-448}$

\subsection{Epidemiologia da Doença Arterial Coronariana}

A Doença Arterial Coronariana (DAC) ainda é a principal causa de morte e incapacidade em países desenvolvidos ${ }^{449}$ e em desenvolvimento. ${ }^{450}$ Nos Estados Unidos, a SCA afeta cerca de 780 mil indivíduos por ano, sendo a maior parte dos casos (70\% a 75\%) representada pela SCASST. ${ }^{451,452}$ A média de idade atual dos pacientes com diagnóstico de SCA é de 68 anos, com prevalência maior em pacientes do sexo masculino (três homens para cada duas mulheres). ${ }^{451,452}$ Assim, aproximadamente a cada 25 segundos um americano tem uma SCA, e a cada minuto há uma morte causada por este tipo de evento. Considerase que, como consequência da SCA, há redução média de 16,6 anos na expectativa de vida, caracterizando um problema crítico de saúde publica. ${ }^{453-456}$

\subsection{Morte Súbita}

Com base nos dados do Framingham Heart Study e do National Heart, Lung and Blood Institute, 50\% dos homens e $64 \%$ das mulheres que morrem subitamente de DVC não apresentam sintomas prévios. A incidência anual é três a quatro vezes maior em homens, com redução desta disparidade em idade mais avançada. Pacientes com diagnóstico prévio de IAM têm risco aumentado em quatro a seis vezes. ${ }^{457,458}$

\subsection{Fatores de Risco}

Fatores de risco para DAC atuam sinergicamente aumentando o risco da doença. De acordo com estudo INTERHEART, realizado em 52 países, a intervenção em fatores de risco potencialmente modificáveis e facilmente medidos pode resultar em redução no risco de IAM inicial de até $90 \% .{ }^{459}$

\subsection{Avaliação de Dor Torácica}

A dor torácica é o principal sintoma sugestivo de SCA. As características da dor torácica sugestivas de isquemia miocárdica estão listadas no Quadro 7.1.

Pacientes com dor anginosa em repouso com mais de 20 minutos de duração, angina limitante de início recente e angina em crescendo (maior frequência, maior intensidade e menor limiar para aparecimento dos sintomas que o habitual) devem ser encaminhados aos serviços de emergência, já que essas características da dor são sugestivas de SCA. ${ }^{448,460}$

A dor torácica pode não estar presente durante um episódio de SCA em até cerca de um terço dos casos. Estes pacientes podem apresentar dispneia isoladamente, náuseas, vômitos, palpitações, síncope, ou mesmo parada cardíaca. Sintomas denominados equivalentes isquêmicos normalmente acometem idosos, mulheres e pacientes diabéticos. A ausência de dor torácica tem implicações prognósticas associada a maior mortalidade intra-hospitalar, devido à falha ou ao atraso no diagnóstico e no tratamento. ${ }^{461}$ Essa apresentação tende a aumentar, devido ao envelhecimento da população e ao aumento na prevalência de doenças neurológicas, como a demência. ${ }^{462-464}$ 


\section{Atualização}

\section{Quadro 7.1 - Etiologias para elevação de troponina ${ }^{466}$}

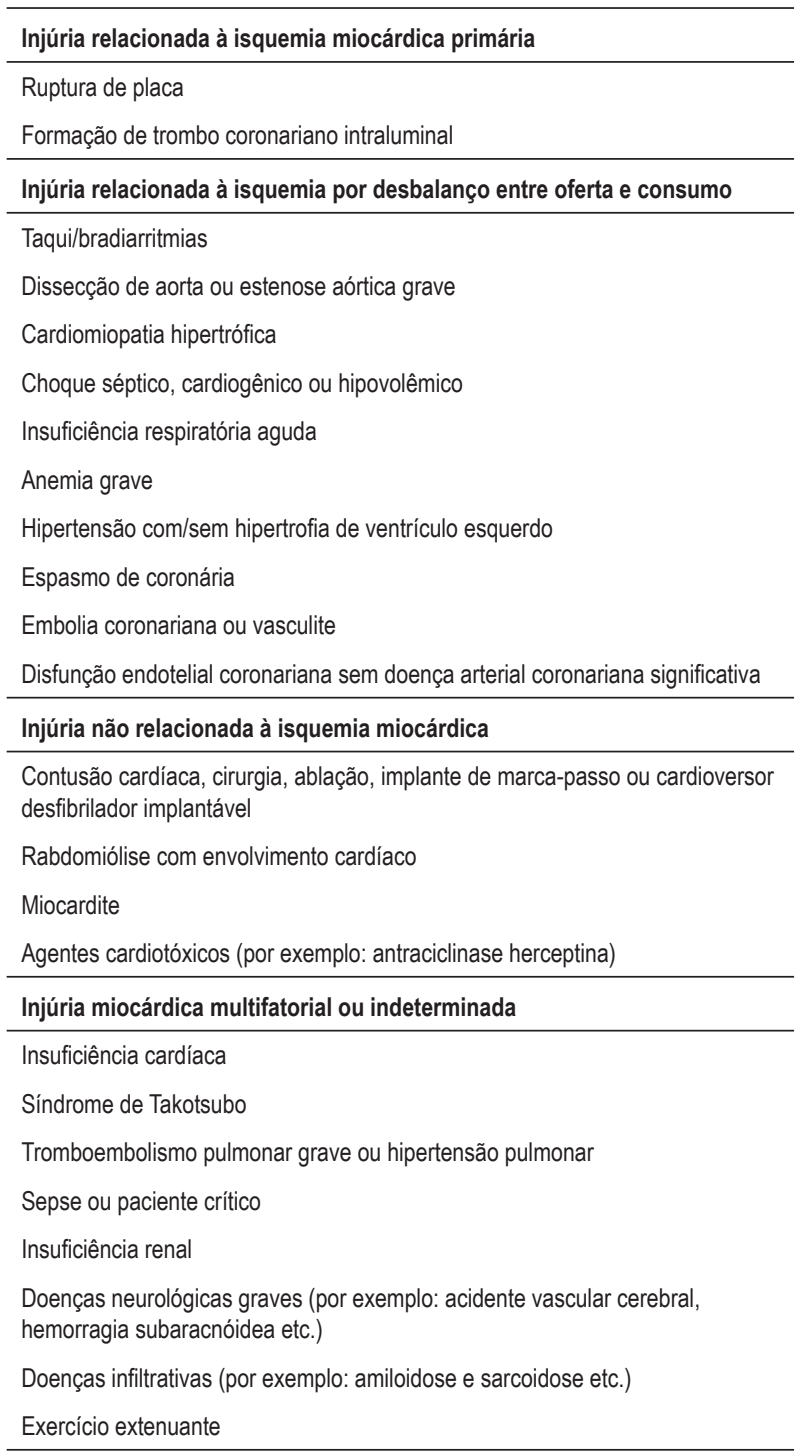

\subsection{Eletrocardiograma}

O ECG é uma ferramenta fundamental para o diagnóstico da SCA, devendo ser realizado nos primeiros 10 minutos de atendimento. Quando disponível em ambiente préhospitalar, pode auxiliar na tomada de decisão em relação ao tratamento. A organização do serviço de APH permite, além do diagnóstico precoce do IAMCST, que sejam iniciados o tratamento medicamentoso, a ativação de um hospital com centro de hemodinâmica disponível e, nos casos em que o transporte não possa ser realizado em tempo adequado, que a terapia de reperfusão ocorra ainda durante o transporte do paciente. ${ }^{465}$ O ECG permite classificar o paciente dentro de dois grupos: ${ }^{447}$

- IAMCST: elevação do segmento ST ou BRE novo ou supostamente novo.
- SCASST: depressão do segmento ST, inversão das ondas $\mathrm{T}$, elevação transitória do segmento ST, alterações inespecíficas da repolarização ventricular ou mesmo ECG normal. A posterior diferenciação entre IAMSST e AI será realizada pela elevação ou não dos marcadores de necrose miocárdica, respectivamente.

O critério eletrocardiográfico para IAMCST inclui elevação do segmento ST em duas derivações contíguas: acima de 1,5 $\mathrm{mm}$ em mulheres, acima de $2 \mathrm{~mm}$ em homens $\geq 40$ anos e acima de 2,5 mm em homens $<40$ anos nas derivações V2-V3 e/ou acima de $1 \mathrm{~mm}$ nas demais derivações. ${ }^{466}$

Em caso de evidência de isquemia na parede inferior (alterações do segmento ST ou da onda T nas derivações II, III e AVF), um ECG com os eletrodos posicionados à direita nas derivações precordiais (V3R, V4R, V5R e V6R) deve ser realizado para investigar o diagnóstico de IAM do Ventrículo Direito (VD), assim como em derivações posteriores (V7 e V8).

Como o ECG inicial muitas vezes apresenta-se normal, ele deve ser repetido em até 20 minutos, caso persista a suspeita de SCA, ou sempre que houver mudança no quadro clínico.

\subsection{Marcadores de Necrose Miocárdica}

São marcadores de lesão miocárdica e podem quantificar o tecido miocárdico que sofreu necrose, tendo utilidade diagnóstica e prognóstica.

\subsubsection{Isoenzima MB da Creatinoquinase}

É o marcador mais amplamente disponível. Eleva-se após 4 a 6 horas, atinge o pico em cerca de 12 a 24 horas e normalizase em 48 horas. Pode ser medida a atividade da Isoenzima MB da Creatinoquinase (CK-MB) ou, com mais acurácia, a massa de CK-MB. Existem algumas poucas descrições de pacientes com IAM diagnosticados por CK-MB massa, sem elevação concomitante de troponina. Assim, os dois métodos podem se complementar.

Uma relação entre CK-MB e Creatinofosfoquinase (CPK) inferior a $4 \%$ sugere lesão muscular, enquanto valor superior a $25 \%$ sugere presença de outras enzimas simulando esta atividade (macroquinases). Se a CK-MB estiver elevada com relação das atividades de CK-MB/CPK entre 4 e $25 \%$, estabelece-se com ótima acurácia o diagnóstico de lesão muscular cardíaca.

\subsubsection{Troponina}

Os marcadores de necrose miocárdica de escolha para o diagnóstico de injúria miocárdica, devido à sua especificidade aumentada e à melhor sensibilidade, quando comparado com a CK-MB. ${ }^{467}$ As troponinas disponíveis para aplicação clínica são as troponinas I e T específicas e, em geral, nenhuma delas é detectada em indivíduos sadios. O critério universal para definição de IAM é o padrão de elevação e/ou a queda de concentração de troponina, com pelo menos um valor acima do percentil 99 de uma população de referência normal, na presença de características clínicas compatíveis com a SCA. As troponinas elevam-se a partir de 4 a 6 horas após IAM, com pico em torno de 14 a 24 horas e com normalização em 5 
a 10 dias, para troponina I, e 10 a 14 dias, para Troponina $T$ (TnT). Outros mecanismos, que não DAC obstrutiva, levam à elevação dos níveis de troponina (Quadro 7.1).

\subsubsection{Troponinas Ultrassensíveis}

Recentemente, as troponinas ultrassensíveis T e I foram introduzidas na prática clínica, com limites de detecção de lesão miocárdica de dez a cem vezes menores. Dessa forma, IAM pode ser detectado de maneira mais precoce. A superioridade desses ensaios, particularmente em pacientes com dor torácica de curta duração, foi demonstrada prospectivamente. Com dor torácica de 3 horas de duração, a sensibilidade para IAM chega a $100 \%$. O valor preditivo negativo em uma única aferição para IAM é de 95\%, valor comparado a troponinas convencionais.

Entretanto, com o advento dessas troponinas de alta sensibilidade, a elevação destes biomarcadores tornou-se mais comum, com benefício da exclusão com segurança dos pacientes que apresentem este marcador ausente, mas observa-se elevação de casos falso-positivos. ${ }^{468}$

Devido à essa dificuldade de interpretação, recomendamse pelo menos duas medidas seriadas de troponina ultrassensível para a definição IAM, com intervalo de ao menos 7 horas, proporcionando ao método uma sensibilidade de $100 \%$ para o IAM.

Nos casos de alta suspeita para IAM nos quais a elevação em 3 horas seja discreta ou não tenha ocorrido, deve-se proceder à nova coleta com 6 horas. Quando a primeira medida for negativa, obtém-se o diagnóstico de IAM quando a segunda aferição com 3 horas estiver positiva e com elevação de pelo menos $50 \%$. Já quando a primeira medida for positiva, aguarda-se nova coleta com 3 horas, e o diagnóstico de IAM é confirmado caso haja elevação de 20\% em relação à primeira medida (Figura 7.1).

\subsubsection{Point-of-care Testing}

A metodologia Point-of-Care Testing (POCT) é agora possível em muitas áreas da medicina de emergência. Desempenha papel importante na identificação rápida e facilita o tratamento. Existem evidências favoráveis do uso clínico do POCT para TnT, em nível dos cuidados primários para o diagnóstico de SCA, o qual tem apresentado boa sensibilidade e especificidade. ${ }^{469}$

Assim, diante de paciente com suspeita de SCA, recomendamos a abordagem conforme quadro 7.2.

\subsection{Estratificação de Risco}

Existem diversos parâmetros e escores validados para estratificação de risco em pacientes que se apresentam com IAMCST. Por necessitar de intervenção imediata para abrir a artéria culpada, seja mecânica ou farmacologicamente, sua estratificação, em uma fase muito inicial, carece de mais implicações práticas e, por isso, não é abordada nesta diretriz.

O prognóstico das SCASST tem sido avaliado a partir de uma série de estudos. Considerando que trata-se de uma entidade heterogênea incluindo pacientes com e sem alteração de MNM, o uso dessas ferramentas de

\section{Dor Torácica Aguda}

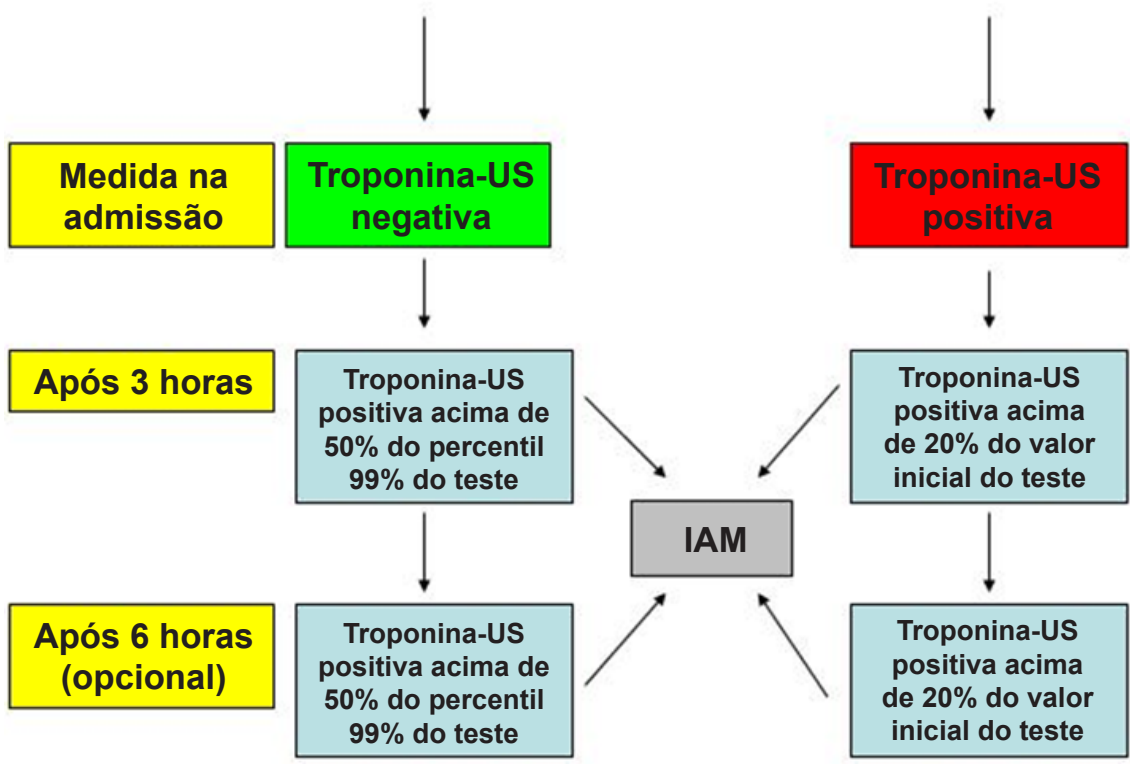

Figura 7.1 - Interpretação da troponina ultrassensivel (US) na emergência. IAM: infarto agudo do miocárdio. 
Quadro 7.2 - Recomendações para uso de eletrocardiografia e marcadores de necrose miocárdica na avaliação de pacientes com síndrome coronária aguda

\begin{tabular}{|c|c|c|}
\hline Indicação & Classe de Recomendação & Nível de Evidencia \\
\hline Eletrocardiograma de 12 derivações em menos de 10 minutos da chegada no hospital. & 1 & C \\
\hline $\begin{array}{l}\text { Coleta sanguínea para avaliação de marcadores de necrose miocárdica em pacientes com suspeita de } \\
\text { síndrome coronária aguda }\end{array}$ & I & C \\
\hline
\end{tabular}

estratificação de risco é fundamental para direcionar a conduta. O prognóstico é obviamente melhor na $\mathrm{Al}$ comparada com o IAM. O prognóstico em curto prazo de pacientes com IAMSST é melhor que o daqueles com IAMCST. Vale ressaltar, no entanto, que a maioria dos estudos aponta prognóstico similar entre os tipos de IAM em longo prazo, ou até mesmo para um pior prognóstico do IAMSST. ${ }^{470,471} \mathrm{O}$ prognóstico do IAMCST tem melhorado com o aumento do número de laboratórios de hemodinâmica, assim como o do IAMSST e AI, pelo aumento dos procedimentos de revascularização precoces e terapia medicamentosa mais segura.

Independentemente dessas classificações, pacientes com SCASST associada às seguintes condições são considerados de alto risco e devem ser encaminhados para angiografia coronariana imediata: choque cardiogênico; IC ou disfunção ventricular grave; angina de repouso refratária, persistente ou recorrente, apesar da terapia médica adequada; instabilidade hemodinâmica devido a isquemia ou complicações mecânicas; e arritmias ventriculares instáveis.

Entre os vários critérios para estratificar o risco de pacientes com SCAST estão as próprias definições de AI e IAMSST. A diferença básica entre ambas está no fato de existir isquemia o suficiente para causar lesão e necrose miocárdica.

Existem diversas ferramentas para essa estratificação de risco, sendo as mais comuns os escores de risco Thrombolysis in Myocardial Infarction (TIMI) e GRACE. Na tomada de decisão terapêutica, deve ser considerado aquele que aponta para maior risco.

Como base nesse escores prognósticos, pode ser adotada, nos pacientes de baixo risco, uma estratégia mais conservadora, que seria a utilização de um teste não invasivo provocativo de isquemia antes da alta hospitalar.

Pacientes de moderado e alto risco são normalmente encaminhados para realização de cinecoronariografia precoce em até 24 horas. ${ }^{456,467,472}$

Outras formas de verificação de risco, como avaliação da função ventricular em repouso, testes provocativos de isquemia e monitorização contínua eletrocardiográfica, com intuito de detectar isquemia silenciosa, podem ser realizadas durante a observação/internação do paciente, mas fogem do escopo dessa diretriz.

\subsubsection{TIMI}

Os dados dos estudos clínicos controlados TIMI 11B e ESSENCE encontraram sete variáveis independentes na predição de desfechos em pacientes com Al e IAMSST. A cada uma destas variáveis dicotômicas é atribuível o valor de 1, em caso de presente, e zero, em caso de ausente, variando o escore de zero até 7 (sendo 7 o maior risco): idade $\geq 65$ anos; presença de, ao menos, três fatores de risco para DAC; estenose coronariana prévia $\geq 50 \%$; presença de desnivelamento do segmento ST no ECG da admissão; ao menos dois episódios anginosos nas 24 horas prévias; biomarcadores cardíacos de necrose miocárdica séricos elevados; e uso de Ácido Acetilsalicílico (AAS) nos últimos 7 dias.

Escore de risco TIMI alto correlaciona-se significantemente com aumento no número de eventos (mortalidade por todas as causas, IAM novo ou recorrente, isquemia grave necessitando revascularização) em 14 dias (Quadro 7.3). ${ }^{473,474}$

São considerados de alto risco os pacientes com escores de 5, 6 ou 7; e de baixo risco os pacientes com escores 0,1 ou 2.

\subsubsection{GRACE}

Derivado do banco de dados de dois ensaios clínicos e desenvolvido a partir de um registro global de pacientes com SCA selecionados de 94 hospitais em 14 países. Foram desenvolvidos dois modelos de estimativa de risco para mortalidade intra-hospitalar e em 6 meses..$^{457,475}$ Oito fatores de risco independentes foram encontrados: idade, classificação de Killip, PAS, presença de infradesnivelamento do segmento ST, parada cardíaca durante a apresentação, creatinina sérica, presença de biomarcadores de necrose miocárdica elevados e FC.

Pontos foram atribuídos a cada variável, de forma a alcançar estimativa de risco de mortalidade intra-hospitalar. Embora desenhado para avaliar o risco de morte hospitalar, o GRACE também estima morte e reinfarto em 1 ano. ${ }^{476} \mathrm{~A}$ utilização desses escores tem auxiliado na decisão terapêutica.

\section{Quadro 7.3 - Escore TIMI}

\begin{tabular}{lc}
\hline Escore & $\%$ \\
\hline $0 / 1$ & 4,3 \\
2 & 8,3 \\
3 & 13,2 \\
4 & 19,2 \\
5 & 26,2 \\
$6 / 7$ & 40,9 \\
\hline
\end{tabular}




\subsection{Tratamento da Síndrome Coronariana Aguda na} Emergência

\subsubsection{Condutas Gerais}

O tratamento da SCA baseia-se em condutas gerais e específicas no cenário de urgência e emergência, relevantes para o conforto e o prognóstico do paciente. O objetivo primordial do tratamento anti-isquêmico para SCA é o ajuste do balanço entre oferta e consumo de oxigênio.

A oxigenoterapia fundamenta-se no fato de que o aumento da oferta de oxigênio reduz a hipóxia no território isquêmico. Estudos experimentais corroboram esse fato, ${ }^{477,478}$ porém faltam evidências advindas de estudos clínicos. Estudo randomizado em indivíduos com IAMCST evidenciou aumento de injúria miocárdica com uso de oxigenoterapia suplementar sem evidência de hipoxemia. ${ }^{479,480}$

O uso de nitratos promove dilatação coronária, levando à reversão de obstrução coronária por vasoespasmo ou redução de isquemia nas SCASST. Seu benefício se restringe à melhora sintomática, não havendo evidência de benefício prognóstico. ${ }^{481} \mathrm{O}$ uso deve ser evitado na vigência de hipotensão e após o uso de inibidores da fosfodiesterase (por exemplo: após 24 horas do uso de sildenafil ou 48 horas após tadalafil). Caso não haja melhora da dor, recomenda-se o uso de opioides com esta finalidade.

A morfina apresenta efeito analgésico e promove redução do consumo de oxigênio, sem impactar em desfechos clínicos. O uso de anti-inflamatórios não esteroidais também pode ser útil nesse cenário, havendo prioridade do AAS em dose anti-inflamatória ou do naproxeno. ${ }^{482}$

\section{Recomendação}

Oxigênio é indicado em pacientes com hipoxemia (saturação de oxigênio $-\mathrm{SatO}_{2}<90 \%$ ou pressão parcial de oxigênio $-\mathrm{PaO}_{2}<60 \mathrm{mmHg}$ ) (Classe de Recomendação I; Nível de Evidência C). ${ }^{483}$

Oxigênio de rotina não é recomendado em pacientes com SatO $\geq 90 \%$ (Classe de Recomendação II; Nível de Evidência B). ${ }^{484}$

Uso de nitratos para alívio de angina, principalmente nos hipertensos, apresentando angina refratária ou sintomas de IC. (Classe de Recomendação I; Nível de Evidência B).

Uso de morfina para alívio de dor em pacientes portadores de SCA com ou sem elevação de ST (Classe de Recomendação Ila; Nível de Evidência C).

\subsubsection{Antiagregantes Plaquetários}

É parte fundamental do tratamento das SCA. O uso de aspirina associado a novas classes de antiagregantes tem seu lugar no manejo inicial das SCA.

\section{Acido acetilsalicílico}

O AAS bloqueia a ativação plaquetária, inativando a Ciclo-Oxigenase (COX) 1 e suprimindo a produção de tromboxano A2. Doses de 75 a 325 mg, em geral, são suficientes para antiegragação.
Seu uso no cenário das SCA é bem fundamentado desde a década de 1980. Estudos recentes, como o CURRENTOASIS 7, demonstraram a equivalência do uso de baixas doses de AAS (150 a 300 mg) comparado a altas doses (300 a $325 \mathrm{mg}$ ) precedidas de dose de ataque (150 a $300 \mathrm{mg}$ ) no cenário da SCA. ${ }^{485-487}$

\section{Clopidogrel}

Uma pró-droga que requer oxidação pelo sistema do citocromo P450 e, em sua forma ativa, inibe irreversivelmente o receptor P2Y12 plaquetário, inibindo a agregação plaquetária induzida por Adenosina Difosfato (ADP).

O uso associado de AAS e clopidogrel tem demonstrado benefício na redução de desfechos cardiovasculares, tanto no cenário das SCASST, como no contexto do IAMCST. ${ }^{487-489}$

Com base nessa evidência, devemos administrar clopidogrel em adição ao tratamento padrão para pacientes portadores de SCASST com moderado a alto risco e naqueles com IAMCST. Nos pacientes com idade menor que 75 anos, uma dose de ataque deve ser guiada pela estratégia de reperfusão adotada: $600 \mathrm{mg}$ naqueles que serão submetidos à estratégia intervencionista e 300 mg quando a estratégia adotada é não invasiva ou trombolise.

A dose ideal para pacientes com idade maior do que 75 anos ainda não está definida, mas devem ser utilizados entre 75 mg a 600 mg. É razoável administrar 300 mg para pacientes intolerantes ou em substituição ao AAS.

\section{Prasugrel}

Uma pró-droga que bloqueia o receptor plaquetário P2Y12, porém de forma mais intensa e com início de ação mais rápido. Seu uso conjuntamente com AAS, em comparação com AAS associado a clopidogrel, resultou em redução de eventos cardiovasculares. ${ }^{490}$ Vale ressaltar, no entanto, o aumento do risco de sangramento fatal e não fatal associado ao prasugrel. ${ }^{491}$ Seu uso não é recomendado em pacientes com antecedente de AVC ou isquemia cerebral transitória, idosos (idade $>75$ anos) ou peso $<65 \mathrm{~kg}$.

\section{Ticagrelor}

Bloqueador reversível do receptor P2Y12, agindo também na receptação da ADP via receptor Equilibrative Nucleoside Transporter 1 (ENT1). Seu início de ação é mais rápido que o do clopidogrel, e sua meia-vida plasmática varia de 6 a 12 horas.

O estudo PLATO incluiu 18.624 pacientes apresentando SCASST de moderado a alto risco e IAMCST, randomizando para receber clopidogrel (300 a $600 \mathrm{mg}$ de ataque seguidos de 75 mg de manutenção) ou ticagrelor (180 mg de ataque, seguidos de $90 \mathrm{mg}$ duas vezes ao dia de manutenção). Observou-se redução do desfecho primário combinado de morte cardiovascular, IAM ou AVC no grupo que recebeu ticagrelor em seguimento de 12 meses.

\section{Inibidores de glicoproteína IIb/IIla}

Os Inibidores de Glicoproteína IIb/IIla (IGPIIb/IIla) bloqueiam a agregação plaquetária por impedirem a 
ligação do fibrinogênio à forma ativada do receptor de GPIIb/IIla plaquetário.

Em metanálise incluindo 29.570 pacientes de seis estudos randomizados com SCASST, observou-se redução de 9\% no risco relativo de morte e IAM não fatal associado ao uso dessa classe, sendo o maior benefício entre aqueles com SCA de alto risco submetidos à intervenção percutânea. ${ }^{492}$ Vale ressaltar, no entanto, que grande parte desses estudos foi realizada sem uso rotineiro de dupla antiagregação com AAS e inibidor de P2Y12. Assim, há pouca experiência na associação dessa classe de drogas com prasugrel e ticagrelor. Seu uso nesses casos deve-se restringir a complicações trombóticas durante angioplastia, carga trombótica alta ou situações emergenciais específicas, quando indicado pelo cardiologista intervencionista.

\section{Recomendações}

- AAS (100 a 325 mg) a todos os pacientes com SCA (Classe de Recomendação I; Nível de Evidência A).

- Clopidogrel para SCA sem supradesnivelamento de ST moderado a alto risco (Classe de Recomendação I; Nível de Evidência A).

- Clopidogrel para IAMCST independentemente da estratégia de reperfusão. (Classe de Recomendação I; Nível de Evidência A).

- Clopidogrel em substituição ao AAS para os pacientes intolerantes ou com hipersensibilidade (Classe de Recomendação Ila; Nível de Evidência B).

- Ticagrelor (180 mg de ataque seguido por 90 mg duas vezes ao dia) em pacientes portadores de Al de risco moderado ou alto, além do IAMSST, independentemente da estratégia de tratamento posterior (clínico, cirúrgico ou percutâneo), por 12 meses (Classe de Recomendação I; Nível de Evidência B).

- Prasugrel 60 mg de ataque seguido por 10 mg ao dia em portadores de Al de risco moderado ou alto, além do IAMSST, com anatomia coronária conhecida, submetidos à angioplastia e sem fatores de risco para sangramento (maior ou igual a 75 anos de idade; menos de $60 \mathrm{~kg}$; AVC ou acidente isquêmico transitório prévios) (Classe de Recomendação I; Nível de Evidência B).

- Adição de um IGPIIb/IIla em pacientes com baixo risco hemorrágico, sob dupla antiagregação plaquetária, submetidos à Intervenção Coronária Percutânea (ICP) de alto risco (presença de trombos, complicações trombóticas da ICP) (Classe de Recomendação Ila; Nível de Evidência C).

- Uso de IGPIIb/IIla de forma rotineira antes de angiografia (Classe de Recomendação III; Nível de Evidência A).

\subsubsection{Anticoagulantes}

O uso de anticoagulantes na fase aguda das SCA se justifica pelo seu efeito na inibição da geração ou atividade da trombina, reduzindo, assim a progressão dos eventos trombóticos. Diversas drogas têm sido utilizadas nesse cenário com ação em diferentes pontos da cascata de coagulação.

\section{Heparina não fracionada}

Apresenta um perfil farmacocinético com grande variabilidade individual e janela terapêutica estreita. Assim, é necessário o controle laboratorial rigoroso.

A despeito de novas drogas anticoagulantes, ainda permanece sendo largamente usada nas SCA com e sem elevação de ST. Estudos iniciais comparando heparina, AAS ou placebo em pacientes portadores de Al atestaram o benefício da heparina e do AAS sobre o placebo na incidência de IAM. ${ }^{493,494}$ Estudos posteriores também demonstraram benefícios na redução de eventos cardiovasculares em associação com AAS, ${ }^{495}$ no cenário do IAMCST ${ }^{496}$ e IAMSST. ${ }^{497}$ Esse benefício tem sido demonstrado no contexto do IAMCST a despeito da terapia de reperfusão: trombólise, ${ }^{498-500}$ ou angioplastia primária. ${ }^{501,502} \mathrm{Uma}$ dose de ataque de 60 a $70 \mathrm{UI} /$ kg (máximo de 5.000 UI) é recomendada, seguida de infusão contínua de 12 a 15 UI/kg/hora (máximo de 1.000 UI/hora) caso se deseje heparinização contínua.

\section{Heparinas de baixo peso molecular}

Composto por grupo heterogêneo de derivados da heparina com menor peso molecular e efeito mais previsível.

A enoxaparina é o agente mais utilizado nessa classe. A dose terapêutica é de $1 \mathrm{mg} / \mathrm{kg} /$ dose duas vezes ao dia na maioria dos pacientes. Naqueles com Clearance de Creatinina $(\mathrm{ClCr})<30 \mathrm{~mL} /$ minuto, a dose é de $1 \mathrm{mg} / \mathrm{kg} /$ dose uma vez ao dia. A monitorização da atividade com a dosagem do anti-Xa deve ser feita em casos selecionados, como na presença de $\mathrm{ClCr}$ sérico de 15 a $30 \mathrm{~mL} /$ minuto ou peso > $100 \mathrm{~kg}$. Não deve ser utilizada em caso de $\mathrm{ClCr}<15 \mathrm{~mL} /$ minuto.

A comparação de enoxaparina com HNF em pacientes com SCA com e sem elevação de ST evidenciou redução do desfecho composto de morte e IAM em 30 dias favorecendo a enoxaparina. ${ }^{501}$ Seu uso no IAMCST mostrou desfechos favoráveis comparada a Heparina Não Fracionada (HNF) independentemente da estratégia de reperfusão. ${ }^{502-506}$

Nos casos de SCASST, não há necessidade de dose adicional de enoxaparina, caso a última dose subcutânea tenha sido administrada há menos de 8 horas. Caso tenha sido administrada $\geq 8$ horas, recomenda-se dose adicional de $0,3 \mathrm{mg} / \mathrm{kg}$ por via intravenosa em bólus. ${ }^{507} \mathrm{O}$ crossover para outro tipo de heparina deve ser evitado, considerando o maior risco de sangramento associado a essa estratégia. ${ }^{508}$

Fondaparinux é um anti-fator $X$ de uso subcutâneo. A meiavida de 17 horas permite uso uma vez ao dia, além de não se associar a trombocitopenia induzida por heparina. A dose recomendada é de 2,5 mg uma vez ao dia. Seu uso no cenário da SCASST associou-se a menores taxas de eventos isquêmicos que a enoxaparina, além de menor incidência de sangramentos maiores. ${ }^{509,510}$ Ressalvas, porém, devem ser feitas quando da escolha da angioplastia como estratégia de revascularização. Associação de trombose relacionada ao cateter durante cinecoronariografia foi mais frequente nesse grupo quando comparado ao que recebeu enoxaparina. Essa complicação pode ser abolida com o uso de HNF durante o procedimento. ${ }^{511}$ $\mathrm{O}$ uso de fondaparinux também deve ser evitado quando angiografia coronária for indicada de emergência. 


\section{Novos anticoagulantes}

Há ainda pouca evidência para o uso dos chamados novos anticoagulantes orais no cenário das SCA. Estudos de fase II comparando rivaroxaban com placebo em pacientes utilizando AAS ou antiagregação dupla evidenciou aumento do risco de sangramento dose-dependente com discreto benefício na redução de desfechos duros. ${ }^{512} \mathrm{~A}$ apixabana também foi testada em contexto semelhante, tendo o estudo sido interrompido precocemente. ${ }^{513}$ Novos estudos estão sendo conduzidos para validar o uso dessas drogas nesse contexto clínico. ${ }^{514,515}$

\section{Recomendações}

- HNF 60 a 70 UI/kg (ataque) por via endovenosa, máximo de 5.000 UI, seguida por infusão contínua de 12 a 15 UI/ $\mathrm{kg} /$ hora, máximo inicial de $1.000 \mathrm{UI} /$ hora, durante período mínimo de 48 horas. Manter Tempo de Tromboplastina Parcialmente Ativada (TTPa) de 1,5 a 2,5 vezes o valor de controle (Classe de Recomendação I nível de evidência A).

- Enoxaparina $1 \mathrm{mg} / \mathrm{kg}$ por via subcutânea a cada 12 horas (se > 75 anos, 0,75 mg/kg por via subcutânea a cada12 horas; se $\mathrm{ClCr}<30 \mathrm{~mL} / \mathrm{min}, 1 \mathrm{mg} / \mathrm{kg}$ por via subcutânea uma vez ao dia) (Classe de Recomendação I; Nível de Evidência A).

- Fondaparinux 2,5 mg por via subcutânea uma vez ao dia em pacientes que permanecerão em tratamento clínico inicial ou estratégia invasiva precoce (Classe de Recomendação I; Nível de Evidência B).

- Nos pacientes em uso de fondaparinux, administrar HNF $85 \mathrm{UI} / \mathrm{kg}$ por via endovenosa no momento da ICP ou 60 $\mathrm{UI} / \mathrm{kg}$ naqueles que estiverem recebendo IGPIIb/IIla (Classe de Recomendação I; Nível de Evidência B).

- Fondaparinux para pacientes elegíveis para coronariografia de emergência (Classe de Recomendação I; Nível de Evidência B).

- Troca de heparinas (HNF ou enoxaparina) (Classe de Recomendação III; Nível de Evidência).

\subsubsection{Inibidores do Sistema Renina-Angiotensina- Aldosterona}

Inibidores do sistema renina-angiotensina-aldosterona orais reduzem mortalidade após o IAM, a despeito da terapia de reperfusão. Seus efeitos benéficos são mais pronunciados em pacientes acometidos de IAM anterior, congestão pulmonar e fração de ejeção < 40\%. Em pacientes intolerantes, devem ser utilizados os Bloqueadores dos Receptores da Angiotensina (BRA). Não devem ser administrados se PAS inferior a 100 mmHg na admissão.

Apesar de vários estudos terem demonstrado redução de mortalidade e remodelamento do Ventrículo Esquerdo (VE) com o uso de Inibidores da Enzima Conversora de Angiotensina (IECA) e BRA nos pacientes acometidos de IAM, nenhum avaliou especificamente seu uso no ambiente préhospitalar ou na chegada ao pronto-socorro. ${ }^{516,517}$

Em relação ao uso de antagonistas de aldosterona, o uso de eplerenone no cenário do IAM demonstrou redução de mortalidade em 30 dias naqueles com FEVE $\leq 40 \%$ e sintomáticos, bem como na população diabética. ${ }^{518}$ A introdução precoce em até uma semana associa-se a maior benefício. ${ }^{519,520}$

\subsubsection{Betabloqueadores}

A administração de bloqueadores beta-adrenérgicos no cenário das SCA é controversa. Vários estudos relatam que a administração precoce dos betabloqueadores estaria relacionada à redução da mortalidade ${ }^{521}$ e da área do infarto. ${ }^{522}$ Embora a administração precoce possa ajudar a prevenir taquiarritmias e reduzir a taxa de reinfarto, tem-se observado aumento concomitante da incidência de choque cardiogênico. ${ }^{522}$

Evidências recentes não indicam benefícios do uso precoce na mortalidade, redução do tamanho do infarto, prevenção de arritmias ou reinfarto, mas foi observada redução estatisticamente significativa a curto prazo, quando do uso venoso em pacientes de baixo risco (Killip 1). ${ }^{523}$

São consideradas contraindicações para seu uso: disfunção moderada a grave do VE, edema pulmonar, bradicardia ( $\mathrm{FC}<60 \mathrm{bpm}$ ), hipotensão (PAS $<100 \mathrm{mmHg}$ ), hipoperfusão periférica, BAV de segundo e terceiro graus e hiperreatividade das vias aéreas. Até o momento, não há evidência para apoiar a administração rotineira de betabloqueadores no cenário de APH. Porém a utilização desta terapia pode ser considerada razoável em situações específicas, como hipertensão grave ou na presença de taquiarritmias em pacientes sem contraindicações.

Ensaio clínico randomizado duplo-cego recente avaliando o uso de metoprolol endovenoso ou placebo no cenário do IAMCST antes de angioplastia primária observou redução de arritmias malignas associadas ao uso do metroprolol, porém sem diferenças no porcentual de área infartada. ${ }^{524}$

$\mathrm{Na}$ ausência de contraindicações, devemos iniciar o uso de betabloqueadores por via oral nas primeiras 24 horas a todos os pacientes com suspeita de SCA (Classe de Recomendação I; Nível de Evidência A). Pacientes com contraindicações iniciais devem ser reavaliados periodicamente.

\subsubsection{Estatinas e Hipolipemiantes}

As estatinas reduzem a incidência de eventos cardiovasculares maiores quando iniciadas nos primeiros dias após início da SCA. ${ }^{523}$ Seu início deve ser considerado nas primeiras 24 horas, salvo contraindicações, com meta de redução da Lipoproteína de Baixa Densidade-Colesterol (LDLcolesterol) para valores $<70 \mathrm{mg} / \mathrm{dL}$. Se os pacientes estiverem em uso de estatinas, esta não deve ser interrompida. ${ }^{525-528} \mathrm{Um}$ aumento da mortalidade em curto prazo e maior incidência de eventos cardíacos são observados com a interrupção da estatina na internação por SCA. ${ }^{529}$ Também foi observada redução da área infartada nos pacientes que são submetidos à intervenção percutânea coronária. ${ }^{530-532} \mathrm{O}$ pré-tratamento com 80 mg de atorvastatina, 12 horas antes da ICP na SCA e acrescido de $40 \mathrm{mg}$ imediatamente, antes do procedimento, reduziu significativamente o evento composto de óbito, infarto e revascularização não planejada quando comparado ao placebo. ${ }^{533}$ 


\section{Recomendações}

- Uso de IECA nas primeiras 24 horas após SCA em pacientes com IC, disfunção sistólica, diabetes melito ou infarto anterior (Classe de Recomendação I; Nível de Evidência A).

- Uso de IECA nas primeiras 24 horas em todos pacientes após SCA, salvo contraindicações (Classe de Recomendação Ila; Nível de Evidência A).

- Uso de betabloqueadores orais em pacientes com IC ou fração de ejeção $\leq 40 \%$, salvo contraindicações (Classe de Recomendação I; Nível de Evidência A).

- Uso de betabloqueadores orais em todos pacientes sem contraindicações (Classe de Recomendação Ila; Nível de Evidência B).

- Uso de betabloqueadores venosos na sala de emergência na vigência de arritmias, angina ou hipertensão (Classe de Recomendação IIb; Nível de Evidência B).

- Uso de bloqueadores de aldosterona em pacientes pós-IAM portadores de disfunção de VE (FEVE $\leq 40 \%$ ) na vigência de sintomas de IC ou diabetes (Classe de Recomendação I; Nível de Evidência B).

- Uso de estatinas em altas doses no contexto das SCA nas primeiras 24 horas (Classe I; Nível de Evidência A).

- Associação de ezetimibe à estatina no contexto da SCA para redução de eventos cardiovasculares (Classe de Recomendação Ila; Nível de Evidência B). ${ }^{534}$

\subsubsection{Terapias de Reperfusão}

Fibrinólise: a utilização de terapias de reperfusão em pacientes com IAMCST representou grande avanço no tratamento das SCA. ${ }^{535}$ Os fibrinolíticos foram a primeira terapia de reperfusão desenvolvida para esse grupo de pacientes. Pelo papel importante do trombo intracoronário na patogênese de grande parte das SCA, a utilização de medicações que levam à ativação do sistema fibrinolítico endógeno visa à rápida redução ou à resolução do trombo, restaurando o fluxo coronário distal à lesão culpada e à reperfusão miocárdica.

Diversos estudos randomizados demonstraram o benefício dos fibrinolíticos no contexto da SCA com elevação do segmento ST, no qual a artéria culpada frequentemente encontra-se ocluída. ${ }^{536}$ Entretanto, nas SCASST, nas quais a obstrução da artéria coronária geralmente não é total, sua utilização oferece mais riscos do que benefícios e não está indicada (Quadro 7.4). ${ }^{472}$

Estreptoquinase: foi o primeiro fibrinolítico a demonstrar sua eficácia no tratamento do IAM.100 Ao combinar-se com o plasminogênio, forma um complexo enzimático capaz de converter outras moléculas circulantes de plasminogênio em plasmina, enzima responsável pela degradação da fibrina. Os estudos GISSI-1 e ISIS-2 demonstraram a superioridade da estreptoquinase em relação ao placebo, levando à redução na mortalidade de até $25 \%$ nas primeiras 5 semanas. ${ }^{485-537}$

Os principais efeitos colaterais da estreptoquinase são hipotensão arterial, reações alérgicas e sangramentos. No estudo ISIS-2, o uso da estreptoquinase esteve associado a
Quadro 7.4 - Doses e formas de administração dos agentes fibrinolíticos

\begin{tabular}{lc}
\hline Agente & Dose \\
\hline Estreptoquinase & 1,5 milhão Ul em $100 \mathrm{~mL}$ de soro glicosado $5 \%$ ou soro \\
fisiológico $0,9 \%$ em $30-60$ minutos
\end{tabular}

um aumento na taxa de sangramentos com necessidade de transfusão quando comparada ao placebo (0,5 \% vs. 0,2\%), bem como de AVC hemorrágico. Embora essa última seja a complicação mais temida do uso de fibrinolíticos, o risco absoluto para a ocorrência do sangramento intracraniano é baixo, em torno de $0,1 \%$ nos primeiros 2 dias após a randomização no ISIS-2. ${ }^{475}$

Alteplase (rt-PA): diferentemente da estreptoquinase, o rt-PA necessita de uma ligação com a fibrina para tornarse ativa na conversão do plasminogênio em plasmina. Os estudos GISSI-2 e ISIS-3 compararam o uso do rt-PA com a estreptoquinase em pacientes com IAM. ${ }^{496,538}$ Embora não tenha havido diferença significativa em relação ao desfecho de mortalidade, a ausência da utilização da heparina endovenosa, normalmente recomendada em associação a um agente fibrino-específico como o rt-PA, deve ser considerada limitação desses estudos.

O estudo GUSTO, utilizando infusão acelerada de rt-PA em 90 minutos associada a heparina endovenosa, demonstrou redução absoluta de $1 \%$ na mortalidade em relação à estreptoquinase $(6,3 \%$ vs. $7,3 \%) .{ }^{539}$

Tenecteplase (TNK-tPA): por sua meia-vida mais longa, pode ser administrada em uma dose única em bólus. $\mathrm{O}$ uso da TNK-tPA esteve associado a menor risco de hemorragia extracraniana e à necessidade de hemotransfusão. ${ }^{540}$

\section{Indicações para o uso de fibrinolíticos}

A fibrinólise como estratégia de reperfusão está associada a menor mortalidade em relação ao placebo e, dessa forma, deve ser utilizada na fase aguda do IAM na presença dos seguintes critérios: ${ }^{541,542}$

- Dor sugestiva de isquemia miocárdica com duração menor que 12 horas.

- ECG com elevação do segmento ST em duas derivações contíguas com os seguintes critérios de voltagem: acima de $1 \mathrm{~mm}$ nas derivações periféricas ou precordiais esquerdas, acima de 1,5 mm de V1 a V3 em mulheres, acima de 2 
mm de $\mathrm{V} 1$ a $\mathrm{V} 3$ em homens acima de 40 anos e acima de 2,5 mm de V1 a V3 em homens abaixo de 40 anos.

- Impossibilidade da realização da angioplastia primária em tempo adequado.

- Ausência de contraindicação absoluta.

Na presença de sintomas típicos, a presença de BRE novo ou supostamente novo substitui o critério eletrocardiográfico descrito, e a fibrinólise também está indicada. ${ }^{543}$

\section{Contraindicações para o uso de fibrinolíticos}

São consideradas contraindicações absolutas para o uso dos fibrinolíticos: ${ }^{536,542}$ história de hemorragia intracraniana prévia; AVC isquêmico nos últimos 3 meses; neoplasia ou malformação vascular do sistema nervoso central; traumatismo craniano ou facial significativo nos últimos 3 meses; sangramento ativo ou diátese hemorrágica (exceto menstruação); e suspeita de dissecção aguda de aorta.

As contraindicações relativas são: história de AVC isquêmico há mais de 3 meses; doenças intracranianas não listadas nas contraindicações absolutas; gravidez; uso atual de anticoagulantes; hemorragia interna há menos de 2 a 4 semanas; RCP traumática e prolongada; cirurgia de grande porte há menos de 3 semanas; hipertensão arterial não controlada (PAS acima de $180 \mathrm{mmHg}$ ou diastólica acima de $110 \mathrm{mmHg}$ ); punções vasculares em sítios não compressíveis; e úlcera péptica ativa.

A exposição prévia à estreptoquinase também constitui contraindicação relativa para sua reutilização, já que a presença de anticorpos pode reduzir sua eficácia. ${ }^{543}$

São limitações do uso de fibrinolíticos: complicações hemorrágicas; contraindicações para o seu uso; incapacidade de normalização do fluxo coronariano (TIMI 3) em até 50\% dos casos; ${ }^{544,545}$ reoclusão do vaso levando ao reinfarto; e redução em sua eficácia como terapia de reperfusão após as primeiras 3 horas do início do infarto. ${ }^{546,547}$

\subsection{Intervenção Coronária Percutânea}

\subsubsection{Angioplastia Primária}

A eficácia da ICP como terapia de reperfusão na fase aguda do IAMCST foi demonstrada em estudos randomizados e metanálises. A angioplastia com cateter balão foi associada a redução de mortalidade, reinfarto e hemorragia intracraniana, quando comparada à fibrinólise. ${ }^{547,548}$

Da mesma maneira, a utilização de stents durante a $\mathrm{ICP}$, ao reduzir o risco de oclusão precoce e reestenose tardia, mostrou-se superior ao tratamento fibrinolítico e à angioplastia com cateter balão. ${ }^{549-552}$ Os stents farmacológicos, sobretudo os de segunda geração, eluídos com everolimus, têm se mostrado seguros no tratamento do IAM quando comparados aos convencionais, com redução nos riscos de nova revascularização e de trombose de stent, bem como no desfecho combinado de morte e infarto. ${ }^{553-555}$

\subsubsection{Escolhendo a Estratégia de Reperfusão}

Características do paciente, da apresentação clínica e do serviço responsável pelo atendimento inicial do IAMCST influenciam na escolha do melhor método de reperfusão. ${ }^{541}$

Pelos resultados superiores da ICP sobre a fibrinólise em relação à restauração do fluxo coronariano normal (TIMI 3), redução de eventos isquêmicos e complicações hemorrágicas, a angioplastia primária é considerada a estratégia de escolha quando disponível em tempo adequado. ${ }^{541}$

Para a angioplastia primária, considera-se adequado o tempo previsto porta-balão, iniciado no primeiro contato com a equipe médica até a restauração do fluxo coronariano, de até 90 minutos para pacientes que procurem hospitais com disponibilidade de serviços de hemodinâmica e de até 120 minutos nos casos em que será necessária a transferência para outro hospital. ${ }^{550,556}$ No caso da fibrinólise, é considerado adequado um tempo porta-agulha inferior a 30 minutos, medido a partir do primeiro contato médico até o início da infusão do agente fibrinolítico.

\subsubsection{Hospitais com Serviço de Hemodinâmica}

- Angioplastia primária com tempo porta-balão inferior a 90 minutos para pacientes que se apresentem nas primeiras 12 horas de início dos sintomas (Classe de Recomendação I; Nível de Evidência A).

- Angioplastia primária para pacientes que se apresentem entre 12 e 24 horas do início dos sintomas, com evidências clínicas ou eletrocardiográficas de isquemia miocárdica persistente (Classe de Recomendação Ila; Nível de Evidência B).

\subsubsection{Hospitais sem Serviço de Hemodinâmica}

- Fibrinólise para pacientes com apresentação nas primeiras 3 horas de início dos sintomas, sem contraindicações para uso de fibrinolíticos, com tempo porta-agulha inferior a 30 minutos (Classe de Recomendação I; Nível de Evidência A).

- Transferência para realização de angioplastia primária para pacientes nas primeiras 3 horas de início dos sintomas, considerados como alto risco para complicações relacionadas ao uso de fibrinolíticos e tempo estimado porta-balão (incluindo a transferência) inferior de 120 minutos (Classe de Recomendação Ila; Nível de Evidência C).

- Transferência para realização de angioplastia primária para pacientes que se apresentem com 3 a 12 horas do início dos sintomas, desde que o tempo estimado porta-balão seja inferior a 120 minutos (Classe de Recomendação I; Nível de Evidência B).

- Fibrinólise para pacientes com apresentação entre 3 e 12 horas do início dos sintomas, sem contraindicações para uso de fibrinolíticos, com tempo porta-agulha inferior a 30 minutos e tempo estimado porta-balão (incluindo a transferência) acima de 120 minutos (Classe de Recomendação Ila; Nível de Evidência A).

- Transferência para realização de angioplastia primária para pacientes com contraindicações absolutas ao uso de fibrinolíticos (Classe de Recomendação I; Nível de Evidência C) 


\subsubsection{Angioplastia de Resgate}

Consideram-se como critérios clássicos de reperfusão a melhora da dor, a presença das chamadas arritmias de reperfusão, e a redução de pelo menos $50 \%$ na magnitude da elevação do segmento ST, avaliada 60 minutos após o início da fibrinólise na derivação, na qual existia a maior elevação do segmento ST no ECG inicial.

$\mathrm{Na}$ ausência de sinais clínicos e eletrocardiográficos evidentes de reperfusão, deve ser considerada a falência da terapia fibrinolítica. ${ }^{541}$

A angioplastia de resgate, realizada imediatamente após a falência da fibrinólise, é considerada a melhor forma de tratamento para essa situação. Estudos randomizados mostraram benefícios em relação a uma nova tentativa de fibrinólise e ao tratamento conservador. ${ }^{557}$ Pacientes submetidos à fibrinólise e que não apresentem resolução de pelo menos $50 \%$ no supradesnivelamento do segmento ST na derivação inicialmente com a maior elevação devem ser encaminhados imediatamente para hospitais com serviços de hemodinâmica, para a realização da angioplastia de resgate (Classe de Recomendação I; Nível de Evidência A).

\section{Angioplastia facilitada}

Esta estratégia refere-se ao uso de fibrinolíticos isoladamente ou em associação à IGPIIb/IIla em pacientes com programação de angioplastia primária. O objetivo da angioplastia facilitada seria aumentar a probabilidade de encontrar fluxo TIMI 3 na artéria culpada no momento da ICP. Entretanto, estudos mostraram aumento de mortalidade, reinfarto e AVC com o uso dessa estratégia de reperfusão. ${ }^{558,559}$

Para pacientes em que a angioplastia primária foi escolhida como estratégia de reperfusão no IAM, a administração rotineira de fibrinolíticos, associados ou não a IGPIIb/IIla, encontra-se contraindicada (Classe de Recomendação III; Nível de Evidência B).

\section{Estratégia fármaco-invasiva}

Pacientes submetidos à fibrinólise como estratégia de reperfusão inicial apresentam riscos de complicações, como reoclusão da artéria culpada e reinfarto, mesmo após sucesso inicial. ${ }^{544}$ Esta estratégiase refere a transferência rotineira e precoce de pacientes submetidos à fibrinólise para realização de coronariografia e angioplastia, mesmo após evidências de reperfusão (Classe de Recomendação I; Nível de Evidência B). ${ }^{560,561}$

\subsection{Situações Especiais}

\subsubsection{Choque Cardiogênico}

O choque cardiogênico se refere ao estado de hipoperfusão tecidual secundário à falência da função de bomba do coração, na presença de pressões de enchimento ventricular adequadas. Representa atualmente a principal causa de morte intra-hospitalar em pacientes com IAM com valores de até $50 \%$ nos primeiros 30 dias. ${ }^{476,560-562}$ A reperfusão miocárdica precoce, associada às terapias farmacológicas adjuntas, constitue as principais medidas adotadas para a redução do tamanho do infarto e do risco de evolução para o choque cardiogêncio.

Os critérios hemodinâmicos para choque cardiogênico são hipotensão arterial persistente (PAS abaixo de 90 mmHg ou queda acima de $30 \mathrm{mmHg}$ em relação ao basal); índice cardíaco abaixo de 1,8 ou 2,2 L/min/ $\mathrm{m}^{2}$ na ausência ou presença do uso de inotrópicos, respectivamente; e pressão capilar pulmonar acima de $15 \mathrm{mmHg}$.

Embora a definição do choque cardiogênico seja baseada em critérios derivados da avaliação hemodinâmica invasiva, seu diagnóstico pode ser realizado com base em critérios clínicos, radiológicos e laboratoriais, como tempo de enchimento capilar lentificado, redução do débito urinário e do nível de consciência, congestão pulmonar, acidose metabólica, elevação dos níveis séricos de lactato e redução na saturação venosa central de oxigênio.

A monitorização hemodinâmica invasiva com o cateter de artéria pulmonar não deve ser utilizada de forma rotineira, já que não está associada à redução na mortalidade e pode resultar em complicações. ${ }^{561,563}$ Entretanto, para pacientes selecionados, em que o mecanismo principal do choque não esteja claro, seu uso pode ser considerado.

O uso de drogas inotrópicas e vasopressoras no IAM está associado a aumento do consumo miocárdico de oxigênio, indução de arritmias ventriculares e supraventriculares. Entretanto, seu uso se faz necessário como medida de estabilização e suporte hemodinâmico, até a recuperação da função ventricular e resolução da resposta inflamatória sistêmica. ${ }^{552}$ A noradrenalina é o agente vasopressor de escolha para pacientes com hipotensão arterial. Na persistência de sinais de hipoperfusão tecidual, o uso de inotrópicos pode ser considerado, sendo a dobutamina o medicamento de escolha.

$\mathrm{O}$ estudo SHOCK demonstrou redução na mortalidade em 6 meses com a revascularização precoce (até 6 horas após a randomização) de pacientes com IAM em choque cardiogênico, em comparação com o tratamento clínico inicial associado à revascularização tardia (após 54 horas). Nesse estudo, $86 \%$ dos pacientes em ambos os grupos receberam suporte circulatório com BIA. ${ }^{564}$

O uso rotineiro do BIA no choque cardiogênico foi avaliado especificamente no estudo IABP-SHOCK II. Embora sua utilização não tenha sido associada a um aumento significativo nas complicações, o BIA não demonstrou redução na mortalidade em 30 dias. Importante ressaltar que a taxa de crossover do grupo controle para o grupo em uso de BIA foi de $10 \%$, e houve tendência ao uso mais frequente de outros dispositivos de assistência ventricular no grupo controle $(7,4 \%$ vs. $3,7 \%$; p 0,053). ${ }^{564,565}$

\section{Tratamento do choque cardiogênico}

- Realização da cinecoronariografia precocemente, com objetivo de revascularização miocárdica percutânea ou cirúrgica (Classe de Recomendação I; Nível de Evidência A).

- Suplementação adicional de oxigênio para pacientes com saturação abaixo de 94\% (Classe de Recomendação I; Nível de Evidência C). 
- Uso de fármacos com propriedades vasopressoras e inotrópicas para pacientes com hipotensão arterial e/ou hipoperfusão tecidual (Classe de Recomendação Ila; Nível de Evidência C).

- Noradrenalina como agente vasopressor de primeira escolha (Classe de Recomendação Ila; Nível de Evidência B).

- BIA para pacientes que persistem com sinais de hipoperfusão tecidual após uso de inotrópicos e/ou vasopressores (Classe de Recomendação Ila; Nível de Evidência C).

- BIA de rotina para pacientes em choque cardiogênico (Classe de Recomendação Ilb; Nível de Evidência B).

- Uso da monitorização invasiva com cateter de artéria pulmonar para pacientes em que a avaliação hemodinâmica não invasiva é considerada insuficiente (Classe de Recomendação Ila; Nível de Evidência C).

- Uso da monitorização invasiva com cateter de artéria pulmonar de rotina para pacientes em choque cardiogênico (Classe de Recomendação III =; Nível de Evidência).

\subsubsection{Infarto do Ventrículo Direito}

Embora possa ocorrer de forma isolada, aparece mais frequentemente no contexto do IAM, envolvendo a parede inferior do VE. ${ }^{566}$ É geralmente causado pela obstrução da artéria coronária direita em região proximal à origem dos ramos marginais direitos responsáveis pela vascularização da parede livre do VD. Está associado à maior incidência de taqui e bradiarritmias, instabilidade hemodinâmica e mortalidade, em relação ao infarto isolado da parede inferior do VE. ${ }^{567,568}$

A disfunção aguda do VD no IAM classicamente se manifesta com hipotensão arterial, jugulares ingurgitadas e ausência de sinais de congestão pulmonar. Entretanto, na presença de disfunção associada do VE ou insuficiência mitral, a congestão pulmonar pode estar presente.

O diagnóstico eletrocardiográfico do infarto do VD é feito na presença de elevação do segmento $\mathrm{ST}>1 \mathrm{~mm}$ em alguma das derivações precordiais direitas (V1, V3R, V4R, V5R e V6R), sendo V4R a derivação com maior sensibilidade e especificidade. ${ }^{52,568-571} A$ realização do ecocardiograma transtorácico deve ser considerada em pacientes com instabilidade hemodinâmica e suspeita de infarto do VD, para análise objetiva da função ventricular direita, entretanto não deve atrasar a terapia de reperfusão.

Uma vez confirmado o infarto do VD, medidas para otimização da pré-carga e da contratilidade ventricular direita devem ser adotadas para estabilização hemodinâmica. Em pacientes com hipotensão arterial e sem sinais de congestão pulmonar, a expansão volêmica deve ser a medida terapêutica inicial. ${ }^{572}$ Medicações geralmente utilizadas no tratamento do IAM, mas que reduzem a pré-carga do VD, como nitratos, diuréticos e opioides, devem ser evitadas. Na ausência de reposta à expansão volêmica inicial, o uso de intotrópicos (dobutamina) e vasopressores (noradrenalina) faz-se necessário. O uso do BIA pode ser considerado em pacientes com disfunção ventricular esquerda associada e sinais de congestão pulmonar; seu efeito na redução da pós-carga do
VE, ao melhorar o DC e reduzir as pressões de enchimento, leva a uma redução na pressão capilar pulmonar e na artéria pulmonar, facilitando o trabalho do VD isquêmico. ${ }^{572}$

A manutenção da sincronia atrioventricular é particularmente importante no contexto do infarto do VD. $\mathrm{O}$ aumento das pressões ventriculares direitas associadas à sua disfunção resulta em maior importância da contração atrial para o enchimento ventricular adequado. Dessa forma, pacientes que necessitam de marca-passo transvenoso podem se beneficiar da estimulação sequencial sincronizada, ao invés da estimulação isolada do VD. ${ }^{573,574}$

Pacientes com infarto de VD devem ser prontamente submetidos a terapia de reperfusão. ${ }^{575,576}$ Embora o infarto do VD esteja associado à maior incidência de complicações na fase intra-hospitalar, a maioria dos pacientes evoluiu com melhora ou mesmo normalização da função ventricular direita, apenas raramente evoluindo para IC direita. ${ }^{572,577,578}$ A persistência da disfunção ventricular direita após 30 dias do infarto está associada a maior mortalidade tardia. ${ }^{567}$

\section{Diagnóstico e tratamento do infarto do ventrículo direito $^{576-579}$}

- Realização de derivações precordiais direitas em pacientes com elevação do segmento ST nas derivações inferiores DII, DIII e AVF (Classe de Recomendação Ila; Nível de Evidência B)

- Realização do ecocardiograma transtorácico para análise da função ventricular direita (Classe de Recomendação Ila; Nível de Evidência C).

- Evitar uso de medicações que reduzam a pré-carga do VD como nitratos, diuréticos e opioides (Classe de Recomendação I; Nível de Evidência C).

- Expansão volêmica como medida inicial no tratamento da hipotensão arterial em pacientes com infarto do VD, na ausência de sinais de congestão (Classe de Recomendação I; Nível de Evidência C).

- Uso de inotrópicos e vasopressores para estabilização hemodinâmica de pacientes não responsivos à expansão volêmica (Classe de Recomendação Ila; Nível de Evidência C).

- Fibrinólise ou angioplastia primária como terapias de reperfusão para pacientes com infarto do VD (Classe de Recomendação I; Nível de Evidência A).

\subsubsection{Complicações Mecânicas do Infarto Agudo do Miocárdio}

O choque cardiogênico após o IAM é causado pela disfunção ventricular esquerda em cerca de $80 \%$ dos casos. ${ }^{580}$ Entretanto, em algumas situações, ele pode ser consequência de complicações mecânicas, como a rotura da parede livre, a comunicação interventricular e a insuficiência mitral.

A rotura da parede livre ocorre mais frequentemente em grandes infartos da parede anterior do VE. ${ }^{581,582}$ Sua apresentação clínica costuma ser dramática, com instabilidade hemodinâmica de rápida instalação ou mesmo morte súbita por tamponamento cardíaco. 
A comunicação interventricular também é uma complicação mais frequente do infarto da parede anterior, consequência de obstruções de artérias descendente anteriores do tipo IV, que dão a volta no ápice cardíaco e são responsáveis pela vascularização da porção superior e inferior do septo interventricular. ${ }^{583,584}$

Já a insuficiência mitral ocorre com maior frequência em infartos da parede inferior, podendo ser causada pelo remodelamento da cavidade ventricular (tethering), isquemia, disfunção ou mesmo rotura do músculo papilar posteromedial. ${ }^{585}$

O exame físico de pacientes em choque cardiogênico ou IC pode mostrar sinais sugestivos de complicações mecânicas. O abafamento de bulhas na ausculta sugere tamponamento cardíaco, podendo este ser consequência da rotura de parede livre. A comunicação interventricular pode levar ao aparecimento de sopro holossistólico rude e intenso, mais audível em borda esternal esquerda, com irradiação para base, ápice e região paraesternal direita. ${ }^{586}$ Já o sopro da insuficiência mitral é mais audível em ápice, sua intensidade não esta diretamente relacionada ao refluxo. ${ }^{587}$

Com a suspeita de complicação mecânica, o ecocardiograma tanstorácico deve ser realizado prontamente. ${ }^{588} \mathrm{Em}$ casos de janela inadequada para análise, o ecocardiograma transesofágico encontra-se indicado.

O uso do cateter de artéria pulmonar pode ser considerado em pacientes cujo ecocardiograma não foi capaz de determinar a etiologia do choque de maneira definitiva. Alguns achados da monitorização hemodinâmica invasiva são típicos das complicações mecânicas do infarto. No caso da insuficiência mitral, observam-se ondas "V" em canhão no traçado da pressão capilar pulmonar, refletindo o jato sistólico direcionado ao átrio esquerdo durante a sístole ventricular. A comunicação interventricular leva ao aparecimento do salto oximétrico, situação em que há súbito aumento da SatO2 em amostras de sangue coletadas da artéria pulmonar em relação àquelas coletadas do átrio direito. ${ }^{586}$

O tratamento definitivo das complicações mecânicas do IAM é geralmente cirúrgico. ${ }^{541}$ Dessa forma, medidas para estabilização clínica, como uso de drogas vasoativas, BIA e Ventilação Mecânica (VM), devem ser consideradas pontes para a cirurgia. ${ }^{589} \mathrm{Em}$ pacientes com insuficiência mitral ou comunicação interventricular, vasodilatadores endovenosos, como o nitroprussiato ou a nitroglicerina, podem ser úteis na redução da pós-carga. A pericardiocentese de urgência pode ser considerada em pacientes com tamponamento cardíaco secundário à rotura de parede livre e franca instabilidade hemodinâmica. ${ }^{590}$ A correção percutânea da comunicação interventricular também pode ser alternativa para pacientes sem condições clínicas para a realização da cirurgia e com anatomia do defeito favorável. ${ }^{591}$

\section{Abordagem e Tratamento da Fase Aguda do Acidente Vascular Cerebral}

\subsection{Introdução}

O cuidado ao paciente na fase aguda do AVC requer abordagem individualizada, levando em conta os aspectos clínicos do paciente, as condições logísticas e tecnológicas do local de atendimento, além do conhecimento e da experiência do médico assistente.

A Sociedade Brasileira de Doenças Cerebrovasculares (SBDCV; www.sbdcv.org.br) publicou, há alguns anos, recomendações e diretrizes sobre o tema. ${ }^{592-594}$ Entretanto, diante do contínuo avanço do conhecimento médico e, sobretudo, das importantes publicações sobre o assunto nos últimos anos, alguns pontos foram revisados e atualizados. As Classes de Recomendação e os Níveis de Evidência seguem o padrão geral utilizado nos demais capítulos desse documento.

\subsection{Aspectos Epidemiológicos}

As doenças cerebrovasculares respondem por cerca de 10\% dos óbitos em todo mundo, consistindo na segunda ou na primeira causa de óbito em diversos países. Este impacto é ainda mais importante em países em desenvolvimento. ${ }^{594}$

Os poucos estudos epidemiológicos conduzidos na América Latina mostraram incidências ajustadas variando entre 35 e 183 por 100 mil habitantes. ${ }^{595}$ No Brasil, apesar do declínio na incidência, ${ }^{596} \mathrm{O}$ impacto, quando representado em anos de vida perdidos, é um dos maiores do mundo. ${ }^{597}$

\subsection{Acidente Vascular Cerebral: uma Emergência Neurológica}

Entender o AVC como emergência médica ainda é um desafio. Em nosso país, estudo realizado em quatro cidades demonstrou que quase um quarto dos entrevistados não reconhecia os sinais de alarme para AVC; apenas um terço sabia que o número 192 deve ser utilizado para acionamento do Serviço de Atendimento Móvel de Urgência (SAMU); e apenas metade ligaria ao SAMU para um familiar com quadro sugestivo de AVC. ${ }^{598}$

Adotando outro enfoque, foram avaliados pacientes que sofreram AVC em um centro terciário na cidade de São Paulo e, a despeito de $66 \%$ reconhecerem sinais de alerta, menos de $25 \%$ chegaram em janela terapêutica e apenas cerca de $8 \%$ sabiam da importância do atendimento nas primeiras 4,5 horas. $^{599}$

\subsubsection{Recomendações}

- Programas educacionais periódicos para aumentar o alerta da população sobre o AVC são recomendados (Classe de Recomendação I; Nível de Evidência B).

- Programas educacionais periódicos para aumentar o alerta para profissionais médicos, não médicos e serviços de emergência também são recomendados (Classe de Recomendação I; Nível de Evidência B) ${ }^{600}$

\subsection{Atendimento Pré-Hospitalar e Transporte}

Apesar do AVC ser uma emergência médica, o atraso ocorre devido a vários fatores, como falta de conhecimento dos sinais de AVC, janela terapêutica e subutilização dos serviços especializados de resgate. . $^{598,601-605}$

Existem cidades que contam com ambulâncias específicas para atendimento do AVC, equipadas com tomografia, 
médico neurologista ou emergencista, telemedicina e exames laboratoriais em sistema POCT (glicemia, RNI etc.). ${ }^{606} \mathrm{No}$ momento, a realidade brasileira ainda não contempla essas iniciativas e até mesmo o SAMU ainda não existe em todas nossas cidades. No Brasil, existem poucos estudos que mostram taxas de pacientes trombolisados muito inferiores, chegando até $2,5 \%$ dos casos. ${ }^{607}$

\subsubsection{Recomendações}

- Campanhas de educação da população com o objetivo de reconhecimento dos sinais de alerta do AVC e imediata ativação dos serviços médicos de emergência pré-hospitalar (Classe de Recomendação I; Nível de Evidência B). 598,608,609

- Estimular o uso do SAMU ou outro serviço pré-hospitalar. No caso da eventual dificuldade de comunicação do paciente, a central de regulação do serviço pré-hospitalar deve ter a possibilidade de localizar a chamada (Classe de Recomendação I; Nível de Evidência B). ${ }^{598,608}$

- O SAMU ou outro serviço pre hospitalar móvel deve dar máxima prioridade para os casos da AVC, e seus profissionais precisam iniciar o manejo do AVC usando escalas e protocolos específicos. O transporte deve ser priorizado no paciente estável para o hospital com melhor relação entre a distância e o preparo técnico, notificando o hospital previamente (Classe de Recomendação I; Nível de Evidência B). ${ }^{608}$

- Treinar e oferecer educação continuada para o SAMU e outros serviços pré-hospitalares (Classe de Recomendação Ila; Nível de Evidência C). ${ }^{609}$

- Adotar, em todo o transporte pré-hospitalar, administração de oxigênio em todos aqueles com saturação < 95\%; administração intravenosa de solução salina 0,9\% se desidratação; obtenção de glicemia capilar e correção em caso de hipoglicemia (Classe de Recomendação I; Nível de Evidência B); ${ }^{608,610}$ e não tratar hipertensão arterial rotineiramente (Classe de Recomendação Ilb; Nível de Evidência B). ${ }^{610}$

- Adotar de forma sistemática escalas de triagem, como Cincinnati e Los Angeles Prehospital Stroke Screen (LAPSS), para identificação candidatos a terapia de reperfusão (Classe de Recomendação I; Nível de Evidência B) ${ }^{608}$

- Estabelecer uma rede de hospitais para adequação para tratamento do AVC na fase aguda, com centro de referência para os casos mais graves e com necessidade de intervenção (Classe de Recomendação I; Nível de Evidência B)

\subsection{Exames de Imagem na Fase Aguda do Acidente Vascular Cerebral}

\subsubsection{Tomografia Computadorizada de Crânio}

O principal exame de imagem é a Tomografia Computadorizada (TC) de crânio, capaz de identificar sinais precoces de infarto cerebral, identificar 90 a 95\% das hemorragias subaracnoides e quase $100 \%$ das hemorragias intraparenquimatosas, além de auxiliar na exclusão de causas não vasculares de sintomas neurológicos. ${ }^{611,612}$ Sinais de comprometimento extenso do território vascular da Artéria Cerebral Média (ACM) estão presentes em aproximadamente $60 \%$ dos casos com apenas 2 horas de evolução ${ }^{613}$ associados com pior evolução. A extensão da área comprometida associase, também, com maior risco de transformação hemorrágica após o uso de trombolítico, principalmente quando o território é maior que um terço do território da ACM.

Uma ferramenta que auxilia na melhor avaliação e dimensionamento da área comprometida (inclusive a detecção precoce de infartos) é o escore Alberta Stroke Program Early CT Score (ASPECTS). ${ }^{614,615}$ O único sinal precoce usado como critério de exclusão para o tratamento trombolítico é hipodensidade maior que um terço do território da ACM.

Apesar de a TC de crânio ter relativa baixa sensibilidade em detectar pequenos infartos agudos, especialmente na fossa posterior, ela ainda é o exame de escolha para a abordagem inicial, sendo a estratégia mais custo-efetiva para avaliação de imagem. ${ }^{616}$ Nos candidatos à trombólise, a TC deve ser realizada em até 25 minutos após a chegada à emergência e a interpretação, em 20 minutos.

\subsubsection{Ressonância Magnética de Crânio}

Alguns centros preferem utilizar Ressonância Magnética (RM) de crânio, com técnica de difusão (diffusion-weighted imaging - DWI) na rotina de investigação do AVC agudo. Oferece maior sensibilidade para reconhecer a área de infarto (35 minutos de evolução) e a aquisição em poucos segundos. ${ }^{617}$ É particularmente interessante no diagnóstico de AVC de circulação posterior, infartos lacunares e infartos pequenos corticais. Ademais, a sequência de gradiente de eco auxilia na exclusão de hemorragias, com sensibilidade e especificidade de $100 \%{ }^{618} \mathrm{O}$ tratamento trombolítico não deve ser postergado em função da realização da RM.

A diferença entre o volume de alteração de sinal na difusão (tecido cerebral já infartado) e a imagem de perfusão (tecido cerebral com hipoperfusão crítica) é chamado mismatch (território de penumbra, com tecido cerebral isquêmico potencialmente reversível). ${ }^{619}$ Esta característica pode ser usada para decisões de trombólise baseada na persistência de penumbra em indivíduos apresentando-se além da janela terapêutica aprovada ou em casos de tempo incerto de início dos sintomas. Recentemente, tem sido usada a TC perfusão como alternativa para este método. ${ }^{620}$

\subsubsection{Angiotomografia ou Angiorressonância}

A realização emergencial de angiotomografia ou angiorressonância de vasos intra e extracranianos para detectar oclusão ou estenose de grandes vasos na fase aguda do AVC pode ser usada em centros com estrutura para tratamento de recanalização endovascular.621

\subsubsection{Doppler Transcraniano}

O Doppler Transcraniano (DTC) pode ser usado no diagnóstico de oclusões de grandes artérias cerebrais e para monitorar os efeitos da terapia trombolítica intravenosa, além de ajudar a determinar o prognóstico. Entretanto, entre 7\% e 20\% dos pacientes não têm janela acústica temporal adequada. ${ }^{622}$ 


\section{Recomendações}

- Nos pacientes com suspeita de AVC agudo, uma TC de crânio sem contraste deve ser realizada de urgência (Classe de Recomendação 1; Nível de Evidência A) ou, alternativamente, RM de crânio com difusão e sequência de gradiente eco (Classe de Recomendação I; Nível de Evidência A).

- Um estudo vascular intracraniano não invasivo é fortemente recomendado como parte do protocolo de neuroimagem da fase aguda do AVC isquêmico para os pacientes com possível indicação de tratamento endovascular (trombectomia mecânica ou trombólise intra-arterial) (Classe de Recomendação I; Nível de Evidência A).

- O exame de imagem cerebral deve ser interpretado por um médico treinado na avaliação de TC/RM de crânio (Classe de Recomendação I; Nível de Evidência C).

- Neuroimagem multimodal pode ser utilizada na seleção para terapia trombolítica nos pacientes com início dos sintomas indefinido ou além de janela de 4,5 horas (Classe de Recomendação Ilb; Nível de Evidência B).

\subsubsection{Outros Exames na Fase Aguda do Acidente Vascular Cerebral}

Exames complementares não devem ser motivo para atraso no uso de trombolíticos.

O exame do liquor só será recomendado quando houver fortes indícios de Hemorragia subaracnóidea (HSA), mas sem evidência de sangue na TC de crânio, ou clínica sugestiva de infecção do sistema nervoso central.

Fica indicada a realização de: ECG, Radiografia de tórax e hemograma, coagulograma e bioquímica. Entretanto, na ausência de contraindicação ao tratamento trombolítico, apenas o resultado da glicemia é obrigatório antes deste (Classe de Recomendação I; Nível de Evidência B).

\subsection{Atendimento Emergencial do Acidente Vascular Cerebral Isquêmico}

Avaliar sinais vitais e instituir suporte básico. $O$ atendimento realizado por neurologista favorece o diagnóstico e o prognóstico (Quadro 8.1). ${ }^{623,624}$

Quadro 8.1 - Tempos máximos recomendados no atendimento emergencial do acidente vascular cerebral isquêmico

\begin{tabular}{l}
\hline Da admissão à avaliação médica: 10 minutos \\
Da admissão à avaliação neurologista: 15 minutos \\
Da admissão à tomografia computadorizada de crânio: 25 minutos \\
Da admissão à tomografia computadorizada de crânio (interpretação): 45 \\
minutos \\
Da admissão à infusão do alteplase: 60 minutos \\
Disponibilidade do neurocirurgião: 2 horas \\
Da admissão ao leito monitorizado: 3 horas
\end{tabular}

Não existe evidência da eficácia de suplementação de oxigênio, mas supõe-se que, na região de penumbra, é importante haver boa oxigenação. ${ }^{625}$

A desidratação costuma se associar a um pior prognóstico. Entende-se que a manutenção de uma hidratação adequada favorece a homeostase, apesar de não haver evidência científica. ${ }^{626}$

Hiperglicemia ocorre em mais da metade dos pacientes na fase aguda, mesmo sem história de diabetes, e se associa à maior morbimortalidade. Níveis superiores a 140 mg/dL estão associados a piores resultados no tratamento trombolítico. Entretanto, não está claro que a normalização glicêmica tenha impacto positivo no prognóstico. Por sua vez, a hipoglicemia pode causar disfunção neurológica ou mesmo lesão tecidual, constituindo-se em diagnóstico diferencial de AVC. ${ }^{627}$

Hipertensão arterial é comumente observada por compensação fisiológica decorrente da isquemia cerebral e aumento reacional da pressão arterial média secundário à progressiva elevação da Pressão Intracraniana (PIC). Ao mesmo tempo que o aumento pressórico está relacionado a pior prognóstico, alguns estudos demonstraram piora associada a redução da pressão arterial (Quadro 8.2). Assim, a resposta permanece controversa, e a tendência é evitar intervenções agressivas na fase aguda (Quadro 8.3). ${ }^{608,628-630}$

\section{Quadro 8.2 - Manejo da hipertensão arterial. Pré-tratamento com trombolíticos intravenoso}

\begin{abstract}
Se PAS $\geq 185 \mathrm{mmHg}$ ou $P A D \geq 110 \mathrm{mmHg}$, não iniciar a infusão de alteplase antes de controlar a pressão arterial

Esmolol (1 ampola = $10 \mathrm{ml}, 10 \mathrm{mg} / \mathrm{ml})$ : aplicar EV, $500 \mu \mathrm{g} / \mathrm{kg} /$ minuto em 1 minuto. Seguir com $50 \mu \mathrm{g} / \mathrm{kg} / \mathrm{min}$ por 4 minutos

Se PA ainda inadequada, novo bólus de $500 \mu \mathrm{g} / \mathrm{kg} /$ minuto em 1 minuto e aumentar a dose de manutenção para $100 \mu \mathrm{g} / \mathrm{kg} /$ minuto

Se PA seguir inadequada nos próximos 4 minutos, novo bólus de $500 \mu \mathrm{g} / \mathrm{kg} /$ minuto em 1 minuto e aumentar a dose de manutenção para $150 \mu \mathrm{g} / \mathrm{kg} /$ minuto

Se PA seguir inadequada nos próximos 4 minutos, novo bólus de $500 \mu \mathrm{g} / \mathrm{kg} /$

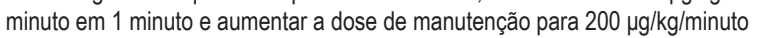
(dose máxima)
\end{abstract}

PAS: pressão arterial sistólica; $P A D$ : pressão arterial diastólica; $E V$ : via endovenosa; $P A$ : pressão arterial.

\section{Quadro 8.3 - Manejo da hipertensão arterial durante e após o tratamento com alteplase}

Monitorizar a pressão arterial durante as primeiras 24 horas após iniciar 0 tratamento

Medir a cada 15 minutos, nas primeiras 2 horas

Medir a cada 30 minutos, nas próximas 6 horas

Medir a cada 60 minutos, até completar 24 horas

Pacientes que necessitem de tratamento com anti-hipertensivos intravenosos devem ser monitorizados a cada 15 minutos, durante as primeiras 24 horas 
A hipotensão arterial é rara e, geralmente, associada a outras condições clínicas. Em uma análise posterior do International Stroke Trial (IST), níveis de pressão sistólica $\leq$ $140 \mathrm{mmHg}$ se associaram com pior prognóstico. ${ }^{631} \mathrm{O}$ controle pode ser feito com uso de expansão volêmica e vasopressores.

Estudos mostram associação entre hipertermia e pior prognóstico, possivelmente pelo aumento da demanda metabólica cerebral em um contexto de isquemia, excitotoxicidade e aumento da resposta inflamatória local. ${ }^{632}$

Após atingir a pressão arterial desejada, manter infusão contínua.

Metoprolol ( 1 ampola $=5 \mathrm{~mL}, 1 \mathrm{mg} / \mathrm{mL}$ ): aplicar por via endovenosa, $5 \mathrm{mg}$ a cada 10 minutos, sendo $1 \mathrm{mg} /$ minuto, máximo de $20 \mathrm{mg}$.

Nitroprussiato de sódio (1 ampola = $50 \mathrm{mg}$ ): diluído em solução de glicose 5\%. Aplicar por via endovenosa: 0,5 a $8 \mu \mathrm{g} / \mathrm{kg} /$ minuto, fazendo reajustes, se necessário, a cada 10 minutos.

\subsubsection{Recomendações}

- O tratamento dirigido para o tipo de AVC diagnosticado deve ser iniciado em até 60 minutos da admissão do paciente no serviço hospitalar, observando-se, em primazia, os tempos relacionados no quadro 8.1 (Classe de Recomendação II; Nível de Evidência B).

- Desenvolvimento e aplicação de protocolos escritos multiprofissionais e integrados para o atendimento de todo e qualquer caso com suspeita de AVC (Classe de Recomendação II; Nível de Evidência B.

- O tratamento do paciente com AVC deve ser orientado por um médico neurologista (Classe de Recomendação I; Nível de Evidência B).

- Realização de exames laboratoriais para exclusão de diagnósticos diferenciais e auxílio na decisão terapêutica (Classe de Recomendação Ilb; Nível de Evidência B).

- Realização de exame de neuroimagem para orientação terapêutica na fase aguda (tomografia ou RM) (Classe de Recomendação I; Nível de Evidência A).

- Monitorização cardiovascular não invasiva e da $\mathrm{SatO}_{2}$ (Classe de Recomendação II; Nível de Evidência B).

- Suplementação de oxigênio deve ser realizada, apenas se necessário, para manter a $\mathrm{SatO}_{2}$ em níveis iguais ou maiores que 95\% (Classe de Recomendação Ilb; Nível de Evidência B).

- A indicação de suporte ventilatório e a proteção de vias aéreas devem ser cuidadosamente avaliadas, especialmente nos pacientes com rebaixamento de nível de consciência e quadro neurológico sugestivo de AVC isquêmico de tronco cerebral (Classe de Recomendação II; Nível de Evidência B).

- O paciente com AVC agudo deve ser adequadamente hidratado com soluções salinas isotônicas (Classe de Recomendação II; Nível de Evidência B).

- Avaliar a possibilidade diagnóstica de diabetes nos pacientes com hiperglicemia, por meio do exame de hemoglobina glicada, e tratar causas secundárias (Classe de Recomendação II; Nível de Evidência B).

- Tratar hiperglicemia na fase aguda do AVC com insulina regular, tendo como meta razoável níveis de glicemia entre 140 e 180 mg/dL (Classe de Recomendação Ila; Nível de Evidência C.

- Corrigir prontamente situações de hipoglicemia (glicemia abaixo de 70 mg/dL) (Classe de Recomendação Ila; Nível de Evidência B)

- Não reduzir a pressão arterial na fase aguda do AVC isquêmico, exceto quando os níveis pressóricos forem PAS > $220 \mathrm{mmHg}$ ou PAD > $120 \mathrm{mmHg}$. Nestes casos, a redução não deve exceder a 15\% dos valores pressóricos iniciais, nas primeiras 24 horas (Classe de Recomendação II; Nível de Evidência B).

- Utilizar medicação anti-hipertensiva em pacientes candidatos ao tratamento trombolítico, mas com níveis pressóricos $\geq 185 \times 110 \mathrm{mmHg}$ antes do início do tratamento (Quadro 8.2) (Classe de Recomendação I; Nível de Evidência A).

- Manter monitorização pressórica intensiva na fase aguda do AVC, com ajuste do tratamento caso necessário, objetivando, nos casos submetidos ao tratamento trombolítico, PAS $\leq 180 \mathrm{mmHg}$ e PAD $\leq 105 \mathrm{mmHg}$ (Quadro 8.3) (Classe de Recomendação I; Nível de Evidência A).

- Não reduzir abruptamente a pressão arterial na fase aguda do AVC isquêmico. Por essa mesma razão, o uso da nifedipina está contraindicado (Classe de Recomendação Ila; Nível de Evidência B).

- A pressão arterial média deve ser mantida acima de 90 $\mathrm{mmHg}$. Isso deve ser feito pela administração de fluidos isotônicos e, quando necessário, drogas vasoativas (Classe de Recomendação II; Nível de Evidência B).

- Manter a temperatura axilar abaixo de 37,5 oC (Classe de Recomendação II; Nível de Evidência B).

- Nos casos de hipertermia, investigar causas infecciosas. Febre de origem central deve ser sempre um diagnóstico de exclusão (Classe de Recomendação Ila; Nível de Evidência B).

\subsection{Anticoagulantes, Antiagregantes Plaquetários e Estatinas no Acidente Vascular Cerebral Isquêmico Agudo}

\subsubsection{Anticoagulantes}

Uma revisão sistemática da Cochrane Collaboration envolveu 23.748 pacientes que utilizaram diversos anticoagulantes. Não houve evidência de que a anticoagulação iniciada nos primeiros 14 dias do AVC tenha reduzido a chance de óbito ao final do seguimento. Da mesma forma, não houve evidência de redução da chance de óbito ou dependência ao final do seguimento. Apesar de a anticoagulação precoce ser associada a menor recorrência de AVC, ela também se associou a maior ocorrência de hemorragia intracraniana sintomática. ${ }^{633}$

A comparação de eficácia entre a Heparina de Baixo Peso Molecular (HBPM) e o AAS foi avaliada em um estudo em pacientes asiáticos com predomínio de doença 
estenótica intracraniana aguda, não tendo sido demonstrado superioridade da heparina. ${ }^{634}$

\section{Recomendações}

- Não se recomenda a anticoagulação de forma rotineira, com HNF ou heparina de baixo peso, em pacientes na fase aguda do AVC isquêmico (Classe de Recomendação III; Nível de Evidência A).

\subsubsection{Antiagregantes Plaquetários}

O efeito da aspirina na redução da mortalidade, morbidade e recorrência de $\mathrm{AVC}$, quando iniciada dentro das primeiras 48 horas da instalação dos sintomas, foi demonstrado há quase 20 anos, nos estudos CAST e IST. ${ }^{635,636}$

O uso de ticlopidina, clopidogrel, dipiridamol ou outro antiagregante plaquetário, de forma isolada, ainda não foi avaliado adequadamente na fase aguda do AVC isquêmico. Se contraindicação ao AAS, outros antiagregantes plaquetários podem ser uma alternativa terapêutica. Recentemente, o estudo SOCRATES, avaliando o uso de ticagrelor em monoterapia comparado com aspirina, em pacientes com AVC leve e não submetidos à trombólise, não mostrou benefício com o uso de ticagrelor. ${ }^{637}$

O uso de dupla antiagregação para pacientes com AVC isquêmico ainda necessita de maior investigação. ${ }^{638}$

\section{Recomendações}

- Recomenda-se o início da administração oral de AAS na dosagem diária de 160 a 300 mg em até 48 horas após a instalação do AVC isquêmico (Classe de Recomendação I; Nível de Evidência A).

- Não existe evidência, até o momento, de benefício para a administração rotineira de outros antiagregantes plaquetários em monoterapia na fase aguda do AVC isquêmico (Classe de Recomendação Ilb; Nível de Evidência C).

- O uso de dupla antiagregação plaquetária parece ser benéfico quando instituído nas primeiras 24 horas e por curto prazo (21 dias) em pacientes com AVC isquêmico menor de etiologia presumivelmente não cardioembólica (Classe de Recomendação Ilb; Nível de Evidência B).

\subsubsection{Estatinas}

O uso de atorvastatina em alta dose $(80 \mathrm{mg})$ em pacientes com AVC isquêmico (iniciada entre 1 e 6 meses do evento) reduziu a recorrência de $\mathrm{AVC}$ associada à redução do LDL. ${ }^{639}$ Seu uso nas primeiras 48 horas ainda necessita de investigações mais robustas. ${ }^{640}$

\section{Recomendações}

- Pacientes com AVC agudo em uso de estatinas devem seguir com seu tratamento (Classe de Recomendação Ila; Nível de Evidência B).

- O uso de estatinas após 48 horas do AVC é seguro (Classe de Recomendação I; Nível de Evidência B).

\subsubsection{Protocolo de Trombólise Intravenosa}

O uso do ativador de plasminogênio tecidual recombinante (rt-PA) endovenoso, quando administrado ao paciente nas primeiras 4 horas e 30 minutos, revelou diminuição na incapacidade funcional, sendo, no momento, uma das intervenções específicas recomendadas para o tratamento na fase aguda do AVC isquêmico (Classe de Recomendação I; Nível de Evidência A). ${ }^{641}$ Estreptoquinase foi avaliada, e seu uso foi proscrito por causa dos altos índices de mortalidade. ${ }^{642}$

Conforme os estudos iniciais e por questões de segurança, a aplicação do rt-PA deve respeitar os critérios a seguir. ${ }^{608,643}$

\section{A) Critérios de Inclusão}

- Défice neurológico compatível com AVC isquêmico em qualquer território encefálico.

- Possibilidade de se iniciar a infusão do rt-PA dentro de 4 horas e 30 minutos do início dos sintomas. Para isso, o horário do início dos sintomas deve ser precisamente estabelecido. Caso os sintomas sejam observados ao acordar ou o horário de início não estiver claro, devese considerar o último horário no qual o paciente foi observado normal.

- TC do crânio ou RM sem evidência de hemorragia.

- Idade superior a 18 anos.

\section{B) Critérios de Exclusão}

Absolutos:

- AVC isquêmico ou traumatismo craniencefálico grave nos últimos 3 meses.

- Suspeita clínica de HSA ou dissecção aguda de aorta.

- Punção arterial em local não compressível na última semana.

- História pregressa de neoplasia cerebral, alguma forma de hemorragia intracraniana, malformação vascular cerebral ou aneurisma.

- Cirurgia intracraniana ou intrarraquiana recente.

- Aumento da pressão arterial, com PAS $\geq 185 \mathrm{mmHg}$ ou PAD $\geq 110$ mmHg (em três ocasiões, com 10 minutos de intervalo), refratário ao tratamento anti-hipertensivo.

- Sangramento interno ativo, diátese hemorrágica, incluindo, mas não limitado a plaquetas $<100.000 / \mathrm{mm}$, uso de varfarina com Tempo de Protrombina (TP) $>15$ segundos ( $\mathrm{RNI}>1,7)$, uso de heparina nas últimas 48 horas com TTPa elevado, uso de novos anticoagulantes orais (inibidores diretos da trombina ou inibidores do fator Xa) com alteração laboratorial associada (TTPa, plaquetas, TP e atividade do fator $\mathrm{Xa}$ ).

- Glicemia menor que 50 ou maior que 400 mg/dL, com reversão dos sintomas após a correção.

- TC de crânio com hipodensidade precoce igual ou maior do que um terço do território da ACM.

\section{Relativos:}

- Défices em melhora rápida no período anterior ao início da trombólise, desde de que leves e não incapacitantes. 
- Gravidez.

- Crise epiléptica na instalação do quadro que mantenha défices neurológicos residuais compatíveis com AVC isquêmico.

- Cirurgia de grande porte ou trauma grave nos últimos 14 dias.

- Hemorragia geniturinária ou gastrintestinal (nas últimas 3 semanas), ou história de varizes esofagianas.

- Infarto do miocárdio recente (3 meses).

- Evidência de endocardite ou embolo séptico.

\section{C) Critérios de Exclusão Relativos Específicos para Janela} de 3 a 4,5 Horas

- Idade > 80 anos.

- AVC grave (National Institutes of Health - NIH > 25).

- Uso de anticoagulantes, mesmo com INR $<1,7$.

- História de diabetes e AVC isquêmico prévio (ambos).

Alguns centros têm utilizado neuroimagem multimodal (RM com difusão/perfusão ou TC com perfusão) para selecionar candidatos à terapia trombolítica, especialmente fora da janela terapêutica ou com tempo indeterminado de início dos sintomas.

Em pacientes sem história recente de uso de anticoagulantes ou outra suspeita de coagulopatia, o tratamento com o rt-PA pode ser iniciado antes dos resultados das provas laboratoriais de coagulação, mas deve ser descontinuado se a rNI estiver maior do que 1,7, o TTPa elevado (acima dos valores de referência locais) ou plaquetas $<100.000$.

Desde a aprovação do rt-PA em 1996 nos Estados Unidos pelo Food and Drugs Administration (FDA), vários pacientes receberam tratamento fora dos critérios clássicos de indicação e contraindicação, com bons resultados e sem aumento significativo do risco hemorragia. Em diretrizes internacionais mais recentes, esta tendência fica clara. ${ }^{608}$ Sugere-se cautela na administração do rt-PA, considerando a relação risco/benefício nos casos com contraindicações relativas.

Além disso, uma publicação revisou o racional científico para os critérios de inclusão e exclusão do rt-PA no AVC isquêmico, descritas a seguir: ${ }^{644}$

- Idade: administração está igualmente recomendada em paciente com $<80$ ou $>80$ anos até 3 horas da instalação (Classe de Recomendação I; Nível de Evidência A).

- Gravidade: no AVC isquêmico, com NIH > 25, também está indicado tratamento em até 3 horas, pois, apesar do aumento do risco de sangramento, existe benefício. No AVC isquêmico leve $(\mathrm{NIH}<5)$, mas com sintomas incapacitantes, o tratamento também está indicado (Classe de Recomendação I; Nível de Evidência A).

- No AVC isquêmico, com défice leve e não incapacitante, os riscos deverão ser pesados em relação aos benefícios (Classe de Recomendação Ilb, Nível de evidência C.

- Défice em melhora: o tratamento é justificado para pacientes que ainda apresentam défices moderados e potencial incapacidade (Classe de Recomendação Ila; Nível de Evidência A).
- Janela estendida (3 a 4,5 horas): o benefício do tratamento existe, e é razoável e seguro em maiores que 80 anos (Classe de Recomendação Ila; Nível de Evidência B)

- RNI < 1,7 (Classe de Recomendação Ilb; Nível de Evidência B); presença de AVC prévio e diabetes (Classe de Recomendação Illb; Nível de Evidência B).

- No AVC isquêmico extenso (NIH > 25), há benefício incerto do tratamento com rt-PA na janela estendida (Classe de Recomendação IIb; Nível de Evidência C).

- Wake-up stroke: para pacientes que acordam com o défice neurológico e apresentam mais de 4,5 horas da última vez em que foram vistos bem, não está recomendado o tratamento com rt-PA. Pelas evidências disponíveis até o momento, em pacientes com wake-up stroke, o uso de critérios de imagem para seleção de candidatos ao tratamento trombolíticos não está recomendado fora do contexto de trabalhos científicos (Classe de Recomendação III; Nível de Evidência B).

- Gravidez: administração de rt-PA pode ser realizada quando os benefícios em pacientes com AVC isquêmico moderado a grave superarem os riscos de sangramento uterino (Classe de Recomendação Ilb; Nível de Evidência C).

- Alterações de coagulação: segurança da trombólise em situações que incluem plaquetas $<100.000$, RNI $>1,7$, TP $>15$ segundos e TTPa $>40$ segundos é desconhecida e não recomendada (Classe de Recomendação III; Nível de Evidência C). Contudo, pelo baixo risco de anormalidades prévias não suspeitadas, é razoável iniciar o tratamento enquanto se aguardam os resultados dos exames laboratoriais, se não exisitrem razões claras para que uma anormalidade seja encontrada (Classe de Recomendação Ila; Nível de Evidência B).

- Uso de anticoagulantes: administração não deve ser realizada se $\mathrm{RNI}>1,7$ ou uso de HBPM nas últimas 24 horas (Classe de Recomendação III; Nível de Evidência B).

- Em relação aos novos anticoagulantes orais, o tratamento concomitante parece ser perigoso e não está recomendado se houver história de uso, exceto se não houver alteração dos testes laboratoriais adequados para o anticoagulantes em uso (TTPa, RNI, plaquetas, ECT, TT e atividade do fator Xa) ou última dose administrada há mais de 48 horas, com função renal normal.

- Trauma grave e cirurgia nos últimos 14 dias: uso cuidadoso e em pacientes selecionados, pesando os benefícios do tratamento frente ao risco de sangramento no sítio cirúrgico (Classe de Recomendação Ilb; Nível de Evidência C).

- Trauma craniano grave e AVC nos últimos 3 meses: o tratamento está contraindicado pelo risco de sangramento, especialmente no trauma grave, ainda na fase inicial intra-hospitalar (Classe de Recomendação III; Nível de Evidência C).

- AVC isquêmico e IAM concomitantes: é razoável o tratamento com rt-PA intravenosa na dose recomendada para AVC isquêmico, seguido de angioplastia percutânea com stent, se indicado (Classe de Recomendação Ila; Nível de Evidência C). 
- IAM nos últimos 3 meses: trombólise é razoável se for IAMSST ou IAMCST envolvendo parede inferior ou VD (Classe de Recomendação Ila; Nível de Evidência C). Também pode ser razoável o tratamento em pacientes com IAM com supradesnivelamento de parede anterior (Classe de Recomendação Ilb; Nível de Evidência C).

- Pericardite: nos pacientes com AVC iquêmico grave e probabilidade de incapacidade funcional importante, o tratamento é razoável e interconsulta cardiológica urgente é recomendada (Classe de Recomendação Ilb; Nível de Evidência C). Nos casos em que a probabilidade de incapacidade significativa é menor, o benefício é incerto (Classe de Recomendação Ilb; Nível de Evidência C).

- Endocardite infecciosa: o tratamento não deve ser realizado nos pacientes com sintomas consistentes de endocardite infecciosa, pelo risco aumentado de sangramento (Classe de Recomendação III; Nível de Evidência C).

- Sangramento geniturinário ou gastrintestinal prévio: literatura sugere baixo risco de sangramento, sendo razoável o tratamento (Classe de Recomendação Ilb; Nível de Evidência C). Pacientes com neoplasia gastrintestinal, ou sangramento nas últimas 3 semanas, são pacientes de risco, e o tratamento pode ser perigoso (Classe de Recomendação III; Nível de Evidência C).

- Angiopatia amiloide e micro-hemorragias: não foi observado aumento do risco de sangramento, e o tratamento nesses casos é razoável, desde que não exista história de hemorragia intracraniana sintomática prévia (Classe de Recomendação Ila; Nível de Evidência B).

- Aneurisma cerebral < $10 \mathrm{~mm}$ não rotos: o tratamento é razoável e provavelmente recomendado (Classe de Recomendação Ila; Nível de Evidência C).

- Em pacientes com aneurismas gigantes não rotos e não tratados, o tratamento com trombolítico tem segurança incerta (Classe de Recomendação Ilb; Nível de Evidência C).

- Malformações arteriovenosas: pacientes com défices graves pelo AVC isquêmico, apesar de terem risco aumentado de sangramento, podem ser considerados, pesando riscos e benefícios incertos (Classe de Recomendação llb; Nível de Evidência C).

- Neoplasia cerebral: tratamento em pacientes com neoplasia extra-axial é provavelmente recomendado (Classe de Recomendação Ila; Nível de Evidência C). Nas neoplasias intra-axiais, é potencialmente perigoso (Classe de Recomendação III; Nível de Evidência C).

- Insuficiência renal crônica em diálise: em pacientes com TTPa normal, rt-PA é recomendado (Classe de Recomendação I; Nível de Evidência C). Naqueles com TTPa aumentado, existe risco aumentado de complicações hemorrágicas.

- Demência: mesmo pacientes demenciados podem se beneficiar do tratamento (Classe de Recomendação Ilb; Nível de Evidência B). A decisão deve ser individualizada.

- Neoplasias sistêmicas: a segurança do uso de rt-PA nesse contexto não é bem estabelecida (Classe de Recomendação Ilb; Nível de Evidência C). Pacientes com sobrevida esperada maior que 6 meses podem se beneficiar do tratamento, se outras contraindicações não coexistirem.
- Incapacidade prévia não aumenta risco de sangramento, mas está associada a menor chance de melhora e maior mortalidade. Nos pacientes com incapacidade prévia (Rankin $\geq 2$ ) pode ser razoável, mas a decisão deve levar em conta outros fatores como qualidade de vida, suporte familiar e diretrizes de cuidado previamente estabelecidas (Classe de Recomendação Ilb; Nível de Evidência B).

- Glicemia: tanto hipoglicemia ( $<50 \mathrm{mg} / \mathrm{dl}$ ) ou hiperglicemia (> $400 \mathrm{mg} / \mathrm{dl}$ ) podem mimetizar um AVC isquêmico, e, portanto, isso deve ser avaliado antes do tratamento, pois o rt-PA não está indicado nas condições não vasculares (Classe de Recomendação III; Nível de Evidência B). É razoável o tratamento dos pacientes que apresentam glicemia acima de 400, que mantém défices após a correção, e são elegíveis pelos outros critérios (Classe de Recomendação Ilb; Nível de Evidência B).

- Crise epiléptica na apresentação: tratamento é razoável nos pacientes em que défice residual persiste após a crise e pode ser atribuído ao AVC e não a um fenômeno pósictal (Classe de Recomendação Ila; Nível de Evidência C).

- Alterações isquêmicas precoces na tomografia: o tratamento é recomendado mesmo na presença de alterações leves a moderadas (Classe de Recomendação I; Nível de Evidência A). Entretanto, francas áreas de hipoatenuação ou extensas áreas sugestivas de isquemia precoce sugerem lesão irreversível e não levam a benefício, não sendo recomendáveis (Classe de Recomendação III; Nível de Evidência A).

- Retinopatia diabética com hemorragia e outras condições com hemorragia ocular: o tratamento é razoável, desde que pesado o risco de sangramento ocular contra possibilidades de sequelas pelo AVC isquêmico (Classe de Recomendação Ila; Nível de Evidência B).

- Sangramento vaginal e menstruação: tratamento é provavelmente indicado sem história de menorragia, contudo devem ser alertadas para possibilidade de aumento do fluxo menstrual (Classe de Recomendação Ila; Nível de Evidência C). Ainda, pelos benefícios potencialmente superiores aos riscos em mulheres com história de menorragia, sem anemia clinicamente significativa ou hipotensão, o tratamento deve ser considerado (Classe de Recomendação IIb; Nível de Evidência C).

- Massa intracardíaca: nos pacientes com mixoma ou fibroelastoma e AVC isquêmico com probabilidade de incapacidade significativa, o tratamento pode ser considerado (Classe de Recomendação Ilb; Nível de Evidência C).

- Dissecção vasos cervicais: no caso de suspeita ou confirmada dissecção de vasos extracranianos, o tratamento é razoavelmente seguro e provavelmente recomendado (Classe de Recomendação Ila; Nível de Evidência C).

- Dissecção de vasos intracranianos: a segurança e a utilidade do uso do rt-PA, no caso de dissecção de vasos intracranianos, permanecem desconhecidas, incertas e não estabelecidas (Classe de Recomendação Ilb; Nível de Evidência C). 
- Punção liquórica: tratamento deve ser considerado nos pacientes, mesmo com história de punção nos últimos 7 dias (Classe de Recomendação IIb; Nível de Evidência C.)

- Suspeita de quadro psicogênico: como o risco de sangramento nesse contexto é muito baixo, o tratamento é provavelmente recomendado em detrimento ao atraso no tratamento para realização de exames diagnósticos adicionais (Classe de Recomendação Ila; Nível de Evidência B).

- AVC isquêmico no contexto de cateterismo cardíaco e procedimentos endovasculares: depende dos critérios de elegibilidade habituais (Classe de Recomendação Ila; Nível de Evidência A).

- Paciente incapaz: recomenda-se realizar o tratamento em pacientes elegíveis, mesmo que incapazes e sem representante legal imediatamente disponível (Classe de Recomendação I; Nível de Evidência C).

- Uso de antiagregantes plaquetários: o tratamento está indicado nos pacientes em uso de AAS em monoterapia ou mesmo quando associado ao clopidogrel, pois o benefício supera os riscos hemorrágicos (Classe de Recomendação I; Nível de Evidência B).

- Uso de cocaína: o tratamento é razoável se não houver outros critérios de exclusão (Classe de Recomendação lla; Nível de Evidência C).

- Anemia falciforme: o tratamento nesses casos deve incluir hidratação, correção da hipoxemia, correção da hipotensão e troca sanguínea para reduzir porcentagem de hemoglobina S (Classe de Recomendação I; Nível de Evidência B). O tratamento com o rt-PA, nesse contexto, não está bem estabelecido (Classe de Recomendação IIb; Nível de Evidência C).

- Consentimento pós-informação: diante dos potenciais riscos do tratamento trombolítico, é altamente recomendável a discussão com o paciente, ou, em sua impossibilidade, com os familiares ou responsáveis sobre os riscos e benefícios do tratamento, registrando em prontuário. Entretanto, é geralmente aceito, do ponto de vista ético e legal, uma exceção à obrigatoriedade de se obter um consentimento pós-esclarecimento em situações de emergência, para prevenir maior dano, ou quando não há condições de imediata obtenção por parte do paciente ou de seu responsável. ${ }^{645}$

\subsection{Rotinas no Uso do Alteplase}

Inicialmente, devem ser obtidos dois acessos venosos periféricos. O rt-PA deve ser administrado na dose de 0,9 mg/ $\mathrm{kg}$, até o total máximo de $90 \mathrm{mg}$. Injetar $10 \%$ da dose por via intravenosa em 1 minuto e o restante em 60 minutos, em bomba de infusão.

Deve haver um rigoroso controle, com avaliações do estado neurológico a cada 15 minutos, durante a infusão do trombolítico; e a cada 30 minutos, durante as primeiras 6 horas. Após isso, durante as primeiras 24 horas, são recomendáveis avaliações do estado neurológico a cada hora. O aumento do escore da National Institute of Health Stroke Scale (NIHSS) é sinal de alerta para hemorragia e sugere reavaliação tomográfica. Também devem ser considerados sinais de alerta: cefaleia intensa, piora do nível de consciência, elevação súbita da pressão arterial, náuseas e vômitos.

O tratamento deve ser realizado preferencialmente por um neurologista experiente ou outro profissional médico orientado por neurologista com auxílio da telemedicina. ${ }^{646}$

Nas primeiras 24 horas pós-trombolítico, não utilizar antitrombóticos, evitar realizar punção venosa central ou arterial e não introduzir sonda nasoenteral.

Não introduzir sonda vesical até pelo menos 30 minutos após o término do rt-PA.

Sugere-se realizar exame de neuroimagem (tomografia ou RM) ao final de 24 horas do tratamento trombolítico, antes de iniciar a terapia antitrombótica.

\subsubsection{Complicacões Hemorrágicas}

Ocorrem com mais frequência nas primeiras 24 horas. Nessa situação, recomenda-se:

- Cessar a infusão se qualquer sinal de deterioração neurológica ou evidência de hemorragia significativa.

- Certificar-se de que duas veias periféricas estejam sendo infundidas com soluções cristaloides.

- Submeter o paciente à TC de crânio de urgência.

- Solicitar hematócrito, TP, TTPa, plaquetas e fibrinogênio.

- Infundir preferencialmente seis a oito unidades de crioprecipitado ou duas a três unidades de Plasma Fresco Congelado (PFC). Se houver continuidade da deterioração clínica após 4 a 6 horas, utilizar hemoderivados de acordo com o coagulograma. Repetir a infusão de crioprecipitado, se o nível de fibrinogênio estiver baixo, ou administrar o PFC, se existir alteração de TP ou TTPa. Infundir seis a oito unidades de plaquetas se estiverem em nível baixo.

- Uso de concentrado de hemácias suficiente para manter o hematócrito adequado.

- Infundir fluidos e/ou drogas vasoativas para tratar a hipotensão, evitando soluções hipotônicas.

- Nos casos de hemorragia no sistema nervoso central, considerar consulta neurocirúrgica e hematológica.

- Considerar o reinício da infusão do trombolítico caso a tomografia não demonstre hemorragia intracraniana.

\subsubsection{Angioedema Orolingual}

Segundo o estudo CASES, essa complicação pode ocorrer em cerca de $5 \%$ dos pacientes submetidos à trombólise intravenosa, especialmente em pacientes com infarto em córtex insular e frontal, associado ao uso de IECA. Em geral, o quadro tem boa evolução. ${ }^{647}$

\subsection{Tratamento Trombolítico Intra-Arterial, Combinado e Trombectomia Mecânica}

As potenciais vantagens da abordagem endovascular no tratamento agudo do AVC isquêmico incluem maior taxa de recanalização arterial e a possibilidade de sua utilização em alguns pacientes com contraindicação para o tratamento trombolítico intravenoso. O estudo PROACT II ${ }^{648}$ demonstrou 
maior taxa de recanalização e melhor desfecho clínico nos pacientes com oclusão proximal de ACM tratados com pró-uroquinase em até 6 horas, com esperado aumento na ocorrência de hemorragia sintomática em relação ao grupo controle. A pró-uroquinase, todavia, nunca chegou a ser aprovada pelo FDA. Diante disso, surgiram estudos clínicos sugerindo o benefício do tratamento intra-arterial com o próprio rt-PA. ${ }^{649,650}$

O uso da trombólise intra-arterial na prática clínica deve ser limitada a casos isolados e criteriosamente selecionados de AVC isquêmicos com oclusão de grande artéria intracraniana, especialmente como tratamento de resgate nos casos de não recanalização com o tratamento intravenoso ou naqueles fora da janela terapêutica para este, em geral entre 4,5 e 6 horas, ou acima disso, em casos selecionados de oclusão de artéria basilar. ${ }^{651}$

Estudos com tratamento combinado (intravenoso e intra-arterial) falharam em demonstrar superioridade nos desfechos clínicos em relação ao tratamento convencional com rt-PA intravenosa. ${ }^{652}$

Uma nova etapa na história dos procedimentos endovasculares na fase aguda do AVC isquêmico surgiu com a trombectomia mecânica. Estudos avaliaram a segurança e a eficácia de recanalização. ${ }^{653}$ Mais recentemente, demonstraram a superioridade da trombectomia mecânica (utilizando os novos stentrivers) associada ao tratamento trombolítico intravenoso no desfecho clínico. ${ }^{654-657}$ Diante disso, novas diretrizes internacionais também têm sido modificadas, inserindo a trombectomia mecânica, para pacientes selecionados, como recomendação de tratamento padrão-ouro. ${ }^{658}$

\subsubsection{Recomendações}

- O paciente com critérios de eligibilidade para uso de rt-PA intravenosa deve recebê-lo mesmo que também tenha indicação de trombectomia mecânica (Classe de Recomendação I; Nível de Evidência A).

- Os critérios de elegibilidade para trombectomia mecânica são (Classe de Recomendação I; Nível de Evidência A): oclusão de artéria carótida interna ou ACM proximal (M1); idade $\geq 18$ anos; pontuação $\geq 6$ na escala de AVC do $\mathrm{NIH}$; tomografia de crânio com pontuação $\geq 6$ na escala ASPECTS; pontuação de zero a 1 na Escala de Rankin Modificada (mRS) antes do AVC isquêmico atual; início do tratamento (punção arterial) em até 6 horas do começo dos sintomas (mas o mais rapidamente possível); ter recebido rt-PA intravenoso em até 4,5 horas do início dos sintomas (se estiver dentro da janela terapêutica para isso).

- É razoável considerar a trombectomia mecânica em pacientes selecionados com AVC isquêmico agudo e oclusão arterial em território carotídeo, que tenham contraindicações ao uso intravenoso do rt-PA, em até 6 horas de evolução do quadro. Entretanto, a eficácia clínica dessa intervenção em pacientes com essas contraindicações não está definida (AVC isquêmico prévio, coagulopatias intrínsecas ou adquiridas, traumatismo craniencefálico grave etc.) (Classe de Recomendação Ila; Nível de Evidência C).
- É razoável considerar a trombectomia mecânica em pacientes selecionados com AVC isquêmico agudo e oclusão arterial intracraniana em outros sítios, como as porções mais distais da ACM (M2-M3), artéria cerebral anterior, artéria cerebral posterior, artéria vertebral e artéria basilar, desde que iniciada em até 6 horas do início dos sintomas (Classe de Recomendação Ilb; Nível de Evidência C).

- É razoável considerar a trombectomia mecânica em pacientes menores de 18 anos, selecionados com AVC isquêmico agudo e oclusão arterial intracraniana proximal (oclusão de artéria carótida interna ou ACM proximal-M1), desde que iniciada em até 6 horas do começo dos sintomas. Entretanto, a eficácia clínica da intervenção nesses pacientes não está definida (Classe de Recomendação Ilb; Nível de Evidência C).

- Em pacientes com critérios para trombectomia mecânica, não se recomenda aguardar avaliação da resposta clínica após a administração intravenosa do rt-PA para indicar a realização do procedimento endovascular (Classe de Recomendação III; Nível de Evidência B).

- Em pacientes com indicação de trombectomia mecânica, é preferível o uso dos stentrivers ao uso do dispositivo MERCI (Classe de Recomendação I; Nível de Evidência A).

- O uso de outros dispositivos pode ser razoável em alguns casos (Classe de Recomendação llb; Nível de Evidência B).

- O objetivo da trombectomia mecânica deve ser a recanalização/reperfusão quase completa ou completa (padrão angiográfico $\mathrm{TICl}$ 2b-3) para aumentar a chance de um bom desfecho clínico (Classe de Recomendação I; Nível de Evidência A).

- Em casos selecionados de oclusão proximal de grande artéria intracraniana e indisponibilidade da trombectomia mecânica, o uso intra-arterial do rt-PA pode ser considerado, embora não exista definição sobre sua dose ou sua eficácia clínica (Classe de Recomendação I; Nível de Evidência B).

- Embora até o presente momento, seja razoável um pequeno favorecimento ao uso de sedação, invés da anestesia geral, a seleção da técnica anestésica para a trombectomia mecânica deve ser individual. Resultados de estudos em andamento podem auxiliar futuramente (Classe de Recomendação Ilb; Nível de Evidência C).

\subsection{Classificação dos Centros de Referência para o Diagnóstico e Tratamento do Acidente Vascular Cerebral}

O Ministério da Saúde, seguindo a linha proposta previamente pela SBDCV, ${ }^{658}$ publicou, em 2012, a portaria $665^{659}$ e, em 2015, a portaria $800^{660}$ (que altera, acresce e revoga dispositivos da portaria anterior), ambas definindo a linha de cuidado em AVC no Brasil, estipulando critérios para a criação das Unidades de AVC. Dessa forma, assim ficou definido: "Art. 5ํ Serão habilitados como Centros de Atendimento de Urgência Tipo I os estabelecimentos hospitalares que desempenham o papel de referência para atendimento aos pacientes com AVC, que disponibilizam e realizam o procedimento com o uso de trombolítico, conforme Protocolo Clínico e Diretrizes Terapêuticas (PCDT) 
específico, e que cumpram os requisitos referentes ao diagnóstico e tratamento, visando os tempos: porta-tomografia $<25$ minutos e porta-agulha $<60$ minutos. (Redação dada pela Portaria GM/MS 800, de 17 de junho de 2015, acrescido pela Portaria GM/MS 800, de 17 de junho de 2015, e alterado pela Portaria GM/MS 800 de 17 de junho de 2015)."

\subsection{Hemorragia Intraparenquimatosa Cerebral Espontânea}

O AVC hemorrágico é causado pela ruptura espontânea (não traumática) de um vaso, com extravasamento de sangue para o interior do cérebro (Hemorragia Intraparenquimatosa HIP), para o sistema ventricular (hemorragia intraventricular) e/ ou espaço Subaracnóideo (HSA). A HIP é o subtipo de AVC de pior prognóstico, com até $65 \%$ de mortalidade em 1 ano. ${ }^{661,662}$

\subsubsection{Epidemiologia}

A HIP é uma manifestação comum e que compreende 10 a $20 \%$ dos acidentes vasculares encefálicos. A incidência média anual varia entre 10 e 20 casos por 100 mil habitantes. ${ }^{663} \mathrm{Em}$ geral, a mortalidade em 30 dias varia entre 30 e 45,4\% e, em 1 ano, é de até $63,6 \%{ }^{664}$

\subsubsection{Fatores de Risco}

\section{A) Não modificáveis}

Idade avançada, raça negra, orientais e sexo masculino. ${ }^{665}$

\section{B) Modificáves}

- Hipertensão Arterial Sistêmica (HAS) é o principal fator de risco, estando presente em 70 a $80 \%$ dos pacientes com este tipo de AVC. ${ }^{664,666} \mathrm{O}$ tratamento anti-hipertensivo é capaz de reduzir aproximadamente $50 \%$ do risco relativo de AVC (incluindo HIP). ${ }^{667}$

- Angiopatia amiloide cerebral é fator de risco para HIP lobar em idosos, estando presente em 80 a 98\% das necrópsias de indivíduos com doença de Alzheimer. ${ }^{668}$

- Tabagismo, com risco aproximadamente duas vezes e meia maior do que não fumantes. ${ }^{669}$

- Álcool é um dos principais fatores de risco. O sangramento intracraniano pode ser precipitado pelo consumo de quantidades moderadas nas 24 horas que antecedem ao íctus. ${ }^{670}$

- Coagulopatias primárias e secundárias estão associadas a maior risco (Quadro 8.4). Os anticoagulantes orais aumentam o risco cerca de oito a dez vezes. ${ }^{671}$ Drogas antiplaquetárias e trombolíticos também estam associados a maior risco de HIP. ${ }^{672,673}$

- Simpaticomiméticos, como fenilpropanolamina, cocaína, anfetaminas ou efedrina, também aumentam o risco de HIP. ${ }^{674}$

- Outros fatores, menos estabelecidos, são: obesidade, perfil lipídico e fatores genéticos, como a mutação no gene que codifica a subunidade alfa do fator XIII da coagulação. ${ }^{675}$ O real efeito do perfil lipídico ainda é controverso. ${ }^{676}$

\subsubsection{Etiologia}

De acordo com a etiologia do sangramento, a HIP pode ser classificada como primária (80 a $85 \%$ dos casos) ou secundária (15 a 25\% dos casos). HIP primária resulta da ruptura de pequenos vasos cronicamente danificados pela HAS, ou está associada à angiopatia amiloide. ${ }^{677} \mathrm{Em}$ contrapartida, a HIP secundária está relacionada a: ruptura de aneurismas ou malformações arteriovenosas cerebrais, anticoagulação oral, drogas antiplaquetárias, coagulopatias, cirrose hepática, neoplasias, vasculites, trauma, doença de Moyamoya, trombose venosa cerebral, eclampsia, entre outras causas.

\subsubsection{Manifestações Clínicas}

O sangramento dentro do parênquima cerebral é indolor. Portanto, a HIP usualmente se apresenta com défice neurológico focal de início brusco e que progride nos minutos a horas subsequentes. A manisfestação clínica focal está relacionada primordialmente com a região cerebral acometida. Embora frequente, cefaleia não é um sintoma presente em todos os casos e costuma se manifestar quando a HIP é acompanhada de irritação meníngea por HSA associada, ou por aumento da PIC. Vômito é um sintoma típico da HIP, geralmente relacionado ao aumento da PIC. Apesar das diversas tentativas de diferenciar clinicamente hemorragia supratentorial de AVC isquêmico, esta distinção não é confiável, e um exame de neuroimagem é fundamental. ${ }^{678}$ Idealmente, os pacientes com HIP devem ser avaliados por meio de escalas clínicas, como a escalas de coma de Glasgow e de AVC do NIH. ${ }^{679,680}$

\subsubsection{Neuroimagem}

Tanto a TC quanto a RM são métodos razoáveis para a avaliação inicial de suspeita de AVC hemorrágico, nesse caso, HIP.

\section{A) Tomografia Computadorizada}

A TC de crânio apresenta alta sensibilidade para identificação e localização da hemorragia aguda, sendo considerada o exame de eleição para o diagnóstico, auxiliando também na suspeita etiológica.

Hemorragias profundas, localizadas nos núcleos da base, tálamo, cápsula interna, cerebelo ou tronco cerebral, são mais frequentemente relacionadas à hipertensão arterial.

Hemorragias lobares estão relacionadas a um número maior de possibilidades, incluindo a própria hipertensão arterial, malformações vasculares, coagulopatias, angiopatia amiloide e outras. ${ }^{664}$ Outros detalhes de neuroimagem podem auxiliar na suspeita etiológica, como a ocorrência de múltiplas hemorragias lobares em diferentes tempos de evolução, sugerindo angiopatia amiloide; a presença de HSA, sugerindo rotura aneurismática; a presença de nível líquido no interior da hemorragia, sugerindo a existência de coagulopatia; e a coexistência de contusões cerebrais e fraturas, sugerindo trauma. Ainda, a realização de um exame contrastado (angiotomografia) pode dar informações etiológicas, como a demonstração de aneurisma sacular, de malformação vascular, 


\section{Atualização}

\section{Quadro 8.4 - Fatores etiológicos para hemorragia intracerebral}

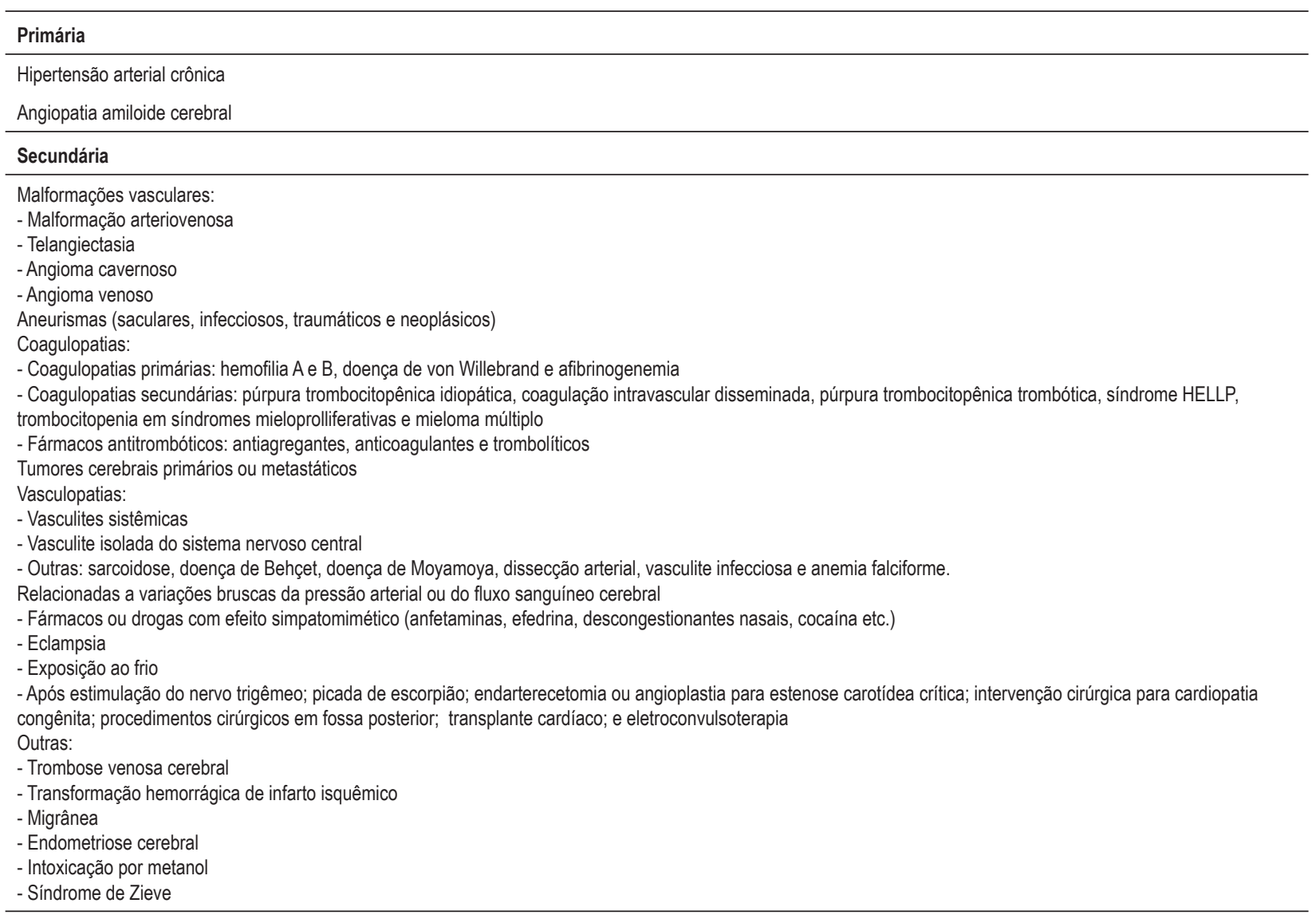

Fonte: Adaptada de Qureshi Al et al., 2001.664

de trombose venosa cerebral, ou até de um padrão vascular de doença de Moyamoya. ${ }^{681}$

A TC de crânio também pode auxiliar na estimativa do volume da hemorragia pela fórmula $\mathrm{ABC} / 2$, na qual (A) corresponde ao maior diâmetro no corte tomográfico com maior área de hemorragia; (B) corresponde ao maior diâmetro perpendicular a (A); e (C) corresponde ao número de cortes tomográficos em que a hemorragia é visível, multiplicado pela espessura dos cortes. ${ }^{682}$ Por ser um importante fator prognóstico, o volume da hemorragia também participa do cálculo dos escores Intracerebral Hemorrhage (ICH) e FUNC, também usados como medida de avaliação prognóstica na HIP (Figura 8.1). ${ }^{683,684}$

A TC de crânio ainda pode ser utilizada para monitoramento evolutivo da HIP, sendo comum o aumento do volume da hemorragia nas primeiras 3 horas de evolução. ${ }^{685} \mathrm{O}$ uso de TC contrastada nas primeiras horas permite investigar a presença do Spot Sign, que se caracteriza por extravasamento do meio de contraste no interior da HIP, e tem grande valor preditivo para aumento do volume da hemorragia nas horas subsequentes e pior prognóstico. ${ }^{686-688}$

\section{B) Ressonância magnética}

A RM tem sensibilidade e especificidade comparáveis às da TC de crânio para o diagnóstico. ${ }^{47,618,687}$ Entretanto, devido ao custo mais elevado, à menor disponibilidade, ao maior tempo para realização do exame e à menor tolerância dos pacientes, costuma ser realizada posteriormente à TC de crânio, nas fases subaguda e crônica, especialmente quando há suspeita de etiologia não HIP. ${ }^{689}$

Na RM, a imagem da hemorragia depende de variáveis técnicas e biológicas que incluem as sequências utilizadas (especialmente T1, T2, T2* ou gradiente eco) e a idade do hematoma.

Como regra geral, pela presença de oxi-hemoglobina, a hemorragia hiperaguda (menos de 24 horas) é isointensa em T1, hiperintensa em T2 e hipointensa em T2*. Na fase aguda (1 a 3 dias), pela presença de deoxi-hemoglobina, é isointensa em T1, hipointensa em T2 e hipointensa em T2*. $\mathrm{Na}$ fase subaguda (a partir do sétimo dia), pela degradação de hemoglobina em meta-hemoglobina, é hiperintensa em T1, hiperintensa em T2 e hipointensa em T2*. Na fase crônica (a partir do 14o dia), pela presença de hemossiderina, é hipointensa em T1, hipointensa em T2 e hipointensa em T2*. 


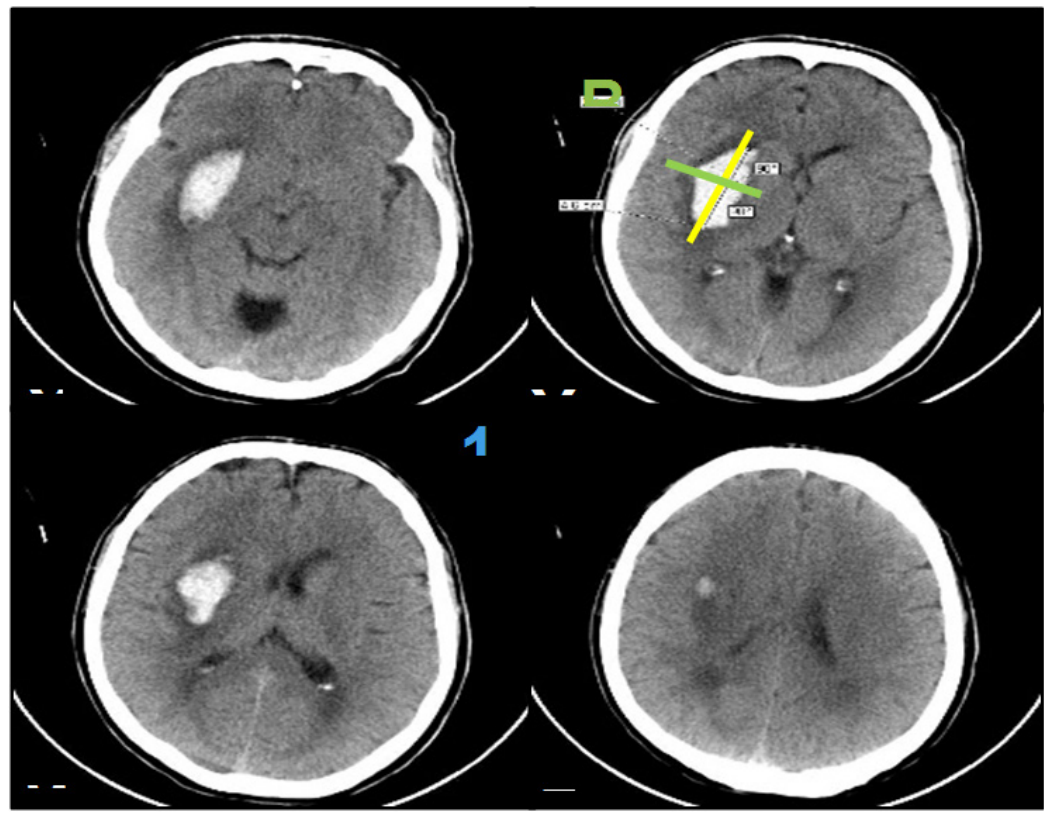

Figura 8.1 - Avalição extensão do hematoma.

Da mesma forma que a angiotomografia, a angiorressonância pode, em alguns casos, auxiliar no diagnóstico etiológico.

Repetição tardia da RM (1 a 4 meses após a HIP) pode ser útil nos casos com suspeita de cavernoma.

\section{C) Angiografia Cerebral Digital}

Pacientes com HIP de localização atípica, com significativa HSA associada, ou idade abaixo de 45 anos (independentemente da presença de HAS) devem ser submetidos ao estudo angiográfico digital para investigação de causas secundárias. ${ }^{690} \mathrm{~A}$ angiografia cerebral digital é o método de escolha para identificação de malformações arteriais de alto fluxo, quando o hematoma pode atrapalhar a identificação pela angiografia por TC. ${ }^{691}$

Nos casos de HIP, especialmente associada à HSA, em que a angiografia cerebral digital demonstra a presença de vasoespasmo, não revelando aneurismas cerebrais, é recomendável a repetição do exame angiográfico após cerca de 2 semanas. ${ }^{692}$

\subsubsection{Evolução e Prognóstico}

\section{Fase pré-hospitalar e intra-hospitalar}

A deterioração neurológica precoce é frequente na HIP, ocorrendo em 20 a 30\% dos pacientes, sendo associada ao aumento do volume do hematoma. ${ }^{685,693}$

O prognóstico a curto prazo é sombrio, com altas taxas de mortalidade e incapacidade funcional. Estima-se que cerca de $50 \%$ dos pacientes evoluam para o óbito dentro do primeiro mês, e metade desses casos ocorre nos primeiros 2 dias.
São fatores de mau prognóstico: volume inicial da hemorragia maior que $30 \mathrm{~cm}^{3}$, rebaixamento do nível de consciência à admissão, sangramento intraventricular, idade avançada e localização primariamente infratentorial.

Dentre as escalas criadas para estimar o prognóstico precoce, o escore de HIP dado pela $\mathrm{ICH}$ e a escala de prognóstico funcional (FUNC) são as mais utilizadas. ${ }^{683,684}$ Entretanto, estudos sugerem cautela no uso dessas escalas como critério absoluto na tomada de decisões. ${ }^{694}$

A mortalidade a longo prazo permanece bem mais alta que a da população geral nos anos subsequentes, e uma revisão sistemática estima que apenas 12 a 39\% dos pacientes recuperam a independência funcional. São fatores preditivos de mortalidade nas primeiras 4 semanas: rebaixamento do nível de consciência na admissão, desvio das estruturas da linha média, pressão arterial média $\geq 134 \mathrm{mmHg}$, hiperglicemia, uso de anticoagulantes e arritmias ventriculares. Já os preditores de morte tardia são idade avançada, sexo masculino e IC. ${ }^{695,696}$

\subsubsection{Tratamento}

Lamentavelmente, não há ainda um tratamento específico para HIP. Dessa forma, sua abordagem não difere daquela dispensada ao paciente com AVC isquêmico. Deve-se atentar para sinais externos de trauma e suas complicações.

Idealmente, após a realização do exame de neuroimagem, os pacientes devem ser rapidamente encaminhados para unidades de terapia intensiva, sendo reavaliados em intervalos curtos. ${ }^{697}$ 


\section{A) Pressão Arterial}

HAS é comum na fase aguda da HIP e está associada com maior risco de piora clínica, morte ou incapacidade. ${ }^{698}$ A monitorização da pressão arterial é fundamental e pode ser realizada de forma não invasiva. Entretanto, a monitorização invasiva é sugerida quando a infusão contínua de medicações anti-hipertensivas for necessária. Em linhas gerais, o tratamento da HAS deve ser mais agressivo na HIP do que no AVC isquêmico e deve ser instituído tão logo possível. Entretanto, a redução excessiva dos níveis pressóricos traz preocupação sobre possível diminuição da Pressão de Perfusão Cerebral (PPC). Entretanto, não está definido qual o nível pressórico ideal na fase aguda da HIP. O estudo ICH-ADAPT avaliou o fluxo sanguíneo do tecido cerebral peri-hematoma por meio de perfusão por TC, não encontrando sinais de isquemia local decorrente da redução mais agressiva da pressão arterial. ${ }^{699}$ Além disso, estudos associam o controle agressivo da HAS com redução na expansão da HIP

Nos pacientes que se apresentam com PAS acima de $220 \mathrm{mmHg}$, essas diretrizes consideram razoável o uso de drogas parenterais em infusão contínua para redução mais agressiva e controlada da PAS. ${ }^{700}$ Nos pacientes com hipertensão intracraniana, a pressão arterial sistólica deve ser mantida acima de $90 \mathrm{mmHg}$ e, idealmente, deve-se utilizar a monitorização da PIC para manter a PPC $(\mathrm{PPC}=\mathrm{PAM}-\mathrm{PIC})$ acima de 50 a 70 mmHg (Quadro 8.5).

Os medicamentos comumente usados em nosso país para o tratamento anti-hipertensivo na fase aguda da HIP são metoprolol, diltiazen ou esmolol, pois labetalol e nicardipina não são disponíveis (Quadro 8.6). Nos casos mais graves ou refratários, pode-se utilizar o nitroprussiato de sódio, com atenção ao possível aumento da PIC. Os medicamentos antihipertensivos por via oral devem ser instituídos e titulados assim que possível.

Diante disso, baseado no estudo INTERACT 2, a redução da PAS para níveis iguais ou menores que $140 \mathrm{mmHg}$ parece ser segura, promovendo a diminuição da expansão da hemorragia, com possível melhora do prognóstico funcional. ${ }^{700-704}$ Redução mais intensa (PAS $\leq 120 \mathrm{mmHg}$ ), todavia, foi avaliada no recente estudo ATACH 2, o qual não mostrou benefício e ainda sugeriu risco aumentado com a redução muito agressiva da pressão arterial na fase aguda da HIP (Tabela 8.7). ${ }^{\text {.01-704 }}$

\section{B) Hipertensão Intracraniana}

A frequência exata do aumento sintomático da PIC em pacientes com HIP é desconhecida. Pacientes com

Quadro 8.5 - Recomendações para controle da pressão arterial (PA) na hemorragia intracerebral

\begin{tabular}{|c|c|}
\hline PA & Conduta recomendada \\
\hline PA sistólica > 220 mmHg (duas leituras com intervalo de 5 minutos) & $\begin{array}{l}\text { Iniciar redução agressiva da PA por infusão contínua de anti-hipertensivo intravenoso com } \\
\text { monitorização da PA a cada } 5 \text { minutos }\end{array}$ \\
\hline $\begin{array}{l}\text { PA sistólica entre } 150 \text { e } 220 \mathrm{mmHg} \\
\text { Suspeita de aumento da PIC }\end{array}$ & $\begin{array}{l}\text { Considerar monitorização da PIC. Iniciar redução da PA por infusão contínua ou intermitente de } \\
\text { anti-hipertensivo intravenoso com monitorização da PA a cada } 5 \text { minutos. Manter PPC > } 50 \text { a } \\
70 \mathrm{mmHg}\end{array}$ \\
\hline $\begin{array}{l}\text { PA sistólica entre } 150 \text { e } 220 \mathrm{mmHg} \\
\text { Sem suspeita de aumento da PIC }\end{array}$ & $\begin{array}{l}\text { Iniciar redução moderada da PA por infusão contínua ou intermitente de anti-hipertensivo } \\
\text { intravenoso com monitorização da PA a cada } 15 \text { minutos (PA sistólica-alvo: } 140 \text { mmHg) }\end{array}$ \\
\hline PA sistólica $<90$ mmHg & $\begin{array}{l}\text { Expansão com cristaloides por via intravenosa e infusão de aminas vasoativas: } \\
\text { - Dopamina } 2-20 \mu \mathrm{g} / \mathrm{kg} / \text { minuto } \\
\text { - Noradrenalina } 0,05 \mathrm{a} 0,2 \mu \mathrm{g} / \mathrm{kg} / \text { minuto }\end{array}$ \\
\hline
\end{tabular}

PA: pressão arterial; PIC: pressão intracraniana; PPC: pressão de perfusão cerebral. Fonte: Adaptado de Davis SM et al., $2006 .{ }^{693}$

Quadro 8.6 - Medicações anti-hipertensivas usadas para hemorragia intracerebral

\begin{tabular}{|c|c|c|c|}
\hline Droga & Mecanismo & Dose intravenosa & Contraindicações \\
\hline Metoprolol & Antagonista seletivo do receptor $\beta 1$ adrenérgico & $\begin{array}{l}5 \mathrm{mg} \text { a } 1 \mathrm{~mL} / \text { minuto a cada } 10 \text { minutos, máximo } \\
\text { de } 20 \text { minutos }\end{array}$ & IC grave, DPOC, asma, hipotensão, bradicardia \\
\hline Enalapril & Inibidor da enzima conversora de angiotensina & $0,625-1,25 \mathrm{mg}$ em 5 minutos a cada 6 horas & $\begin{array}{l}\text { Queda súbita da PA em estados de aumento da } \\
\text { renina. IRA se estenose da artéria renal }\end{array}$ \\
\hline Diltiazen & Antagonista de canal de cálcio & $\begin{array}{l}\text { 0,25-0,35 mg/kg em } 10 \text { minutos } \\
\text { Infusão } 5-15 \text { mg/hora }\end{array}$ & $\begin{array}{c}\text { Doença do nó sinusal ou nó atrioventricular. IC } \\
\text { grave }\end{array}$ \\
\hline Nitroprussiato & Vasodilatador arterial e venoso & $0,25-10 \mathrm{mcg} / \mathrm{kg} / \mathrm{minuto}$ & $\begin{array}{l}\text { Potencial aumento da PIC, resposta variável, } \\
\text { intoxicação por cianeto e tiocianeto }\end{array}$ \\
\hline Esmolol & Antagonista seletivo do receptor $\beta 1$ adrenérgico & $\begin{array}{c}250 \text { a } 500 \mathrm{mcg} / \mathrm{kg} / \mathrm{minuto} \text { em bolus a cada } \\
10 \text { minutos ou infusão } \\
25-300 \mathrm{mcg} / \mathrm{kg} / \text { minuto }\end{array}$ & $\begin{array}{c}\text { IC grave, DPOC, asma, hipotensão e } \\
\text { bradicardia }\end{array}$ \\
\hline
\end{tabular}

IC: insuficiência cardiaca; DPOC: doença pulmonar obstrutiva crônica; PA: pressão arterial; IRA: insuficiência renal aguda; PIC: pressão intracraniana. 
hemorragias pequenas provavelmente não necessitam de medidas específicas para controle da PIC. Já pacientes comatosos com sinais de hipertensão intracraniana podem se beneficiar de medidas como elevação da cabeceira a $30^{\circ}$, analgesia, sedação, doses moderadas de manitol a 20\%, solução salina hipertônica e hiperventilação para atingir Pressão Pacial de Dióxido de Carbono $\left(\mathrm{PaCO}_{2}\right)$ entre 28 e 32 $\mathrm{mmHg}$. O uso de corticosteroides não mostrou benefícios e revelou aumento no risco de infecções. ${ }^{705,706}$

\section{C) Terapia Homeostática}

O tratamento hemostático indicado na HIP secundária a coagulopatias primárias ou secundárias depende da coagulopatia existente.

A terapia anticoagulante com antagonistas da vitamina $\mathrm{K}$ (varfarina) aumenta em cinco a dez vezes o risco de HIC. Aproximadamente 15\% das HIP estão associadas com o uso de anticoagulantes. Pacientes com HIP em uso de varfarina devem receber imediatamente PFC ou Concentrado de Complexo Protrombínico (CCP) e vitamina K, para normalização do TP para valores $<1,3$. Este tratamento não deve ser adiado até a chegada dos resultados dos testes laboratoriais da coagulação.

O Fator VII Ativado Recombinante (rFVIla) não é capaz de repor todos os fatores de coagulação vitamina $\mathrm{K}$ dependentes, podendo não restaurar efetivamente a geração de trombina. ${ }^{707-711}$

\section{D) Drogas Antiepilépticas}

Cerca de $8 \%$ dos pacientes com HIP apresentam crises epilépticas nos primeiros 30 dias do ictus, principalmente nos casos de hematoma lobar, evoluindo pata estado de mal epiléptico em 1 a $2 \%$ dos casos. O monitoramento com EEG contínuo deve ser considerado em pacientes com rebaixamento de nível de consciência desproporcional ao grau de lesão parenquimatosa para procura de crises epilépticas ou do estado de mal epiléptico. Se necessário, o tratamento deve ser prontamente instituído com medicamentos intravenosos, de forma semelhante ao do estado de mal epiléptico por outras etiologias.

Estudos sugerem que o uso de drogas anticonvulsivantes profiláticas em HIP estão associadas com aumento da mortalidade..$^{712,713}$

\section{E) Controle da Temperatura}

A temperatura corporal deve ser mantida em níveis normais. Febre é comum em pacientes com HIP, principalmente quando há hemorragia intraventricular, e deve ser investigada e tratada agressivamente. Embora não existam estudos randomizados avaliando especificamente o controle da temperatura em pacientes com HIP, sugere-se usualmente a utilização de acetaminofeno ou dipirona. ${ }^{714}$

\section{F) Profilaxia de Trombose Venosa Profunda}

Pacientes com HIP estão sob elevado risco de TVP e TEP. Idealmente, dispositivos de compressão pneumática de membros inferiores devem ser utilizados desde a admissão.
As diretrizes internacionais recomendam anticoagulação profilática para TVP nos pacientes com HIP recente, nos quais tenha ocorrido cessação da expansão da hemorragia A decisão de manter a terapia antitrombótica profilática prolongada deve ser pesada em relação ao risco de novo sangramento e individualizada. ${ }^{715}$

\section{G) Tratamento Cirúrgico}

O papel do tratamento cirúrgico, para remoção da hemorragia intracerebral, permanece controverso.

$\mathrm{O}$ estudo STICH I não encontrou diferença significativa na mortalidade ou prognóstico funcional entre os pacientes tratados cirurgicamente ou clinicamente, mas sugeriu, em análise de subgrupo, que pacientes jovens com pontuação na escala de coma de Glasgow entre 9 e 12, com hematomas lobares volumosos e em até $1 \mathrm{~cm}$ da superfície do córtex cerebral, poderiam ter maior benefício com o tratamento cirúrgico. ${ }^{715-717}$

Com respeito às hemorragias na região da fossa posterior, estudos não randomizados têm sugerido que, nos pacientes com hemorragia cerebelar de diâmetro superior a $3 \mathrm{~cm}$, que apresentem deterioração neurológica, sinais de herniação, compressão do tronco encefálico ou hidrocefalia, a craniectomia descompressiva de fossa posterior e a drenagem do hematoma devem ser realizadas o mais brevemente possível. Abordagens cirúrgicas minimamente invasivas para a drenagem da hemorragia intracerebral também têm sido estudadas. ${ }^{718,719} \mathrm{O}$ estudo MISTIE II sugeriu segurança da técnica.

Hemorragia intraventricular é uma complicação comum, ocorrendo em quase $50 \%$ dos casos de hemorragia intracerebral, geralmente como extensão da HIP. O estudo CLEAR-IVH avaliou a utilização intraventricular de baixas doses de rt-PA para auxiliar na drenagem da hemorragia intraventricular e sugeriu perfil satisfatório de segurança. ${ }^{720}$

Drenagem endoscópica da hemorragia intraventricular é outra forma de tratamento cujos resultados foram semelhantes aos obtidos com uso de derivação ventricular.

Além do efeito de massa pelo hematoma, a presença de hidrocefalia pode contribuir substancialmente para o aumento da PIC. Assim, uma derivação ventricular externa pode ser necessária durante o período crítico, não devendo esta exceder 7 dias, devido ao risco de infecção. Não existem, entretanto, estudos que comparem diferentes tipos de drenagem, ou com o tratamento conservador para a hidrocefalia. ${ }^{716-721}$

\section{Recomendações}

- Para o diagnóstico de HIP, é recomendada a rápida realização de exame de neuroimagem por TC ou RM de crânio (Classe de Recomendação I; Nível de Evidência A).

- Recomenda-se que pacientes na fase aguda de HIP sejam internados em leitos monitorizados em unidades de AVC ou unidades de terapia intensiva, idealmente em unidades de terapia intensiva neurológica (Classe de Recomendação I; Nível de Evidência B). 
- Recomenda-se o uso de drogas antiepilépticas de rotina apenas em pacientes com HIP que apresentam evidências clínicas ou eletroencefalográficas de crises epilépticas (Classe de Recomendação I; Nível de Evidência A).

- Recomendam-se monitoramento e controle da glicemia, evitando-se tanto hiperglicemia quanto hipoglicemia. Entretanto, o melhor nível de glicemia não está claramente definido (Classe de Recomendação I; Nível de Evidência C).

- Recomendam-se monitoramento e controle da hipertermia (temperatura axilar $\geq 37,5^{\circ} \mathrm{C}$ ) na fase aguda da HIP (Classe de Recomendação IIb; Nível de Evidência C).

- Recomendam-se mobilização e reabilitação precoces nos pacientes com HIP (Classe de Recomendação Ila; Nível de Evidência B).

- Recomenda-se que o tratamento inicial da hipertensão intracraniana inclua medidas simples, como elevação da cabeceira, analgesia e sedação (Classe de Recomendação Ila; Nível de Evidência C).

- Adicionalmente, em casos selecionados, podem ser empregados agentes osmóticos (manitol, salina hipertônica etc.), drenagem liquórica por cateter ventricular, bloqueio neuromuscular e hiperventilação (Classe de Recomendação Ilb; Nível de Evidência C).

- Baseados em dados limitados, a redução da pressão arterial nos pacientes com PAS entre 150 e 220 mmHg, e que não apresentam contraindicações a redução aguda da pressão arterial, para uma PAS em torno de $140 \mathrm{mmHg}$ parece segura (Classe de Recomendação I; Nível de Evidência A).

- Em pacientes com rebaixamento de nível de consciência e suspeita de hipertensão intracraniana pode ser razoável monitorar a PIC e mantê-la entre 50 e 70 mmHg (Classe de Recomendação Ilb; Nível de Evidência C).

- Não se recomenda o uso de Fator VII ativado em pacientes com HIP espontânea (Classe de Recomendação III; Nível de Evidência A).

- Em pacientes com HIP, recomenda-se profilaxia de TVP e TEP, com a instituição de dispositivos de compressão pneumática intermitente nos membros inferiores desde o dia inicial da admissão hospitalar (Classe de Recomendação I; Nível de Evidência A).

- Com a documentação da estabilidade da hemorragia, após 1 a 4 dias de evolução, e redução da motricidade, recomenda-se iniciar profilaxia para TVP, com heparina subcutânea ou HBPM (Classe de Recomendação IIb; Nível de Evidência B).

- Em pacientes com HIP associada ao uso de heparina, recomenda-se o uso de sulfato de protamina (Classe de Recomendação IIb, Nível de Evidência C.

- Em pacientes com HIP com RNI elevada e uso de antagonistas da vitamina $K$, recomendam-se suspensão imediata do respectivo anticoagulante oral, uso de complexo protrombínico ou PFC até normalização da $\mathrm{RNI}$, além da administração de vitamina $\mathrm{K}$ (Classe de Recomendação 1; Nível de Evidência C).
- O complexo protrombínico pode corrigir a RNI mais rapidamente que o PFC e, possivelmente, com menor risco de efeitos colaterais (Classe de Recomendação IIb; Nível de Evidência B).

- O fator VII ativado não é recomendado para tratamento da HIP associada ao uso de antagonistas da vitamina K, pelo fato de não repor todos os fatores de coagulação depletados (Classe de Recomendação III; Nível de Evidência C).

- Em pacientes com HIP sintomática associada ao uso de trombolíticos, recomenda-se a administração de PFC, crioprecipitado e plaquetas (Classe de Recomendação Ilb; Nível de Evidência B).

- Pacientes com HIP cerebelar evoluindo com deterioração neurológica ou apresentando sinais de compressão de tronco cerebral ou hidrocefalia sintomática não comunicante devem ser submetidos à evacuação cirúrgica o mais rápido possível (Classe de Recomendação l; Nível de Evidência B).

- A evacuação cirúrgica de HIP supratentorial, na maioria dos casos, não é recomendada (Classe de Recomendação Ilb; Nível de Evidência A), podendo ser considerada em pacientes jovens, com Glasgow entre 9 e 12, e em hematomas lobares volumosos até $1 \mathrm{~cm}$ da superfície do córtex cerebral (Classe de Recomendação Ilb; Nível de Evidência B).

- Evacuação cirúrgica precoce de HIP não é claramente superior no benefício quando comparada com a abordagem cirúrgica da HIP no momento que o paciente deteriora (Classe de Recomendação Ilb; Nível de Evidência A).

- Descompressão cirúrgica com ou sem remoção cirúrgica da HIP supratentorial pode reduzir a mortalidade dos pacientes que estão em coma, que apresentam HIP volumosas com desvio de estruturas da linha média, ou que apresentam hipertensão intracraniana refratária ao tratamento clínico (Classe de Recomendação Ilb; Nível de Evidência C).

- Embora a administração intraventricular de rt-PA na HIC tenha baixo risco de complicação, sua utilização não parece trazer benefício no desfecho clínico (Classe de Recomendação I; Nível de Evidência A).

- A eficácia da cirurgia minimamente invasiva ou do tratamento endoscópico na HIP é incerta (Classe de Recomendação Ilb; Nível de Evidência B).

- O uso de anticoagulantes após HIP não lobar é razoável nos casos com forte indicação para seu uso (Classe de Recomendação Ilb; Nível de Evidência B).

- O uso de antiagregantes em monoterapia após HIP é razoável nos casos com forte indicação para seu uso (Classe de Recomendação Ilb; Nível de Evidência B).

- O momento ideal para o reinício da anticoagulação oral nos pacientes com HIP associada ao uso de anticoagulantes é incerto. No pacientes sem prótese valvar metálica, aguardar pelo menos 4 semanas para o reinício pode reduzir o risco de recorrência (Classe de Recomendação Ilb; Nível de Evidência B). 
Quadro 8.7 - Escore de hemorragia intraparenquimatosa cerebra

\begin{tabular}{lc}
\hline Componente & Pontos \\
\hline Escala de coma de Glasgow & 2 \\
$3-14$ & 1 \\
$5-12$ & 0 \\
$13-15$ & \\
Volume do hematoma & 1 \\
$\geq 30 \mathrm{~cm}^{3}$ & 0 \\
$30 \mathrm{~cm} 3$ & \\
Hemorragia intraventricular & 1 \\
Sim & 0 \\
Não & \\
Origem infratentorial & 1 \\
Sim & 0 \\
Não & \\
Idade & 1 \\
$\geq 80$ anos & \\
$<80$ anos & 0 \\
Toral & $0-6$ \\
\hline Adaptada &
\end{tabular}

Adaptada de Hemphill et al., 2001.683

\section{Ressuscitação Cardiopulmonar em Situações Especiais}

\subsection{Introdução}

Frente a uma PCR, reconhecer precocemente o evento, chamar rapidamente por ajuda e/ou ativar o sistema médico de emergência, manter compressões torácicas de excelente qualidade com mínimas interrupções, providenciar desfibrilação precoce e tratar causas reversíveis são as intervenções mais importantes para o prognóstico da vítima. Em situações especiais, entretanto, as diretrizes de atendimento requerem algumas modificações. ${ }^{722-724}$ Considerando os fatores desencadeantes, dividimos este capítulo em três partes: causas, ambientes e pacientes especiais. Os ambientes especiais envolvem recomendações de atendimento em locais como estruturas de saúde, eventos desportivos e cenários externos. Já pacientes especiais dizem respeito a uma abordagem modificada de acordo com determinadas comorbidades (obesos e portadores de asma brônquica).

\subsection{Causas Especiais}

Aborda o tratamento de causas potencialmente reversíveis de PCR, com orientações direcionadas aos seguintes tópicos: hipóxia, hipovolemia, anafilaxia, hipotermia, TEP e intoxicação.

\subsubsection{Hipóxia}

O uso na regra mnemônica " $\mathrm{H}$ " de hipóxia nos remete rapidamente à principal causa não cardiológica de PCR.
Qualquer condição clínica que impeça a correta troca gasosa pode causar asfixia e consequente hipoxemia (Quadro 9.1).

O ritmo de PCR mais frequente associado a esta condição é a AESP, que se instala após 5 a 10 minutos da obstrução da via aérea. ${ }^{725}$

Nesse grupo, deve-se priorizar ventilação efetiva associada ao aporte suplementar de oxigênio. ${ }^{726}$ A sobrevida, no entanto, é bastante reduzida (cerca de 3\%), quando o fator desencadeante é enforcamento. ${ }^{726,727} \mathrm{Em}$ virtude da hipóxia, os sobreviventes, com frequência, evoluem com sequelas neurológicas significativas.

\subsubsection{Hipovolemia}

Apontada, ao lado da hipoxemia, como uma das causas mais frequentes de PCR não cardiológica. A despeito do potencial de resolução com a infusão de fluidos intravenosos, os resultados para PCR após trauma permanecem alarmantes, com a sobrevivência inferior a 10\%, apesar de técnicas de RCP mais agressivas.

A velocidade de sangramento por lesão vascular maior, o curto intervalo de tempo entre a PCR e ocorrência da isquemia cerebral, e a eficácia reduzida da RCP na hipovolemia grave secundária à hemorragia contribuem para limitar a eficácia do RCE. Assim, a rápida tomada de decisão e a agilidade na abordagem são essenciais para o sucesso da RCP nestas situações.

Em todo paciente em condição de hipovolemia grave, é importante assegurar que o volume intravascular retorne em nível ótimo. Enquanto persistir a síndrome do choque, deve-se administrar volume, até que a pressão venosa central fique na faixa de 10 a 12 mmHg (12 a 16 em $\mathrm{cmH}_{2} \mathrm{O}$ ). ${ }^{728}$

O tipo de expansor volêmico escolhido para reposição deve ser adaptado à causa desencadeante. O sangue constitui indicação clara, quando a perda é devido à hemorragia. Podem-se usar soluções isotônicas para repor líquido e eletrólitos perdidos através do trato gastrintestinal. Fluidos que contêm albumina são adequados para os que perderam grandes quantidades de plasma, como ocorre em queimados e em hepatopatas graves. Não existem evidências sólidas de que os líquidos que contêm coloides sejam superiores às soluções cristaloides. ${ }^{729}$

A correção da acidose e da hipoxemia é vital no tratamento da PCR associada à hipovolemia. ${ }^{729}$ A incorporação da ecocardiografia ao atendimento da PCR propiciou o diagnóstico de causas comuns e potencialmente reversíveis não arritmogênicas. ${ }^{730-733} \mathrm{~A}$ expansão volêmica rotineira na

Quadro 9.1 - Causas de hipoxemia como desencadeante de parada cardiorrespiratória

\begin{tabular}{lc}
\hline Obstrução de via aérea & Hipoventilação central \\
Asma brônquica & Doença pulmonar obstrutiva crônica \\
Afogamento & Enforcamento \\
Pneumonia & Pneumotórax hipertensivo \\
\hline
\end{tabular}


PCR para todas as causas é considerada como Classe de Recomendação Ilb, Nível de Evidência C.

\subsubsection{Anafilaxia}

Trata-se de reação alérgica multissistêmica mediada por imunoglobulinas IgE e IgG e um antígeno imunoglobulina específico que envolve pele, vias aéreas, sistema vascular e trato gastrintestinal. Em casos mais graves, pode promover a obstrução completa e total das vias aéreas, bem como o colapso cardiovascular com choque distributivo grave..$^{734,735}$ A urticária costuma ser o achado mais frequente e a rinite, o sinal inicial de envolvimento das vias aéreas; o comprometimento mais grave está associado ao estridor laríngeo e sibilância. ${ }^{736-738} \mathrm{O}$ choque distributivo anafilático caracteriza-se por vasodilatação e aumento da permeabilidade capilar com redução de pré-carga e hipovolemia relativa de até $37 \%$ do volume sanguíneo total que rapidamente pode levar à $\mathrm{PCR}^{739,740}$ por isquemia miocárdica e ocorrência de arritmias graves. ${ }^{741-743}$

\section{Recomendações}

- A presença de um profissional que saiba manusear as vias aéreas com segurança se faz necessária, incluindo intervenção cirúrgica (Classe de Recomendação I; Nível de Evidência C).

- A administração intramuscular de epinefrina deve ser realizada em todos com sinais de reação anafilática: dose de 0,2 a 0,5 mg (1:1.000) por via intramuscular e repetida a cada 5 a 15 minutos na ausência de melhora clínica ${ }^{744-747}$ (Classe de Recomendação I; Nível de Evidência C).

- Uso de caneta injetora de epinefrina para adultos (0,3 $\mathrm{mg})$ e crianças $(0,10 \mathrm{mg})$ : pouco disponível no Brasil, para anafilaxia grave ou PCR (Classe de Recomendação I; Nível de Evidência C).

- Reposição volêmica: $1.000 \mathrm{~mL}$ de solução cristaloide para manter a PAS de $90 \mathrm{mmHg}$ como estratégia inicial e repetida, se necessário ${ }^{748}$ (Classe de Recomendação Ila; Nível de Evidência C).

- Se o uso de epinefrina por via intramuscular não for suficiente para estabilização clinica, ${ }^{749}$ a via endovenosa para epinefrina $(5-15 \mathrm{mcg} / \mathrm{min})$ contínua pode ser alternativa (Classe de Recomendação Ila; Nível de Evidência C). ${ }^{748-752}$
- Considerar o uso de vasopressina e o metaraminol em caso de anafilaxia com ou sem $\mathrm{PCR}^{753-757}$ se não responsivo à epinefrina (Classe de Recomendação Ilb; Nível de Evidência C).

\subsubsection{Hipotermia Acidental}

Condição na qual a temperatura central atinge valores inferiores a $35^{\circ} \mathrm{C}$ levando a múltiplas disfunções orgânicas progressivas, que, caso não sejam revertidas a tempo, podem evoluir para PCR e óbito. O tratamento consiste em RCP eficiente e reaquecimento.

A medida precisa da temperatura central com termômetro bem calibrado é importante na tomada de decisão, porém muitas vezes não está disponível. Termômetros convencionais dispõem da mesma acurácia.

Há diversas classificações de hipotermia, mas nas situações em que não se consiga aferir a temperatura, deve-se usar o Swiss Staging System, ${ }^{722}$ que se baseia em sinais clínicos (Quadro 9.2).

Deve-se suspeitar de hipotermia nos casos de história de exposição ao frio (hipotermia primária) ou na presença de patologia predisponente (hipotermia secundária). Entre as causas secundárias, devemos considerar: anorexia nervosa, transecção medular, AVC, toxinas, cetoacidose diabética, acidose lática, hipoglicemia, entre outras.

A abordagem varia de acordo com a apresentação. Inicialmente, devemos buscar e manter sinais vitais, evitar a perda de calor e oferecer reaquecimento. Recomenda-se:

- Na hipotermia I (32-35 $\left.{ }^{\circ} \mathrm{C}\right)$ : aquecer o ambiente, usar roupas e cobertas, oferecer a ingestão de bebidas quentes e estimular a movimentação. ${ }^{723}$

- Na hipotermia II (28 a $\left.32^{\circ} \mathrm{C}\right)$ : restringir movimentos para evitar arritmias e realizar o aquecimento com técnicas minimamente invasivas (fluído aquecido intravenoso, cobertor ou manta térmica, aquecimento do ambiente). ${ }^{724}$

- Na hipotermia III (24 a $\left.28^{\circ} \mathrm{C}\right)$, empregar todas medidas acima, além de garantir as vias aéreas de preferência com gases aquecidos. ECMO deve ser considerada no casos refratários. ${ }^{725,726,727}$

- Na hipotermia IV $\left(<24^{\circ} \mathrm{C}\right)$, estando paciente em PCR, deve-se instituir todas as medidas acima e RCP convencional. Deve-se considerar aquecimento de cavidade intratorácica quando ECMO não for disponível.

Quadro 9.2 - Classificação de hipotermia (Swiss staging system)

\begin{tabular}{|c|c|c|c|}
\hline Grau de hipotermia & Classificação & Clínica & Temperatura \\
\hline Hipotermia I & Leve & Consciência preservada e tremor & $32-35^{\circ} \mathrm{C}$ \\
\hline Hipotermia II & Moderada & Rebaixamento de consciência e ausência de tremor & $28-32^{\circ} \mathrm{C}$ \\
\hline Hipotermia III & Grave & Ausência de consciência e presença de sinais vitais & $24-28^{\circ} \mathrm{C}$ \\
\hline Hipotermia IV & & PCR ou sinais vitais mínimos & $<24^{\circ} \mathrm{C}$ \\
\hline Hipotermia V & & Óbito & $<13,7^{\circ} \mathrm{C}$ \\
\hline
\end{tabular}

PCR: parada cardiorrespiratória. 


\section{Peculiaridades no Tratamento}

- Deve-se checar pulso em artéria de grande calibre por 1 minuto. Caso disponível, pode-se utilizar Doppler; em caso de dúvida, sempre instituir RCP. ${ }^{730}$

- A hipotermia enrijece a parede torácica, podendo dificultar ventilação e massagem. ${ }^{731}$

- Pode ser observada refratariedade ao uso de drogas vasoativas, marca-passo e desfibrilação. Recomenda-se utilizá-los quando reaquecimento atingir $30^{\circ} \mathrm{C}$. Nesta condição, o intervalo de administração das drogas deve ser dobrado, em comparação com a normotermia, sendo sugerida adrenalina a cada 6 a 10 minutos. Acima de $35^{\circ} \mathrm{C}$, seguir protocolo habitual de drogas. ${ }^{732}$

- Na presença de hipotermia graus III (com instabilidade hemodinâmica) e IV, há consenso na indicação de ECMO. ${ }^{734-737}$ Caso não esteja disponível, está indicada a lavagem torácica (taxa de reaquecimento $3{ }^{\circ} \mathrm{C} /$ hora). ${ }^{738}$ Há estudos com outros procedimentos como diálise peritoneal (taxa de reaquecimento 1 a $3^{\circ} \mathrm{C} /$ hora $)^{739}$ e hemodiálise (taxa de reaquecimento 2 a $4^{\circ} \mathrm{C} /$ hora). ${ }^{740}$

\subsubsection{Tromboembolismo Pulmonar}

O TEP é uma causa potencialmente reversível de choque e PCR, e o tratamento é determinado pela gravidade. ${ }^{791-793}$

$\mathrm{O}$ aumento agudo da pressão do VD, devido à obstrução da artéria pulmonar e à liberação de mediadores vasoativos, produz choque cardiogênico que pode progredir rapidamente para o colapso cardiovascular.

O TEP maciço fulminante é caracterizado por PCR ou instabilidade hemodinâmica grave, e menos de 5\% dos pacientes agudos progridem para esta condição associada à mortalidade de $65 \%$ a $90 \% .{ }^{741,742}$ A PCR pode ocorrer em algumas horas do início dos sintomas, sendo AESP o ritmo de apresentação em $36 \%$ a 53\% do casos, enquanto o ritmo chocável primário é incomum. ${ }^{743,744}$ Entre $5 \%$ e $13 \%$ das PCR inexplicáveis estão associadas com TEP fulminante. ${ }^{743-746}$

As terapias farmacológicas e mecânicas para reverter rapidamente a oclusão da artéria pulmonar e restaurar a circulação pulmonar e sistêmica surgiram como terapias primárias para TEP maciço, incluindo opções de tratamento avançadas, como trombólise sistêmica, embolectomia mecânica cirúrgica ou percutânea e ECMO. ${ }^{777,748} \mathrm{O}$ uso de trombolíticos no atendimento à PCR em pacientes sem embolia pulmonar diagnosticada ou reconhecida não demonstrou benefício e não é recomendado (Classe de Recomendação III; Nível de Evidência A). ${ }^{749,750}$

Para pacientes em PCR, com provável associação com TEP, o uso de fibrinolíticos oferece chance de sobrevivência maior, ${ }^{749,750}$ apesar de aumentar o risco de sangramentos, sendo considerável sua indicação neste cenário (Classe de Recomendação Ila; Nível de Evidência B); a infusão sistêmica ou por angiografia do trombolítico se demonstrou similar em eficiência. ${ }^{751}$

Cateteres com ultrassonografia que otimizam a qualidade da trombólise e o uso de Circulação Extracorpórea (CEC) (Classe de Recomendação Ilb; Nível de Evidência B) têm surgido como opções de suporte avançado, a despeito de ainda demandar melhores evidências. ${ }^{752}$

\section{Recomendações}

- A administração de fibrinolíticos para PCR quando TEP é a causa suspeita de PCR é apoiada em recomendação fraca e evidência de baixa qualidade.

- O uso de drogas fibrinolíticas, embolectomia cirúrgica ou trombectomia mecânica percutânea para PCR, quando TEP é a causa conhecida, segue com recomendação fraca e de muito baixa qualidade, mantendo também sua possibilidade de uso.

- Deve se considerar o potencial risco de sangramento após a fibrinólise e acesso na escolha de intervenção, tendo em conta a localização, a disponibilidade de intervenções e as contraindicações para a fibrinólise.

- Não há consenso sobre a dose ideal de terapêutica trombolítica em PCR por TEP.

- Exemplos de regimes de trombólise em emergência para TEP fulminantes incluem rt-PA $50 \mathrm{mg}$ por via intravenosa em bólus com uma opção para repetir bólus em 15 minutos, ou TNK-tPA baseada no peso de dose única; fibrinolíticos são administrados juntamente de anticoagulação sistêmica. ${ }^{750,751}$

\subsubsection{Intoxicações}

Substâncias tóxicas que promovem lesão celular, alteração de receptores, canais iônicos, organelas e disfunção orgânica incompatível com a vida. $\mathrm{O}$ atendimento segue o tratamento padrão adotado de SBV e SAV, sendo indicado o uso de antídotos ou intervenções toxino-específicas, nem sempre únicos ou específicos para este fim. Desta forma, sempre, ao se obter o RCE, faz-se necessária a consulta urgente a um médico toxicologista. No Brasil, recomenda-se o contato com os centros de tratamento de intoxicação (CEATOX). ${ }^{752}$

A descontaminação do trato gastrintestinal, habitualmente, a primeira conduta a ser lembrada, tem papel menos relevante nos dias atuais, pelo risco de broncoaspiração. $\mathrm{O}$ uso de carvão ativado em dose única pode ser administrado para as situações em que o antídoto não está disponível, e o tempo de ingestão é inferior a 1 hora. Doses múltiplas de carvão ativado podem ser usadas em situações específicas (carbamazepina, dapsona, fenobarbital, quinine ou teofilina) e não devem ser administradas em intoxicações por substâncias cáusticas, metais e hidrocarbonetos. O carvão ativado só pode ser administrado se houver proteção adequada das vias aéreas. ${ }^{751-753}$

\section{Opioides}

O naloxone é um potente antagonista, revertendo a depressão respiratória na overdose; no entanto, não tem indicação no manuseio da PCR. Nos casos de depressão respiratória sem $\mathrm{PCR},{ }^{753}$ seu uso gera melhor resultado (Classe de Recomendação I; Nível de Evidência A). Deve ser administrado em pequenas doses $(0,04$ a $0,4 \mathrm{mg})$ por vias intramuscular, intravenosa ou inalatória e ser escalonado até 
$2 \mathrm{mg}$, para evitar efeitos como agitação e agressividade. ${ }^{753-755}$ O naloxone pode precipitar síndrome de abstinência aguda em dependentes de opiáceos, sintomas minimizados utilizando a menor dose eficaz ${ }^{756}$ (Classe de Recomendação Ila; Nível de Evidência C).

\section{Benzodiazepínicos}

O flumazenil é um potente e rápido antagonista da ligação de benzodiazepinas ao nível do sistema nervoso central. Sua utilização no coma de origem indeterminada não é recomendada (Classe de Recomendação III; Nível de Evidência B). Pode precipitar convulsões, arritmia e hipotensão, particularmente se associado a antidepressivos tricíclicos. ${ }^{757}$

\section{Betabloqueadores}

Necessita do antídoto glucagon, altas doses de insulina ou cloreto/gluconato de cálcio (Classe de Recomendação IIb; Nível de Evidência A). Glucagon deve ser administrado em bólus de 3 a $10 \mathrm{mg}$, lentamente, por via intravenosa, de 3 a 5 minutos, seguido de 3 a $5 \mathrm{mg} /$ hora $(0,05$ a 0,15 mg/kg e infusão contínua de 0,05 a 0,10 mg/kg por hora) (Classe de Recomendação IIb; Nível de Evidência C), sem exceder 100 mg em 24 horas.

\section{Cocaína e derivados}

A principal complicação, além de hiperexcitabilidade e hipertensão, dá-se pela manifestação da insuficiência coronária aguda, que deve ser abordada com nitratos, fentolamina, benzodiazepínicos, antagonistas do cálcio para controle da hipertensão e agitação (Classe de Recomendação Ilb; Nível de Evidência B). A administração de betabloqueadores pode piorar o quadro e facilitar vasoespamo dos óstios coronários, não estando indicada para uso rotineiro. (Classe de Recomendação IIb; Nível de Evidência C). ${ }^{758,759}$

\section{Anestésicos Locais}

A terapia com Infusão Lipídica (ILE) foi desenvolvida pela primeira vez como um tratamento para a PCR resultante de intoxicação por anestésico local por bupivacaína. ${ }^{760,761}$ Este inibe a atividade dos canais de sódio, limitando o potencial de ação e a condução de impulsos nervosos; a toxicidade sistêmica pode apresentar-se com colapso cardiovascular fulminante e refratário a medidas de RCP padrão. A fase de toxicidade do sistema nervoso central pode preceder à PCR. Desta forma, quando um anestésico local é administrado, recomenda-se monitoração neurológica e cardiovascular, emprego de dose fracionada, injeção lenta e uso concomitante de fármaco intravascular, para redução da absorção sistêmica (epinefrina 10 a $15 \mathrm{ug}$ ). ${ }^{761}$

A administração de ILE cria um compartimento de lípideos no soro, reduzindo por sequestro a concentração de medicamentos lipofílicos na administração tissular. Ao longo do tempo, a aplicação terapêutica de ILE tem sido expandida para incluir o envenenamento por outros anestésicos locais e medicamentos ${ }^{762}$ (Classe de Recomendação Ilb; Nível de Evidência C).

\section{Antidepressivos Tricíclico}

Podem alargar o QRS por seu mecanismo similar a antiarrítmicos e bloqueadores do canal de sódio, sendo o bicarbonato de sódio utilizado na overdose (Classe de Recomendação IIb; Nível de Evidência C). ${ }^{763,764}$

\subsection{Cenários Especiais}

Ambientes nos quais as diretrizes universais têm que ser adaptadas: pós-operatório de cirurgia cardíaca, sala de hemodinâmica e eventos desportivos.

Cenários externos específicos: danos elétricos ou eletrocussão por raios, trauma e afogamento.

\subsubsection{Parada Cardiorrespiratória no Pós-Operatório de Cirurgia Cardíaca}

A PCR no período perioperatório de cirurgia cardíaca é relativamente comum, com incidência de 0,7 a 8\%. ${ }^{765,766}$ Existem várias causas, e muitas delas são reversíveis, como FV, hipóxia, pneumotórax, hipovolemia, perda de comando de marca-passo, tamponamento cardíaco, acidose e distúrbios eletrolíticos. O rápido reconhecimento da deterioração, uma RCP eficiente e o tratamento das causas passíveis de reversão determinam o prognóstico.

Casos de FV/TV com instabilidade hemodinâmica devem ser tratadas imediatamente com desfibrilação, enquanto assistolia deve ser tratada com estimulação por marca-passo. $\mathrm{Na}$ falta de resposta, devem-se iniciar compressões torácicas para manter pressão arterial média $>60 \mathrm{mmHg}$.

Situações como hipóxia por mal posicionamento do tubo traqueal, pneumotórax e assistolia por falha de marca-passo devem ser pensadas, pois podem ser revertidas.

A compressão torácica neste cenário aumenta a chance de lesão de esterno e complicações cirúrgicas, de modo que, em casos de FV, pode-se desfibrilar até três vezes sucessivamente. ${ }^{767}$ Caso não haja resposta, reiniciar compressões e acionar equipe cirúrgica, para esternotomia de urgência, que está indicada após 5 minutos de RCP não revertida, por equipe com habilidade e capacidade para tal. Permite $\mathrm{MCl}$, reversão de possíveis causas como tamponamento, hemorragias por falhas de sutura ou coagulopatias e instalação de suporte circulatório.

Diversos estudos mostraram melhor prognóstico nos casos tratados com esternotomia que com protocolo convencional. Nos pacientes que não responderam às manobras habituais, há evidências de melhora de sobrevida em pacientes que usaram CEC. ${ }^{768}$

\subsubsection{Parada Cardiorrespiratória no Laboratório de Hemodinâmica}

A ocorrência de PCR durante a realização de ICP pode ocorrer em 1,3\% da intervenções, com aumento determinado pelos procedimentos de emergência. Caso o paciente desenvolva FV, recomenda-se que a desfibrilação seja imediata, não se devendo realizar compressões torácicas antes do choque. Se a FV persistir após desfibrilação inicial ou o RCE não puder ser imediatamente reconhecido, ciclos de compressões torácicas e ventilações devem ser iniciados 
sem demora, e a pesquisa de causas para a refratáriedade deve ser ponderada.

Um possível componente obstrutivo deve ser afastado, com a realização de uma nova angiografia coronária. Se a PCR for causada por ritmo não chocável, um ecocardiograma transtorácico imediato pode diagnosticar tamponamento cardíaco ou outras condições causadoras da PCR. ${ }^{769}$

\subsubsection{Parada Cardiorrespiratória durante Atividades Desportivas}

O colapso súbito e inesperado de um atleta não associado com contato ou trauma é provavelmente de origem cardíaca e requer rápido reconhecimento e efetivo tratamento.

A morte súbita cardíaca é a causa mais comum de morte em atletas e as estimativas variam 1:11.394 em jogadores de basquete, 1:21.293 em nadadores e 1:41.695 para atletas de cross-country, com ampla variação entre homens e mulheres (incidência expressa em número de atletas por ano). ${ }^{770}$

A Cardiomiopatia Hipertrófica $(\mathrm{CMH})$ e a Cardiomiopatia Arritmogênica do VD (CAVD) são as causas mais comuns em atletas jovens ( $<35$ anos), enquanto a doença aterosclerótica coronária responde por $80 \%$ das mortes súbitas cardíacas em atletas acima de 35 anos. Anomalias congênitas das artérias coronárias têm sido relatadas em 12 a 33\% dos atletas. ${ }^{771,772}$

Atletas lutadores de artes marciais são grupos de risco para FV desencadeada por trauma frontal no precórdio, o commotio cordis, facilitado pelo choque de um objeto contra precórdio em uma janela de tempo de 20 milissegundos do pico da onda $\mathrm{T}$ (fenômeno $\mathrm{R}$ sobre $\mathrm{T}$ ) apresenta incidência de cerca de $3 \%$. ${ }^{773,774}$

\subsubsection{Parada Cardiorrespiratória por Eletrocussão por Raios e Eletricidade}

A injúria elétrica é uma lesão relativamente incomum, mas potencialmente causadora de dano multissistêmico devastador, com elevadas morbidade e mortalidade, respondendo por cerca de 0,54 morte em 100 mil pessoas por ano em todo mundo.

Em adultos, injúrias elétricas são comuns em locais de trabalho e choques de alta voltagem; enquanto as crianças são mais afetadas no ambiente domiciliar, onde a voltagem é menor (110 a 220V). ${ }^{775}$

Os danos são causados por efeitos diretos da corrente elétrica sobre as membranas celulares e sobre o músculo liso vascular. A energia térmica associada com eletrocussão de alta voltagem também pode causar queimaduras. Danos estão relacionados a contrações musculares intensas (rabdomiólise e fraturas ósseas) e liberação de catecolaminas. ${ }^{776,777}$

São fatores que influenciam na gravidade do dano: padrão da corrente elétrica (alternada ou contínua), voltagem, magnitude da energia liberada, resistência à corrente elétrica pelos tecidos, trajeto da corrente através do paciente, área exposta à passagem da corrente e duração do contato. ${ }^{776}$ Choques de baixa voltagem costumam causar queimaduras brandas nos locais de entrada. Os pontos de entrada mais comuns são os membros superiores. ${ }^{777}$
O contato com a corrente elétrica alternada (habitualmente presente nas residências) pode causar contrações tetânicas no músculo esquelético, o que faz com que a vítima permaneça estática, sem conseguir se afastar da fonte de eletricidade. Neste contexto, falência miocárdica ou respiratória pode causar morte imediata. A PCR pode ser causada por paralisia do sistema de controle respiratório central ou dos músculos respiratórios ou pela passagem da corrente elétrica através do coração em um período vulnerável (fenômeno R sobre $\mathrm{T})$, precipitando a FV.

De todos os países do mundo, o Brasil é o mais atingido por descargas elétricas, sendo registrados aproximadamente 100 milhões de raios por ano. Entre 2000 e 2009, ocorreram 1.321 mortes por raios no país (média de 132 mortes por ano). ${ }^{776}$

Raios podem liberar até $300 \mathrm{kV}$ de energia durante poucos milissegundos. Diferente da corrente elétrica domiciliar, os choques por raios emitem correntes de alta voltagem e contínuas.

O padrão e a gravidade do trauma varia consideravelmente, mesmo em um grupo de indivíduos afetados por uma única descarga. ${ }^{778}$ Embora o automatismo cardíaco seja capaz de reiniciar a atividade elétrica, na maioria dos casos, o dano do sistema nervoso central leva a uma parada respiratória mais duradoura, que facilita uma PCR secundária e FV por hipóxia. A mortalidade por eletrocussão por raios é alta, chegando a $30 \%$.

\section{Medidas de Segurança}

Ao chegar no local, como em qualquer outro atendimento, a prioridade é a segurança dos socorristas e a segurança pública. Neste sentido, antes de começar o atendimento, garanta que qualquer fonte de eletricidade esteja desligada e o local esteja seguro. Correntes elétricas de alta voltagem podem arquear e serem conduzidas através do solo por até alguns metros. ${ }^{778}$

\section{Particularidades da Ressuscitação Cardiopulmonar}

O manejo da via aérea pode ser difícil se ocorrerem queimaduras elétricas em torno da face e do pescoço. A IOT precoce é necessária nesses casos.

- Paralisia muscular, especialmente após choques de alta voltagem, pode persistir por horas, e o suporte ventilatório é necessário durante este período.

- A FV é a arritmia inicial mais comum após um choque elétrico em corrente alternada. O tratamento deve ser realizado com tentativa de desfibrilação imediata.

- Intervenção cirúrgica precoce deve ser considerada para pacientes com danos térmicos severos.

\section{Tratamentos Adicionais e Prognóstico}

Todos os sobreviventes de um dano elétrico devem ser monitorados em um hospital se tiverem história de problemas cardiorrespiratórios, ou se tiverem apresentado perda de consciência, PCR, anormalidades eletrocardiográficas, danos tissulares em partes moles ou queimaduras. 
Queimaduras graves (térmicas ou elétricas), necrose miocárdica, dano ao sistema nervoso central e insuficiência de múltiplos órgãos e sistemas secundária ao evento inicial determinam a morbidade e o prognóstico a longo prazo. Não existe terapia específica para o dano elétrico, e o manejo é de suporte. A prevenção permanece como o melhor modo de minimizar a prevalência e a gravidade de choques elétricos.

\subsubsection{Parada Cardiorrespiratória no Trauma}

No Brasil, de 1996 a 2013, causas externas ocuparam a terceira colocação dentre as causas de mortalidade geral, com 2.347.798 óbitos no período, ficando atrás apenas das doenças do aparelho circulatório e neoplasias. Desse total, 870.256 óbitos são atribuídos a agressões e 663.626 a acidentes de trânsito. ${ }^{779}$ É importante lembrar que a decisão de não iniciar a RCP deve ser considerada em casos de trauma incompatível com a vida (perda de massa encefálica, por exemplo) ou na ausência prolongada de sinais vitais. ${ }^{780,781}$

\section{Atendimento pré-hospitalar}

No APH ou em serviços sem equipe cirúrgica de emergência é necessário ponderar entre os conceitos de "socorrer e correr" ("scoop and run") e "ficar e cuidar" ("stay and play"), de acordo com a característica do trauma, os recursos disponíveis no local e logística de transporte considerando tempo e a distância até um centro de atendimento avançado.

De modo geral, recomenda-se execução apenas de intervenções salvadoras na cena e sua continuidade durante a remoção do paciente. ${ }^{782,783}$

\section{Particularidades dos Suportes Básico e Avançado no Trauma}

O algoritmo de atendimento do Advanced Trauma Life Support (ATLS) preconiza o direcionamento para os seguintes cuidados: estabilização da coluna cervical no politrauma ou naquele com envolvimento da cabeça e pescoço, por meio da manobra da "tração da mandíbula" (jaw thrust), ao invés das habituais "hiperextensão da cabeça" (head tilt) e "elevação do mento" (chin lift); prioridade no tratamento de causas reversíveis, como hipovovelmia (48\%), hipoxemia (13\%), pneumotórax hipertensivo (13\%) e tamponamento cardíaco (10\%), uma vez que as compressões torácicas têm menor eficácia em situações como hipovolemia, tamponamento cardíaco e pneumotórax hipertensivo. ${ }^{784}$

O princípio de "ressuscitação no controle de dano" deve nortear a abordagem da hipovolemia por hemorragia não controlada, combinando hipotensão permissiva, ressuscitação hemostática e cirurgia no controle de dano, para anular o efeito da tríade letal representada por hipotermia, coagulopatia e acidose. ${ }^{785,786} \mathrm{~A}$ hipotensão permissiva consiste no manejo conservador da administração de fluidos intravenosos, com alvo de PAS entre 80 e $90 \mathrm{mmHg}$, por não mais que 60 minutos e sob cautela em casos de trauma craniencefálico, no qual o risco de hipertensão intracraniana exige maior PPC. ${ }^{787}$ A ressuscitação hemostática traduz-se pelo uso precoce de hemoderivados, visando evitar a coagulopatia induzida pelo trauma, em uma razão de 1:1:1 de concentrado de hemácias, PFC e plaquetas. Essa estratégia de transfusão maciça está indicada em perdas volêmicas significativas, estimadas à beira do leito pela presença de dois ou mais dos seguintes critérios: $\mathrm{FC} \geq 120 \mathrm{bpm}, \mathrm{PAS} \leq 90 \mathrm{mmHg}$, trauma penetrante e Focused Assessment Sonography for Trauma (FAST) positivo. ${ }^{788}$

Deve-se cogitar o emprego de toracotomia de reanimação na PCR por trauma torácico contuso com menos de 10 minuto, trauma penetrante com menos de 15 minutos e trauma de pescoço ou extremidade com sangramento maciço com menos de 5 minutos. Os pré-requisitos são uma equipe qualificada e estrutura adequada. A taxa de sucesso é de aproximadamente $35 \%$ para pacientes com trauma cardíaco penetrante e de apenas $2 \%$ em traumas torácicos contusos. Os objetivos do procedimento são: acesso para realização de $\mathrm{MCl}$ (sob técnica bimanual com compressão do ápice para base do coração), possibilidade de injeção intracardíaca de epinefrina, desfibrilação com 30 J com pás internas se indicado, controle de hemorragias maciças intratorácicas ou subdiafragmáticas por oclusão temporária da aorta descendente ou hilo pulmonar, tratamento de embolia gasosa e descompressão de tamponamento cardíaco.

O pneumotórax hipertensivo causa comprometimento hemodinâmico pela entrada de ar para o espaço pleural por mecanismo de válvula unidirecional. O diagnóstico é clínico e a confirmação radiológica não deve atrasar sua descompressão imediata. A toracocentese de alívio com inserção rápida de agulha de grosso calibre no segundo espaço intercostal na linha hemiclavicular é a primeira medida, mas nem sempre efetiva. A toracostomia de resgate pode ser realizada, com a incisão da pele e dissecção muscular até o espaço pleural, mas sem a inserção do dreno durante a fase de RCP, evitando atrasos no procedimento, obstrução por coágulos ou acotovelamento com retorno da tensão pulmonar durante. ${ }^{788}$

Tamponamento cardíaco é desencadeado pela presença de efusão pericárdica com restrição ao enchimento ventricular e que pode se manifestar classicamente pela presença de pulso paradoxal e da tríade hipotensão arterial/ turgência jugular/ abafamento de bulhas. Durante a RCP, pode-se realizar a toracotomia de reanimação, sendo a pericardiocentese guiada por ultrassonografia ou pela técnica de Marfan, na indisponibilidade do ultrassom, constituindo uma alternativa à toracotomia. ${ }^{789}$

\subsection{Afogamento}

O afogamento é uma das principais causas evitáveis de morte acidental. Acomete sobretudo jovens, sendo o abuso do álcool um dos seus maiores fatores contribuintes, além da imprudência decorrente do excesso de confiança da vítima em suas habilidades de natação ou negligência dos pais, em casos envolvendo crianças. Também podem ser precipitados por convulsão, traumatismos, doenças cardiopulmonares e acidentes de mergulho. ${ }^{790}$

Em 2002, durante o I Congresso Mundial Sobre Afogamentos uma nova definição de afogamento e uma terminologia foram estabelecidas e estão em uso atualmente pela Organização Mundial da Saúde (OMS), sendo considerado afogamento a "aspiração de líquido não corporal por submersão (abaixo da superfície do líquido) ou imersão (água na face)". Se a vítima é resgatada e o processo é interrompido, o que é denominado um afogamento não fatal, se evoluir a óbito será considerado afogamento fatal. ${ }^{790}$ 
Esta nova proposta de um modelo sistemático sobre afogamento - linha do tempo (Figura 9.1) - resolve e reforça o importante papel da prevenção no combate ao afogamento no mundo (Figura 9.2). ${ }^{790-795} \mathrm{~A}$ prevenção permanece a mais poderosa intervenção e a de menor custo, podendo evitar mais de $85 \%$ dos casos. Campanhas de prevenção estão disponíveis em no endereço eletrônico www.sobrasa.org.

9.4.1. Particularidades dos Suportes Básico e Avançado no Afogamento

- Cuidados com o socorrista: evitar a submersão e usar uma boia ou outro objeto de flutuação intermediária entre ele e as vítimas, sempre que possível.
- Na ocorrência de parada respiratória, mas ainda na presença de pulso, a realização de cinco a dez ventilações ainda dentro d'água aumenta as chances de sucesso do salvamento. Para isto, é necessário que se tenham o treinamento adequado e a segurança para sua execução.

- De modo geral, as compressões torácicas não devem ser realizadas dentro d'água.

- Fora d'agua, a modalidade de "só compressões" cardíacas (hands only), embora possa ser alternativa para o socorrista leigo, tem menor impacto no cenário do afogamento.

- A imobilização da coluna cervical não é recomendada rotineiramente, exceto em casos de afogamento em

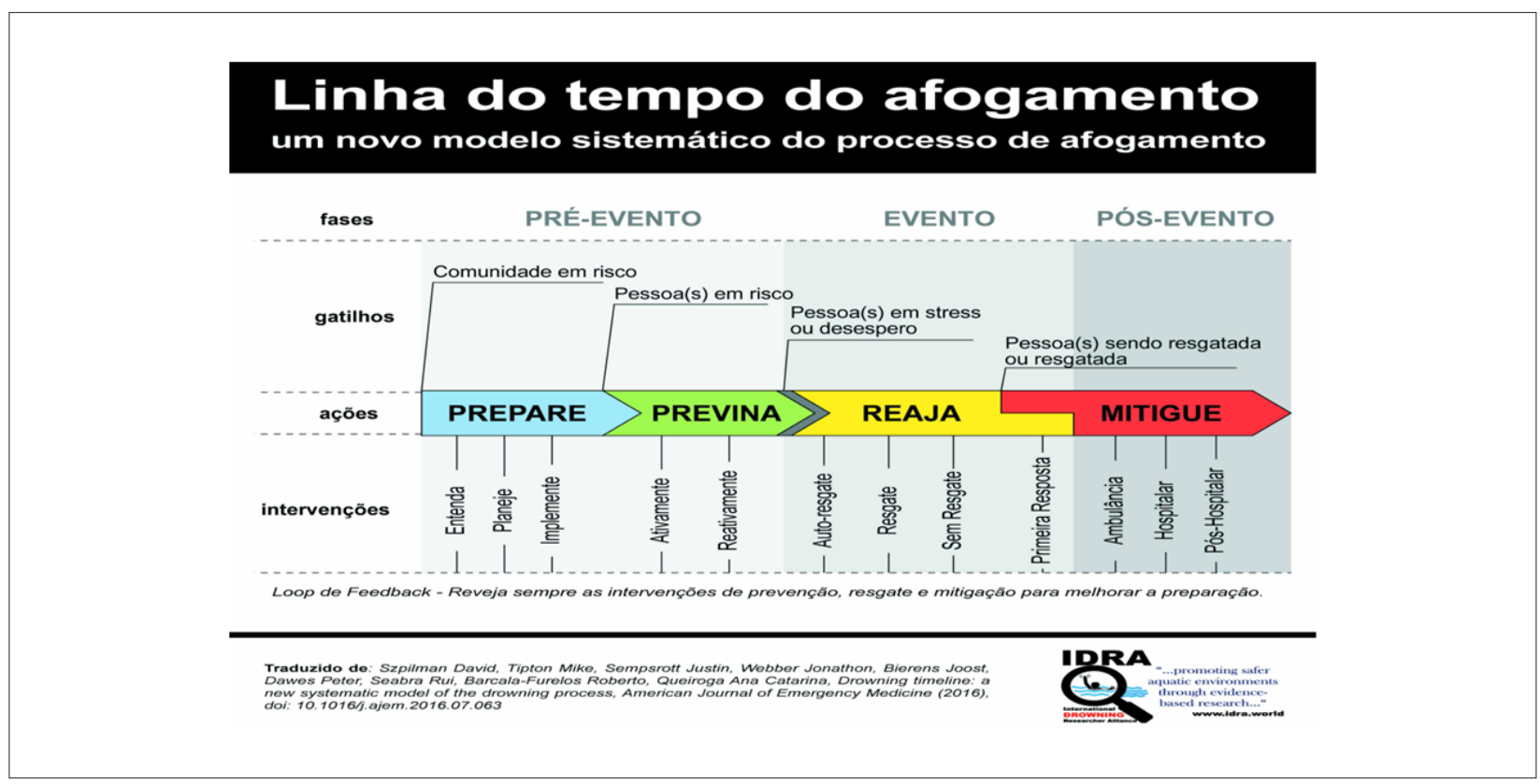

Figura 9.1 - Linha do tempo no afogamento. Fonte: Szpilman D et al., 2016. ${ }^{792}$

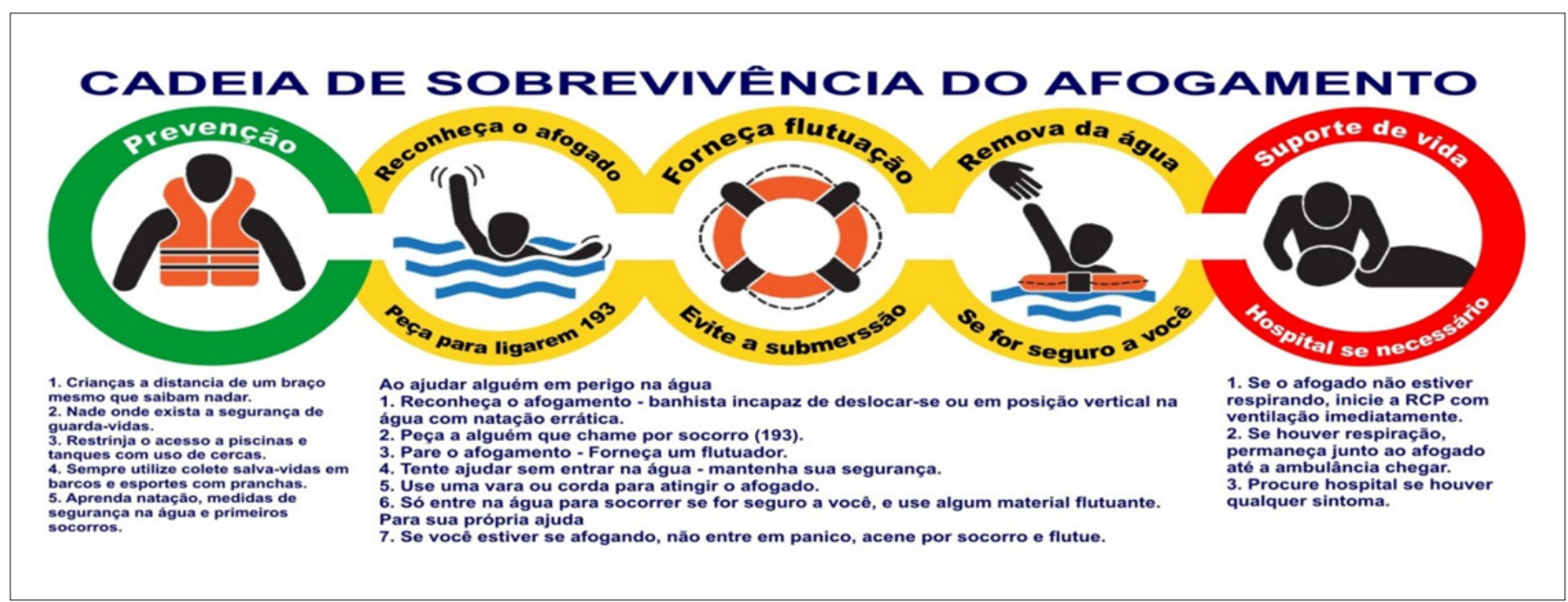

Figura 9.2 - Cadeia de sobrevivência no afogamento. 
local pouco profundo, em pacientes politraumatizados, acidentes presenciados ou com mecanismo compatível.

- Evitar tentativas de drenagem da água aspirada.

- A RCP em casos de afogamento deverá continuar utilizando o ABC, pela natureza de sua PCR ser hipóxica. O socorrista deverá abrir as vias aéreas (A), realizar ventilação de resgate (B) e iniciar compressões torácicas (C) na relação de 30 compressões para 2 ventilações.

- O DEA pode ser usado após secar o tórax da vítima, mas lembrar que a PCR por causa respiratória ocorre predominantemente em ritmo não chocável, exceto quando a FV acontece como consequência evolutiva ou quando o afogamento é desencadeado por comorbidade clínica.

- O Suporte Avançado, por sua vez, envolve a intubação traqueal precoce, com restrição do uso de dispositivos supraglóticos, uma vez que pode ser necessária a titulação de Pressão Positiva Expiratória Final (PEEP) alta e ventilação protetora, de acordo com a hipoxemia e a instalação de Síndrome do Desconforto Respiratório Agudo (SDRA).

- Antibióticos profiláticos não estão indicados, embora seja comum a ocorrência de pneumonia após afogamento.

\subsection{Pacientes Especiais: Obesos e Asmáticos}

\subsubsection{Obesidade}

É um problema crescente de saúde pública e, de acordo com dados do Ministério da Saúde, a prevalência na população adulta atinge cerca de $17 \%$, sendo registrado aumento de $5 \%$ em 6 anos. ${ }^{796,797}$

As manobras de RCP em pacientes obesos devem seguir as mesmas recomendações descritas nesta diretriz. Fatores anatômicos e fisiológicos dificultam a realização dos procedimentos. Pelo risco fadiga, devem-se considerar uma troca mais rápida dos socorristas (menos de 2 minutos) e a IOT precoce por médico experiente, para diminuir a hiperinsuflação gástrica e o risco de aspiração. Recomendase, a seguir, a carga para pacientes com índice de massa corporal normal. ${ }^{797}$

Embora a obesidade esteja associada a dificuldades técnicas, a mortalidade deste grupo não se mostrou elevada em relação a pacientes com peso adequado, por vezes com melhores desfechos a curto e longo prazo, fato chamado por alguns autores de "paradoxo da obesidade". ${ }^{\text {797-799 }}$

\subsubsection{Asma Brônquica}

Acomete por volta de 300 milhões de pessoas no mundo e, segundo dados do Ministério da Saúde, cerca de 6,4 milhões de brasileiros acima dos 18 anos, com 105 mil internações no período de janeiro a novembro de 2014. ${ }^{800-802}$ Devemos identificar o risco de evolução desfavorável e potencial de PCR.

- Sinais de alerta: necessidade de intubação em exacerbação prévia, internação nos últimos 12 meses, baixa aderência a dispositivos inalatórios, aumento do uso de medicações inalatórias de resgate, ansiedade ou outros distúrbios psiquiátricos associados e antecedente de alergia a comida em paciente asmático.
- Sinais de gravidade: alteração do nível de consciência, fala entrecortada, frequência respiratória $>30$ ipm, uso de musculatura acessória, FC > 120 bpm, saturação arterial $<90 \%$.

A PCR está associada ao broncoespasmo grave ou a obstrução por muco na via aérea, levando à asfixia. São causas menos frequentes: arritmias ventriculares secundárias a hipoxemia, pneumotórax hipertensivo e, em pacientes em $\mathrm{VM}$, a presença de auto-PEEP elevada, que pode dificultar o retorno venoso, piorando a hemodinâmica cardiovascular.

O tratamento baseia-se no uso de oxigênio, com o objetivo de atingir uma saturação arterial de 93 a 95\%. Deve-se atentar para pacientes com potencial de retenção de dióxido de carbono.

Broncodilatadores inalatórios (beta2-agonistas) representam a principal ferramenta terapêutica, devendo ser iniciados precocemente. Em pacientes com crises moderadas a graves ou nos casos refratários, recomenda-se o uso de drogas anticolinérgicas inalatórias (ipratrópio) como adjuvantes. Além disso, corticoides sistêmicos são fundamentais no controle do componente inflamatório, sem diferença entre as vias de administração (oral ou venosa). A terbutalina e a adrenalina são reservadas para casos que apresentam evolução desfavorável de desconforto respiratório importante, sendo esta última indicada quando há suspeita de anafilaxia.

O sulfato de magnésio intravenoso não é indicado de forma rotineira e deve ser considerado para os não respondedores a broncodilatadores inalatórios. Não há evidência no cenário agudo para o uso de metilxantinas ou de antagonistas de leucotrienos (Quadro 9.3). ${ }^{801-803}$

A garantia precoce da via aérea por meio de IOT deve ser priorizada. A tentativa de ventilação por BVM está associada à hiperinsuflação gástrica e à hipoventilação, em virtude da resistência elevada das vias aéreas. Cuidados especiais devem ser tomados no paciente em VM:

- A auto-PEEP, facilitada pela dificuldade no fluxo expiratório e consequente aprisionamento de ar, deve ser evitada.

- Ventilação em volume corrente reduzido e realização de manobras que promovam o aumento do tempo expiratório (oito a dez incursões por minuto).

- Deve-se considerar a desacoplagem do tubo orotraqueal da BVM, na tentativa de eliminar o ar aprisionado, evitando gerar um ciclo vicioso de aumento de pressões intratorácicas.

\section{Quadro 9.3 - Medicações na asma brônquica}

\begin{tabular}{lc}
\hline $\begin{array}{l}\text { Broncodilatadores } \\
\text { inalatórios }\end{array}$ & $\begin{array}{c}\text { Fenoterol: } 5-10 \text { gotas } \\
\text { Ipatrópio: } 35-40 \text { gotas } \\
\text { Repetir } 3 \text { vezes, a cada } 20 \text { minutos }\end{array}$ \\
Corticoides sistêmicos & $\begin{array}{c}\text { Metilprednisolona } 125 \text { mg endovenoso } \\
\text { Terbutalina }\end{array}$ \\
Adrenalina & $\begin{array}{c}\text { vezes, a cada } 20 \text { minutos } \\
\text { ver via subcutânea, podendo repetir } 3\end{array}$ \\
Sulfato de magnésio & vezes, a cada 20 minutos \\
\hline
\end{tabular}


Nesses pacientes, por exemplo, principalmente quando há dificuldade de ventilação, a hipótese de pneumotórax hipertensivo deve ser considerada.

\section{Emergências Cardiológicas em Gestantes}

\subsection{Introdução}

Nessa seção, serão abordadas as emergências cardíacas que ocorrem na gestação, considerando os diversos aspectos da gravidez em cardiopatas e com destaque especial para as doenças com potencial risco no prognóstico materno-fetal.

Atualmente, nos países industrializados, 0,2 a 4\% das gestações são complicadas por DCV, porcentual que tende a aumentar em decorrência da maior idade materna, da prevalência de fatores de risco e do avanço terapêutico, que permite às portadoras de cardiopatias congênitas alcançar a idade fértil. ${ }^{804}$

No Brasil, os dados do Departamento de Informática do Sistema Único de Saúde (DATASUS) mostram que a cardiopatia é a primeira causa não obstétrica de morte materna e ocupa a quarta causa na mortalidade geral durante a gestação. ${ }^{805}$ Em países desenvolvidos, como Estados Unidos, as cardiopatias congênitas são as mais frequentes (75 a 82\%), enquanto nos países em desenvolvimento, a doença valvar reumática predomina (56 a 89\%). ${ }^{804,806}$

Entre os anos de 1989 e 1999, foram incluídas 1.000 gestantes com DCV em um estudo nacional que evidenciou que cerca de 55\% delas apresentavam valvopatia reumática e 20\%, cardiopatia congênita, e, ainda, que 23,5\% tiveram complicações. A mortalidade encontrada foi de 2,7\% predominantemente entre as portadoras de cardiomiopatias e cardiopatias congênitas. ${ }^{807,808}$

\subsection{Gestantes Portadoras de Valvopatia}

A valvopatia reumática é entidade relevante em nosso meio, considerando-se que as estenoses valvares e as lesões de câmaras esquerdas com maior descompensação. ${ }^{807,809} \mathrm{Em}$ contrapartida, as insuficiências valvares, em geral, são mais bem toleradas, em virtude da vasodilatação sistêmica que se acentua durante a gravidez (Quadro 10.1). ${ }^{810}$

\subsubsection{Próteses Valvares}

A gestação em portadoras de próteses valvares impõe desafios ao clínico, sobretudo no controle da anticoagulação, que se associa a riscos teratogênicos e à hemorragia

Quadro 10.1 - Principais valvopatias encontradas durante a gestação, com seus riscos associados e orientações gerais de manejo clínico e obstétrico ${ }^{810}$

\begin{tabular}{|c|c|c|c|c|c|}
\hline Lesão & $\begin{array}{l}\text { Etiologias mais } \\
\text { comuns na } \\
\text { gravidez }\end{array}$ & Riscos para a mãe & Riscos para o feto & Intervenções possíveis na gravidez & $\begin{array}{l}\text { Via de parto } \\
\text { preferencial }\end{array}$ \\
\hline Estenose mitral & Reumática & $\begin{array}{l}\text { Se área valvar }<1,5 \mathrm{~cm}^{2} \\
\text { ou na presença de FA: } \\
\text { risco de IC sintomática e } \\
\text { mortalidade de até } 3 \%\end{array}$ & $\begin{array}{c}\text { Prematuridade }(20-30 \%) \text {; } \\
\text { retardo de crescimento } \\
\text { intrauterino }(5-20 \%) ; \\
\text { natimorto (1-3\%). Riscos } \\
\text { são maiores na mãe em } \\
\text { CF > II (NYHA) }\end{array}$ & $\begin{array}{l}\text { Betabloqueadores e duréticos. Se FA: } \\
\text { digoxina e anticoagulação } \\
\text { Valvoplastia mitral percutânea com } \\
\text { cateter balão: se CF III/IV da NYHA ou } \\
\text { PSAP > } 50 \text { mmHg apesar de terapia } \\
\text { medicamentosa otimizada. Considerar } \\
\text { cirurgia se anatomia valvar desfavorável } \\
\text { para tratamento percutâneo }\end{array}$ & $\begin{array}{l}\text { Preferência via vaginal. } \\
\text { Cesariana se CF III ou } \\
\text { IV ou com HP apesar de } \\
\text { terapia medicamentosa } \\
\text { otimizada }\end{array}$ \\
\hline $\begin{array}{l}\text { Estenose } \\
\text { aórtica }\end{array}$ & $\begin{array}{l}\text { Reumática, } \\
\text { congênita } \\
\text { bicúspide }\end{array}$ & $\begin{array}{l}\text { Estenose aórtica grave } \\
\text { sintomática: IC (10\%), } \\
\text { arritimias }(3-25 \%)\end{array}$ & $\begin{array}{l}\text { Prematuridade, retardo de } \\
\text { crescimento intrauterino, } \\
\text { baixo peso ao nascer (até } \\
25 \% \text { de complicações) }\end{array}$ & $\begin{array}{l}\text { Restringir atividades físicas. Se FA: } \\
\text { betabloqueador ou verapamil/diltiazem } \\
\text { para controle de FC. Valvoplastia aórtica } \\
\text { percutânea ou tratamento cirúrgico se } \\
\text { manutenção de sintomas limitantes. }\end{array}$ & $\begin{array}{l}\text { Preferência pela } \\
\text { via vaginal. Em } \\
\text { estenose aórtica grave } \\
\text { sintomática, cesariana } \\
\text { deve ser considerada }\end{array}$ \\
\hline $\begin{array}{l}\text { Insuficiência } \\
\text { aórtica }\end{array}$ & $\begin{array}{l}\text { Reumática, } \\
\text { congênita, } \\
\text { degenerativa }\end{array}$ & $\begin{array}{l}\text { Insuficiência aórtica grave, } \\
\text { associada a disfunção VE: } \\
\text { alto risco de IC e arritmias }\end{array}$ & $\begin{array}{l}\text { Sem aumento conhecido } \\
\text { no risco de complicações } \\
\text { fetais }\end{array}$ & $\begin{array}{l}\text { Manejo sintomático com diuréticos e } \\
\text { repouso no leito }\end{array}$ & $\begin{array}{l}\text { Preferência pela via } \\
\text { vaginal. Considerar } \\
\text { anestesia epidural e } \\
\text { fórcipe de alívio }\end{array}$ \\
\hline $\begin{array}{l}\text { Insuficiência } \\
\text { tricúspide }\end{array}$ & $\begin{array}{l}\text { Funcional, } \\
\text { endocardite, } \\
\text { anomalia } \\
\text { de Ebstein, } \\
\text { reumática }\end{array}$ & $\begin{array}{l}\text { Insuficiência tricúspide } \\
\text { grave, associada a } \\
\text { disfunção ventricular direita: } \\
\text { risco de IC e arritmias }\end{array}$ & $\begin{array}{l}\text { Sem aumento conhecido } \\
\text { no risco de complicações } \\
\text { fetais }\end{array}$ & $\begin{array}{l}\text { Mesmo nas formas graves, sintomas } \\
\text { de IT mais comumente podem ser bem } \\
\text { manejados com terapia diurética }\end{array}$ & $\begin{array}{l}\text { Preferência pela via } \\
\text { vaginal. }\end{array}$ \\
\hline
\end{tabular}

FA: fibrilação atrial; IC: insuficiência cardiaca; CF: Classe Funcional; NYHA: New York Heart Association; PSAP: pressão sistólica de artéria pulmonar; HP: hipertensão pulomar; FC: frequência cardiaca; VE: ventrículo esquerdo; IT: insuficiência triscúspide. Fonte: Adaptado de Sliwa K, $2015 .{ }^{811}$ 


\section{Atualização}

materno-fetal. ${ }^{812}$ A varfarina é passível de apresentar efeitos teratogênicos no primeiro trimestre, mesmo quando utilizada em doses inferiores a $5 \mathrm{mg} / \mathrm{dia} .{ }^{813} \mathrm{O}$ uso de HBPM, entretanto, acaba por resultar em níveis erráticos de fatores anti-Xa, o que pode aumentar a incidência de trombose de prótese valvar metálica, mesmo com a monitorização adequada deste fator (Figura 10.1). ${ }^{814}$

Na ocorrência de hemorragia materna ou trabalho de parto na vigência do uso de varfarina ou HNF ou de HBPM, recomenda-se o uso de plasma fresco intravenoso ou concentrado protrombínico, além de sulfato de protramina como coadjuvante terapêutico. ${ }^{810}$

\subsubsection{Diagnóstico e Conduta perante Trombose de Prótese Valvar}

Em gestantes portadoras de prótese mecânica sem disfunção ventricular que se apresentam com sinais de IC aguda, a suspeita diagnóstica de trombose da prótese deve ser fortemente considerada. Outro sinal que pode estar presente é o desaparecimento dos "cliques" na ausculta cardíaca. ${ }^{815}$ O ecocardiograma transesofágico é o exame de escolha. ${ }^{816}$
Nas assintomáticas com anticoagulação inadequada e trombos pequenos, a conduta recomendada é a internação, seguida de anticoagulação com heparina intravenosa plena, objetivando o TTPa de 2 a 2,5 vezes o valor normal e a realização de ecocardiogramas seriados. ${ }^{84}$

Em pacientes sintomáticas, com ou sem comprometimento hemodinâmico, as opções terapêuticas são fibrinólise ou cirurgia cardíaca. Embora exista o risco materno de hemorragia, a fibrinólise é um tratamento seguro para o feto, visto que os trombolíticos não ultrapassam a barreira placentária. ${ }^{817}$ Neste contexto, a cirurgia cardíaca permanece como tratamento de escolha, quando houver contraindicação à fibrinólise ou sua falha.

\subsubsection{Endocardite Infecciosa}

Trata-se de condição grave, com incidência desconhecida durante a gestação. ${ }^{818}$ Por isso, em pacientes com fatores de risco, é recomendada a profilaxia no momento do parto e em outras situações de risco, conforme preconizado pela Diretriz Brasileira de Valvopatias da SBC. ${ }^{809} \mathrm{O}$ diagnóstico e o tratamento são conduzidos de forma semelhante aos da

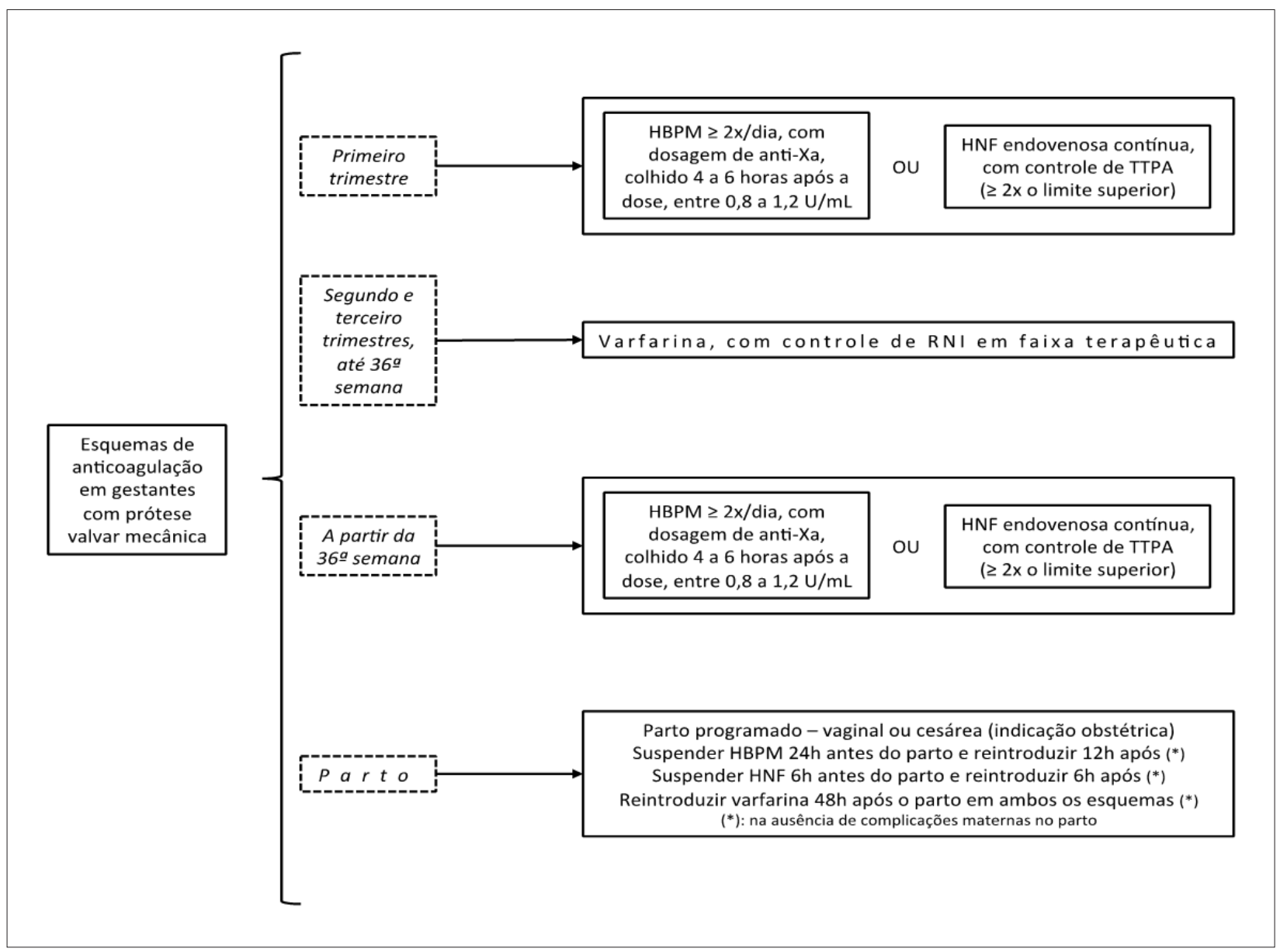

Figura 10.1 - Orientações para manejo da anticoagulação em gestantes portadoras de próteses valvares metálicas. * Na ausência de complicações maternas no parto. HBPM: heparina de baixo peso molecular; HNF: heparina não fracionada; RNI: Razão Normalizada Internacional; TTPa: tempo de tromboplastina parcial ativada. 
população geral, devendo se considerar o potencial tóxico dos antimicrobianos no feto. ${ }^{819}$

Agentes que podem ser usados com segurança em todos os trimestres da gestação são: penicilinas, ampicilina, amoxacilina e cefalosporinas (classe B do FDA). Vancomicina, teicoplanina, imipenem e rifampicina são drogas de classe $\mathrm{C}$, enquanto que aminoglicosídeos e quinolonas são agentes de classe D. Cirurgia valvar durante a gestação reserva-se a casos refratários ao tratamento clínico (Quadro 10.2). ${ }^{820}$

\subsection{Insuficiência Cardíaca}

O aumento do trabalho cardíaco durante a gestação pode precipitar o surgimento de IC com taxa de mortalidade ao redor de 4,8\%, maior taxa de óbito fetal e partos prematuros. ${ }^{810}$ A maioria das descompensações acontercem no final do segundo trimestre ou no período periparto, sobretudo na primeira semana do puerpério. ${ }^{821} \mathrm{O}$ manejo desta condição segue o da população geral, exceto pela observação de que algumas medicações devem ser evitadas - sobretudo IECA, bloqueadores do receptor de angiotensina e antagonistas mineralocorticoides (espironolactona). ${ }^{804}$

Assim, a combinação hidralazina e nitrato é a opção de escolha para vasodilatação oral em gestantes. A vasodilatação intravenosa pode ser realizada com nitroprussiato ou nitroglicerina. ${ }^{822}$ Para aumento do inotropismo, a digoxina é considerada medicação segura e ainda empregada. Se houver necessidade de suporte inotrópico endovenoso, dobutamina, dopamina, milrinone ou levosimendana podem ser utilizados. ${ }^{223}$ Os diuréticos devem ser usados com parcimônia, visto que podem reduzir o fluxo sanguíneo placentário.

\subsection{Cardiomiopatia Periparto}

Cardiomiopatia Periparto (CMP) é a IC que ocorre em gestantes sem cardiopatias prévias, caracterizada por disfunção sistólica do VE no último mês da gestação ou nos 6 meses após o parto, na ausência de outra etiologia. ${ }^{19}$

Trata-se de doença rara, com incidência variável entre 1:300 e 1:4.000 gestações e parece estar relacionada a gemelaridade, desnutrição, hipertensão, pré-eclâmpsia, tabagismo e extremos de idade materna. Sua fisiopatologia é desconhecida, mas acredita-se que esteja relacionada a mecanismos autoimunes, aumento do estresse oxidativo e infecções virais, entres outros. ${ }^{824}$ Cerca de $85 \%$ dos casos ocorrem entre o primeiro e 10 o dia após o parto e têm a chamada "cura" com a normalização da FEVE após 6 meses do início do tratamento otimizado. ${ }^{825}$ Recentemente, temse estudado o bloqueio da prolactina pela bromocriptina (adjuvante), o que encontra racional nas novas teorias fisiopatológicas. ${ }^{826,827}$ A figura 10.2 apresenta sugestão de conduta inicial ao atendimento da CMP.

Assim, recomendações gerais para o tratamento da CMP incluem: 828

- Considerar adicionar bromocriptina ao tratamento da IC ( $2,5 \mathrm{mg}$ via oral, duas vezes ao dia, por 2 semanas, seguidos por 2,5 mg uma vez ao dia, por mais 6 semanas). Salientase que esta medicação é incompatível com a lactação.

\section{Quadro 10.2 - Recomendações para o manejo das valvopatias durante a gestação}

\begin{tabular}{|c|c|c|}
\hline Recomendação & Classe de Recomendação & Nível de Evidência \\
\hline $\begin{array}{l}\text { Em pacientes com estenose mitral sintomática ou com hipertensão pulmonar, deve ser recomendada restrição } \\
\text { de atividade física e terapia com betabloqueadores. Diuréticos são recomendados na persistência dos sintomas }\end{array}$ & I & B \\
\hline $\begin{array}{l}\text { Gestantes com estenose mitral e fibrilação atrial devem receber terapia anticoagulante, exceto na presença de } \\
\text { contraindicações }\end{array}$ & I & C \\
\hline $\begin{array}{l}\text { Em pacientes com estenose mitral com sintomas extremamente limitantes (Classe IV da NYHA) apesar de } \\
\text { terapia medicamentosa otimizada e hipertensão pulmonar com pressão sistólica de artéria pulmonar }>50 \\
\text { mmHg, comissurotomia mitral por cateter balão deve ser considerada, se anatomia valvar favorável. Se } \\
\text { anatomia desfavorável, avaliar tratamento cirúrgico }\end{array}$ & Ila & C \\
\hline $\begin{array}{l}\text { Gestantes portadoras de estenose aórtica grave, associada a sintomas de insuficiência cardíaca refratária } \\
\text { ao manejo clínico, baixo fluxo cerebral ou baixo fluxo coronariano, apresentam indicação de interrupção da } \\
\text { gestação e/ou de tratamento cirúrgico da válvula aórtica, independentemente da idade gestacional }\end{array}$ & I & C \\
\hline $\begin{array}{l}\text { Nos casos descritos no item acima, a valvoplastia aórtica pode ser considerada, sobretudo se alto risco } \\
\text { cirúrgico, embora a morbidade associada ao procedimento seja alta }\end{array}$ & $1 \mathrm{lb}$ & C \\
\hline $\begin{array}{l}\text { Durante a gestação, pacientes com insuficiências valvares que começam a desenvolver sintomas devem ser } \\
\text { manejadas clinicamente }\end{array}$ & I & C \\
\hline $\begin{array}{l}\text { Em pacientes com próteses valvares metálicas, cumarínicos são recomendados no segundo e terceiro } \\
\text { trimestres, com o objetivo de atingir uma RNI terapêutica }\end{array}$ & I & B \\
\hline $\begin{array}{l}\text { A varfarina deve ser descontinuada, e deve ser iniciada HNF intravenosa ou HBPM subcutânea antes de parto } \\
\text { vaginal, programado em gestantes portadoras de próteses valvares metálicas }\end{array}$ & I & C \\
\hline $\begin{array}{l}\text { Pacientes com prótese valvar mecânica devem ter a varfarina suspensa durante no primeiro trimestre, e a } \\
\text { terapia anticoagulante deve ser realizada preferencialmente com HBPM, com ajuste de dose pelo fator anti-Xa. } \\
\text { HNF com ajuste de dose pelo TTPa é outra opção terapêutica possível }\end{array}$ & Ila & B \\
\hline
\end{tabular}

NYHA: New York Heart Association; RNI: Razão Normalizada Internacional; HNF: heparina não fracionada; HBPM: heparina de baixo peso molecular; TTPA: tempo de tromboplastina parcial ativada. 


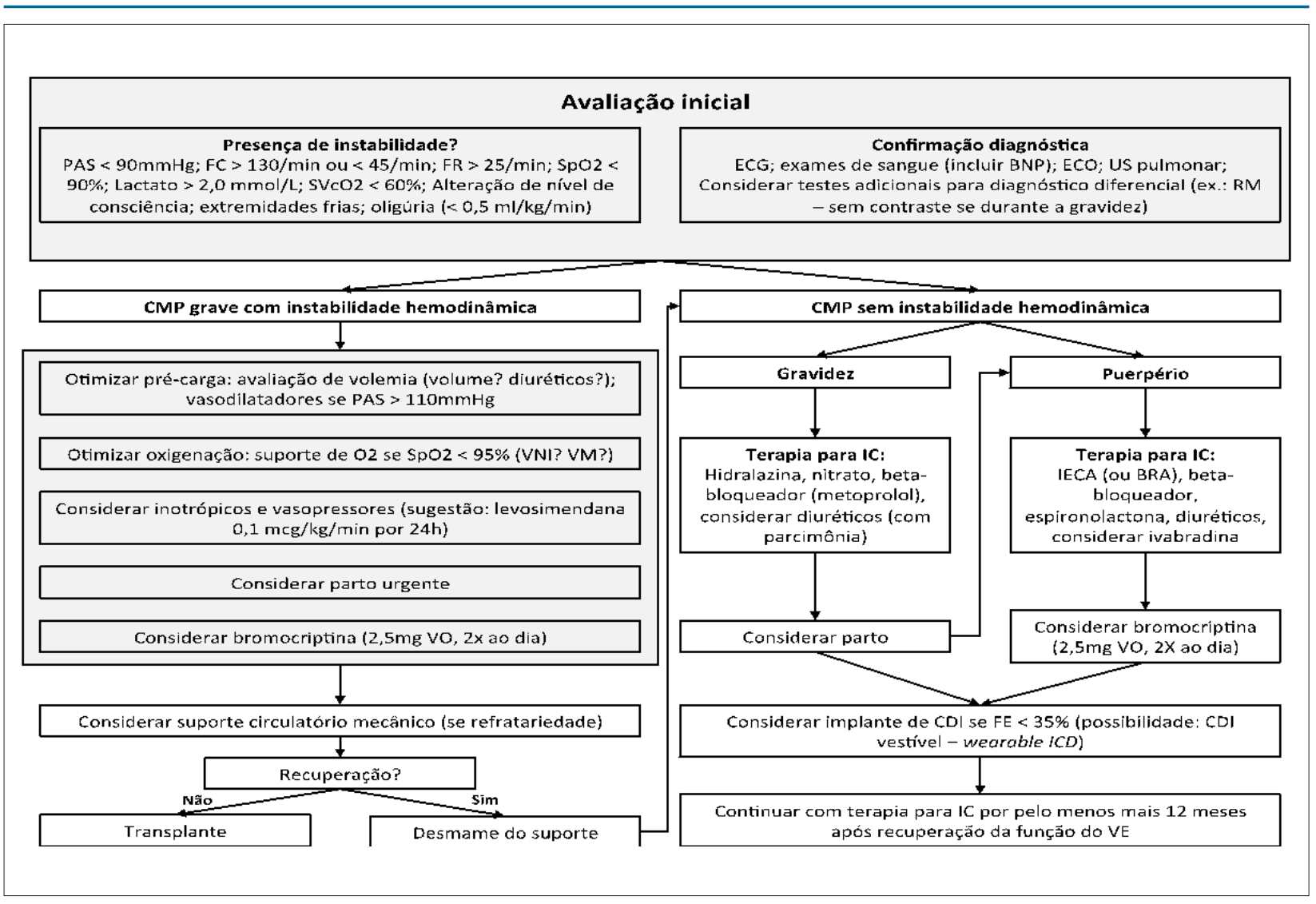

Figura 10.2 -Algoritmo para as condutas iniciais na cardiomiopatia periparto (CMP). PAS: pressão arterial sistólica; FC: frequência cardiaca; FR: frequência respiratória; SpO2: saturação periférica de oxigênio; $\mathrm{SVCO}_{2}$ : saturação venosa central de oxigênio; ECG: eletrocardiograma; ECO: ecocardiograma; US: ultrassonografia; RM: ressonância magnética; PAS: pressão arterial sistólica; VNI: ventilação não invasiva; VM: ventilação mecânica; VO: via oral; IC: insuficiência cardiaca; IECA: inibidor da enzima conversora da angiotensina; BRA: bloqueador do receptor da angiotensiva; CDI: cardiodesfibrilador implantável; VE: ventrículo esquerdo. Fonte: Adaptado de Bauersachs J, 2016. 828

- Prevenção de complicações cardioembólicas com anticoagulação (plena ou ao menos profilática) com heparina se fração de ejeção < 35\% ou em uso de bromocriptina, visto que a medicação possivelmente aumenta o risco de eventos tromboembólicos.

- No caso de choque cardiogênico, considerar levosimendana como inotrópico de primeira linha, além de avaliação de terapia de suporte circulatório mecânico em casos refratários.

- Prevenção de morte súbita cardíaca em pacientes com fração de ejeção < 35\%.

Nos raros casos de CMP que ocorrem durante a gestação, o parto deve ser realizado somente depois da melhora da condição hemodinâmica. A prioridade do tratamento é materna, ou seja, não se indica parto terapêutico com objetivo de salvar a vida do feto, porque as modificações hemodinâmicas podem levar à morte materna.

O diagnóstico diferencial entre a CMP e a cardiomiopatia dilatada é, por vezes, difícil de ser realizado, visto que uma cardiomiopatia dilatada prévia pode originar sintomas pela primeira vez na vida durante a gestação. ${ }^{829}$

\subsection{Edema Agudo de Pulmão na Gestante}

Estima-se que o Edema Agudo de Pulmão (EAP) ocorra em cerca de $0,08 \%$ a $0,5 \%$ das gestações, e aproximadamente metade dos casos foi atribuída ao uso de agentes tocolíticos e a causas cardiogênicas. ${ }^{830}$ Outras são as síndromes hipertensivas, iatrogenia e embolia amniótica (Figura 10.3). ${ }^{831}$

\subsection{Arritmias Cardíacas na Gestação}

Arritmias cardíacas são decorrentes das modificações hemodinâmicas e do sistema nervoso autônomo. ${ }^{804,832}$ Deve se considerar que todos os antiarrítmicos ultrapassam a barreira placentária e podem estar relacionados com efeitos nocivos ao feto. ${ }^{833}$ De maneira geral, lidocaína e sotalol são fármacos da classe B do FDA, enquanto amiodarona e atenolol são classe D. A maioria dos demais antiarrítmicos são da classe $C$, dentre os quais propafenona, propranolol, metoprolol, verapamil, diltiazem, digoxina e adenosina (Figura 10.4).

\subsubsection{Taquiarritmias Supraventriculares}

As manifestações clínicas e eletrocardiográficas dessas arritmias em gestantes são similares às da população geral. ${ }^{834}$ 


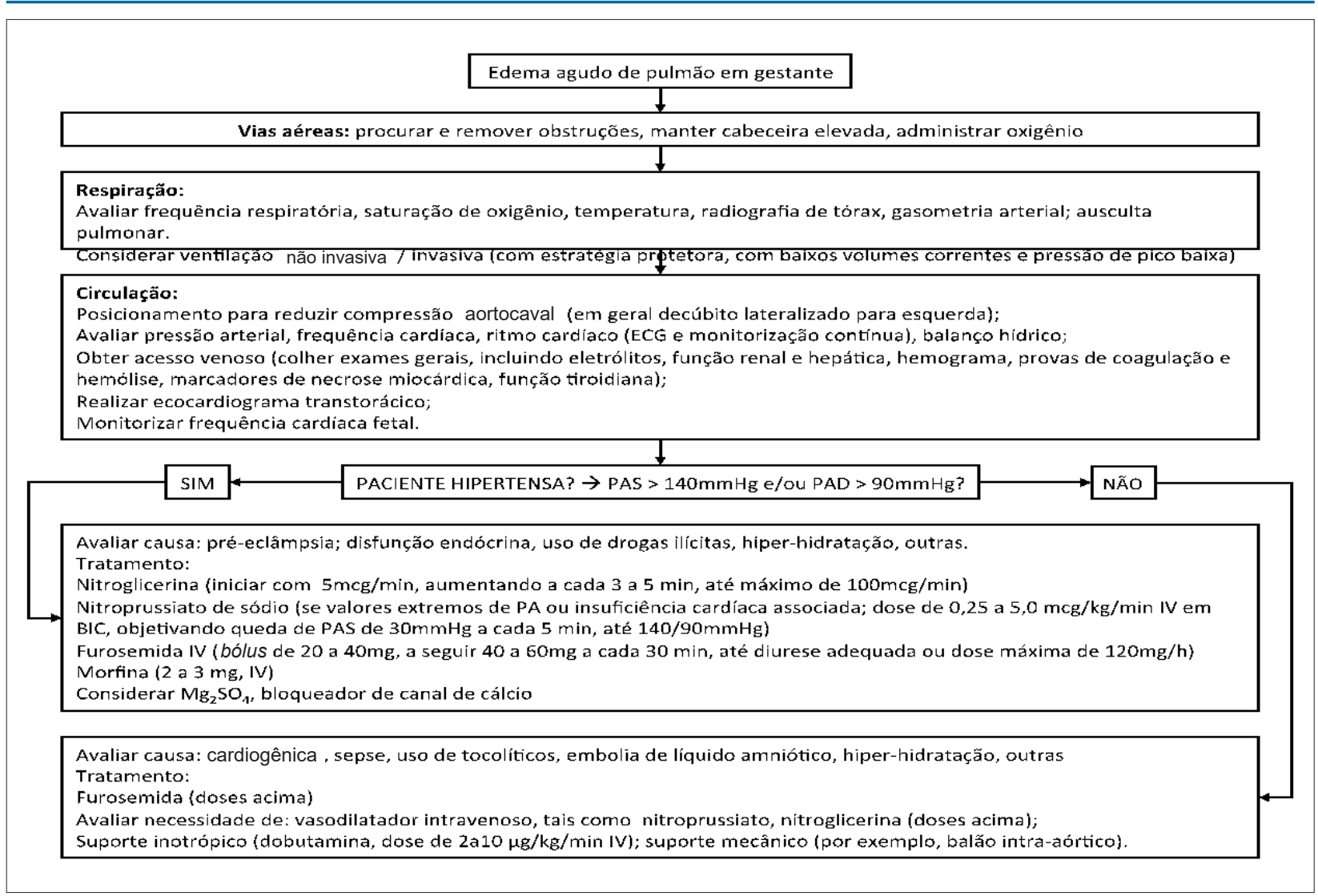

Figura 10.3 - Sugestão de algoritmo para manejo do edema agudo de pulmão em gestantes. ECG: eletrocardiograma; PAS: pressão arterial sistêmica; PAD:pressão arterial diastólica; IV: via intravenosa; BIC: bomba de infusão contínua . Fonte: Adaptado de Dennis AT, 2012. ${ }^{830}$

Importante é descartar a presença de alteração estrutural, alterações tiroidianas e distúrbios hidroeletrolíticos, além de isquemia miocárdica, a depender do contexto clínico. ${ }^{810}$

\section{Arritmias por Reentrada Nodal ou Átrio-Ventricular}

As manobras vagais são o primeiro tratamento, seguido por adenosina endovenosa. Na falha de reversão do ritmo, recomenda-se o controle de FC com metoprolol endovenoso. ${ }^{834}$ As doses recomendadas são as mesmas para a população geral. ${ }^{835}$

\section{Taquicardias Atriais}

Costumam apresentar maior resistência ao tratamento farmacológico, sendo o controle da FC (com betabloqueadores ou digitálicos) muitas vezes necessário, para evitar taquicardiomiopatia. Como auxílio à decisão de se anticoagular, utiliza-se, na gestação, o escore CHADS2. ${ }^{804} \mathrm{Na}$ eventualidade de evoluir com instabilidade hemodinâmica, a CVE sincronizada deve ser realizada, em qualquer estágio da gestação. O procedimento é considerado seguro para o feto, considerando a pequena quantidade de energia que costuma atingi-lo, sendo aconselhável, entretanto, a monitorização do ritmo cardíaco fetal. ${ }^{836} \mathrm{~A}$ anestesia pode ser realizada com propofol (classe B do FDA) ou etomidato (classe C). Sempre que possível, recomenda-se a presença de anestesista. ${ }^{809}$

\subsubsection{Taquiarritmias Ventriculares}

\section{Taquiarritmias Ventriculares}

Em pacientes sem cardiopatias estruturais, a taquiarritmia mais comum é a taquicardia de via de saída do VD. ${ }^{837}$ Em gestantes com cardiopatia estrutural, está associada a pior prognóstico. Quando ela tem episódio inicial nas 6 semanas finais da gravidez ou no começo do puerpério, deve ser investigada presença de CMP. Em situações de comprometimento hemodinâmico, a CVE imediata é o tratamento de escolha. ${ }^{804}$

\section{Taquicardias Ventriculares Sustentadas sem Instabilidade Hemodinâmica}

As condutas possíveis são CVE, uso de antiarrítmicos ou até mesmo overdrive supression com emprego de marca-passo temporário transvenoso (casos selecionados). Recomendase uso de lidocaína endovenosa como primeira opção de tratamento, seguida pela CVE. ${ }^{810}$

A dose de lidocaína é a mesma da população geral. Atenção: pode causar depressão do sistema nervoso central do feto. 


\section{Atualização}

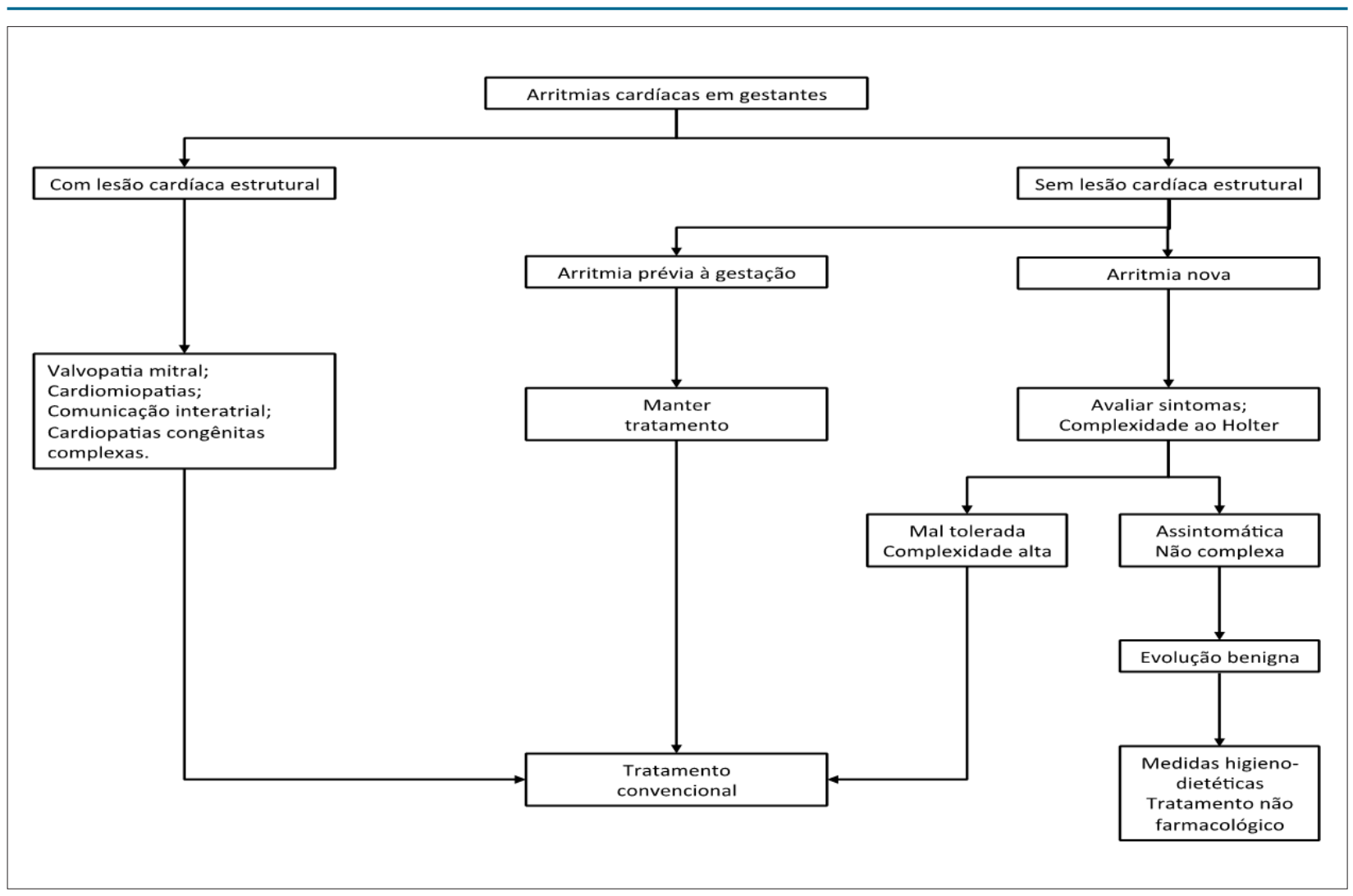

Figura 10.4 - Orientações gerais na avaliação de gestantes com arritmias cardiacas.

Recomenda-se reservar a amiodarona endovenosa apenas para casos refratários ao tratamento inicial. Cuidados: a função tiroidiana materna e a do neonato devem ser monitorizadas.

Betabloqueadores por via oral, como metoprolol e propranolol, podem ser úteis para prevenção secundária.

A indicação de cardiodesfibrilador implantável pode ser feita, preferencialmente por equipe experiente. ${ }^{838}$

Se indicada, a ablação percutânea pode ser realizada e, se possível, a partir do segundo trimestre da gravidez, com medidas de redução de exposição à radiação. ${ }^{804}$

\subsubsection{Bradiarritmias}

Não são comuns na gestação. Quando presentes em portadoras de cardiopatia estrutural, podem apresentar sintomas mais facilmente e ter pior evolução clínica.

Bradicardias sinusais podem ocorrer sobretudo no momento do parto, como efeito vagal da manobra de Valsalva. Em raras situações em que pode se tornar sintomática, orientase posicionar a gestante em decúbito lateral esquerdo. ${ }^{839}$ Bloqueios da condução atrioventricular podem estar presentes em gestantes com cardiopatias congênitas corrigidas cirurgicamente no passado.

Bloqueio de ramo congênito pode eventualmente ser diagnosticado durante a gestação e não está, via de regra, associado a maior risco à gravidez, sobretudo quando apresentar QRS de escape estreito. A via de parto preferencial nesses casos é a vaginal, exceto se contraindicação obstétrica.

O uso de marca-passo temporário transvenoso durante a gestação não é comum. Sua indicação se dá nos casos de bloqueios atrioventricular completo e sintomático. Sua instalação, sempre que possível, recomenda-se que seja guiada por ecocardiografia transtorácica e não por radioscopia. ${ }^{804}$ Em bradicardias sintomáticas, atropina (classe C do FDA) pode eventualmente ser utilizada nas mesmas doses que para a população geral, apesar dos poucos dados disponíveis. Atropina atravessa a barreira placentária, causando taquicardia fetal após cerca de 10 a 15 minutos da administração intravenosa em bólus na mãe e com duração de aproximadamente 60 a 90 minutos (Quadro 10.3). ${ }^{840}$

\subsection{Tromboembolismo Pulmonar}

A partir do segundo trimestre, ocorre o aumento dos fatores de coagulação, da agregação plaquetária, do fibrinogênio e redução da fibrinólise, favorecendo o chamado estado de hipercoagulabilidade materna, além de aumento da estase venosa do plexo uterino e membros inferiores. A incidência de Tromboembolismo Venoso (TEV) em gestantes está estimada em 1 a 2 por 1.000, sendo cerca de cinco vezes maior do que o existente em não grávidas na mesma faixa etária. ${ }^{841}$ Acredita-se que cerca de 43 a $60 \%$ dos episódios de TEP ocorram, na verdade, nas primeiras 
Quadro 10.3 - Recomendações para o manejo emergencial de gestantes coarritmias cardíacas

\begin{tabular}{lcc}
\hline Recomendação & Classe de Recomendação & Nível de Evidência \\
\hline $\begin{array}{l}\text { Para reversão de taquicardias supraventriculares, recomenda-se uso de manobras vagais, seguidas de } \\
\text { administração de adenosina IV, se necessário }\end{array}$ & I & C \\
$\begin{array}{l}\text { Cardioversão elétrica sincronizada é recomendada para o manejo de qualquer taquicardia com } \\
\text { comprometimento hemodinâmico na gravidez }\end{array}$ & I & C \\
Cardioversão elétrica é recomendada para retorno ao ritmo sinusal em taquicardias ventriculares estáveis & I & C \\
$\begin{array}{l}\text { Para controle de ritmo em taquicardias supraventriculares, metoprolol ou propranolol intravenosos podem ser } \\
\text { utilizados }\end{array}$ & Ila \\
$\begin{array}{l}\text { Implante de marca-passo permanente ou CDI pode ser considerado, guiado preferencialmente por } \\
\text { ecocardiografia no primeiro trimestre da gestação }\end{array}$ & Ila \\
$\begin{array}{l}\text { Amiodarona endovenosa pode ser considerada para tratamento de TV sustentada monomórfica com } \\
\text { instabilidade hemodinâmica refratária a tentativa de cardioversão elétrica e sem resposta a outros antiarrítmicos }\end{array}$ & Ila \\
Ablação com cateter pode ser considerada em taquicardias com instabilidade hemodinâmica e refratárias ao & \\
tratamento com drogas & Ilb \\
Atenolol não deve ser utilizado para o controle de nenhuma taquiarritmia & C \\
\hline
\end{tabular}

IV: via intravenosa; $C D I$ : cardiodesfibrilador implantável.

4 a 6 semanas do puerpério, sendo que, até a $12^{\text {a }}$ semana pós-parto, ainda permanece um risco elevado. ${ }^{842}$

Fatores de risco adicionais são TEV prévio, idade maior que 35 anos, obesidade, multiparidade, tabagismo, comorbidades clínicas (câncer, doenças inflamatórias e trombofilias), fatores de risco obstétricos (pré-eclâmpsia, gestação múltipla, cesariana de emergência, trabalho de parto prolongado e hemorragia periparto), além de fatores transitórios, como imobilidade, infecção, ou necessidade de procedimento cirúrgico. ${ }^{804}$

\subsubsection{Diagnóstico}

A clínica de TEP pode ser de difícil reconhecimento, visto que sintomas e sinais de dispneia e taquicardia podem estar presentes na gestação normal. ${ }^{810}$

Radiografia de tórax pode ser útil para excluir outras doenças. ECG pode evidenciar taquicardia sinusal ou sinais de sobrecarga de VD. ${ }^{843}$

Em gestantes com suspeita de TEP, a presença de sinais de TVP de membros inferiores, confirmados com ultrassonografia, é suficiente para se introduzir terapêutica anticoagulante, sem necessidade de prosseguir com investigação diagnóstica. ${ }^{843}$ Quando necessário, recomenda-se que o próximo exame a ser realizado seja a cintilografia pulmonar de ventilação-perfusão, se radiografia de tórax normal. Inicia-se pela fase de perfusão e, sendo esta normal, pode-se cancelar a fase de ventilação, reduzindo a exposição à radiação. Na impossibilidade de ser realizada (ou se com resultado indeterminado), recomenda-se, então, a angiotomografia de artérias pulmonares. ${ }^{810}$

A exposição fetal estimada à radiação é menor na angiotomografia do que na cintilografia, com ambos os valores, entretanto, sendo muito abaixo dos limiares de segurança recomendados. A preferência pela cintilografia se dá pelo maior risco de indução de neoplasia mamária em mulheres expostas à radiação e pela não necessidade de uso de contraste iodado (Figura 10.5). ${ }^{843}$

\subsubsection{Tratamento}

As HBPM têm se tornado a medicação preferencial para tratamento de TEP na gestação e no puerpério. ${ }^{844}$ Em relação à HNF, além das comodidades posológicas e da não necessidade de controle com TTPa, as HBPM apresentam menores taxas de trombocitopenia induzida por heparina ou de osteoporose.

A dosagem recomendada de HBPM é calculada pelo peso da gestante, não sendo claro se a melhor estratégia seria usar o peso pré-gestacional: enoxaparina $1 \mathrm{mg} / \mathrm{kg}$ a cada 12 horas ou 1,5 mg/kg uma vez ao dia; dalteparina $100 \mathrm{ui} / \mathrm{kg}$ a cada 12 horas ou 200 ui/kg uma vez ao dia. A necessidade de monitorização com fator anti-Xa não é clara no tratamento do TEV, exceto em mulheres com extremos de peso ou com doença renal. ${ }^{845}$

A HNF é medicação igualmente segura de ser utilizada, não atravessando a placenta. Seu uso hoje deve ser preferencial, na presença de doença renal e situações nas quais pode ser necessária a rápida suspensão. As doses endovenosas recomendadas são ataque de $80 \mathrm{UI} / \mathrm{kg}$ e manutenção de $18 \mathrm{Ul} / \mathrm{kg} /$ hora, com controle de TTPa inicialmente a cada 6 horas. ${ }^{842}$ Nos momentos que antecedem o parto ou cesariana, as HBPM devem ser substituídas por HNF endovenosa, idelamente 36 horas antes. Cerca de 6 a 4 horas antes, devem ser suspensas e retomadas 6 horas após parto normal e 12 horas após cesariana, na ausência de hemorragias. Antagonistas de vitamina K (mais comumente a varfarina) podem ser iniciados 48 horas após o parto, devendo ser suspensa a HNF endovenosa ou as HBPM quando o $\mathrm{RNI}$ atingir faixa terapêutica entre 2 e 3. Antagonistas de vitamina K, HNF e as HBPM podem ser utilizadas durante a amamentação, conforme necessidade.

Recomenda-se tempo mínimo total de anticoagulação entre 3 a 6 meses, sendo obrigatória sua manutenção durante as seis primeiras semanas do puerpério. Sugere-se não utilizar novos anticoagulantes (fondaprinux, rivaroxabana, dabigatrana, apixabana e edoxabana), inclusive no puerpério, pela ausência de dados clínicos. ${ }^{843}$ 


\section{Atualização}

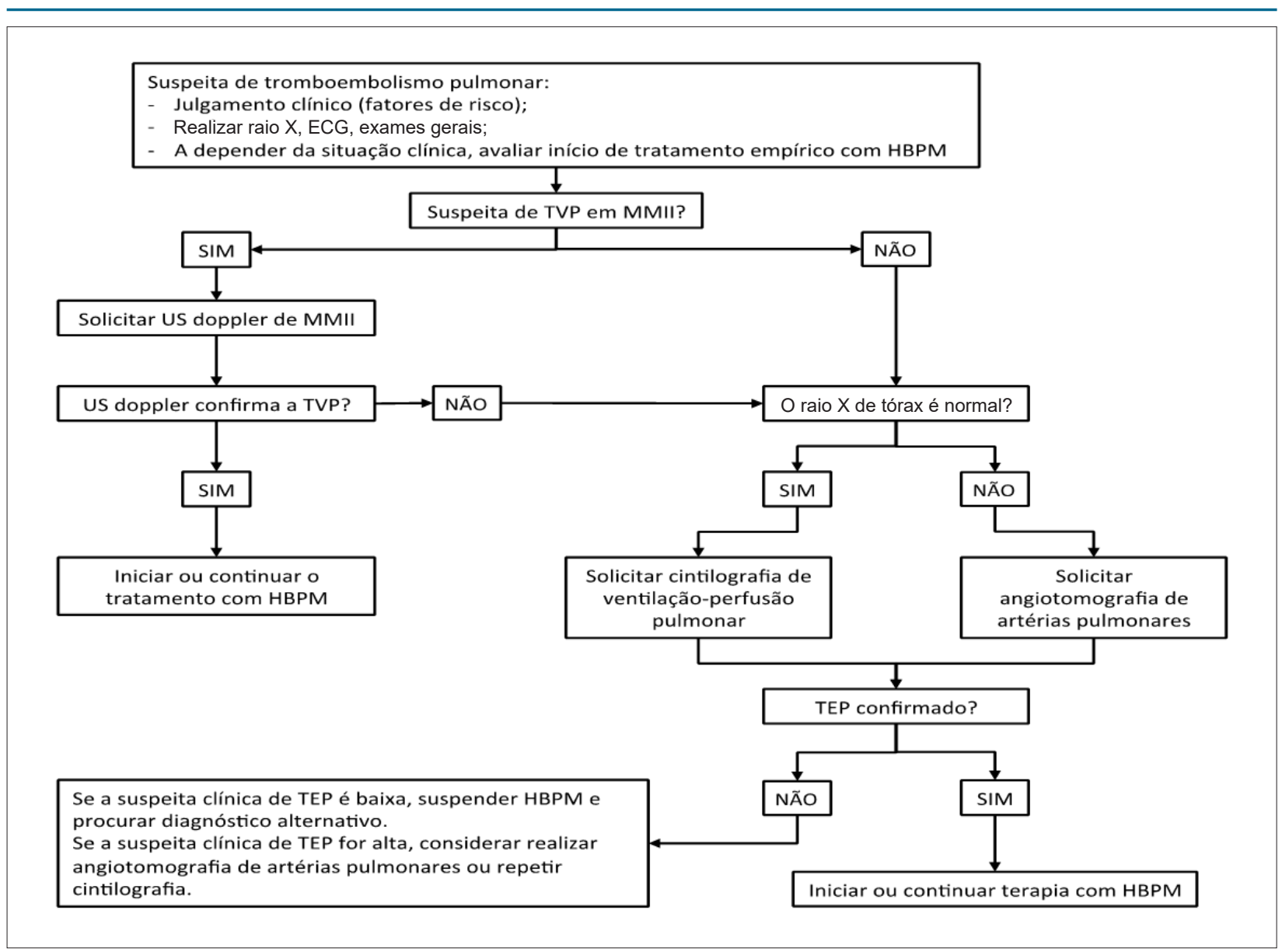

Figura 10.5 - Fluxograma para investigação diagnóstica de tromboembolismo pulmonar (TEP) em gestantes. ECG: eletrocardiograma; TVP: trombose venosa profunda; MMII: membros inferiores; US: ultrassonografia; HBPM: heparina de baixo peso molecular. Fonte: adaptado de Green-top Guideline, $2015{ }^{843}$

A trombólise em gestantes com TEP deve ser realizada na presença de hipotensão grave ou choque secundários. Estratégias mais liberais de trombólise não são previstas durante a gestação. ${ }^{846}$ Taxas de hemorragia são da ordem de $8 \%$ (sobretudo ginecológica), e as taxas de perdas fetais e nascimentos pré-termo giram em torno de $6 \%$ cada. Ao se optar pela trombólise, aconselha-se não administrar a dose de ataque de HNF (Quadro 10.4). ${ }^{804,810}$

\subsection{Cardiopatias Congênitas}

O progresso no diagnóstico e no tratamento contribuiu para um número crescente de pacientes portadoras de cardiopatias congênitas atingisse a idade adulta. ${ }^{847}$ Dentre os fatores de risco, destacam-se o grau de comprometimento cardíaco estrutural, a hipertensão pulmonar, a função ventricular, a cianose e a dessaturação. ${ }^{848,849} \mathrm{Em}$ especial, nas gestantes com hipertensão pulmonar e síndrome de Eisenmenger, o risco de mortalidade materna pode chegar a 50\%, com a maioria dos óbitos ocorrendo no terceiro trimestre ou nos primeiros meses do puerpério, devido a crises de hipertensão pulmonar, TEP ou disfunção de VD refratária. ${ }^{850,851}$ As taxas de sobrevida neonatal variam em torno de 87 a $89 \%$. Assim, recomenda-se que seja oferecida interrupção da gravidez a essas pacientes e, se a opção for por mantê-la, sugere-se que o manejo clínico seja feito em centro terciário e com equipe especializada. ${ }^{804}$

Oxigenoterapia suplementar e prostaciclinas endovenosas (no período periparto) podem ser alguns dos tratamentos oferecidos, além de repouso no leito e profilaxia para TEV (ou anticoagulação plena, se indicada). Deve-se também discutir com a paciente os riscos e os benefícios das terapias, como a bosentana, que pode ter efeito teratogênico. ${ }^{852}$ Monitorização invasiva da pressão de artéria pulmonar em geral não é indicada, devido aos seus riscos potenciais.

A via de parto deve ser individualizada, e de decisão obstétrica, sempre que possível, evitando procedimentos de emergência ou urgência. Recomenda-se um baixo limiar para hospitalização, sendo que, a partir da 20aㅡ semana, em geral, a paciente com síndrome de Eisenmenger deve ser internada até o parto. ${ }^{804,810}$

As complicações maternas são esperadas em $30 \%$, sendo este risco maior quando a saturação periférica de oxigênio ao repouso for menor que $85 \%{ }^{853}$ Para o parto, a preferência é pela via vaginal..$^{804}$ 
Quadro 10.4 - Recomendações para o manejo do tromboembolismo pulmonar (TEP) durante a gestação

\begin{tabular}{|c|c|c|}
\hline Recomendação & Classe de Recomendação & Nível de Evidência \\
\hline $\begin{array}{l}\text { Ultrassom Doppler deve ser realizado em gestantes com suspeita de TEP e que também apresentam sinais de } \\
\text { TPV. Se ultrassom confirmar presença de TVP, não há necessidade de investigação adicional }\end{array}$ & I & C \\
\hline $\begin{array}{l}\text { Em gestantes com alta suspeita ou confirmação diagnóstica de TEP, as heparinas de baixo peso molecular } \\
\text { devem ser iniciadas e são o tratamento de escolha }\end{array}$ & I & B \\
\hline $\begin{array}{l}\text { Em gestantes com TEP agudo, recomenda-se que a anticoagulação seja mantida pelo menos até as } 6 \\
\text { primeiras semanas após o parto, com duração mínima total de } 3 \text { meses }\end{array}$ & Ila & C \\
\hline $\begin{array}{l}\text { Em gestantes com suspeita de TEP, porém sem sinais de TVP, cintilografia pulmonar de ventilação/perfusão ou } \\
\text { angiotomografia de artérias pulmonares devem ser realizadas }\end{array}$ & Ila & C \\
\hline $\begin{array}{l}\text { Na presença de doença pulmonar prévia conhecida ou alterações na radiografia de tórax, a angiotomografia de } \\
\text { artérias pulmonares deve ser o exame de eleição }\end{array}$ & $\| \mathrm{lb}$ & C \\
\hline Dímero D não deve ser solicitado na investigação de TEP na gravidez & $\| \mathrm{lb}$ & C \\
\hline
\end{tabular}

TVP: trombose venosa profunda.

Para paciente com cardiopatia congênita sem diagnóstico prévio ou com seguimento irregular, podem ocorrer descompensações da própria cardiopatia, com necessidade intervenção invasiva ainda durante a gravidez ${ }^{854}$ Se possível, deve-se realizar a intervenção radiológica no segundo semestre, devido ao aumento das dimensões uterinas. Em relação às cirurgias com $\mathrm{CEC}$, há risco elevado de perda fetal. Se o procedimento puder ser adiado até a 28aㅗ semana, deve-se avaliar a possibilidade de indução do parto após a estimulação da maturidade pulmonar fetal. ${ }^{855}$ Outras complicações são: arritmias, descompensação de IC, complicações da anticoagulação, além das complicações obstétricas. ${ }^{854,855}$

\subsection{Hipertensão Arterial}

A doença hipertensiva continua sendo a causa mais importante de morbidade e mortalidade materna e perinatal em todo o mundo, acometendo quase $10 \%$ das gestações. A classificação estabelecida por Hughes, modificada por Kahhale e Zugaib, permite melhor assistência às formas graves da doença hipertensiva na gravidez. ${ }^{856,857} \mathrm{O}$ diagnóstico e tratamento adequados é extremamente importante, já que a mortalidade decorrente da doença hipertensiva representa 20 a $25 \%$ das causas de óbito materno. ${ }^{858}$

\section{Pré-eclâmpsia}

Hipertensão de novo, diagnosticada após a 20ª semana, acompanhada de proteinúria significativa (proteinúria de fita $\geq 1+$, ou proteinúria de 24 horas igual ou superior a 300 $\mathrm{mg}$ ou ainda relação proteína/creatinina em amostra isolada de urina $\geq 0,3-$ ambas medidas em $\mathrm{mg} / \mathrm{dL}$ ). Na ausência de proteinúria, aceita-se o diagnóstico de pré-eclâmpsia na presença dos seguintes sintomas e sinais (previamente inexistentes): trombocitopenia (contagem de plaquetas inferior a $\left.100.000 / \mathrm{mm}^{3}\right)$; alteração da função hepática (transaminases acima do dobro do valor de normalidade); piora da função renal (creatinina $>1,1 \mathrm{mg} / \mathrm{dL}$ ou duas vezes o valor de base); edema pulmonar e sintomas cerebrais ou distúrbios visuais.

\section{Eclâmpsia}

É a fase convulsiva da pré-eclâmpsia, indicativa de maior gravidade, e, frequentemente, precedida de sinais premonitórios (cefaleia, distúrbios visuais e hiperrreflexia).

\section{Hipertensão Arterial Crônica (ou Pré-Existente)}

Hipertensão diagnosticada previamente à gestação ou até a $20^{\mathrm{a}}$ semana.

\section{Hipertensão Arterial Crônica com Pré-Eclâmpsia Superajuntada}

Hipertensão diagnosticada antes da gestação ou até a 20aㅗ semana, na qual se observa proteinúria.

\section{Hipertensão Gestacional}

Hipertensão de novo, diagnosticada após a 20ạ semana, sem proteinúria significativa (e na ausência dos demais sinais e sintomas acima descritos). A pré-eclâmpsia acomete 1,5\% das gestações no Brasil ${ }^{859}$ e não tem etiologia definida.

\section{Síndrome HELLP}

Significa hemólise $(H)$, alteração hepática (EL de elevated liver enzymes) e plaquetopenia (LP de low platelets). ${ }^{860}$ Trata-se de quadro associado à mortalidade e morbidade materna grave. O diagnóstico é fundamentalmente laboratorial, uma vez que as alterações clínicas (icterícia, coagulopatia e rotura hepática) são observadas apenas nos quadros mais dramáticos. ${ }^{861}$

\subsubsection{Tratamento}

O tratamento da hipertensão arterial nos quadros não graves ou não complicados ainda é controverso. Estudos que incluem pequenas séries de casos verificaram que qualquer terapêutica anti-hipertensiva vs. não terapêutica reduziria transitoriamente a hipertensão grave, mas sem diferença nos resultados finais, incluindo a pré-eclâmpsia. Recomenda-se que o tratamento medicamentoso seja iniciado quando a PAS estiver maior que 150 mmHg. ${ }^{862,863}$ 
O objetivo terapêutico é evitar a morbiletalidade materna e perinatal, associada à hipertensão grave com o controle pressórico adequado e não necessariamente com a normalização dos níveis da pressão arterial. Deve-se manter a PAS entre 130 e 150 mmHg e a PAD entre 80 e $100 \mathrm{mmHg} .{ }^{863,864}$

Os medicamentos de uso intravenoso estão reservados para pacientes com níveis pressóricos elevados (PAS > 160 $\mathrm{mmHg}$ e PAD $>110 \mathrm{mmHg}$ ) na presença de sinais e sintomas indicativos de urgências ou emergências hipertensivas (iminência de eclâmpsia, cefaleia, sintomas visuais e epigastralgia) ou congestão pulmonar. ${ }^{856,865,866}$

- Hidralazina por via intravenosa: diluir $20 \mathrm{mg} \mathrm{em} 19 \mathrm{~mL}$ de soro fisiológico e administrar 5 mg a cada 30 minutos até redução de $25 \%$ dos níveis pressóricos (até dose cumulativa de $20 \mathrm{mg})$.

- Nitroprussiato de sódio ou nitroglicerina: estarão indicadas na falha da terapêutica com hidralazina ou na presença de EAP. Evitar reduções bruscas, que possam comprometer o fluxo útero-placentário.

- Nifedipina de ação rápida: é controversa. Usada na dose de 5 a 10 mg em cápsula ou comprimidos de 10 mg (Retard) a cada 30 minutos, com rigorosa monitorização pelo risco de hipotensão arterial acentuada.

- Labetalol: início com 20 mg intravenoso, podendo repetir 20 a 80 mg por via intravenosa a cada 30 minutos ou 1 a $2 \mathrm{mg} /$ minuto até, no máximo, $300 \mathrm{mg}$ e, posteriormente, sendo substituído pela via oral. Esta medicação não está disponível no Brasil.

O sulfato de magnésio está indicado na eclâmpsia, nas pacientes com pré-eclâmpsia grave e sintomas neurológicos (iminência de eclâmpsia) e ainda durante o trabalho de parto (deve ser administrado até 24 horas após convulsão ou parto). ${ }^{856,866} \mathrm{O}$ esquema de Pritchard (intramuscular) tem melhor estabilidade da magnesemia, menor risco de intoxicação, mais segurança no transporte de pacientes e menor necessidade de monitoração dos níveis de magnésio (Tabela 10.1). ${ }^{856,857}$

Dentre os bloqueadores de canal de cálcio, o verapamil (dose de 240 a 320 mg por dia dividida em três tomadas) é considerado um fármaco seguro para a gestante e o concepto. Proporciona redução prolongada da pressão arterial materna, possui efeitos de vasodilatação coronária, melhora a perfusão miocárdica, causa relaxamento ventricular e não tem efeito teratogênicos. ${ }^{867-869}$
Os IECAs e os BRA estão contraindicados, pelo risco de teratogênese e pela interferência com o sistema reninaangiotensina-aldosterona fetal. ${ }^{866-870}$

\section{Conduta Obstétrica}

O tratamento definitivo da Doença Hipertensiva Específica da gestação (DHEG) é o parto, mas, para evitar a alta taxa de mortalidade neonatal associada ao parto prematuro terapêutico, aceita-se a conduta conservadora, até o termo nas pacientes compensadas, sem eclâmpsia, iminência de eclâmpsia ou síndrome HELLP progressiva, quando a vitalidade fetal está preservada. ${ }^{856,866,870}$

Nas formas graves da hipertensão na gravidez, a paciente deve permanecer internada até o termo, com vigilância materno-fetal rigorosas. Nas pacientes com pré-eclâmpsia leve e hipertensão crônica não complicada, objetiva-se chegar até a 40å semana. Já nas pacientes com préeclâmpsia grave ou hipertensão crônica complicada (DHEG superajuntada ou na presença de IC ou renal), o objetivo é a 37aㅗ semana. Em pacientes com síndrome HELLP estáveis, tentamos chegar à 34aㅡ semana e, por fim, nas pacientes com eclâmpsia ou iminência de eclâmpsia, está preconizado o parto a partir da viabilidade fetal. O quadro 10.5 lista as condições que indicam o parto antes destes limites propostos. O emprego de corticoterapia para aceleração da maturidade pulmonar fetal deve ser cauteloso nas pacientes com hipertensão arterial, estando contraindicado naquelas com instabilidade pressórica. ${ }^{857}$

\section{Quadro 10.5 - Indicações maternas e fetais de resolução da} gravidez nas síndrome hipertensivas (conduta sugerida)

\begin{tabular}{cc}
\hline $\begin{array}{c}\text { Impossibilidade do controle da doença materna (apesar de } 3 \\
\text { drogas) } \\
\text { Emergência hipertensiva } \\
\text { Diástole reversa }\end{array}$ \\
Mediata* $\quad$ Alteração do ducto venoso (IP $\geq 1,5)$ \\
PBF $\leq 6$ \\
Desacelerações tardias de repetição \\
Oligoâmnio severo (ILA < 3) \\
Imediata $\quad$ Oligoâmnio (ILA entre 3 e 5)
\end{tabular}

* Permite o uso de corticoterapia para aceleração da maturidade pulmonar fetal. IP: índice de pulsabilidade; PBF: perfil biofísico fetal; ILA: índice de líquido amniótico.

Tabela 10.1 - Esquemas terapêuticos empregados para administração do sulfato de magnésio na prevenção da eclâmpsia

\begin{tabular}{lcc}
\hline & Dose de ataque & Manutenção \\
\hline Pritchard & $M g S O 4(20 \%)-20 \mathrm{~mL}(2 \mathrm{~g})$ IV lento $\mathrm{E}$ & $\mathrm{MgSO} 4(50 \%)-10 \mathrm{~mL}(5 \mathrm{~g}) \mathrm{IM}$ a cada 4 horas \\
Zuspan & $M g S O 4(50 \%)-20 \mathrm{~mL}(10 \mathrm{~g}) \mathrm{IM}$ profundo $(10 \mathrm{~mL}$ em cada nádega) & Infusão contínua IV $-1 \mathrm{~g} / \mathrm{hora}$ \\
Sibai & $4 \mathrm{~g} \mathrm{IV} \mathrm{em} 10$ minutos & Infusão contínua IV $-2-3 \mathrm{~g} /$ hora \\
\hline
\end{tabular}

IV: por via intravenosa; IM: por via intramuscular. Adaptado de Zugaib M, $2016^{856}$ e Zugaib M, 2015. ${ }^{857}$ 


\subsection{Infarto Agudo do Miocárdio}

O IAM durante a gravidez e puerpério é incomum, porém pode ter graves consequências. Estima-se que ocorra em três a dez casos para cada 10 mil gestações, sendo mais frequente no terceiro trimestre. ${ }^{810}$ Os principais fatores de risco são tabagismo, uso de anticoncepcional e idade materna avançada ( $>35$ anos). Fatores de risco adicionais incluem multiparidade, hipertensão ou diabetes gestacional, pré-eclâmpsia e eclâmpsia, estado fisiológico de hipercoagulabilidade, anemia fisiológica e redução da PAD. ${ }^{806,810,871}$ A principal etiologia é aterosclerose coronariana (43\% dos casos), mas também pode estar relacionado à trombofilias (21\%), dissecção espontânea de coronárias (16\%) e, inclusive, coronárias normais (29\%). ${ }^{810,872-875}$

O IAM com coronárias normais ocorre no período periparto e pode ser decorrente de um espasmo coronariano isolado ou associado à formação de trombos, não detectados no momento do exame. Também pode ser espontâneo ou induzido por drogas geralmente usadas por indicação obstétrica (beta-agonistas, ergotamínicos ou bromocriptina), por hipertensão gestacional, disfunção endotelial e liberação de renina pelo útero gravídico. ${ }^{810}$ Não existe explicação bem definida, mas sugere-se que ocorra por alterações estruturais da parede arterial. ${ }^{810,874,876}$

O diagnóstico do IAM baseia-se no quadro de dor torácica, alterações eletrocardiográficas e de marcadores de necrose miocárdica. Deve-se preferir dosagem de troponina I, já que CK-MB pode estar aumentada devido a alterações uterinas. ${ }^{877}$ O exame diagnóstico de escolha é a cineangiocoronariografia, com proteção do abdome, de preferência por artéria radial e com redução do tempo de radioscopia.

\subsubsection{Tratamento}

O tratamento é semelhante ao de não gestantes, devendose levar em conta as possíveis ações de medicamentos sobre o feto, e envolve analgesia, antiplaquetários, anticoagulantes, betabloqueadores, nitratos, fibrinolíticos, angioplastia e revascularização cirúrgica. IECAs e BRAs são contraindicados na gestação, porém liberados no puerpério. Estatinas têm seu uso contraindicado na gestação e na amamentação. Se necessário podem ser usados inotrópicos e BIA. ${ }^{873,875}$

A analgesia deve ser feita com analgésicos potentes, como morfina por via intravenosa, na dose de 1 a $5 \mathrm{mg}$. Nitratos devem ser administrados preferencialmente por via sublingual e, se necessário, por via endovenosa. Mmonitorar a pressão arterial, para se evitar hipotensão. ${ }^{810}$

O AAS deve sempre ser prescrito. A dose inicial é de 200 mg. É seguro tanto para a mãe quanto para o feto. Entre os derivados tienopiridínicos, o clopidogrel parece ser o mais seguro. Deve ser suspenso 5 a 7 dias antes de parto cirúrgico ou anestesia regional. Prasugrel, ticagrelor e os IGPIIbIIla devem ser evitados, pois há poucos dados de segurança. ${ }^{810,875}$

A anticoagulação pode ser feita com HNF (dose de 60 $\mathrm{U} / \mathrm{kg}$ em bólus - máximo de $4.000 \mathrm{U}$, seguida de $12 \mathrm{U} /$ kg/hora - máximo de $1.000 \mathrm{U} /$ hora, com ajuste de dose para manter TTPa em 1,5 a 2,0 vezes o controle basal) ou HBPM (dose de $1 \mathrm{mg} / \mathrm{kg}$, via subcutânea, a cada 12 horas).
A anticoagulação deve ser mantida durante todo o período de internação. ${ }^{810}$

Betabloqueadores devem ser usados na ausência de contraindicação em pacientes estáveis. O mais empregado é o metoprolol. Verapamil ou diltiazem pode ser usados na isquemia refratária ou em pacientes intolerantes a essas medicações. ${ }^{810}$

$\mathrm{Na}$ angioplastia, os stents convencionais são preferíveis aos farmacológicos, pela necessidade de antiagregação plaquetária dupla prolongada nos últimos. ${ }^{874}$

Se existirem instabilidade e indisponibilidade de angiografia coronária, pode-se realizar a trombólise, levando-se em conta o risco aumentado de hemorragia placentária, além de poder haver progressão da dissecção, se este for o caso. ${ }^{875}$ A trombólise pode ser feita com estreptoquinase (1.500.000 U em $100 \mathrm{~mL}$ de soro fisiológico por via intravenosa durante 1 hora) ou rt-PA (15 mg em bólus, seguida de 0,75 mg/kg em 30 minutos e 0,5 mg/kg em 60 minutos, não devendo ultrapassar a dose total de $100 \mathrm{mg}$ em 90 minutos). ${ }^{810}$

No caso de dissecção espontânea de coronárias, a heparina, tratamento de rotina em casos de infarto agudo, deve ser descontinuada. IGPIIbllla e trombolíticos são contraindicados pelo risco de aumento do hematoma intramural. O tratamento pode ser conservador (de escolha), para minimizar riscos, já que a maioria das dissecções se resolvem espontaneamente. ${ }^{878}$ Se indicada pode ser realizada angioplastia e colocação de stent (Quadro 10.6).

Depois do IAM, o parto deve ser após pelo menos 2 semanas, e a escolha da melhor via de parto deve ser individualizada, sendo que a maioria pode tolerar bem a via vaginal. ${ }^{804,810} \mathrm{O}$ risco de morte é maior no terceiro trimestre e durante o trabalho de parto pode haver descompensação, com sintomas de isquemia. ${ }^{873,875,879-881}$

\subsection{Doenças da Aorta}

Em pacientes na idade fértil, as doenças que acometem a aorta torácica de forma mais frequente são síndrome de Marfan, valva aórtica bicúspide, síndromes de Ehlers-Danlos e de Turner, entre outras malformações congênitas, como coarctação de aorta. ${ }^{804}$

Admite-se que, durante a gravidez, ocorram alterações histológicas na aorta, que aumentam a chance de dissecção, principalmente em pacientes com aortopatias prévias, destacando-se maior risco no terceiro trimestre e no pós-parto precoce. ${ }^{804,882}$ A mortalidade materna chega até 20 a 30\% nas primeiras 24 horas, e o prognóstico depende do diagnóstico e do tratamento imediatos. ${ }^{875,882-885}$

A clínica de dor torácica geralmente é subestimada e, com relativa frequência, ocorre hipotensão arterial seguida de choque e PCR. ${ }^{883,884} \mathrm{O}$ diagnóstico é feito pela clínica e confirmado pelo ecocardiograma transtorácico ou transesofágico, ou pela angiotomografia de aorta torácica. O desfecho fetal é pior nos casos de dissecção tipo B. ${ }^{875}$ O tratamento de escolha nos casos de disseção tipo A é cirúrgico, geralmente optando-se por realização de cesárea seguida de correção da aorta ascendente; já na dissecção tipo B, o tratamento pode ser conservador. ${ }^{875,882,885}$ 


\section{Atualização}

\section{Quadro 10.6 - Recomendações para o manejo emergencial de gestantes com doença arterial coronária}

\begin{tabular}{|c|c|c|}
\hline Recomendação & Classe de Recomendação & Nível de Evidência \\
\hline $\begin{array}{l}\text { Eletrocardiograma e dosagem de níveis séricos de troponina devem ser realizados quando houver dor torácica } \\
\text { em pacientes gestantes }\end{array}$ & I & C \\
\hline $\begin{array}{l}\text { Angioplastia coronária é a terapia de reperfusão de escolha em paciente com síndrome coronariana aguda com } \\
\text { supradesnivelamento do segmento ST na gestação }\end{array}$ & 1 & C \\
\hline $\begin{array}{l}\text { O tratamento conservador deve ser considerado em pacientes com síndrome coronariana aguda sem } \\
\text { supradesnivelamento do segmento ST sem critérios de gravidade. }\end{array}$ & Ila & C \\
\hline $\begin{array}{l}\text { Tratamento invasivo deve ser considerado em pacientes com síndrome coronariana aguda sem } \\
\text { supradesnivelamento do segmento ST com critérios de gravidade }\end{array}$ & Ila & C \\
\hline
\end{tabular}

\subsection{Síndrome de Marfan}

As maiores causa de morbidade e mortalidade são as complicações cardiovasculares. ${ }^{885}$ Nos casos de indicação cirúrgica, o procedimento deve ser feito antes da gestação. ${ }^{804,885}$

O aconselhamento genético se faz necessário (risco herança da mutação de 50\%). O seguimento inclui medidas seriadas por ecocardiograma ou, se necessário, RM sem gadolínio. O tratamento inclui betabloqueadores (metoprolol ou propranolol), e o atenolol deve ser evitado, pelo risco de restrição de crescimento intrauterino. ${ }^{885}$

\subsection{Valva Aórtica Bicúspide}

Revisão da literatura mostrou que $6 \%$ das gestantes com dissecção de aorta tinham valva aórtica bicúspide. ${ }^{883,886}$ Todas as gestantes com valva aórtica bicúspide descritas nesta revisão apresentaram alguma complicação cardiovascular (Quadro 10.7). ${ }^{804,886}$

\subsection{Parada Cardiorrespiratória}

As recomendações no quadro 10.8 são baseadas nas condutas para tratamento de PCR propostas pela AHA. ${ }^{875}$

Quadro 10.7 - Recomendações gerais para manejo das doenças da aorta durante a gestação

\begin{tabular}{|c|c|c|}
\hline Recomendação & Classe de Recomendação & Nível de Evidência \\
\hline $\begin{array}{l}\text { Mulheres com síndrome de Marfan ou outras doenças conhecidas da aorta devem ser orientadas quanto ao } \\
\text { risco de dissecção durante a gestação e de ocorrência da doença nos filhos }\end{array}$ & I & C \\
\hline $\begin{array}{l}\text { Exames de imagem (TC ou RM) devem ser realizados antes da gestação em mulheres com síndrome de } \\
\text { Marfan ou outras doenças da aorta }\end{array}$ & I & C \\
\hline $\begin{array}{l}\text { Mulheres com síndrome de Marfan e dilatação da aorta ascendente maior que } 45 \mathrm{~mm} \text { devem ser submetidas a } \\
\text { tratamento cirúrgico antes da gestação }\end{array}$ & 1 & C \\
\hline $\begin{array}{l}\text { Em mulheres gestantes com aneurisma de aorta, história de dissecção tipo B ou predisposição genética para } \\
\text { dissecção devem ser tratadas com controle rígido de pressão arterial }\end{array}$ & 1 & C \\
\hline $\begin{array}{l}\text { Ecocardiogramas seriados a cada } 4 \text { a } 8 \text { semanas devem ser realizados durante a gestação em pacientes com } \\
\text { dilatação de aorta ascendente }\end{array}$ & I & C \\
\hline $\begin{array}{l}\text { RM sem gadolíneo é recomendada para avaliação da aorta ascendente distal, arco aórtico e aorta descendente } \\
\text { em pacientes gestantes com alterações nesses segmentos }\end{array}$ & I & C \\
\hline $\begin{array}{l}\text { Em mulheres com valva aórtica bicúspide, avaliação da aorta ascendente com exame de imagem é } \\
\text { recomendada }\end{array}$ & 1 & C \\
\hline Em mulheres com aorta ascendente $<40 \mathrm{~mm}$, a via de parto vaginal deve ser preferida & I & C \\
\hline $\begin{array}{l}\text { Mulheres com dilatação da aorta ou história de dissecção devem ser submetidas ao parto em centro com } \\
\text { disponibilidade de cirurgia cardiotorácica }\end{array}$ & I & C \\
\hline Em paciente com aorta ascendente $>45 \mathrm{~mm}$, a realização de cesárea deve ser considerada & 1 & C \\
\hline $\begin{array}{l}\text { O tratamento cirúrgico pré-grestacional deve ser considerado em mulheres com valva aórtica bicúspide } \\
\text { associado a diâmetro }>50 \mathrm{~mm} \text { (ou }>27 \mathrm{~mm} / \mathrm{m}^{2} \text { de superfície corpórea) }\end{array}$ & lla & C \\
\hline $\begin{array}{l}\text { Cirurgia profilática deve ser considerada durante a gestação se o diâmetro da aorta for } \geq 50 \mathrm{~mm} \text { e estiver } \\
\text { aumentando rapidamente }\end{array}$ & Ila & $\mathrm{C}$ \\
\hline $\begin{array}{l}\text { Na síndrome de Marfan ou outras pacientes com aorta entre } 40-45 \mathrm{~mm} \text {, a via vaginal com anestesia epidural } \\
\text { deve ser considerada }\end{array}$ & Ila & C \\
\hline Na síndrome de Marfan ou outras pacientes com aorta entre 40-45 mm, cesárea pode ser considerada & $\mathrm{llb}$ & C \\
\hline Pacientes com dissecção tipo B devem ser orientadas a não engravidar & III & C \\
\hline
\end{tabular}

TC: tomografia computadorizada; RM: ressonância magnética. 
A prevalência de PCR varia de 1/20.000 a 1/50.000 gestações. As causas mais comuns encontradas nos Estados Unidos e no Reino Unido são TEP (29\%), hemorragia (17\%), sepse (13\%), CMP (8\%), AVC (5\%), pré-eclâmpsia e eclâmpsia (2,8\%), além de complicações relacionadas a anestesia, embolia de líquido amniótico, IAM, doença cardíaca preexistente e trauma (Quadro 10.8). ${ }^{887}$

As compressões torácicas, as ventilações e a desfibrilação, se indicadas, devem ser realizadas da mesma forma que em não gestantes, com a atenção de se deslocar o útero para a esquerda de forma manual durante todo o período de RCP com a intenção de descomprimir a veia cava e a aorta, e melhorar o fluxo sanguíneo. Toda gestante deve ser considerada como tendo via aérea difícil, e o tubo orotraqueal deve ser de tamanho menor, devido ao edema de glote encontrado nessas pacientes. Se a intubação não for possível, deve-se tentar via aérea com dispositivos supraglóticos.

Se não houver RCE em 4 minutos e o útero estiver na altura da cicatriz umbilical (pelo menos 20 semanas de gestação), deve-se considerar realização de cesárea de emergência.
Essa medida deve ser tomada para diminuir a compressão aortocaval e oferecer maior chance do RCE. A retirada do feto não deve demorar mais que 5 minutos, procedimento que deve ser realizado no local do atendimento, sem interromper as manobras de RCP e a lateralização do útero para a esquerda.

Se o prognóstico materno for grave e os esforços de RCP parecerem fúteis, a realização da cesárea parece apropriada, se o feto for viável. Se a PCR não for presenciada com período prolongado suspeito, deve-se priorizar a retirada do feto.

\subsection{Considerações sobre Exposição à Radiação Durante a Gestação}

Os potenciais efeitos deletérios da radiação ionizante são: perdas gestacionais, malformações, distúrbios de crescimento e desenvolvimento e estímulo à mutagênese e carcinogênese. ${ }^{888}$ A ocorrência desses efeitos depende da idade no momento da exposição e da dose de radiação (Tabela 10.2) ${ }^{804,889}$ Nota-se que os valores estão consideravelmente abaixo desse limiar de segurança de dose

\section{Quadro 10.8 - Recomendações para o manejo de gestantes com parada cardiorrespiratória (PCR)}

\begin{tabular}{|c|c|c|}
\hline Recomendação & Classe de Recomendação & Nível de Evidência \\
\hline $\begin{array}{l}\text { Se houver instabilidade, a gestante deve ser colocada em decúbito lateral esquerdo, para aliviar a compressão } \\
\text { aortocaval }\end{array}$ & I & C \\
\hline $\begin{array}{l}\text { Se houver instabilidade, administração de oxigênio a } 100 \% \text { por máscara facial é recomendada para prevenir } \\
\text { hipoxemia }\end{array}$ & I & C \\
\hline $\begin{array}{l}\text { O acesso intravenoso deve ser obtido acima da linha do diafragma, para garantir que a medicação administrada } \\
\text { não seja impedida de circular pelo útero gravídico }\end{array}$ & I & C \\
\hline Fatores predisponentes devem ser investigados e tratados rapidamente & I & C \\
\hline $\begin{array}{l}\text { Durante o atendimento da PCR, se o útero estiver na linha da cicatriz umbilical ou mais alto, deve ser deslocado } \\
\text { manualmente para a esquerda, continuamente, durante todo o atendimento }\end{array}$ & I & C \\
\hline $\begin{array}{l}\text { As mesmas recomendações em relação aos protocolos de desfibrilação são feitas para gestantes ou não } \\
\text { gestantes. Não há mudança na indicação ou na carga do choque }\end{array}$ & I & C \\
\hline $\begin{array}{l}\text { A ventilação deve ser feita com máscara com reservatório, para oferta de oxigênio a } 100 \% \text {, e é preferível a } \\
\text { ventilação com dois socorristas }\end{array}$ & I & C \\
\hline $\begin{array}{l}\text { Hipoxemia deve sempre ser considerada como causa da PCR, pois as reservas de oxigênio são menores e } \\
\text { as demandas metabólicas maiores nas gestantes, comparadas às não gestantes. Logo, suporte ventilatório } \\
\text { precoce é necessário }\end{array}$ & I & C \\
\hline $\begin{array}{l}\text { Intubação orotraqueal deve ser tentada por médico experiente, com tubo de } 6 \text { a } 7 \mathrm{~mm} \text { de diâmetro, não mais } \\
\text { que duas vezes }\end{array}$ & I & $C$ \\
\hline $\begin{array}{l}\text { Se a intubação não for possível, devem-se seguir os protocolos de via aérea invasiva (chamar ajuda, } \\
\text { providenciar materiais, dispositivos supraglóticos e cricotireoidostomia) }\end{array}$ & I & C \\
\hline Todas as medicações devem ser feitas conforme indicação, independente do risco de teratogenicidade & $\| l b$ & $C$ \\
\hline $\begin{array}{l}\text { Cesárea de emergência deve ser considerada para todas as gestantes que não recuperam a circulação } \\
\text { espontânea em até } 4 \text { minutos de ressuscitação }\end{array}$ & Ila & $C$ \\
\hline $\begin{array}{l}\text { Se a sobrevida materna não for possível (lesão fatal ou PCR prolongada), a cesárea deve se iniciar } \\
\text { imediatamente }\end{array}$ & I & C \\
\hline $\begin{array}{l}\text { A cesárea deve ser realizada no local do atendimento, ou seja, a gestante não deve ser transportada durante o } \\
\text { atendimento da PCR }\end{array}$ & Ila & $B$ \\
\hline $\begin{array}{l}\text { Se houver retorno se circulação espontânea, a paciente deve ser colocada em decúbito lateral esquerdo. Se } \\
\text { não for possível, o deslocamento manual do útero para a esquerda deve ser mantido continuamente }\end{array}$ & I & $C$ \\
\hline $\begin{array}{l}\text { Após retorno da circulação espontânea, os batimentos cardíacos fetais devem ser monitorizados de forma } \\
\text { contínua }\end{array}$ & I & $C$ \\
\hline
\end{tabular}




\section{Atualização}

Tabela 10.2 - Exposição à radiação durante a gestação

\begin{tabular}{|c|c|}
\hline Procedimento & Exposição fetal \\
\hline Radiografia de tórax (posteroanterior e perfil) & $<0,01 \mathrm{mGy}$ \\
\hline Tomografia de tórax & $0,3 \mathrm{mGy}$ \\
\hline Angiografia coronária & $1,5 \mathrm{mGy}$ \\
\hline $\begin{array}{l}\text { Angioplastia ou ablação por cateter com } \\
\text { radiofrequência em estudo eletrofisiológico }\end{array}$ & $3 \mathrm{mGy}$ \\
\hline Cintilografia pulmonar de perfusão com tecnécio-99 & 0,06 a $0,12 \mathrm{mGy}$ \\
\hline Cintilografia pulmonar de ventilação & 0,01 a 0,19 mGy \\
\hline \multicolumn{2}{|c|}{$\begin{array}{l}\text { Dose de radiação fetal estimada para alguns testes diagnósticos } \\
\text { comumente utilizados em Cardiologia. Para os dois últimos, a dose pode } \\
\text { variar, a depender do número de projeções realizadas. Adaptado de } \\
\text { Regitz-Zagrosek V, } 2011 .{ }^{.04}\end{array}$} \\
\hline
\end{tabular}

Nos primeiros 14 dias após a concepção, a exposição à radiação pode tanto ter efeito letal ao embrião quanto não determinar qualquer consequência (efeito "tudo ou nada"). Até a 10ํㅗㄹ semana após a última menstruação, alterações na organogênese e no desenvolvimento podem ocorrer. Após a 20 a 25ํㅗ semana, o feto torna-se mais resistente e, acredita-se, doses muito maiores seriam necessárias para produzir efeitos adversos. ${ }^{890,891}$ Sempre que possível, optar por métodos que não utilizam radiação ionizante. Cintilografia cardíaca deve ser evitada, visto que outros testes sem uso de radiação podem ser realizados. ${ }^{804}$

Cintilografia pulmonar para diagnóstico de TEP pode ser utilizada a depender do contexto clínico. Importante comentar que, ao se realizarem ambas as fases da cintilografia pulmonar, a dose total de radiação fetal é maior do que a dose emitida pela tomografia de pulmão. Durante a lactação, sugere-se descartar a próxima mamada após a exposição. ${ }^{843}$ Finalmente, cabe ressaltar que exames de ecocardiografia e RM (com campo de até 1,5 Tesla e sem gadolíneo) não emitem radiação ionizante e são considerados seguros. ${ }^{804}$

\subsection{Considerações sobre Uso de Meios de Contraste na Gestação}

O contraste iodado, apesar de atravessar a placenta e poder causar alterações transitórias na tiroide do feto, é considerado seguro e pode ser empregado durante a lactação, dadas suas baixas concentrações no leite. ${ }^{891,892}$

O uso de contraste com gadolíneo não deve ser utilizado durante a gestação, devido à escassa informação disponível. Seu uso durante a lactação é considerado seguro. ${ }^{893}$

\subsection{Considerações sobre Procedimentos Invasivos Durante a Gestação}

\subsubsection{Intervenção Coronária Percutânea}

Considerações sobre radiação ionizante e contraste iodado podem ser encontradas nos dois tópicos anteriores. Se a necessidade de realizar ICP durante a gestação for incontornável, o melhor período para fazê-lo é no segundo trimestre, quando a organogênese está completa, a tiroide fetal está inativa, e o útero não está ainda no ápice de seu tamanho. Deve-se usar proteção radiológica fetal, limitar o número de incidência ao mínimo necessário, dar preferência ao acesso radial, e a heparina deve ser administrada em dose de 40 a 70 U/kg, objetivando-se Tempo de Coagulação Ativado (TCA) entre 200 e 300 segundos. $^{804}$

\subsubsection{Valvoplastia Mitral Percutânea por Cateter Balão}

As indicações deste tratamento da estenose mitral são similares às indicações fora da gestação. Comentários sobre uso de radiação ionizante e contraste iodado foram feitos em seções anteriores. Complicações deste procedimento descritas na gestação são arritmias maternas, insuficiência mitral, tamponamento cardíaco, contrações uterinas e sofrimento fetal. Recomenda-se inibição profilática da atividade uterina antes da realização deste procedimento em gestantes. ${ }^{810,894}$

\subsubsection{Outros Procedimentos Intervencionistas Valvares Percutâneos}

Ainda de maneira mais esporádica, pode-se realizar valvoplasita aórtica percutânea, procedimento de efeito transitório, com o principal objetivo de alívio sintomático. Sua realização bem-sucedida durante a gestação já foi descrita anteriormente. ${ }^{895}$ Não há dados suficientes na literatura para embasar o uso de procedimentos, como Implante Percutâneo de Válvula Aórtica (TAVI) ou MitraClip ${ }^{\circledR}$ durante a gravidez. ${ }^{811}$

\subsubsection{Cirurgia Cardíaca com Circulação Extracorpórea}

Cirurgia cardíaca durante a gestação é recomendada apenas na falência de tratamentos clínicos e de outras intervenções percutâneas. A mortalidade materna é similar à da população geral, mas há aumento significativo na morbidade e na mortalidade fetal. O melhor período para realizar a cirurgia é entre a $13^{\underline{a}}$ e $28^{\underline{a}}$ semanas, visto que, no primeiro trimestre, o risco de malformações é maior e, no terceiro trimestre, aumenta-se o risco de trabalho de parto prematuro e complicações maternas. Para gestações acima de 28 semanas, recomenda-se avaliar a possibilidade de término da gestação por cesariana, após indução da maturação pulmonar com corticoterapia, sempre que a situação clínica materna permitir. ${ }^{804,810} \mathrm{O}$ tempo de CEC deve ser o menor possível. ${ }^{844,896}$

\subsubsection{Implante de Marca-Passo e Cardiodesfibrilador Implantável}

Idealmente, mulheres com risco aumentado de morte súbita devem ser avaliadas previamente à gravidez, para implante de CDI. As indicações de implante de ambos os dispositivos são similares à população geral. ${ }^{897-899}$ Assim, devese preferir realizar os implantes após a oitava semana e com proteção radiológica fetal.

\subsubsection{Ablação Percutânea de Arritmias por Radiofrequência}

Deve-se, sempre que possível, preferir utilizar durante o procedimento o ecocardiograma intracavitário e o mapeamento eletroanatômico como medidas de redução de 
exposição à radiação. A indicação mais frequente para ablação foi palpitação recorrente, apesar de terapia antiarrítmica.

\subsection{Cuidados Gerais e Uso de Agentes Farmacológicos na Gestação e no Puerpério}

Esta seção apresenta um sumário dos cuidados gerais (Quadro 10.9) e o uso de diversas medicações de ação cardiovasculares em mulheres durante a gestação e o puerpério.

As principais fontes utilizadas para confecção dos quadros a seguir foram: Micromedex ${ }^{\circledR} 2.0$, (electronic version); ${ }^{900}$ Drugs and Lactation Database (LactMed); ${ }^{901}$ E-lactancia (versão eletrônica) ${ }^{902}$ Para a prescrição de medicações a gestantes, utilizamos a classificação tradicional do FDA, apresentada no quadro 10.10. Desde o final de 2014, o uso desta classificação não está mais sendo estimulado pelo próprio FDA, que agora sugere o uso de uma classificação descritiva dos riscos de cada medicação. ${ }^{900,904}$ Até o momento da publicação dessas diretrizes, entretanto, a classificação tradicional ainda é a mais usada, sobretudo em nosso meio. Em relação às drogas cardiovasculares, nenhuma é considerada da classe A; cerca de $25 \%$ são da classe B; $50 \%$ são da classe $C$ e as demais são das categorias D e X. ${ }^{905}$

Dentre as medicações cardiovasculares de uso mais corriqueiro, as principais contraindicações na gestação são IECAS, bloqueador do receptor da angiotensina, espironolactona, amiodarona, atenolol e, possivelmente, as estatinas. A varfarina também apresenta efeitos teratogênicos no primeiro trimestre e deve ser evitada nesse período. Demais informações no quadro 10.11. ${ }^{905}$

\section{Quadro 10.9 - Recomendações gerais para manejo da gestante cardiopata}

\begin{tabular}{|c|c|c|}
\hline Recomendação ${ }^{804,900,901,902,903}$ & Classe de Recomendação & Nível de Evidência \\
\hline $\begin{array}{l}\text { Pacientes cardiopatas de alto risco, apresentando-se com doença cardíaca aguda, devem ser } \\
\text { preferencialmente conduzidas em centro terciário por equipe multidisciplinar com experiência no manejo dessas } \\
\text { pacientes }\end{array}$ & 1 & C \\
\hline $\begin{array}{l}\text { Ecocardiograma deve ser realizado em toda gestante que apresente sintoma cardiovascular novo ou sem } \\
\text { explicação conhecida }\end{array}$ & I & C \\
\hline Parto vaginal é a via de parto preferencial para a maioria das gestantes cardiopatas & I & C \\
\hline $\begin{array}{l}\text { Ressonância magnética cardíaca, sem gadolíneo, pode ser considerada durante a gravidez se o } \\
\text { ecocardiograma for insuficiente para fornecer o diagnóstico da condição cardiológica }\end{array}$ & Ila & C \\
\hline $\begin{array}{l}\text { Parto cesárea deve ser considerado quando houver indicação obstétrica ou para pacientes com dilatação da } \\
\text { aorta ascendente }>45 \mathrm{~mm} \text {, estenose aórtica grave, parto prematuro em vigência de terapia anticoagulante, } \\
\text { síndrome de Eisenmenger ou insuficiência cardíaca grave }\end{array}$ & Ila & C \\
\hline $\begin{array}{l}\text { Radiografia de tórax, com proteção fetal, deve ser considerada quando outros métodos não são suficientes } \\
\text { para elucidação diagnóstica }\end{array}$ & $\mathrm{Ilb}$ & C \\
\hline $\begin{array}{l}\text { Intervenção coronariana percutânea na gestação pode ser considerada em casos muito específicos, sempre } \\
\text { com proteção fetal }\end{array}$ & $\mathrm{Ilb}$ & C \\
\hline $\begin{array}{l}\text { Em pacientes selecionados, com doenças ameaçadoras à vida, a realização de tomografia computadorizada e } \\
\text { de estudo eletrofisiológico (ambos com proteção fetal) podem ser considerados }\end{array}$ & $\mathrm{Ilb}$ & C \\
\hline $\begin{array}{l}\text { Cirurgia de revascularização miocárdica ou cirurgia valvar cardíaca podem ser consideradas em situação de } \\
\text { risco materno extremo (pela cardiopatia) ou quando o tratamento médico otimizado não for capaz de oferecer } \\
\text { bom controle sintomático, desde que procedimentos percutâneos não sejam adequados }\end{array}$ & $\mathrm{Ilb}$ & C \\
\hline
\end{tabular}

Quadro 10.10 - Classificação geral de risco para o feto imposto por medicações, segundo o Food and Drug Administration

\begin{tabular}{|c|c|}
\hline Classe & Descrição \\
\hline A & $\begin{array}{l}\text { Estudos controlados em mulheres não demonstram risco para o feto no primeiro trimestre, sem evidência de risco nos demais trimestres, e a possibilidade de } \\
\text { perigo ao feto parece remota }\end{array}$ \\
\hline B & $\begin{array}{l}\text { Estudos em animais não demonstraram risco fetal, e não existem estudos controlados em mulheres OU estudos em animais demonstraram efeitos adversos, } \\
\text { que não foram confirmados em estudos controlados em mulheres no primeiro trimestre, sem evidência de risco nos demais trimestres. }\end{array}$ \\
\hline$C$ & $\begin{array}{l}\text { Estudos em animais revelaram risco fetal (teratogênese e morte embrionária), e não há estudos adequados em mulheres OU não há estudos controlados em } \\
\text { mulheres nem em animais. A droga deve ser administrada quando o risco potencial justifica o benefício potencial }\end{array}$ \\
\hline D & $\begin{array}{l}\text { Há evidências positivas de risco em fetos humanos, mas os benefícios de uso em mulheres grávidas podem superar os riscos (por exemplo, em situações } \\
\text { ameaçadoras à vida, sem outras alternativas terapêuticas eficazes mais seguras) }\end{array}$ \\
\hline 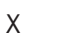 & Estudos em animais e humanos demonstraram anormalidades fetais, sendo a droga contraindicada em mulheres que estão ou querem se tornar gestantes \\
\hline
\end{tabular}

Fonte: Adaptado de Micromedex, $2016^{900}$ e Tedoldi CL, 2009. ${ }^{810}$ 


\section{Atualização}

Quadro 10.11 - Recomendações para o uso de diversas medicações ao longo da gravidez e puerpério

\begin{tabular}{|c|c|c|c|c|c|c|}
\hline Droga & Classe & FDA & $\begin{array}{l}\text { Permeabilidade } \\
\text { placentária }\end{array}$ & Presente no leite & $\begin{array}{l}\text { Risco potencial } \\
\text { para o lactente* }\end{array}$ & Comentários \\
\hline AAS em dose baixa & Antiplaquetário & B & Sim & Sim & Risco baixo & $\begin{array}{l}\text { Sem efeitos teratogênicos } \\
\text { conhecidos }\end{array}$ \\
\hline Abciximabe & $\begin{array}{l}\text { Anticorpo } \\
\text { monoclonal com } \\
\text { ação antiplaquetária/ } \\
\text { antitrombótica }\end{array}$ & C & Desconhecido & Desconhecido & Risco baixo & $\begin{array}{l}\text { Poucos estudos em gravidez ou } \\
\text { lactação }\end{array}$ \\
\hline Adenosina & Antiarrítmico & C & Não & Não & Risco muito baixo & $\begin{array}{c}\text { Sem efeitos adversos fetais } \\
\text { conhecidos; poucas informações } \\
\text { na lactação }\end{array}$ \\
\hline Adrenalina & Vasopressor & C & Sim & Desconhecido & Risco muito baixo & $\begin{array}{c}\text { Utilizada em emergências apenas } \\
\text { (anafilaxia e PCR). Poucos dados } \\
\text { disponíveis }\end{array}$ \\
\hline Alteplase & Fibrinolítico & C & Desconhecido & Desconhecido & Risco muito baixo & $\begin{array}{c}\text { Poucos dados na gravidez estão } \\
\text { disponíveis }\end{array}$ \\
\hline Amicacina & $\begin{array}{l}\text { Antimicrobiano } \\
\text { (aminoglicosídeo) }\end{array}$ & D & Sim & Sim & Risco muito baixo & $\begin{array}{c}\text { Fabricante recomenda não } \\
\text { prescrever na lactação e gestação }\end{array}$ \\
\hline Amiodarona & $\begin{array}{l}\text { Antiarrítmico (classe } \\
\text { III) }\end{array}$ & D & Sim & Sim & Risco alto & $\begin{array}{c}\text { Pode causar bradicardia fetal/ } \\
\text { neonatal, hipo ou hipertiroidismo } \\
\text { neonatal, retardo de crescimento, } \\
\text { parto prematuro. }\end{array}$ \\
\hline Ampicilina & $\begin{array}{l}\text { Antimicrobiano } \\
\text { (betalactâmico) }\end{array}$ & B & Sim & Sim & Risco muito baixo & \\
\hline Anfotericina B & Antifúngico & B & Sim & Desconhecido & Risco baixo & \\
\hline Anlodipino & $\begin{array}{l}\text { Bloqueador de canal } \\
\text { de cálcio }\end{array}$ & C & Desconhecido & Sim & Risco baixo & $\begin{array}{l}\text { Poucos dados disponíveis. } \\
\text { Dar preferência a outros anti- } \\
\text { hipertensivos, tanto na gestação } \\
\text { quanto na lactação. }\end{array}$ \\
\hline Atenolol & Betabloqueador & $D$ & $\operatorname{Sim}$ & $\operatorname{Sim}$ & Risco alto & $\begin{array}{l}\text { Alguns efeitos adversos relatados } \\
\text { são: hipospádia, bradicardia fetal, } \\
\text { hipoglicemia fetal e baixo peso ao } \\
\text { nascer. }\end{array}$ \\
\hline Atropina & Anticolinérgico & C & Sim & Sim & Risco muito baixo & $\begin{array}{c}\text { Atropina pode reduzir o volume de } \\
\text { leite materno }\end{array}$ \\
\hline Bisoprolol & Betabloqueador & C & Sim & Desconhecido & Risco baixo & $\begin{array}{l}\text { Preferir outras opções de } \\
\text { betabloqueadores, tanto na } \\
\text { gravidez quanto na lactação }\end{array}$ \\
\hline Bosentana & $\begin{array}{l}\text { Antagonista } \\
\text { do receptor de } \\
\text { endotelina }\end{array}$ & $x$ & Sim & Desconhecido & Risco baixo & $\begin{array}{l}\text { Contraindicado na gestação; } \\
\text { recomenda-se evitar na lactação }\end{array}$ \\
\hline Candesartana & BRA & D & Desconhecido & Desconhecido & Risco baixo & $\begin{array}{l}\text { Contraindicado na gestação; } \\
\text { recomenda-se evitar na lactação }\end{array}$ \\
\hline Captopril & IECA & D & Sim & Sim & Risco muito baixo & $\begin{array}{c}\text { Contraindicado na gestação; } \\
\text { aceitável na lactação, com atenção } \\
\text { ao ganho de peso da criança no } \\
\text { primeiro mês }\end{array}$ \\
\hline Carvedilol & Betabloqueador & C & Desconhecido & Desconhecido & Risco baixo & $\begin{array}{l}\text { Preferir outros agentes tanto na } \\
\text { gestação quanto na lactação } \\
\text { (poucos dados) }\end{array}$ \\
\hline Cedilanide & Glicosídeo cardíaco & C & Sim & Sim & Risco muito baixo & $\begin{array}{l}\text { Recomenda-se aguardar } 2 \text { horas } \\
\text { para retomar amamentação após } \\
\text { dose materna de digitálico IV }\end{array}$ \\
\hline Ceftriaxona & $\begin{array}{l}\text { Antimicrobiano } \\
\text { (cefalosporina) }\end{array}$ & B & Sim & Sim & Risco muito baixo & \\
\hline Clindamicina & Antimicrobiano & $B$ & $\operatorname{Sim}$ & $\operatorname{Sim}$ & Risco baixo & $\begin{array}{l}\text { Fabricante não recomenda } \\
\text { amamentação; pode resultar em } \\
\text { colite em lactentes }\end{array}$ \\
\hline
\end{tabular}




\begin{tabular}{|c|c|c|c|c|c|c|}
\hline Clonidina & $\begin{array}{l}\text { Anti-hipertensivo } \\
\text { (agonista alfa-2 } \\
\text { central) }\end{array}$ & C & Sim & Sim & Risco baixo & $\begin{array}{l}\text { Preferir outros agentes anti- } \\
\text { hipertensivos durante gestação ou } \\
\text { lactação (pode inibir prolactina). }\end{array}$ \\
\hline Clopidogrel & Antiplaquetário & B & Desconhecido & Desconhecido & Risco alto & $\begin{array}{l}\text { Sem informações na gravidez ou } \\
\text { lactação }\end{array}$ \\
\hline Clortalidona & Diurético tiazídico & B & Sim & Sim & Risco muito alto & $\begin{array}{c}\text { Pode causar icterícia neonatal e } \\
\text { trombocitopenia quando usados } \\
\text { durante a gravidez. Evitar na } \\
\text { lactação }\end{array}$ \\
\hline Colestiramina & Antilipemiante & C & Desconhecido & Desconhecido & Risco muito baixo & $\begin{array}{c}\text { Apesar de poucos dados, trata-se } \\
\text { de medicação não absorvida pelo } \\
\text { organismo materno }\end{array}$ \\
\hline Dalteparina & $\begin{array}{l}\text { Anticoagulante } \\
\text { (heparina de baixo } \\
\text { peso molecular) }\end{array}$ & B & Não & Sim & Risco muito baixo & \\
\hline Digoxina & Glicosídeo cardíaco & C & Sim & $\operatorname{Sim}$ & Risco muito baixo & \\
\hline Diltiazem & $\begin{array}{l}\text { Bloqueador de canal } \\
\text { de cálcio }\end{array}$ & C & Não & $\operatorname{Sim}$ & Risco muito baixo & $\begin{array}{l}\text { Avaliar riscos e benefícios durante } \\
\text { a gestação e, se possível, optar por } \\
\text { outros anti-hipertensivos }\end{array}$ \\
\hline $\begin{array}{l}\text { Dinitrato de } \\
\text { isossorbida }\end{array}$ & Nitrato & C & Desconhecido & Desconhecido & Risco baixo & Pode causar bradicardia fetal \\
\hline Dobutamina & $\begin{array}{l}\text { Inotrópico } \\
\text { intravenoso }\end{array}$ & B & Desconhecido & Desconhecido & Risco muito baixo & $\begin{array}{c}\text { Não usar como agente diagnóstico } \\
\text { (teste de estresse), apenas para } \\
\text { terapêutica }\end{array}$ \\
\hline Dopamina & $\begin{array}{l}\text { Agonista } \\
\text { dopaminérgico } \\
\text { intravenoso }\end{array}$ & c & Deconhecido & Desconhecido & Risco baixo & Pode inibir lactação \\
\hline Enalapril & IECA & $\mathrm{D}$ & Sim & Sim & Risco muito baixo & \\
\hline Enoxaparina & Anticoagulante & B & Não & Sim & Risco muito baixo & $\begin{array}{l}\text { Uso por longo tempo está } \\
\text { relacionado com menos } \\
\text { osteoporose e plaquetopenia do } \\
\text { que heparina não fracionada }\end{array}$ \\
\hline Esmolol & Betabloqueador & C & Sim & Desconhecido & Risco baixo & $\begin{array}{l}\text { Poucos dados disponíveis. } \\
\text { Pode causar bradicardia fetal; } \\
\text { não deve ser primeira escolha } \\
\text { para tratamento de taquicardias } \\
\text { supraventriculares em gestantes }\end{array}$ \\
\hline Espironolactona & $\begin{array}{l}\text { Antagonista da } \\
\text { aldosterona }\end{array}$ & D & $\operatorname{Sim}$ & Sim & Risco muito baixo & $\begin{array}{l}\text { Pode estar relacionado a efeitos } \\
\text { anti-androgênicos e fenda palatina }\end{array}$ \\
\hline Estatinas & Antilipemiantes & $x$ & Sim & Desconhecido & Risco alto & $\begin{array}{l}\text { Recomenda-se evitar tanto na } \\
\text { gravidez quanto na lactação }\end{array}$ \\
\hline Estreptoquinase & Fibrinolítico & c & Desconhecido & Desconhecido & Risco muito baixo & $\begin{array}{c}\text { Poucos dados na gravidez estão } \\
\text { disponíveis. }\end{array}$ \\
\hline Etomidato & Sedativo & c & Desconhecido & $\operatorname{Sim}$ & $?$ & $\begin{array}{l}\text { Uso não recomendado em trabalho } \\
\text { de parto (poucos dados disponíveis) }\end{array}$ \\
\hline Ezetimibe & Antilipemiante & C & Desconhecido & Desconhecido & Risco baixo & $\begin{array}{l}\text { Uso contraindicado durante a } \\
\text { gestação e sem evidência suficiente } \\
\text { para uso durante lactação }\end{array}$ \\
\hline Fenobibrato & Antilipemiante & C & Sim & Sim & $?$ & $\begin{array}{l}\text { Poucos dados na gestação e } \\
\text { lactação. }\end{array}$ \\
\hline Fentanil endovenoso & Analgésico & C & Sim & Sim & Risco muito baixo & $\begin{array}{l}\text { Se uso crônico durante a gestação: } \\
\text { atentar para síndrome de } \\
\text { abstinência do recém-nascido. }\end{array}$ \\
\hline Fluconazol & Antifúngico & D & Desconhecido & Sim & Risco muito baixo & $\begin{array}{l}\text { Poucos dados na gravidez e } \\
\text { lactação para uso intravenoso. } \\
\text { Teratogenicidade em animais }\end{array}$ \\
\hline Fondaparinux & Anticoagulante & B & Sim & Não & Risco muito baixo & $\begin{array}{l}\text { Poucos dados na gestação e } \\
\text { lactação }\end{array}$ \\
\hline
\end{tabular}




\begin{tabular}{|c|c|c|c|c|c|c|}
\hline Furosemida & Diurético de alça & C & Sim & Desconhecido & Risco baixo & $\begin{array}{l}\text { Monitorizar peso fetal. Pode reduzir } \\
\text { produção de leite }\end{array}$ \\
\hline Gentamicina & $\begin{array}{l}\text { Antimicrobiano } \\
\text { (amionoglicosídeo) }\end{array}$ & D & Sim & Sim & Risco muito baixo & $\begin{array}{c}\text { Possibilidade de surdez irreversível } \\
\text { bilateral em recém-nascidos } \\
\text { se usado na gestação (efeito } \\
\text { observado com estreptomicina) }\end{array}$ \\
\hline $\begin{array}{l}\text { Heparina não } \\
\text { fracionada }\end{array}$ & Anticoagulante & C & Não & Não & Risco muito baixo & $\begin{array}{c}\text { Uso em longo prazo apresenta risco } \\
\text { maior de desenvolver osteoporose } \\
\text { e plaquetopenia em relação à } \\
\text { HBPM. Utilizar formulações sem } \\
\text { álcool benzílico durante gestação } \\
\text { e puerpério }\end{array}$ \\
\hline Hidralazina & Vasodilatador & C & Sim & Sim & Risco muito baixo & $\begin{array}{l}\text { Pode causar sintomas lúpus-like } \\
\text { na mãe e taquicardia fetal (se uso } \\
\text { materno) }\end{array}$ \\
\hline Hidroclorotiazida & Diurético & B & Sim & Sim & Risco muito baixo & Pode causar oligodrâmnio \\
\hline Imepenem & $\begin{array}{l}\text { Antimicrobiano } \\
\text { (carbapenêmico) }\end{array}$ & C & Sim & Sim & Risco muito baixo & \\
\hline Inibidores da PCSK-9 & Antilipemiantes & D & Desconhecido & Desconhecido & ? & Ainda não há estudos em gestantes \\
\hline Ivabradina & $\begin{array}{l}\text { Diminui a FC por } \\
\text { atuação no nó } \\
\text { sinoatrial }\end{array}$ & C & Desconhecido & Desconhecido & Risco alto & Recomenda-se não amamentar \\
\hline Levosimendan & Inotrópico & C & Desconhecido & Desconhecido & Risco baixo & Poucos estudos em gestantes \\
\hline Lidocaína & $\begin{array}{l}\text { Antiarrítmico (classe } \\
\text { lb) }\end{array}$ & B & Sim & Sim & Risco muito baixo & $\begin{array}{l}\text { Pode causar bradicardia fetal, } \\
\text { acidose e toxicidade de SNC }\end{array}$ \\
\hline Lisinopril & IECA & $\mathrm{D}$ & Sim & Desconhecido & Risco baixo & Contraindicado \\
\hline Losartana & BRA & $\mathrm{D}$ & Sim & Desconhecido & Risco baixo & Contraindicada \\
\hline Meropenem & $\begin{array}{l}\text { Antimicrobiano } \\
\text { (carbapenêmico) }\end{array}$ & B & Sim & Sim & Risco muito baixo & Medicação segura \\
\hline Metildopa & $\begin{array}{c}\text { Agonista } \\
\text { alfadrenérgico de } \\
\text { ação central }\end{array}$ & B & Sim & Sim & Risco muito baixo & Seguro para uso em longo prazo \\
\hline Metoprolol & $\begin{array}{l}\text { Betabloqueador } \\
\text { (classe II) }\end{array}$ & C & Sim & Sim & Risco muito baixo & $\begin{array}{l}\text { Pode causar bradicardia e } \\
\text { hipoglicemia no feto }\end{array}$ \\
\hline Midazolan & Sedativo & D & Sim & Sim & Risco muito baixo & $\begin{array}{l}\text { Relacionado a prematuridade e ao } \\
\text { baixo peso ao nascer }\end{array}$ \\
\hline Milrinone & $\begin{array}{l}\text { Inotrópico (inibidor da } \\
\text { fosfodiesterase) }\end{array}$ & C & Desconhecido & Desconhecido & Risco baixo & Poucos estudos em gestantes \\
\hline $\begin{array}{l}\text { Mononitrato de } \\
\text { isossorbida }\end{array}$ & Nitrato & B & Desconhecido & Desconhecido & Risco baixo & $\begin{array}{l}\text { Usado como vasodilatador } \\
\text { associado à hidralazina para } \\
\text { tratamento de IC em gestantes; } \\
\text { não recomendado uso como anti- } \\
\text { hipertensivo }\end{array}$ \\
\hline Nebivolol & Betabloqueador & c & Desconhecido & Desconhecido & Risco alto & $\begin{array}{l}\text { Pode causar bradicardia e } \\
\text { hipoglicemia }\end{array}$ \\
\hline Nifedipina & $\begin{array}{l}\text { Bloqueador de canal } \\
\text { de cálcio }\end{array}$ & C & Sim & Sim & Risco muito baixo & $\begin{array}{c}\text { Somente deve ser usada a de ação } \\
\text { prolongada }\end{array}$ \\
\hline Nitroglicerina & Vasodilatador & $\mathrm{B} / \mathrm{C}$ & Sim & Desconhecido & Risco muito baixo & Indicada no edema pulmonar \\
\hline Nitroprussiato & Vasodilatador & c & Sim & Desconhecido & Alto risco & $\begin{array}{l}\text { Deve-se atentar para intoxicação } \\
\text { por cianeto (materna e fetal) }\end{array}$ \\
\hline Noradrenalina & Vasopressor & C & Sim & Desconhecido & Risco muito baixo & \\
\hline Olmesartana & BRA & D & Desconhecido & Desconhecido & Risco baixo & Contraindicada \\
\hline Oxacilina & $\begin{array}{l}\text { Antimicrobiano } \\
\text { (betalactâmico) }\end{array}$ & B & Sim & Sim & ? & \\
\hline Penicilina G & $\begin{array}{l}\text { Antimicrobiano } \\
\text { (betalactâmico) }\end{array}$ & B & Sim & Sim & Risco muito baixo & $\begin{array}{l}\text { Droga de escolha em algumas } \\
\text { infecções na gestação }\end{array}$ \\
\hline
\end{tabular}




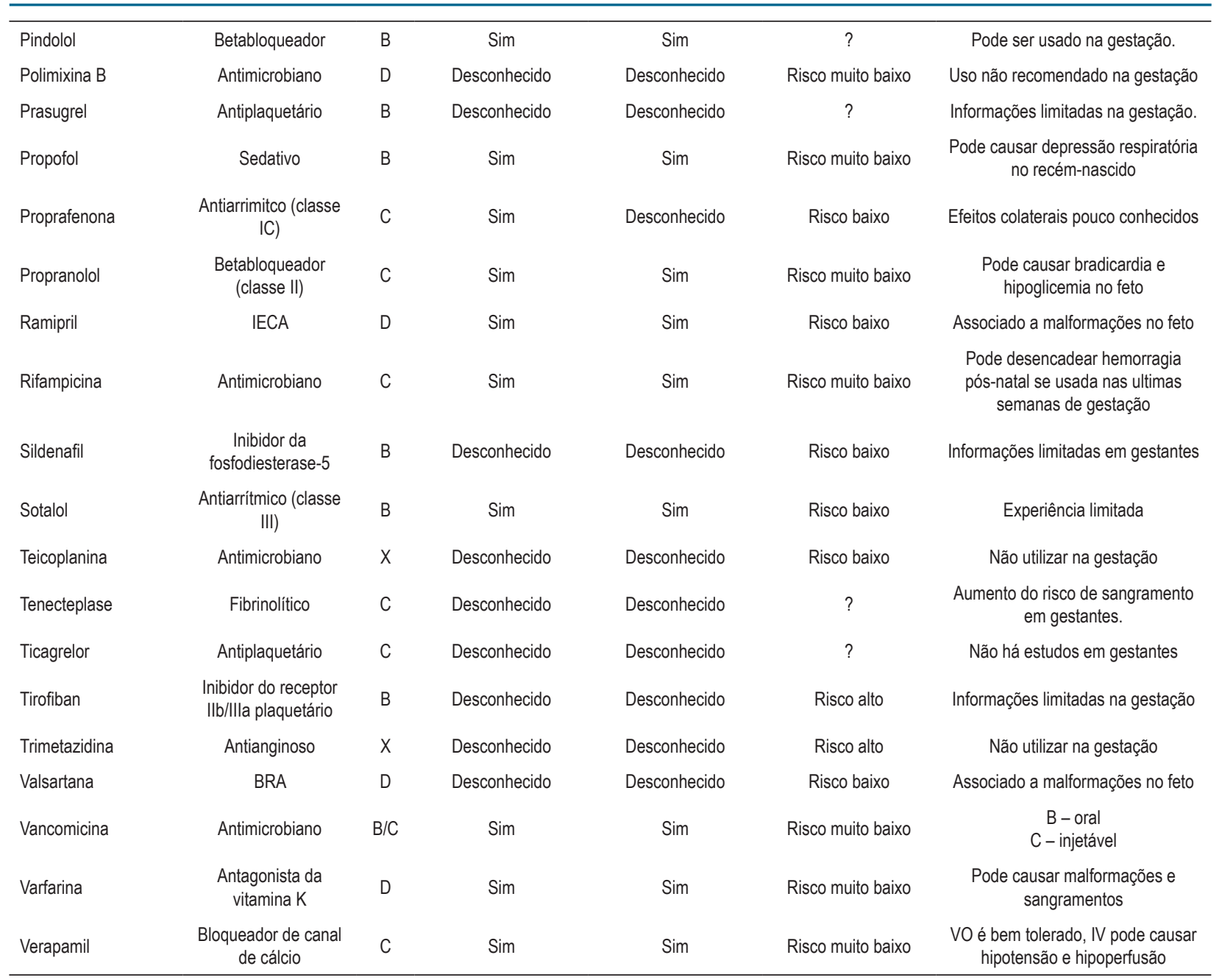

* Risco potencial para o lactente: risco potencial de complicações ou efeitos adversos ao lactente caso a mãe use a medicação durante a lactação. Classificação estabelecida pela Association for the Promotion of and Scientific and Cultural Research into Breastfeeding (APILAM), disponivel em www.e-lactancia.org. Medicações marcadas com o símbolo (?) não constam nessa base de dados. Categorias de riscos (1) risco muito baixo: compatível com a lactação, sem demonstração de risco clinicamente significante para a processo de lactação ou para o lactente, baseado em informações confiáveis publicadas na literatura científica; (2) risco baixo: segurança moderada. É possivel haver um risco pequeno. Recomenda-se acompanhamento clínico da mãe e da criança. Informações obtidas a partir de publicações da literatura científica ou do que é esperado a partir das características físico-químicas e farmacocinéticas da substância; (3) risco alto: pouca segurança para recomendar o uso durante a lactação, a partir das mesmas fontes de informações descritas nas categorias anteriores. Avaliar risco-benefício e, sempre que possível, optar por medicações alternativas; (4) risco muito alto: uso não recomendado durante a lactação. Avaliar uso de medicação alternativa ou suspender lactação, a depender da situação clínica. Dados disponiveis apontam para alto risco de toxicidade. AAS: ácido acetilsalicílico; PCR: parada cardiorrespiratória; BRA: bloqueador do receptor da angiotensina; IECA: inibidor da enzima conversora de angiotensina; HBPM: heparina de baixo peso molecular; FC: frequência cardíaca; SNC: sistema nervoso central; IC: insuficiência cardíaca; VO: via oral.

\section{Suporte Básico de Vida em Pediatria}

\subsection{Introdução}

A PCR em pediatria ocorre em consequência da deterioração da função respiratória ou choque, ocasionando hipoxemia e acidose progressiva, culminando na PCR secundária. A PCR primária de causa cardíaca, como nos adultos (FV e TV), constitui causa menos frequente, entre $5 \mathrm{a}$ $15 \%$ das PCR pediátricas pré-hospitalares. ${ }^{906,907}$

O SBV é a base do SAV em pediatria. Apesar dos avanços em RCP, apenas $17 \%$ dos adultos e $27 \%$ das crianças sobrevivem à alta hospitalar após PCR. ${ }^{196,908,909}$ A prevenção da PCR, o início precoce da RCP e o pronto acionamento do serviço médico de emergência constituem os fundamentos do SBV de qualidade.

A II Diretriz de Ressuscitação Cardiopulmonar e Cuidados Cardiovasculares de Emergência da Sociedade Brasileira de Cardiologia segue as atualizações das diretrizes de 2015 da AHA para RCP e ACE, no que refere ao SBV em Pediatria. As Diretrizes de Ressuscitação devem levar em consideração a variação local da infraestrutura médica de emergência, permitindo alguma flexibilidade quando necessário, e considerar que o atendimento é iniciado, muitas vezes, por profissionais não pediatras. ${ }^{910,911}$ 


\subsection{Suporte Básico de Vida em Pediatria}

São destaques das principais atualizações: as alterações sugeridas para o SBV em pediatria seguem os mesmos princípios do SBV em adultos. As principais diferenças entre os conselhos de ressuscitação são a sequência RCP pediátrica C-A-B vs. A-B-C e o limite superior da frequência de compressão torácica. Todas as demais recomendações são semelhantes entre os conselhos de ressuscitação. ${ }^{909,912}$ Os tópicos revisados incluem: ${ }^{910,913}$ reafirmação da sequência C-A-B como preferencial na faixa etária pediátrica; novos algoritmos para um e múltiplos ressuscitadores provedores de saúde na era da telefonia celular; estabelecimento de um limite máximo de $6 \mathrm{~cm}$ profundidade de compressão em adolescentes; recomendação de 100 a 120 compressões por minuto, semelhantes aos adultos; reafirmação da necessidade das compressões e ventilações na RCP pediátrica.

\subsubsection{Evidências de Aspectos Relacionados ao Período Pré-PCR}

O reconhecimento e o tratamento precoce de condições que levam à deterioração clínica ainda são prioridades na prevenção da parada cardíaca. ${ }^{910,912,913}$

\subsubsection{Time de Resposta Rápida ou Time de Emergência Médica Pediátrica}

Os TRR permitem a detecção e a intervenção precoces frente a um paciente em deterioração clínica, a fim de se evitar a parada cardíaca intra-hospitalar (PCR-IH), utilizando sistemas de classificação de risco, como, por exemplo,o Pediatric Early Warning Score (PEWS). ${ }^{910,913,914}$ Esse conjunto tem se mostrado efetivo na redução da ocorrência de PCR e da mortalidade (Classe de Recomendação Ila; Nível de Evidência C-LD). ${ }^{910,913}$

\subsubsection{Sistemas de Classificação de Risco: o PEWS}

A prevenção da PCR ou respiratória pediátrica no ambiente hospitalar pode ocorrer pelo reconhecimento e pela intervenção precoce no paciente em deterioração. A utilização de um sistema de classificação de risco pode ser considerada, mas sua eficácia no contexto hospitalar precisa ser melhor estabelecida ${ }^{910,913,914}$ (Classe de Recomendação Ilb; Nível de Evidência C-LD).

\subsubsection{Cardiomiopatia Dilatada Pediátrica ou Miocardite}

Os estudos são limitados e contemplam os casos de miocardite aguda fulminante. Como o Nível de Evidência é muito baixo, não há nenhuma recomendação específica nos cuidados pré-PCR em pacientes com miocardite aguda e cardiomiopatia dilatada. ${ }^{910,913,914}$

\subsection{Definição das Faixas Etárias para o Atendimento nas Emergências Pediátricas}

O atendimento pediátrico inclui algumas particularidades, dependendo da faixa etária. Deste modo, empregaremos as seguintes definições:

- Lactentes: menores de 1 ano, excluindo os RecémNascidos (RN).
- Crianças: maiores de 1 ano e antes de apresentar sinais de puberdade (aparecimento do broto mamário em meninas e em meninos, pela presença de pelos em região axilar).

- Adolescentes: apresentam sinais de puberdade. Nesta grupo, aplicam-se as recomendações dos adultos.

\subsection{Sequência Compressão Torácica e Ventilação: $C-A-B$ vs. A-B-C}

A despeito da ausência de evidência científica, alguns conselhos de ressuscitação, em 2010, como a AHA, implementaram a sequência de RCP para a pediatria, C-A-B. As razões que sustentaram esta recomendação foram a ênfase no início precoce das compressões torácicas, a uniformização da RCP em adultos e crianças, e um atraso mínimo no início das ventilações. Várias questões ainda permanecem em aberto, como o grau de retardo no início das ventilações interferindo no desfecho da PCR.

Ambas as sequências C-A-B e A-B-C apresentam argumentos que justificam a sua recomendação. A abordagem C-A-B permite simplificação do ensino de SBV, pois uniformiza a sequência para adultos e crianças. Já a abordagem A-B-C considera a etiologia da asfixia da maioria das PCR em pediatria, valorizando o início precoce das ventilações. Deste modo, a sequência C-A-B é recomendada em pediatria, como nos adultos, pois o atraso na ventilação é mínimo e uniformiza a RCP em adultos e crianças, além de simplificar o ensino de RCP para profissionais de saúde e comunidade. ${ }^{915-917}$

\subsection{Profundidade de Compressão Torácica}

Estudo pediátrico observacional em PCR pediátrica intrahospitalar evidenciou associação entre profundidade de compressão $>51 \mathrm{~mm}$, sobrevida 24 horas e alta hospitalar com bom prognóstico neurológico. ${ }^{918}$

Recomendação: a profundidade de compressão do tórax de lactentes deve ser no mínimo de um terço do diâmetro anteroposterior ou aproximadamente de $4 \mathrm{~cm}$. Em crianças, a compressão deve ser, no mínimo, de um terço do diâmetro anteroposterior ou aproximadamente $5 \mathrm{~cm}$ (recomendação fraca, qualidade de evidência muito baixa). Apesar dos dados limitados em pediatria, estudo em adultos demonstra resultados consistentes de associação com pior desfecho quando a profundidade de compressão torácica ultrapassa $6 \mathrm{~cm} .{ }^{919}$

\subsection{Ressuscitação Cardiopulmonar Convencional vs. Só Compressão}

O treinamento em SBV para público leigo por meio da técnica só compressão tem sido amplamente divulgado. Porém, os dados disponíveis até o momento, ressaltam a extrema importância da ventilação na PCR pediátrica. Deste modo, é recomendada a ventilação intercalada com as compressões torácicas em crianças e adolescentes. ${ }^{912,914}$

Recomendação: A RCP convencional intercalando ventilação e a compressão torácica está indicada na PCR pediátrica intra e extra-hospitalar. Se não for possível ventilar o paciente, os ressuscitadores devem, ao menos, realizar as compressões torácicas (forte recomendação, baixo nível de evidência). ${ }^{920,921}$ 


\subsection{Características do Suporte Básico de Vida de alta} qualidade ${ }^{912,914,922,923}$

O SBV de alta qualidade deve incluir algumas características que devem ser rigorosamente observadas pelos socorristas, com a finalidade de oferecerem RCP de qualidade (Quadro 11.1). ${ }^{912,914,922,923}$

\subsection{Sequência do Suporte Básico de Vida em Lactentes e Crianças para um ou mais Profissionais de Saúde}

No atendimento da PCR, a sequência de atendimento adotada é C-A-B, ou seja, após a identificação do paciente inconsciente, apneia ou respiração agônica e sem pulso central, iniciamos as compressões torácicas, a abertura de vias aéreas e a ventilação adequada (Figura 11.1 e 11.2).

Deve-se checar a segurança do local. Se o local não for seguro, remova a vítima para um local seguro e inicie o atendimento.

Checar a responsividade (classe Ila - LOE C - LD). Em lactentes, bater na região plantar de um dos pés do bebê por três vezes. Em crianças, chamar e tocar nos ombros por três vezes. Em caso de resposta, avalie e chame ajuda, se necessário.

Se a vítima não responde e se encontra fora do ambiente hospitalar, gritar por socorro ou ativar o serviço de emergência por telefone celular - 192 para chamar o SAMU, para atendimentos clínicos, e 193 para acionar o Corpo de Bombeiros, em atendimentos de trauma, se disponível (classe I - LOE C - LD).
Se um segundo socorrista estiver disponível, ele deve chamar ajuda do serviço médico de emergência e buscar um DEA no extra-hospitalar. No intra-hospitalar, se houver o TRR, este deve ser ativado. Caso não haja disponibilidade TRR no hospital, prosseguir o atendimento.

Se o colapso for súbito, deixe a vítima e acione o serviço médico de emergência pelo telefone celular para trazer um DEA. Se houver outras pessoas, peça para realizar o acionamento do serviço médico de emergência enquanto permanece com a criança e inicia RCP.

Checar respiração e pulso central simultaneamente (braquial em lactentes e carotídeo em crianças) por, no mínimo, 5 e máximo de 10 segundos (Classe I LOE C - LD).

Se o pulso estiver presente, realize respirações de resgate (12 a 20 respirações por minuto). Para as ventilações, realizar a abertura das vias aéreas, utilizando a técnica da inclinação da cabeça para trás e elevação do mento. Se a frequência do pulso for menor que 60 bpm e não aumentar rapidamente após o início das ventilações de resgate, observe se há sinais de má perfusão. Na presença de hipoperfusão, a bradicardia apresenta repercussão hemodinâmica e está indicado o início precoce das compressões torácicas intercaladas com ventilação. Reavaliar em 2 minutos; se o pulso estiver ausente ou houver dúvida da presença de pulso após 10 segundos, reiniciar compressões torácicas.

Para compressões torácicas e ventilações (Classe I LOE C - LD), a frequência deve ser de 100 a 120 compressões por minuto. A relação compressão/ ventilação é a seguinte:

Quadro 11.1 - Componentes do Suporte Básico de Vida de alta qualidade

\begin{tabular}{|c|c|}
\hline Componente & $\begin{array}{c}\text { Bebês } \\
\text { (<1 ano, exclui recém-nascido) }\end{array}$ \\
\hline Segurança do local & Checar segurança do ressuscitador e da vítima \\
\hline Reconhecimento & $\begin{array}{c}\text { Não responsivo } \\
\text { Sem respiração ou gasping } \\
\text { Sem pulso, tempo máximo } 10 \text { segundos } \\
\text { Checagem respiração e pulso pode ser simultânea }<10 \text { segundos }\end{array}$ \\
\hline Ativação do serviço emergência & $\begin{array}{l}\text { Colapso presenciado } \\
\text { Colapso não presenciado }\end{array}$ \\
\hline $\begin{array}{l}\text { Frequência Compressão } \\
\text { Ventilação de via aérea avançada }\end{array}$ & $\begin{array}{l}\text { Mínimo 100/minuto e máximo 120/minuto } \\
1 \text { ventilação cada } 6 \text { segundos (10 ventilações/minuto) }\end{array}$ \\
\hline Profundidade compressão & $\begin{array}{l}\text { 1/3 diâmetro anteroposterior } \\
\text { Cerca de } 4 \mathrm{~cm}\end{array}$ \\
\hline Sequência & C-A-B \\
\hline Posicionamento das mãos & $\begin{array}{c}1 \text { ressuscitador: } 2 \text { dedos centro tórax logo abaixo linha } \\
\text { mamilar } \\
2 \text { ou mais ressuscitadores }\end{array}$ \\
\hline Retorno do tórax & Permitir retorno completo tórax após cada compressão \\
\hline Minimizar as interrupções & Limitar interrupção compressões em $<10$ segundos \\
\hline Via aérea & Inclinação da cabeça e elevação queixo (sem trauma) \\
\hline Relação compressão/ventilação & $30: 2$ se 1 socorrista e $15: 2$ se 2 socorristas \\
\hline Desfibrilação & $\begin{array}{l}\text { Assim que disponível, minimizar interrupções. Reiniciar RCP pelas compressões logo após o choque. DEA pode ser } \\
\text { usado }<1 \text { ano na ausência desfibrilador manual }\end{array}$ \\
\hline
\end{tabular}

RCP: ressuscitação cardiopulmonar; DEA: desfibrilador externo automático. 


\section{Atualização}

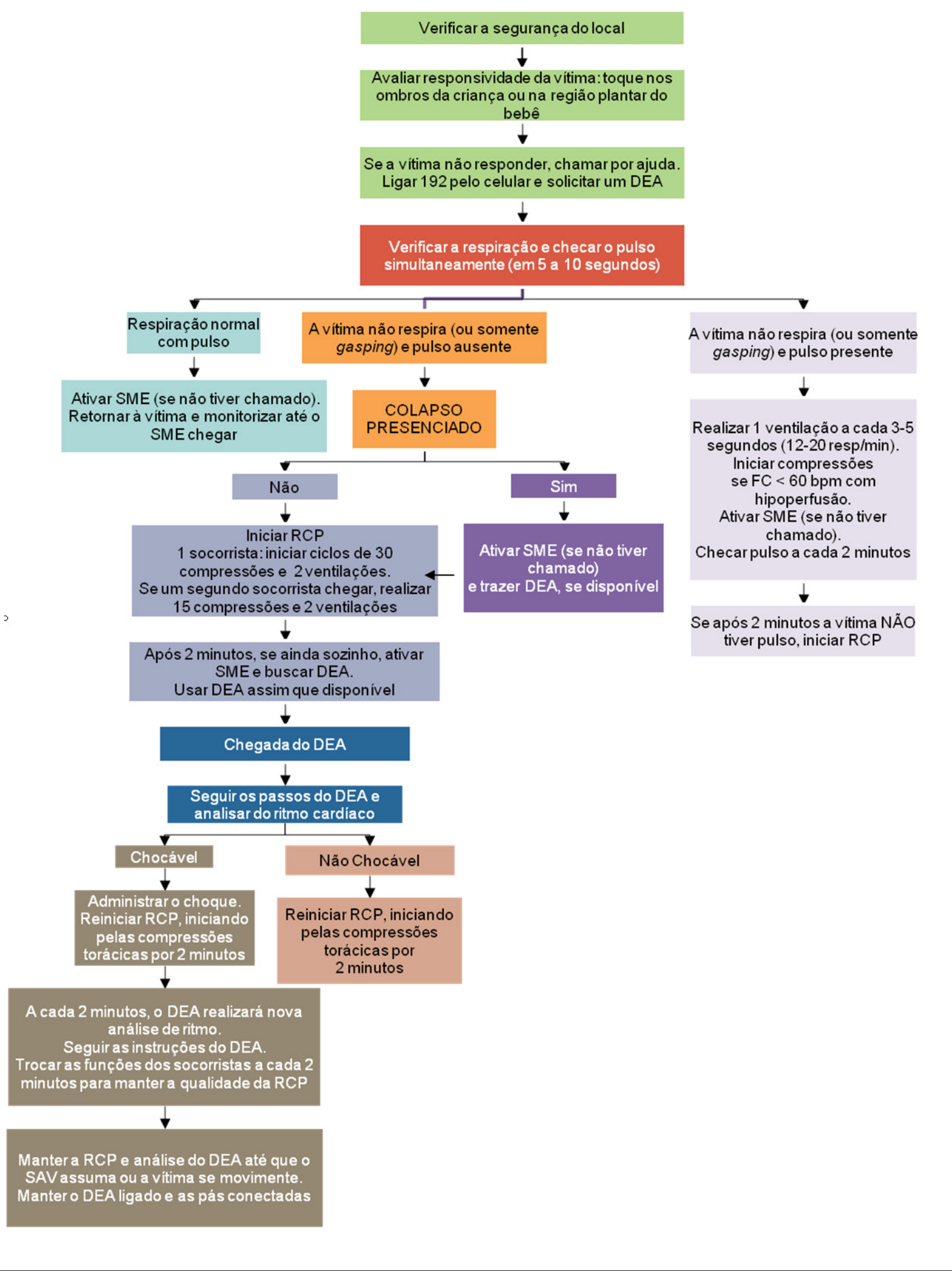

Figura 11.1 - Algoritmo de Suporte Básico de Vida pediátrico para profissionais de saúde para 1 ressuscitador. DEA: desfibrilador externo automático; FC: frequência cardíaca; RCP: ressuscitação cardiopulmonar; SME: serviço médico de emergência. 


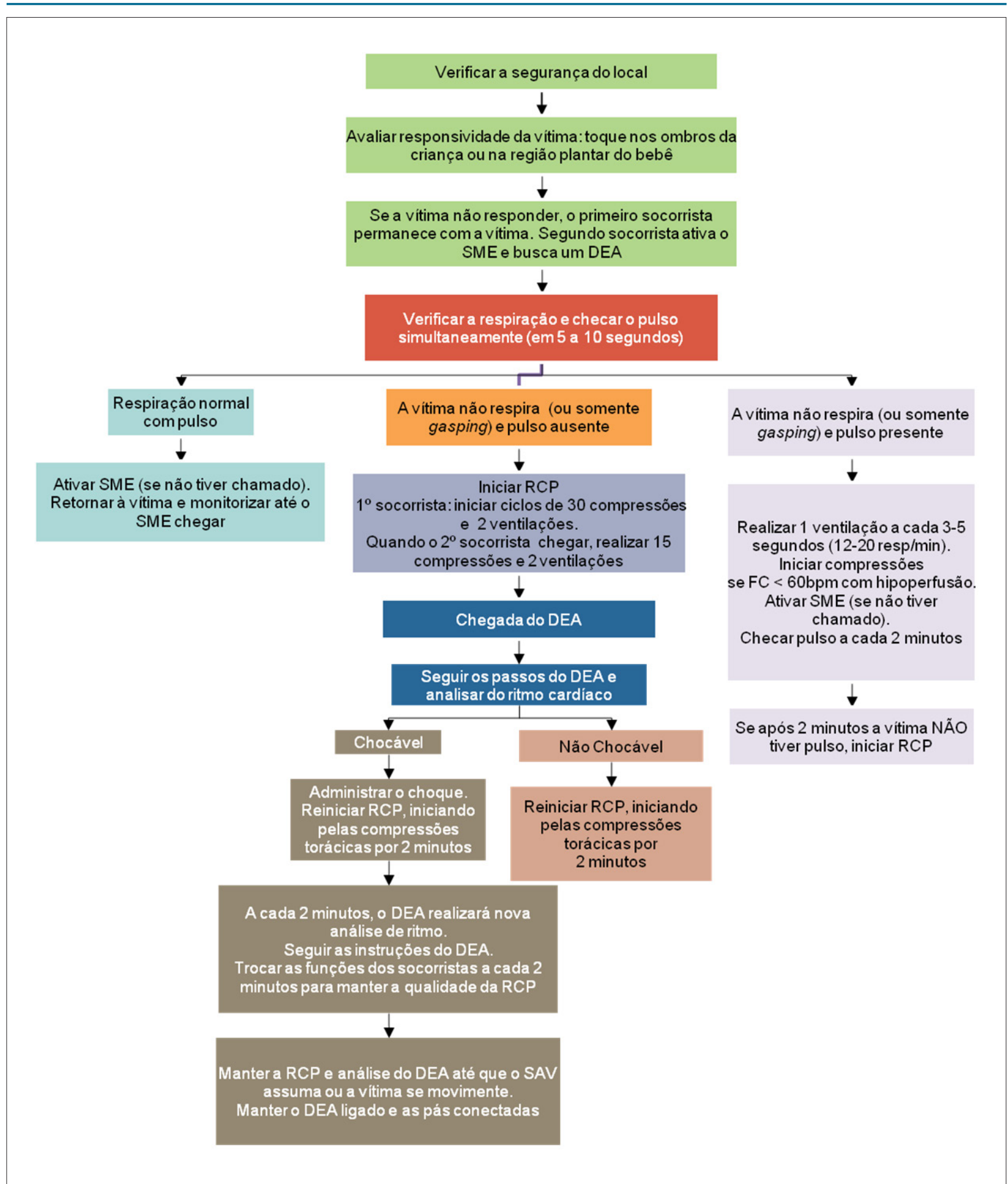

Figura 11.2 - Algoritmo de Suporte Básico de Vida (SBV) pediátrico para profissionais de saúde para dois ou mais ressuscitadores. DEA: desfibrilador externo automático; FC: frequência cardíaca; RCP: ressuscitação cardiopulmonar; SME: serviço médico de emergência. ${ }^{912,914,922,923}$ 
30 compressões e duas ventilações com um socorrista (Classe I - LOE B), ou 15 compressões e duas ventilações com dois socorristas.

Sobre o local e a técnica de compressão, em lactentes, traçar uma linha imaginária entre os mamilos e colocar dois dedos logo abaixo da linha intermamilar (Classe IIb - LOE C). Com dois socorristas, envolver o tórax e sustentar as costas com os dedos de ambas as mãos, utilizando os polegares lado a lado, para realizar as compressões torácicas no terço inferior do esterno, evitando o apêndice xifoide. Os polegares podem se sobrepor em bebês muito pequenos (Classe Ila - LOE B).

Em crianças, usar uma ou duas mãos, no terço inferior do esterno, evitando-se o apêndice xifoide (Classe IIb - LOE C).

A profundidade de compressão é de um terço do diâmetro anteroposterior ou aproximadamente $4 \mathrm{~cm}$ em lactentes e 5 $\mathrm{cm}$ em crianças.

Reavaliar a cada 2 minutos o pulso central e rodiziar, quando houver mais de um ressuscitador, a função de compressão do tórax, para minimizar a fadiga. Caso esteja presente e a FC for maior que 60 bpm com respiração regular, deixar a criança em posição de recuperação (decúbito lateral). Se pulso central ausente ou menor 60 bpm, manter as compressões torácicas.

Utilizar o DEA assim que disponível no extra-hospitalar, se a criança não tiver pulso central palpável. Já no intrahospitalar, o DEA também pode ser indicado se a PCR ocorrer em áreas sem disponibilidade de desfibrilador manual (Classe I - LOE A).

O uso do DEA com atenuador de carga é preferível em crianças menores de 8 anos, incluindo lactentes ou com menos de $25 \mathrm{~kg}$. Caso as pás pediátricas não estejam disponíveis, podemos utilizar o DEA sem atenuador de carga (Classe IIb - LOE C).

O DEA analisa o ritmo e informa se o choque está indicado ou não. Se o choque estiver indicado, deve ser realizado seguindo os passos de segurança. Após o choque, reiniciar as compressões torácicas imediatamente. Se o choque não for indicado, manter a RCP de alta qualidade.

\subsection{Atendimento da Parada Cardiorrespiratória por Público Leigo}

As diferenças do público leigo em relação ao profissional de saúde são:

- O socorrista leigo não checa o pulso, assim, se a criança ou o bebê apresenta-se inconsciente e não respira, a compressão torácica está indicada.

- Manter a relação de 30 compressões para duas ventilações para todas as faixas etárias.

- Utilizar a técnica de compressão com dois dedos nos lactentes com um ou dois socorristas.

- Se o socorrista leigo não souber realizar as ventilações, ele pode manter somente as compressões, até que o serviço médico de emergência chegue ao local.
11.10. Obstrução de Vias Aéreas Superiores por Corpo Estranho

A obstrução de vias aéreas superiores ocorre predominantemente em menores de 5 anos, sendo $65 \%$ abaixo de 1 ano. Os líquidos são responsáveis pela obstrução na maioria dos casos, porém pequenos objetos, como balóes, alimentos (salsichas, castanhas e uvas), podem obstruir a via aérea em crianças.

\subsubsection{Reconhecimento da Obstrução de Vias Aéreas Superiores}

Devemos suspeitar de Obstrução de Vias Aéreas por Corpo Estranho (OVACE) quando houver aparecimento abrupto de estridor, tosse, cansaço e broncoespasmo na ausência de febre ou sintomas prodrômicos. Em geral, os episódios de engasgo ocorrem durante a alimentação ou recreação.

A entrada de um corpo estranho em vias aéreas desencadeia imediatamente o reflexo de tosse na tentativa de expulsá-lo. Entretanto, se a tosse é silenciosa e o paciente não consegue chorar ou falar, podem ser indícios de obstrução completa. Neste momento, estão indicadas as manobras de desobstrução, na tentativa de deslocar o corpo estranho somente quando este for sólido. Estas manobras dependem do nível de consciência e da faixa etária. As manobras visam aumentar a pressão intratorácica para expulsar o corpo estranho da via aérea. Devido a maior possibilidade de complicações em lactentes, as manobras de desobstrução são diferentes em lactentes e crianças. ${ }^{913}$

\section{A) Paciente Consciente com Obstrução de Vias Aéreas Superiores}

Em menores 1 ano, iniciar as manobras com cinco golpes nas costas e cinco compressões torácicas, até que ocorram sinais de desobstrução (choro ou tosse efetiva) ou o paciente fique inconsciente. Em maiores de 1 ano, realizar as compressões abdominais (manobra Heimlich) na região entre a cicatriz umbilical e apêndice xifoide. Estas manobras visam criar uma tosse artificial, aumentando a pressão intratorácica para desalojar o corpo estranho sólido da via aérea.

Em crianças obesas, quando o socorrista não puder abraçar totalmente o abdômen, devem-se realizar as compressões torácicas. Os braços do socorrista devem ser colocados por baixo das axilas da criança e com as mãos na metade inferior do esterno, realizar as compressões torácicas.

\section{B) Paciente Inconsciente com Obstrução de Vias Aéreas Superiores}

Quando a vítima estiver inconsciente, iniciar RCP pelas compressões (sem palpação de pulso). Posicionar sobre uma superfície rígida, gritar ou enviar alguém para ajuda, iniciar RCP pelas compressões e, ao abrir a via aérea, inspecioná-la. Caso seja visível, retirar em movimento de pinça sem realizar varredura, pois há risco de mobilizar o objeto. Ao ventilar, verificar se ocorre expansão torácica. Se o tórax não expandir, reposicionar a via aérea e ventilar novamente. Prosseguir com as manobras de desobstrução até que o objeto seja desalojado da via aérea, algoritmo na figura 11.3. ${ }^{912,914,922,923}$ 


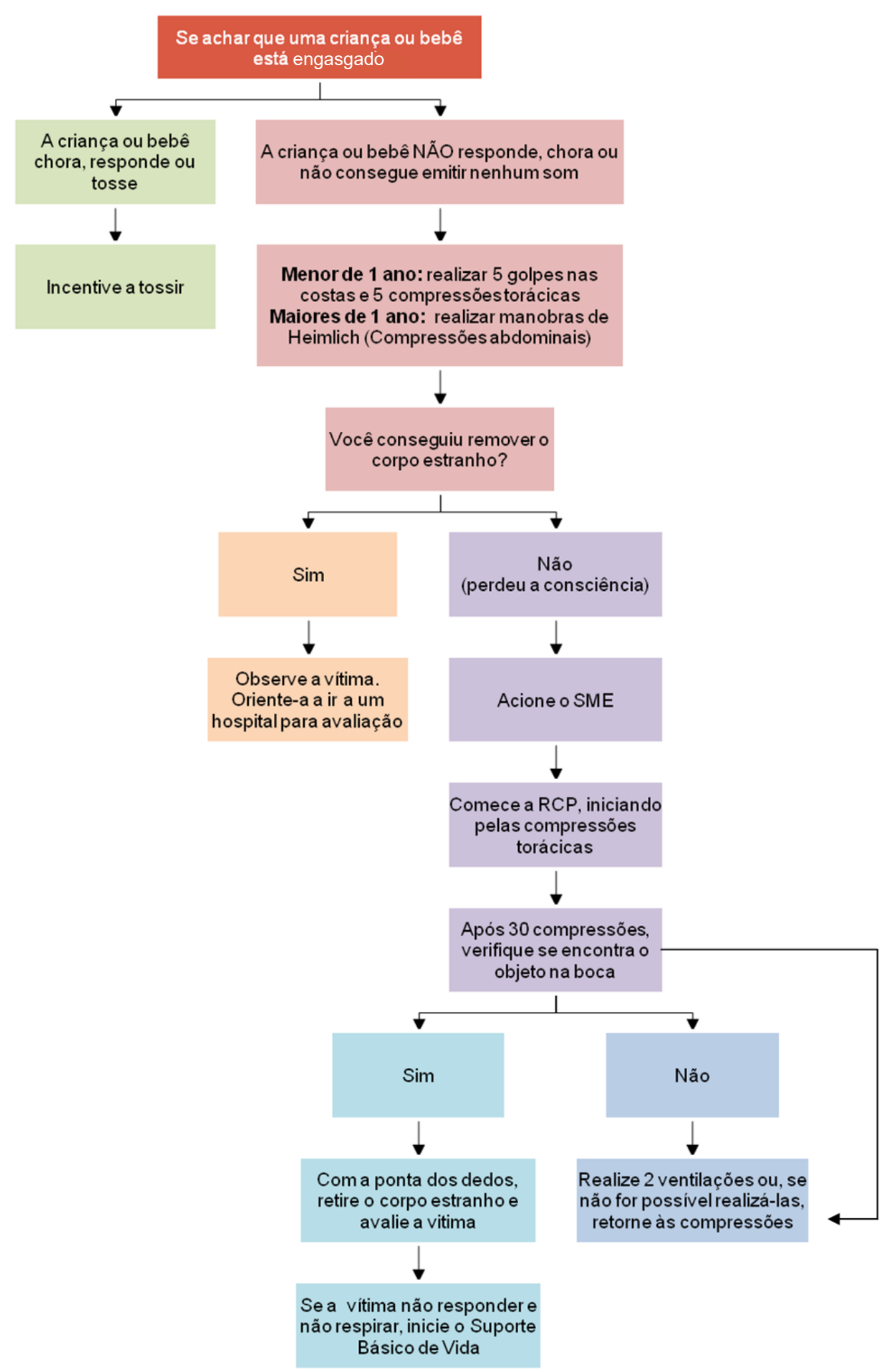

Figura 11.3 - Algoritmo de tratamento da obstrução de vias aéreas superiores em pediatria. RCP: ressuscitação cardiopulmonar; SME: serviço médico de emergência.. ${ }^{912,914,922,923}$ 


\section{Suporte Avançado de Vida em Pediatria}

\subsection{Introdução}

O diagnóstico da PCR é feito com a presença de inconsciência, ausência de pulsos em grandes artérias e apneia ou respiração agônica (gasping). Na monitorização cardíaca, durante a PCR, observa-se um dos quatro seguintes ritmos: assistolia, AESP, FV ou TVSP.

A epidemiologia da PCR da criança é diferente daquela do adulto, na qual, na maioria das vezes, é um evento súbito de origem cardíaca primária com predomínio do ritmo em FV. Nas crianças, a PCR é tipicamente o resultado da deterioração progressiva das funções respiratória e/ou circulatória, sendo a assistolia e a AESP os ritmos mais frequentemente observados. ${ }^{924}$

A RCP no paciente pediátrico também está indicada na bradicardia com hipoperfusão, ou seja, pulso central palpável em uma FC abaixo de 60 bpm, com inconsciência e apneia ou respiração agônica. ${ }^{925-926}$

A PCR pediátrica pré-hospitalar apresenta sobrevida muito baixa, ao redor de 6 a $8 \%$, correspondendo a $4 \%$ em lactentes, $10 \%$ em crianças e $13 \%$ em adolescentes. A maioria desses sobreviventes evolui com dano cerebral grave. Por outro lado, vem ocorrendo melhora no prognóstico da PCR pediátrica hospitalar nos últimos 10 anos, com índices de sobrevivência de 36 a $43 \%$ à alta. ${ }^{927}$

A implementação de diretrizes de RCP, e o treinamento no reconhecimento precoce e emprego imediato das manobras de RCP pediátrica pelos profissionais de saúde, que atuam nos hospitais, vêm sendo pontuados como contribuintes no aumento da sobrevida.

O SAV ou a RCP avançada deveriam ocorrer nos locais onde, em geral, há equipamento adequado e pessoal treinado para a realização de RCP de alta qualidade. No Suporte Avançado, as manobras e intervenções não são realizadas de forma sequencial, como descritas no SBV, mas simultaneamente. Ao se deparar com uma PCR, a compressão torácica deve ser imediatamente iniciada por um membro da equipe, enquanto outro se prepara para iniciar a ventilação.

A qualidade das compressões está estreitamente ligada ao prognóstico e à chance de RCE, sendo provavelmente o passo mais importante da RCP.

RCP de alta qualidade significa compressões torácicas de alta qualidade: comprimir na frequência de 100 a 120 por minuto; na profundidade de pelo menos um terço do diâmetro anteroposterior do tórax (cerca de $5 \mathrm{~cm}$ na criança e $4 \mathrm{~cm}$ no lactente); permitir total relaxamento do tórax após cada compressão; colocar a vítima em uma superfície firme; evitar ventilação excessiva e hiperinsuflação; e minimizar interrupções da compressão.

A sequência C-A-B (compressão cardíaca, abrir via aérea, ventilação) foi mantida na diretriz 2015. A razão reside nas evidências de que, embora a ventilação seja importante, as compressões cardíacas são elementos críticos na RCP, não podendo ser postergadas, como muitas vezes ocorria na sequência A-B-C. O início das ventilações é frequentemente prejudicado por problemas com equipamento e dificuldade de abertura da via aérea.
Simultaneamente às compressões e à ventilação, os demais profissionais se preparam e iniciam os outros procedimentos: monitorização cardíaca e desfibrilação, acesso venoso e preparo de medicações. As funções devem ser coordenadas por um "líder", o qual, em geral é o indivíduo mais experiente e treinado do grupo.

\subsection{Terapia Elétrica}

As principais questões relacionadas à terapia elétrica incluem segurança e efetividade da dose de energia, choques sequenciais ou único, uso do DEA em crianças abaixo de 1 ano de idade, bem como o tamanho, o tipo e a posição das pás durante a cardioversão/desfibrilação.

A recomendação de uma dose inicial de 2 a 4 J/kg está baseada em estudos que demonstram a baixa porcentagem de sucesso em tratar a FV em crianças com $2 \mathrm{~J} / \mathrm{kg} .{ }^{928-930}$ Doses mais altas de energia (até $10 \mathrm{~J} / \mathrm{kg}$ ) parecem ser seguras e efetivas.928,931-936 Não há estudo em humanos que compare diretamente ondas mono e bifásicas na desfibrilação ventricular em pediatria. Desta forma, recomenda-se a dose inicial de 2 a $4 \mathrm{~J} / \mathrm{kg}$ e, se necessário, aumentar progressivamente as doses subsequentes até $10 \mathrm{~J} / \mathrm{kg} .{ }^{937-943}$

Não é recomendada mudança na posição ou no tamanho das pás, e deve-se utilizar o maior tamanho de pás que couber no tórax do paciente sem que uma toque na outra. Três estudos pediátricos, Classe de Recomendação IIb LOE C, ${ }^{944-946}$ demonstrando que a impedância transtorácica diminui com o aumento do tamanho das pás (com a diminuição da impedância transtorácica, a corrente transtorácica aumenta e, consequentemente, a corrente transmiocárdica). A posição das pás (anteroposterior ou anterolateral) também não parece ter diferença nas taxas de RCE. Tanto as pás adesivas quanto as do desfibrilador manual podem ser utilizadas com a mesma efetividade. ${ }^{928}$

O DEA tem demonstrado alta sensibilidade e especificidade em detectar ritmos chocáveis em lactentes. Para o tratamento da FV/TVSP de crianças em ambiente extra-hospitalar, ${ }^{947} \mathrm{O}$ método recomendado de administração de choques está listado em ordem de preferência: ${ }^{948}$ desfibrilador manual; DEA com atenuador de carga pediátrico; e DEA sem atenuador de carga.

Se houver qualquer tipo de atraso na disponibilidade do dispositivo recomendado, deve ser utilizado o que estiver disponível de imediato.

Não se conhece a energia mínima eficaz e nem o limite superior para desfibrilação segura. Em crianças e modelos animais, cargas entre 4 e $9 \mathrm{~J} / \mathrm{kg}$ têm apresentado desfibrilação eficaz sem efeitos adversos significativos. ${ }^{929,935,949-951}$

\subsection{Vias Aéreas}

No manuseio das vias aéreas, é importante garantir e manter permeabilidade das mesmas. A ventilação artificial na RCP deve ser iniciada ao final do primeiro ciclo de 2 minutos da RCP. Cada ventilação deve ser feita em 1 segundo com elevação visível do tórax, e sua frequência varia de acordo com a situação clínica vivenciada (Tabela 12.1).

No Suporte Avançado, as ventilações podem ser fornecidas como se segue. 
Tabela 12.1 - Frequência das ventilações, de acordo com a situação clínica

\begin{tabular}{lc}
\hline Situação clínica & Frequência das ventilações \\
\hline Apneia sem parada cardíaca & 12 a 20/minuto \\
& 2 para cada 30 compressões \\
& torácicas (um socorrista) OU \\
& 2 para cada 15 compressões \\
PCR sem via aérea definitiva & torácicas (2 socorristas) \\
& 10 ventilações/minuto com \\
PCR com via aérea definitiva & compressões torácicas contínuas de \\
(intubação traqueal ou máscara & 100 a 120/minuto \\
laríngea) & \\
\hline
\end{tabular}

PCR: parada cardiorrespiratória.

A) Ventilação com BVM: preferencialmente conectada à fonte de oxigênio. Em RN prematuros, utilizam-se bolsas com volume de $250 \mathrm{~mL}$; em RN de termo e lactente, bolsas com volume mínimo de 450 a $500 \mathrm{~mL}$; para crianças a partir de 1 ano, volumes acima de $750 \mathrm{~mL}$.

- O uso do balão autoinflável permite fração de oxigênio inspirada próxima a $100 \%$ com fluxo de oxigênio de 10 a $15 \mathrm{~L}$ /minuto e uso de reservatório a ela acoplado. Volume e pressão excessivos podem comprometer o DC por aumento da pressão intratorácica e diminuição do retorno venoso, além de provocar distensão alveolar e barotrauma. Volume excessivo pode, também, causar distensão gástrica, comprometer a ventilação e aumentar o risco de regurgitação e broncoaspiração.

B) Máscara laríngea: é uma opção na PCR, para assegurar a via aérea e promover a ventilação no paciente inconsciente, quando não é possível realizar a IOT, em decorrência de via aérea difícil e/ou inexperiência do profissional. Pode ser utilizada naqueles com via aérea sabidamente difícil ou malformações craniofaciais ou síndromes genéticas.

C) IOT: é a forma mais segura de garantir adequada oxigenação, quando realizada por profissional experiente. Deve ser realizada precocemente se não houver retorno da respiração espontânea efetiva com a BVM. Podem ser utilizadas Cânulas Orotraqueais (COT) para crianças com e sem cuff, sendo cânulas com cuff preferíveis nos casos de complacência pulmonar reduzida, alta resistência em via aérea ou escape de ar com cânula sem cuff.

Tubos endotraqueais com cuff podem ser usados em lactentes (exceto em RN) e crianças, em ambientes intrahospitalares, desde que a pressão de insuflação do cuff seja mantida abaixo de $20 \mathrm{~cm}$ de água. ${ }^{952-954}$

Os números das COT são equivalentes ao diâmetro interno delas e podem variar de 2 a 8 , com intervalos de $0,5 \mathrm{~mm}$ entre um número e outro. A escolha do número da COT depende da idade do paciente (Tabela 12.2).

Para a IOT, a lâmina reta do laringoscópio é preferível em crianças de até 4 anos de idade, pois promove melhor visualização da glote, em posição anterior e cefálica nessa faixa etária.
Tabela 12.2 - Número da cânula orotraquea|955

\begin{tabular}{lc}
\hline Idade da criança & $\begin{array}{c}\text { Diâmetro interno da cânula de } \\
\text { intubação orotraqueal }(\mathrm{mm})\end{array}$ \\
\hline Recém-nascido/prematuro & $2 ; 2,5$ ou 3 (sem cuff) \\
Lactente até 6 meses & 3 a 3,5 (sem cuff) \\
Lactente de 6 a 12 meses & 4 a 4,5 (sem cuff) \\
1 a 8 anos & (Idade em anos/4) + 4 (sem cuff) \\
Acima de 8 anos e adolescentes & 7 a 8 (com cuff) \\
\hline
\end{tabular}

Em maiores de 4 anos, é preferível a lâmina curva, de base mais larga e com flange que permite maior deslocamento da língua e melhor visualização.

A maioria das COT tem inscrita uma marca de corda vocal, indicando que o tubo provavelmente encontra-se inserido na profundidade adequada com a cabeça da criança em posição neutra. A profundidade de inserção pode ser estimada por meio de fórmulas:

número de inserção $(\mathrm{cm})=$ diâmetro interno da COT $\times 3$

A confirmação da IOT é feita pela visualização do tubo passando entre as cordas vocais, saída de vapor d'água pelo tubo durante sua introdução, observação de expansibilidade torácica bilateral, ausculta simétrica em ambos os campos pulmonares, ausência de sons em epigástrio e detecção de dióxido de carbono expirado no capnógrafo.

D) A capnografia é altamente recomendada, pois geralmente confirma o posicionamento correto do tubo endotraqueal na via aérea e pode indicar mais rapidamente a colocação incorreta/deslocamento do que a monitorização da saturação de oxi-hemoglobina. Deve ser utilizada em todos os ambientes.

No paciente em PCR, o dióxido de carbono expirado confirma a localização traqueal do tubo, mas sua ausência não confirma nem exclui a adequada localização do tubo, pois, nesses pacientes, o fluxo sanguíneo pulmonar é limitado e, assim, o dióxido de carbono expirado pode não estar detectável, apesar da intubação adequada. Deve ser realizada a laringoscopia direta para confirmar o posicionamento do tubo se o dióxido de carbono exalado não for detectado e houver outras evidências de que o tubo esteja na traqueia (por exemplo: elevação do tórax e sons respiratórios bilaterais).

As evidências atuais ${ }^{956}$ nos estudos em PCREH não demonstram nenhuma vantagem em relação à IOT sobre a ventilação eficaz com BVM, quando o tempo de transporte para o serviço de emergência for curto. Esse estudo sugere que a intubação imediata talvez não seja necessária. ${ }^{957}$ Assim, cabe ao líder do time de RCP determinar qual o momento ideal para a IOT.

Uma vez restabelecido o RCE, recomenda-se que a administração de oxigênio seja titulada, para manter a 
saturação de oxi-hemoglobina $\geq 94 \%$, pois a hiperóxia acentua a lesão oxidativa. ${ }^{955}$

\subsection{Medicações Administradas durante a Ressuscitação Cardiopulmonar}

A utilização de medicamentos tem como objetivo aumentar a taxa de sucesso da RCP. Este processo envolve o estímulo e a intensificação da contratilidade miocárdica, o tratamento de arritmias, a otimização das perfusões coronariana (aumento de pressão diastólica aórtica) e cerebral, e a correção de acidose metabólica. ${ }^{958,959}$

As doses das drogas devem ser baseadas no peso corpóreo atual (crianças não obesas) ou no ideal estimado pela altura (crianças obesas) para minimizar o risco de toxicidade; não se deve ultrapassar a dose preconizada para adultos. Caso não haja conhecimento do peso, utilizam-se tabelas com a altura/comprimento e doses pré-calculadas. ${ }^{960,961}$

O acesso vascular na PCR deve ser o de maior calibre e mais acessível, sem comprometer as manobras de RCP. São eles veia periférica (em braços, mãos, pernas ou pés), e veia central (em crianças em PCR é difícil de realizar e deve ser feita por profissional habilitado). O acesso vascular não é recomendado, por necessitar de interrupção das compressões torácicas, além de poder levar a complicações como laceração vascular, hematomas, hemotórax e pneumotórax. Quando necessário, a punção de veia femoral é uma via de fácil a ser lembrada na PCR.

O acesso intraósseo deve ser estabelecido se o acesso venoso não for conseguido. É via preferível em relação à via endotraqueal. Podem ser administrados por esta via medicamentos, fluidos, cristaloides, coloides e hemoderivados. A punção é realizada geralmente na porção proximal da tíbia ou distal do fêmur, com agulha apropriada ou de punção de medula óssea.

Se outras vias não forem possíveis, a via endotraqueal pode ser utilizada. São administradas drogas lipossolúveis, como epinefrina, lidocaína e naloxona. A absorção das drogas é variável e sua eficácia ainda não comprovada.

\subsubsection{Epinefrina}

Atecolamina endógena, com propriedades alfa e beta-adrenérgicas, utilizada na PCR e na bradicardia sintomática. ${ }^{958,962}$

\section{Recomendações de Tratamento}

Em lactentes e crianças com PCR pré-hospitalar e hospitalar, dose de 0,01 mg/kg ou 0,1 mL/kg de 1:10.000 intravascular ou intraóssea para a primeira dose e as subsequentes (intervalos de 3 a 5 minutos). A dose máxima única é de $1 \mathrm{mg}$.

$A$ via endotraqueal não é mais recomendada, mas se for a via obtida, a dose deve ser aumentada em dez vezes $(0,1$ $\mathrm{mg} / \mathrm{kg}$ ou $0,1 \mathrm{~mL} / \mathrm{kg}$ de $1: 1.000) .{ }^{960,962}$

Doses altas de epinefrina não são recomendadas na rotina, pois não melhoram o prognóstico neurológico e nem a sobrevida do paciente..$^{962}$

\section{Precauções}

Podem ocorrer isquemia tecidual e necrose se houver infiltração pelo uso endovenoso periférico. As catecolaminas são inativadas por soluções alcalinas (não misture com bicarbonato de sódio).

Doses altas podem causar vasoconstrição excessiva, taquicardias, arritmias ventriculares e HAS. ${ }^{962,963}$

\subsubsection{Cálcio}

É fundamental para a função miocárdica (excitaçãocontração). Entretanto, após lesão isquêmica e de reperfusão, quando ocorre o aumento de cálcio intracelular, as enzimas para a via de necrose e morte celular são ativadas. ${ }^{959,964}$

\section{Recomendações de Tratamento}

O uso rotineiro de cálcio na RCP infantil não é recomendado na ausência de hipocalcemia, overdose de bloqueador de canal de cálcio, hipermagnesemia ou hipercalemia, e sua administração pode ser nociva. ${ }^{960-963}$

Se houver indicação, podem ser usados gluconato ou cloreto de cálcio. Nas crianças criticamente doentes, o cloreto é preferido porque resulta em um aumento mais significativo do cálcio iônico. Em um contexto diferente da PCR, diante de acesso venoso periférico, o gluconato é mais adequado pela menor osmolaridade e pela irritação venosa.

A dose recomendada é 5 a $7 \mathrm{mg}$ de cálcio elementar ou $20 \mathrm{mg} / \mathrm{kg}$ de cloreto de cálcio a 10\% intravenoso ou intraóssea $(5,4 \mathrm{mg} / \mathrm{kg}$ de cálcio elementar). A dose de gluconato é três vezes a de cloreto para dose equivalente de cálcio elementar. ${ }^{959,961}$

\section{Precauções}

Evite administração rápida (sobretudo em bradicardia, se o paciente estiver recebendo digoxina).

O cálcio pode causar esclerose de veias periféricas e queimadura química. Quando houver necessidade de se infundir cálcio e bicarbonato de sódio, irrigar o cateter com soro fisiológico antes e depois da infusão, pois pode haver formação de precipitado insolúvel. ${ }^{963}$

\subsubsection{Bicarbonato de Sódio}

Sua administração resulta em reação ácido-base, que gera água e dióxido de carbono. Como a maior causa de PCR em crianças é a insuficiência respiratória, seu uso na RCP pode piorar uma acidose respiratória preexistente. ${ }^{958}$

\section{Recomendações de Tratamento}

O uso rotineiro de bicarbonato de sódio na RCP infantil não é recomendado. As indicações potenciais seriam a acidose metabólica grave com suporte ventilatório adequado, a hipercalemia, a hipermagnesemia e a intoxicação por bloqueadores dos canais de sódio (antidepressivos tricíclicos). Dose na acidose grave e hipercalemia: $1 \mathrm{mEq} / \mathrm{kg}$ em bólus lento intravenoso/intraóssea. Dose na overdose de bloqueadores de 
canais de sódio: 1 a $2 \mathrm{mEq} / \mathrm{kg}$ até $\mathrm{pH}$ sérico > 7,45 seguido de infusão contínua, para manter alcalose. ${ }^{959,961,963}$

\section{Precauções}

Assegure ventilação adequada, para não resultar em acidose liquórica paradoxal e intracelular (o dióxido de carbono cruza membrana hematoencefálica rapidamente).

Quando combinado com cálcio, há formação de precipitado.

Irrigar o cateter intravenoso/intraóssea com soro fisiológico 0,9\% antes e após as infusões.

Cuidado com inativação de catecolaminas.

Não administrar por via endotraqueal.

\subsubsection{Sulfato de Magnésio}

Eletrólito, cofator de muitos sistemas enzimáticos, incluindo a $\mathrm{Na} / \mathrm{K}$ ATPase miocárdica, com ação antiarrítmica e broncodilatadora. ${ }^{961,963,964}$

\section{Recomendações de Tratamento}

Não há evidência suficiente para recomendar ou contraindicar o uso rotineiro de magnésio na RCP. Sua administração está indicada apenas nos casos de hipomagnesemia documentada ou torsades de pointes.

A dose deve ser a seguinte: bólus intravenoso/intraóssea de $25 \mathrm{mg}$ a $50 \mathrm{mg} / \mathrm{kg}$ se TVSP com torsades; 25 a $50 \mathrm{mg} / \mathrm{kg}$ em 10 a 20 min para TV com pulso associada a torsades ou hipomagnesemia. A dose máxima é 2 g. ${ }^{961,963}$

\section{Precauções}

Bólus rápidos podem causar vasodilatação com hipotensão e bradicardia.

Sua toxicidade é revertida pela infusão de cálcio. ${ }^{963}$

\subsubsection{Glicose}

É o principal substrato metabólico para o miocárdio de neonatos e fonte de energia nos episódios de isquemia. Lactentes e crianças cronicamente enfermas têm reservas limitadas de glicogênio e são rapidamente depletadas em episódios de estresse cardiovascular, gerando hipoglicemia. Os sinais clínicos de hipoglicemia podem simular choque/ hipoxemia/PCR. ${ }^{959,961}$

\section{Recomendações de Tratamento}

Checar concentração de glicose sérica durante a RCP e tratar prontamente a hipoglicemia.

Não administrar soluções glicosadas durante RCP, se não houver hipoglicemia documentada.

Evitar hipo ou hiperglicemia após RCE. O controle rigoroso da glicemia não se mostrou superior ao controle moderado, em termos de benefícios na sobrevida em adultos, e aumentou os riscos de hipoglicemia, em adultos e crianças. ${ }^{962}$
Dose: 0,5 a $1 \mathrm{~g} / \mathrm{kg}$ intravenoso/intraóssea (soro glicosado $25 \% 2$ a $4 \mathrm{~mL} / \mathrm{kg}$; soro glicosado $10 \% 5$ a $10 \mathrm{~mL} / \mathrm{kg}$; soro glicosado 5\% 10 a $20 \mathrm{~mL} / \mathrm{kg}$ ).

A terapia para hipoglicemia documentada deve ser seguida pela infusão contínua de glicose. ${ }^{959,963}$

\section{Precauções}

A concentração máxima recomendada para administração em bólus é soro glicosado 25\% (evitar lesões vascular e tissular locais).

A concentração máxima para RN é soro glicosado 12,5\%. ${ }^{963}$

\subsubsection{Amiodarona}

Antiarrítmico da classe III que age prolongando a duração do potencial de ação e o período refratário efetivo. Também diminui a frequência sinusal; prolonga o intervalo QT; e inibe os receptores alfa e beta-adrenérgicos não competitivamente.

\section{Recomendações de Tratamento}

Em casos de TSV; TV com pulso; PCR sem pulso (FV/TVSP).

Dose: TSV e TV com pulso, $5 \mathrm{mg} / \mathrm{kg}$ intravenoso como dose de ataque, em 30 a 60 minutos, diluídos; dose máxima de $300 \mathrm{mg}$.

Na PCR sem pulso (FV/TVSP): $5 \mathrm{mg} / \mathrm{kg}$ em bólus, com dose máxima de $300 \mathrm{mg}$, podendo ser repetido até uma dose máxima diária de 15 mg/kg (2,2 g em adolescentes).

\section{Precauções}

Monitorizar o ECG e a pressão arterial. Pode causar hipotensão arterial, bradicardia, assistolia, intervalo QT prolongado e torsades de pointes.

\subsubsection{Lidocaína}

Antiarrítmico da classe IB que age aumentando o limiar de estimulação elétrica do ventrículo e do sistema HissPurkinje, estabilizando a membrana cardíaca e reduzindo a automaticidade. Reduz a PIC por inibição dos canais de sódio nos neurônios, que reduzem a atividade metabólica.

\section{Recomendações de Tratamento}

Em casos de FV/TVSP; taquicardia de complexo QRS largo (com pulso); sequência rápida de intubação para proteção da PIC.

Dose: $1 \mathrm{mg} / \mathrm{kg}$ em bólus, intravenoso/intraóssea como dose de ataque; 20 a $50 \mathrm{mcg} / \mathrm{kg}$ por minuto em infusão contínua intravenoso/intraóssea; 2 a $3 \mathrm{mg} / \mathrm{kg}$ se a via endotraqueal for a utilizada.

\section{Precauções}

Monitorizar a pressão arterial e o ECG. Pode causar convulsões (altas concentrações), hipotensão arterial sistêmica, depressão miocárdica, bradicardia, bloqueio cardíaco, arritmias e parada cardíaca.

Não usar se houver batimentos de escape ventricular de complexo largo com bradicardia e em BAV avançado. 


\subsection{Medicamentos para a Manutenção do Débito Cardíaco Adequado}

Os medicamentos para manter o DC adequado podem ajudar a evitar a PCR e a tratar a disfunção miocárdica pósressuscitação.

\subsubsection{Dopamina}

É uma catecolamina endógena, que estimula diretamente os receptores alfa 1 e beta 1, e age como pré-requisito para produção de noradrenalina.

\section{Recomendações de Tratamento}

Indicada para choque cardiogênico (inclusive após cirurgia cardíaca), choque distributivo (séptico) e hipotensão em RN prematuros.

Dose: intravenoso/intraóssea 2 a $20 \mathrm{mcg} / \mathrm{kg} /$ minuto em infusão, titulados até efeito desejado.

\section{Precauções}

Pode causar taquicardia, arritmias, hipertensão, necrose local (se houver infiltração) e vasoconstrição periférica. A função da tireoide pode ser afetada por uso prolongado (a dopamina pode inibir liberação do Hormônio Estimulante da Tireoide - TSH). ${ }^{958,959,965}$

\subsubsection{Dobutamina}

É uma catecolamina sintética, que age principalmente em receptores beta 1 com algum efeito alfa e beta 2 , melhorando o inotropismo cardíaco, com pouco efeito cronotrópico.

\section{Recomendações de Tratamento}

É útil no tratamento do choque cardiogênico e da IC congestiva, especialmente na disfunção de VE com aumento das pressões de enchimento. É importante em pacientes com regurgitação mitral e aórtica, que necessitam da redução de pós-carga e do aumento do inotropismo. ${ }^{958,959,965}$ Dose: intravenoso/intraóssea 2 a $20 \mathrm{mcg} / \mathrm{kg} /$ minuto em infusão titulado até efeito desejado.

\section{Precauções}

Pode levar ao aparecimento de arritmias, náuseas e mielossupressão.

O extravasamento pode produzir isquemia local. É inativado por soluções alcalinas. ${ }^{958,959,965}$

\subsubsection{Milrinona}

Inibidor da fosfodiesterase, que aumenta o monofosfato cíclico da adenosina no miocárdio e na musculatura dos vasos. Promove aumento de cálcio intracelular, com melhora da contratilidade miocárdica e redução da pós-carga e précarga, por relaxamento da musculatura lisa vascular periférica.

\section{Recomendações de Tratamento}

Indicada na disfunção miocárdica e no aumento da Resistência Vascular Sistêmica (RVS) e Pulmonar (RVP). Por exemplo: IC congestiva após cirurgia cardíaca, choque cardiogênico com RVS alta e o choque séptico não hiperdinâmico para otimizar índice cardíaco.

Dose intravenoso/intraóssea: dose de ataque de 50 a 75 $\mathrm{mcg} / \mathrm{kg}$ em 10 a 60 minutos; 0,25 a 0,75 mcg/kg/minuto.

\section{Precauções}

Pode causar hipotensão (que pode ser agravada por hipovolemia), plaquetopenia, hipopotassemia e se acumular em pacientes com insuficiência renal. Monitorize ECG, pressão arterial e plaquetas. ${ }^{958,963,965}$

\subsubsection{Epinefrina}

Droga de escolha na RCP. Por ser alfa e beta-agonista, tem papel inotrópico, cronotrópico e vasoconstritor (altas doses).

\section{Recomendações de Tratamento}

Está indicada também para pacientes com choque hipotensivo.

Dose intravenoso/intraóssea: 0,1 a $1 \mathrm{mcg} / \mathrm{kg} /$ minuto em infusão, titulado até efeito desejado (doses mais altas s/n).

\section{Precauções}

Já mencionadas anteriormente, item 12.4.1.963

\subsubsection{Norepinefrina}

Catecolamina endógena, com potente efeito beta 1 e alfaagonistas. Tem mínimo efeito beta $2 .{ }^{965}$

\section{Recomendações de Tratamento}

Indicado no choque com vasodilatação não responsivo à dopamina ou epinefrina. ${ }^{965}$

Dose intravenoso/intraóssea: 0,1 a $2 \mathrm{mcg} / \mathrm{kg} / \mathrm{minuto}$, titulados até efeito desejado.

\section{Precauções}

Pode causar arritmias e hipertensão, deveria ser administrada somente em acesso venoso central. Extravasamento pode causar necrose tecidual. A medicação é inativada por soluções alcalinas. ${ }^{959,965}$

\subsubsection{Nitroprussiato de Sódio}

Vasodilatador, anti-hipertensivo, relaxa o tônus em todos os leitos vasculares, arteriais e venosos, pela liberação de óxido nítrico, resultando em redução nas pressões de enchimento cardíaco (pré-carga) e na pós-carga ventricular direita e esquerda.

\section{Recomendações de Tratamento}

Choque cardiogênico (associado à RVS elevada) e hipertensão arterial grave. Dose: $0,1 \mathrm{a} 8 \mathrm{mcg} / \mathrm{kg}$ por minuto em infusão contínua intravenoso/intraóssea.

\section{Precauções}

Monitorizar a Saturação Periférica de Oxigênio $\left(\mathrm{SpO}_{2}\right)$ e o ECG. 
A hipovolemia pode agravar os efeitos hipotensores da medicação.

Nos casos de tratamento prolongado (acima de 48 horas), doses superiores a $2 \mathrm{mcg} / \mathrm{kg} /$ minuto ou em pacientes com disfunção hepática ou renal, os níveis de tiocianato (devem ser menor que $50 \mathrm{mg} / \mathrm{L}$ ) e de cianeto (tóxico se maior que $2 \mathrm{mcg} / \mathrm{mL}$ ) devem ser monitorados. Pode causar convulsões (toxicidade pelo tiocianato), agitação; hipotensão arterial, bradicardia e taquicardia; náuseas, vômitos e câimbras abdominais (toxicidade pelo tiocianato); e hipotiroidismo.

É fotossensível.

\subsection{Miscelânia}

\subsubsection{Naloxona}

Antagonista dos receptores opioides. Age competindo em seus sítios receptores, revertendo seus efeitos. Exerce alguns efeitos analgésicos.

\section{Recomendações de Tratamento}

A reversão total é indicada para a toxicidade por narcóticos secundária à overdose. Doses menores são necessárias para pacientes com depressão respiratória associada ao uso de narcóticos terapêuticos. A dose para a reversão não total é de 1 a 5 mcg/kg intravenosa/intraóssea/intramuscular/subcutânea, titulada até obtenção do efeito; 0,002 a 0,16 mg/kg por hora em infusão intravenosa/intraóssea. Na reversão total, 0,1 mg/ kg intravenosa/intraóssea/intramuscular/subcutânea em bólus a cada 2 minutos, se necessário (dose máxima: $2 \mathrm{mg}$ ).

\section{Precauções}

Monitorizar $\mathrm{SpO}_{2}$, pressão arterial e ECG. Pode apresentar hiperpneia, edema pulmonar; FV e/ou TV, hipertensão e assistolia (principalmente se for administrada a dose total de reversão); convulsões, sonolência e nervosismo; náusea e vômitos.

A repetição da dose pode ser necessária, pois a meia-vida é normalmente mais curta que a meia-vida do opioide que está sendo revertido. Pode ser administrada em lactentes filhos de mulheres viciadas ou na presença de outros sintomas de abstinência. A medicação reverte os efeitos dos analgésicos narcóticos, devendo se considerar a administração de analgésicos não narcóticos para o tratamento da dor.

\subsubsection{Prostaglandina}

Este vasodilatador age nos receptores Prostaglandina E1 (PGE1), causando vasodilatação de todas as artérias e arteríolas, inclusive do ducto arterioso. Inibe a agregação plaquetária e estimula a musculatura lisa uterina e intestinal.

\section{Recomendações de Tratamento}

Nas cardiopatias congênitas com circulação pulmonar (tipo atresia pulmonar ou tipo transposição de grandes artérias) ou sistêmica (lesões obstrutivas graves do coração esquerdo, síndrome de hipoplasia do coração esquerdo) dependentes da patência do canal arterial. Dose: 0,01 a 0,05 mcg/kg por minuto intravenosa contínua.

\section{Precauções}

Monitorizar $\mathrm{SpO}_{2}$, frequência respiratória, pressão arterial, ECG e temperatura. Os principais efeitos adversos são apneia e febre; rubor ou rash cutâneo. Doses mais elevadas estão associadas a aumento no risco dos efeitos adversos.

\subsection{Arritmias}

Na avaliação da criança com arritmia, devemos determinar se há necessidade de tratamento de emergência ou se esta pode ser avaliada em consulta ambulatorial. ${ }^{966}$

Em casos de emergência, independentemente da arritmia, devemos sempre iniciar os passos a seguir:

1. Verificar sinais vitais (FC, frequência respiratória, pressão arterial sistêmica e perfusão periférica).

2. Pesquisar pulso central.

3. Se não houver sinais vitais, tratar como PCR.

4. Se os sinais vitais estiverem presentes e o pulso central palpável, avaliar o estado hemodinâmico.

5. Se houver comprometimento hemodinâmico, proceder aos seguintes passos.

5.1. Abrir a via aérea, administrar oxigênio e ventilar, se necessário.

5.2. Ligar o monitor de ECG ou desfibrilador e avaliar o ritmo.

5.3. Verificar se o ritmo é lento ou rápido para a idade.

5.4. Verificar se o ritmo é regular ou irregular.

5.5. Medir a duração do complexo QRS $(<0,08$ segundo: complexos estreitos; $>0,08$ segundo: complexos largos).

\subsubsection{Bradiarritmias}

As bradiarritmias ${ }^{967,968}$ são as alterações de ritmo mais comuns que precedem a PCR no paciente pediátrico e quase sempre associadas à hipoxemia, hipotensão e acidose. Podem se manifestar com sintomas inespecíficos, como alterações no nível de consciência, sensação de cabeça vazia, tontura, síncope e fadiga, sendo potencialmente fatais.

Os principais sinais de gravidade incluem choque com hipotensão, perfusão insuficiente de órgão-alvo, alteração do nível de consciência e parada cardíaca.

FC inferior a 60 bpm, com perfusão inadequada, é uma indicação para o início das compressões torácicas.

A bradicardia pode ser classificada como:

- Primária: quando resulta de condições cardíacas congênitas e adquiridas, que lentificam a FC de despolarização espontânea diretamente nas células marca-passo normais do coração ou sua propagação através do sistema de condução cardíaca. As causas incluem problemas intrínsecos com o marca-passo cardíaco (por exemplo: anormalidade congênita), uma lesão pós-cirúrgica do marca-passo ou do sistema de condução, miocardiopatia e miocardite. 
- Secundária: resulta de condições que alteram a função normal do coração (isto é, lentificação do marca-passo do nó sinusal ou da condução através da junção. As causas incluem a hipóxia, acidose, hipotensão, hipotermia e efeito de medicações (Quadro 12.1).

\section{A) Tratamento das Bradiarritmias: Algoritmo de Bradicardia com Pulso em Pediatria}

O algoritmo para bradicardia966 apresentado a seguir contém as diversas etapas diagnósticas e terapêuticas a serem seguidas frente ao caso clínico.

\section{Fase 1}

Verifique a FC comparativamente ao normal em crianças (Tabela 12.1) e identifique as seguintes características da bradicardia no ECG: FC menor que 60 bpm; presença ou ausência de ondas $P$; duração normal ou aumentada do complexo QRS; relação entre as ondas P e os complexos QRS; e a onda $\mathrm{P}$ e complexo QRS podem não estar relacionados (dissociação atrioventricular).

\section{Fase 2}

Mantenha a perviabilidade das vias aéreas pérvias e adequada ventilação (assistida, como, por exemplo, com BVM) e oxigenação em alta concentração. Instalar monitor e desfibrilador. Providenciar um acesso vascular (intravenosa ou intraóssea) para administração de possíveis medicações é uma medida importante.

\section{Fase 3}

Deve-se determinar se a bradicardia está associada ou não a comprometimento cardiorrespiratório grave. A bradicardia clinicamente significativa é caraterizada por FC menor que 60 bpm, associada à evidência de perfusão sistêmica inadequada: hipotensão, má perfusão de órgãos-alvo, dificuldade respiratória e alterações de consciência.

\section{Fase 4}

Se a bradicardia não estiver associada à evidência de perfusão sistêmica inadequada, deve-se reavaliar o paciente, observando e criando condições para a perviabilidade das vias aéreas, ventilação e circulação adequadas. A seguir, devem-se investigar possíveis causas.

\section{Fase 5}

São apresentadas, no quadro 12.2, as principais condições a serem lembradas na presença de bradicardia com perfusão sistêmica preservada e respectivas condutas iniciais. As causas potencialmente reversíveis podem ser lembradas usando a regra mnemônica dos Hs, Bs e Ts.

Outra causa é o transplante cardíaco, no qual os receptores têm quase sempre "corações denervados" e podem necessitar de grandes doses de simpaticomiméticos ou marca-passo. Os medicamentos anticolinérgicos podem não ser efetivos, porque corações transplantados carecem de inervação vagal.

\section{Quadro 12.1 - Causas de bradicardias}

\begin{tabular}{|c|c|}
\hline Tipo & Causa \\
\hline Sinusal & $\begin{array}{l}\text { Disfunção do nó sinusal } \\
\text { Ação do sistema nervoso parassimpático com tônus vagal acentuado ou reflexos neurocardiogênicos } \\
\text { Efeito de medicações e substâncias tóxicas } \\
\text { Distúrbios metabólicos }\end{array}$ \\
\hline Primeiro grau & $\begin{array}{l}\text { Doença nodal atrioventricular intrínseca ou cardiopatias congênitas que acometam a estrutura do nó atrioventricular } \\
\text { Tônus autonômico exacerbado } \\
\text { Afecções inflamatórias (miocardite e cardite reumática) } \\
\text { Distúrbios eletrolíticos (por exemplo: hipercalemia) } \\
\text { Infarto de miocárdio (origem anômala de artéria coronária, doença de Kawasaki) } \\
\text { Intoxicações por medicações (por exemplo: bloqueadores dos canais de cálcio, bloqueador beta-adrenérgico e digitálicos) }\end{array}$ \\
\hline Segundo grau Mobitz tipo I & $\begin{array}{c}\text { Intoxicações por medicações (por exemplo: bloqueadores dos canais de cálcio, bloqueador beta-adrenérgico e digitálicos) } \\
\text { Qualquer condição que estimule o tono parassimpático } \\
\text { Infarto de miocárdio (origem anômala de artéria coronária e doença de Kawasaki) } \\
\text { Também pode ser observado em pessoas saudáveis }\end{array}$ \\
\hline Segundo grau Mobitz tipo II & $\begin{array}{l}\text { Geralmente resulta de lesão orgânica nas vias de condução } \\
\text { É raramente causada por tono parassimpático aumentado ou por medicações } \\
\text { Síndrome coronariana aguda (origem anômala de coronária e doença de Kawasaki) }\end{array}$ \\
\hline Terceiro grau & $\begin{array}{c}\text { QRS estreito - bloqueio congênito (lúpus eritematoso materno doença do tecido conjuntivo e cardiopatia congênita) ou adquirido } \\
\text { por intoxicação (medicamentos e substâncias tóxicas), processos inflamatórios (febre reumática), pós-operatório de cardiopatias } \\
\text { congênitas, ou infecciosos } \\
\text { QRS largo - lesão no sistema His-Purkinje, bloqueios em geral associados a cardiopatias estruturais (transposição corrigida de } \\
\text { grandes artérias, defeito do septo atrioventricular, ventrículo único) ou secundários à correção cirúrgica de cardiopatias congênitas; } \\
\text { esses bloqueios se revestem de gravidade } \\
\text { Infarto de miocárdio (origem anômala de coronária, doença de Kawasaki) }\end{array}$ \\
\hline
\end{tabular}


Quadro 12.2 - Causas reversíveis de bradicardia e tratamentos

\begin{tabular}{|c|c|}
\hline Causa reversível & Tratamento \\
\hline Hipóxia & Providencie a adequada oxigenação do paciente \\
\hline Hipotermia & Providencie o adequado aquecimento do paciente \\
\hline Hiperpotassemia & Restaure as concentrações normais de potássio \\
\hline Bloqueio atrioventricular & $\begin{array}{l}\text { Pode resultar de uma variedade de condições congênitas ou adquiridas. Deve ser considerada a possibilidade de } \\
\text { uso de atropina, juntamente de medicações cronotrópicas, além de marca-passo }\end{array}$ \\
\hline Toxinas, venenos e fármacos & $\begin{array}{l}\text { Pode haver necessidade de antídotos específicos. As causas toxicológicas mais importantes de bradiarritmia } \\
\text { incluem: } \\
\begin{array}{r}\text { - Inibidores da colinesterase (organofosforados, carbamatos e agentes neurotóxicos) } \\
\text { - Bloqueadores dos canais de cálcio } \\
\text { - Bloqueadores beta-adrenérgicos } \\
\text { - Digoxina e outros glicosídeos cardiacos } \\
\text { - Clonidina e outros agonistas alfa } 2 \text { de ação central } \\
\text { - Opioides } \\
\text { - Succinilcolina }\end{array}\end{array}$ \\
\hline Trauma & $\begin{array}{l}\text { Trauma craniencefálico: } \\
\text { - Se a pressão intracraniana estiver elevada e houver comprometimento do tronco cerebral, deve-se providenciar a } \\
\text { oxigenação e ventilação; se estiverem presentes sinais de herniação, a hiperventilação leve está indicada }\end{array}$ \\
\hline
\end{tabular}

\section{Fase 6}

Se a bradicardia (com FC $<60$ bpm) estiver associada com grave comprometimento cardiorrespiratório, apesar da efetiva oxigenação e ventilação, deve ser providenciada a compressão torácica (100 compressões/minuto). A hipoxemia é a principal causa das bradiarritmias. Deve-se providenciar a IOT, e garantir a ventilação e oxigenação adequadas.

Se o ritmo bradicárdico persistir, apesar das adequadas oxigenação e ventilação, são necessários medicamentos para aumentar a FC e melhorar a perfusão (ou seja, simpaticomiméticos, vide Fase 7), ou para inibir a estimulação vagal (ou seja, anticolinérgicos, vide Fase 8). Os pacientes que não respondem a estas intervenções podem requerer marcapasso transcutâneo ou transvenoso.

\section{Fase 7}

A administração da epinefrina está indicada se a bradicardia é sintomática e persistente, apesar da oxigenação e da ventilação efetivas. A ação das catecolaminas pode ser reduzida pela acidose e pela hipoxemia, indicando que a perviabilidade das vias aéreas, ventilação, oxigenação e manutenção da massagem cardíaca externa são essenciais.

A epinefrina deve ser administrada a cada 3 a 5 minutos se necessário. Dose: $0,01 \mathrm{mg} / \mathrm{kg}(0,1 \mathrm{~mL} / \mathrm{kg}$ da solução 1:10.000), intravenosa ou intraóssea, ou $0,1 \mathrm{mg} / \mathrm{kg}(0,1 \mathrm{~mL} /$ kg da solução 1:1000), endotraqueal.

Repetir a cada 3 a 5 minutos, se necessário. Diante da bradicardia persistente, pode-se realizar infusão contínua de epinefrina $(0,1$ a $0,3 \mathrm{mcg} / \mathrm{kg} /$ minuto) ou dopamina (2 a $20 \mathrm{mcg} / \mathrm{kg} / \mathrm{minuto})$, regulando-se a dose, de acordo com a resposta clínica.

\section{Fase 8}

Se houver suspeita de aumento do tônus vagal ou toxicidade por colinérgicos, ou ainda BAV primário, deve ser administrada a atropina, de preferência após o estabelecimento da oxigenação e da ventilação. Embora a atropina possa ser usada para o tratamento da bradicardia acompanhada de perfusão inadequada, a epinefrina é mais efetiva nesta situação.

O sulfato de atropina é um fármaco parassimpaticolítico, que acelera os batimentos sinusais e atriais, e aumenta a condução AV.

Não há nenhuma evidência que respalde o uso rotineiro de atropina como pré-medicação para evitar a bradicardia em IOT de emergência, sendo recomendada em situações em que exista maior risco de bradicardia e, nesta indicação, é permitido utilizar doses inferiores de 0,1 mg.

Dose: 0,02 mg/kg (limites em crianças, 0,1 a 0,5 mg; adolescentes, 0,1 a $1 \mathrm{mg}$ ) por dose, intravenosa ou intraóssea. A administração pode ser repetida em 5 minutos, até 1 mg em crianças (dose total) e $2 \mathrm{mg}$ em adolescente. A via endotraqueal pode ser usada (dose de 0,04 a 0,06 mg/kg) se o acesso venoso não estiver prontamente disponível. Aqui, a absorção para a circulação pode não ser confiável, e uma dose maior pode ser requerida (duas a três vezes a dose intravenosa). Um aumento exagerado da FC pode ocorrer após administração de atropina, mas este geralmente é bem tolerado no paciente pediátrico.

\section{Fase 9}

$\mathrm{Na}$ bradicardia persistente, deve-se realizar infusão contínua de epinefrina $(0,1$ a $0,3 \mathrm{mcg} / \mathrm{kg} / \mathrm{minuto})$ ou dopamina (2 a $20 \mathrm{mcg} / \mathrm{kg} / \mathrm{minuto}$ ), regulando-se a dose de infusão pela resposta clínica. $\mathrm{O}$ isoproterenol, a amina simpaticomimética e o agonista beta-adrenérgico podem ser também alternativas para a bradicardia persistente na dose de 0,1 a $1 \mathrm{mcg} / \mathrm{kg} /$ minuto.

Em casos selecionados de bradicardia causada por bloqueio cardíaco completo ou função anormal do nó 
sinusal, um marca-passo de emergência pode salvar vidas. O marca-passo transcutâneo não invasivo tem sido usado para tratar adultos com bradicardia, mas a experiência em crianças é limitada. Formas alternativas de estimulação de marca-passo não invasivo (transesofágico) ou invasivo (transtorácico ou transvenoso), usualmente requerem supervisão especializada.

\section{Fase 10}

Se ocorrerem outros ritmos ou PCR, deve-se recorrer à RCP.

\subsubsection{Taquiarritmias}

As taquicardias são definidas como FC acima do normal para a idade. Podem ser divididas, de acordo com a duração do complexo QRS, em taquicardias de complexo QRS largo ou estreito.

As taquiarritmias ${ }^{967,968}$ podem causar sinais e sintomas inespecíficos, que diferem conforme a idade do paciente, e os achados clínicos podem incluir palpitações, sensação de cabeça vazia, tontura, fadiga e síncope. Em lactentes, a taquiarritmia pode passar sem ser detectada por longos períodos (por exemplo: por horas, em casa) até que o DC seja significativamente comprometido, e o lactente desenvolva sinais de IC congestiva, como alimentação inadequada, respiração rápida e irritabilidade. Episódios de FC extremamente rápida são potencialmente fatais, caso comprometam significativamente o DC.

Solicite exames laboratoriais adequados (como determinação dos níveis de potássio, glicemia, cálcio ionizado, magnésio, gasometria para determinação do pH e causas de variação do $\mathrm{pH}$ ), conforme indicado (não adie as intervenções de emergência para realizar esses exames).

Avalie a condição neurológica. Trate a hipotermia.

Verifique a necessidade de medicações adequadas, dependendo do tipo de distúrbio do ritmo (por exemplo: supraventricular vs. ventricular).

Diante de uma taquicardia, deveremos avaliar se a perfusão sistêmica encontra-se adequada ou inadequada, antes de iniciarmos o tratamento. Seguem os organogramas de tratamento das taquicardias. ${ }^{966}$

\section{A) Taquicardias com Perfusão Adequada}

As TSV são originadas e mantidas por estruturas localizadas acima da bifurcação do feixe de Hiss. Os complexos QRS apresentam duração de 0,09 segundo ou menos, na maioria dos casos. As TSV podem se originar: no nó sinusal (taquicardia sinusal, por hiperautomatismo ou reentrada); nos átrios (TA ectópica, TA multifocal, flutter ou FA); no nó atrioventricular (TSV paroxística por reentrada nodal); e no tronco do feixe de Hiss (taquicardia juncional). Podem ainda envolver uma via acessória (síndrome de Wolff-Parkinson-White).

Durante a avaliação, é fundamental identificar alguma causa alternativa para a FC elevada, como a hipertermia. A seguir, apresentamos o algoritmo de orientação frente a taquicardias com perfusão adequada.

\section{Fase 1}

Manter as vias aéreas pérvias, e adequadas ventilação e oxigenação, além de um acesso vascular (intravenosa ou intraóssea). De acordo com a necessidade, utilizar máscara de oxigênio ou IOT. Monitor e desfibrilador devem ser instalados. O ECG deve ser realizado em 12 derivações.

\section{Fase 2}

Deve-se determinar se a taquicardia está associada ou não à perfusão adequada. A taquicardia é definida como FC acima do normal para a idade e condição clínica.

\section{Fase 3}

É importante determinar a duração do QRS em relação à idade e à FC. O QRS estreito remete à fase 4, e o QRS alargado para a idade, à fase 9.

\section{Fase 4}

Nesta fase, a alteração do ritmo deve ser analisada.

\section{Fase 5}

Manobras vagais devem ser realizadas. Deve ser obtido um ECG de 12 derivações antes e depois da manobra, registrando-se os batimentos continuamente, durante todo o procedimento. Em lactentes e crianças, a FC diminui com a estimulação do nervo vago. Nos pacientes com TSV, a estimulação vagal intensa pode interromper as taquicardias que utilizam o nó atrioventricular em seu circuito.

Várias manobras estimulam a atividade vagal, e as taxas de sucesso destas manobras variam, dependendo das condições da criança, do nível de cooperação e da idade. Em crianças pequenas, neonatos e lactentes, a manobra vagal mais efetiva é a aplicação de gelo na face. Um método é a colocação de gelo triturado (misturado ou não com água) em uma bolsa ou luva de plástico, e aplicar na face e região submandibular da criança por período de 5 a 20 segundos, sem que haja obstrução da ventilação (cobrindo somente a testa, os olhos e a ponte nasal). Se houver sucesso com este método, a TSV termina em segundos. Se não houve reversão e o paciente estiver estável, pode-se repetir a tentativa. Caso a segunda tentativa falhe, deve ser selecionado outro método ou terapia farmacológica.

As crianças podem realizar manobra de Valsalva soprando através de um canudo obstruído. Pode-se, ainda, provocar estímulo vagal por reflexo do vômito, mediante estimulação da orofaringe. Outros métodos para induzir a atividade vagal, como a massagem carotídea, podem ser efetivos, segundo dados obtidos em crianças maiores, adolescentes e adultos, mas podem causar complicações, não devendo ser usadas indiscriminadamente.

\section{Fase 6}

Não havendo resolução da taquiarritmia com as medidas descritas, os passos seguintes requerem via vascular para a administração de drogas. O acesso vascular é de suma 
importância neste estágio, tanto para sedação como para administração de DAA. A sedação pode ser realizada com uma das alternativas apresentadas a seguir (mais usadas nesta prática clínica).

\section{Fase 7}

Adenosina é o fármaco de escolha para o tratamento da TSV em crianças.

Dose: com monitorização contínua (ECG), administrar 0,1 $\mathrm{mg} / \mathrm{kg}$ (dose máxima inicial de $6 \mathrm{mg}$ ) em bólus intravenoso rápido, seguido de infusão também em bólus de água destilada ou soro fisiológico (3 a $5 \mathrm{~mL}$ ). A adenosina tem meia-vida muito curta, devendo ser administrada em segundos. Pode ser necessária dose mais alta na administração venosa periférica, em relação à administração em veia central. Se o fármaco for efetivo, haverá conversão imediata do ritmo. Ao contrário, se não houver efeito, a dose deve ser dobrada $(0,2 \mathrm{mg} / \mathrm{kg}$, segunda dose máxima de $12 \mathrm{mg}$ ).

A adenosina não é efetiva para flutter, fibrilação, TA e TV que não utilizam o nó atrioventricular em seu circuito de reentrada. Pode reforçar, porém, o diagnóstico destes distúrbios, especialmente se o ECG é gravado durante sua administração.

\section{Fase 8}

Caso não haja reversão da taquiarritmia com o uso da adenosina, outras drogas podem ser utilizadas, na tentativa de se obter o ritmo sinusal. Tais drogas podem ter ação no nó atrioventricular, no tecido atrial e nas vias acessórias.

Além disso, nos pacientes com taquiarritmia de difícil reversão ou com recorrências, apesar do uso de antiarrítmicos, a alternativa é tentar diminuir a resposta ventricular. Para isso, utilizam-se digitálicos, betabloqueadores ou bloqueadores de canais de cálcio por via oral, ou amiodarona intravenosa, além da procainamida e propafenona. As drogas podem ser administradas isoladamente ou em associação (exceção feita à amiodarona e procainamida, que não devem ser dadas em associação).

\section{Fase 9}

Diferenciar as taquicardias com QRS largo.

Fase 9.1

A TSV com QRS largo, ou seja, com condução aberrante (produzindo QRS maior do que 0,09 segundo) é incomum. O diagnóstico correto e a diferenciação entre TSV com condução aberrante e TV requerem a análise cuidadosa de 12 derivações. Ambas TSV e TV podem causar instabilidade hemodinâmica; assim, a evidência de estado de choque não é útil para diferenciá-las. Para simplicidade de abordagem, a taquicardia com QRS largo não diagnosticada previamente em um lactente ou uma criança, deve ser tratada como TV até prova em contrário.

\section{Fase 9.2}

Sobre a taquicardia ventricular, a TV com perfusão adequada é menos comum e de menor gravidade do que a
TV com perfusão inadequada. Depois de se avaliar o ECG de 12 derivações, deve-se providenciar acesso vascular para a administração de medicamentos, como a lidocaína, amiodarona, procainamida, propafenona ou verapamil. Neste momento, pode-se também considerar a cardioversão sincronizada, com adequadas sedação e analgesia. Tentamse, também, identificar e tratar as causas reversíveis da arritmia: oxigenoterapia nos quadros de hipóxia; reposicionamento de cateteres intracardíacos, caso estejam com a ponta localizada na parede ventricular; correção de distúrbios hidroeletrolíticos, quando existirem; suspensão de drogas que possam ser responsabilizadas como fatores etiológicos da arritmia, como, por exemplo, os digitálicos, em casos de intoxicação.

\section{Fase 10}

Sobre DAA, os pontos importante são os que seguem.

\section{Fase 10.1 - lidocaína}

Dose: $1 \mathrm{mg} / \mathrm{kg}$, intravenosa, em bólus, que poderá ser repetido a cada 5 minutos, caso seja necessário.

Bloqueia os canais de sódio, diminuindo a automaticidade e suprimindo as arritmias ventriculares de complexo largo. A lidocaína é um agente alternativo para tratamento de TV estável e TV com pulso ausente.

As demais drogas (amiodarona, procainamida e propafenona) são utilizadas nas mesmas doses da TSV. O uso do verapamil em TV é restrito à forma denominada TV idiopática fascicular de VE, também denominada TV sensível ao verapamil, devido à pronta resposta, com reversão ao ritmo sinusal após sua infusão.

\section{Fase 10.2 - amiodarona}

Dose: ataque de $5 \mathrm{mg} / \mathrm{kg}$, intravenosa, durante 20 a 60 minutos; impregnação de 10 a 40 mg/kg/dia, intravenosa, até cessar a arritmia.

\section{Fase 10.3 - procainamida}

Dose: ataque de 10 a $15 \mathrm{mg} / \mathrm{kg}$, intravenosa, durante 30 a 60 minutos, com monitorização contínua do ECG e monitorização frequente da PAS.

Fase 10.4 - propafenona

Dose: 1 a $2 \mathrm{mg} / \mathrm{kg}$, intravenosa, infundida em 5 minutos.

Fase 10.5 - verapamil

Dose: 100 a $150 \mathrm{mcg} / \mathrm{kg}$, intravenosa, em um período de infusão de 5 minutos; indicada nos pacientes com TV idiopática do VE.

\section{Fase 11}

A CVE consiste na aplicação de descarga elétrica sincronizada com a onda $\mathrm{R}$, na tentativa de se despolarizar totalmente o coração e interromper os circuitos de 
reentrada. A sincronização da energia fornecida com a onda $\mathrm{R}$ do ECG reduz a possibilidade de indução de FV, porque evita que a descarga elétrica ocorra durante o período vulnerável (onda T) do ciclo cardíaco. A CVE sincronizada pode também ser usada eletivamente em crianças com TV ou TSV estáveis.

No preparo para a CVE, deve ser estabelecido acesso vascular e devem ser providenciadas sedação e analgesia. Se houver instabilidade hemodinâmica do paciente, não devemos atrasar a CVE sincronizada para a obtenção do acesso vascular.

A dose inicial de energia para a CVE sincronizada é 0,5 a 1 joule/kg para TSV. Se a taquiarritmia persiste depois da primeira tentativa, devemos duplicar dose para 1 a 2 joules $/ \mathrm{kg}$. Se o ritmo não se converte ao sinusal, é necessária reavaliação do diagnóstico de TSV vs. TV.

Pacientes em uso de drogas, como betabloqueadores e inibidores dos canais de cálcio, podem apresentar bradicardia acentuada ou mesmo assistolia. Nestes casos, pode ser necessário o uso de drogas simpaticomiméticas, cronotrópicas positivas, bem como marca-passo provisório ou, ainda, a instalação de manobras de RCP. Nos pacientes digitalizados, com função ventricular comprometida e nível sérico baixo de potássio, pode ocorrer FV. Aqui, a desfibrilação ventricular é imperativa. Na presença de lesões orovalvares (insuficiência mitral e/ou tricúspide), átrios grandes e disfunção ventricular, devem ser pesquisados trombos intracavitários; se presentes, a CVE eletiva deve ser evitada, até que a anticoagulação plena seja instituída.

\section{B) Taquicardia com Perfusão Inadequada}

O algoritmo para taquicardia em lactentes e crianças com evidência de perfusão inadequada deve ser prontamente considerado se a criança mostrar sinais de comprometimento cardiorrespiratório grave, como choque com hipotensão ou perfusão inadequada dos órgãos-alvo; alteração de consciência; e perda súbita de consciência com atividade pulsátil detectável rápida.

A seguir, apresentaremos o algoritmo para taquicardia com perfusão inadequada, e as fases identificadas são correspondentes às do texto.

Fase 1

A manutenção das vias aéreas pérvias, as adequadas ventilação e oxigenação, e um acesso vascular (intravenoso ou intraósseo) se fazem necessários nesta situação. De acordo com a conveniência, deve-se utilizar cateter/máscara de oxigênio ou IOT. Devem-se ainda instalar monitor e desfibrilador tão logo seja possível. A realização de ECG de 12 derivações, se as condições cardiorrespiratórias assim o permitirem, é fundamental.

\section{Fase 2}

A identificação de ausência ou presença de pulso é necessária, orientado, respectivamente, para as fases 3 ou 4.

\section{Fase 3}

Manobras de RCP devem ser iniciadas na ausência de pulso.

\section{Fase 4}

Frente à FC aumentada para idade, deve-se considerar a duração do QRS, caminhando-se para a fase 5 ou 10, na dependência de ele estar normal para a idade ou alargado.

\section{Fase 5}

Nesta fase, recomenda-se obtenção de um ECG de 12 derivações e, se possível, derivação esofágica, para auxiliar na identificação do ritmo, desde que sua realização não retarde o tratamento.

\section{Fase 5.1 - Taquicardia Sinusal}

Esse tipo de taquicardia se desenvolve frente às necessidades orgânicas de aumentar o DC ou demanda aumentada de oxigênio por diversas causas.

\section{Fase 5.2 - Taquicardia Supraventricular}

A TSV é a taquiarritmia mais comum que produz comprometimento cardiovascular durante a infância. Embora a TSV seja inicialmente bem tolerada pela maioria dos lactentes e crianças, ela pode conduzir a IC congestiva, colapso cardiovascular e choque, particularmente se a função miocárdica estiver prejudicada.

A função cardiopulmonar durante episódios de TSV é influenciada pela idade da criança, pela função ventricular prévia e pela frequência ventricular. Crianças maiores sentem tontura, atordoamento ou desconforto torácico, ou simplesmente notam a FC mais rápida. Nos lactentes, entretanto, ritmos muito rápidos podem não ser detectados por longos períodos, até que o DC esteja significativamente prejudicado.

Algumas formas incessantes de TSV podem evoluir com quadro de IC congestiva e cardiomegalia, dependendo do tempo de duração e da FC (taquicardiomiopatia); as mais frequentes são a TA, a taquicardia atrioventricular tipo Coumel, a fibrilação e flutter atriais.

Se a função miocárdica de base está prejudicada (por exemplo, em uma criança com enfermidade cardíaca congênita ou miocardiopatia), a TSV pode produzir sinais de choque, em tempo relativamente curto. Pode ser difícil diferenciar a TSV como a causa primária do choque da taquicardia sinusal como tentativa de resposta compensatória frente à hipotensão de outra etiologia.

Devemos tratar a TSV com perfusão inadequada (IC congestiva, trabalho respiratório aumentado, alteração de consciência e choque) com CVE ou cardioversão química imediata (adenosina).

\section{Fase 6}

Se o paciente estiver instável, manobras vagais devem ser tentadas somente enquanto se prepara a CVE ou farmacológica. A cardioversão não deve ser retardada. Um ECG de 12 derivações deve ser obtido, com registro contínuo. 


\section{Fase 7}

Uma via para administração de drogas deve ser obtida, e a sedação, providenciada. A obtenção de acesso vascular é importante, porém não deve atrasar a CVE.

\section{Fase 8}

A administração de adenosina pode ser feita enquanto se aguarda a CVE.

Dose: $0,1 \mathrm{mg} / \mathrm{kg}$ (dose máxima inicial de $6 \mathrm{mg}$ ), em bólus intravenoso rápido, seguido de infusão também em bólus de água destilada ou soro fisiológico (3 a $5 \mathrm{~mL}$ ). Se não houver efeito, a dose deve ser dobrada $(0,2 \mathrm{mg} / \mathrm{kg}$, segunda dose máxima de $12 \mathrm{mg}$ ). Deve ser realizada sempre com monitorização cardíaca contínua.

\section{Fase 9}

É importante tentar diferenciar TSV com aberrância de condução da TV.

\section{Fase 9.1 - Taquicardia Supraventricular com QRS Largo}

Ambas TSV e TV podem causar instabilidade hemodinâmica. A evidência de estado de choque não é útil para diferenciálas. Para simplicidade de abordagem, a taquicardia de QRS largo não diagnosticada previamente em um lactente ou uma criança deve ser tratada como TV.

\section{Fase 9.2 - Taquicardia Ventricular}

Na história clínica, avalia-se a importância da arritmia como causa de sintomas como palpitações e tonturas. Antecedente de síncope deve ser considerado, pois é manifestação de comprometimento hemodinâmico secundário à TV (afastando-se, evidentemente, a possibilidade de outras causas, como neurológica, vascular ou endócrina).

Devemos tentar identificar a taquicardia do tipo torsades des pointes e a TV com pulso ausente, porque estas formas requerem tratamento específico (como, por exemplo, magnésio e desfibrilação, respectivamente), diferentemente da TV com pulso presente.

\section{Fase 10}

A CVE sincronizada é o tratamento de escolha para pacientes com taquiarritmias (TSV e TV) que têm perfusão inadequada, hipotensão, ou IC. Se a condição do paciente é instável, não devemos atrasar a cardioversão sincronizada na tentativa de conseguir acesso vascular.

A energia para a CVE é 0,5 a 1 joule/kg na TSV. Se a taquiarritmia persiste depois da primeira tentativa, a energia deve ser duplicada para 1 a 2 joules $/ \mathrm{kg}$. Se o ritmo não se converte ao sinusal, reavaliar o diagnóstico de TSV vs. TV.

\section{Fase 11}

No controle da arritmia, é recomendado utilizar apenas um antiarrítmico, e em caso de insucesso, recorrer novamente à CVE. Devemos evitar a associação de outros fármacos, pelo alto risco de indução de arritmias.
Fase 11.1 - Lidocaína

Dose: $1 \mathrm{mg} / \mathrm{kg}$, intravenosa, em bólus, que pode ser repetida a cada 5 minutos caso seja necessário. A lidocaína é um agente alternativo para tratamento de TV instável ou não.

\section{Fase 11.2 - Amiodarona}

Dose: ataque de $5 \mathrm{mg} / \mathrm{kg}$, intravenosa, durante 20 a 60 minutos; impregnação de 10 a 40 mg/kg/dia, intravenosa, até cessar a arritmia.

Fase 11.3 - Procainamida

Dose: infusão inicial de 10 a $15 \mathrm{mg} / \mathrm{kg}$, intravenosa, durante 30 a 60 minutos. Em pacientes com disfunção miocárdica, a infusão deve ser feita lentamente, a fim de se evitar hipotensão arterial sistêmica.

\subsection{Situações Especiais em Pediatria}

\subsubsection{Choque Séptico}

Iniciar a terapia do choque séptico com solução cristaloide isotônica (Classe Ila, LOE C - LD). Não parece haver diferença na sobrevivência da criança tratada com coloide comparada com a tratada com solução salina isotônica no choque séptico. ${ }^{969-973}$ A monitorização da saturação venosa de oxigênio central em veia cava superior pode ser útil na titulação da terapia em lactentes e crianças com choque séptico. Valores acima de $70 \%$ estão relacionados à melhor prognóstico em sepse com instabilidade.

Ventilação assistida precoce deve ser considerada como parte de estratégia de tratamento neste grupo. ${ }^{970}$

\subsubsection{Choque Hipovolêmico}

Usar solução cristaloide isotônica (Ringer com lactato ou solução salina isotônica) no início do tratamento do choque hipovolêmico (Classe I, LOE C - EO). Não existe benefício no uso de coloides como a albumina durante a fase inicial da ressuscitação volêmica.

Tratar sinais de choque com infusão em bólus de 20 $\mathrm{mL} / \mathrm{kg}$ de solução cristaloide isotônica mesmo se a pressão arterial estiver normal (Classe II B, LOE B - R). Os cristaloides têm associado um benefício maior que os coloides na sobrevivência de crianças com choque secundário a trauma, injúria cerebral traumática e queimados. Não há evidência para o uso de uma solução cristaloide específica. Se não melhorar a perfusão, administrar mais $20 \mathrm{~mL} / \mathrm{kg}$.

Não há dados suficientes para se recomendar a utilização de solução salina hipertônica em choque associado a injúria cerebral ou hipovolemia. ${ }^{971,972}$

\subsubsection{Trauma}

Alguns aspectos da RCP no trauma requerem maior atenção porque, quando realizados de modo impróprio, são responsáveis pela maior ocorrência de morte pediátrica prevenível. ${ }^{973,974}$ 
Erros comuns na ressuscitação de crianças vítimas de trauma incluem o manuseio e a manutenção da via aérea aberta; falha em prover adequada ressuscitação da volemia; e falha em reconhecer e tratar hemorragias internas. Envolve a necessidade precoce de cirurgião qualificado, e o transporte adequado de criança com politraumatismo para centro pediátrico especializado.

A seguir, alguns dos aspectos importantes na ressuscitação do trauma:

1. Se suspeita de lesão cervical: restringir a movimentação da coluna cervical e prevenir tração ou movimento da cabeça e pescoço. Abrir e manter a via aérea com elevação da mandíbula, e não inclinar a cabeça.

2. Se a via aérea não puder ser aberta com elevação da mandíbula, estender a cabeça e levantar o queixo, pois é importante estabelecer uma via aérea pérvia. Devido à desproporção da cabeça, que é maior nas crianças, o bom posicionamento necessita de apoio da porção occipital, com elevação do tronco, evitando a flexão cervical.

3. A hiperventilação de rotina não deve ser realizada, mesmo na presença de injúria cerebral (Classe III, LOE C). Breve hiperventilação intencional pode ser usada como terapia de resgate, se houver sinais de herniação cerebral iminente (aumento súbito de medidas de PIC, dilatação de uma ou ambas as pupilas, diminuição da resposta à luz, bradicardia e hipertensão arterial). ${ }^{975}$

4. Lesão torácica deve ser suspeitada em todos os traumas tóraco-abdominais, mesmo na ausência de lesões externas. Pneumotórax hipertensivo, hemotórax ou contusão pulmonar podem dificultar a ventilação e oxigenação.

5. Se trauma maxilofacial ou suspeita de fratura craniana basilar deve-se inserir tubo orogástrico em vez de nasogástrico ${ }^{976}$ (Classe Ila, LOE C).

6. Em criança com PCR por trauma penetrante com pouco tempo de transporte, deve ser considerada a realização de toracotomia de ressuscitação (Classe IIb, LOE C).

7. Considerar hemorragia intra-abdominal, pneumotórax hipertensivo, tamponamento pericárdico, lesão de medula óssea em lactentes e crianças, e hemorragia intracraniana em lactentes, como causas de choque.

\subsubsection{Parada Cardiorrespiratória por Afogamento}

A OMS estima que ocorram aproximadamente 372 mil mortes por ano por afogamento, sendo 90\% dos óbitos em países de baixa e média renda. ${ }^{977}$ Os fatores associados com afogamento (suicídio, acidentes de tráfego, abuso de drogas e álcool) variam de país para país. ${ }^{978}$ Dentre as causas, as externas são os principais responsáveis por óbitos em menores que 4 anos de idade no Brasil.

O ILCOR define afogamento como um processo que resulta em insuficiência respiratória decorrente de imersão/submersão em líquido. ${ }^{979}$ Após a submersão, a vítima inicialmente segura a respiração antes de desenvolver laringoespasmo. Durante este processo, a vítima frequentemente engole grande quantidade de água e pode broncoaspirar também. Como resultado, evolui para hipóxia e hipercapnia. Sem ajuda e retorno da ventilação, a vítima apresenta bradicardia antes de evoluir com PCR, ${ }^{979-982}$ sendo a correção da hipóxia fator determinante para o RCE.

O tratamento de uma vítima de afogamento envolve quatro fases distintas, mas interrelacionadas entre si: o resgate na água, SBV, SAV e cuidados pós-ressuscitação.

O resgate e a ressuscitação de uma vítima de afogamento envolvem equipe multiprofissional.

\section{A) Resgate na água}

Certifique-se da sua segurança, e minimize os riscos para si e para a vítima.

Sempre que possível, salve a vítima de afogamento sem entrar na água.

Se entrar na água for essencial para o resgate da vítima, pegue um resgate flutuante ou algum objeto flutuante.

É mais seguro entrar na água com dois socorristas do que sozinho.

Nunca afunde a cabeça primeiro na água, pois você pode perder contato visual com a vítima e corre o risco de uma lesão espinhal.

A incidência de lesão de coluna cervical em vítimas de afogamento é muito baixa (aproximadamente 0,5\%). ${ }^{983}$ Imobilização da coluna pode ser difícil dentro da água e pode retardar a remoção, colares cervicais mal posicionados podem causar obstrução da via aérea em pacientes inconscientes. ${ }^{982}$ A imobilização da coluna cervical não é indicada, a menos que sinais de injúria severa sejam aparentes ou se a história for consistente.

Se a vítima está em apneia e sem pulso, remova-a da água o mais rápido possível, enquanto tenta limitar a flexão e extensão do pescoço. ${ }^{984-986}$

\section{B) Suporte Básico de Vida no Resgate por Afogamento}

\section{Ventilações de resgate}

O primeiro e mais importante tratamento para a vítima de afogamento é o alívio da hipoxemia. O pronto início das ventilações de resgate ou Ventilação com Pressão Positiva (VPP) melhora a sobrevida. ${ }^{986,987}$ Se possível, suplemente as respirações de resgate ou ventilações com oxigênio. Administre cinco ventilações/respirações de resgate, assim que possível.

\section{Compressões Torácicas}

A vítima deve estar em uma superfície plana, pois as compressões na água não são efetivas, aplique e mantenha 30 compressões para duas ventilações. A maioria das vítimas de afogamento tem PCR sustentada secundária à hipóxia. Desta forma, RCP apenas com compressões deve ser evitada.

\section{Desfibrilador Externo Automático}

Se estiver disponível, seque o tórax da vítima, fixe as pás, e ligue e administre os choques conforme solicitação do DEA. 
Regurgitação durante a Ressuscitação Cardiopulmonar

Esteja preparado para aspiração devido à alta probabilidade de vômitos pela água engolida; vire o paciente de lado e descomprima o estômago, de preferência com uma sonda nasogástrica ou orogástrica, após assegurar a via aérea. Cuidado especial para a lesão de coluna cervical, que não deve retardar as manobras de RCP. ${ }^{988-990}$

\section{C) Suporte Avançado de Vida no Resgate por Afogamento}

\section{Via Aérea e Respiração}

Administre oxigênio de alto fluxo, idealmente através de uma máscara com reservatório, a uma vítima que está respirando espontaneamente. ${ }^{991}$

Considere Ventilação Não Invasiva (VNI) ou pressão positiva contínua em vias aéreas na falha de resposta com oxigênio de alto fluxo. ${ }^{992}$

Considere intubação endotraqueal precoce nos pacientes que falharam com as medidas iniciais e naqueles com depressão do nível de consciência.

Utilize indução com sequência rápida com pressão cricoide para reduzir o risco de aspiração. ${ }^{993}$

Depois de confirmada a posição do tubo, titule a Fração Inspirada de Oxigênio $\left(\mathrm{FiO}_{2}\right)$ para atingir SatO ${ }_{2}$ entre 94 e $98 \% .{ }^{992}$

- Ajuste a PEEP em pelo menos 5 a $10 \mathrm{cmH}_{2} \mathrm{O}$. PEEP mais elevadas (15 a $20 \mathrm{cmH}_{2} \mathrm{O}$ ) podem ser necessárias para pacientes severamente hipóxicos. ${ }^{994}$

\section{Circulação e Desfibrilação}

Diferenciar se a vítima está em parada respiratória ou cardíaca é particularmente importante no afogamento. O retardo no início das compressões torácicas se a vítima está em parada cardíaca pode reduzir a sobrevida. A ocorrência do gasping pós-PCR muitas vezes é difícil de distinguir dos esforços respiratórios iniciais da recuperação de uma vítima de afogamento. A palpação de pulso como único indicador de PCR pode gerar incertezas, devendo ser iniciadas as compressões torácicas após 10 segundos de checagem. ${ }^{995} \mathrm{Se}$ a vítima está em PCR, siga os protocolos do SAV.

\section{Descontinuação dos esforços de ressuscitação}

A decisão de descontinuar os esforços de RCP em uma vítima de afogamento é notoriamente difícil. ${ }^{996}$ Continue as manobras a não ser que você tenha claras evidências de que seus esforços serão inúteis (inúmeras lesões traumáticas, rigor mortis, putrefação etc.) ou se o deslocamento para um local com auxílio médico não for possível. Sobrevida sem dano neurológico tem sido relatado em vítimas submersas por mais de 60 minutos, mas esses casos raros quase invariavelmente ocorrem em água gelada. ${ }^{996,997}$

\section{Cuidados Pós-Ressuscitação: Injúria Pulmonar}

Vítimas de afogamento são de risco para desenvolver a Síndrome da Angústia Respiratória Aguda (SARA). ${ }^{998,999}$
A severidade da lesão pode variar desde leve/autolimitada até hipoxemia refratária. Nos casos mais graves, a ECMO tem sido utilizada com sucesso. ${ }^{1000,1001}$ Pneumonia é comum após o afogamento, mas o uso de antibioticoterapia profilática não tem mostrado benefícios.

\section{Hipotermia após Afogamento}

Vítimas de afogamento podem desenvolver hipotermia primária (submersão em água gelada $<5^{\circ} \mathrm{C}$ ) ou secundária (perda de calor pela evaporação durante a tentativa de RCP). Não há evidências que guiem o tratamento deste tipo de paciente, pois os trabalhos atuais mostram tanto benefícios no reaquecimento80 quanto na manutenção da hipotermia. ${ }^{1002,1003}$

\subsubsection{Anafilaxia}

Anafilaxia é uma reação de hipersensibilidade sistêmica grave com risco de morte. Caracteriza-se pela rápida falência ventilatória e/ou respiratória e/ou cardiocirculatória, geralmente associada a alterações cutâneo-mucosas. A liberação maciça de histamina e de outros mediadores inflamatórios causa vasodilatação sistêmica, aumento da permeabilidade capilar e edema extracelular.

Nos casos de anafilaxia, devemos utilizar as manobras de RCP, além do tratamento específico. Deve-se administrar adrenalina a todos os doentes em risco de morte, por via intramuscular, nas seguintes doses:

- 12 anos e adultos: 500 mcg.

- 6 a12 anos: 300 mcg.

- 6 meses a 6 anos: 150 mcg.

- < 6 meses: 150 mcg.

Deve-se administrar oxigênio no início na maior concentração disponível, utilizando máscara com reservatório, e infundir rapidamente $20 \mathrm{~mL} / \mathrm{kg}$ de fluidos por via endovenosa na criança; se necessário, repetir.

Outros medicamentos como corticosteroides e antihistamínicos são indicados na continuidade do tratamento hospitalar. Se ocorrer PCR, iniciar medidas de RCP. Se possível, deve-se realizar a dosagem de triptase dos mastócitos, que auxilia na confirmação do diagnóstico de anafilaxia (três amostras: a primeira, logo que a reanimação começa, outra 1 a 2 horas depois do início dos sintomas, e a terceira amostra 24 horas após, no período de convalescença). ${ }^{1004}$

\subsubsection{Choque Anafilático}

O choque anafilático resulta de uma reação grave a uma droga, vacina, alimento, toxina, planta, veneno ou outro antígeno. $\mathrm{O}$ óbito pode ocorrer imediatamente ou a criança pode desenvolver sintomas de fase aguda, que geralmente começam a 5 a 10 minutos após a exposição.

Os sinais e sintomas podem incluir ansiedade ou agitação, náuseas e vômitos, urticária (erupção cutânea), angioedema (inchaço da face, lábios e língua), angústia respiratória com estridor ou sibilos, hipotensão e taquicardia.

O tratamento do choque anafilático enfoca o tratamento de problemas cardiorrespiratórios potencialmente fatais e a 
reversão ou bloqueio dos mediadores liberados como parte da resposta alérgica descontrolada. Como o angioedema pode resultar em uma obstrução total da via aérea superior, a pronta intervenção na via aérea é indicada. $\mathrm{O}$ aspecto mais importante da terapia é a administração de epinefrina para reverter a hipotensão e a liberação de histamina e de outros mediadores da resposta alérgica. A ressuscitação volêmica também pode ser útil para restaurar a pressão arterial.

Além da epinefrina, administrar o albuterol, se necessário, para o tratamento do broncoespasmo, por nebulização intermitente ou nebulização contínua e/ou anti-histamínicos como os bloqueadores $\mathrm{H}_{1}$ (difenidramina) e $\mathrm{H}_{2}$. A combinação de bloqueadores $\mathrm{H}_{1}$ e $\mathrm{H}_{2}$ pode ser mais eficaz que cada anti-histamínico administrado isoladamente. O uso de corticosteroides, como a metilprednisolona ou equivalente, muitas vezes se faz necessário.

A observação é indicada para identificar e tratar os sintomas de fase tardia, que podem ocorrer várias horas após os sintomas de fase aguda. A probabilidade de sintomas de fase tardia aumenta na proporção da gravidade dos sintomas de fase aguda.

\subsubsection{Crise Hipoxêmica}

A hipoxemia é responsável por cerca de 10 a 15\% dos $\operatorname{casos}^{1005,1008}$ nas unidades de emergência pediátrica, sendo dois terços devidos a queixas do trato respiratório, como a bronquiolite, as crises de sibilância e a pneumonia.

Estas afecções podem acompanhar ou mesmo ser a forma de apresentação clínica de uma cardiopatia congênita, que tem incidência de aproximadamente $1 \%$ na população.

Dentre as cardiopatias que apresentam cianose, destacamos: tetralogia de Fallot em 10\%, transposição de grandes artérias em $7 \%$, atresia tricúspide em $2 \%$, tronco arterial comum em 1 a 2,5\%, drenagem anômala total de veias pulmonares em 1\% e anomalia de Ebstein em 0,5\%. ${ }^{1009,1010}$

O estado hipoxêmico é uma situação clínica caracterizada por um importante decréscimo do conteúdo arterial de oxigênio, e por redução do transporte e da oferta do mesmo aos tecidos. As crises hipoxêmicas são mais frequentes entre os 3 meses e 2 anos de vida, devido à redução e/ou ao fechamento do canal arterial, à presença de anemia fisiológica, ao aumento de massa corpórea, ao aumento da atividade física da criança e à hipertrofia infundibular progressiva. Tem duração entre 15 a 60 minutos e, clinicamente, há aumento da cianose, com taquipneia e agitação com progressão para flacidez, hipotonia, sonolência e possibilidade de convulsão, coma e morte.

O tratamento tem por objetivo atuar rapidamente no ciclo vicioso. São medidas gerais: sedação e analgesia quando a criança estiver agitada; adequação da volemia, mantendo a administração endovenosa de fluidos, bem como a correção de anemia/poliglobulia; correção agressiva dos distúrbios metabólicos / hidroeletrolíticos; oferta de oxigênio da forma mais confortável possível, para que não piore a agitação do paciente; atuação precoce em processos infecciosos. Compõem as medidas específicas:
- Clínica: aumentar a RVS, relaxar o infundíbulo ventricular direito e tratar processos infecciosos, quando presentes. Para aumentar a RVS, podemos colocar o paciente em posição genopeitoral, ou usar drogas como fenilefrina e noradrenalina. No relaxamento infundibular direito, podemos administrar morfina, que atua como sedativo e diminui a hiperpneia, por atuação direta no sistema nervoso central. Outra droga que atua no infundíbulo ventricular é o metoprolol (betabloqueador).

- Hemodinâmica: realizada para criar condições, paliativas ou corretivas, que aumentem o fluxo pulmonar ou a mistura nas cardiopatias com circulações sanguíneas em paralelo.

- Cirurgia: na emergência, são indicadas quando há falha nas condutas anteriores. O objetivo é criar mecanismos que favoreçam a oferta de oxigênio aos tecidos, seja pelo direcionamento de fluxo sanguíneo aos pulmões ou pela desobstrução ao fluxo pulmonar. Podem ser paliativas ou corretivas.

As doses dos medicamentos preconizados na crise hipoxêmica estão expostas na tabela 12.3.

\subsection{Cardiopatia Congênita - Ventrículo Único}

Manobras de RCP padronizadas devem ser realizadas em lactentes e crianças com cardiopatia congênita e anatomia de ventrículo único, que são submetidas à cirurgia com shunt sistêmico para aumentar o fluxo pulmonar ou reconstrução paliativa estagiada na síndrome de hipoplasia do coração esquerdo.

Neonatos com alto fluxo pulmonar sistêmico, antes do primeiro estágio da cirurgia paliativa, devem ter VM com redução da ventilação por minuto, aumentando a fração inspirada de dióxido de carbono com $\mathrm{PaCO}_{2}$ de 50 a 60 $\mathrm{mmHg}$ ou com sedação, administrando opioides. O manuseio no pós-operatório objetiva manter o delicado equilíbrio entre as resistências vasculares. A administração de oxigênio deve ser ajustada visando ao equilíbrio do fluxo sistêmico e pulmonar, monitorando a saturação de oxi-hemoglobina e mantendo-a próximo a $80 \% .^{1011}$

A pressão parcial de dióxido de carbono no final da expiração $\left(\mathrm{PET} \mathrm{CO}_{2}\right)$ no paciente com ventrículo único durante a PCR não é indicador confiável, devido à rápida mudança do fluxo pulmonar, e não reflete o DC real durante a RCP. ${ }^{1012}$

\section{Tabela 12.3 - Doses dos medicamentos preconizados na crise} hipoxêmica

\begin{tabular}{|c|c|}
\hline Analgesia e sedação & Morfina $0,1 \mathrm{mg} / \mathrm{kg} /$ dose IV ou IM \\
\hline Betabloqueador & Metoprolol 0,05 a 0,1 mg/kg/dose IV \\
\hline $\begin{array}{l}\text { Aumentar a resistência vascular } \\
\text { periférica }\end{array}$ & $\begin{array}{c}\text { Fenilefrina } 5 \text { a } 20 \mathrm{mcg} / \mathrm{kg} / \mathrm{dose} \text { a cada } \\
10 \text { a } 15 \text { minutos OU } \\
\text { Noradrenalina } 0,05 \text { a } 2 \mathrm{mcg} / \mathrm{kg} / \text { minuto } \\
\text { IV contínuo }\end{array}$ \\
\hline
\end{tabular}

IV: via intravenosa; IM: via intramuscular. 
Neonatos em baixo DC podem se beneficiar do uso de vasodilatadores sistêmicos, como bloqueadores de receptores alfadrenérgicos (fenoxibenzamina), que podem aumentar a liberação sistêmica de oxigênio (Classe Ila, LOE B), ${ }^{1013}$ assim como a milrinona ou o nipride, ${ }^{1014}$ que também reduzem a RVS e melhoram a oferta sistêmica de oxigênio, diminuindo a incidência de choque cardiogênico e melhorando sua sobrevida. A monitorização do consumo de oxigênio na veia cava superior e a espectroscopia após o primeiro estágio da cirurgia podem ajudar a detectar mudanças hemodinâmicas, evitando a PCR, considerando a indicação da instalação de ECMO (Classe II a, LOE B). ${ }^{1015}$

Em neonatos e lactentes portadores de ventrículo único, que necessitam de shunt para aumentar o fluxo pulmonar, a heparina deve ser utilizada.

Crianças em pós-operatório de cirurgia cavopulmonar bidirecional ou total (Fontan) devem ter hipoventilação e pressão negativa na ventilação respiratória que melhoram a oferta de oxigênio e o DC (Classe Ila, LOE B). ${ }^{1016}$ Em falência da circulação de Fontan e na reanimação, a ECMO pode beneficiar o paciente (Classe II a, LOE B). ${ }^{1017}$

\subsection{Hipertensão Pulmonar}

Dois estudos pediátricos observacionais ${ }^{1018,1019}$ mostraram que crianças com hipertensão pulmonar apresentam maior risco de PCR. Não existem estudos que demostrem superioridade de alguma terapia específica no tratamento da PCR nestas crianças. ${ }^{1020-1025}$

Não há evidências sobre malefícios ou benefícios a respeito de hiperventilação em crianças com hipertensão pulmonar durante a PCR.

Quatro estudos (Classe Ila, LOE C) em adultos e crianças portadoras de hipertensão pulmonar em descompensação ou PCR ${ }^{1025}$ mostraram que o suporte mecânico ventricular melhora a sobrevida.

Os reanimadores devem seguir as recomendações do SVA em crianças, incluindo oxigenação e ventilação na PCR em crianças com hipertensão pulmonar, enfatizando $\mathrm{FiO}_{2}$ elevada e alcalose/hiperventilação para reduzir a RVP. Se a medicação anti-hipertensiva pulmonar de uso contínuo, quer sejam por via endovenosa ou inalatórias, foi interrompida por algum motivo, elas devem ser reinstituídas imediatamente. ${ }^{1026}$

O óxido nítrico inalatório, ou a prostaciclina inalatória, ou similares devem ser considerados na tentativa de reduzir a RVP. Se indisponível, considerar o uso de prostaciclina por via endovenosa em bólus (não disponível no Brasil até o momento)

\subsection{Morte Súbita}

PCR pode ser súbita, mas geralmente é precedida de causas como hipovolemia, tamponamento cardíaco, infarto do miocárdio, pneumotórax hipertensivo e arritmias, que deterioram progressivamente a condição do paciente. Se detectadas e tratadas precocemente, podem ser reversíveis, melhorando a sobrevida. Em casos de PCR em criança ou adolescente, deve-se fazer uma anamnese com antecedentes pessoais e familiares adequados, além de rever todos os ECG disponíveis. Todos os lactentes, crianças e adolescentes com morte súbita, devem ser submetidos à autópsia, para a determinação de uma canalopatia, e os familiares devem ser avaliados.

\subsection{Transplante Cardíaco}

O transplante cardíaco tem possibilitado sobrevida das crianças com cardiopatias complexas e refratárias à terapêutica convencional. ${ }^{1027,1028}$

No seguimento há situações em que estas crianças podem necessitar de cuidados imediatos, incluindo RCP, que são: rejeição aguda, que pode levar a quadros de choque cardiogênico, arritmias ventriculares e PCR; doença vascular do enxerto, por lesões nas artérias coronarianas com oclusão do seu lume e infarto do miocárdio, arritmias e morte súbita; e choque séptico: pela própria condição da criança submetida à imunossupressão.

\subsection{Disfunção Miocárdica Aguda em Pós-Operatório}

\subsubsection{Oxigenação por Membrana Extracorpórea}

A ECMO é o uso de dispositivos mecânicos como forma alternativa de prover oxigenação tecidual, por períodos prolongados de tempo, a pacientes com falência pulmonar e/ ou cardíaca. ${ }^{1029,1030}$ Trata-se de suporte cardiopulmonar usado enquanto ocorre a recuperação desses órgãos.

Sua aplicação permite a redução de outras opções terapêuticas e seus efeitos iatrogênicos, como uso de altas frações inspiradas de oxigênio, altas pressões de VM e altas doses de agentes inotrópicos e vasopressores. ${ }^{1030}$

Basicamente ocorrem a drenagem de sangue da circulação venosa e o bombeamento desse sangue para uma membrana de oxigenação artificial, capaz também de remover o gás carbônico e, então, há o retorno de sangue aquecido para a circulação arterial ou venosa do paciente. ${ }^{1029-1032}$

\subsubsection{Populações de Pacientes Tratados com Oxigenação por Membrana Extracorpórea}

\section{Neonatos}

As causas respiratórias são as mais frequentes indicações nesse grupo (Quadro 12.3). No entanto, o surgimento da ventilação de alta frequência e de terapêuticas, como o óxido nítrico e o surfactante, reduziram as necessidades de sua aplicação. Da mesma forma, as melhorias no manejo de pacientes infectados com Streptococcus do grupo B e da falência cardiorrespiratória por síndrome de aspiração de mecônio também reduziram o uso de ECMO. Houve expansão de sua utilização, porém, nos neonatos com outros tipos de choque séptico. Os pacientes com hérnia diagragmática congênita continuam tendo a pior taxa de sobrevida na população neonatal. ${ }^{1030}$

\section{Crianças}

Nesse grupo de pacientes, a maior parte das indicações de ECMO são de etiologia cardiocirculatória segundo dados 
Quadro 12.3 - Critérios de inclusão para suporte extracorpóreo em causas respiratórias neonatais

\begin{tabular}{l}
\hline Gestação > 34 semanas \\
Peso maior que $2 \mathrm{~kg}$ \\
Ventilação mecânica por menos de 14 dias \\
Doença pulmonar reversivel \\
Índice de oxigenação > 35 \\
Ausência de doença congênita cardíaca \\
Ausência de anomalia congênita letal \\
Ausência de evidência de dano cerebral irreversível|26 \\
\hline
\end{tabular}

do International Registry for Extracorporeal Life Support (Quadro 12.4). Em relação à sobrevida, as crianças mais velhas (10 a 18 anos) têm estatisticamente $(p<0,01)$ menor sobrevida (50\%) do que as mais jovens (até 61\%). ${ }^{1030}$ Há tendência ao aumento de ECMO venovenosa nessa faixa etária. ${ }^{1029-1031}$

\section{Paciente com Patologias Cardíacas}

Atualmente este é o grupo que mais cresce como indicação de ECMO (Quadros 12.5 e 12.6). Nos neonatos, o mais frequente é ser colocado em ECMO por disfunção cardíaca no pós-operatório, mas estão aumentando os casos em que a ECMO é instalada para estabilização pré-operatória e na falência miocárdica relacionada à sepse. Nos pacientes cardíacos pediátricos, após o período neonatal, as doenças cardíacas congênitas, as miocardites e as cardiomiopatias são as indicações básicas de ECMO. ${ }^{1030}$

\subsubsection{Fisiologia da Oxigenação por Membrana Extracorpórea}

Compreender a fisiologia da ECMO depende do entendimento da fisiologia respiratória e da interação entre as duas. O objetivo final da ECMO é manter adequadamente a oferta de oxigênio aos tecidos e a remoção do gás carbônico.

A melhor medida para avaliação clínica da oferta adequada de oxigênio aos tecidos é a saturação venosa mista de

Quadro 12.4 - Critérios de inclusão para suporte extracorpóreo em causas respiratórias em crianças

\begin{tabular}{l}
\hline Insuficiência pulmonar de etiologia potencialmente reversível \\
Índice de oxigenação $>40$ e insuficiência respiratória mesmo com suporte \\
ventilatório máximo \\
Hipercarbia e $\mathrm{pH}<7,1$ \\
Relação $\mathrm{PaO}_{2} / \mathrm{FiO}_{2}<100$ \\
Ventilação mecânica por menos de 14 dias \\
Nenhuma contra-indicação, tais como dano neurológico irreversível, falência de \\
múltiplos órgãos, acometendo mais de 3 órgãos
\end{tabular}

$\mathrm{PaO}_{2} / \mathrm{FiO}_{2}$ : pressão parcial de oxigênio/fração inspirada de oxigênio. oxigênio, cujo valor normal está entre aproximadamente 65 e $80 \%$, dependendo da fisiopatologia e assumindo anatomia cardíaca normal.

O oxigenador de membrana é um pulmão artificial incorporado ao circuito da ECMO. É um componente que dirige o fluxo de sangue em uma grande superfície de área em espiral, envelopes de silastic ou membranas de fibra oca, na qual ocorre a troca de gases pelo mesmo princípio da difusão. ${ }^{1031} \mathrm{O}$ fluxo de gás adicionado ao oxigenador é chamado de sweep gas.

\subsubsection{Tipos de Suporte com Oxigenação por Membrana Extracorpórea}

É importante ressaltar que ECMO é sempre um bypass parcial, diferente do bypass total, que é requerido em algumas cirurgias cardíacas. Enquanto os princípios da troca de gases e do fluxo sanguíneo são os mesmos, há grandes e importantes diferenças entre a CEC usada durante a cirurgia cardiovascular e a ECMO. Na CEC, sempre se usa um bypass venoarterial total. Uma cânula drena o retorno venoso das veias cavas, e outra retorna o fluxo direto na aorta, ficando sangue estagnado na circulação pulmonar. Isso requer anticoagulação plena do paciente com altas doses de heparina. O sangramento decorrente da anticoagulação é submetido à aspiração e à filtração com a autotransfusão, sendo realizada com o auxílio de um reservatório venoso. São toleradas doses mais baixas de hematócrito, o que reduz a oferta tecidual de oxigênio e, por isso, realiza-se hipotermia para redução do consumo de oxigênio, minimizando acidose.

\section{Quadro 12.5 - Indicações relativas para suporte extracorpóreo cardíaco}

Baixo débito após circulação extracorpórea - falência no desmame ou evolução
progressiva da disfunção no pós-operatório
Cardiomiopatia
Miocardite
Parada cardiorrespiratória
Hipertensão pulmonar
Arritmias refratárias
Ponte para transplante
Doenças não cardiacas (choque séptico e síndrome do desconforto respiratório
agudo)

Quadro 12.6 - Contraindicações relativas para suporte extracorpóreo cardíaco.

Doença inoperável ou terminal

Dano neurológico significativo

Síndrome de disfunção multiorgânica estabelecida

Sangramento incontrolável

Limitação para o acesso vascular devido à anatomia ou tamanho 
Em contraste, na ECMO, o bypass pode ocorrer com canulações extratorácicas, em vigência de normotermia, fluxo de sangue normal e hematócrito normal, com a intenção de que a oferta de oxigênio seja adequada às necessidades do organismo. No circuito venovenoso de ECMO, toda a circulação é dependente de haver função miocárdica normal. ${ }^{1032}$

\subsection{Dispositivos de Assistência Ventricular}

Dispositivos de assistência ventricular aplicam alguns princípios de suporte de vida extracorpóreo, mas têm muitas diferenças comparadas com a ECMO venoarterial. A função pulmonar nativa deve estar preservada, e a circulação pulmonar é mantida. A anticoagulação pode ser reduzida ou eliminada, devido à diminuição da superfície de área do circuito da assistência.

É efetivo para dar suporte a crianças com severa disfunção cardíaca, após cirurgia cardíaca, ou como ponte para transplante cardíaco ou implante de outro VAD, por exemplo.

Há numerosos dispositivos disponíveis comercialmente (Berlin Heart e Thoratec), que podem ser trocados por outros dispositivos, considerados terapia final (HeartMate Ile HeartWare). Alguns desses dispositivos podem ser também implantados como terapia de destino.

Eles podem ter custo elevado e requererem canulação cirúrgica intracardíaca direta por cardiotomia, sendo frequentemente usados como possibilidade terapêutica, se não houver recuperação ventricular após a ECMO venoarterial.

Novas gerações de bombas centrífugas (Levitronix) têm recentemente sido introduzidas para curto intervalo de uso (15 a 30 dias), inclusive como ponte para a decisão da terapêutica a ser utilizada a seguir, já que têm menor custo que outros VAD.

\subsection{Manejo do Paciente em Extracorporeal Life Support}

O manejo de um paciente em Extracorporeal Life Support (ECLS) requer uma equipe especializada e a optimização terapêutica com o uso de protocolos.

Avaliação do paciente inclui o exame clínico e a revisão de sinais vitais, do balanço sanguíneo e hídrico das últimas 24 horas. É importante observar a coloração, a perfusão e a temperatura das extremidades, a qualidade dos pulsos centrais e periféricos, e a presença de edema periférico e abdominal. Os sítios de canulação devem ser examinados para a contenção de perdas sanguíneas e exsudação.

A maioria das complicações mais graves é geralmente relacionada ao sistema nervoso central. $\mathrm{O}$ paciente deve estar confortável em uso de medicações que minimizem movimentos excessivos e ainda permitam avaliar o status neurológico, evitando o uso de paralisantes neuromusculares.

Hemorragia intracraniana ocorre em aproximadamente $5 \%$ dos pacientes em ECLS, ${ }^{1032}$ e esse risco aumenta com a ocorrência de hipóxia, hipercarbia, acidose, hipotensão, sepse, coagulopatia, trombocitopenia, hipertensão e convulsões. ${ }^{1033} \mathrm{Na}$ presença de hemorragia intracraniana significativa, a assistência circulatória deve ser reduzida ou mesmo descontinuada.
O fluido extracelular, o volume de água corporal total e o peso corpóreo aumentam durante a ECLS. Em parte, isso se deve à resposta inflamatória, bem como ao contato do sangue com a superfície do circuito da ECLS. O balanço hídrico é difícil de ser calculado, devido às perdas pela pele e à demanda metabólica.

Lesões induzidas pela ventilação, durante a otimização do recrutamento pulmonar, devem ser prevenidas. Os parâmetros do ventilador são reduzidos o suficiente para manter os pulmões expandidos. Outras modalidades, como a ventilação de alta frequência e APRV, sigla em inglês da modalidade bi-vent, têm sido usadas para melhora o recrutamento pulmonar.

Para otimizar a oferta de oxigênio para as artérias coronárias, a fração de oxigênio inspirada é mantida ao menos em 0,50, já que, no suporte venoarterial, a perfusão coronariana depende do débito nativo.

No suporte venovenoso, são mantidos altos parâmetros ventilatórios, pela dificuldade de alcançar uma boa saturação arterial.

Como o paciente está heparinizado, devem-se evitar vibrações torácicas pelo risco de sangramento.

Dentro das primeiras 24 horas de ECMO, os pulmões geralmente ficam completamente opacos na radiografia, o que se explica pela ativação da cascata do complemento, pela transudação alveolar e pela alteração na relação ventilação:perfusão. $\mathrm{O}$ uso de circuitos biocompatíveis reduz dramaticamente esse fenômeno.

A anticoagulação do circuito de ECMO previne a formação de trombos em qualquer dos componentes ou cânulas. O controle da heparinização é feito utilizando-se o TCA, que deve ser mantido entre 180 e 200 segundos (valores normais: 90 a 100 segundos), para infusão contínua de heparina entre 20 e 50U/kg/hora. Deve-se lembrar que o efeito da heparinização depende de nível adequado de antitrombina, a qual deve ser administrada no caso de deficiência.

Sangramentos normalmente ocorrem nos sítios de drenos e incisões. Essa complicação pode ser minimizada com a manutenção adequada dos níveis de plaquetas entre 80.000 e 100.000 céls $/ \mathrm{mm}^{3}$, fibrinogênio e de TP.

O tempo em ECMO pode ser de poucos dias, para pacientes cardiopatas, a 6 a 8 semanas para pacientes com SDRA. Com a redução do fluxo na ECMO, aumenta-se o risco de formação de trombos no circuito e de embolização para o paciente. Durante o desmame, o fluxo ofertado pelo paciente pode ser reduzido, enquanto se mantém alto o fluxo no circuito, criando-se um shunt com o uso de um clamp ajustável. Independente do tamanho do circuito, mesmo estando o fluxo do paciente baixo, não se deve manter fluxo menor do que $500 \mathrm{~mL} /$ minuto no circuito.

Nos cardiopatas, com a melhora da função cardíaca, o suporte de ECLS é menos necessário para manter níveis adequados de saturação arterial e venosa mista. A pressão de pulso aumenta, e a contratilidade melhora. Nesta fase, inicia-se o uso de baixas doses de inotrópicos.

O ideal é fazer o desmame sem clampear as linhas, e sim evoluir para a decanulação, reduzindo o fluxo até níveis baixos 
de suporte, como 5 a $10 \mathrm{~mL} / \mathrm{kg} /$ minuto, por um curto período de tempo (30 a 60 minutos).

Este processo será finalizado assim que o paciente tolere com sucesso o processo de desmame. ${ }^{1028,1031,1034}$

\subsection{Cuidados Pós-Ressuscitação}

A abordagem do período pós-ressuscitação deve incluir todas as opções terapêuticas que permitam a recuperação neurológica. Dentre os principais objetivos, podemos destacar a reversão da lesão cerebral, e o tratamento da disfunção miocárdica e da isquemia sistêmica, além do tratamento de todas as condições precipitantes da parada, que persistam neste período. ${ }^{1035}$

\subsubsection{Modulação da Temperatura}

A indicação de modulação da temperatura para os pacientes pediátricos que se mantêm em coma após a RCP foi revisada. Em crianças comatosas após a PCR intra ou extrahospitalar, deve-se monitorar a temperatura continuamente e tratar a febre agressivamente.

Em crianças comatosas ressuscitadas de uma PCR extra-hospitalar, os responsáveis pelo tratamento devem manter 5 dias de normotermia $\left(36\right.$ a $\left.37,5^{\circ} \mathrm{C}\right)$ ou 2 dias de hipotermia contínua inicial $\left(32\right.$ a $\left.34^{\circ} \mathrm{C}\right)$, seguidos de 3 dias de normotermia. ${ }^{1035}$ Sobre as crianças que permanecem comatosas após uma PCR intra-hospitalar, não há dados suficientes para se recomendar a hipotermia sobre normotermia. ${ }^{1036-1038}$

Durante a modulação da temperatura, podem ocorrer tremores, que podem ser controlados com bloqueadores neuromusculares. Outras complicações, como a ocorrência de coagulopatias, infecções, instabilidade cardiovascular e distúrbios eletrolíticos, podem ocorrer com o emprego da hipotermia.

Um estudo prospectivo e multicêntrico sobre as vítimas pediátricas de PCR extra-hospitalar que foram submetidas à hipotermia $\left(32\right.$ a $\left.34^{\circ} \mathrm{C}\right)$ ou à normotermia $\left(36\right.$ a $\left.37,5^{\circ} \mathrm{C}\right)$ não mostrou diferença no desfecho funcional no primeiro ano entre os dois grupos. ${ }^{1035}$ Este e os outros grupos observacionais não demonstraram complicação no grupo tratado com HT. Há resultados pendentes de um grande estudo multicêntrico, randomizado e controlado sobre HT para pacientes comatosos após o retorno ao ritmo cardíaco espontâneo seguinte a uma PCR intra-hospitalar pediátrica. ${ }^{1039}$

\subsubsection{Drogas Vasoativas}

É recomendado que lactentes e crianças pós-PCR utilizem drogas vasoativas e fluidos para manter a pressão arterial sistólica maior que o percentil 5 para a faixa etária (fortemente recomendado, nível de evidência muito baixo). ${ }^{1035,1036}$

\subsubsection{Controle Glicêmico}

Tanto a hipoglicemia quanto a hiperglicemia podem provocar prejuízo na evolução do paciente crítico adulto e pediátrico, e devem ser evitadas. ${ }^{1037}$

As evidências são insuficientes para indicar estratégia de controle glicêmico no período pós RCP.
Deste modo, é recomendável monitorizar a glicemia para evitar a hipoglicemia e a hiperglicemia prolongada no período pós-ressuscitação. Não há evidências para recomendar abordagem específica da hiperglicemia em lactentes e crianças que evoluem com RCE.

\subsubsection{Suporte Ventilatório}

Estudos no período neonatal ${ }^{1040,1041}$ e em animais ${ }^{1042-1048}$ sugerem que é prudente titular o oxigênio inspirado (saturação de oxi-hemoglobina de $94 \%$ ou superior) após o RCE, para evitar a hiperóxia. ${ }^{1049,1050}$ Considerar que estes parâmetros devem ser ponderados para populações específicas, como as crianças com cardiopatias congênitas cianogênicas.

Estratégias de ventilação após o RCE devem procurar atingir uma $\mathrm{PaCO}_{2}$ adequada a cada paciente, evitando extremos de hipercapnia ou hipocapnia. Não há estudos pediátricos sugerindo $\mathrm{PaCO}_{2}$ adequada, no entanto, a $\mathrm{PaCO}_{2}$ deve ser mensurada e ajustada, conforme as características e as necessidades do paciente. ${ }^{1051-1054}$

\section{Ressuscitação Neonatal}

\subsection{Introdução}

No Brasil, nascem cerca de 3 milhões de crianças ao ano. ${ }^{1055} \mathrm{~A}$ maioria delas nasce com boa vitalidade, entretanto manobras de suporte vital podem ser necessárias e, às vezes, de maneira inesperada, sendo essencial o conhecimento e a habilidade em reanimação neonatal por todos os profissionais que atendem ao RN em sala de parto. ${ }^{1056,1057}$ A mortalidade neonatal precoce associada à asfixia perinatal em RN com peso ao nascer $\geq 2.500$ g e sem malformações congênitas é elevada em nosso meio. Estudo feito pelo Programa de Reanimação Neonatal da Sociedade Brasileira de Pediatria (SBP) mostrou que, entre 2005 e 2010, no Brasil, ocorreram cinco a seis mortes precoces por dia de neonatos $\geq 2.500$ g sem anomalias congênitas por causas associadas à asfixia perinatal. ${ }^{1058}$ Quanto ao RN pré-termo, dados da Rede Brasileira de Pesquisas Neonatais, composta por 20 centros universitários públicos, indicam que, nos anos de 2012 a 2015, dos 5.810 nascidos vivos com idade gestacional entre 23 e $33^{1059,1061}$ semanas, sem malformações, $62 \%$ foram ventilados com máscara facial ou cânula traqueal, e $6 \%$ receberam ventilação acompanhada de massagem cardíaca e/ou medicações na sala de parto. ${ }^{1059}$

Assim, de maneira geral, ao nascimento, um em cada dez RN necessita de VPP para iniciar e/ou manter movimentos respiratórios efetivos ao nascimento; um em cada cem neonatos precisa de intubação e/ou massagem cardíaca; e um em cada mil requer intubação, massagem e medicações, desde que a VPP seja aplicada adequadamente. ${ }^{1060}$ Dessa maneira, estima-se que, no país, 300 mil crianças, a cada ano, necessitem de ajuda para iniciar e manter a respiração ao nascer.

Nesse contexto, as diretrizes de 2016 sobre reanimação neonatal delineadas a seguir foram elaboradas pelo Programa de Reanimação Neonatal da Sociedade Brasileira de Pediatria (SBP), por meio de um consenso de neonatologistas das 27 
Unidades Federativas brasileiras, sendo divulgadas em janeiro de 2016. ${ }^{1061-1063}$ Tais diretrizes tomaram por base as revisões sistemáticas e recomendações elaboradas pela força-tarefa neonatal do ILCOR ${ }^{1064}$ e as diretrizes em reanimação neonatal da América do Norte ${ }^{1065}$ e da Europa. ${ }^{1066}$

O fluxograma resume os principais procedimentos que podem ser necessários para a reanimação em sala de parto (Figura 13.1).

\subsection{Preparo para a Assistência}

O preparo para a assistência ao nascimento inclui a obtenção da anamnese materna, o preparo dos equipamentos e a disponibilização de equipe capacitada a reanimar o RN. A anamnese materna detalhada possibilita a detecção de situações no período pré-natal e no trabalho de parto e parto, que chamam atenção para a possível necessidade de reanimação. Equipamentos para avaliação do paciente, manutenção da temperatura, aspiração e ventilação, além das medicações, devem estar preparados, testados e disponíveis em local de fácil acesso, antes de qualquer nascimento, conforme quadro 13.1. ${ }^{1061-1063}$ É fundamental que pelo menos um profissional de saúde capaz de realizar os passos iniciais e a VPP por meio de máscara facial esteja presente em todo parto. A única responsabilidade desse profissional deve ser atender ao RN. Quando, na anamnese, identificam-se fatores de risco perinatais, podem ser necessários dois a três profissionais treinados e capacitados a reanimar o $\mathrm{RN}$ de maneira rápida e efetiva. Desse grupo de profissionais, pelo menos um médico apto a intubar e indicar massagem cardíaca e medicações precisa estar presente na sala de parto - de preferência um pediatra. No caso de prematuro, é necessária a presença de dois a três profissionais de saúde aptos a realizarem todos os procedimentos de reanimação neonatal. Desse grupo de profissionais, pelo menos um pediatra apto a intubar e indicar massagem cardíaca e medicações precisa estar presente na sala de parto. É preciso decidir quem vai ser o líder e quais os papéis e as responsabilidades dos membros da equipe antes do nascimento. A atuação coordenada da equipe, com comunicação efetiva entre seus membros, confere qualidade ao atendimento e segurança ao paciente. ${ }^{1065,1066}$

Para a recepção do $\mathrm{RN}$, utilizar precauções padrão que compreendem lavagem/higienização das mãos e uso de luvas, aventais, máscaras ou proteção facial, para evitar o contato do profissional com material biológico do paciente. ${ }^{1067}$

\subsection{Avaliação da Vitalidade ao Nascer}

A reanimação depende da avaliação simultânea da FC e da respiração imediatamente após o nascimento. A FC é o principal determinante da decisão de indicar as diversas manobras de reanimação e deve ser avaliada inicialmente por meio da ausculta do precórdio com estetoscópio. Uma vez indicada a VPP, recomenda-se o uso do monitor cardíaco, pois permite a detecção acurada, rápida e contínua da FC. ${ }^{1061-1066} \mathrm{Na}$ avaliação feita pelo monitor cardíaco nos minutos iniciais depois do nascimento, o objetivo primário é o acompanhamento da $\mathrm{FC}$, e não a detecção de ritmos anômalos no traçado eletrocardiográfico. Ressalta-se que a avaliação da coloração da pele e das mucosas do RN não é

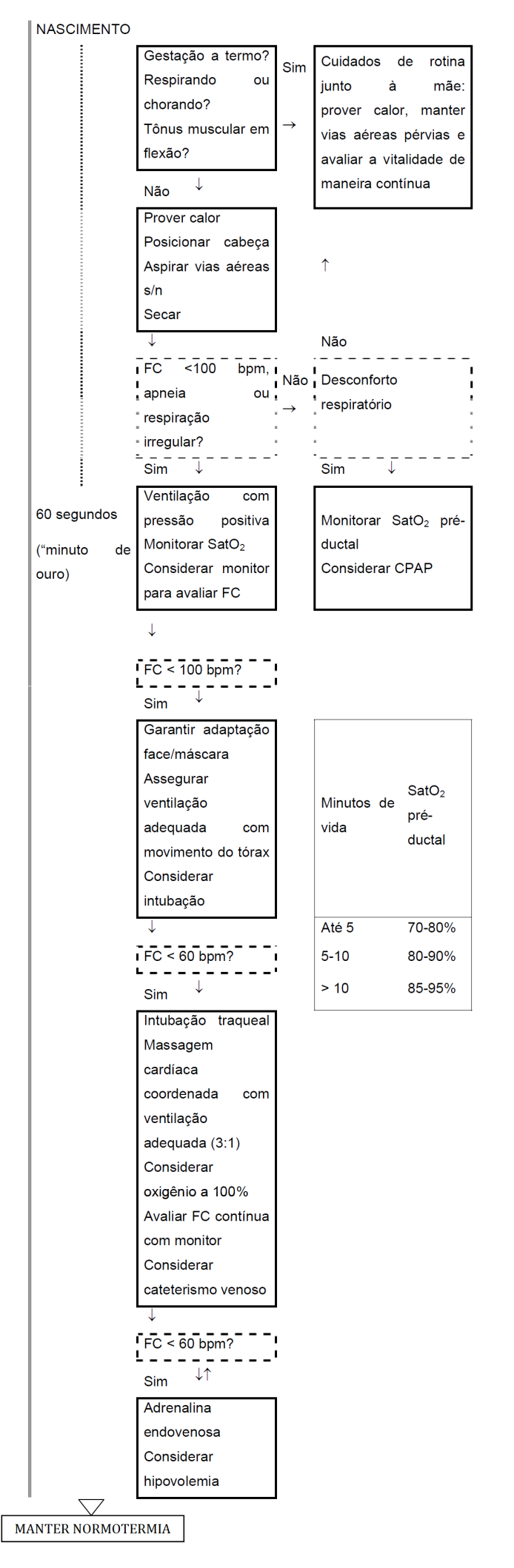

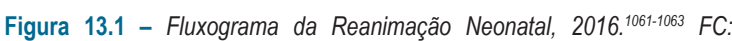
frequência cardíaca; $\mathrm{SatO}_{2}$ : saturação de oxigênio; CPAP: pressão positiva contínua nas vias aéreas. 
Quadro 13.1 - Material necessário para reanimação neonatal na sala de parto

\begin{tabular}{|c|c|}
\hline $\begin{array}{l}\text { Sala de parto el } \\
\text { ou de reanimação } \\
\text { com temperatura } \\
\text { ambiente de } 23-26^{\circ} \mathrm{C}\end{array}$ & $\begin{array}{c}\text { Mesa de reanimação com acesso por } 3 \text { lados } \\
\text { Fontes de oxigênio umidificado e de ar comprimido, } \\
\text { com fluxômetro } \\
\text { Blender para mistura oxigênio/ar } \\
\text { Aspirador a vácuo com manômetro } \\
\text { Relógio de parede com ponteiro de segundos }\end{array}$ \\
\hline $\begin{array}{l}\text { Material para } \\
\text { manutenção de } \\
\text { temperatura }\end{array}$ & $\begin{array}{c}\text { Fonte de calor radiante } \\
\text { Termômetro ambiente digital } \\
\text { Campo cirúrgico e compressas de algodão estéreis } \\
\text { Saco de polietileno de } 30 \times 50 \mathrm{~cm} \text { para prematuro } \\
\text { Touca de lã ou algodão } \\
\text { Colchão térmico químico } 25 \times 40 \mathrm{~cm} \text { para prematuro } \\
<1.000 \mathrm{~g} \\
\text { Termômetro clínico digital }\end{array}$ \\
\hline $\begin{array}{l}\text { Material para } \\
\text { avaliação }\end{array}$ & $\begin{array}{c}\text { Estetoscópio neonatal } \\
\text { Oxímetro de pulso com sensor neonatal } \\
\text { Monitor cardíaco de três vias com eletrodos } \\
\text { Bandagem elástica para fixar o sensor do oxímetro e } \\
\text { os eletrodos }\end{array}$ \\
\hline $\begin{array}{l}\text { Material para } \\
\text { aspiração }\end{array}$ & $\begin{array}{l}\text { Sondas traqueais números } 6,8 \text { e } 10 \text { e gástricas curtas } \\
\text { números } 6 \text { e } 8 \\
\text { Dispositivo para aspiração de mecônio } \\
\text { Seringas de } 10 \mathrm{~mL}\end{array}$ \\
\hline
\end{tabular}

Material para ventilação

Material para intubação traqueal

Medicações

Material para cateterismo umbilical

Outros
Reanimador manual neonatal (balão autoinflável com volume máximo de $750 \mathrm{~mL}$, reservatório de oxigênio e válvula de escape com limite de $30 \mathrm{a}^{4} \mathrm{cmH}_{2} \mathrm{O}$ e/ ou manômetro)

Ventilador mecânico manual neonatal em T com circuitos próprios

Máscaras redondas com coxim números 00,0 e 1

Máscara laríngea para recém-nascido número 1

Laringoscópio infantil com lâmina reta números 00 , 0 e 1

Cânulas traqueais sem balonete, de diâmetro interno uniforme 2,5/3,0/3,5 e 4,0 mm

Material para fixação da cânula: fita adesiva e algodão com soro fisiológico

Pilhas e lâmpadas sobressalentes para laringoscópio Detector colorimétrico de dióxido de carbono expirado

Adrenalina 1/10.000 em 1 seringa de 5,0 mL para administração única endotraqueal Adrenalina $1 / 10.000$ em seringa de $1,0 \mathrm{~mL}$ para administração endovenosa

Expansor de volume (soro fisiológico) em 2 seringas de $20 \mathrm{~mL}$

Campo fenestrado esterilizado, cadarço de algodão e gaze

Pinça tipo kelly reta de $14 \mathrm{~cm}$ e cabo de bisturi com lâmina número 21

Porta-agulha de $11 \mathrm{~cm}$ e fio agulhado mononylon 4.0

Cateter umbilical $3,5 \mathrm{~F}, 5 \mathrm{~F}$ e $8 \mathrm{~F}$ de $\mathrm{PVC}$ ou poliuretano Torneira de três vias

Luvas e óculos de proteção individual para os profissionais de saúde

Gazes esterilizadas e álcool etílico Cabo e lâmina de bisturi

Tesoura de ponta romba e clampeador de cordão umbilical utilizada para decidir procedimentos na sala de parto, uma vez que essa avaliação é subjetiva e não tem relação com a $\mathrm{SatO}_{2}$ ao nascimento. ${ }^{1068}$

\subsection{Clampeamento do Cordão Umbilical}

Ao nascimento, se o $\mathrm{RN}$ for prematuro tardio, de termo ou pós-termo e estiver respirando ou chorando, com tônus muscular em flexão, independentemente do aspecto do líquido amniótico, ele apresenta boa vitalidade. Neste caso, recomenda-se o clampeamento de cordão 1 a 3 minutos após o nascimento. ${ }^{1069}$ Durante o clampeamento, deixar o RN em contato pele a pele sobre o abdome ou tórax da mãe, e cobri-lo com campos secos e pré-aquecidos, em temperatura ambiente de 23 a $26^{\circ} \mathrm{C}$, para evitar a perda de calor. ${ }^{1061,1062}$

O clampeamento tardio de cordão em prematuros $<34$ semanas de idade gestacional com boa vitalidade ao nascer após 30 segundos resulta em menor frequência de pacientes com hemorragia intracraniana e enterocolite necrosante, além de diminuição do número de transfusões sanguíneas. ${ }^{1070}$ Dessa maneira, se o pré-termo começou a respirar ou chorar e está ativo, recomenda-se o clampeamento do cordão umbilical, depois de 30 a 60 segundos. ${ }^{1061-1066}$

Se a circulação placentária não estiver intacta (descolamento prematuro de placenta, placenta prévia, ou rotura ou prolapso ou nó verdadeiro de cordão), ou se o RN não iniciar a respiração ou não mostrar atividade/tônus muscular adequado, recomenda-se o clampeamento imediato do cordão. ${ }^{1061-1066}$

\subsection{Passos Iniciais da Estabilização/Reanimação}

Todos os pacientes prematuros ou pós-termo e aqueles de qualquer idade gestacional sem vitalidade adequada ao nascer (respiração ausente/irregular ou tônus diminuído) precisam ser conduzidos à mesa de reanimação, indicando-se os seguintes passos: prover calor e manter as vias aéreas pérvias (posição da cabeça em leve extensão e, se necessária, aspiração do excesso de secreção da boca e narinas). Tais passos devem ser executados em, no máximo, 30 segundos, com o paciente em decúbito dorsal horizontal a zero grau, sem lateralização da cabeça.

O primeiro passo consiste em manter a temperatura corporal entre 36,5 e $37,5^{\circ} \mathrm{C}$ (normotermia), evitando-se tanto a hipertermia como a hipotermia. ${ }^{1061-1066}$ Para diminuir a perda de calor, é importante pré-aquecer a sala de parto e a sala onde serão realizados os procedimentos de reanimação, mantendo temperatura ambiente de 23 a $26^{\circ} \mathrm{C}$. Após o clampeamento do cordão, o RN é levado em campo seco aquecido e colocado sob calor radiante. Nos neonatos $\geq 34$ semanas de idade gestacional, após a colocação sob fonte de calor radiante e as medidas para manter as vias aéreas pérvias, secar o corpo e a região da fontanela, e desprezar os campos úmidos.

Em RN < 34 semanas de idade gestacional, a presença de temperatura corporal abaixo de $36,0^{\circ} \mathrm{C}$, considerada hipotermia, 1071 na admissão à UTI neonatal, é fator independente de risco para mortalidade e morbidade. ${ }^{1072,1073}$ Assim, após recepcionar o $\mathrm{RN}<34$ semanas em campos aquecidos e coloca-lo sob calor radiante, sem secar, introduz- 
se o corpo, exceto a face, dentro do saco plástico e, a seguir, realizam-se as manobras necessárias. ${ }^{1074} \mathrm{O}$ saco plástico só será retirado depois da estabilização térmica na UTI. Deve-se também colocar touca dupla para reduzir a perda de calor na região da fontanela: cobrir a cabeça com triângulo plástico e, por cima, touca de lã ou algodão. Em RN < 34 semanas, enquanto estão sendo tomadas as medidas para prover calor, simultaneamente, locar o sensor do oxímetro de pulso na palma da mão ou pulso radial direito, para monitorar a $\mathrm{SatO}_{2}$ pré-ductal, lembrando que a leitura confiável da $\mathrm{SatO}_{2}$ e da FC demora cerca de 1 a 2 minutos após o nascimento, desde que haja DC suficiente, com perfusão periférica. ${ }^{1075}$

O próximo passo consiste em manter a permeabilidade das vias aéreas, posicionando-se a cabeça do RN com leve extensão do pescoço. Na sequência, se houver excesso de secreções nas vias aéreas, a boca e, depois, as narinas são aspiradas delicadamente, ressaltando-se que a aspiração de vias aéreas está reservada aos pacientes que apresentam obstrução à respiração espontânea por secreções.

Uma vez feitos os passos iniciais da reanimação, avaliam-se a respiração e a FC com estetoscópio no precórdio. Se houver vitalidade adequada, com respiração rítmica e regular, e FC $>100 \mathrm{bpm}$, o RN deve receber os cuidados de rotina na sala de parto. Quando o RN < 34 semanas apresenta FC > 100 bpm e respiração espontânea, mas está com desconforto respiratório e/ou $\mathrm{SatO}_{2}$ abaixo da esperada na transição normal (Figura 13.1), logo após o nascimento, pode-se aplicar Pressão Positiva Contínua nas Vias Aéreas (CPAP). Entretanto, se, após os passos iniciais, o RN apresentar apneia, respiração irregular e/ou FC $<100$ bpm, indica-se a VPP.

\subsection{Assistência ao Recém-Nascido com Líquido Amniótico Meconial}

Logo após o nascimento, se o RN com líquido amniótico meconial é de termo, está respirando ou chorando, e com tônus muscular em flexão, ele deve continuar junto de sua mãe depois do clampeamento tardio do cordão. ${ }^{1076}$ Se o paciente com líquido amniótico meconial é pré-termo tardio ou póstermo, ou não iniciou movimentos respiratórios regulares ou o tônus muscular está flácido, é necessário levá-lo à mesa de reanimação e realizar os passos iniciais, sendo prudente incluir a aspiração de boca e narinas suavemente com sonda traqueal número 10. A seguir, se o RN está com boa vitalidade, deixá-lo em contato pele a pele com a mãe, mantendo a observação do tônus muscular e da respiração.

No RN com líquido amniótico meconial de qualquer viscosidade levado à mesa de reanimação para os passos iniciais, que apresenta apneia, respiração irregular e/ou FC < 100 bpm, é fundamental iniciar a VPP com máscara facial e ar ambiente nos primeiros 60 segundos de vida. Se, após 30 segundos de VPP efetiva, o neonato não melhora e há forte suspeita de obstrução de vias aéreas, pode-se indicar a retirada do mecônio residual da hipofaringe e da traqueia sob visualização direta. A aspiração traqueal propriamente dita é feita por meio da cânula traqueal conectada a um dispositivo para aspiração de mecônio e ao aspirador a vácuo, com pressão máxima de 100 mmHg. Nessa situação, aspirar o excesso de mecônio uma única vez. ${ }^{1061-1066}$

\subsection{Ventilação com Pressão Positiva}

A ventilação pulmonar é o procedimento mais importante e efetivo na reanimação do $\mathrm{RN}$ em sala de parto. A VPP está indicada quando, após os cuidados para manter a temperatura e a permeabilidade das vias aéreas, o RN apresenta apneia, respiração irregular e/ou FC < 100 bpm. A VPP precisa ser iniciada nos primeiros 60 segundos de vida ("The Golden Minute").

Em $R N \geq 34$ semanas de idade gestacional, enquanto um profissional inicia a VPP, outro fixa os três eletrodos do monitor cardíaco (braços próximos ao ombro e face anterior da coxa) para acompanhar a FC e, a seguir, loca o sensor do oxímetro de pulso no pulso radial direito para monitorar a $\mathrm{SatO}_{2}$ pré-ductal.

Em RN $<34$ semanas de idade gestacional, o sensor do oxímetro foi locado nos passos iniciais. Se há indicação de VPP, enquanto um profissional inicia a VPP, o outro fixa os três eletrodos do monitor cardíaco (braços próximos ao ombro e face anterior da coxa) para acompanhar a FC.

\subsubsection{Oxigênio Suplementar}

$E m R N \geq 34$ semanas de idade gestacional, um profissional inicia a VPP sempre em ar ambiente. A necessidade de oxigênio suplementar é excepcional nesses pacientes, se a VPP é feita com a técnica adequada. Nos poucos casos em que é necessário o uso do oxigênio suplementar, indica-se a aplicação da mistura oxigênio/ar, ajustando-se a concentração de oxigênio por meio de um blender para atingir a $\mathrm{SatO}_{2}$ desejável (Figura 13.1). É necessário um período de cerca de 30 segundos para haver equilíbrio da concentração de oxigênio oferecida pela ventilação por toda a área pulmonar. Quando há necessidade de oxigênio suplementar durante a VPP, fazer incrementos de $20 \%$, ou seja, aumentar a concentração de $21 \%$ para $40 \%$, e aguardar cerca de 30 segundos, para verificar a $\mathrm{SatO}_{2}$ e indicar novos incrementos se necessário. ${ }^{1077}$

Quanto à ventilação do prematuro em sala de parto, as pesquisas ainda não responderam qual a concentração de oxigênio ideal. Se, por um lado, o uso de ar ambiente pode não ser suficiente para que tais pacientes atinjam oxigenação adequada, por outro lado, o emprego de oxigênio a 100\% pode ser excessivo e deletério. ${ }^{1078}$ Dessa maneira, iniciar a VPP do RN < 34 semanas com oxigênio de 30\%, titulando-se sua oferta de acordo com a monitoração da $\mathrm{SatO}_{2}$ pré-ductal (Figura 13.1). ${ }^{1061-1066}$

\subsubsection{Ventilação com Balão Autoinflável e Máscara Facial}

Os equipamentos empregados para ventilar o RN em sala de parto compreendem o balão autoinflável e o ventilador mecânico manual em T.

O balão autoinflável é de fácil manuseio e não necessita de fonte de gás para funcionar, tratando-se de equipamento de baixo custo, que permite a ventilação efetiva do RN e deve estar sempre disponível em toda sala de parto.

A VPP com balão e máscara deve ser feita na frequência de 40-60 movimentos/minuto, de acordo com a regra prática "aperta/solta/solta/aperta...". Quanto à pressão a ser aplicada, esta deve ser individualizada, para que o 
RN alcance e mantenha FC > 100 bpm. De modo geral, iniciar com pressão inspiratória ao redor de $20 \mathrm{cmH}_{2} \mathrm{O}$, considerando que a pressão inspiratória máxima a ser administrada é limitada pela válvula de escape, ativada em 30 a $40 \mathrm{cmH}_{2} \mathrm{O}$ para evitar o barotrauma.

Se, após 30 segundos de VPP com balão e máscara, o paciente apresentar FC > 100 bpm e respiração espontânea e regular, suspender o procedimento. Considera-se como falha se, após 30 segundos de VPP, o RN mantém FC < 100 bpm ou não retoma a respiração espontânea rítmica e regular. Nesse caso, verificar o ajuste entre face e máscara, a permeabilidade das vias aéreas (posicionando a cabeça, aspirando secreções e abrindo a boca do RN) e a pressão no balão, corrigindo o que for necessário. Se o paciente, após a correção da técnica da ventilação com máscara não melhorar, deve-se aumentar a oferta de oxigênio com base na monitorização da $\mathrm{SatO}_{2}$ pré-ductal (Figura 13.1). Se, mesmo assim, a ventilação não for efetiva, está indicada a intubação traqueal para ventilar o paciente.

É importante ressaltar que, de cada dez RN que recebem VPP com balão e máscara ao nascer, nove melhoram e não precisam de outros procedimentos de reanimação.

\subsubsection{Ventilação com Balão Autoinflável e Cânula Traqueal}

As indicações de ventilação por cânula traqueal incluem: ventilação com máscara facial não efetiva, ou seja, se, após a correção de possíveis problemas técnicos, a FC permanece < 100 bpm; ventilação com máscara facial prolongada, ou seja, se o paciente não retoma a respiração espontânea; e aplicação de massagem cardíaca.

A indicação da intubação no processo de reanimação depende da habilidade e da experiência do profissional responsável pelo procedimento. ${ }^{1079} \mathrm{Em}$ mãos menos experientes, existe elevado risco de complicações, como hipoxemia, apneia, bradicardia, pneumotórax, laceração de tecidos moles, perfuração de traqueia ou esôfago, além do risco de infecção. Cada tentativa de intubação deve durar, no máximo, 30 segundos. Em caso de insucesso, o procedimento é interrompido, e a VPP com máscara deve ser iniciada, sendo realizada nova tentativa de intubação após a estabilização do paciente. Quando a intubação traqueal não é possível, a máscara laríngea é alternativa para manter as vias aéreas pérvias e assegurar a ventilação pulmonar do $\mathrm{RN} \geq 34$ semanas com peso > 2.000 g. ${ }^{1061-1066,1080}$

Para intubar, usar cânulas traqueais de diâmetro uniforme, sem balão, com linha radiopaca e marcador de corda vocal. Escolher o material de intubação, de acordo com a idade gestacional ou o peso estimado ao nascer (Tabela 13.1). A ponta distal da cânula deve se localizar no terço médio da traqueia, na altura da primeira vértebra torácica. Recomendase usar a idade gestacional para calcular o comprimento da cânula a ser inserido na traqueia, considerando a distância entre a ponta da cânula e a marca, em centímetros, a ser fixada no lábio superior, conforme tabela 13.2. ${ }^{1066,1081}$ Caso a idade gestacional seja desconhecida, usar a regra prática "peso estimado $(\mathrm{kg})+6$ " para calcular o comprimento da cânula a ser inserido na traqueia, sendo o resultado correspondente à marca, em centímetros, a ser fixada no lábio superior. ${ }^{1082}$
Para confirmar a posição da cânula, a detecção colorimétrica de dióxido de carbono exalado é recomendada. Após a intubação, inicia-se a ventilação com balão autoinflável, nas mesmas frequência e pressão descritas na ventilação com balão e máscara.

Há melhora se o RN apresenta FC > 100 bpm, além de movimentos respiratórios espontâneos e regulares. Nesta situação, a ventilação é suspensa e o RN é extubado. Considera-se como falha se, após 30 segundos de VPP por meio da cânula traqueal, o RN mantém FC < 100 bpm ou não retoma a respiração espontânea ou, ainda, a SatO ${ }_{2}$ permanece abaixo dos valores desejáveis ou não é detectável (Figura 13.1). Nesse caso, verificar a posição da cânula, a permeabilidade das vias aéreas e a pressão aplicada, corrigindo o que for necessário. Após essa correção, pode-se aumentar a oferta de oxigênio até 60 a 100\%. Se o RN mantém apneia ou respiração irregular, continuar a VPP por cânula traqueal. Se $\mathrm{FC}<60$ bpm, indicar a massagem cardíaca coordenada à VPP.

\subsubsection{Uso do Ventilador Mecânico Manual em T}

$\mathrm{O}$ ventilador mecânico manual em $\mathrm{T}$ é um respirador controlado a fluxo e limitado a pressão, que tem sido utilizado de maneira crescente, em especial em $\mathrm{RN}<34$ semanas de gestação, para aplicar CPAP e a VPP.

$\mathrm{O}$ uso do CPAP é indicado nos RN < 34 semanas que apresentam FC > 100 bpm e respiração espontânea, mas que mostram desconforto respiratório e/ou $\mathrm{SatO}_{2}$ abaixo da

Tabela 13.1 - Material para intubação traqueal, de acordo com idade gestacional ou peso estimado ao nascer

\begin{tabular}{lcccc}
\hline $\begin{array}{l}\text { Idade } \\
\text { gestacional } \\
\text { (semanas) }\end{array}$ & $\begin{array}{c}\text { Peso } \\
\text { estimado } \\
(\mathrm{g})\end{array}$ & $\begin{array}{c}\text { Cânula } \\
\text { traqueal } \\
(\mathrm{mm})\end{array}$ & $\begin{array}{c}\text { Sonda } \\
\text { traqueal }(\mathrm{F})\end{array}$ & $\begin{array}{c}\text { Lâmina reta } \\
(\mathrm{n} .0)\end{array}$ \\
\hline$<28$ & $<1.000$ & 2,5 & 6 & 00 \\
$28-34$ & $1.000-2.000$ & 3,0 & 6 ou 8 & 0 \\
$34-38$ & $2.000-3.000$ & 3,5 & 8 & 1 \\
$>38$ & $>3.000$ & 3,5 ou 4,0 & 8 & 1 \\
\hline
\end{tabular}

Tabela 13.2 - Profundidade de inserção da cânula traqueal, conforme idade gestacional

\begin{tabular}{lc}
\hline $\begin{array}{l}\text { Idade gestacional } \\
\text { (semanas) }\end{array}$ & $\begin{array}{c}\text { Marca no lábio superior } \\
\text { (cm) }\end{array}$ \\
\hline $23-24$ & 5,5 \\
$25-26$ & 6,0 \\
$27-29$ & 6,5 \\
$30-32$ & 7,0 \\
$33-34$ & 7,5 \\
$35-37$ & 8,0 \\
$38-40$ & 8,5 \\
41 ou mais semanas & 9,0 \\
\hline
\end{tabular}


esperada na transição normal (Figura 13.1). O CPAP é aplicado por meio da máscara conectada ao ventilador mecânico manual em T, com PEEP de 4 a $6 \mathrm{cmH}_{2} \mathrm{O}$ e fluxo gasoso de 5 a $15 \mathrm{~L} /$ minuto, estando a máscara firmemente ajustada à face do paciente. A quantidade de oxigênio a ser ofertada deve ser a menor possível para manter a $\mathrm{SatO}_{2}$ entre 70 e $80 \%$ nos primeiros 5 minutos e 80 e $90 \%$ entre 5 e 10 minutos de vida (Figura 13.1).

Para a aplicação da VPP com o ventilador mecânico manual em T em RN com apneia, respiração irregular e/ou FC < 100 bpm, fixar o fluxo gasoso em 5 a $15 \mathrm{~L} /$ minuto, limitar a pressão máxima do circuito em $30 \mathrm{a} 40 \mathrm{cmH}_{2} \mathrm{O}$, selecionar a pressão inspiratória a ser aplicada em cada ventilação, em geral ao redor de 20 a $25 \mathrm{cmH}_{2} \mathrm{O}$, ajustar a PEEP em 4 a 6 $\mathrm{CmH}_{2} \mathrm{O}$, e iniciar com oferta de oxigênio em ar ambiente ( $R N \geq 34$ semanas) ou em $30 \%$ ( $R N<34$ semanas), guiada pela oximetria de pulso. Ventilar com frequência de 40 a 60 mpm, que pode ser obtida com a regra prática "ocluuui/solta/ solta", "ocluuui/solta/solta"..., sendo o "ocluuui" relacionado à oclusão do orifício da peça $T$ do ventilador mecânico manual. ${ }^{1062} \mathrm{~A}$ conduta quanto à melhora ou à piora do $\mathrm{RN}$ depende da FC e da retomada da respiração espontânea, de modo similar ao descrito para a VPP com balão com máscara e com cânula traqueal.

\subsection{Massagem Cardíaca}

A asfixia pode desencadear vasoconstrição periférica, hipoxemia tecidual, diminuição da contratilidade miocárdica, bradicardia e, eventualmente, parada cardíaca. A ventilação adequada reverte esse quadro na maioria dos pacientes. Dessa maneira, a massagem cardíaca só é indicada se, após 30 segundos de VPP com técnica adequada, a FC < 60 bpm. Como a massagem cardíaca diminui a eficácia da ventilação e a última é a ação mais efetiva na reanimação neonatal, as compressões só devem ser iniciadas quando a expansão e a ventilação pulmonares estiverem bem estabelecidas. Assim, na prática clínica, a massagem cardíaca é iniciada se FC < 60 bpm após 30 segundos de VPP com técnica adequada por meio da cânula traqueal.

Embora não existam dados clínicos, recomenda-se oferecer concentração de oxigênio de $100 \%$ no RN que recebe VPP e massagem cardíaca. Essa recomendação leva em conta os efeitos deletérios da hipóxia profunda e persistente no RN asfixiado. Para reduzir o risco de complicações associadas à hiperóxia, a oferta de oxigênio suplementar deve ser reduzida assim que houver recuperação da FC. A partir desse momento, é possível ajustar a oferta de oxigênio segundo as saturaçõesalvo ${ }^{1061-1066}$ (Figura13.1).

A compressão cardíaca é realizada com a aplicação dos dois polegares sobrepostos no terço inferior do esterno, ou seja, logo abaixo da linha intermamilar, poupando o apêndice xifoide. O restante das mãos circunda o tórax, dando suporte ao dorso durante a massagem. O profissional de saúde que vai executar a massagem cardíaca se posiciona atrás da cabeça do RN, enquanto aquele que ventila se desloca para um dos lados. ${ }^{1083} \mathrm{~A}$ profundidade da compressão deve englobar um terço da dimensão anteroposterior do tórax, de maneira a produzir um pulso palpável. É importante permitir a reexpansão plena do tórax após a compressão, para haver enchimento das câmaras ventriculares e das coronárias; no entanto, os dedos não devem ser retirados do terço inferior do tórax. As complicações da massagem cardíaca incluem a fratura de costelas, com pneumotórax e hemotórax, e laceração de fígado.

No RN, a ventilação e a massagem cardíaca são realizadas de forma sincrônica, mantendo-se relação de 3:1, ou seja, três movimentos de massagem cardíaca para um movimento de ventilação, com frequência de 120 eventos por minuto (90 movimentos de massagem e 30 ventilações). Deve-se aplicar a massagem cardíaca coordenada à ventilação por 60 segundos, antes de reavaliar a FC, pois este é o tempo mínimo para que a massagem efetiva possa restabelecer a pressão de perfusão coronariana. O monitor cardíaco é útil para avaliar de forma contínua e instantânea a FC, sem interromper a ventilação e a massagem. A massagem deve continuar enquanto a FC estiver $<60$ bpm. Lembrar que a VPP, durante a massagem cardíaca, deve ser ministrada por cânula traqueal, para garantir a expansão plena pulmonar. A única situação, no período neonatal, em que se pode considerar a aplicação de 15 compressões cardíacas intercaladas com duas ventilações é a do paciente internado em UTI com PCR de origem cardíaca, como nos portadores de cardiopatias congênitas. ${ }^{1065,1066}$

A melhora é considerada quando, após a VPP acompanhada de massagem cardíaca, o RN apresenta FC > 60 bpm. Neste momento, interrompe-se apenas a massagem. Caso o paciente apresente respirações espontâneas regulares e a FC atinja valores > $100 \mathrm{bpm}$, a ventilação também é suspensa com retirada gradual, de acordo com a SatO ${ }_{2}$ verificada na oximetria de pulso. Em geral, quando o RN recebeu massagem cardíaca na sala de parto, é mais prudente transportá-lo intubado à UTI neonatal em incubadora de transporte, sendo a decisão quanto à extubação realizada de acordo com a avaliação global do RN na unidade.

Considera-se falha do procedimento se, após 60 segundos de VPP com cânula traqueal e oxigênio a 100\% acompanhada de massagem cardíaca, o RN mantiver FC < 60 bpm. Nesse caso, verificar a posição da cânula, a permeabilidade das vias aéreas e a pressão de ventilação, além da técnica da massagem propriamente dita, corrigindo o que for necessário. Se, após a correção da técnica da VPP e massagem, não houver melhora, considera-se o cateterismo venoso umbilical de urgência e indica-se a adrenalina endovenosa.

\subsection{Adrenalina e Expansor de Volume}

Quando a FC permanece abaixo de 60 bpm, a despeito de ventilação efetiva e de massagem cardíaca adequada, o uso de adrenalina, expansor de volume ou ambos está indicado. A diluição, o preparo, a dose e a via de administração estão descritas na tabela 13.3. A via preferencial para a infusão de medicações na sala de parto é a endovenosa, sendo a veia umbilical de acesso fácil e rápido. O cateter venoso umbilical deve ser inserido de emergência, assim que houver indicação do uso de medicações na sala de parto. A administração de medicações por via traqueal só pode 
ser usada para a adrenalina e uma única vez, sabendo-se que a absorção por via pulmonar é lenta, imprevisível e a resposta, em geral, é insatisfatória. ${ }^{1084}$

A adrenalina está indicada quando a ventilação adequada e a massagem cardíaca efetiva não elevaram a FC acima de 60 bpm. Quando não há reversão da bradicardia com o uso da adrenalina, pode-se repeti-la a cada 3 a 5 minutos (sempre por via endovenosa, na dose $0,03 \mathrm{mg} / \mathrm{kg}$ ) e considerar o uso de expansores de volume, caso o paciente esteja pálido ou existam sinais de choque.

A expansão de volume é feita com soro fisiológico, na dose de $10 \mathrm{~mL} / \mathrm{kg}$, que pode ser repetida a critério clínico. Com o uso do expansor, espera-se o aumento da pressão arterial e a melhora dos pulsos e da palidez. Se não houver resposta, deve-se verificar a posição da cânula traqueal, o uso do oxigênio a $100 \%$, a técnica da ventilação e da massagem e a permeabilidade da via de acesso vascular.

Lembrar que doses elevadas de adrenalina (>0,1 mg/kg) não devem ser empregadas em RN, pois levam à hipertensão arterial grave, diminuição da função miocárdica e piora do quadro neurológico; a expansão rápida da volemia pode se associar à hemorragia intracraniana nos prematuros. A presença de assistolia aos 10 minutos de vida é forte preditor de mortalidade e morbidade em todas as idades gestacionais, sendo razoável interromper os procedimentos de reanimação. Entretanto, a decisão de continuar ou interromper tais procedimentos precisa ser individualizada.

\subsection{Consideração Final}

Um resumo das principais recomendações da reanimação neonatal em sala de parto que foram lançadas em 2015, acompanhada pelo Nível de Evidência, ${ }^{1085}$ encontra-se nos quadros 13.2 e 13.3 .

A ventilação pulmonar é o procedimento mais importante e efetivo na reanimação em sala de parto e, quando necessária, deve ser iniciada nos primeiros 60 segundos de vida ("Minuto de Ouro"). O risco de morte ou morbidade aumenta em 16\% a cada 30 segundos de demora para iniciar a VPP, de modo independente do peso ao nascer, da idade gestacional ou de complicações na gravidez ou no parto. ${ }^{1086}$

A reanimação ao nascimento é uma das oito intervenções estratégicas para diminuir a mortalidade infantil em nível mundial. Estima-se que o atendimento ao parto por profissionais de saúde habilitados possa reduzir em 20 a 30\% as taxas de mortalidade neonatal, enquanto o emprego das técnicas de reanimação resulte em diminuição adicional de $5 \%$ a $20 \%$ nestas taxas, com redução de até $45 \%$ das mortes neonatais por asfixia. ${ }^{1087}$

\section{Suporte Avançado de Vida em Insuficiência Cardíaca}

\subsection{Introdução}

A IC Aguda (ICA) é a principal causa de internação hospitalar nos países desenvolvidos e no Brasil, ocupando a terceira posição geral e a primeira dentre as causas cardiovasculares. Trata-se de uma doença com elevado índice de mortalidade, cujo tratamento é complexo e individualizado, devido às distintas formas de apresentação clínica. A IC, em sua fase descompensada, é uma síndrome diferente da IC crônica, que necessita de estratégias, abordagem diagnóstica e terapêutica distintas. ${ }^{1088,1089}$

\subsection{Definição}

A ICA é definida como doença de rápida instalação, cuja disfunção pode ser de origem sistólica ou diastólica, como também decorrente das alterações do ritmo cardíaco, da pré e pós-carga do VE, podendo ser classificada na forma aguda ou como uma exacerbação aguda da IC crônica.

\subsubsection{Insuficiência Cardíaca Aguda}

É uma síndrome clínica de IC, que acomete pacientes sem diagnóstico prévio, desencadeada por situações clínicas

Tabela 13.3 - Medicações para reanimação do recém-nascido na sala de parto

\begin{tabular}{|c|c|c|c|}
\hline Medicações & Adrenalina endovenosa & Adrenalina endotraqueal & Expansor de volume \\
\hline Diluição & $\begin{array}{c}1: 10.000 \\
1 \mathrm{~mL} \text { adrenalina } 1: 1.000 \mathrm{em} 9 \mathrm{~mL} \text { de SF }\end{array}$ & $\begin{array}{c}1: 10.000 \\
1 \mathrm{~mL} \text { adrenalina } 1: 1.000 \mathrm{em} 9 \mathrm{~mL} \text { de SF }\end{array}$ & SF \\
\hline Preparo & $1 \mathrm{~mL}$ & $5 \mathrm{~mL}$ & 2 seringas de $20 \mathrm{~mL}$ \\
\hline Dose & $0,1-0,3 \mathrm{~mL} / \mathrm{kg}$ & $0,5-1,0 \mathrm{~mL} / \mathrm{kg}$ & $10 \mathrm{~mL} / \mathrm{kg} \mathrm{EV}$ \\
\hline \multicolumn{4}{|l|}{ Peso ao nascer, kg } \\
\hline 1 & $0,1-0,3 \mathrm{~mL}$ & $0,5-1,0 \mathrm{~mL}$ & $10 \mathrm{~mL}$ \\
\hline 2 & $0,2-0,6 \mathrm{~mL}$ & $1,0-2,0 \mathrm{~mL}$ & $20 \mathrm{~mL}$ \\
\hline 3 & $0,3-0,9 \mathrm{~mL}$ & $1,5-3,0 \mathrm{~mL}$ & $30 \mathrm{~mL}$ \\
\hline 4 & 0,4-1,2 mL & $2,0-4,0 \mathrm{~mL}$ & $40 \mathrm{~mL}$ \\
\hline Velocidade e precauções & $\begin{array}{l}\text { Infundir rápido na veia umbilical seguido } \\
\text { por } \\
0,5-1,0 \mathrm{~mL} \text { de SF }\end{array}$ & $\begin{array}{l}\text { Infundir na cânula traqueal e ventilar. } \\
\text { Uso único }\end{array}$ & $\begin{array}{l}\text { Infundir na veia umbilical lentamente, } \\
\text { em } 5 \text { a } 10 \text { minutos }\end{array}$ \\
\hline
\end{tabular}

SF: soro fisiológico; EV: via endovenosa. 
Quadro 13.2 - Classe de Recomendação e Nível de Evidência das diretrizes elaboradas ou revisadas em 2015 relativas aos passos iniciais e à ventilação com pressão positiva na reanimação neonatal em sala de parto

\begin{tabular}{|c|c|c|c|}
\hline Tópico & Recomendação & Classe de Recomendação & Nível de Evidência \\
\hline $\begin{array}{l}\text { Clampeamento do cordão } \\
\text { umbilical }\end{array}$ & $\begin{array}{l}\text { Sugere-se o clampeamento tardio do cordão, depois de } 30 \text { segundos do nascimento, } \\
\text { em RN termo e pré-termo que não necessitam de reanimação ao nascer }\end{array}$ & Ila & C \\
\hline $\begin{array}{l}\text { Clampeamento do cordão } \\
\text { umbilical }\end{array}$ & $\begin{array}{l}\text { Não existe evidência suficiente para recomendar o tempo para clampear o cordão } \\
\text { umbilical em RN que precisam de reanimação ao nascer }\end{array}$ & $11 \mathrm{~b}$ & C \\
\hline Temperatura corporal & $\begin{array}{l}\text { Recomenda-se que a temperatura corporal do RN não asfixiado seja mantida entre } \\
36,5-37,5^{\circ} \mathrm{C} \text { desde o nascimento até a admissão na unidade neonatal }\end{array}$ & I & C \\
\hline Temperatura corporal & $\begin{array}{c}\text { Sugere-se evitar a hipertermia }\left(>38^{\circ} \mathrm{C}\right) \text { desde o nascimento até a admissão na } \\
\text { unidade neonatal pelos riscos potenciais associados }\end{array}$ & III & C \\
\hline $\begin{array}{l}\text { Líquido amniótico } \\
\text { meconial }\end{array}$ & $\begin{array}{l}\text { No RN com líquido amniótico meconial com hipotonia ou apneia ou FC }<100 \text { bpm, } \\
\text { fazer os passos iniciais, seguido pela VPP, se necessária. Sugere-se não aspirar a } \\
\text { traqueia sob visualização direta logo após o nascimento }\end{array}$ & Ilb & C \\
\hline Avaliação da FC & $\begin{array}{l}\text { Sugere-se o uso do monitor cardíaco com } 3 \text { eletrodos para a medida rápida e } \\
\text { acurada da FC em RN a termo e pré-termo durante a reanimação }\end{array}$ & Ilb & C \\
\hline $\begin{array}{l}\text { Uso de oxigênio } \\
\text { suplementar }\end{array}$ & $\begin{array}{l}\text { Recomenda-se não iniciar a reanimação do RN com altas concentrações de oxigênio } \\
\qquad(65 \% \text { ou mais })\end{array}$ & III & B \\
\hline VPP & Sugere-se administrar a VPP em RN pré-termo com PEEP aproximado de $5 \mathrm{cmH}_{2} \mathrm{O}$ & $\| \mathrm{lb}$ & B \\
\hline VPP & $\begin{array}{c}\text { Sugere-se que a VPP seja aplicada com balão autoinflado, balão inflado por fluxo ou } \\
\text { ventilador mecânico manual em T }\end{array}$ & Ila & $\mathrm{B}$ \\
\hline Máscara laríngea & $\begin{array}{l}\text { Recomendação de uso de máscara laríngea no } \mathrm{RN} \geq 34 \text { semanas quando a } \\
\text { intubação traqueal no foi bem-sucedida ou não é factivel }\end{array}$ & I & C \\
\hline CPAP & $\begin{array}{c}\text { Sugere-se o uso do CPAP por via não invasiva no RN pré-termo com respiração } \\
\text { espontânea e desconforto respiratório }\end{array}$ & Ilb & B \\
\hline
\end{tabular}

RN: recém-nascido; FC: frequência cardíaca; VPP: ventilação com pressão positiva; PEEP: pressãopositiva expiratória final; CPAP: pressão positiva continua nas vias aéreas.

Quadro 13.3 - Classe de Recomendação e Nível de Evidência das diretrizes elaboradas ou revisadas em 2015, relativas à reanimação neonatal avançada em sala de parto

\begin{tabular}{|c|c|c|c|}
\hline Tópico & Recomendação & Classe de Recomendação & Nível de Evidência \\
\hline Massagem cardíaca & $\begin{array}{l}\text { Recomenda-se realizar a massagem cardíaca no terço inferior do esterno, na } \\
\text { profundidade aproximada de um terço do diâmetro anteroposterior do tórax }\end{array}$ & $\| \mathrm{lb}$ & C \\
\hline Massagem cardíaca & $\begin{array}{l}\text { Sugere-se, como técnica preferível para a massagem cardíaca, o posicionamento } \\
\text { dos dois polegares no esterno, com o restante das mãos envolvendo o tórax }\end{array}$ & $\| \mathrm{lb}$ & C \\
\hline Massagem cardíaca & $\begin{array}{c}\text { Recomenda-se, durante a massagem cardíaca, o uso da razão } 3: 1 \text { ( } 3 \text { compressões } \\
\text { intercaladas com } 1 \text { ventilação), perfazendo } 90 \text { compressões e } 30 \text { ventilações por } \\
\text { minuto }\end{array}$ & Ila & C \\
\hline Massagem cardíaca & $\begin{array}{l}\text { Sugere-se o uso da razão 15:2 (15 compressões intercaladas com } 2 \text { ventilações) } \\
\text { apenas para RN com colapso cardiovascular decorrente de cardiopatia congênita }\end{array}$ & $\| \mathrm{lb}$ & C \\
\hline Massagem cardíaca & Sugere-se o uso do oxigênio a 100\% para VPP durante a massagem cardíaca & $\| l a$ & C \\
\hline Massagem cardíaca & $\begin{array}{l}\text { Recomenda-se a diminuição gradual do oxigênio suplementar, assim que houver } \\
\text { recuperação da FC para evitar a hiperóxia }\end{array}$ & I & C \\
\hline Interrupção da reanimação & $\begin{array}{c}\text { Sugere-se que, em RN com assistolia após } 10 \text { minutos de reanimação, é razoável } \\
\text { interromper a reanimação. Entretanto a decisão de continuar ou interromper a } \\
\text { reanimação deve ser individualizada }\end{array}$ & $11 \mathrm{~b}$ & C \\
\hline
\end{tabular}

RN: recém-nascido; VPP: ventilação com pressão positiva; FC: frequência cardíaca. 
diversas, como SCA, miocardites, emergência hipertensiva ou ruptura de cordoalha tendínea da valva mitral. Nesse contexto, apresentam-se com congestão pulmonar sem congestão sistêmica e volemia sanguínea normal, de modo que doses altas de diuréticos não estão indicadas nesse grupo, e o tratamento é direcionado à causa desencadeante. ${ }^{1090}$

\subsubsection{Exacerbação Aguda da Insuficiência Cardíaca Crônica}

Situação clínica de piora progressiva ou abrupta dos sinais e sintomas de IC em repouso de pacientes já sabidamente portadores da síndrome e que, nesse contexto, necessitam de terapia adicional. É a forma de apresentação clínica mais frequente, sendo desencadeada por múltiplas causas (Tabela 14.1). Em geral, há congestão pulmonar e sistêmica, sendo crucial o manejo com diuréticos em altas doses associados à correção do fator desencadeante quando identificado. ${ }^{1090,1091}$

\subsection{Abordagem Inicial}

Várias condutas são instituídas simultaneamente. O Suporte Avançado de Vida em Insuficiência Cardíaca (SAVIC) procura sistematizar tais condutas, propondo a sequência A-B-C-D-EFG-H, conforme apresentado no quadro 14.1 e na figura 14.1.

Após determinar clinicamente o perfil hemodinâmico do paciente, inicia-se rapidamente seu tratamento, procurandose avaliar os oito itens sistematizados pelo SAVIC - não obrigatoriamente na sequência das letras.

\section{A - Avaliação Clínica/Hemodinâmica}

A classificação do paciente em um dos quatro perfis clínico/ hemodinâmicos é realizada pela interpretação de sinais e sintomas característicos de congestão e má perfusão ou baixo débito (Figura 14.2). ${ }^{1091}$

\section{Perfil A: quente e seco}

Engloba cerca de $9,6 \%{ }^{1092}$ dos casos. É representado por pacientes sem sinais de congestão ou de baixo débito, compensados do ponto de vista clínico/hemodinâmico; logo, a conduta é de seguimento ambulatorial.

Tabela 14.1 - Causas de descompensação da insuficiência cardíaca (IC) segundo registro BREATHE ${ }^{1090}$

\begin{tabular}{lc}
\hline Causa da descompensação da IC & $\begin{array}{c}\% \\
\text { (n=1.250) }\end{array}$ \\
\hline Má aderência medicamentosa & 29,9 \\
Infecção & 22,7 \\
Arritmia cardíaca & 12,5 \\
Aumento da ingesta de sódio e água. & 8,9 \\
Doença valvar aguda & 6,6 \\
Embolia pulmonar & 0,4 \\
Outros & 32,4 \\
\hline
\end{tabular}

\section{Perfil B: quente e úmido}

Este é o perfil mais comum, ocorrendo em $67,4 \%$ dos casos que chegam à sala de emergência. ${ }^{5}$ Caracterizado pela presença de elevadas pressões de enchimento ventricular e clinicamente manifesto por queixas de ortopneia e dispneia paroxística noturna, além de achados ao exame físico, como estertores crepitantes, estase jugular, hepatomegalia, refluxo hepatojugular, ascite e edema de membros inferiores. A perfusão tecidual deve estar adequada, e esses pacientes devem apresentar nível de consciência preservado, pulsos cheios e extremidades quentes.

Os diuréticos são medicações de primeira linha para melhora da congestão pulmonar e sistêmica, preferencialmente por via endovenosa, como os diuréticos de alça (por exemplo: furosemida), porém naqueles já em uso prévio e que apresentarem sinais de resistência, é possível associar o diurético tiazídico para potencializar o efeito (Tabela 14.2 e Figura 14.3).

Neste perfil, os vasodilatadores são fundamentais para redução da congestão e para demanda miocárdica de oxigênio, ao promoverem redução na pré-carga e pós-carga.

\section{Perfil C: frio e úmido}

O perfil C representa cerca de $17,8 \%{ }^{1092}$ dos pacientes e apresenta tanto baixo débito quanto sinais de hipervolemia. São sinais sugestivos: índice cardíaco reduzido $<2,2 \mathrm{~L} / \mathrm{min} /$ $\mathrm{m}^{2}$; relação entre a pressão de pulso (sistólica-diastólica) e pressão sistólica menor que 25\%; débito urinário $<0,5 \mathrm{~mL} / \mathrm{kg}$ / hora; PAS < 90 mmHg (não obrigatória); nível de consciência inadequado; tempo de enchimento capilar reduzido; pulso fino; e extremidades frias. ${ }^{1093}$

Caso o paciente persista em baixo débito após terapia inicial com diurético, é escolhido o inotrópico para iniciar, a depender da PAS e do uso de betabloqueadores previamente, como demonstrado na figura 14.4 e no quadro 14.2, com suas respectivas doses na tabela 14.3. Outra opção para os que ainda permanecem com a pressão sistólica igual ou maior a $90 \mathrm{mmHg}$, é a utilização de vasodilatadores para melhora da pós-carga, sejam eles de forma oral, como o IECA, BRA e nitrato com hidralazina, ou de forma endovenosa, como nitroglicerina ou nitroprussiato. ${ }^{1088,1089}$

\section{Quadro 14.1 - Abordagem mnemônica do Suporte Avançado de Vida em Insuficiência Cardíaca ${ }^{1092}$}

\begin{tabular}{cc}
\hline A & Avaliação clínica/hemodinâmica \\
B & Boa ventilaçãoo/respiraçãoo com oxigenaçãoo e ventilação adequadas \\
C & Circulação com reposiçãoo volêmica (avaliar necessidade) \\
D & Diuréticos (avaliar necessidade) \\
E & Eletrocardiograma (avaliar isquemia, arritmias e bloqueios) \\
F & Frequência cardíaca (controle de bradi ou taquiarritmias) \\
G & Garantir a não suspensão rotineira das medicações \\
H & Feparina (profilaxia de trombose venosa profunda e tromboembolismo \\
\end{tabular}




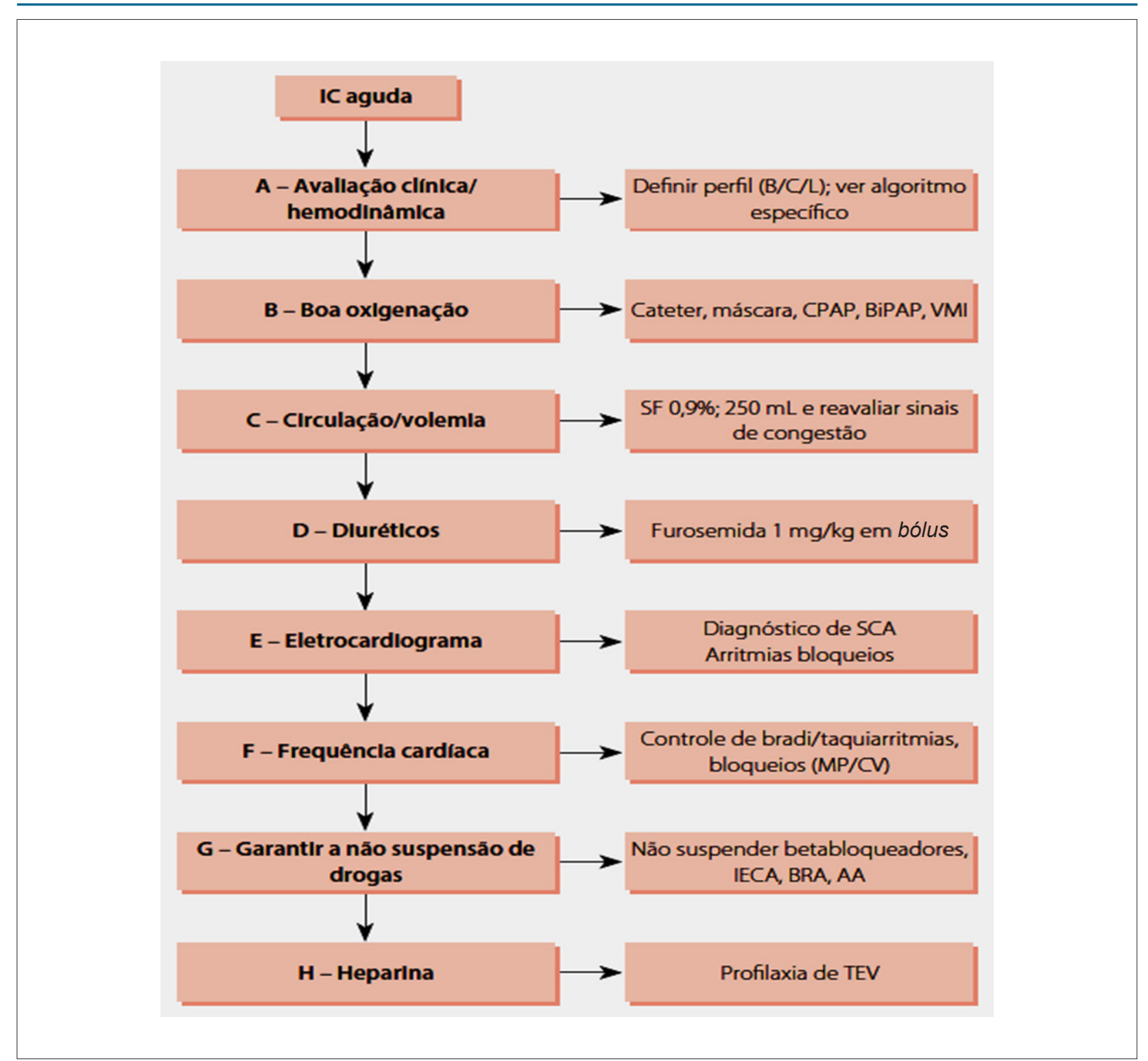

Figura 14.1 -Algoritmo para o manejo inicial da insuficiência cardíaca (IC) aguda. ${ }^{1092}$ CPAP: pressão positiva contínua nas vias aéreas; BiPAP: pressão positiva bifásica nas vias aéreas; VMI: ventilação mecânica invasiva; SF: soro fisiológico; SCA: síndrome coronariana aguda; MP: marca-passo; CV: cardioversão; IECA: inibidores da enzima conversora de angiotensina; BRA: bloqueadores de receptores da angiotensina; AA: angiotenisina aldosterona; TEV: tromboembolismo venoso.

Nos pacientes em que a perfusão ainda persista inadequada a despeito de inotrópicos e que não toleram os vasodilatadores, a noradrenalina ou a epinefrina devem ser associadas, e o uso de suporte mecânico deve ser considerado (choque cardiogênico refratário).

\section{Perfil L: frio e seco}

O perfil L, muitas vezes decorrente da própria terapia da IC, facilitada pelo uso de diuréticos, está presente em cerca de $5,2 \%{ }^{1092}$ dos pacientes admitidos em IC descompensada, como mostra a figura 14.5.

$\mathrm{O}$ "C", da circulação, é o aspecto mais importante neste subgrupo. Observando a figura 14.1, podemos notar que os pacientes incluídos nesse perfil são aqueles com baixo débito e sem evidências clínicas de pressão de enchimento elevada. Apresentam-se sintomáticos, mas com pouca evidência de congestão. Nesta fase, uma prova de volume controlado com $250 \mathrm{~mL}$ de soro fisiológico 0,9\% e reavaliações clínicas, a fim de melhorar a volemia, pode ser útil. Após melhorar a volemia, é importante reavaliar o perfil, para definir a melhor opção terapêutica a seguir, como mostra a figura $14.6 .{ }^{1088,1089}$

\section{B - Boa Ventilação e Adequada Oxigenação}

Dispositivos não invasivos de aporte de oxigênio são indicados, de acordo com a necessidade do paciente na chegada à emergência. A VNI intermitente, com pressão 


\section{Atualização}

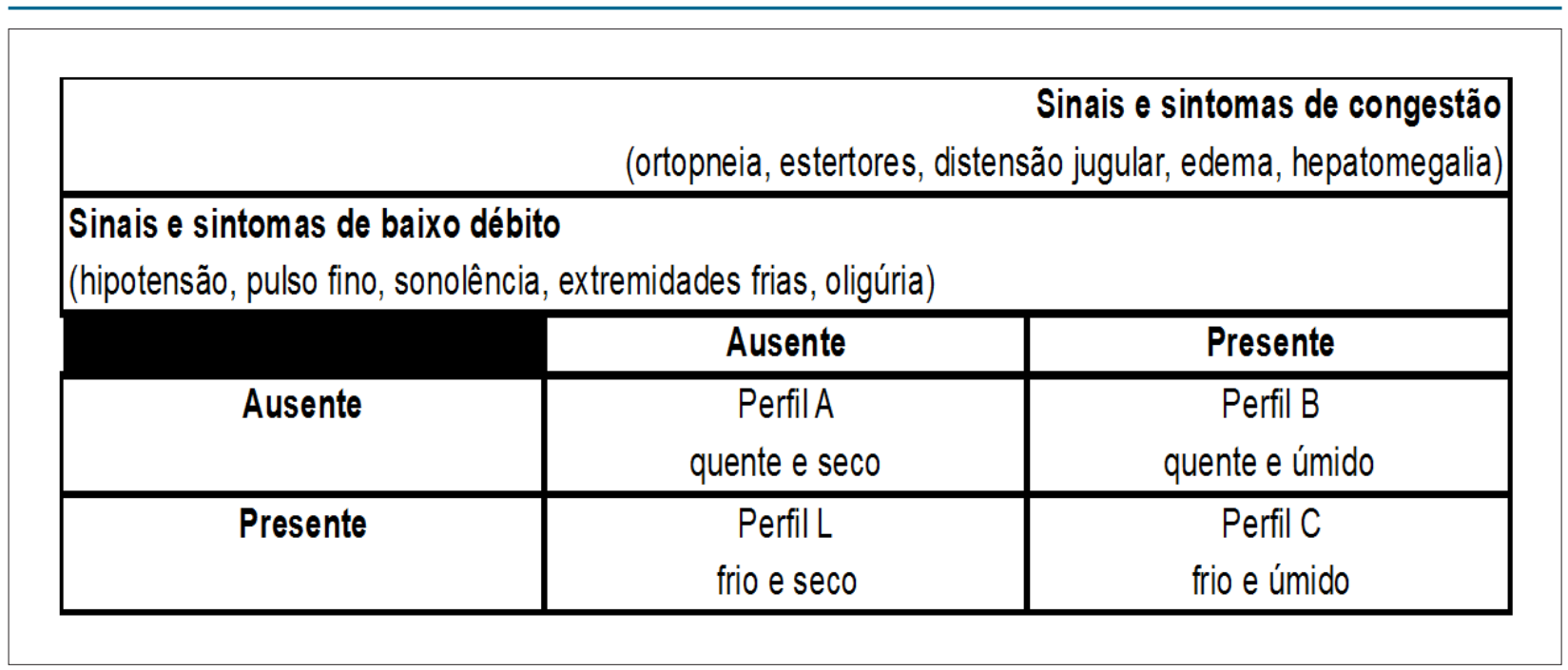

Figura 14.2 - Avaliação clínica/hemodinâmica do Suporte Avançado de Vida em Insuficiência Cardiaca. 1088, 1089, 1092

Tabela 14.2 - Tipos de diuréticos e doses (inicial e máxima) na insuficiência cardíaca aguda ${ }^{1088,1089}$

\begin{tabular}{lcc}
\hline Diuréticos & $\begin{array}{c}\text { Dose inicial } \\
(\mathrm{mg})\end{array}$ & $\begin{array}{c}\text { Dose máxima } \\
(\mathrm{mg})\end{array}$ \\
\hline De alça & & 240 \\
$\quad$ Furosemida & 20 & 10 \\
$\quad$ Bumetanida & $0,5-2,0$ & \\
Tiazídicos & & 100 \\
$\quad$ Hidroclorotiazida & 25 & 50 \\
Clortalidona & 12,5 & 5 \\
$\quad$ Indapamida & 2,5 & \\
Poupadores de & & \\
potássio & & 50 \\
Espironolactona & 25 & 20 \\
Amilorida & 2,5 & \\
\hline
\end{tabular}

positiva, deve ser considerada em pacientes com congestão pulmonar de origem cardiogênica. Sua ação primordial deve-se principalmente à diminuição do retorno venoso e, com isso, há redução da pré-carga. A VNI, na forma de CPAP, demonstrou reduzir a necessidade de VM e a mortalidade neste grupo de pacientes. ${ }^{1093}$

Ao se comparar CPAP com BiPAP, ambas as modalidades de $\mathrm{VNI}$ foram superiores ao tratamento convencional, em relação às taxas de VM, mas não diferiram entre si. A VM é reservada para casos refratários à terapêutica empregada, ${ }^{1094}$ como mostrado no quadro 14.3.

\section{C - Circulação e Reposição Volêmica}

Deve ser considerada a prova de volume, de forma cuidadosa e monitorada, nos casos em que não há evidências de congestão pulmonar ou sistêmica, como os pacientes com perfil L (Quadro 14.4). ${ }^{1088,1089}$

\section{D - Diuréticos}

Diuréticos de alça administrados de forma endovenosa são de primeira escolha e, por consequência do seu efeito venodilatador nos primeiros minutos após infusão, ocorre o alívio sintomático, mesmo antes do efeito diurético. ${ }^{1088,1089,1095}$ Devem-se monitorizar de forma cuidadosa os níveis de potássio e de magnésio.

Diuréticos tiazídicos (clortalidona, hidroclorotiazida e indapamida) agem principalmente no controle da HAS e como potencializadores dos diuréticos de alça. Os efeitos colaterais se traduzem em hiponatremia, aumento da resistência à glicose e nos níveis séricos dos triglicerídeos e do ácido úrico.

Espironolactona é um diurético poupador de potássio e exerce seu efeito antagonizando o efeito mineralocorticoide da aldosterona. Possui mecanismo "hormonal", e seu início de ação pode levar horas a dias. ${ }^{1088,1089,1095}$

\section{E - Eletrocardiograma}

A obtenção do ECG de 12 derivações deve ser realizada na chegada de todo paciente à sala de emergência para estabelecer o diagnóstico diferencial e o início do tratamento apropriado. ${ }^{1088,1089}$

\section{F - Frequência Cardíaca e Controle de Arritmias}

Taquiarritmias ou bradiarritmias reduzem o DC e devem ser corrigidas.

O flutter e a FA agudos são causas frequentes de descompensação nos pacientes com IC, com risco de ocorrência aumentado em 3,5 vezes em relação à população geral 1096

A incidência de arritmias ventriculares na IC é alta, caracterizando um grupo de elevado risco para morte 


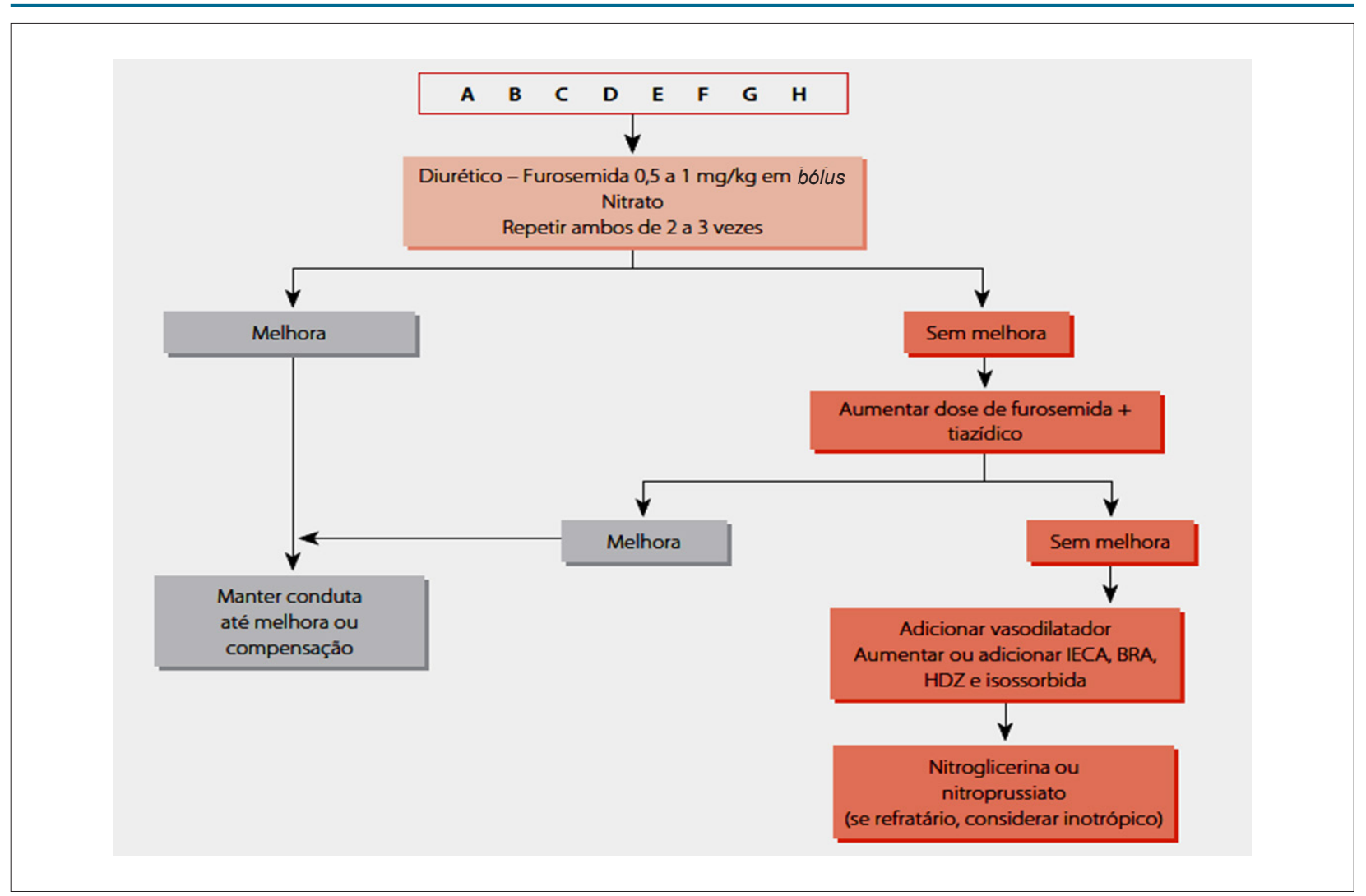

Figura 14.3 - Algoritmo para o perfil B (quente e úmido).1092 IECA: inibidores da enzima conversora de angiotensina; BRA: bloqueadores de receptores da angiotensina; HZD: hidroclorotiazida.

súbita. ${ }^{1097,1098}$ Os distúrbios metabólicos e eletrolíticos devem ser investigados e corrigidos, e as DAA com propriedades inotrópicas negativas ou vasodilatadoras devem ser utilizadas com cautela.

\section{G - Garantir a não Suspensão Rotineira de Medicações}

Aspecto importante éa não suspensão dos betabloqueadores, devendo a dose ser ajustada e a suspensão somente ser realizada em casos de instabilidade hemodinâmica grave, BAV avançados ou efeito colateral comprovadamente relacionado ao medicamento (Quadro 14.5).

Assim como os betabloqueadores, o IECA, ou BRA, e a espironolactona são as principais medicações que oferecem sobrevida aos pacientes com IC crônica, devendo ser mantidos, exceto se insuficiência renal em piora ou creatinina maior que $3 \mathrm{mg} / \mathrm{dL}$ ou hiperpotassemia maior que $5,5 \mathrm{meq} / \mathrm{L} .^{1099,1100}$

\section{H - Heparina (Profilaxia de Trombose Venosa Profunda e Tromboembolismo Pulmonar)}

A TVP e o TEP contribuem significativamente para aumentar a morbimortalidade de pacientes com ICA.

A IC isoladamente já é considerada fator de alto risco para TVP e TEP, podendo chegar a $15 \%$ em pacientes internados. ${ }^{1101}$ É bem indicada a profilaxia medicamentosa, salvo suas contraindicações. O uso de compressão pneumática intermitente deve ser discutido individualmente. ${ }^{1102}$

\subsection{Padrão de Abordagem e Drogas Vasoativas}

Uma vez iniciadas as medidas de suporte, é importante que estejamos conscientes do perfil clínico em que melhor se encaixa o paciente avaliado.

- Nitratos: classe de medicamentos de grande utilidade na fase aguda da IC, em associação aos vasodilatadores diretos, especialmente quando intolerantes ao IECA. O dinitrato de isossorbida possui pico de ação em 3 a 5 minutos, e promove diminuição da pré-carga, vasodilatação coronariana e da artéria pulmonar. A nitroglicerina promove redução da pré e da pós-carga, bem como das pressões de enchimento ventricular esquerdo, e melhora a perfusão das áreas isquêmicas, devido à vasodilatação coronariana (Quadro 14.6). ${ }^{1103}$

- Nitroprussiato de sódio: pode ser empregado no controle da fase aguda de pacientes com ICA. Seu efeito é dado pela conversão em óxido nítrico e óxido de cianeto, tornandose potente vasodilatador, principalmente arterial, capaz de reduzir rapidamente a pós-carga, de forma titulável, permitindo-se atingir o efeito hemodinâmico desejado (Tabela 14.4). 


\section{Atualização}

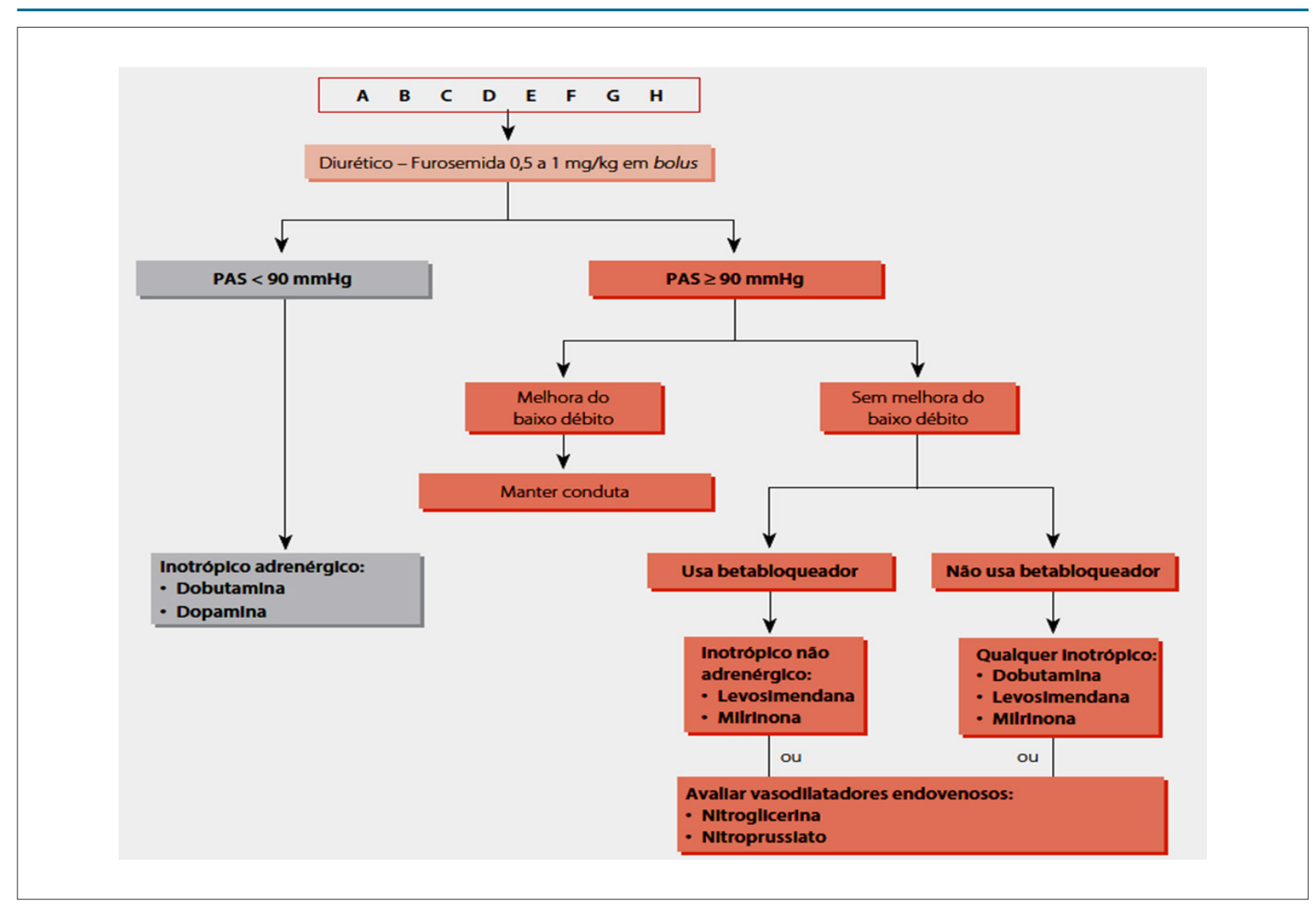

Figura 14.4 - Algoritmo para o perfil C (frio e úmido).1092 PAS: pressão arterial sistólica.

\section{Quadro 14.2 - Recomendações do uso de inotrópicos em insuficiência cardíaca aguda ${ }^{1088,1089}$}

\begin{tabular}{|c|c|c|}
\hline Recomendação & Classe de Recomendação & Nível de Evidência \\
\hline $\begin{array}{l}\text { Dobutamina para pacientes em choque cardiogênico, para suporte hemodinâmico, independentemente da } \\
\text { etiologia da cardiomiopatia }\end{array}$ & I & B \\
\hline $\begin{array}{l}\text { Levosimendana para pacientes com sinais de baixo débito, sem choque cardiogênico, em uso de } \\
\text { betabloqueador }\end{array}$ & Ila & B \\
\hline $\begin{array}{l}\text { Milrinone para pacientes com sinais de baixo débito, sem choque cardiogênico, com etiologia não isquêmica, } \\
\text { em uso de betabloqueador }\end{array}$ & Ila & B \\
\hline $\begin{array}{l}\text { Dobutamina e/ou milrinone para suporte hemodinâmico para pacientes em baixo débito e em fila de espera } \\
\text { para transplante cardiaco em situação de prioridade }\end{array}$ & Ila & C \\
\hline $\begin{array}{l}\text { Dobutamina, milrinone ou levosimendana para melhora dos sintomas de pacientes em baixo débito sem } \\
\text { hipotensão arterial }\end{array}$ & $\mathrm{llb}$ & B \\
\hline Associação de levosimendana na tentativa de retirada de dobutamina & $\| l b$ & C \\
\hline Dobutamina, milrinone ou levosimendana para pacientes sem sinais de baixo débito & III & B \\
\hline
\end{tabular}

- Epinefrina ou norepinefrina: utilizadas para atingir estabilização hemodinâmica naqueles que evoluem com hipotensão importante, principalmente nos perfis $\mathrm{C}$ e $\mathrm{L}$, a despeito do manejo inicial e de inotrópicos em dose adequada. Os vasopressores têm papel fundamental naqueles com maior grau de descompensação ou quando a causa desencadeante está associada à sepse. ${ }^{1091}$
- Inotrópicos: classificados pelo mecanismo de ação como agonistas beta-adrenérgicos (dobutamina e dopamina), inibidores da fosfodiesterase 3 (milrinona) e sensibilizadores da troponina C aos íons cálcio (levosimedana). (Quadro 14.2). A dobutamina é habitualmente utilizada nas doses de 5 a $20 \mathrm{mcg} / \mathrm{kg} /$ minuto. Devemos lembrar que, em pacientes que utilizam betabloqueadores, a dose inicial deve ser mais 
Tabela 14.3 - Dose de inotrópicos endovenosos da insuficiência cardíaca aguda ${ }^{1088,1089,1092}$

\begin{tabular}{|c|c|c|}
\hline Inotrópicos & Dose inicial & $\begin{array}{l}\text { Dose máxima } \\
\mu \mathrm{g} / \mathrm{kg} / \text { minuto }\end{array}$ \\
\hline Dobutamina & $\begin{array}{l}2,5 \mu \mathrm{g} / \mathrm{kg} / \text { minuto } \\
\text { Avaliar ajuste a cada } 10 \text { minutos. Efeito } \\
\text { hemodinâmico em até } 2 \text { horas }\end{array}$ & 20 \\
\hline Milrinone & $\begin{array}{c}\text { Ataque: } 50 \mu \mathrm{g} / \mathrm{kg} \text { em } 10 \text { minutos (risco de } \\
\text { hipotensão - evitar se PAS }<110 \mathrm{mmHg} \text { ) } \\
\text { Manutenção: } 0,375 \mu \mathrm{\mu g} / \mathrm{kg} / \text { minuto } \\
\text { (necessidade de correção pela função } \\
\text { renal) }\end{array}$ & 0,75 \\
\hline Levosimendana & $\begin{array}{c}\text { Ataque: } 6-12 \mu \mathrm{g} / \mathrm{kg} \text { em } 10 \text { minutos (risco } \\
\text { de hipotensão - evitar se PAS < } 110 \\
\mathrm{mmHg} \text { ) } \\
\text { Manutenção: } 0,05-0,10 \mu \mathrm{g} / \mathrm{kg} / \text { minuto } \\
\text { por } 24 \text { horas }\end{array}$ & 0,20 \\
\hline
\end{tabular}

PAS: pressão arterial sistólica.

elevada em torno de $10 \mathrm{mcg} / \mathrm{kg} /$ minuto. ${ }^{1093,1104}$ A dopamina é uma catecolamina precursora imediata da noradrenalina e possui efeito hemodinâmico dose-dependente. A milrinona promove maior disponibilidade de Monofosfato Cíclico de Adenosina (cAMP), exercendo, com isso, efeito cardiotônico. ${ }^{1103,1105}$ Os fármacos cálcio-sensibilizantes, representados no Brasil pela levosimendana, possuem mecanismo de ação dupla: primeiro inibem parcialmente a fosfodiesterase cardíaca e, depois, agem como sensibilizadores da troponina $\mathrm{C}$ aos íons de cálcio disponíveis. ${ }^{1106}$ Essa ação promove efeito cardiotônico, sem aumentar a demanda de oxigênio pelo miocárdio. Além de seu efeito inotrópico, altera também os canais de potássio periféricos, promovendo efeito vasodilatador arterial (Tabela 14.3).

- Digitálicos: têm seu efeito inotrópico inibindo a bomba $\mathrm{Na} / \mathrm{K}$ - ATPase e promovendo maior concentração de cálcio intracelular. Na fase aguda da descompensação, têm indicação no controle da FC, principalmente quando da presença de taquiarritmias supraventriculares de alta resposta (por exemplo: FA de alta resposta ventricular), em que há contraindicação de outros antiarrítmicos. ${ }^{1088,1089}$

\subsection{Indicações de Suporte Mecânico}

A assistência circulatória mecânica (ACM) é uma forma artificial de substituição ou auxílio ao desempenho ventricular, sendo indicada em diferentes cenários e possibilidades clínicas para os pacientes com choque cardiogênico refratário. O registro norte-americano INTERMACS (Interagency Registry for Mechanically Assisted Circulatory Support) define a gravidade da IC (Quadro 14.7) e tem sido utilizado como parâmetro para indicação de dispositivos de ACM (Quadro 14.8). ${ }^{1106}$

No choque cardiogênico refratário (INTERMACS I e II), os dispositivos de ACM podem ser utilizados visando ao resgate hemodinâmico e à estabilidade clínica, incluindo a possibilidade de recuperação da função cardíaca, bem como a realização do transplante, definindo, assim, três estratégias: ${ }^{1107}$

1. Ponte para decisão: considerada em pacientes quando a necessidade de suporte hemodinâmico é imediata, devido ao alto risco de morte por falência cardíaca. Neste contexto, diferentes cenários podem ocorrer (ausência de recuperação neurológica, disfunção de múltiplos órgãos, estabilização hemodinâmica com necessidade de outros dispositivos, entre outros), não sendo possível estabelecer, no momento do implante, a estratégia final de tratamento (por exemplo: pós-PCR).

2. Ponte para recuperação: situação na qual existe a perspectiva de melhora da função ventricular após insulto agudo, sendo retirado o dispositivo com a melhora da função ventricular, como, por exemplo, disfunção ventricular pós-IAM, Takotsubo e miocardite.

3. Ponte para transplante cardíaco: situação em que os dispositivos podem oferecer suporte hemodinâmico e estabilidade clínica, até a realização do transplante

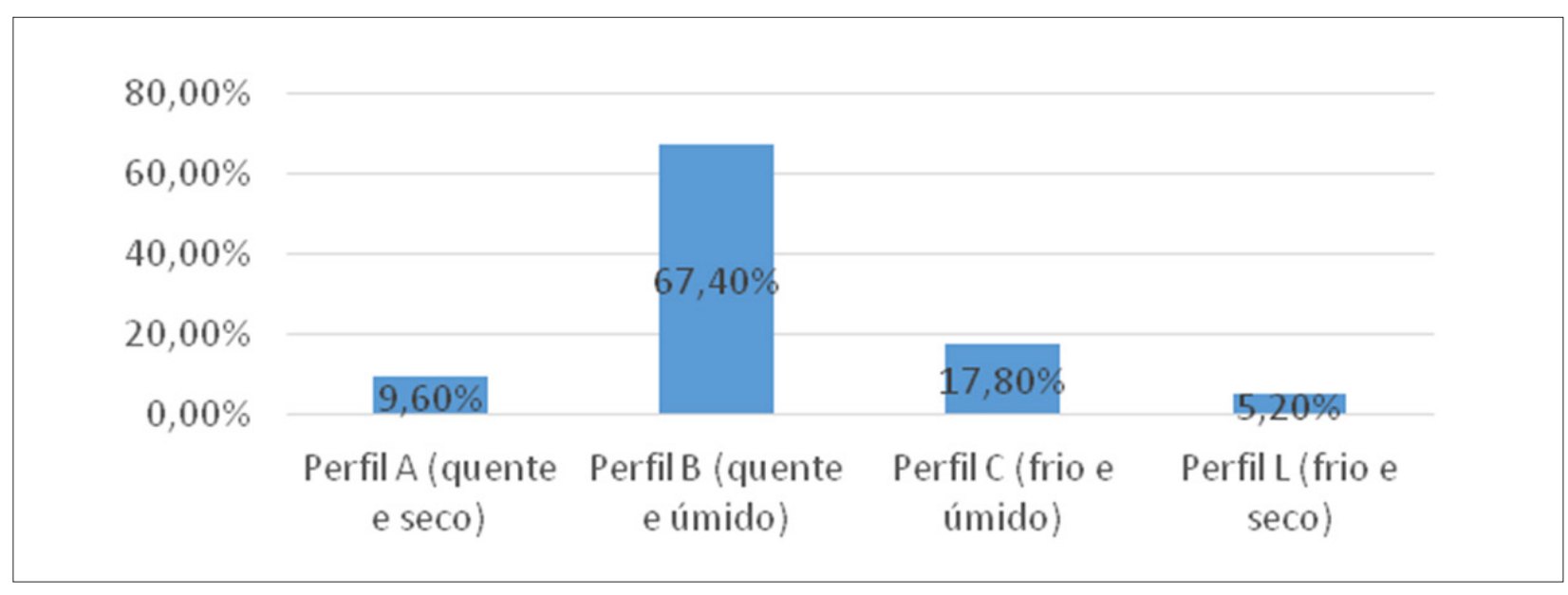

Figura 14.5 - Perfil clínico/hemodinâmico do registro BREATHE. ${ }^{1090}$ ICA: insuficiência cardíaca aguda. 


\section{Atualização}

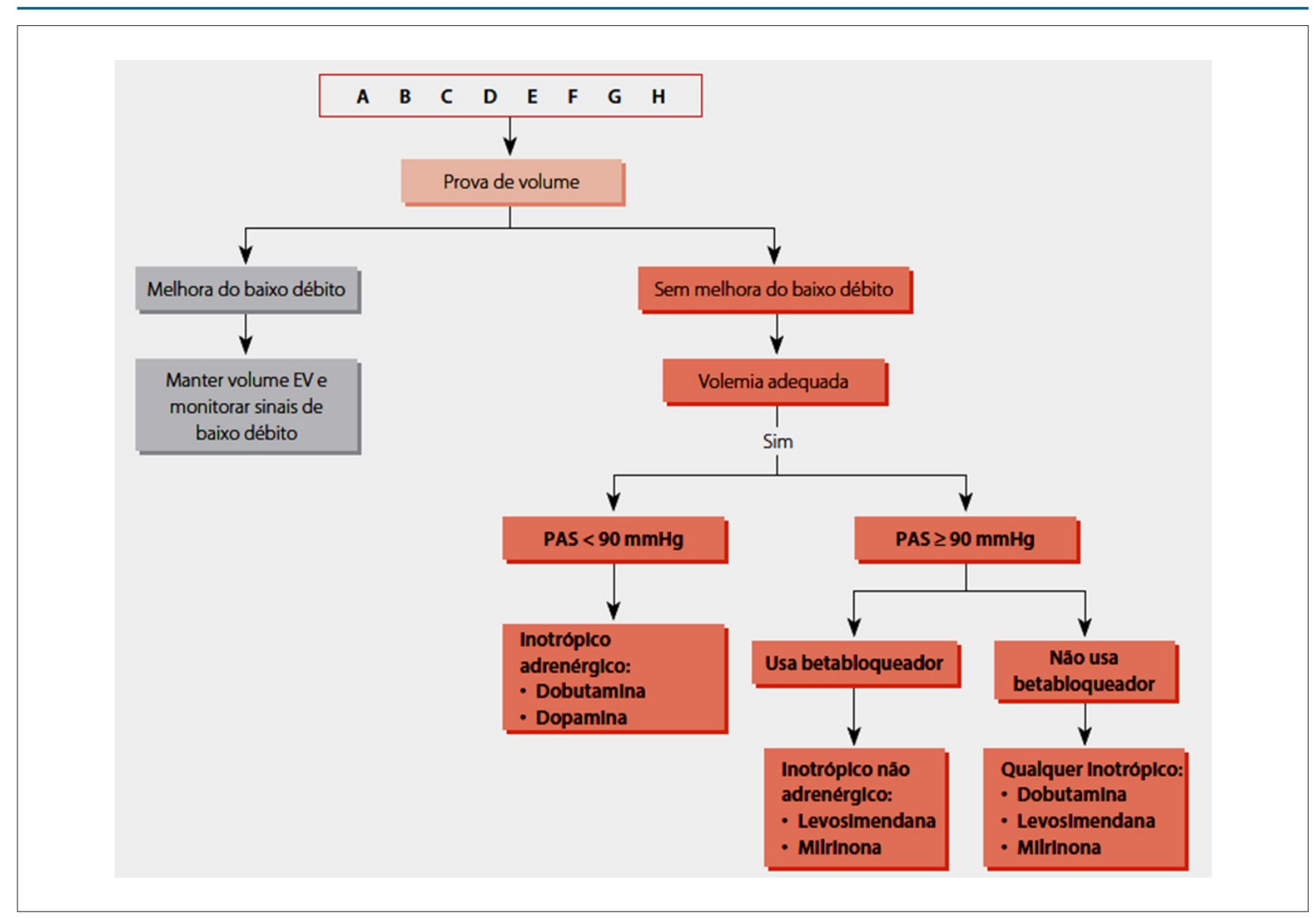

Figura 14.6 - Algoritmo para o perfil L (frio e seco). ${ }^{1092}$ EV: via endovenosa; PAS: pressão parcial sistólica.

Quadro 14.3 - Suporte ventilatório na insuficiência cardíaca aguda ${ }^{1088,1089}$

\begin{tabular}{lcc}
\hline Recomendação & Classe de Recomendação & Nível de Evidência \\
\hline $\begin{array}{l}\text { Oxigênio suplementar aos pacientes com desconforto respiratório (visando saturação de oxigênio > 95\% ou > } \\
90 \% \text { para pneumopatas com hipercapnia) }\end{array}$ & । & C \\
$\begin{array}{l}\text { Suporte mecânico respiratório não invasivo (CPAP ou BiPAP) para pacientes com edema agudo de pulmão } \\
\text { sem hipotensão e na persistência de desconforto respiratório, a despeito da utilização de outras formas não } \\
\text { invasivas de ventilação }\end{array}$ & । & B \\
$\begin{array}{l}\text { Suporte mecânico respiratório invasivo para pacientes sintomáticos e/ou hipoxêmicos, a despeito de suporte } \\
\text { não invasivo ou que apresentem contraindicação a suporte não invasivo }\end{array}$ & । & C \\
\hline
\end{tabular}

BiPAP: pressão positiva bifásica nas vias aéreas; CPAP: pressão positiva contínua nas vias aéreas.

cardíaco, no contexto da gravidade progressiva dos pacientes e da indisponibilidade de realização do transplante em curto prazo.

Durante uma apresentação clínica de choque cardiogênico refratário, os dispositivos que permitem acesso percutâneo são mais adequados, por serem menos invasivos, propiciando implante mais simples e rápido, em comparação aos dispositivos de implante cirúrgico. ${ }^{1108} \mathrm{O}$ dispositivo ideal é aquele que permite tanto o suporte hemodinâmico quanto a proteção miocárdica, além disso, apresenta baixa incidência de complicações. Dentre as complicações dos dispositivos de curta duração, podemos destacar: isquemia de membros, eventos tromboembólicos sistêmicos e de sistema nervoso central, sangramento, infecção e hemólise. ${ }^{1108}$ Entre os dispositivos de curta duração de implante percutâneo disponíveis no Brasil, temos o BIA, o TandemHeart ${ }^{\circledR}$ ou TransCore, o Impella ${ }^{\circledR}$ e a ECMO. Apesar das evidências limitadas neste contexto clínico, a escolha do dispositivo depende de características clínicas, da intensidade de suporte requerido e da disponibilidade. 
Atualização

Quadro 14.4 - Recomendação para reposição volêmica na insuficiência cardíaca aguda ${ }^{1088,1089}$

\begin{tabular}{|c|c|c|}
\hline Recomendação & Classe de Recomendação & Nível de Evidência \\
\hline Reposição volêmica nos pacientes com comprovação de hipovolemia & I & C \\
\hline $\begin{array}{l}\text { Valores baixos de PVC e ou POAP }(<5 \mathrm{mmHg}) \text {, associados a hipofluxo tecidual, indicam infusão hídrica } \\
\text { imediata }\end{array}$ & I & C \\
\hline Uso de medidas dinâmicas para avaliação da responsividade cardiovascular e volume & Ila & C \\
\hline Prova de volume com infusão rápida de $250 \mathrm{~mL}$ de cristaloide na suspeita de hipovolemia & Ila & C \\
\hline $\begin{array}{l}\text { A avaliação do DC para orientação da RV está indicada quando há suspeita de sobrecarga volêmica e/ou } \\
\text { manutenção da hipoperfusão após ressuscitação inicial }\end{array}$ & Illb & C \\
\hline Utilização de valores médios da PVC para guiar a ressuscitação volêmica. & III & B \\
\hline
\end{tabular}

PVC: pressão venosa central; POAP: pressão de oclusão da artéria pulmonar; $D C$ : débito cardiaco; RV: resistência vascular.

Quadro 14.5 - Recomendação do uso do betabloqueador (BB) na insuficiência cardíaca aguda ${ }^{1088,1089}$

\begin{tabular}{|c|c|c|}
\hline Recomendação & Classe de Recomendação & Nível de Evidência \\
\hline $\begin{array}{l}\text { Iniciar BB, sempre que possível, naqueles que não estavam em uso prévio, após compensação clínica/melhora } \\
\text { da congestão pulmonar e sistêmica, ainda durante a internação }\end{array}$ & I & A \\
\hline $\begin{array}{l}\text { Manter a dose de BB em pacientes que já estejam em uso crônico e que, sob nova descompensação, } \\
\text { apresentam-se sem sinais de baixo débito }\end{array}$ & I & C \\
\hline Suspender o BB naqueles pacientes que já estejam em uso crônico e apresentem choque cardiogênico & I & C \\
\hline $\begin{array}{l}\text { Após estabilização do quadro, manter BB com redução de } 50 \% \text { da dose naqueles pacientes que estavam em } \\
\text { uso crônico e apresentavam sinais de baixo débito }\end{array}$ & I & $\mathrm{C}$ \\
\hline $\begin{array}{l}\text { Iniciar BB precocemente naqueles que não estejam em uso prévio e apresentem choque cardiogênico, } \\
\text { instabilidade hemodinâmica grave ou, ainda, na persistência da congestão, apesar do tratamento }\end{array}$ & III & $\mathrm{B}$ \\
\hline
\end{tabular}

Quadro 14.6 - Indicação de vasodilatadores endovenosos na insuficiência cardíaca (IC) aguda ${ }^{1088,1089}$

\begin{tabular}{|c|c|c|}
\hline Recomendação & Classe de Recomendação & Nível de Evidência \\
\hline Nitroglicerina para o tratamento da IC descompensada em pacientes sem hipotensão & I & B \\
\hline $\begin{array}{l}\text { Nitroprussiato para o tratamento da IC descompensada associada à emergência hipertensiva, sem evidência de } \\
\text { isquemia miocárdica aguda. }\end{array}$ & I & B \\
\hline $\begin{array}{l}\text { Nitroprussiato em pacientes em uso de monitorização hemodinâmica invasiva e resistência vascular periférica } \\
\text { aumentada, associada ou não a inotrópicos. }\end{array}$ & I & $B$ \\
\hline $\begin{array}{l}\text { Nitroprussiato para o tratamento da IC descompensada associada à emergência hipertensiva, sem evidência de } \\
\text { isquemia miocárdica aguda }\end{array}$ & I & $B$ \\
\hline
\end{tabular}

Tabela 14.4 - Dose de vasodilatadores endovenosos da insuficiência cardíaca aguda ${ }^{1088,1089}$

\begin{tabular}{lcc}
\hline Vasodilatadores & Dose inicial & Dose máxima \\
\hline Nitroglicerina & $0,2 \mu \mathrm{g} / \mathrm{kg} /$ minuto & Titular até melhora ou \\
& PAS $<90 \mathrm{mmHg}$ \\
$\begin{array}{l}\text { Nitroprussiato de } \\
\text { sódio }\end{array}$ & $0,3 \mu \mathrm{g} / \mathrm{kg} /$ minuto & Titular até melhora ou \\
\end{tabular}

PAS: pressão artéria sistêmica.

\subsection{Conclusão}

A inclusão do capítulo de ICA na Atualização da Diretriz de Ressuscitação Cardiopulmonar e Cuidados Cardiovasculares de Emergência 2019 é fundamental, por ser doença de altíssima taxa de internação, morbidade e mortalidade. As recomendações descritas nesta diretriz foram elaboradas a partir da construção da I Diretriz Brasileira de Insuficiência Cardíaca Aguda ${ }^{1088,1089}$ e têm como finalidade sistematizar o diagnóstico e o tratamento aos pacientes em ICA que procuram atendimento de emergência. 


\section{Atualização}

Quadro 14.7 - Classificação INTERMACS (Interagency Registry for Mechanically Assisted Circulatory Support) de gravidade da insuficiência cardíca

\begin{tabular}{|c|c|c|c|}
\hline Perfil & Descrição & Estado hemodinâmico & Tempo para intervenção \\
\hline 1 & Choque cardiogênico grave & $\begin{array}{l}\text { Hipotensão persistente apesar do uso de inotrópicos e balão } \\
\text { intra-aórtico, associada à disfunção orgânica }\end{array}$ & Horas \\
\hline 2 & $\begin{array}{l}\text { Declínio progressivo apesar do uso } \\
\text { de inotrópico }\end{array}$ & $\begin{array}{l}\text { Declínio da função renal, hepática, nutricional e lactatemia, a } \\
\text { despeito do uso de agentes inotrópicos em doses otimizadas }\end{array}$ & Dias \\
\hline 3 & Estável às custas de inotrópico & $\begin{array}{l}\text { Estabilidade clínica em vigência de terapia inotrópica, mas com } \\
\text { histórico de falência do desmame }\end{array}$ & Semanas a meses \\
\hline 4 & Internações frequentes & $\begin{array}{l}\text { Sinais de retenção hídrica, sintomas ao repouso e passagens } \\
\text { frequentes em unidades de emergência }\end{array}$ & Semanas a meses \\
\hline 5 & Em casa, intolerante aos esforços & $\begin{array}{l}\text { Limitação marcante para atividades, porém confortável ao } \\
\text { repouso, a despeito de retenção hídrica }\end{array}$ & $\begin{array}{l}\text { Urgência variável, dependente do estado } \\
\text { nutricional e do grau de disfunção orgânica }\end{array}$ \\
\hline 6 & Limitação aos esforços & $\begin{array}{c}\text { Limitação moderada aos esforços, ausência de sinais de } \\
\text { hipervolemia }\end{array}$ & $\begin{array}{l}\text { Urgência variável, dependente do estado } \\
\text { nutricional e do grau de disfunção orgânica }\end{array}$ \\
\hline 7 & NYHA III & Estabilidade hemodinâmica e ausência da hipervolemia & Sem indicação \\
\hline
\end{tabular}

Quadro 14.8 - Recomendação para dispositvos de assistência circulatória mecânica no choque cardiogênico refratário

\begin{tabular}{lcc}
\hline Indicações & Classe de Recomendação & Nível de Evidência \\
\hline Choque cardiogênico refratário em ICA "nova" - INTERMACS I e II & C & \|la \\
Choque cardiogênico refratário em miocardiopatia crônica isquêmica ou não isquêmica - INTERMACS I e II & \|la \\
\hline
\end{tabular}

ICA: insuficiência cardíaca aguda.

\section{Suporte de Vida Extracorpóreo Neonatal, Pediátrico e Adulto}

\subsection{Introdução}

"Suporte de vida extracorpóreo", do inglês "extracorporeal life support", é um termo utilizado quando queremos nos referir à tecnologia desenvolvida nas últimas décadas para promover suporte cardíaco, respiratório ou ambos em pacientes com disfunção orgânica grave. Estes dispositivos têm como finalidade oferecer condições de sobrevida para recuperação efetiva e atuar como ponte para transplante, para implante de dispositivo de longa permanência ou para tomada de decisões. ${ }^{1109}$ A Extracorporeal Life Support Organization (ELSO) considera a Terapia Renal Substitutiva Contínua (CRRT, sigla do inglês Continuous Renal Replacement Therapy) e a Terapia de Substituição Plasmática (TPE, Therapeutic Plasma Exchange) outros tipos de ECLS.

A introdução de um capítulo sobre suporte de vida extracorpóreo nas diretrizes de RCP e emergências clínicas vem ao encontro do desenvolvimento e da implantação dessa tecnologia nas unidades de emergência e de terapia intensiva no mundo todo.

Apesar de abordar a maioria dos ECLS, o foco principal nesta diretriz será a ECMO. Pacientes em choque cardiogênico e insuficiência respiratória refratária ao tratamento clínico podem se beneficiar desta terapia.
A ECMO é composta basicamente por uma cânula de drenagem, uma bomba centrífuga, uma membrana de oxigenação e uma cânula de reinjeção sanguínea. Por esse sistema, pode-se otimizar a perfusão sistêmica com oferta de débito > $6 \mathrm{~L} /$ minuto, além de promover oxigenação sanguínea e depuração de gás carbônico. ${ }^{1110}$ A posição de inserção das cânulas define se o suporte será apenas pulmonar (ECMO venovenosa) ou cardiopulmonar (ECMO venoarterial).

\subsection{Resumo das Situações Clínicas com Indicação de Oxigenação Extracorpórea}

A seguir os principais diagnósticos, indicações e contraindicações para o emprego da ECMO (Quadros 15.1 a 15.5). ${ }^{1111}$

O assunto referente ao uso de ECMO durante a parada cardiopulmonar (E-CPR: extracorporeal cardiopulmonary resuscitation) será abordado em outro capítulo.

\subsection{Centros Especializados em Oxigenação Extracorpórea}

A qualidade da assistência prestada com ECMO está diretamente ligada ao número de pacientes com este dispositivo que o serviço atende anualmente. Centros com maior volume apresentam menores taxas de mortalidade. ${ }^{112-114}$

Pacientes com necessidade de ECMO precisam estar próximos a grandes centros hospitalares, com disponibilidade de terapia de substituição renal contínua, capacidade para 
Atualização

Quadro 15.1 - Indicações de oxigenação extracorpórea em neonatos

\begin{tabular}{|c|c|c|}
\hline Diagnósticos & Indicações & Contraindicações \\
\hline $\begin{array}{l}\text { Síndrome de aspiração de mecônio } \\
\text { Hérnia diafragmática congenital } \\
\text { Hipertensão pulmonar persistente } \\
\text { Sepse } \\
\text { Pneumonia } \\
\text { Síndrome do desconforto respiratório } \\
\text { Choque refratário a drogas e volume } \\
\text { Falência cardiorrespiratória pós-cardiotomia } \\
\text { Ponte para transplante cardíaco ou pulmonar }\end{array}$ & $\begin{array}{c}\qquad \mathrm{I}^{*}>40 \text { por mais de } 4 \text { horas } \\
I \mathrm{O}^{*}>20 \text { por mais de } 24 \text { horas com terapia otimizada }> \\
24 \text { horas ou frequentes episódios de descompensação } \\
\text { IResp hipoxêmica grave com descompensação aguda } \\
\text { (PaO2 < 40) que não responde à intervenção } \\
\text { IResp progressiva e/ou hipertensão pulmonar } \\
\text { com evidência de disfunção ventricular direita ou } \\
\text { necessidade de altas doses de inotrópico } \\
\text { PCR refratária por } 5 \text { minutos } \\
\text { Incapacidade de desconexão da circulação } \\
\text { extracorpórea apos cirurgia cardíaca }\end{array}$ & $\begin{array}{c}\text { Absolutas } \\
\text { Distúrbio cromossômico letal (inclui trissomia 13, 18, } \\
\text { mas não 21) ou outra anomalia letal } \\
\text { Dano cerebral irreversível } \\
\text { Hemorragia não controlada } \\
\text { Hemorragia intracraniana } \geq \text { grau III } \\
\text { Relativas } \\
\text { Peso }<2 \mathrm{~kg} \\
\text { Idade gestacional }<34 \text { semanas } \\
\text { VM }>10-14 \text { dias } \\
\text { Disfunções orgânicas outras não passíveis de } \\
\text { transplante }\end{array}$ \\
\hline
\end{tabular}

*Pressão média de vias aéreas × fração inspirada de oxigênio × 100). I0: índice de oxigenação; IResp: insuficiência respiratória; PaO : pressão parcial de oxigênio; PCR: parada cardiorrespiratória; VM: ventilação mecânica.

Quadro 15.2 - Indicações de oxigenação extracorpórea respiratória em pediatria

\begin{tabular}{|c|c|c|}
\hline Diagnósticos & Indicações & Contraindicações \\
\hline $\begin{array}{l}\text { Pneumonias bacterianas } \\
\text { Pneumonias virais } \\
\text { Sepse } \\
\text { Síndromes aspirativas pulmonares } \\
\text { Síndrome do desconforto respiratório agudo } \\
\text { Ponte para transplante pulmonar }\end{array}$ & $\begin{array}{c}\mathrm{PaO}_{2} / \mathrm{FiO}_{2}<60-80 \text { por 3-6 horas } \mathrm{IO}>40 \text { por } 4 \\
\text { horasFalta de resposta à ventilação mecânica e } \\
\text { terapia de resgate (ventilação oscilatória de alta } \\
\text { frequência - HFOV, NO inalado, posição prona) } \\
\text { Elevadas pressões na ventilação mecânica (pressão } \\
\text { média das vias aéreas }>20-25 \mathrm{cmH}_{2} \mathrm{O} \text { em ventilação } \\
\text { convencional ou }>3020-25 \mathrm{cmH}_{2} \mathrm{O} \text { em HFOV ou } \\
\text { evidência de barotrauma) } \\
\text { Hipercapnia refratária com pH }<7.1\end{array}$ & $\begin{array}{c}\text { Absolutas } \\
\text { Anormalidades cromossômicas letais (como } \\
\text { trissomia } 13 \text { ou 18) } \\
\text { Comprometimento neurológico grave } \\
\text { Transplante alogênico de medula óssea, receptores } \\
\text { de transplante com infiltrados pulmonares } \\
\text { Cancer incurável } \\
\text { Relativas } \\
\text { Ventilação mecânica > 14 dias } \\
\text { Procedimentos neurocirúrgicos recentes ou } \\
\text { hemorragia intracraniana (nos últimos 1-7 dias) } \\
\text { Doença crônica pré-existente }\end{array}$ \\
\hline
\end{tabular}

$\mathrm{PaO}_{2} \mathrm{FiO}_{2}$ : relação entre pressão parcial de oxigênio plasmática/fração inspirada de oxigênio; IO: índice de oxigenação: HFOV: high frequency oscillation ventilation (ventilação oscilatória de alta frequência); NO: óxido nítrico.

Quadro 15.3 - Indicações de oxigenação extracorpórea cardiovascular em pediatria

\begin{tabular}{|c|c|c|}
\hline Diagnósticos & Indicações & Contraindicações \\
\hline & Síndrome pós-cardiotomia & Absolutas \\
\hline Miocardites & Altas doses de vasopressor e inotrópicos, acidose & Baixa probabilidade de recuperação da criança \\
\hline Contusão miocárdica & metabólica, oligúria & Reanimação cardíaca com coração parado > \\
\hline Choque com altas doses de drogas & PCR refratária por qualquer causa com 5 minutos de RCP & 5 minutos \\
\hline Falência cardiorrespiratória pós-cardiotomia & Insuficiência cardíaca (miocardite, miocardiopatia e & \\
\hline Depressão cardiovascular nas intoxicações exógenas & overdose) & Relativas \\
\hline
\end{tabular}

PCR: parada cardiorrespiratória; RCP: ressuscitaçãoo cardiopulmonar. 


\section{Atualização}

\section{Quadro 15.4 - Indicações de oxigenação extracorpórea venovenosa em adultos}

\begin{tabular}{|c|c|c|}
\hline Diagnósticos & Indicações & Contraindicações \\
\hline $\begin{array}{l}\text { Pneumonias bacterianas } \\
\text { Pneumonias virais } \\
\text { Síndromes aspirativas pulmonares } \\
\text { Síndrome do desconforto respiratório agudo } \\
\text { Tromboembolismo pulmonar } \\
\text { Crise asmática grave } \\
\text { Ponte para transplantepulmonar }\end{array}$ & $\begin{array}{c}\text { Hipercapnia com manutenção do } \mathrm{pH} \leq 7,20 \mathrm{com} \mathrm{FR} \geq 35 \\
\text { ipm e volume corrente } \geq 6 \mathrm{~mL} / \mathrm{kg} \\
\text { Escore de Murray (Lung Injury Score) }>3 \text { com o paciente } \\
\text { em piora do quadro clínico } \\
\mathrm{PaO}_{2} / \mathrm{FiO}_{2} \leq 80 \text { com } \mathrm{FiO}_{2} \geq 0,8 \text { por } \geq 6 \text { horas, apesar de } \\
\text { manobras de resgate (prona e bloqueador neuromuscular) }_{\text {Necessidade de intubação em um paciente na lista de }} \\
\text { transplante de pulmão }\end{array}$ & $\begin{array}{c}\text { Absolutas } \\
\text { Pacientes moribundos } \\
\text { IMC }>40-45 \mathrm{~kg} / \mathrm{m}^{2} \\
\text { Pneumopatas crônicos em uso domiciliar } \\
\text { de oxigênio sem perspectiva de transplante } \\
\text { pulmonar } \\
\text { Doença crônica limitante }\end{array}$ \\
\hline
\end{tabular}

FR: frequência respiratória; $\mathrm{PaO}_{2} / \mathrm{FiO}_{2}$ : relação entre pressão parcial de oxigênio plasmática/fração inspirada de oxigênio; IMC: índice de massa corporal.

Quadro 15.5 - Indicações de oxigenação extracorpórea venoarterial em adultos

\begin{tabular}{|c|c|c|}
\hline Diagnósticos & Indicações & Contraindicações \\
\hline $\begin{array}{l}\text { Miocardites } \\
\text { Infarto agudo do miocárdio } \\
\text { Takotsubo } \\
\text { Contusão miocárdica } \\
\text { Choque cardiogênico refratário a drogas vasoativas } \\
\text { Falência cardiorrespiratória pós-cardiotomia } \\
\text { Depressão cardiovascular nas intoxicações exógenas } \\
\text { Ponte para transplante cardíaco } \\
\text { PCR refratária não responsiva às manobras habituais } \\
\text { de ressuscitação }\end{array}$ & $\begin{array}{c}\text { Choque cardiogênico refratário a inotrópicos e } \\
\text { vasoconstritores, além de BIA, se for o caso } \\
\text { PCR prolongada (5-30 minutos) se o paciente for } \\
\text { considerado recuperável, desde que a parada tenha } \\
\text { sido assistida e a ECMO estabelecida dentro de, no } \\
\text { máximo, } 1 \text { hora e em locais com programa de ECMO bem } \\
\text { estabelecido }\end{array}$ & $\begin{array}{c}\text { Absolutas } \\
\text { Miocardiopatia terminal em paciente não } \\
\text { candidato para transplante ou ventrículo artificial } \\
\text { Idade avançada, disfunção crônica de órgãos } \\
\text { (enfisema, cirrose e insuficiência renal), } \\
\text { compliance (limitações financeiras, cognitivas, } \\
\text { psiquiátricas ou sociais) } \\
\text { RCP prolongada sem perfusão tecidual } \\
\text { adequada } \\
\text { Relativas } \\
\text { Contraindicação para anticoagulação } \\
\text { Obesidade }\end{array}$ \\
\hline
\end{tabular}

BIA: balão intra-aórtico; PCR: parada cardiorrespiratória; ECMO: oxigenação por membrana extracorporeal; RCP: reanimação cardiopulmonar.

realização de transplante pulmonar e cardíaco, equipe de cirurgia cardiovascular habilitada em menos de 30 minutos, radiologia intervencionista e neurocirurgia. ${ }^{1144,1115}$

\section{Classe de Recomendação}

Recomenda-se: a estruturação de poucos centros especializados em ECMO como referência para a captação de pacientes (Classe de Recomendação I; Nível de Evidência C);

- O implante de ECMO ou de qualquer outro dispositivo de ECLS deve ser realizado por profissionais capacitados e com treinamento prévio (Classe de Recomendação I; Nível de Evidência C)

- Pacientes que necessitem de ECMO devem ser transferidos para serviços especializados após RCP inicial (Classe de Recomendação Ila; Nível de Evidência B)

- A distribuição dos centros deve ser de tal forma que atenda, no mínimo, de 12 a 20 pacientes ao ano (Classe de Recomendação Ila; Nível de Evidência B)

\subsection{Extracorporeal Life Support no Choque Cardiogênico}

A IC pode se apresentar de várias formas clínicas. A mais crítica é o choque cardiogênico, caracteriza do por pressão arterial sistólica $<80$ a $90 \mathrm{mmHg}$ (ou valor de 30 $\mathrm{mmHg}$ inferior ao nível basal, por 30 minutos sem resposta à reposição volêmica), índice cardíaco $<2,2 \mathrm{~L} / \mathrm{min} / \mathrm{m}^{2} \mathrm{com}$ suporte inotrópico ou 1,8 L/min/ $/ \mathrm{m}^{2}$ sem suporte terapêutico, pressão de oclusão da artéria pulmonar > $18 \mathrm{mmHg}$; parâmetros clínicos-laboratoriais de má perfusão periférica, como oligúria, alteração do nível de consciência, pele fria e pegajosa, e aumento do lactato arterial. ${ }^{1109,1110}$

Após otimização terapêutica, alguns pacientes podem manter DC abaixo do esperado e necessitar de suporte extracorpóreo adicional, o que chamamos de Suporte Mecânico Circulatório (MCS, Mechanical Circulatory Support) (Figura 15.1).

Os principais recursos de suporte circulatório disponíveis no Brasil são os descritos a seguir.

\subsubsection{Balão Intra-Aórtico de Contrapulsação}

Este é o dispositivo de assistência ventricular mais utilizado e pode ser instalado a beira leito, com capacidade de aumentar o DC. Locado por via percutânea na aorta descendente por punção na artéria femoral, é capaz de aumentar a pressão de perfusão das coronárias quando se infla durante a diástole e diminuir a pós-carga durante seu esvaziamento completo na sístole ventricular. Entretanto, apesar de fisiologicamente o uso de BIA estar indicado, seu emprego rotineiro em pacientes com choque cardiogênico pós-SCA vem sendo questionado. ${ }^{1111-1113}$ 


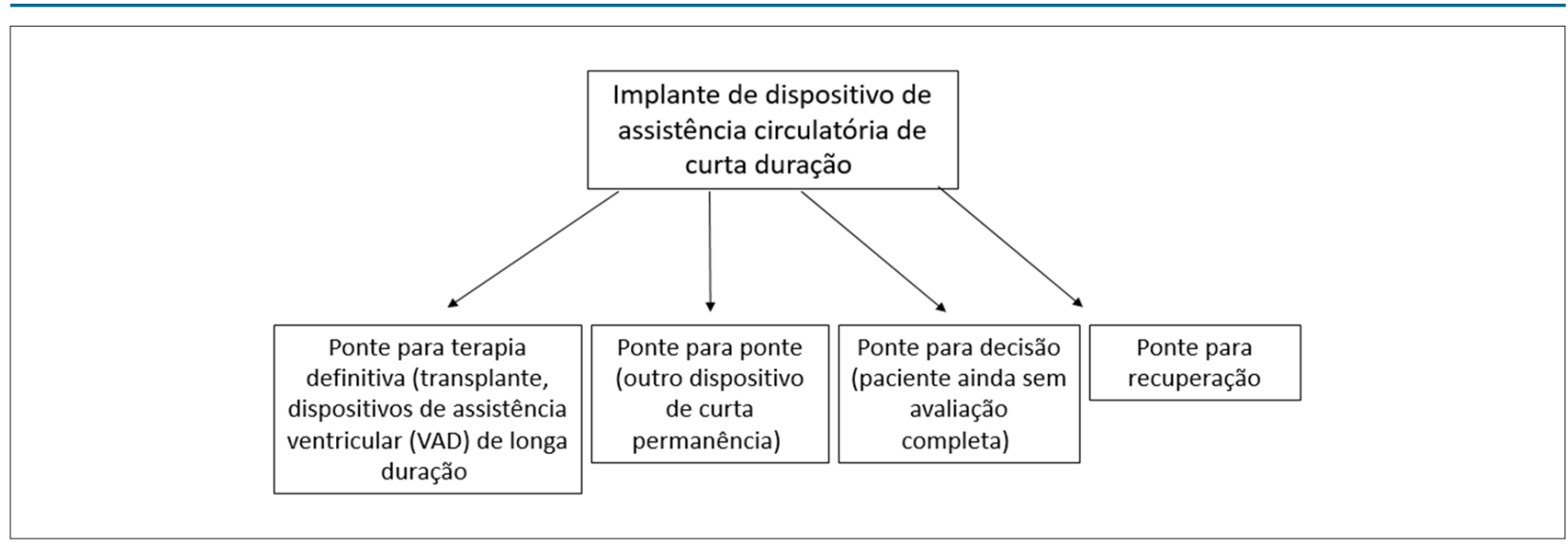

Figura 15.1 - Modalidades de Suporte Mecânico. VAD: dispositivo de assistência ventricular.

\subsubsection{Membrana de Oxigenação Extracorpórea}

Apesar de descrita primariamente para suporte respiratório, na configuração venoarterial, a ECMO é capaz de promover débito suficiente para manter a perfusão sistêmica adequada e evitar hipoxemia tecidual, mesmo em pacientes com o consumo de oxigênio elevado.

Segundo levantamento da ELSO, até janeiro de 2016, 7.850 pacientes fizeram uso de ECMO para choque cardiogênico, com sobrevida até a alta hospitalar de 41\%. ${ }^{1114}$

A maioria das indicações de ECMO venoarterial é realizada em pacientes INTERMACS I e II, perfil no qual a taxa de mortalidade estimada, caso não seja utilizado nenhum MCS, é superior a $80 \%{ }^{1115}$

O INTERMACS é um registro que acompanha os resultados clínicos de pacientes que receberam assistência mecânica circulatória (Quadro 15.6). ${ }^{1115-1118}$

As doenças que podem levar ao choque cardiogênico com necessidade de ECMO são várias. Entre elas, estão a SCA, a IC crônica descompensada, o TEP com repercussão hemodinâmica, a miocardite aguda, a disfunção miocárdica associada à sepse, entre outras.

Além dos escores SAVE-Score e ENCOURAGE, algumas condições clínicas, como idade avançada, índice de massa corporal > $25 \mathrm{~kg} / \mathrm{m}^{2}$, rebaixamento do nível de consciência, aumento da creatinina sérica e do lactato, e diminuição da atividade de protrombina, estão relacionadas ao aumento na mortalidade nesse grupo de pacientes. ${ }^{1119,1120}$

Até o presente momento, não existem parâmetros ou doses de inotrópicos que indiquem o momento correto de implante de ECMO. Essa decisão deve ser individualizada e baseada em discussão de heart team e ECMO team. No geral, são candidatos para o implante de ECMO venoarterial pacientes com baixa fração de ejeção $(<30 \%)$; índice cardíaco $<2,2$ $\mathrm{L} / \mathrm{min} / \mathrm{m}^{2}$; e hipotensão com necessidade de vasopressor.

Para implantação da ECMO, a canulação periférica de ECMO em adultos com choque cardiogênico INTERMACS I deve ser feita, preferencialmente, por meio de técnica percutânea de Seldinger guiada por ultrassonografia. ${ }^{1121,1122}$ A cânula inserida na veia é responsável pela drenagem do
Quadro 15.6 - Classificação da insuficiência cardíaca pelo INTERMACS (Interagency Registry for Mechanically Assisted Circulatory Support)

\begin{tabular}{|c|c|c|c|}
\hline Nível & Descrição & Estado hemodinâmico & $\begin{array}{c}\text { Tempo para } \\
\text { suportemecânico }\end{array}$ \\
\hline 1 & $\begin{array}{c}\text { Choque } \\
\text { cardiogênico }\end{array}$ & $\begin{array}{l}\text { Hipotensão persistente. } \\
\text { DMOS. Risco de morte } \\
\text { iminente a despeito de } \\
\text { medicamentos }\end{array}$ & Horas \\
\hline 2 & $\begin{array}{l}\text { Declínio } \\
\text { progressivo, } \\
\text { apesar dos } \\
\text { inotrópicos }\end{array}$ & $\begin{array}{c}\text { Uso de inotrópicos em } \\
\text { doses altas. Piora da } \\
\text { função renal e do estado } \\
\text { nutricional }\end{array}$ & Dias \\
\hline 3 & $\begin{array}{l}\text { Estável à custa } \\
\text { de inotrópicos }\end{array}$ & $\begin{array}{l}\text { Estabilidade atingida com } \\
\text { uso de inotrópicos em } \\
\text { doses moderadas }\end{array}$ & Semanas \\
\hline 4 & $\begin{array}{l}\text { Sintomas ao } \\
\text { repouso }\end{array}$ & $\begin{array}{c}\text { Possibilidade de desmame } \\
\text { de inotrópicos }\end{array}$ & Semanas a meses \\
\hline 5 & $\begin{array}{l}\text { Intolerante ao } \\
\text { esforço }\end{array}$ & $\begin{array}{l}\text { Confortável ao repouso, } \\
\text { mas com limitação severa. } \\
\text { Sinais de congestão }\end{array}$ & Urgência variável \\
\hline 6 & $\begin{array}{l}\text { Limitação aos } \\
\text { esforços }\end{array}$ & $\begin{array}{l}\text { Limitação moderada, sem } \\
\text { hipervolemia }\end{array}$ & Urgência variável \\
\hline 7 & $\begin{array}{l}\text { Classe funcional: } \\
\text { NYHA III }\end{array}$ & $\begin{array}{l}\text { Manejo de volume } \\
\text { adequado }\end{array}$ & Sem indicação \\
\hline
\end{tabular}

DMOS: disfunção de múltiplos órgãos e sistemas; NYHA: New York Heart Association. Fonte: adaptado de Stevenson et al. ${ }^{1115}$

sangue venoso para a bomba centrífuga e para membrana de oxigenação, enquanto a cânula inserida na artéria transportará o sangue oxigenado de volta para o paciente, após passar pelo oxigenador. ${ }^{1123}$

A reinjeção de sangue na artéria femoral contra o fluxo normal tem como consequência o aumento da pós-carga e pode surgir complicações como o EAP e a síndrome do arlequim. O EAP pode ser prevenido e até mesmo revertido com uso de um BIA ou Impella ${ }^{\circledR}$ (Abiomed, Aachen, Alemanha) concomitante à $\mathrm{ECMO}$ venoarterial. 
Outras complicações são infecção de sítio de punção, sangramentos e tromboses.

Pacientes que mantêm boa função pulmonar e nível neurológico adequado devem ser preferencialmente mantidos extubados e com analgesia, conforme necessário. A utilização de sedativos e o bloqueio neuromuscular em pacientes com ECMO prolongam a necessidade de estadia em ambiente de terapia intensiva. ${ }^{1124,1125}$

O desmame de ECMO venoarterial deve seguir parâmetros clínicos, laboratoriais e ecocardiográficos. Pacientes sem deterioração hemodinâmica, com fração de ejeção > 20 a $25 \%$ que mantiverem a integral entre o tempo e a velocidade (VTI) $>12 \mathrm{~cm}$ e TDSa (tissue Doppler lateral mitral annulus peak systolic velocity) $\geq 6 \mathrm{~cm} / \mathrm{s}$ durante teste com diminuição do débito da ECMO venoarterial para $<1$ a 1,5 L/minuto podem ter a ECMO retirada. ${ }^{1126}$ Por outro lado, pacientes que não preencherem esses critérios podem necessitar de mais tempo de ECMO, ou modificação da MCS para suporte de longa permanência ou transplante cardíaco.

\subsubsection{Dispositivos de Assistência Circulatória de Curta Duração}

Além da ECMO, outros dispositivos de assistência de curta duração disponíveis são: Impella ${ }^{\circledR}$ (Abiomed, Aachen, Alemanha), disponível nas versões 2.5, CP e 5.0, com capacidade de ofertar, respectivamente, até 2,5, 4 e $5 \mathrm{~L} / \mathrm{m}$; e TandemHeart ${ }^{\circledR}$ (CardiacAssist, Inc, Pittsburgh, PA), canulado via veia femoral, até o átrio esquerdo, por punção transeptal e artéria femoral.

\subsubsection{Dispositivos de Assistência Circulatória de Longa Duração}

Estes são exemplos de dispositivos de assistência ventricular esquerda de longa permanência (LVAD, left ventricular assist devices): HeartMate II e III (Thoratec Corporation), Berlin Heart EXCOR ${ }^{\circledR}$ e HeartWare HVAD ${ }^{\circledR}$. Implantados por meio de toracotomia em centro cirúrgico, são mais caros e não são indicados no choque cardiogênico INTERMACS I (Quadro 15.7)..$^{1127}$

\subsubsection{Recomendação}

- O uso de BIA, no contexto de choque cardiogênico por SCA, não é recomendado de rotina (Classe de Recomendação Ilb; Nível de Evidência B).

- Sugere-se o uso de BIA no contexto de SCA apenas em pacientes com choque cardiogênico por complicações mecânicas (Classe de Recomendação: Ila; Nível de Evidência C).

- Sugere-se o uso de dispositivos de assistência extracorpórea para pacientes que apresentem choque cardiogênico com perspectiva de transplante, recuperação, implante de assistência de longa permanência ou como ponte para decisão, quando necessário, e que sejam refratários ao tratamento clínico inicial (Classe de Recomendação Ila; Nível de Evidência B).

- Sugere-se o uso de ECMO venoarterial como primeira opção para pacientes em INTERMACS I, que mantenham choque cardiogênico apesar de otimização da volemia, do uso de drogas vasoativas e inotrópicos positivos, independentemente da etiologia do choque (Classe de Recomendação Ila; Nível de Evidência B).

- Sugere-se monitoramento hemodinâmico diário por meio de ecocardiogramapara pacientes com ECMO (Classe de Recomendação Ila; Nível de Evidência C).

\subsection{Extracorporeal Life Support na Insuficiência respiratória aguda}

Pacientes com comprometimento grave da oxigenação secundário a edema pulmonar não cardiogênico são classificados com quadro de SDRA. ${ }^{1129}$

Aqueles com hipoxemia grave $\left(\mathrm{PaO}_{2} / \mathrm{FiO}_{2}<100\right)$ apresentam menor oferta de oxigênio aos tecidos, o que pode levar à disfunção orgânica e morte.

Quadro 15.7 - Características dos dispositivos de assistência circulatória

\begin{tabular}{|c|c|c|c|c|c|c|}
\hline & BIA & Impella $囚 2,5$ & TandemHeart $\circledast$ & Impella $® 5,0$ & ECMO VA & Centrimag \\
\hline Suportemáximo & $1 \mathrm{~L} /$ minuto & 2,5 L/minute & $5 \mathrm{~L} /$ minuto & $5 \mathrm{~L} /$ minuto & $6 \mathrm{~L} /$ minuto & $10 \mathrm{~L} /$ minuto \\
\hline $\begin{array}{l}\text { Facilidade de inserção } \\
\text { (1: fácil, } 5 \text { : complexo) }\end{array}$ & 1 & 2 & 4 & 3 & 2 & 5 \\
\hline Suporte para VE & + & ++ & +++ & +++ & ++++ & ++++ \\
\hline Suporte para VD & - & - & - & - & ++ & $\begin{array}{c}+++ \text { (se do lado } \\
\text { direito) }\end{array}$ \\
\hline Suporteventilatório & - & - & - & - & + & - \\
\hline Hemólise & - & +++ & ++ & ++ & + & + \\
\hline Sangramento & - & - & ++ & + & +++ & ++ \\
\hline Trombocitopenia & ++ & + & $+?$ & + & ++ & + \\
\hline Tempo de uso & Dias & Dias & Dias & Semanas & Semanas & Meses \\
\hline
\end{tabular}

BIA: balão intra-aórtico; ECMO: oxigenação por membrana extracorpórea; VA: assistência ventricular; VE: ventrículo esquerdo; VD: ventrículo direito. Fonte: adaptado de Sayer et al. ${ }^{1128}$ 
Existem dois tipos de ECLS para suporte respiratório: a ECMO e os dispositivos extracorpóreos de remoção de dióxido de carbono (ECCO 2 , extracorporeal carbono dioxide removal). ${ }^{1130}$

A ECMO pode ser utilizada como terapia de resgate para casos de insuficiência respiratória refratária, visto que a configuração venovenosa (ECMO venovenosa) permite a oxigenação sanguínea sem o risco de punção arterial, sem aumento da pós-carga ventricular esquerda e com manutenção da oxigenação cerebral. ${ }^{1131}$

Apesar do uso crescente da ECMO para o tratamento de SDRA grave, ainda não há consenso sobre o melhor momento para seu início. ${ }^{1132} \mathrm{~A}$ indicação deve ser discutida com equipe multiprofissional e que esteja habituada ao manejo de pacientes em SDRA. Alguns critérios objetivos que podem auxiliar nessa decisão são escore de Murray (Tabela 15.1) $\geq$ III, $\mathrm{PaO}_{2} / \mathrm{FiO}_{2}<50 \mathrm{mmHg}$ com $\mathrm{FiO}_{2} \geq 80 \%$ por mais de 3 horas; $\mathrm{PaO}_{2} / \mathrm{FiO}_{2}<80 \mathrm{mmHg}$ com $\mathrm{FiO}_{2} \geq 80 \%$ por $>6$ horas ou $\mathrm{pH}<7,25$ por $>6$ horas, apesar de otimização da VM e de manobras como recrutamento e prona. ${ }^{1132,1133}$

Classicamente a ECMO é utilizada quando os valores descritos são atingidos. Entretanto, a decisão de colocar um paciente em ECMO venovenosa na insuficiência respiratória continua sendo de cunho clínica e não apenas baseada nos valores de $\mathrm{PaO}_{2}$ e $\mathrm{pH} .{ }^{1134}$

\subsubsection{Considerações da Oxigenação Extracorpórea Venovenosa}

As contraindicações absolutas para ECMO venovenosa são pacientes moribundos com disfunção de múltiplos órgãos e sistemas, presença de doença metastática avançada sem proposta terapêutica, doenças crônicas respiratórias sem perspectiva de transplante pulmonar ou limitações que contraindiquem a anticoagulação. ${ }^{1131}$

A ECMO para insuficiência respiratória, caso não exista comprometimento cardíaco ou instabilidade hemodinâmica importante, é instalada de maneira venovenosa por técnica de Seldinger. ${ }^{1135,1136}$

Tabela 15.1 - Escore de Murray

\begin{tabular}{|c|c|c|c|c|c|}
\hline & 0 & 1 & 2 & 3 & 4 \\
\hline $\begin{array}{l}\text { Hipoxemia } \\
\left(\mathrm{PaO}_{2} / \mathrm{FiO}_{2}\right) \text {, } \\
\mathrm{mmHg}^{2}\end{array}$ & $\geq 300$ & $225-299$ & $175-224$ & $100-174$ & $<100$ \\
\hline $\begin{array}{l}\text { Número de } \\
\text { quadrantes com } \\
\text { consolidação } \\
\text { alveolar no raio X }\end{array}$ & 0 & 1 & 2 & 3 & 4 \\
\hline PEEP, $\mathrm{cmH}_{2} \mathrm{O}$ & $\leq 5$ & $6-8$ & $9-11$ & $12-14$ & $\geq 15$ \\
\hline $\begin{array}{l}\text { Complacência } \\
\text { pulmonar*, } \\
\mathrm{mL} / \mathrm{cmH}_{2} \mathrm{O}\end{array}$ & $\geq 80$ & $60-79$ & $40-59$ & 20-39 & $\leq 19$ \\
\hline
\end{tabular}

A pontuação é a somatória dos pontos da tabela dividindo-se pelo número de variáveis analisadas. * Volume corrente/driving pressure. $\mathrm{PaO} / \mathrm{FiO}$ : pressão parcial de oxigênio/fração inspirada de oxigênio; PEEP: pressã́o positiva expiratória final. Fonte: Adaptado de Murray, et al. ${ }^{1133}$
A ECMO venovenosa, através de sua membrana, possui alto poder de oxigenação e de depuração de dióxido de carbono. ${ }^{1137}$ Pacientes com hipoxemia grave podem se beneficiar desta terapia, desde que implantada precocemente. É importante ressaltar que pacientes que fazem uso de ECMO com início após mais de 7 dias de VM apresentam maiores taxas de mortalidade. ${ }^{1138,1139}$

Em relação aos parâmetros ventilatórios durante o uso de ECMO, a ELSO sugere o uso do modo de VM controlada a pressão, com $\mathrm{PEEP}$ de $10 \mathrm{~cm}$ de $\mathrm{H}_{2} \mathrm{O}$, driving pressure $(\triangle \mathrm{P})$ de $10 \mathrm{cmH}_{2} \mathrm{O}$ e frequência respiratória entre 4 e 5 irpm. Apesar da discussão em torno deste assunto, de forma geral, a maioria dos centros que usam ECMO têm como objetivo deixar o pulmão descansar, estratégia conhecida como lung rest.

Além de ECMO, outros dispositivos têm a proposta de remover gás carbônico $\left(\mathrm{ECCO}_{2} \mathrm{R}\right)$ e permitir o uso de ventilação ultraprotetora com expectativa de diminuição de lesão induzida por VM (VILI) e, consequentemente, oferecer melhor prognóstico a pacientes com insuficiência respiratória grave. Esses dispositivos apresentam baixo fluxo sanguíneo (500 a 1000 mL/minuto), sendo possível realizar a depuração do gás carbônico produzido e permitir a utilização de parâmetros ventilatórios menos lesivos aos pulmões. Visto que esses dispositivos são utilizados com apenas uma punção venosa, com cânula de menor calibre que a ECMO e não necessitam de alto fluxo sanguíneo com consequente menor risco de hemólise e sangramento, os $\mathrm{ECCO}_{2} \mathrm{R}$ são preferidos para pacientes com acidose respiratória que não consigam ser ventilados com parâmetros protetores. ${ }^{1138-1140}$

A figura 15.2 mostra, de maneira esquemática, o uso de ECLS na insuficiência respiratória refrataria.

\subsubsection{Classe de Recomendação}

- Recomenda-se o uso de ECMO venovenosa em pacientes com SDRA que não consigam manter oxigenação e depuração de dióxido de carbono adequadas, apesar de VM protetora, ou que só consigam fazê-lo à custa de altos valores de driving pressure (Classe de Recomendação Ila; Nível de Evidência B).

- Recomenda-se o uso de prona em pacientes com SDRA refratária antes de iniciar terapia com ECMO (Classe de Recomendação Ila; Nível de Evidência B).

- Recomenda-se realização de avaliação de equipe especializada em ECMO para decisão sobre implante em pacientes com insuficiência respiratória aguda (Classe de Recomendação I; Nível de Evidência C).

- Contraindica-se a ECMO venovenosa em pacientes moribundos ou com doença pulmonar terminal, que não sejam candidatos a transplante pulmonar (Classe de Recomendação III; Nível de Evidência C).

\subsection{Extracorporeal Life Support em Neonatos}

As causas respiratórias são as mais frequentes indicações de ECMO na população de neonatos. No entanto, o surgimento da ventilação de alta frequência e de terapêuticas, como o óxido nítrico e o surfactante, reduziu as necessidades de sua aplicação. Da mesma forma, melhorias no manejo de 


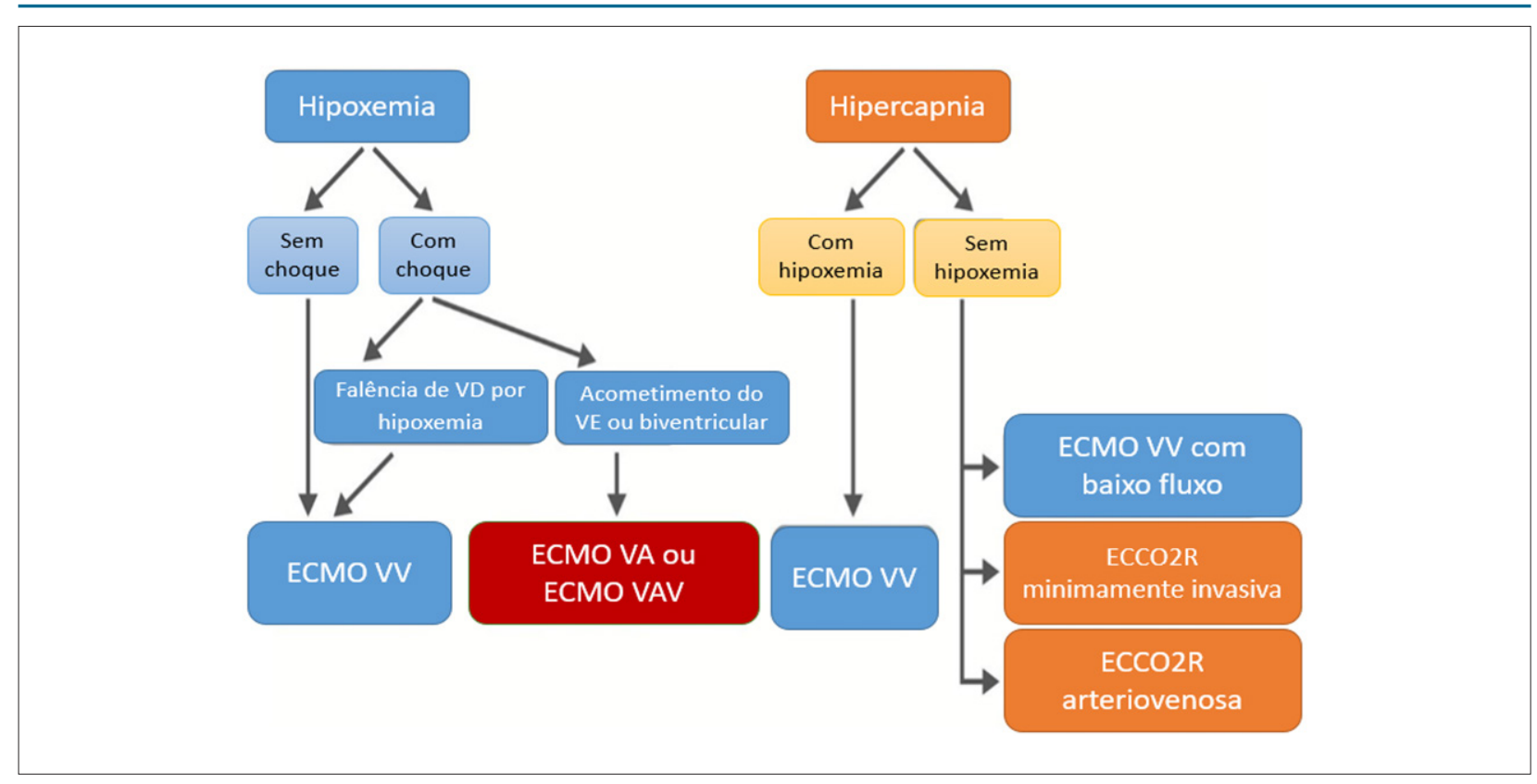

Figura 15.2 - Sugestão para utilização de Extracorporeal Life Support na insuficiência respiratória aguda. VD: ventrículo direito; VE: ventrículo esquerdo; ECMO VV: oxigenação por membrana extracorpórea venovenosa; ECMO VA: oxigenação por membrana extracorpórea venoarterial; ECMO VAV: oxigenação por membrana extracorpórea com uma cânula venosa de aspiração, uma cânula arterial de reinjeção e uma cânula venosa de reinjeção; $E_{C C O} R$ : dispositivos extracorpóreos de remoção de dióxido de carbono. Fonte: Baseado em Fan et al. ${ }^{1131}$

pacientes infectados com Streptococcus do grupo B e da falência cardiorrespiratória por síndrome de aspiração de mecônio também reduziram o uso de ECMO.

Os pacientes com hérnia diafragmática congênita continuam com a pior taxa de sobrevida na população neonatal. Nos neonatos com problemas cardiocirculatórios, a causa mais frequente é a ECMO por disfunção cardíaca no pós-operatório, mas aumentam os casos em que a ECMO é instalada para estabilização pré-operatória e na falência miocárdica relacionada à sepse.

\subsection{Extracorporeal Life Support em Pediatria}

Nas crianças, a maior parte das indicações de ECMO é de etiologia cardiocirculatória, segundo dados da ELSO. As faixas etárias de 10 a 18 anos apresentam menor sobrevida (50\%) do que as mais jovens (até 61\%). Nos pacientes cardíacos pediátricos, após o período neonatal, as doenças cardíacas congênitas, as miocardites e as cardiomiopatias são as indicações básicas de ECMO. ${ }^{1141}$

\subsubsection{Dispositivos de Assistência Circulatória Mecânica em Crianças}

Assim como na população de adultos, o MCS em pediatria pode ser classificado em suporte de longa e de curta duração. Entre os dispositivos de curta duração, os mais comuns são a ECMO e a bomba centrífuga. Diversos dispositivos de longa duração estão disponíveis em nos Estados Unidos e na Europa para suporte circulatório no adulto, mas há menos opções em pediatria. O Berlin Heart EXCOR ${ }^{\circ}$ Pediatric é o mais utilizado, em especial nas crianças menores. $\mathrm{O}$ uso desse dispositivo aumentou significativamente a sobrevida geral em 12 meses para $75 \%$ dos pacientes em fila de espera para transplante, incluindo os $64 \%$ transplantados nesse período, $6 \%$ retirados da fila devido à recuperação da função e 5\% que permaneceram vivos durante esse período. ${ }^{1142}$

Historicamente, a ECMO, no Brasil, está fortemente relacionada a serviços de cirurgia cardiovascular. Com a formação da ELSO latino-americana associada a um intenso programa de treinamento seguindo as diretrizes internacionais de formação de especialistas em ECMO, hoje contamos com mais de dez centros ao redor do Brasil e um número crescente de publicações sobre o tema de autores brasileiros na literatura internacional. ${ }^{1143}$

Os resultados após o treinamento ordenado e a adoção protocolos bem estabelecidos têm mostrado um impacto positivo nos resultados e no custo-efetividade no Brasil e em diversos países da América Latina. ${ }^{144-1147}$

Nosso país tem um dos maiores programas de transplante financiado pelo sistema público de saúde, mas, até o momento, não temos nenhum tipo de financiamento para emprego dos dispositivos de assistência nesses pacientes que aguardam o transplante. O Berlin Heart EXCOR $®$ foi utilizado na população pediátrica em nosso meio esporadicamente e em paciente do sistema de saúde suplementar. Devido a essas restrições, nossa maior experiência como ponte para transplante ainda se limita a dispositivos de curta duração, mais recentemente associadas a cânulas de implantáveis em ponta de VE, o que possibilitou sobrevida maior até o transplante e/ou alta hospitalar. ${ }^{1148}$ 


\subsection{Perspectivas}

A realização de trabalhos multicêntricos controlados, randomizados e com avaliação de custo-benefício é urgente, assim como dispositivos mais acessíveis, em termos de custo, duração, manejo e menor tamanho, que possam vir a ampliar suas indicações, para um melhor entendimento e aplicação otimizada.

\section{Simulação no Ensino das Emergências}

\subsection{Introdução}

$\mathrm{O}$ avanço científico em relação à ciência de RCP deve ser acompanhado de medidas que possibilitem a disseminação do conhecimento e a implementação de rotinas adequadas de atendimento ao paciente vítima de PCR nos mais diversos locais.

\subsection{Conceitos em Simulação}

A educação continuada constitui critério de avaliação de qualidade no ensino nas instituições. A simulação é uma das fases mais importantes na capacitação dos profissionais da saúde, atualizando, aprimorando e reduzindo a distância existente entre o que se ensina na teoria e sua prática. ${ }^{149-1152}$ Segundo Gaba, simulação pode ser definida como um processo de instrução, que substitui o atendimento a pacientes reais por modelos artificiais, como atores, ou virtuais, reproduzindo cenários de cuidados em um ambiente próximo da realidade, com o objetivo de analisar e refletir as ações realizadas de forma segura. ${ }^{1150-1152}$

O princípio básico por trás da simulação é promover a integração dos conhecimentos teóricos e das habilidades técnicas, estimulando os participantes a coordenarem todas as competências simultaneamente, facilitando a transferência do que foi aprendido para a solução de novos problemas. ${ }^{153-1154}$

\subsection{Treinamento de Habilidades (Part Task Trainer)}

As terminologias para treinamento de habilidades técnicas específicas ou part task trainer empregam o uso de pacientes padronizados, realidade virtual e simulação, contemplando diversas áreas de estudos na medicina (Quadro 16.1).

A finalidade didática da simulação pode ser dividia em dois tempos: treinamento de habilidades e treinamento por meio de cenários. No entanto, vale esclarecer que os diferentes tipos de recursos podem variar de acordo com a complexidade e fidelidade dos equipamentos: ${ }^{1153}$

- Alta fidelidade: manequins computadorizados.

- Moderada fidelidade: com tecnologia intermediária e interação limitada.

- Baixa fidelidade: manequins estáticos, sem interação.

\subsection{Treinamento com Cenários}

Destina-se ao treinamento de situações clínicas, possibilitando o raciocínio e o treinamento comportamental em ambiente controlado (Figura 16.1). Este treinamento pode ser dividido em três momentos: elaboração, execução e debriefing. Ao envolver os alunos em cenários e orientá-los por meio de um debriefing estruturado, os facilitadores podem maximizar a transferência de conhecimento para eventos da vida real. O ponto crítico desta aprendizagem é que a experiência não é suficiente para promover a mudança. ${ }^{1155,1156}$

\subsection{Treinamento em Ressuscitação Utilizando a Simulação}

Um componente essencial da educação de ressuscitação é a aprendizagem experiencial que ocorre por meio da simulação e do debriefing estruturado. O ciclo de aprendizagem experiencial é um modelo de representação de como as pessoas aprendem. Ele possui quatro etapas: sentir (experiência concreta), observar (observação reflexiva), pensar (conceituação abstrata) e fazer (experimentação ativa). ${ }^{1157}$

Ressuscitações clínicas são eventos estressantes. Por isso enfatiza-se a importância do aprendizado em cenários simulados, para, então, agir quando houver eventos na vida real. ${ }^{1154}$

A utilização da simulação em universidades, escolas de medicina e outras áreas da saúde é recente no Brasil, especialmente na simulação de alta fidelidade, que exige um alto investimento financeiro em robôs e infraestrutura e docentes capacitados.

Os cursos que envolvem conceitos de Cardiologia, em nosso país, são: Treinamentos em Emergências Cardiovasculares da Sociedade Brasileira de Cardiologia Avançado e Básico (TECA A e B), SBV (Basic Life Support - BLS), SAVC (Advanced

Quadro 16.1 - Principais estratégias educacionais em simulação realística ${ }^{1154}$

\begin{tabular}{|c|c|}
\hline Estratégia & Definição geral \\
\hline $\begin{array}{l}\text { Habilidades específicas (part task } \\
\text { trainer) }\end{array}$ & $\begin{array}{l}\text { Manequins que permitem o treino de procedimentos específicos, como intubação orotraqueal, entre outros. Não necessariamente } \\
\text { utilizam um cenário contextualizando a situação }\end{array}$ \\
\hline $\begin{array}{l}\text { Paciente estandarizado e/ou } \\
\text { padronizado (standardized patient) }\end{array}$ & $\begin{array}{l}\text { Utilizam-se atores especializados em simulação, alunos treinados ou os próprios pacientes. Muito utilizado para capacitação em } \\
\text { habilidades comportamentais e avaliação de estudantes }\end{array}$ \\
\hline $\begin{array}{l}\text { Simulação de alta fidelidade (high } \\
\text { fidelity simulation) }\end{array}$ & $\begin{array}{l}\text { Robôs que possuem respiração espontânea e são operados de forma a apresentar hemodinâmica e procedimentos muito } \\
\text { próximos ao real. Normalmente são utilizados cenários trabalhados por uma equipe e que são discutidos em fase posterior, } \\
\text { denominada debriefing }\end{array}$ \\
\hline Realidade virtual & Bastante utilizado em simulações cirúrgicas em que há a necessidade de computação gráfica, para replicar um procedimento \\
\hline Simulação híbrida & Associação entre um manequim de habilidades técnicas e um paciente padronizado \\
\hline
\end{tabular}




\section{Atualização}

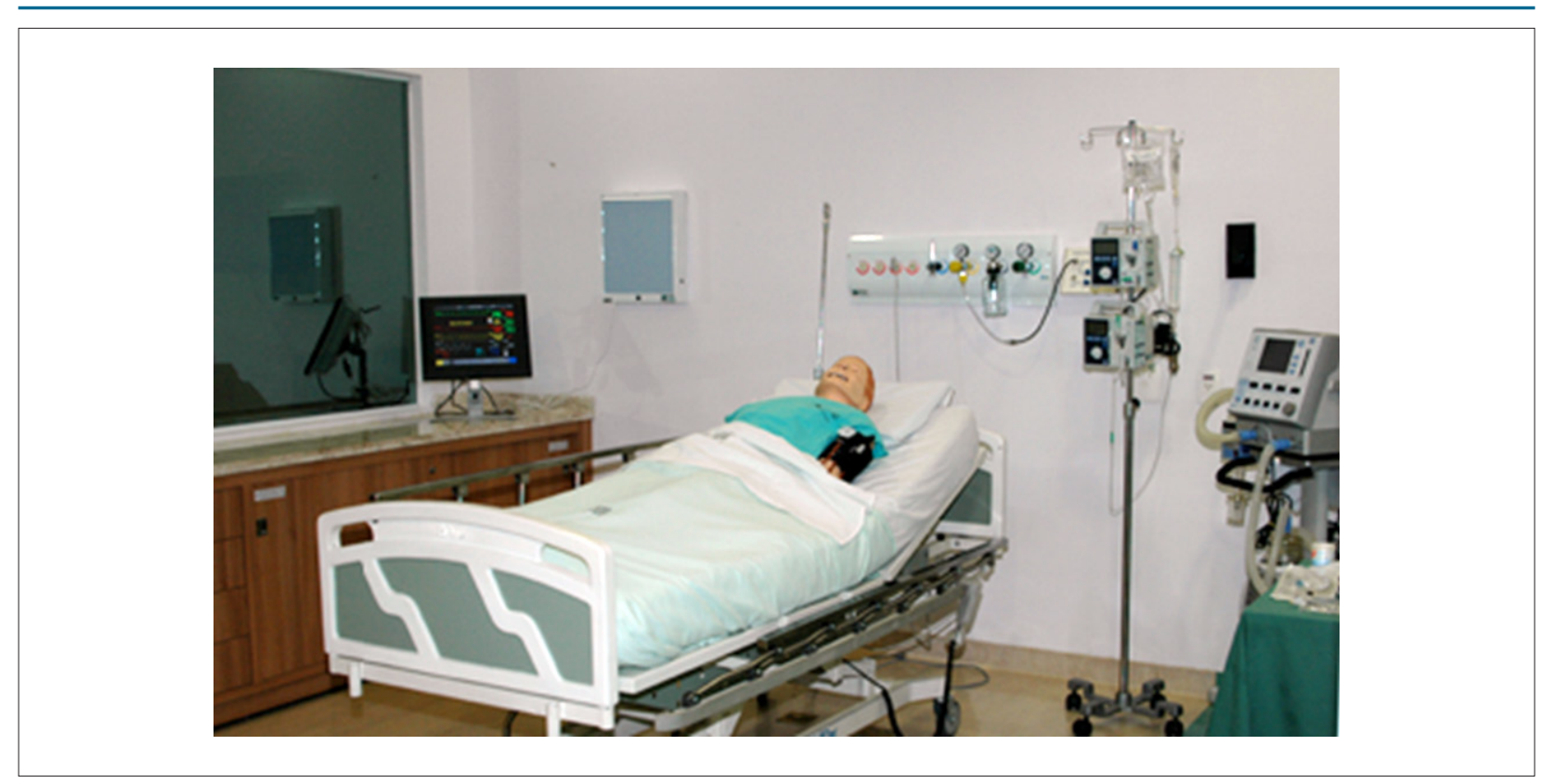

Figura 16.1 - Cenário de alta fidelidade.

Cardiac Life Support - ACLS), Suporte Avançado de Vida em Pediatria (Pediatric Advanced Life Support - PALS), Suporte Avançado de Vida em Hipotermia (SAVEH) e SAVIC. ${ }^{1158,1159}$

16.6. Treinamento em Suporte Básico de Vida: Ênfase na Ressuscitação Cardiopulmonar de Qualidade

A RCP de alta qualidade salva vidas. As recomendações do consenso internacional de RCP 2015 apontam que vários componentes das compressões torácicas podem alterar sua eficácia e enfatizam a importância de RCP de alta qualidade. ${ }^{1160-1163}$

Contudo, estudos têm demonstrado que a qualidade de desempenho da RCP durante a PCR real é baixa, mesmo quando os esforços são realizados por profissionais treinados, tanto em PCR intra quanto na extra-hospitalar. ${ }^{1164,1165}$ Em 2013, a AHA publicou um consenso sobre RCP de qualidade, direcionado aos parâmetros críticos que podem ser melhorados para ajudar as pessoas treinadas a aperfeiçoarem o desempenho. Para esta finalidade, há dispositivos disponíveis no mercado, que avaliam a frequência, a profundidade das compressões e o tempo efetivo de RCP, entres outros, contribuindo para a qualidade do aprendizado (Figura 16.2). ${ }^{11165-1169}$

\section{Time de Resposta Rápida, Código Azul, Registro de Ressuscitação Intra-Hospitalar e Padronização do Carro de Emergência}

\subsection{Time de Resposta Rápida}

Nos últimos anos, houve diversos avanços nas estratégias para o atendimento das emergências cardiovasculares, dentre

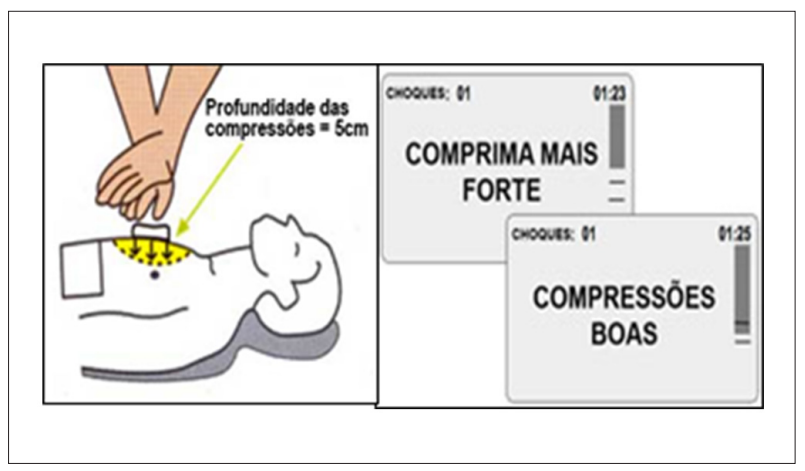

Figura 16.2 - Feedback audiovisual para o socorrista. ${ }^{1166}$

as quais, destaca-se a criação dos TRR ou, Time de Alto Desempenho (TAD). Esses times começaram a ser implantados a partir do resultado de alguns estudos, que evidenciaram que a PCR era precedida de deterioração clínica, em média de 6 a 8 horas antes do evento. ${ }^{1170-1175}$

Em 2005, foi iniciada a campanha de 100 mil vidas do Institute for Healthcare Improvement (IHI), cujo objetivo foi prevenir as mortes hospitalares e, dentre as seis intervenções recomendadas, a primeira foi a implementação dos TRR. ${ }^{1176}$ Atualmente, os TRR vêm sendo implementados em várias partes do mundo, como Austrália, muitos países da Europa, Estados Unidos e Brasil.. $1172,1177,1178$

Os TRR são compostos por equipe multiprofissional (médicos, enfermeiros e fisioterapeutas) $1171,1172,1179,1180$ e têm como objetivo identificar e tratar precocemente os pacientes (adultos e pediátricos) que apresentam deterioração clínica ou estão em risco de morte, fora do 
ambiente de unidades críticas. ${ }^{1172,1181-1186}$ Diversos são os fatores que podem ser considerados como preditivos da PCR em adultos, a saber, as alterações significativas da FC, ${ }^{1180,1187-1189}$ da pressão arterial, ${ }^{1180,1187-1189}$ da frequência respiratória, ${ }^{1180,1186-1190}$ do DC, ${ }^{1187}$ da $\mathrm{SatO}_{2,}{ }^{1180,1188-1190}$ da temperatura corporal (de forma inexplicada), ${ }^{1180,1188-1190}$ do estado mental, ${ }^{1180,1181,1187,1189}$ da característica da fala, ${ }^{1187}$ da diurese nas últimas 4 horas, ${ }^{1180}$ bem como a presença de dor, ${ }^{1187}$ sangramento agudo significante, ${ }^{1180}$ arritmias, ${ }^{1180}$ relato do paciente de que não está se sentindo bem e/ou quando o médico ou o enfermeiro relatam estar preocupados com a situação clínica do paciente. ${ }^{1181,1187,1188}$ Ressalta-se que esses parâmetros devem ser contextualizados de acordo com a população atendida. ${ }^{1187}$

A implementação dos TRR tem mostrado efetividade na prevenção de PCR, bem como na diminuição das taxas de mortalidade hospitalar e nas admissões em unidade de terapia intensiva. ${ }^{1172,1188,1191-1199}$

Além disso, o treinamento contínuo da equipe, tanto para a atuação nos TRR quanto para o trabalho conjunto com a equipe local, é imperioso. ${ }^{1171,1172,1191,1195}$

\subsection{Código Azul}

Código Azul é um modelo de acionamento de TRR para atendimento da PCR fora de unidades críticas (unidade de terapia intensiva, pronto-socorro ou centro cirúrgico).

As tarefas são divididas para multiplicar a chance do resultado favorável. O time deve objetivar chegar à emergência em 4 minutos para o Código Amarelo e em 3 minutos no Código Azul. Cada componente assume papel fundamental, e o líder organiza a equipe, monitora a atuação e a asistência a cada membro, facilita o entendimento, e concentra-se no tratamento abrangente do paciente.

\subsubsection{Objetivos}

- Sistematizar o atendimento de pacientes com suspeita de PCR, de forma a abreviar, ao máximo, o acesso ao SBV e SAV.

- Aumentar a taxa de sobrevida em pacientes com PCR.

- Verificar a incidência e analisar a forma como são atendidas as PCR.

- Diminuir os custos hospitalares e sociais das PCR. ${ }^{1178,1200}$

\subsubsection{Registro de Ressuscitação Intra-Hospitalar: Importância}

Reconhecidamente, os registros são fundamentais sob os aspectos ético e legal, como instrumentos de avaliação das intervenções realizadas e indicador de qualidade. ${ }^{1202}$ No contexto do atendimento da PCR, o modelo Utstein é utilizado para padronizar os registros, possibilitando a comparação adequada, de forma sistemática, dos resultados obtidos na RCP. ${ }^{1200,1201,1203-1212}$

\subsection{Padronização do Carro de Emergência}

É fundamental a padronização dos carros de emergência nas diferentes unidades hospitalares, com o objetivo de uniformizar o conteúdo, de acordo ao público ao qual se destina. ${ }^{1200,1210}$ Baseado no The Code Cart Statement da AHA, o carro de emergência deve ser dividido de acordo com quatro finalidades: avaliação diagnóstica; controle das vias aéreas; acesso vascular e controle circulatório; e, por último, medicamentos. O conteúdo deve ser classificado em níveis de prioridades a saber: ${ }^{1201,1210}$

- Nível 1: itens essenciais, que devem estar disponíveis imediatamente.

- Nível 2: itens altamente recomendados, que devem estar disponíveis em, no máximo,15 minutos.

- Nível 3: itens recomendados, mas são opcionais.

Caso os fármacos e os equipamentos classificados como nível 2 não possam estar disponíveis na unidade para acesso em até 15 minutos, devem permanecer nos carros de emergência.

As portarias GM/MS 3.432, de 12 de agosto de 1998, e SAS/MS 123, de 28 de fevereiro de 2005, ${ }^{1213,1214}$ determinam a necessidade de carro de emergência com desfibrilador/ cardioversor, contendo material de intubação, medicamentos e material para atendimento de emergência na proporção de um carro para cada dez leitos.

Todas as unidades de atendimento de pacientes devem ter carro de emergência disponível, em local de fácil acesso, de modo que possa ser deslocado rapidamente, e os profissionais de saúde que atuam no atendimento devem conhecer a disposição de seu conteúdo e ter habilidade em seu manuseio.

A manutenção do carro de emergência, que sempre deve estar em perfeito estado e pronto para o uso, é de fundamental importância. Para tal, é imprescindível que, após cada uso, sejam realizadas a reposição e a conferência de todos os materiais e medicamentos; seja utilizado lacre de segurança, para assegurar a composição completa do carro de emergência; sejam feitos a conferência e o registro diários do lacre de segurança, além de teste do monitor/ desfibrilador; sejam realizadas manutenções preventivas periódicas do monitor/desfibrilador; sejam verificadas e conferidas mensalmente as datas de validade dos materiais e medicamentos, bem como seja feita sua limpeza.

A seguir, serão apresentadas sugestões e que devem ser planejadas de acordo com a realidade de trabalho de cada local, dispondo de um estoque mínimo de materiais e medicamentos, uma vez que o excesso ou a falta deles prejudicam o atendimento (Quadros 17.1 a 17.3). ${ }^{1178,1200,1210}$

\section{Atendimento Pré-Hospitalar, Regulação e Transporte}

\subsection{Introdução}

$\mathrm{O} \mathrm{APH}$ e o transporte sanitário no Brasil devem fundamentar-se na portaria GM/MS 2.048, de 5 de novembro de 2005, que normatiza a equipe de atendimento de urgência e emergência, os veículos de SBV e SAV e e as Centrais de Regulação Médica. Esse modelo é influenciado pelos sistemas francês e norte-americano, que utilizam profissionais 


\section{Atualização}

\section{Quadro 17.1 - Padronização do carro de emergência na unidade de internação}

\begin{tabular}{|c|c|c|}
\hline Finalidade & Prioridade & Pacientes adultos \\
\hline \multirow{3}{*}{$\begin{array}{l}\text { Avaliação e } \\
\text { diagnóstico }\end{array}$} & 1 & $\begin{array}{l}\text { Desfibrilador externo automático; material de proteção individual (luvas, máscaras e óculos); monitor/desfibrilador com marca- } \\
\text { passo externo (com monitorização nas pás com, no mínimo, três derivações e onda bifásica) }\end{array}$ \\
\hline & 2 & Oxímetro de pulso \\
\hline & 3 & Gerador de marcapasso; glicosímetro capilar \\
\hline \multirow[t]{3}{*}{$\begin{array}{l}\text { Controle de vias } \\
\text { aéreas }\end{array}$} & 1 & $\begin{array}{l}\text { Cânula orofaríngea (números } 3 \text { e 4); bolsa-válvula-máscara com reservatório de oxigenio } \\
\text { Tubo endotraqueal (números } 6,0 \text { a 9,0); cânula para traqueostomia (números } 6,0 \text { a 9,0) } \\
\text { Laringoscópio com lâmina curva números } 3 \text { e 4; máscara de oxigênio com reservatório } \\
\text { Cânula nasal, tipo óculos; umidificador; nebulizador } \\
\text { Extensão para nebulizador; extensão de PVC para oxigênio } \\
\text { Cânula de aspiração flexível número } 12 \text { ou 10; fixador de cânula orotraqueal }\end{array}$ \\
\hline & 2 & Sonda nasogástrica número 16 ou 18; capnográfo \\
\hline & 3 & Máscara laríngea de adulto \\
\hline $\begin{array}{l}\text { Acesso vascular e } \\
\text { controle circulatório }\end{array}$ & 1 & $\begin{array}{l}\text { Cateter intravenoso periférico números } 14,16,18,20,22 \text {; torneirinhas } \\
\text { Agulha de cateter intravenoso central (para caso de tamponamento e/ou pneumotórax hipertensivo) } \\
\text { Soro fisológico } 1.000 \mathrm{~mL} \text {, Ringer com lactato } 1.000 \mathrm{~mL} \text {, soro glicosado } 5 \% 500 \mathrm{~mL} \\
\text { Equipo macrogotas; equipo para hemoderivados; bureta } \\
\text { Seringa de } 3 \mathrm{~mL}, 5 \mathrm{~mL}, 10 \mathrm{~mL} \text { e } 20 \mathrm{~mL} \text {; agulha } 40 \times 12 \text { ou } 25 \times 12 \text {, para aspiração } \\
\text { Gases; fita microporosa }\end{array}$ \\
\hline \multirow[t]{3}{*}{ Medicamentos } & 1 & $\begin{array}{l}\text { Água destilada } 10 \mathrm{~mL} \text { (ampola); água destilada } 250 \mathrm{~mL} \text { (frasco) } \\
\text { Água destilada } 500 \mathrm{~mL} \text { (para nitroglicerina), frasco } \\
\text { Aspirina } 300 \mathrm{mg} \text {; atropina 0,5 mg; adrenalina } 1 \mathrm{mg} \\
\text { Amiodarona; lidocaína; adenosina } \\
\text { Betabloqueador (metoprolol); nitroglicerina; nitroprussiato de sódio } \\
\text { Cloreto de cálcio; gluconato de cálcio; sulfato de magnésio } \\
\text { Bicarbonato de sódio; glicose } 50 \% \text {; furosemida } \\
\text { Broncodilatador (fenoterol, salbutamol) }\end{array}$ \\
\hline & 2 & $\begin{array}{l}\text { Diazepan; morfina; midazolan fentanil (sedação em geral) } \\
\text { Dobutamina; dopamina }\end{array}$ \\
\hline & 3 & $\begin{array}{l}\text { Naloxone; pancurônio } \\
\text { Bloqueador de canal de cálcio (diltiazeme verapamil); Manitol }\end{array}$ \\
\hline
\end{tabular}

técnicos de emergência (EMT/paramedics), conhecidos como "paramédicos". ${ }^{1215,1216}$

Segundo a legislação brasileira, a regulação médica e intervenções como IOT, desfibrilação convencional, procedimentos cirúrgicos e prescrição de medicamentos só podem ser realizadas por médicos. ${ }^{1215}$ Esta diretriz baseia-se nas legislações nacionais, as quais diferem das internacionais para o APH e de transporte de pacientes. Assim, recorremos a algumas adaptações, para definir tais procedimentos considerados como sendo médicos, no Brasil.

\subsection{Regulação Médica das Urgências e Emergências}

A portaria GM/MS 2.048 define que a Central de Regulação Médica é o elemento ordenador e orientador dos Sistemas Regionais e Estaduais de Urgência e Emergência, organizando a relação entre os vários serviços, qualificando o fluxo dos pacientes no sistema de saúde e garantindo acesso aos pedidos de socorro. Todas as instituições que APH devem pautar-se na portaria mecionada. Todos os agravos a saúde de causa clínica, traumática, psiquiátrica, dentre outros, devem ter acesso, por meio do telefone 192, à Central de Regulação Médica, a qual tem que acolher a pessoa que solicita por ajuda, assistindo-a em sua necessidade e redirecionando-a para os locais adequados à continuidade do tratamento. ${ }^{1215}$

\subsection{Médico Regulador ${ }^{1215}$}

A regulação médica é de responsabilidade do profissional médico, que necessita ser capacitado para exercer essa função com qualidade, julgando e discernindo o grau presumido de urgência e prioridade de cada caso, segundo as informações disponíveis. As funções do médico regulador são: julgar e decidir sobre a gravidade de um caso que lhe está sendo comunicado via rádio ou telefone, estabelecendo uma gravidade presumida; enviar os recursos necessários ao atendimento, considerando as necessidades e ofertas disponíveis; monitorar e orientar o atendimento feito por outro profissional de saúde habilitado por profissional da área de segurança ou bombeiro militar ou, ainda, por leigo que encontra-se no local da situação de urgência; definir e acionar o serviço de destino do paciente, informando-o sobre suas condições e previsão de chegada; avaliar a necessidade ou não do envio de meios móveis de atenção; reconhecer que, como a atividade do médico regulador envolve o exercício da telemedicina, expõe-se à gravação contínua das comunicações, ao correto preenchimento das fichas médicas de regulação e das fichas de atendimento médico, e ao seguimento de protocolos institucionais consensuados e normatizados, que definam os passos e as bases para a decisão do regulador; estabelecer claramente, em protocolo 
Quadro 17.2 - Padronização do carro de emergência na unidade de terapia intensiva e pronto-socorro ${ }^{1178,1200,1210}$

\begin{tabular}{|c|c|c|}
\hline Finalidade & Prioridade & Pacientes adultos \\
\hline \multirow[t]{3}{*}{$\begin{array}{l}\text { Avaliação e } \\
\text { diagnóstico }\end{array}$} & 1 & $\begin{array}{l}\text { Desfibrilador externo automático } \\
\text { Material de proteção individual (luvas, máscaras e óculos) } \\
\text { Monitor/desfibrilador com marca-passo externo (com monitorização nas pás com, no mínimo, três derivações e onda bifásica) } \\
\text { Oxímetro de pulso }\end{array}$ \\
\hline & 2 & Glicosímetro capilar \\
\hline & 3 & Gerador de marca-passo \\
\hline \multirow[t]{3}{*}{$\begin{array}{l}\text { Controle de vias } \\
\text { aéreas }\end{array}$} & 1 & $\begin{array}{c}\text { Cânula orofaríngea (números } 3 \text { e 4); bolsa-válvula-máscara com reservatório de oxigênio } \\
\text { Máscara facial tamanho adulto; tubo endotraqueal (números 6,0 a 9,0) } \\
\text { Cânula para traqueostomia (números } 6,0 \text { a 9,0); laringoscópio com lâmina curva números } 3 \text { e } 4 \\
\text { Máscara de oxigênio com reservatório; cânula nasal, tipo óculos } \\
\text { Umidificador; nebulizador; extensão para nebulizador } \\
\text { Extensão de PVC para oxigênio; cânula de aspiração flexível números } 12 \text { e } 10 \\
\text { Fixador de cânula orotraqueal }\end{array}$ \\
\hline & 2 & Sonda nasogástrica números 16 e 18; capnográfo \\
\hline & 3 & $\begin{array}{c}\text { Máscara laríngea adulto } \\
\text { Via aérea alternativa (um ou mais dos seguintes itens: agulha para cricotireostomia e conjunto para traqueostomia } \\
\text { percutânea) }\end{array}$ \\
\hline $\begin{array}{l}\text { Acesso vascular e } \\
\text { controle circulatório }\end{array}$ & 1 & $\begin{array}{l}\text { Cateter intravenoso periférico números } 14,16,18,20 \text { e } 22 \\
\text { Torneirinha; agulha de cateter intravenoso central (para caso de tamponamento e/ou pneumotórax hipertensivo) } \\
\text { Soro fisiológico } 1.000 \mathrm{~mL} \text {, Ringer de lactato } 1.000 \mathrm{~mL} \text {, soro glicosado } 5 \% 500 \mathrm{~mL} \\
\text { Equipo macrogotas; equipo para hemoderivados; bureta } \\
\text { Seringa de } 3 \mathrm{~mL}, 5 \mathrm{~mL}, 10 \mathrm{~mL} \text { e } 20 \mathrm{~mL} \text {; agulha } 40 \times 12 \text { ou } 25 \times 12 \text {, para aspiração } \\
\text { Gase; fita microporosa }\end{array}$ \\
\hline \multirow[t]{3}{*}{ Medicamentos } & 1 & $\begin{array}{l}\text { Água destilada } 10 \mathrm{~mL} \text { (ampola); água destilada } 250 \mathrm{~mL} \text { (frasco) } \\
\text { Água destilada } 500 \mathrm{~mL} \text { (para nitroglicerina) (frasco) } \\
\text { Aspirina } 175 \text { a } 325 \mathrm{mg} \\
\text { Atropina } 0,5 \mathrm{mg} \text {; adrenalina } 1 \mathrm{mg} \text {; amiodarona; lidocaína; adenosina } \\
\text { Betabloqueador (metoprolol); nitroglicerina; nitroprussiato de sódio } \\
\text { Cloreto de cálcio; gluconato de cálcio; sulfato de magnésio } \\
\text { Bicarbonato de sódio; glicose } 50 \% \text {; furosemida } \\
\text { Broncodilatador (fenoterol e salbutamol) }\end{array}$ \\
\hline & 2 & $\begin{array}{l}\text { Diazepan; midazolan; fentanil (sedação em geral) } \\
\text { Morfina; dobutamina; dopamina; norepinefrina }\end{array}$ \\
\hline & 3 & $\begin{array}{l}\text { Naloxone; rocurônio; pancurônio } \\
\text { Bloqueador de canal de cálcio (diltiazem e verapamil); manitol }\end{array}$ \\
\hline
\end{tabular}

de regulação, os limites do Técnico Auxiliar De Regulação Médica (TARM), o qual não pode substituir a prerrogativa de decisão médica e seus desdobramentos, sob pena de responsabilização posterior do médico regulador; definir e pactuar a implantação de protocolos de intervenção médica pré-hospitalar, garantindo perfeito entendimento entre o médico regulador e o intervencionista, quanto aos elementos de decisão e intervenção, objetividade nas comunicações e precisão nos encaminhamentos decorrentes; monitorar os atendimentos e as demandas pendentes, registrando sistematicamente os dados das regulações - os protocolos correspondentes devem estar claramente constituídos, e a autorização deve estar assinada na ficha de regulação médica e na ficha de $\mathrm{APH}$; conhecer, com exatidão, as habilidades de sua equipe, de forma a dominar as possibilidades de prescrição/orientação/intervenção e a fornecer dados que permitam viabilizar programas de capacitação, que qualifiquem os intervencionistas; submeter-se à capacitação específica e à habilitação formal para a função de regulador, e acumular a capacidade e a experiência na assistência médica em urgência, inclusive na intervenção do pré-hospitalar móvel; participar de programa de educação permanente; zelar para que todos os envolvidos na atenção pré-hospitalar observem, rigorosamente, a ética e o sigilo profissional, mesmo nas comunicações radiotelefônicas; manter-se nos limites do sigilo e da ética médica ao atuar como porta-voz em situações de interesse público; tomar decisões de gestão sobre os recursos de saúde disponíveis, possuindo delegação direta dos gestores municipais e estaduais para acionar tais recursos, de acordo com seu julgamento. O médico regulador, assim, deve, ainda decidir qual recurso deverá ser mobilizado frente a cada caso; decidir o destino hospitalar ou ambulatorial dos pacientes atendidos no pré-hospitalar, não aceitando a inexistência de leitos vagos como argumento para não direcionar os pacientes para a melhor hierarquia disponível, em termos de serviços de atenção de urgências (a chamada "vaga zero"); decidir o destino baseado na planilha de hierarquias pactuada e disponível para a região e nas informações atualizadas; regular as portas de urgência, considerando o acesso a leitos como uma segunda etapa que envolve a regulação médica das 


\section{Atualização}

Quadro 17.3 - Padronização do carro de emergência pediátrica na unidade de internação, terapia intensiva e pronto-socorro' ${ }^{1178,1200,1210}$

\begin{tabular}{|c|c|c|}
\hline Finalidade & Prioridade & Pacientes pediátricos \\
\hline \multirow[t]{2}{*}{$\begin{array}{l}\text { Avaliação e } \\
\text { diagnóstico }\end{array}$} & 1 & $\begin{array}{c}\text { Desfibrilador externo automático } \\
\text { Material de proteção individual (luvas, máscaras e óculos) } \\
\text { Monitor; desfibrilador com marca-passo externo (com monitorização nas pás com, no mínimo, três derivações e onda bifásica) }\end{array}$ \\
\hline & 2 & Oxímetro de pulso; glicosímetro capilar \\
\hline \multirow{3}{*}{$\begin{array}{l}\text { Controle de vias } \\
\text { aéreas }\end{array}$} & 1 & $\begin{array}{c}\text { Cânula orofaríngea (números } 00,0,1,2 \text { ); bolsa-válvula-máscara com reservatório de oxigênio } \\
\text { Máscara facial tamanho neonato, lactente, criança; tubo endotraqueal (números } 2,5 \text { a } 7,0 \text { ) } \\
\text { Laringoscópio com lâmina reta (números } 00,0,1,2 \text { ); máscara de oxigênio com reservatório } \\
\text { Cânula nasal, tipo óculos; umidificador; nebulizador; extensão para nebulizador } \\
\text { Extensão de PVC para oxigênio; cânula de aspiração flexivel números } 6 \text { e } 8 \\
\text { Fixador de cânula orotraqueal }\end{array}$ \\
\hline & 2 & Sonda nasogátrica números 6 e 8; capnógrafo \\
\hline & 3 & $\begin{array}{c}\text { Via aérea alternativa (um ou mais dos seguintes itens: aguha para cricotireostomia e conjunto para traqueostomia } \\
\text { percutânea) } \\
\text { Máscara laríngea }\end{array}$ \\
\hline $\begin{array}{l}\text { Acesso vascular e } \\
\text { controle circulatório }\end{array}$ & 1 & $\begin{array}{l}\text { Cateter intravenoso periférico números } 22 \text { e 24; agulha de punção intraóssea } \\
\text { Torneirinha } \\
\text { Agulha de cateter intravenoso central (para caso de tamponamento e/ou pneumotórax hipertensivo) } \\
\text { Soro fisiológico } 1.000 \mathrm{~mL} \text {, Ringer com lactato } 1.000 \mathrm{~mL} \text {, soro glicosado } 5 \% 500 \mathrm{~mL} \\
\text { Equipo macrogotas; equipo para hemoderivados; bureta } \\
\text { Seringa de } 3 \mathrm{~mL}, 5 \mathrm{~mL}, 10 \mathrm{~mL}, 20 \mathrm{~mL} \text {; agulha } 40 \times 12 \text { ou } 25 \times 12 \text {, para aspiração } \\
\text { Gases; fita microporosa }\end{array}$ \\
\hline \multirow{3}{*}{ Medicamentos } & 1 & $\begin{array}{l}\text { Água destilada } 10 \mathrm{~mL} \text { (ampola); água destilada } 250 \mathrm{~mL} \text { (frasco) } \\
\text { Água destilada } 500 \mathrm{~mL} \text { (para nitroglicerina), frasco; aspirina } 175 \text { a } 325 \mathrm{mg} \\
\text { Atropina } 0,5 \mathrm{mg} \text {; adrenalina } 1 \mathrm{mg} \text {; amiodarona; lidocaína; adenosina } \\
\text { Betabloqueador (metoprolol); nitroglicerina; nitroprussiato de sódio } \\
\text { Cloreto de cálcio; gluconato de cálcio; sulfato de magnésio; furosemida } \\
\text { Bicarbonato de sódio; glicose } 50 \% \text {; broncodilatador (fenoterol e salbutamol) }\end{array}$ \\
\hline & 2 & $\begin{array}{l}\text { Diazepan; midazolan; fentanil (sedação em geral) } \\
\text { Morfina; dobutamina; dopamina; noradrenalina Quetamina } \\
\text { Naloxone; rocurônio; pancurônio }\end{array}$ \\
\hline & 3 & $\begin{array}{l}\text { Bloqueador de canal de cálcio (diltiazem e verapamil) } \\
\text { Manitol }\end{array}$ \\
\hline
\end{tabular}

transferências inter-hospitalares, bem como das internações; acionar planos de atenção a desastres que estejam pactuados com os outros, frente à situações excepcionais, coordenando o conjunto da atenção médica de urgência; requisitar recursos públicos e privados em situações excepcionais, conforme pactuação a ser realizada com as autoridades competentes; exercer a autoridade de regulação pública das urgências sobre a atenção pré-hospitalar móvel privada, sempre que esta necessitar conduzir pacientes ao setor público, sendo o pré-hospitalar privado responsabilizado pelo transporte e pela atenção do paciente até seu destino definitivo no sistema; contar com acesso às demais centrais do complexo regulador, de forma que possa ter as informações necessárias e o poder de dirigir os pacientes para os locais mais adequados, em relação às suas necessidades.

O médico que trabalha em pronto-socorro ou outro serviço de saúde, classificados como unidades fixas de $\mathrm{APH}$, precisa conhecer o papel do médico regulador. O bom relacionamento ajudará na qualidade da assistência, mesmo que seja necessária a regulação com o critério de "vaga zero". ${ }^{1217}$

Lembramos que, em situações esporádicas, como catástrofes ou falta de recurso médico disponível, este profissional pode dirigir-se ao local da ocorrência, prestando atendimento e fazendo a regulação médica do local, sendo que, em sua ausência, todos os atendimentos devem ser gravados por uma central.

18.4. Classificação da Ambulância e Tripulação Necessária para Atendimento Pré-Hospitalar e Transporte de Pacientes $^{1215}$

A portaria GM/MS 2.048, ${ }^{1215}$ além de definir a atenção às urgências e emergências, com a implantação das Centrais de Regulação Médica, como medida para organização do fluxo na Rede de Atenção à Saúde, também classifica os tipos de viaturas, conforme os profissionais que as tripulam. A classificação da ambulância e tripulação necessária para $\mathrm{APH}$ e transporte de pacientes é a seguinte:

- Viatura tipo A: ambulância de transporte em decúbito horizontal de pacientes que não apresentam risco de morte, para remoções simples e de caráter eletivo. Tripulada apenas por motorista capacitado.

- Viatura tipo B - Ambulância de Suporte Básico: transporte inter-hospitalar de pacientes sem risco de morte, mas que necessitam de acompanhamento do profissional de saúde, 
por estarem com venóclise, oxigenoterapia, entre outros e ao APH de pacientes com risco desconhecido, não classificado, com potencial de necessitar de intervenção de um profissional de saúde no local e/ou durante transporte. Tripulada por motorista e um técnico ou auxiliar de enfermagem capacitado.

- Viatura tipo C - Ambulância de Resgate: atendimento de urgências pré-hospitalares para vítimas de acidentes ou pacientes clínicos em locais de difícil acesso, que necessitem de equipamentos de salvamento. Tripulada por um motorista e dois profissionais treinados em salvamento.

- Viatura tipo D - Ambulância de Suporte Avançado: atendimento e transporte de pacientes com risco de morte conhecido em emergências pré-hospitalares e/ou de transporte inter-hospitalar, que necessitam de cuidados médicos intensivos. Deve contar com os equipamentos necessários, como respirador, desfibrilador e medicações, para o atendimento de emergência no local ou durante o transporte. Tripulada por motorista, médico e enfermeiro.

- Viatura tipo E - Aeronave de Transporte Médico: de asa fixa ou rotativa, utilizada para transporte inter-hospitalar, e de asa rotativa, para ações de resgate, dotada de equipamentos médicos homologados pela Agência Nacional de Aviação Comercial (ANAC). A tripulação deve ter treinamento específico e estar certificada pela ANAC como operador de equipamento especial. No Brasil, somente as aeronaves militares têm autorização para fazer resgate em locais não homologados. Já as transferências inter-hospitalares devem ser entre locais homologado, conforme normas da ANAC. Tripulada por piloto, médico e enfermeiro.

- Viatura tipo F - Embarcação de Transporte Médico: veículo motorizado aquaviário, destinado ao transporte por via marítima ou fluvial. Precisa possuir os equipamentos médicos necessários à assistência de pacientes conforme sua gravidade. Tripulada de acordo com a classificação Básica ou Avançada.

- Veículos de Intervenção Rápida: veículos leves, rápidos ou de ligação médica com equipamentos que possibilitem oferecer SAV nas ambulâncias dos tipos A, B, C e F. A finalidade é melhorar o tempo resposta em situações com risco de morte, tanto no atendimento primário como no apoio às viaturas de Suporte Básico. Não se destinam ao embarque e nem ao transporte de pacientes. Tripulados por motorista, médico e enfermeiro.

\subsection{Etapas do Atendimento Pré-Hospitalar ${ }^{1215}$}

\subsubsection{Pedido de Ajuda e Acionamento}

Por meio de um chamado, a vítima de um agravo à saúde ou um solicitante pede ajuda, pelo telefone 192. Ele é atendido pelo TARM e regulado por um médico.

No Brasil, o telefone 192 é o número de emergência nacional para agravos de saúde, mas vários locais ainda não contam com o SAMU, sendo importante saber previamente o número de emergência local, que pode ser do Corpo de Bombeiros por meio do número 193. Lembramos que o chamado de ajuda é o primeiro elo da corrente de sobrevida e precisa ser amplamente divulgado e fácil de memorizar. Os cidadãos necessitam ter conhecimento prévio sobre o serviço de emergência, compreendendo que responder as perguntas do TARM e do médico regulador se faz necessário para o envio do recurso adequado.

\subsubsection{Regulação e Aconselhamento Médico}

O TARM colhe informações básicas para o atendimento por meio de um questionário breve, que dura por volta de 30 segundos a 1 minuto. Após, o médico recebe a ligação, avaliando e presumindo a gravidade de cada caso, para o envio de recursos necessários. Caso o médico regulador decida que não se trata de um caso de urgência ou emergência, ele realiza o aconselhamento médico. A seguir, breves considerações sobre este recurso:

- O médico regulador pode orientar e aconselhar o paciente, se não julgar necessário o envio de viaturas, transmitindo segurança ao solicitante nos casos que não caracterizar urgência ou emergência, e direcionando o paciente para a rede básica de saúde, se julgar necessário.

- O médico regulador deve transmitir tranquilidade e segurança, orientando o solicitante ou o paciente que se encontra consciente a manter a calma e a se manter na posição em que ele se sentir mais confortável, definindo as queixas e enviando os recursos necessários com as hipóteses do agravo à saúde.

\subsubsection{Reconhecimento e Ações do Médico Regulador em Casos de Vítimas com Dor Torácica}

Solicitações de pedido de ajuda para pacientes com dor torácica sugestiva de SCA devem ter prioridade no envio da viatura, com a chegada o mais breve possível de um desfibrilador no local.

A recomendação é do envio do recurso com prioridade, já que 51\% dos pacientes apresentam parada cardíaca por arritmia antes da chegada no hospital. O médico regulador pode orientar o paciente a tomar 200 mg de AAS não tamponado antes da chegada da equipe no local, exceto nos casos de alergia ou sangramento ativo conhecidos. ${ }^{1218} \mathrm{O}$ transporte de um paciente com dor torácica em um veículo particular é considerado alternativa aceitável, em um local onde um veículo de emergência demora mais do que 20 a 30 minutos. $^{1219}$

18.5.4. Reconhecimento e Ações do Médico Regulador em Casos de Vítimas com Parada Cardiorrespiratória ${ }^{1220}$

Nos casos de solicitação para vítimas inconscientes, o questionário deve ser rápido e objetivo, para o reconhecimento de pessoas em parada cardíaca. Medidas iniciais de ressuscitação devem ser orientadas, e o envio do recurso adequado deve ser feito o mais rápido possível.

Pergunte: "A vítima esta acordada? A vítima respira de forma normal, igual quando esta dormindo? Ou respira de forma estranha, agônica?"

Para vítimas inconscientes que não respiram de forma normal, o solicitante deve ser orientado a iniciar as compressões torácicas fortes e rápidas, sem interrupções 
(Hands Only) (Classe de Recomendação Ila; Nível de Evidência B) $i^{1221}$ e deve ser feita a instalação de um DEA, assim que disponível no local. Uma equipe de SAV ou outra viatura equipada com o DEA deve ser prontamente disponibilidade e enviada ao local. ${ }^{1220,1221}$ (Classe de Recomendação Ila; Nível de Evidência C).

O médico regulador não deve pedir para o leigo checar pulso, pois o índice de erros é alto. Deve orientar o início das compressões torácicas por telefone se a vítima estiver inconsciente, sem respirar ou com respiração agônica. Pedir calma e informar que ambulância já está a caminho e que as manobras de RCP não devem ser interrompidas até sua chegada no local. Mantenha o solicitante na linha para orientações e informações complementares. ${ }^{1220}$

Nos casos clínicos em que a vítima está inconsciente, mas respira de forma normal como se estivesse dormindo, o médico regulador deve enviar a equipe de SAV e orientar a abertura das vias aéreas, por meio da elevação da mandíbula, com inclinação da cabeça para trás na posição de recuperação em decúbito lateral até a chegada da equipe no local. ${ }^{1221}$

\section{Despacho}

O médico regulador envia os recursos necessários, respeitando a gravidade e quando houver a necessidade de apoio de outros órgãos, como Corpo de Bombeiros, polícia, dentre outros. Outras instituições, como serviços de resgate privados ou públicos, podem ser acionadas, considerando a gravidade da ocorrência e o número de vítimas. ${ }^{1215}$

\section{Atendimento no Local}

Ações necessárias para estabilização da vítima no local do atendimento devem demorar o menor tempo possível.

\section{Regulação do Hospital de Referência}

Verifica o melhor recurso e a disponibilidade de vaga, determinando o serviço a ser encaminhado, comunicando as condições da vítima com tempo estimado da chegada ao hospital determinado. Dessa forma, preferencialmente o contato deve ser feito de médico a médico.

\section{Rede Hospitalar}

Não é necessário o contato prévio dos casos considerados rotineiros, em que a pactuação prévia da rede já determina a unidade de saúde como referência. O conhecimento da rede hospitalar de referência é de extrema importância.

\section{Transporte}

O tempo gasto entre o local e o hospital de referência deve ser o menor possível. O Código Nacional de Trânsito, inclusive com o limite de velocidade da via, deve ser respeitados por ambulâncias. Todos os tripulantes da viatura devem utilizar o cinto de segurança. A maca deve estar fixa em trava apropriada, e o paciente, preso pelos cintos de segurança.

\section{Entrega}

Passagem do caso pela equipe de APH para equipe de emergência.

\section{Recuperação de Materiais e Limpeza da Viatura}

Após a entrega do paciente, a equipe de APH necessita se colocar a disposição, o mais rápido possível, podendo depender de liberação da maca e outros materiais, para deixar o hospital em condições de realizar outro atendimento.

\section{A) Inter-Relacionamento do Pronto-Socorro e o Atendimento Pré-Hospitalar}

É importante o inter-relacionamento das equipes do APH e do pronto-socorro em todas suas fases do atendimento. O médico regulador pode evitar o transporte inadequado com prejuízos a vítima e o desgaste das equipes envolvidas. Ressaltamos que o socorro adequado é a "Vítima certa para o hospital certo".

Na primeira fase do atendimento, ou seja, no acionamento, a Central de Regulação pode fazer contato de ALERTA, ao ser confirmada a presença de uma ou mais vítimas potencialmente graves, com intuito de que a equipe inicie os preparativos para a recepção desses pacientes.

\section{B) O Atendimento Pré-Hospitalar}

Diferente da equipe de atendimento dos serviços de resgate, como o SAMU, que tem treinamento específico para atuar fora do hospital em condições adversas, qualquer médico, independente da especialidade, pode deparar-se com uma situação de emergência. Salientamos que o treinamento de SBV deve ser de conhecimento de todos os profissionais de saúde.

\subsection{Ações ao se Deparar com um Acidente ou Atendimento Fora do Hospital}

O atendimento a emergências pode ocorrer em diferentes locais e situações. O profissional médico necessita ser capaz de avaliar a segurança do local. A regra a ser seguida é a dos "3s": segurança, situação e scene (cena). ${ }^{1222}$ Nesse momento, preocupe-se com os seguintes fatos:

- Sinalize o local. Em muitas ocorrências é a melhor ajuda para evitar novas vítimas. Durante o dia, utilize bandeiras, camisas, toalhas de cores fortes a $100 \mathrm{~m}$ da ocorrência, sem entrar na faixa de rolamento e, durante, a noite use lanternas. Nunca pare seu veículo sobre a faixa para sinalizar, pois são comuns outras colisões.

- Só entre na faixa de rolamento quando estiver certo de que a cena está segura.

- Peça ajuda pelo sistema de emergência local. Informe sobre a cena, o número de vítimas, a localização exata da ocorrência e os recursos necessários.

- Cuidado com cabos elétricos. Quando houver colisões em postes, a empresa responsável deve ser acionada. Não toque nos cabos e não tenha contato com áreas que possam conduzir eletricidade. 
- Cuidado com locais de violência urbana, com vítimas de arma de fogo ou outras agressões. Nesse caso, o atendimento só pode ser realizado quando os agressores não estiverem no local e, de preferência, com a chegada das forças de segurança.

- Lembre-se sempre de identificar-se como médico, assumindo a liderança até a chegada de ajuda.

- Não retire as vítimas do local sem imobilização, a não ser que exista risco iminente.

- Utilize equipamentos de proteção individual. Considere a cena não segura em caso de risco pessoal, aguardando a chegada dos recursos necessários.

\subsubsection{Atendimento de Pacientes Clínicos após Reconhecer a Cena como Segura}

Em pacientes inconscientes, estabeleça os elos da corrente da sobrevivência, solicite ajuda com DEA e, por meio do telefone 192 ou 193, peça o envio de uma equipe de primeira resposta. Tenha certeza de que a ajuda está a caminho com o desfibrilador, cheque o pulso carotídeo (não gaste mais que 10 segundos) e, se ausente, inicie as compressões torácicas de 100 a 120 por minuto, comprimindo o tórax pelo menos $5 \mathrm{~cm}$ e, no máximo, $6 \mathrm{~cm}$ (Classe de Recomendação I; Nível de Evidência C). ${ }^{1221}$

Se você não dispõe de dispositivo para ventilação ou não é treinado, mantenha apenas as compressões torácicas (Hands Only) (Classe de Recomendação Ila; Nível de Evidência C). ${ }^{1221}$ Entretanto, se optar por fazer ventilação e for treinado, deve intercalar 30 compressões torácicas com duas ventilações artificiais, até a chegada do DEA.

$\mathrm{O}$ atendimento de PCR sem trauma têm maiores chances de reversão no local, já o transporte não deve acontecer se a vítima não retornar à circulação espontânea, exceto em caso de risco para a equipe, por questões de segurança ou nas situações em que os recursos necessários para o SAV não estejam disponíveis. Em nosso país, somente médicos podem constatar morte, exceto em casos evidentes (rigidez cadavérica, decaptação, carbonização ou despostejamento).

\subsubsection{Chegada do Desfibrilador Externo Automático}

Com a chegada do DEA, as manobras de compressões torácicas não devem ser interrompidas, a não ser que tenha apenas um socorrista treinado, que deve dar prioridade para instalação do DEA.

O DEA não pode ser utilizado durante o transporte, pois os movimentos da viatura podem interferir na análise do ritmo, podendo causas erros. Ressaltamos que o ideal e o recomendado é que o SAV chegue no local em apoio à equipe de SBV com tempo inferior a 20 minutos, de acordo com a portaria GM/MS 2.048. ${ }^{1217}$

\subsubsection{Chegada da Equipe de Suporte Avançado}

Com a chegada da equipe de SAV, o médico ${ }^{1223}$ assume a liderança e certifica-se do tempo da parada cardíaca, se foi assistida ou não, e se foram indicados choques do DEA.
As compressões torácicas não devem ser interrompidas. O ritmo cardíaco deve ser avaliado por meio do monitor cardíaco, com as pás convencionais ou o acoplamento das pás adesivas no desfibrilador. Neste instante, as compressões torácicas devem ser interrompidas, para análise. Se o ritmo for FV ou TVSP, o choque deve ser entregue, sendo de 360 joules para os desfibriladores monofásicos e de 200 joules para bifásicos. A sequência do atendimento segue as recomendações do capítulo de SAV desta diretriz. ${ }^{1223}$

\section{A) Acesso Venoso Periférico}

Sua obtenção não pode retardar as manobras de RCP. ${ }^{1223}$ Outras alternativas, na ordem de prioridade, são punção da veia jugular externa ou interna, acesso intraósseo, acesso venoso central e via endotraqueal. Fístulas arteriovenosas e cateteres de longa permanência podem ser usados, mas evitados, pelo risco de infecção. Lembrar que áreas queimadas não contraindicam punções venosas.

\section{B) Acesso Intraósseo}

Pode ser utilizado em qualquer faixa etária. A inserção pode ser feita em três locais: esternal (não recomendado para menores de 3 anos, pelo risco de lesão cardíaca e de grandes vasos), tíbia proximal (tuberosidade) e tíbia distal (acima do tornozelo).

\section{C) Acesso Endotraqueal}

Realizado apenas com tubo orotraqueal. Podem ser administradas vasopressina, atropina, naloxona, adrenalina e lidocaína.

\subsection{Medicamentos Durante a Parada Cardiorrespiratória ${ }^{1223}$}

A administração de medicamentos não pode comprometer as compressões torácicas de alta qualidade, nem retardar a análise do ritmo e a desfibrilação imediata, quando indicada. O uso destes medicamentos segue o algoritmo do SAV desta diretriz.

\subsection{Cuidados Pós-Parada Cardíaca}

Após RCE, devemos preparar o paciente para o transporte adequado para o hospital correto, com capacidade de realizar intervenções para pacientes com SCA, cuidados neurológicos e terapêutica com hipotermia.

\subsection{Quando Devemos Interromper os Esforços e Declarar Morte ${ }^{1224,1225}$}

No Brasil, somente médicos podem interromper as manobras de RCP e declarar óbito, exceto em situações que existam sinais de morte evidente. Equipes de SBV devem manter as manobras de RCP até a chegada da equipe de SAV ou transportar para o pronto-socorro, até avaliação de um médico. Apesar de não ser recomendado o transporte de pacientes sem pulso, nesta situação, faz-se necessário, por conta da legislação brasileira. 
A equipe de SAV deve interromper as manobras de RCP se o a paciente apresentar ritmo de assistolia refratária a todas as intervenções que foram descritas. Não existe regra de quanto tempo devem ser mantidas as manobras e a equipe de SAV deve considerar: o tempo de PCR e o tempo resposta da primeira equipe; se a PCR foi assistida ou não pelo solicitante; se foram iniciadas manobras de RCP antes da chegada da equipe de primeira resposta; o ritmo inicial da PCR e se houve choque indicado; a existência de doenças prévias e outros dados que podem orientar a equipe em relação ao prognóstico e a continuidade ou não da manobras de RCP.

Recentemente, o uso da $\mathrm{EtCO}_{2}$ (end tidal- $\mathrm{CO}_{2}$ : medida do $\mathrm{CO}_{2}$ ao final da expiração) foi incorporado como variável auxiliar na decisão de cessar os esforços. A falha em atingir pelo menos $10 \mathrm{mmHg}$ após 20 minutos de RCP é um indicativo de que não haverá retorno à circulação espontânea.

\subsection{Atendimento de Vítimas de Trauma Fora do Hospital $^{1222}$}

\subsubsection{Conceitos Básicos}

Salientamos que a segurança, a situação e a cena precisam ser analisadas com rigor e, apenas quando o local estiver seguro, o atendimento será iniciado.

Imobilize a cabeça e mantenha a coluna cervical em posição neutra. Abra as vias aéreas, por meio de manobras manuais (tração da mandíbula). Avalie se a vítima respira e adote o protocolo de SBV. Siga a sequência $\mathrm{ABCDE}$, e não perca tempo no local com vítimas com sinais de choque e traumatismo craniencefálico grave, pois podemos fazer muito pouco fora do hospital. Garanta acesso à via aérea; descomprima o pneumotórax, se necessário, por punção com agulha de grosso calibre, no segundo espaço intercostal, na linha hemiclavicular. Estes procedimentos só devem ser realizados por médicos treinados e com equipamento adequado. Não atrase o transporte, se houver dificuldade no acesso venoso ou com imobilizações de extremidades. Avalie a pelve, pois fraturas instáveis podem ser causa de choque, e a imobilização adequada ameniza o sangramento, que pode agravar-se durante o transporte. Faça o acesso venoso durante o transporte, se for possível.Avise o hospital de referência sobre as condições das vítimas.

Lembre-se de que a primeira hora é a Hora de Ouro. Considerando que pouco pode ser feito no local, a equipe não deve demorar mais que 10 minutos.

\subsubsection{Atendimento de Múltiplas Vítimas ${ }^{1222}$}

Em caso de múltiplas vítimas, não devemos iniciar a RCP naquelas sem pulso, de acordo com os protocolos de triagem como o Simples Triagem e Tratamento Rápido (START). É preciso conhecer e usar estes protocolos para salvar o maior número de vítimas possível, dando prioridade a vítimas graves, porém com chance de sobrevida. Esta triagem deve ser realizada quando a ocorrência ultrapassar a capacidade de atendimento da equipe. São utilizados cartões que facilitam a identificação e a triagem de acordo com a gravidade:

- Código Vermelho: vítimas graves (prioridade I).
- Código Amarelo: vítimas intermediárias (prioridade II).

- Código Verde: vítimas leves (sem prioridade).

- Código Preto: vítimas inviáveis.

Ainda se a capacidade no local superar a capacidade de atendimento e transporte, lonas com as cores do START devem definir as áreas de atendimento, com os recursos médicos concentrados nas áreas vermelha e amarela. ${ }^{1222}$

\subsubsection{Critérios de Ressuscitação Cardiopulmonar no Trauma ${ }^{1222,1225,1226}$}

Critérios de RCP no trauma diferem do paciente clínico, mesmo quando se trata de vítima única. A justificativa é o prognóstico, que é muito mais desfavorável no trauma, quando atendido nos primeiros minutos. Os pacientes em PCR por trauma apresentam, frequentemente, lesões incompatíveis com a vida, com morte imediata pelo local. Nestes casos, quando a morte é evidente, torna-se importante preservar a cena e o local, que necessita ser periciado. Somente a autoridade policial pode liberar o corpo, quando a morte é evidente.

A taxa de sobrevida no trauma é baixa - por volta de 0 a 2,6\%, sendo as tentativas de RCP consideradas fúteis na maioria dos estudos. ${ }^{1226,1227}$ As tentativas de RCP podem ser suspensas ou não iniciadas em: pacientes sem pulso em apneia na chegada da equipe ao local em traumas fechados; sem pulso e sem sinais de vida, mesmo com ritmo cardíaco organizado, se a FC for menor de 40 bpm (AESP), em traumas penetrantes; em morte evidente; e em múltiplas vítimas.

As manobras podem ser suspensas e o óbito pode ser declarado nos casos em que a equipe presenciou a PCR e foi iniciada RCP no local sem sucesso, ou seja, sem RCE após 15 minutos de tentativas ou quando o recurso necessário (hospital) esteja mais de 15 minutos do local da ocorrência. ${ }^{1226,1227}$

Se o transporte for indicado, as manobras de RCP não devem ser interrompidas, pois muitas ações só podem ser realizadas no hospital, na sala cirúrgica e com reposição de sangue.

Salientamos que estas recomendações estão no PréHospital Trauma Life Support (PHTLS) ${ }^{1222}$ e podem diferir de outros protocolos. As decisões de iniciar ou não a RCP podem ser consideradas caso a caso com profissionais médicos experientes; ocorrendo dúvida, deve ser iniciada.

No Brasil, o SBV só pode decidir por não iniciar RCP nos casos de morte evidente e somente médicos podem decidir por não iniciar ou interromper as manobras de ressuscitação nas demais situações. Ainda devemos ressaltar que, uma vez iniciada a RCP pela equipe do SBV, só é possível interromper com a presença de um médico. ${ }^{1226,1227}$

\section{Primeiros Socorros e Emergências Ambientais}

\subsection{Introdução}

Os primeiros socorros são definidos como avaliações e intervenções iniciais para uma doença ou lesão aguda, que podem ser realizadas por qualquer pessoa, inclusive pela própria 
vítima, com ou sem equipamentos médicos, com o objetivo de preservar a vida, aliviar o sofrimento, prevenir progressão de novas patologias e promover a recuperação. ${ }^{1228-1230}$

As intervenções de primeiros socorros não devem adiar o acionamento do serviço de emergência ou de outro serviço de assistência médica, quando necessário. ${ }^{1228}$

Toda vítima que se encontra em situação de perigo deve idealmente ser atendida de forma rápida e eficaz. Para que isso aconteça, normatizações de condutas devem ser feitas e seguidas pelo maior número de pessoas possível. Infelizmente, a maior parte das vítimas que apresentam alguma emergência não tem acesso à assistência de saúde para o atendimento inicial em condições ideais. Dessa forma, é fundamental que todos estejam preparados para lidar com situações que colocam em risco a vida de seus próximos.

Recomenda-se que a educação em primeiros socorros seja universalmente disponível, diminuindo a morbimortalidade por lesões e doenças, e promovendo aumento nas taxas de sobrevivência. ${ }^{1229}$

Estudos recentes demonstram que o leigo (não profissional da saúde) é o primeiro a chegar à cena de emergência e prestar os primeiros socorros à vítima. Nesta diretriz, titularemos leigo de "socorrista", por ser, muitas vezes, a primeira pessoa que atende uma vítima em situação de emergência no ambiente pré-hospitalar, e, adaptando o atendimento à realidade brasileira, entende-se por serviço médico de emergência os serviços pré-hospitalares presentes em diversas regiões do país, por exemplo: SAMU (192), Corpo de Bombeiros (193), serviços de ambulâncias, etc. Ressalta-se a importância de disseminar o telefone do serviço de emergência pré-hospitalar presente na região para toda a comunidade.

\subsection{Segurança da Cena}

A primeira preocupação do socorrista, ao se aproximar de qualquer cena, é a segurança do local, observando se existe perigo para ele e para os outros.

Se o local for seguro, não mova a vítima, principalmente se o socorrista suspeitar que a vítima sofreu um trauma, ou possa ter uma lesão pélvica ou da coluna vertebral.

Quando o local não for seguro, remova a vítima para uma área segura, antes que sejam iniciados a avaliação e o tratamento necessários. Se a via aérea da vítima estiver bloqueada devido à posição, mova a vítima (somente o necessário) para abrir a via áerea. ${ }^{1229-1231}$

Caso o socorrista esteja sozinho e tenha um celular, pode acionar o serviço médico de emergência, deixando o aparelho no viva-voz.

\subsection{Atendimento à Vítima}

Durante a realização da avaliação inicial, verifique se a pessoa responde, batendo em seus ombros e perguntando: "Você está bem?".

\subsubsection{Vítima Consciente}

Caso a vítima esteja consciente, o socorrista deve apresentar-se dizendo seu nome, identificando-se como pessoa capacitada e perguntando se pode ajudar (pedido formal de consentimento para prestar o socorro).

Se a vítima consentir, o socorrista deve iniciar o atendimento, até a equipe de emergência especializada chegar ao local, caso contrário, o socorrista deve acionar o serviço médico de emergência e permanecer no local até a chegada do mesmo. Se a vítima estiver confusa ou não puder responder, presuma que ela deseja atendimento de primeiros socorros. ${ }^{1231}$

Após a aceitação do atendimento pela vítima, a primeira meta do socorrista é determinar seu estado geral. ${ }^{1231}$

A fim de facilitar a realização de uma entrevista simplificada da vítima, abordando os tópicos principais de investigação e direcionando o socorrista às emergências potencialmente graves, podemos utilizar um recurso mnemônico, denominado SAMUDE. Cada letra da palavra representa uma avaliação ou pergunta que deverá ser feita ao paciente:

- Sinais e sintomas: pergunte à vítima o que ela está sentindo e observe sinais de confusão mental, dispneia, palidez cutânea, sudorese, sangramento, etc.

- Alergias: questione a vítima se ela é alérgica a medicamentos, alimentos ou picada de insetos.

- Medicações: pergunte se ela faz uso de algum medicamento.

- Última refeição: questione a pessoa sobre o horário da última refeição e o que foi ingerido.

- Doenças: pergunte para vítima se ela possui alguma doença prévia.

- Eventos relacionados (com o trauma ou doença): observe a cena e a relacione com a ocorrência, com as queixas da vítima e pergunte como aconteceu o incidente.

Desta forma, o socorrista conseguirá identificar se a vítima está grave, se é necessário o acionamento imediato do serviço médico de emergência, ou se, por meio do estabelecimento de condutas simples, ele conseguirá realizar um tratamento efetivo, melhorando a situação inicial da vítima.

\subsubsection{Atendimento à Vítima Inconsciente}

Após verificar a segurança do local, o socorrista deve primeiramente reconhecer se a vítima está em PCR, avaliando a responsividade e checando a respiração. 5,6

Ao encontrar uma vítima inconsciente (que não responde), o socorrista deve, imediatamente, acionar o serviço médico de emergência e solicitar um DEA. Depois, deve avaliar sua respiração (5 a 10 segundos). Se a vítima não estiver respirando ou apresentar respiração anormal (gasping), o socorrista deve iniciar as manobras de RCP. ${ }^{1232}$

O treinamento em SBV deve ser estimulado e disponibilizado ao máximo, possibilitando maior chance de um indivíduo com PCR ser reanimado com sucesso (Quadro 19.1 e Figura 19.1). ${ }^{1233}$

\subsection{Desmaio e Síncope}

A síncope é caracterizada por perda transitória da consciência e do tônus postural, que ocorre de forma súbita e com recuperação espontânea. ${ }^{1232,1233}$ 


\section{Atualização}

Quadro 19.1 - Recomendações para atendimento de primeiros socorros de vítimas em situação de emergência

\begin{tabular}{|c|c|c|}
\hline Indicações & Classe de Recomendação & Nível de Evidência \\
\hline Treinamento em primeiros socorros para leigos & I & C \\
\hline Remover a vítima, quando encontrada em ambiente perigoso, para uma área segura & I & C \\
\hline Acionar o serviço de emergência e iniciar ressuscitação cardiopulmonar em vítimas inconscientes & I & A \\
\hline $\begin{array}{l}\text { Avaliar, de forma rápida, o nível de consciência da vítima, a fim de estabelecer se ela está na eminência de } \\
\text { condição grave }\end{array}$ & I & A \\
\hline
\end{tabular}

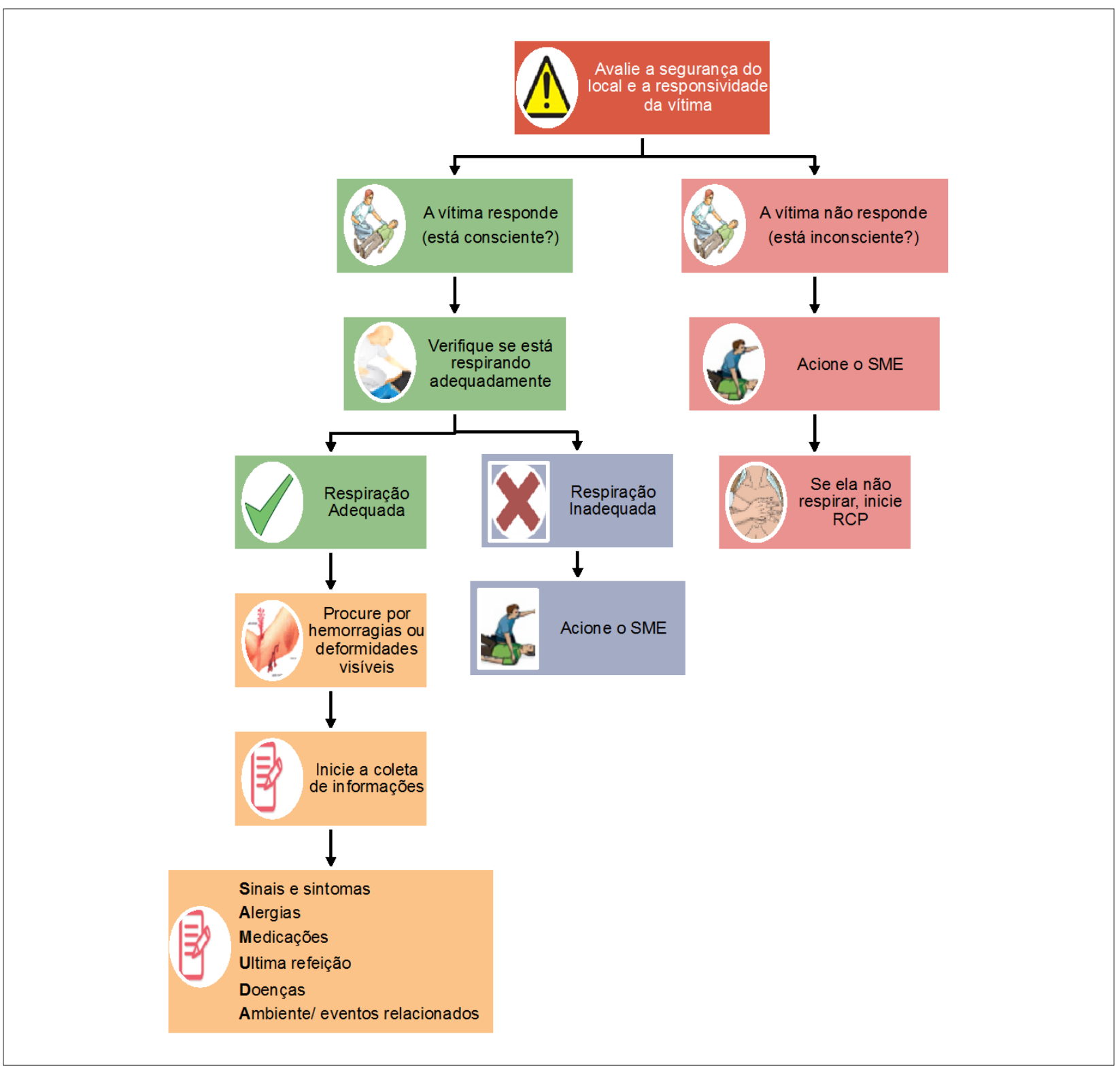

Figura 19.1 - Atendimento de primeiros socorros de vítimas em situação de emergência. SME: serviço médico de emergência; RCP: ressuscitação cardiopulmonar. 
O episódio de síncope pode ser originado por várias causas: reflexo vasovagal, induzido por calor excessivo, dor intensa, tosse, posição ortostática prolongada, esforço ao urinar ou evacuar, por medo ou estados de ansiedade extrema e por esforço físico demasiado; síndrome do seio carotídeo; síndromes de insuficiência autonômica, tais como o Parkinson; alterações do sistema autônomo, desencadeadas pelo uso de álcool, diabetes, amiloidose e hipovolemia; induzida pelo uso de determinados medicamentos, como antiarrítmicos, betabloqueadores, drogas vasodilatadoras, diuréticos, antidepressivos e antipsicóticos, entre outros; síncope de origem cardíaca; síncope cerebrovascular, ocasionadas por cefaleia, isquemia cerebral, epilepsia e outros.

O tratamento da síncope está relacionado à sua causa. Sabe-se que a síncope vasovagal é a mais frequente, correspondendo a $50 \%$ dos diagnósticos. Neste caso, as medidas não farmacológicas são suficientes, como hidratação vigorosa, evitar locais quentes e abafados, uso de meia elástica, treinamento postural passivo, dentre outras (Quadro 19.2).

\subsection{Obstrução de Vias Aéreas por Corpo Estranho}

Entende-se por obstrução de vias aéreas toda situação que impeça total ou parcialmente o trânsito de ar ambiente até os alvéolos pulmonares. A restauração e a manutenção da permeabilidade das vias aéreas nas vítimas de trauma são essenciais e devem ser feitas de maneira rápida e prioritária, podendo resultar em morte dentro de minutos, se não for tratada. ${ }^{1234,1235}$

Uma vítima pode desenvolver obstrução de vias aéreas devido a causas intrínsecas (obstrução das vias aéreas por relaxamento da língua) ou extrínsecas (aspiração de corpo estranho, alimentos e outros)..$^{1229,1234,1235}$

No Brasil, a OVACE é a terceira maior causa de acidentes seguidos por morte, em crianças e lactentes. ${ }^{1229,1236}$

Classifica-se a OVACE em leve (parcial) ou grave (total). Na obstrução leve, existe passagem de ar, e a vítima é capaz de tossir. Enquanto houver uma troca gasosa satisfatória, o socorrista deve encorajar a vítima a persistir na tosse espontânea e nos esforços respiratórios, pois a tosse promove a saída de ar dos pulmões, estimulando a expulsão do objeto que está causando a obstrução. ${ }^{1235}$ Os sinais de obstrução grave (total) das vias aéreas incluem:

- Incapacidade de respirar, tossir e falar, cianose de lábios e extremidades, indicando que não há passagem de ar.

- A vítima pode fazer o sinal universal da asfixia (segurando o pescoço com uma ou ambas as mãos) ou apenas apontar com as mãos voltadas para o pescoço, indicando que está engasgada e precisa de ajuda. ${ }^{1235,1236}$
- Em caso de obstrução grave das vias aéreas em vítima consciente, deve-se utilizar a manobra de Heimlich (Figura 19.2). Esta manobra (impulso abdominal) eleva o diafragma e aumenta a pressão na via aérea, forçando a saída de ar dos pulmões, suficiente para criar uma tosse artificial e expelir um corpo estranho. Relatos de complicações incluem danos aos órgãos internos, ${ }^{1237}$ portanto toda vítima que receber a manobra de Heimlich deve ser encaminhada para o hospital.

- Se a vítima estiver grávida ou for obesa, aplique compressões torácicas, ao invés de compressões abdominais (Figura 19.3). Se a vítima for menor que o socorrista, o mesmo deve posicionar-se de joelhos atrás da vítima e realizar a manobra de Heimlich. Atualmente, um novo dispositivo de sucção está sendo especialmente desenvolvido para desobstrução das vias aéreas para as situações de falha com as manobras habituais descritas. ${ }^{1238}$

- Se a vítima adulta com OVACE tornar-se inconsciente, o socorrista deve apoiar a vítima cuidadosamente no chão e imediatamente ativar o serviço médico de emergência (ou solicitar ajuda ou ligar pelo viva-voz) e, em seguida, iniciar a RCP. Cada vez que o socorrista abrir as vias aéreas para realizar as ventilações, o mesmo deverá olhar para o interior da cavidade oral; se o corpo estranho estiver visível, deverá ser removido, evitando varredura digital às cegas e não retardando as manobras de RCP (Quadro 19.3). ${ }^{1235}$

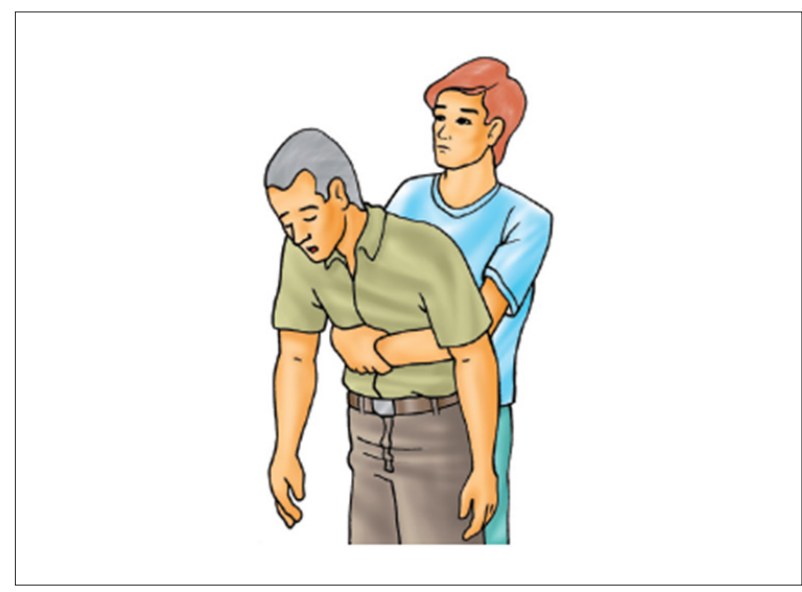

Figura 19.2 - Manobra de Heimlich

Quadro 19.2 - Recomendações para atendimento em casos de desmaio

\begin{tabular}{|c|c|c|}
\hline Recomendações & Classe de Recomendação & Nível de Evidência \\
\hline $\begin{array}{l}\text { Ajudar a vítima a deitar-se no chão em decúbito dorsal horizontal e esperar ela se recuperar. Se ela não se } \\
\text { recuperar acionar o serviço médico de emergência }\end{array}$ & $\|$ & B \\
\hline Em caso de síncope, elevar as pernas da vítima, carca de 30 a $60^{\circ}$, exceto em situações de trauma & $\mathrm{Ilb}$ & C \\
\hline
\end{tabular}




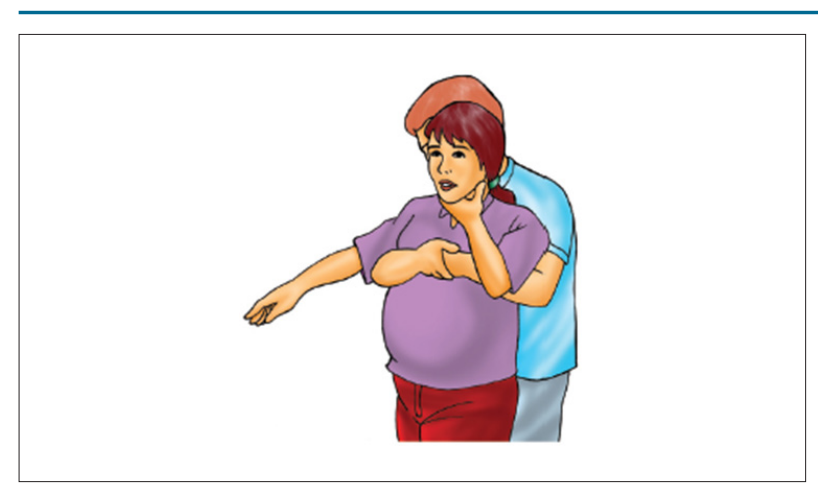

Figura 19.3 - Compressões torácicas em vítimas de engasgo grávidas ou obesas.

\subsection{Dor Torácica Sugestiva de Isquemia Miocárdica}

A alta prevalência de DAC, assim como a alta morbimortalidade na SCA, faz com que seja mandatória a identificação precoce de seus sinais e sintomas. ${ }^{1239}$

O período pré-hospitalar do atendimento de SCA, compreende dois momentos: o início dos sintomas e a o da decisão de procurar atendimento até a chegada ao hospital. ${ }^{1240}$

A dor torácica aguda é o sintoma prevalente na SCA, que geralmente é intensa, intermitente ou contínua ( $>10$ minutos de duração), em aperto, peso ou queimação, em região precordial, retroesternal ou epigástrica, com frequente irradiação para membros superiores, dorso, pescoço e região da mandíbula, além de sintomas associados, como dispneia, sudorese, náuseas, vômitos e tonturas. ${ }^{1241}$

A presença de sintomas atípicos não exclui a suspeita clínica, principalmente em mulheres, idosos e diabéticos (Quadro 19.4).461,1242
Campanhas de orientação contribuem para aumentar o conhecimento da população no reconhecimento precoce de sinais e sintomas da SCA. ${ }^{1243,1244} \mathrm{O}$ uso de AAS precoce, na fase pré-hospitalar, reduz a mortalidade de pacientes com SCA. ${ }^{1245,1246}$ Enquanto aguardam a chegada do serviço médico de emergência, pacientes com suspeita de SCA devem ingerir o AAS na dose de $200 \mathrm{mg}$ via oral mastigado, desde que não haja contraindicação ao mesmo (alergia ou história de sangramento ativo). ${ }^{1246-1248}$

Com a chegada do serviço médico de emergência, é fundamental a agilidade no transporte ao hospital de referência. ${ }^{1249,1250}$ No local, a equipe do serviço médico de emergência deve estar habilitada para o reconhecimento do início dos sintomas, além de iniciar monitorização dos sinais vitais, ritmo cardíaco e, se possível, obter um ECG. ${ }^{1251,1252}$

\subsection{Suspeita de Acidente Vascular Cerebral}

O AVC, ou doença cerebrovascular, ainda é uma das principais causas de morbimortalidade no mundo. Estimase que cerca de 80 a $85 \%$ sejam de origem isquêmica e 15 a 20\%, hemorrágicos, sendo uma emergência clínica e, eventualmente, cirúrgica. Uma vez que a terapia adequada é tempo-dependente, é fundamental que o reconhecimento dos sinais clínicos sejam precoces, assim como a ativação do SAMU pelo telefone 192 .

Em 2008, o estudo ECASS-3 evidenciou benefício da fibrinólise com rt-PA na janela terapêutica entre 3 e 4 horas e 30 minutos, mostrando redução na disfunção neurológica de $34 \%$ em 3 meses. ${ }^{1253}$ Para que a fibrinólise seja possível, assim como a administração de AAS via oral, é necessário que a forma hemorrágica do AVC seja descartada, por meio de exame de imagem (TC de crânio ou ressonância magnética de crânio), além da avaliação clínica em ambiente hospitalar (NIHSS). ${ }^{1254,1255}$

Quadro 19.3 - Recomendações para atendimento de primeiros socorros em casos de obstrução de vias aéreas por corpo estranho

\begin{tabular}{lc}
\hline Recomendações & Classe de Recomendação \\
\hline $\begin{array}{l}\text { Realização da manobra de Heimlich nas vítimas de obstrução de vias aéreas acima de 1 ano de idade que } \\
\text { estão conscientes }\end{array}$ & B I \\
$\begin{array}{l}\text { Realização de ressuscitação cardiopulmonar nas vítimas de obstrução de vias aéreas que perdem a } \\
\text { consciência }\end{array}$ & C \\
Varredura digital em busca do objeto que causou obstrução & C III \\
\hline
\end{tabular}

Quadro 19.4 - Classificação de dor torácica

\begin{tabular}{lr}
\hline Classificação & Tipo de dor torácica \\
\hline $\begin{array}{l}\text { Definitivamente anginosa } \\
\text { Provavelmente anginosa }\end{array}$ & $\begin{array}{r}\text { Pesconforto retroesternal precipitado pelo esforço, com irradiação típica para o ombro, mandíbula ou face interna do braço, aliviado características de dor definitivamente anginosa } \\
\text { pelo repouso ou nitrato, em menos de } 10 \text { minutos }\end{array}$ \\
$\begin{array}{l}\text { Provavelmente não anginosa } \\
\text { Definitivamente não anginosa }\end{array}$ & $\begin{array}{c}\text { Padrão atípico de dor torácica que possui a minoria das características da dor definitivamente anginosa } \\
\text { Dor não relacionada ao esforço, não aliviada por nitratos, com aspecto evidente de origem não cardíaca }\end{array}$ \\
\hline
\end{tabular}

Fonte: Adaptado de Hacke W, et al., 2008. ${ }^{1256}$ 
Mais da metade dos casos acontece em domicílio, e poucas vítimas de AVC são encaminhadas para o hospital em tempo hábil para terapia fibrinolítica. ${ }^{1256,1257}$ Isso ocorre por uma série de fatores, como a falta de reconhecimento dos sinais da doença; subutilização do SAMU; uso de veículos privados para transporte ao hospital; ou avaliação inicial em atendimento médico primário. ${ }^{698,1258,1259}$

Para que não ocorram atrasos, é fundamental o reconhecimento dos primeiros sinais e sintomas da doença. ${ }^{604,1260}$ Uma maneira acessível de identificação de uma vítima com possível AVC é a aplicação da escala pré-hospitalar de acidentes vasculares de Cincinnati (Quadro 19.5), baseada no exame físico. ${ }^{1261,1262}$ Nessa escala, o socorrista deve procurar por três achados: desvio de rima labial, fraqueza em um dos membros superiores e anormalidades na fala (Figura 19.4). Na existência de qualquer um destes sinais, a probabilidade de a vítima apresentar AVC é de $72 \% .{ }^{1263}$

Portanto, são fundamentais campanhas educacionais, com o objetivo de informar a população quanto ao reconhecimento dos primeiros sinais e sintomas do AVC, assim como a ativação imediata do SAMU. $598,1248,1258,1260$

Uma vez ativado o serviço médico de emergência, o atendimento às vítimas de AVC deve ser priorizado, com profissionais habilitados para diagnóstico e estabilização inicial do paciente, com escalas e protocolos específicos. O transporte deve ser realizado, após contato telefônico inicial, para hospital com melhor estrutura e mais próximo do local. ${ }^{1262,1264}$ Durante o transporte, deve ser realizada a monitorização de oximetria e avaliação clínica quanto à presença de desidratação, ${ }^{610,625}$ além de não corrigir a hipertensão arterial, inicialmente. ${ }^{1262}$

Atualmente, apesar da ausência de evidência científica, o auxílio de aplicativos de telefone celular, o uso de mídias digitais ou a telemedicina parecem promissores na melhora do reconhecimento inicial dos sintomas, na ativação mais rápida do serviço médico de emergência, no tratamento e no desfecho dos casos de vítimas de AVC (Quadro 19.6).

\subsection{Crise Asmática}

Asma é uma doença heterogênea, caracterizada por inflamação crônica de vias aéreas. ${ }^{1265,1266} \mathrm{~A}$ causa da morte por asma é a obstrução total das vias aéreas na quase totalidade dos casos. Por isso, é preciso identificar aspectos que indiquem maior risco.

As orientações devem incluir informações sobre a doença, habilidades no manejo dos dispositivos inalatórios (Quadro
19.7), ${ }^{1267}$ aderência ao uso das medicações, estratégias para reconhecimento e manejo das crises (plano de ação), visitas regulares ao médico para avaliação do controle da asma e, se disponível, automonitorização com peak flow, um dispositivo usado para medir o fluxo expiratório de pacientes de asma.

Reconhecimento dos fatores de risco para asma fatal: história de asma quase fatal, necessitando de IOT e VM; duas ou mais hospitalizações, ou mais de três visitas ao prontoatendimento devido à crise, no último ano; uso frequente ou recente de corticosteroides orais; não aderência ao uso de corticosteroides inalatórios; uso de dois ou mais frascos de broncodilatador por mês; problemas psicossociais (por exemplo, depressão, baixo nível socioeconômico, dificuldade de acesso à assistência, falta de aderência a tratamentos prévios); alergia alimentar em paciente com asma.

Pacientes asmáticos, quando em crises de broncoespasmo, muitas vezes já possuem consigo medicação broncodilatadora (sob a orientação médica), e podem realizar sua autoadministração. ${ }^{1267,1268}$

\subsection{Anafilaxia}

A anafilaxia pode ser caracterizada como reação sistêmica aguda, grave, que acomete vários órgãos e sistemas simultaneamente e é determinada pela atividade de mediadores farmacológicos liberados por mastócitos e basófilos ativados.

Os principais agentes relacionados à anafilaxia são medicamentos, veneno de insetos e alimentos. ${ }^{1269-1272}$

A anafilaxia tem muitas apresentações clínicas, mas o comprometimento respiratório e o colapso cardiovascular podem causar a maior preocupação, devido à alta mortalidade. Para caracterização da anafilaxia, são considerados três critérios clínicos (Quadro 19.8).

Estima-se que a incidência de reações anafiláticas varie entre 10 e 20/100 mil habitantes por ano. Não há dados brasileiros, porém estudos epidemiológicos europeus demonstraram que mais de um terço das reações alérgicas graves foram inicialmente tratadas por um médico de emergência $(34,5 \%) ; 37,6 \%$ por outros médicos e 10\% receberam tratamento em primeiros socorros por meio de não profissionais (socorristas leigos). ${ }^{1274}$

A administração precoce de epinefrina para reações alérgicas graves pode salvar vidas e retardar a progressão de uma reação anafilática. ${ }^{1275,1276}$

Quadro 19.5 - Escala pré-hospitalar de acidentes vasculares de Cincinnati

\begin{tabular}{lccc}
\hline Sinais/sintomas & Como testar & Normal & Anormal \\
\hline Queda facial & $\begin{array}{c}\text { Pede-se para a vítima mostrar os dentes } \\
\text { ou sorrir }\end{array}$ & $\begin{array}{c}\text { Ambos os lados da face movem-se } \\
\text { igualmente }\end{array}$ & $\begin{array}{c}\text { Um lado da face não se move tão bem } \\
\text { quanto o outro }\end{array}$ \\
Força motora nos braços & A vítima fecha os olhos e mantém os & Ambos os braços movem-se igualmente ou \\
braços estendidos & não se movem & Observa-se a queda de um dos braços \\
Fala anormal & $\begin{array}{c}\text { Pede-se para a vítima falar uma frase: "o } \\
\text { rato roeu a roupa do rei de Roma" }\end{array}$ & $\begin{array}{c}\text { Usa as palavras corretas, com pronúncia } \\
\text { clara }\end{array}$ & Pronuncia palavras inteligíveis, usa \\
& & palavras incorretas ou é incapaz de falar
\end{tabular}




\section{Atualização}

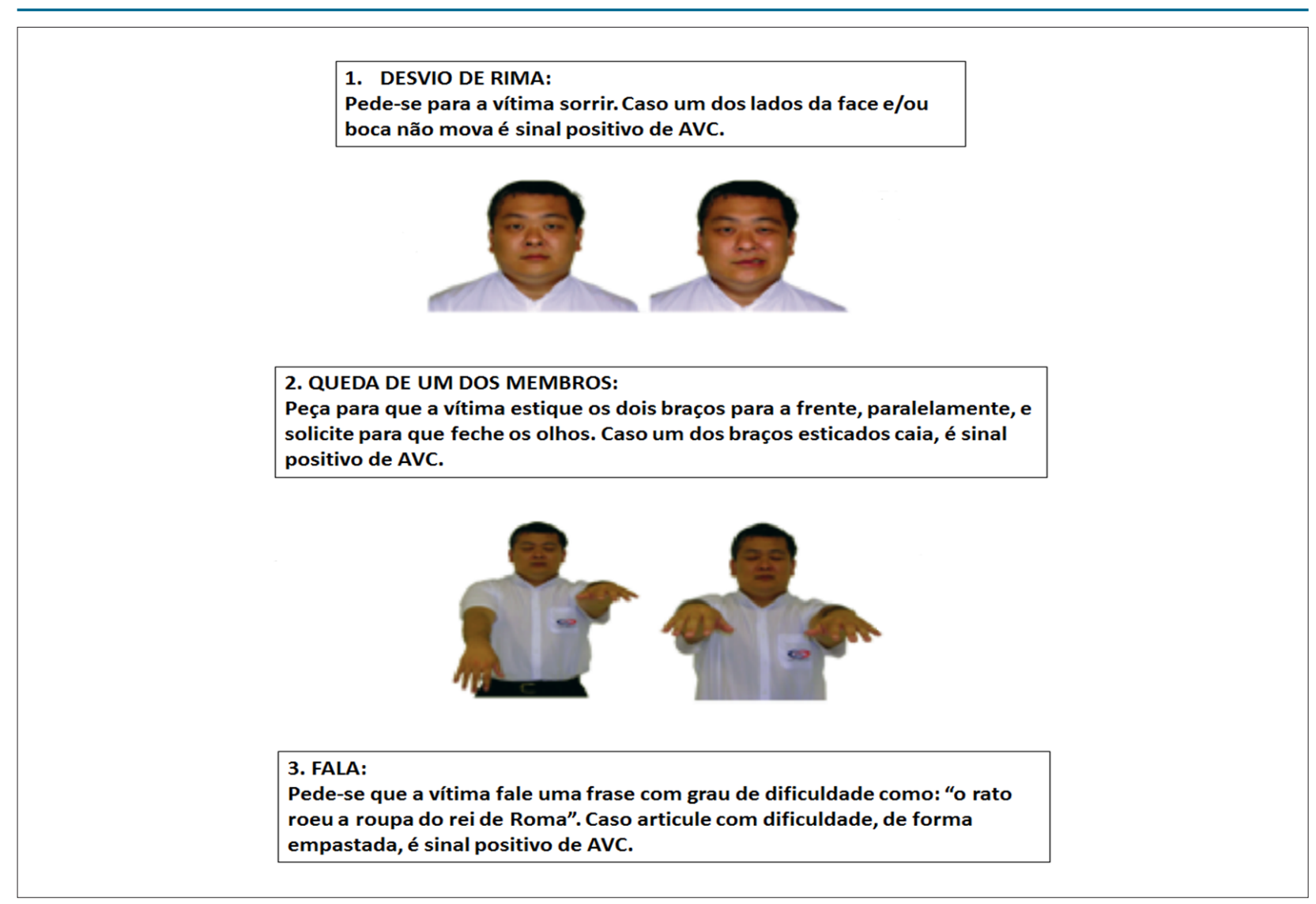

Figura 19.4 - Escala pré-hospitalar de acidentes vasculares de Cincinnati. AVC: acidente vascular cerebral.

Quadro 19.6 - Recomendações para atendimento de primeiros socorros em casos de suspeita de acidente vascular cerebral (AVC)

\begin{tabular}{|c|c|c|}
\hline Recomendações & Classe de Recomendação & Nível de Evidência \\
\hline Ativação do serviço médico de emergência por socorristas ou pela vítima & I & $\mathrm{B}$ \\
\hline $\begin{array}{l}\text { O serviço médico de emergência deve priorizar o atendimento de vítimas que apresentam sinais e sintomas de } \\
\text { AVC }\end{array}$ & I & B \\
\hline $\begin{array}{l}\text { Recomendam-se programas educacionais para conscientização da população sobre os sinais e sintomas do } \\
\text { AVC }\end{array}$ & I & B \\
\hline $\begin{array}{l}\text { O uso de uma escala de identificação, tal como a escala pré-hospitalar de acidentes vasculares de Cincinnati, } \\
\text { deve ser divulgado }\end{array}$ & I & $\mathrm{B}$ \\
\hline Avaliação da glicemia capilar e correção de hipoglicemia em vítimas com suspeita de AVC & I & $\mathrm{B}$ \\
\hline
\end{tabular}

Com orientação adequada, os pacientes e socorristas podem usar corretamente a caneta injetora de epinefrina. ${ }^{1277,1278}$ Estes dispositivos são disponibilizados em doses fixas $(0,15 \mathrm{mg}$ crianças até $30 \mathrm{~kg}$; 0,3 mg para crianças maiores/adultos). Aplicar na face anterolateral da coxa. Caso não haja melhora dos sintomas, uma segunda dose pode ser realizada cerca de 5 a 10 minutos após a primeira. A aplicação deve ser feita por cima da roupa para evitar perda de tempo (Quadro 19.8). ${ }^{1279}$

Socorristas leigos devem ser orientados a perceber os sinais e sintomas de uma reação alérgica grave e, se a vítima não possuir caneta injetora de epinefrina, devem imediatamente ativar o serviço médico de emergência, informando os sinais e sintomas apresentados pela vítima. ${ }^{1278,1280}$

\subsection{Convulsão}

A crise epiléptica é uma ocorrência transitória de sinais e/ou sintomas devido à atividade neuronal excessiva e anormal. Já a epilepsia é um distúrbio cerebral caracterizado por uma predisposição em gerar crises epilépticas e, por consequência, neurobiológicas, cognitivas, psicológicas e sociais desta condição. ${ }^{1281}$ Afeta aproximadamente $2 \%$ da 


\section{Quadro 19.7 - Orientações para utilização dos dispositivos} inalatórios ${ }^{1267}$

\begin{tabular}{l}
\hline Aerossol dosimetrado - spray \\
\hline 1. Retirar a tampa \\
2. Agitar o dispositivo \\
3. Posicionar a saída do bocal verticalmente 2 a $3 \mathrm{~cm}$ da boca \\
4. Manter a boca aberta \\
5. Expirar normalmente \\
6. Coordenar o acionamento do dispositivo no início da inspiração lenta e \\
profunda \\
7. Fazer pausa pós-inspiratória de, no mínimo, 10 segundos \\
8. Nova aplicação pode ser repetida após 15 a 30 segundos \\
\hline Inaladores de medicação em pó \\
\hline 1. Retirar a tampa do inalador de pó e colocar uma cápsula. Em seguida, \\
perfurá-la, comprimindo as garras laterais \\
2. Expirar normalmente e colocar o dispositivo na boca \\
3. Inspirar o mais rápido e profundo possível (fluxo mínimo de $30 \mathrm{~L} /$ minuto) \\
4. Fazer pausa pós-inspiratória de 10 segundos \\
\hline
\end{tabular}

população mundial e há pouca divulgação pública, tornandose importante a apresentação do assunto às comunidades, especialmente no âmbito escolar. ${ }^{1282}$

Além da epilepsia, há outras causas de convulsão, como: hipoglicemia, lesão relacionada ao calor e intoxicações. O primeiro atendimento visa proteger o indivíduo de danos durante a crise. ${ }^{1283,1284}$

O que fazer:

- Mantenha-se calmo e explique às pessoas ao seu redor. ${ }^{1285}$

- Acomode o indivíduo em local seguro (sem objetos em torno com os quais possa se machucar). ${ }^{1285}$

- Acomode a cabeça do indivíduo (exemplo: um travesseiro ou outro material macio).
- Posicione o indivíduo de lado para que o excesso de saliva, vômito ou sangue escorra da boca, evitando broncoaspiração.

- Permaneça junto à vítima até a recuperação da consciência.

- Ao término da convulsão explique à pessoa o que ocorreu.

- Observe a duração da crise convulsiva, caso seja superior a 5 minutos sem sinais de melhora, peça ajuda médica. O que não fazer:

- Não impeça os movimentos da vítima, não segure ou a agarre. ${ }^{1285}$

- Não coloque a mão dentro da boca da vítima (inconscientemente a pessoa poderá mordê-lo).

- Não jogue água na vítima.

Após o episódio, o socorrista deve avaliar a respiração da vítima e, se necessário, manter a via aérea pérvia (manobra de inclinação da cabeça - elevação do queixo) e colocar a vítima em posição de recuperação, evitando, broncoaspiração. Se a crise durar mais de 5 minutos, pode haver estado de mal epiléptico, sendo necessária a administração de medicações. ${ }^{1286-1288}$ Nesse momento, é fundamental a presença do serviço médico de emergência (Quadro 19.9).

\subsection{Atendimento Inicial à Vítima com Hipoglicemia}

Manifestação de hipoglicemia pode ocorrer em pessoas diabéticas ou não quando em jejum prolongado, com ingestão inadequada de alimento para determinada atividade física, ou administração de uma dose de insulina não programada. Os sintomas são sonolência, náuseas, vômitos, confusão mental, entre outros. ${ }^{1289}$

Diabéticos que apresentarem os sintomas descritos devem ser caracterizados pelo primeiro socorrista como crise de hipoglicemia. Se o indivíduo estiver inconsciente,

Quadro 19.8 - Critérios clínicos para anafilaxia (apenas um critério indica a probabilidade de anafilaxia) ${ }^{1273}$

Início agudo da doença (minutos a várias horas), com envolvimento da pele e/ou mucosa (por exemplo: urticária generalizada, prurido ou rubor, lábios/
língua/úvula edemaciados) e pelo menos uma das seguintes opções:
Critério 1 - Comprometimento respiratório (por exemplo: dispneia, sibilos, broncoespasmo, estridor e hipoxemia)
Hipotensão ou sintomas associados à disfunção de órgãos-alvo (por exemplo, hipotonia, síncope e incontinência)
Dois ou mais dos seguintes itens podem ocorrer rapidamente após a exposição a um alérgeno (podem ocorrer em minutos a várias horas):
- Envolvimento da pele/mucosa (por exemplo: urticária generalizada, prurido ou rubor, lábios/lingua/úvula edemaciados)
- Comprometimento respiratório (por exemplo: dispneia, sibilos, broncoespasmo, estridor e hipoxemia)
- Hipotensão ou sintomas associados (por exemplo: hipotonia, síncope e incontinência)
- Sintomas gastrintestinais persistentes (por exemplo: cólica, dor abdominal e vômitos)
Critério 3
Hipotensão após a exposição ao conhecido do alérgeno (minutos a várias horas).

Quadro 19.9 - Recomendações para atendimento de primeiros socorros em casos de convulsão

\begin{tabular}{|c|c|c|}
\hline Recomendações & Classe de Recomendação & Nível de Evidência \\
\hline Durante a convulsão, deve-se proteger a vítima de possíveis objetos que possam causar lesões & I & $\mathrm{C}$ \\
\hline Após a convulsão, manter a via aérea pérvia e colocar a vítima em posição de recuperação & I & C \\
\hline Abrir a boca da vítima ou tentar colocar qualquer objeto entre seus dentes ou na boca & III & C \\
\hline
\end{tabular}


apresentar convulsão ou impossibilidade de seguir comandos simples e engolir com segurança, o primeiro socorrista deve ligar para o serviço médico de emergência imediatamente, ligar também, após 10 a 15 minutos da administração de uma fonte de glicose, caso não ocorra melhora dos sintomas da hipoglicemia. ${ }^{1290,1291}$ Revisão feita pelo ILCOR em 2015 destacou fontes de glicose já conhecidas com produtos comerciais, como balas em quantidades equivalentes a $20 \mathrm{~g}$ de carboidratos no tratamento da hipoglicemia. Nos estudos, a melhora da hipoglicemia não ocorreu em um tempo menor de 10 minutos, e houve superioridade dos comprimidos de glicose em relação a outras fontes de glicose avaliadas. ${ }^{1290,1291}$

Se a vítima estiver alerta, o socorrista pode administrar glicose por via oral dando preferência para utilização de comprimidos de glicose, que demostraram aliviar os sintomas da hipoglicemia de forma mais rápida em comparação a outras várias fontes de glicose, como sacarose (açúcar comum/de mesa), alimentos contendo frutose, balas, entre outras. Na prática, os comprimidos de glicose não são uma realidade disponível, e outras fontes de glicose descritas anteriormente podem ser utilizadas. Se não houver certeza de que a vítima está em hipo ou hiperglicemia, um alimento açucarado deverá ser oferecido, pois isso aliviará rapidamente as baixas taxas glicêmicas, sendo improvável que venha a comprometer estados hiperglicêmicos (Quadro 19.10).

\subsection{Intoxicação Exógena - Envenenamento}

É importante compreender a natureza tóxica da substância química no ambiente e do equipamento adequado de proteção, assim como procedimentos de emergência, em caso de exposição a substâncias tóxicas. $\mathrm{Na}$ maioria das vezes, a intoxicação acontece por ingestão do material venenoso.

Segundo dados do Sistema Nacional de Informações Tóxico-Farmacológicas (Sinitox), foram notificados, em 2013, 42.128 casos de intoxicação humana por agente tóxico, sendo $22,57 \%$ dos casos em crianças com faixa etária de 1 a 4 anos. Os registros são realizados pela Rede Nacional de Centros de Informação e Assistência Toxicológica. ${ }^{1292-1294}$

A prevenção é o primeiro passo e é essencial no controle do envenenamento, especialmente em crianças.

A maioria dos Estados no Brasil possui um Centro de Controle de Intoxicações $(\mathrm{CCl})$. É importante informar ao atendente a natureza e o tempo da exposição, e onome do produto ou a substância tóxica, além de dados oferecidos na embalagem do produto. Todas as instruções fornecidas devem ser seguidas: ${ }^{1295}$

- O socorrista deve utilizar os equipamentos de proteção individual e não realizar ventilação boca a boca na presença de algumas toxinas, como cianeto, sulfeto de hidrogênio, corrosivos ou organofosforados. ${ }^{1295}$

- Exposição a produtos alcalinos e ácidos em ambos os olhos e sobre a pele tem apresentado melhoria quando lava-se a região com água abundante logo após a exposição. ${ }^{1295}$

- Atenção deve ser dada ao pó de cal virgem (óxido de cálcio), que reage com o suor da vítima e com água, produzindo queimaduras, pois, em contato com a água, este pó gera calor e seca excessivamente, de modo que as lesões apresentam-se como queimaduras horas depois do contato. Assim, em exposição à cal virgem e a qualquer pó tóxico, a vítima deve ser orientada a retirar o pó com um pano limpo e seco. ${ }^{1296}$

- Não existem estudos sobre o efeito do tratamento da exposição cáustica oral com a terapia de diluição em água ou leite, e também não foram encontradas evidências para sugerir que o carvão ativado é eficaz, quando usado como medida de primeiros socorros (embora o uso seja seguro).

- Os dados sobre experiência com carvão ativado na suspeita de envenenamento são limitados. É importante ressaltar que a maioria das crianças não ingere a dose recomendada de carvão ativado. ${ }^{1297}$

- No caso de inalação de um gás tóxico, a vítima deve ser removida da área, mas isso só deve ser feito mantendo a segurança do socorrista (Quadro 19.11). ${ }^{1295}$

\subsection{Abordagem à Vítima de Trauma}

A vítima traumatizada possui lesões que afetam mais de um sistema do organismo. Assim, o socorrista deve ser orientado a realizar avaliações dos sinais e sintomas de gravidade, acionar o serviço médico de emergência e realizar condutas simples e seguras que salvam vidas.

Mais de $90 \%$ dos traumatizados têm somente ferimentos simples, que envolvem apenas um sistema do organismo (por exemplo, fratura isolada de um membro). ${ }^{107}$ Para estas vítimas, o socorrista deve garantir a segurança da cena, permanecer no local e ativar o serviço médico de emergência. ${ }^{1298}$

Em vítimas com traumatismos graves, o socorrista deve assegurar a segurança da cena, ativar o serviço médico de emergência e realizar avaliação rápida das vias aéreas e circulação (controle de sangramento).

Quadro 19.10 - Recomendações para atendimento de primeiros socorros em casos de hipoglicemia

\begin{tabular}{|c|c|c|}
\hline Recomendações & Classe de Recomendação & Nível de Evidência \\
\hline $\begin{array}{l}\text { Se a vítima estiver alerta, o socorrista pode administrar glicose por via oral: } 20 \mathrm{~g} \text { de açúcar (duas colheres) em } \\
\text { meio copo d'água }\end{array}$ & I & C \\
\hline Se a vítima tornar-se sonolenta ou inconsciente, acionar serviço médico de emergência & I & C \\
\hline Se não houver melhora da vítima após 15 minutos, acionar o serviço médico de emergência & Ila & $\mathrm{B}$ \\
\hline
\end{tabular}


Quadro 19.11 - Recomendações para atendimento de primeiros socorros em caso de intoxicação exógena (envenenamento)

\begin{tabular}{lcc}
\hline Recomendações & Classe de Recomendação & Nível de Evidência \\
\hline $\begin{array}{l}\text { Equipamento de Proteção Individual (luvas, óculos etc.) deve ser usado pelo socorrista durante a remoção do } \\
\text { produto químico (toxina) }\end{array}$ & I & B \\
$\begin{array}{l}\text { Contato precoce com o Centro de Controle de Intoxicações e transporte da vítima para serviço médico de } \\
\text { emergência mais próximo }\end{array}$ & Ila & A \\
$\begin{array}{l}\text { Na exposição à cal virgem e a qualquer pó tóxico, retirar o pó com um pano limpo e seco } \\
\text { Não administrar carvão ativado para uma vítima que ingeriu uma substância tóxica, a menos que tenha sido } \\
\text { orientado pelo Centro de Controle de Intoxicações ou pelo serviço médico de emergência }\end{array}$ & Ilb & Blb \\
$\begin{array}{l}\text { Não realizar ventilação boca a boca na presença de toxinas como cianeto, sulfeto de hidrogênio, corrosivos ou } \\
\text { organofosforados }\end{array}$ & III \\
$\begin{array}{l}\text { Para as vítimas que ingeriram uma substância cáustica, a administração de uma diluição (leite ou água) por um } \\
\text { socorrista não é recomendada }\end{array}$ & IIII \\
\hline
\end{tabular}

\subsubsection{Avaliação das Vias Aéreas}

À medida que o socorrista aborda a vítima, ele pode ver se ela está respirando efetivamente ou com dificuldades, e se está acordada ou sem resposta.

Quando o socorrista pergunta à vítima "O que aconteceu?" e obtém uma explicação coerente, ele pode concluir que ela está com as vias aéreas liberadas, apresenta funções respiratórias suficientes que permitem a fala e função neurológica razoável, ou seja, não há risco de morte imediato. ${ }^{1296}$

Estas informações são de suma importância para o serviço médico de emergência e para a decisão quanto ao despacho das unidades de atendimento.

Se o socorrista se deparar com uma vítima que não reponde (ao avaliar sua responsividade) e não respira, ou respira anormalmente, deve acionar o serviço médico de emergência e imediatamente realizar as manobras de RCP, de acordo com a sessão de SBV no adulto desta diretriz.

\subsubsection{Imobilização da Coluna Cervical}

Traumatismo craniano leve e contusões são comuns em crianças, jovens e adultos. Perda de consciência é incomum na maioria dos ferimentos na cabeça e, se houver duração de mais de 30 segundos, isso pode indicar um traumatismo craniano. Embora a evidência seja questionável quanto à capacidade de um socorrista identificar uma lesão na coluna vertebral, ele deve ter um alto índice de suspeita, baseado na avaliação da cena e na descrição do evento (atropelamento, queda brusca, acidente automobilístico etc.), e tratar como se houvesse lesão na coluna vertebral. ${ }^{1299,1300}$

Os dados publicados indicam que uma pequena proporção de crianças com traumatismo craniano leve terá lesão intracraniana significativa. A presença de qualquer perda de consciência ou amnésia indica probabilidade de que uma lesão está presente em muitos - mas não em todos - os casos. Estudos evidenciam que aproximadamente 2\% dos adultos, vítimas de trauma contuso, avaliados no serviço de emergência, sofrem lesão na coluna; este risco é triplicado em pacientes com traumatismo craniofacial. ${ }^{1299,1300}$

Não existem relatos na literatura que demonstrem que os prestadores de primeiros socorros podem reconhecer uma lesão na coluna vertebral, nem mesmo usar corretamente dispositivos de imobilização da coluna cervical (colar cervical), ${ }^{1296}$ uma vez que a colocação de tal dispositivo exige treinamento extenso e prática, para ser executada corretamente, não sendo considerada primeiros socorros. ${ }^{1229}$

Assim, ao detectar uma emergência traumática que possa comprometer a coluna vertebral, a primeira providência deve ser a estabilização manual da coluna da vítima e aguardar o serviço médico de emergência. ${ }^{1229}$

\subsubsection{Controle de Sangramento}

O sangramento é causa mais comum de choque em vítimas traumatizadas. A abordagem do socorrista deve considerar todos os casos de choque como hemorrágicos, procurando primeiro por hemorragias visíveis, a fim de controlá-las (aplicação de curativo compressivo). Caso não existam evidências de hemorragia externa, deve-se suspeitar de hemorragias internas (pesquisar lesão no tórax, abdome e pelve). ${ }^{1298}$ Embora a hemorragia interna não seja tratada no ambiente pré-hospitalar, a identificação facilita o acionamento do serviço médico de emergência.

O sangramento na fase pré-hospitalar pode ser causado por lesões que resultem em danos "compressíveis" e/ ou hemorragia não compressível (hemorragia interna). O sangramento compressível, na fase pré-hospitalar, pode ser efetivamente tratado de forma direta, pela pressão manual, aumentando a pressão extraluminal e reduzindo a pressão transmural (interna versus externa).

A avaliação da coloração da pele, da temperatura e da umidade contribui para estimar a quantidade de sangue perdido. O material empregado na compressão não deve ser retirado do local, e, após o controle, deve ser providenciada uma bandagem elástica.

Ao comparar o uso da pressão direta no controle do sangramento com a pressão de pontos específicos, elevação do membro, aplicação local de gelo, torniquetes e uso de bandagens hemostáticas, concluiu-se que não há evidência para apoiar que o uso da pressão de pontos específicos ou elevação do membro da lesão controle o sangramento externo. $^{1229,1301,1302}$ 
O uso de torniquetes, das mais diversas formas, é outro método razoavelmente difundido e, muitas vezes, praticado por profissionais que não possuem a experiência necessária.

Os torniquetes podem ser efetivos para sangramentos externos severos dos membros. ${ }^{1303-1307}$

Potenciais complicações, incluindo síndrome compartimental, lesão do nervo, comprometimento dos vasos sanguíneos e amputação do membro, podem ocorrer relacionadas à pressão e à duração do uso. As evidências, até o momento, são insuficientes para determinar o tempo mínimo crítico para ocorrência de complicações irreversíveis. ${ }^{1229}$

A utilização do torniquete pelo primeiro socorrista, independente do tipo, seja pré-fabricado ou improvisado, exige treinamento. É indicada em situações de sangramentos severos, locais não seguros para permanecer até o controle do sangramento, acidente com múltiplas vítimas, entre outras.

$\mathrm{O}$ uso de agentes hemostáticas vem sendo feito com maior frequência onde existe a disponibilidade e, principalmente, nos ambientes militares. A nova geração dos agentes hemostáticos impregnado nas bandagens tem se mostrado melhor, e os efeitos adversos são incomuns, além do aumento do uso nos ambiente civis. ${ }^{1308,1309}$

A utilização de agentes hemostáticas exige treinamento. Seu uso pode ser considerado pelo primeiro socorrista quando a compressão direta do local de sangramento não for eficaz e não existir disponibilidade de um torniquete (Quadro 19.12 e Figura 19.5).

\subsection{Queimaduras}

Queimaduras são lesões que se originam por elevação da temperatura local, de qualquer área exposta do corpo, por uma variedade de agentes, como líquidos quentes e fogo, entre outros. Podem ter consequências drásticas ou não, a depender da área, da extensão e da gravidade da lesão. O cálculo da extensão do agravo é classificado de acordo com a idade. Nestes casos, normalmente utiliza-se a conhecida regra dos nove, criada por Wallace e Pulaski, que leva em conta a extensão atingida, a chamada Superfície Corporal Queimada (SCQ) (Figura 19.6). ${ }^{1310}$
As condições que classificam a queimadura como grave, necessitando de atendimento médico o quanto antes, são: ${ }^{1310}$ extensão/profundidade maior do que 20\% de SCQ em adultos; extensão/profundidade maior do que 10\% de SCQ em crianças; idade menor do que 3 anos ou maior do que 65 anos; presença de lesão inalatória; politrauma e doenças prévias associadas; queimadura química; trauma elétrico; áreas nobres/especiais; violência, maus-tratos, tentativa de autoextermínio (suicídio), entre outras.

A pele, ao ser lesionada, não faz seu papel de barreira efetivamente, sendo um risco para perda de líquido e para infecções, podendo existir risco de morte se a lesão for extensa.

No atendimento às queimaduras locais, o resfriamento da lesão deve ser feito com água em temperatura ambiente (15 a $25^{\circ} \mathrm{C}$ ) nos primeiros 30 minutos do contato com o agente causador da queimadura. Esse procedimento tem por objetivo minimizar a dor e a profundidade da queimadura. O uso de água muito gelada ou mesmo gelo está relacionado à piora da extensão e da profundidade da lesão. ${ }^{1311}$

Estudos demostraram que a utilização de água fria, mas não gelada, reduziu o risco de lesão maior e sua profundidade. O resfriamento deve ser realizado com cuidados em grandes áreas queimadas e em crianças, em relação ao risco de hipotermia. Este resfriamento com água fria, mas não gelada, deve ser realizado o mais breve possível e por, pelo menos, 10 minutos. Caso não exista disponibilidade de resfriamento por água fria, podem ser utilizadas compressas frias, mas não gelada, em subistituição. ${ }^{1312,1313}$

Se houver formação de bolhas na área da queimadura, certifique-se de que elas permaneçam intactas. Dessa forma, o processo de cicatrização ocorre mais rapidamente e há redução da dor. ${ }^{1314}$

Em caso de lesões extensas, mesmo que de primeiro grau, o recomendado é que se acione o serviço médico de emergência, já que existe grande risco de morte, e o resfriamento de uma grande área queimada não seria eficaz.

Em relação à cobertura da área queimada, estudos mostram resultados limitados em relação aos benefícios de utilizar uma

\section{Quadro 19.12 - Recomendações para primeiros socorros em situação de trauma}

\begin{tabular}{|c|c|c|}
\hline Recomendações & Classe de Recomendação & Nível de Evidência \\
\hline As vias aéreas devem ser rapidamente verificadas, para assegurar que estão pérvias e desobstruídas & 1 & A \\
\hline $\begin{array}{l}\text { A primeira providência do socorrista deve ser a estabilização manual da coluna do paciente, sendo que o colar } \\
\text { cervical deve ser utilizado somente por profissionais treinados }\end{array}$ & $\| l b$ & C \\
\hline Socorrista leigos não devem usar dispositivos de imobilização cervical & III & C \\
\hline $\begin{array}{l}\text { Controlar hemorragia externa por meio da aplicação de pressão direta sobre o local até a chegada do serviço } \\
\text { médico de emergência }\end{array}$ & 1 & A \\
\hline $\begin{array}{l}\text { Caso o socorrista seja treinado e não exista possibilidade de compressão direta do local de sangramento, } 0 \\
\text { torniquete pode ser considerado }\end{array}$ & $\mathrm{Ilb}$ & C \\
\hline Uso rotineiro e indiscriminado do torniquete para controle de sangramento & III & C \\
\hline Vítimas em choque devem ser transportadas em decúbito dorsal horizontal & \|la & B \\
\hline
\end{tabular}




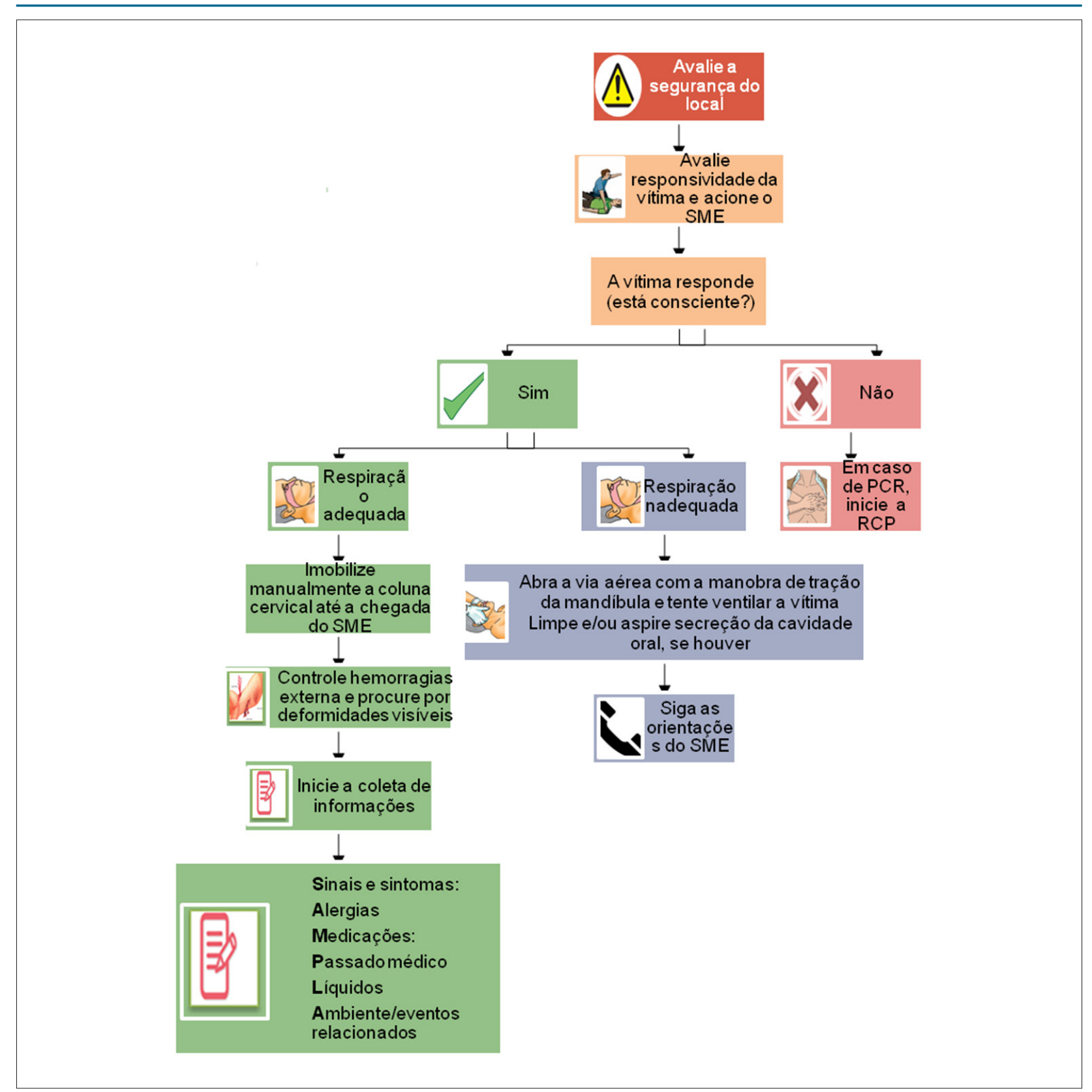

Figura 19.5 - Atendimento de primeiros socorros em situação de trauma. SME: serviço médico de emergência; PCR: parada cardiorrespiratória; RCP: ressuscitação cardiopulmonar.

cobertura seca ou molhada, sendo razoável que se utilize uma cobertura seca e estéril. ${ }^{1229}$

Uma revisão sistemática de quatro estudos de intervenção sobre o tratamento de queimaduras com Aloe Vera ${ }^{1315}$ e uma revisão sistemática de nove estudos sobre o mel para queimaduras ${ }^{1316}$ revelaram que esses produtos podem reduzir o tempo de cicatrização (Quadro 19.13).

\subsection{Acidentes por Animais Peçonhentos}

Os animais peçonhentos podem causar envenenamentos com efeitos locais e sistêmicos, que variam conforme o mecanismo de ação das toxinas presentes nos venenos de cada grupo. A rapidez e a precisão na intervenção terapêutica são fatores cruciais para evitar o óbito e reduzir danos. 


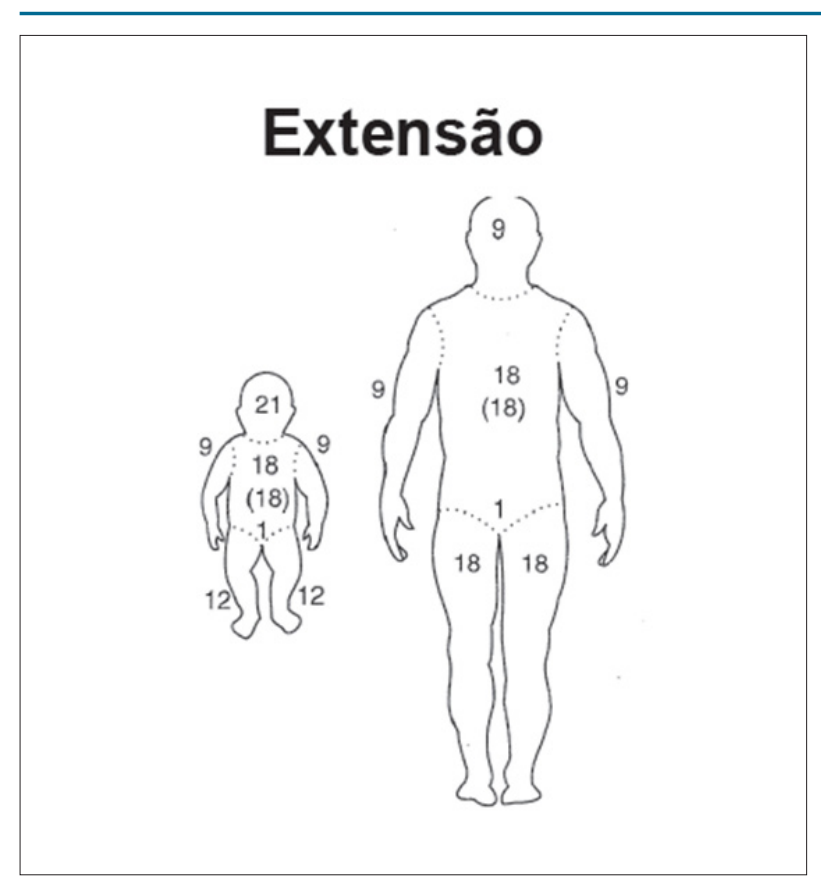

Figura 19.6 - Regra dos nove para adultos e bebês.

No Brasil, são considerados animais peçonhentos de importância médica que podem determinar diferentes tipos de envenenamento alguns tipos de serpentes, aranhas, insetos e escorpiões (Quadro 19.14). ${ }^{1317}$

Em 2014, foram notificados 171.238 acidentes por animais peçonhentos no país, cuja distribuição indica a predominância dos envenenamentos escorpiônicos e ofídicos.

\subsubsection{Acidentes Ofídicos ${ }^{1319}$}

São de importância médica no Brasil quatro gêneros de serpentes, responsáveis por 27.170 acidentes ofídicos notificados em 2014, com incidência de 13,3 casos/100 mil habitantes. Desse total, cerca de 71,4\% (Quadro 19.15) são causados por serpentes do gênero Bothrops. A letalidade geral dos acidentes ofídicos, para os casos tratados, tem-se mantido em menos de 0,5\% nos últimos anos.

Na maioria dos casos, o reconhecimento das manifestações clínicas (Quadro 19.16) e a história epidemiológica do acidente permitem o diagnóstico do tipo de envenenamento.
O diagnóstico por meio da identificação do animal é pouco frequente. A gravidade depende da quantidade de veneno inoculado, da região atingida e da espécie envolvida.

Nos acidentes botrópico e laquético, o quadro local costuma ser proeminente, enquanto nos acidentes crotálico e elapídico, prevalecem as manifestações neurológicas sistêmicas, decorrentes da paralisia muscular. A alteração na coagulação sanguínea predispõe a sangramentos espontâneos.

O tratamento com o antiveneno específico está indicado quando há evidências de envenenamento, sendo o número de ampolas proporcional à gravidade presumida ${ }^{1318}$ (Quadro 19.17). ${ }^{1319}$

No Brasil, os antivenenos são adquiridos pelo Ministério da Saúde e distribuídos por meio das Secretarias Estaduais de Saúde a hospitais credenciados em municípios estratégicos. Sempre que possível, após a avaliação inicial do paciente e da gravidade do envenenamento, encaminhar o paciente ao serviço de referência mais próximo, onde há o antiveneno.

No APH, recomenda-se: ${ }^{1320}$ lavar o local da picada, de preferência com água e sabão; na medida do possível, manter a vítima em repouso; se houver edema, manter o membro elevado; não realizar torniquete; não furar, cortar, queimar, espremer, realizar sucção local ou aplicar folhas, pó de café ou terra sobre a lesão, pois nenhum remédio caseiro substitui a aplicação do

\section{Quadro 19.14 - Animais peçonhentos, segundo grupo e tipo de} veneno ${ }^{1317,1318}$

\begin{tabular}{|c|c|c|}
\hline Grupo & & $\begin{array}{l}\text { Tipo de envenenamento } \\
\text { (nome popular do animal) }\end{array}$ \\
\hline \multirow{4}{*}{ Serpentes } & & Botrópico (jararaca) \\
\hline & & Laquético (pico-de-jaca) \\
\hline & & Crotálico (cascavel) \\
\hline & & Elapídico (coral verdadeira) \\
\hline \multirow[t]{2}{*}{ Escorpiões } & & Escorpiônico \\
\hline & & Loxoscelismo (aranha marrom) \\
\hline \multirow[t]{2}{*}{ Aranhas } & & Foneutrismo (aranha armadeira) \\
\hline & & Latrodectismo (aranha viúva-negra) \\
\hline \multirow[t]{2}{*}{ Insetos } & Lagartas & $\begin{array}{c}\text { Síndrome hemorrágica por Lonomia } \\
\text { Outras lagartas }\end{array}$ \\
\hline & Himenópteros & Picadas por abelhas e vespas \\
\hline
\end{tabular}

Quadro 19.13 - Recomendações para atendimento de primeiros socorros em queimaduras ${ }^{1315,1316}$

\begin{tabular}{|c|c|c|}
\hline Recomendações & Classe de Recomendação & Nível de Evidência \\
\hline Aplicação de água fria, não gelada, no local de lesão, por pelo menos 10 minutos & I & B \\
\hline $\begin{array}{l}\text { Em caso de formação de bolhas, elas devem permanecer intactas, para que não ocorra piora do processo de } \\
\text { cicatrização e a dor seja amenizada }\end{array}$ & Ila & B \\
\hline Aplicação de mel pode reduzir o tempo de cicatrização & $\| l b$ & C \\
\hline Aplicação de outras substâncias, como pastas, cremes e produtos medicinais, não são recomendados & III & C \\
\hline
\end{tabular}


Quadro 19.15 - Tipos de acidentes ofídicos, distribuição geográfica das serpentes e frequência dos acidentes ${ }^{1319}$

\begin{tabular}{lccc}
\hline Tipo de envenenamento & Gênero causador & Nomes populares & Distribuição geográfica \\
\hline Botrópico & Bothrops & $\begin{array}{c}\text { Jararaca, jararacuçu, urutu, } \\
\text { cruzeira, comboia } \\
\text { acidentes* }\end{array}$ & $\begin{array}{c}\text { Ampla distribuição em todo território, desde florestas a } \\
\text { áreas abertas }\end{array}$ \\
Laquético & Lachesis & Surucucu, pico-de-jaca & Floresta Amazônica e remanescentes de Mata Atlântica \\
Crotálico & Crotalus & Cascavel & Cerrado, regiões áridas e semiáridas, campos abertos \\
Elapídico & Micrurus & Coral verdadeira & Distribuição em todo o território nacional \\
\hline
\end{tabular}

* Excluindo os acidentes por serpentes não peçonhentas e ignoradas.

Quadro 19.16 - Quadro clínico de acordo com o tipo de envenamento

\begin{tabular}{|c|c|c|c|c|c|}
\hline Quadro clínico & & Acidente botrópico & Acidente laquético & Acidente crotálico & Acidente elapídico \\
\hline \multirow[t]{2}{*}{ Local } & & $\begin{array}{l}\text { Edema, dor, equimose e } \\
\text { bolha }\end{array}$ & $\begin{array}{c}\text { Edema, dor, equimose e } \\
\text { bolha }\end{array}$ & Edema e dor discretos & Parestesia \\
\hline & $\begin{array}{l}\text { Manifestações } \\
\text { hemorrágicas }\end{array}$ & $\begin{array}{l}\text { Equimose, gengivorragia, } \\
\text { hematúria, epistaxe, } \\
\text { hemorragia digestiva, } \\
\text { pulmonar, em sistema } \\
\text { nervoso central etc. }\end{array}$ & $\begin{array}{l}\text { Equimose, gengivorragia, } \\
\text { hematúria, epistaxe, } \\
\text { hemorragia digestiva etc. }\end{array}$ & $\begin{array}{c}\text { Podem ocorrer equimose e } \\
\text { gengivorragia }\end{array}$ & Ausente \\
\hline \multirow[t]{2}{*}{ Sistêmico } & $\begin{array}{l}\text { Manifestações } \\
\text { neurológicas }\end{array}$ & Ausente & Ausente & $\begin{array}{l}\text { Turvação visual, diplopia, } \\
\text { ptose palpebral, anisocoria, } \\
\text { diminuição da força muscular } \\
\text { e insuficiência respiratória }\end{array}$ & $\begin{array}{l}\text { Turvação visual, diplopia, } \\
\text { ptose palpebral, anisocoria, } \\
\text { diminuição da força muscular } \\
\text { e insuficiência respiratória }\end{array}$ \\
\hline & Outras & - & $\begin{array}{c}\text { Náuseas, vômitos, sudorese, } \\
\text { dor abdominal, diarreia e } \\
\text { hipotensão }\end{array}$ & $\begin{array}{l}\text { Mialgia e coluria decorrentes } \\
\text { de rabdomiolise }\end{array}$ & - \\
\hline \multirow[t]{2}{*}{ Complicação } & Local & $\begin{array}{l}\text { Infecção, necrose e síndrome } \\
\text { compartimental }\end{array}$ & $\begin{array}{l}\text { Infecção, necrose e síndrome } \\
\text { compartimental }\end{array}$ & Infecção é muito rara & Não descrita \\
\hline & Sistêmica & Insuficiência renal aguda & Insuficiência renal aguda & Insuficiência renal aguda & Atelectasia, broncoaspiração \\
\hline
\end{tabular}

soro antiofídico; retirar adornos e vestimentas apertadas do local lesionado; e acionar o serviço médico de emergência.

\subsubsection{Acidentes por Serpentes não Peçonhentas}

A maioria das mordidas causadas por serpentes consideradas não peçonhentas leva apenas a traumatismo local. Entretanto, acidentes causados por algumas serpentes, como Philodryas (cobra-verde e cobra-cipó), Clelia (muçurana e cobra-preta) e Thamnodynastes (cobra-espada), podem evoluir com manifestações locais, como edema, dor e equimose na região da picada, porém sem alterações sistêmicas. Para esses acidentes, não há indicação de terapia antiveneno.

\subsubsection{Acidente Escorpiônico}

Os escorpiões têm ampla distribuição no país. Nos últimos anos, os registros de acidentes têm apresentado aumento significativo. O gênero Tityus é considerado o principal causador de acidentes de importância em saúde e a espécie Tityus serrulatus (escorpião amarelo) está associada a casos graves em crianças.
O veneno escorpiônico ativa canais de sódio, promovendo despolarização das terminações nervosas sensitivas, motoras e do sistema nervoso autônomo, com liberação maciça de neurotransmissores adrenérgicos e colinérgicos. ${ }^{1321}$

A dor é a principal manifestação e ocorre imediatamente após. Sua intensidade é variável, sendo, às vezes, insuportável. As manifestações sistêmicas, quando ocorrem, são mais frequentes em crianças e surgem precocemente. A classificação da gravidade está exposta no quadro 19.18.

O tratamento, na maioria das vezes, é voltado para o controle da dor. Para os casos moderados e graves, o antiveneno está indicado, podendo ser utilizado o soro antiaracnídico (Loxosceles, Phoneutria e Tityus) ou o soro antiescorpiônico. No $\mathrm{APH}$, recomenda-se ${ }^{1321}$ realizar compressa morna; não colocar gelo no local da picada; não realizar torniquete; não furar, cortar, queimar, espremer, realizar sucção local ou aplicar folhas, pó de café ou terra sobre a lesão; acionar o serviço médico de emergência; se possível, levar o animal para identificação 


\section{Atualização}

Quadro 19.17 - Estadiamento de gravidade e doses de soro nos acidentes ofídicos ${ }^{1319}$

\begin{tabular}{|c|c|c|c|c|}
\hline Acidente & Gravidade & Manifestações clínicas & Tipo de soro & $\begin{array}{l}\text { Número de ampolas de } \\
\text { antiveneno }\end{array}$ \\
\hline \multirow{3}{*}{ Botrópico } & Leve & $\begin{array}{l}\text { Quadro local discreto, sangramento discreto em pele ou mucosas; } \\
\text { pode haver apenas distúrbio na coagulação }\end{array}$ & \multirow{3}{*}{ Antibotrópico (pentavalente) ${ }^{*}$} & $2-4$ \\
\hline & Moderado & $\begin{array}{l}\text { Edema e equimose evidentes, sangramento sem comprometimento } \\
\text { do estado geral; pode haver distúrbio na coagulação }\end{array}$ & & $4-8$ \\
\hline & Grave & $\begin{array}{c}\text { Alterações locais intensas, hemorragia grave, hipotensão/choque, } \\
\text { insuficiência renal e anúria }\end{array}$ & & 12 \\
\hline \multirow{2}{*}{ Laquético } & Moderado & $\begin{array}{l}\text { Quadro local presente; pode haver sangramento, sem } \\
\text { manifestações vagais }\end{array}$ & \multirow{2}{*}{$\begin{array}{l}\text { Antibotrópico (pentavalente) e } \\
\text { antilaquético }\end{array}$} & 10 \\
\hline & Grave & $\begin{array}{c}\text { Quadro local intenso, hemorragia intensa, com manifestações } \\
\text { vagais }\end{array}$ & & 20 \\
\hline \multirow{3}{*}{ Crotálico } & Leve & $\begin{array}{l}\text { Alterações neuroparalíticas discretas; sem mialgia, escurecimento } \\
\qquad \text { da urina ou oligúria }\end{array}$ & \multirow{3}{*}{ Anticrotálico† } & 5 \\
\hline & Moderado & $\begin{array}{c}\text { Alterações neuroparalíticas evidentes, mialgia e mioglobinúria } \\
\text { (urina escura) discretas }\end{array}$ & & 10 \\
\hline & Grave & $\begin{array}{l}\text { Alterações neuroparalíticas evidentes, mialgia e mioglobinúria } \\
\text { intensas, oligúria }\end{array}$ & & 20 \\
\hline Elapídico & \multicolumn{2}{|c|}{ Considerar todos os casos potencialmente graves, pelo risco de insuficiência respiratória } & Antielapídico & 10 \\
\hline
\end{tabular}

* Na ausência do soro antibotrópico, pode ser utilizado o soro antibotrópico-crotálico ou antibotrópico-laquético, nas mesmas doses preconizadas; †na ausência do soro anticrotálico, pode ser utilizado o soro antibotrópico-crotálico.

\subsubsection{Acidentes Causados por Aranhas}

As aranhas consideradas de importância médica no Brasil pertencem a três gêneros:

- Loxosceles: também chamada de "aranha marrom". Não é agressiva, é encontrada sob telhas, tijolos e cantos escuros. Os acidentes podem evoluir com necrose cutânea, com extensão e profundidade variáveis. Mais raramente, ocorrem hemólise intravascular e lesão renal aguda. ${ }^{1318}$

- Phoneutria: conhecida como "aranha armadeira", tem hábitos noturnos, sendo encontrada em cachos de banana e palmeiras; esconde-se dentro dos calçados. $\mathrm{O}$ acidente evolui semelhante ao escorpionismo. Há dor local imediata, edema e eritema. Mais raramente, há

Quadro 19.18 - Classificação da gravidade de acordo com as manifestações clínicas ${ }^{1321}$

\begin{tabular}{lcc}
\hline Classificação & Manifestações clínicas & $\begin{array}{c}\text { Número de ampolas } \\
\text { de antiveneno }\end{array}$ \\
\hline Leve & $\begin{array}{c}\text { Dor, eritema, sudorese e piloereção } \\
\text { Quadro local e uma ou mais } \\
\text { manifestações como náuseas, } \\
\text { vômitos, sudorese, sialorreia } \\
\text { discreta, agitação, taquipneia e } \\
\text { taquicardia }\end{array}$ & 2-3 \\
Além das manifestações acima, há \\
presença de vômitos, sudorese, \\
sialorreia intensa, prostração, \\
convulsão, coma bradicardia, \\
insuficiência cardíaca, edema agudo \\
de pulmão e choque
\end{tabular}

manifestações sistêmicas, mas aparecem precocemente e são mais comuns em crianças. O tratamento, é direcionado para o controle da dor. O antiveneno está indicado nas manifestações sistêmicas.

- Latrodectus: também chamada de "viúva-negra", raramente causa acidentes no Brasil. As manifestações locais são de dor, pápula, eritema e sudorese localizada. Raramente há manifestações sistêmicas. O tratamento é sintomático. ${ }^{1320}$

A classificação de gravidade no acidente por Loxosceles e Phoneutria orienta a terapia antiveneno (Quadro 19.19). ${ }^{1320}$

Para os acidentes causados por Phoneutria ("armadeira"), recomenda-se, para $\mathrm{APH},{ }^{1320}$ realizar compressas mornas; não colocar gelo local; não furar, cortar, queimar, espremer, realizar sucção local ou aplicar folhas, pó de café ou terra sobre a lesão; acionar o serviço médico de emergência; se possível, levar o animal para identificação. ${ }^{1317}$

\subsubsection{Acidente por Lagartas do Gênero Lonomia ${ }^{1312}$}

Várias famílias e gêneros de lagartas denominadas urticantes podem causar acidentes benignos, com repercussão limitada ao local de contato das cerdas com a pele. Apenas o gênero Lonomia é responsável por quadro sistêmico, que pode levar a complicações e a óbito, decorrente de sangramentos. ${ }^{1312}$ São acidentes particularmente importantes na Região Sul, com registros isolados na Amazônia e outras regiões, sendo registrados cerca de 400 casos anualmente. Os sinais e sintomas são dor em queimação, de início imediato, muitas vezes intensa e irradiada para o membro, eventualmente acompanhada por prurido; edema e eritema, muitas vezes com lesões puntiformes decorrentes da compressão das cerdas na pele; 
Quadro 19.19 - Estadiamento de gravidade e doses de soro nos acidentes por aranhas Phoneutria (foneutrismo) e Loxosceles (loxoscelismo)

\begin{tabular}{|c|c|c|c|}
\hline Acidente & Gravidade & Manifestações clínicas & $\begin{array}{l}\text { Número de ampolas de } \\
\quad \text { antiveneno }\end{array}$ \\
\hline \multirow{3}{*}{ Foneutrismo } & Leve & Dor local, edema, eritema, sudorese e piloereção & - \\
\hline & Moderado & Dor local intensa, sudorese, vômitos ocasionais, agitação psicomotora e hipertensão arterial & $2-4$ \\
\hline & Grave & Sudorese profusa, sialorreia, vômitos profusos, priapismo, choque e edema pulmonar agudo & $5-10$ \\
\hline \multirow{3}{*}{ loxoscelismo } & Leve & Aranha identificada, lesão incaracterística, ausência de comprometimento sistêmico & -- \\
\hline & Moderado & $\begin{array}{l}\text { Lesão sugestiva ou característica, manifestações sistêmicas inespecíficas (exantema, febre) e } \\
\text { ausência de hemólise }\end{array}$ & 5 \\
\hline & Grave & $\begin{array}{l}\text { Lesão característica, manifestações clínicas e/ou evidências laboratoriais de hemólise } \\
\text { intravascular }\end{array}$ & 10 \\
\hline
\end{tabular}

infartamento ganglionar regional; manifestações inespecíficas, como cefaleia, mal-estar, náuseas e dor abdominal, muitas vezes associada ou antecedendo sangramentos; manifestações hemorrágicas, como gengivorragia, equimoses de aparecimento espontâneo ou provocado por traumatismo/venopunção, epistaxe e em outros sítios, que podem determinar maior gravidade, como hematúria, hematêmese, hemoptise e hemorragia intracraniana.

O tratamento específico com o soro antilonômico (Salon) está indicado para pacientes que evoluem com alteração de coagulação, com ou sem sangramento espontâneo, nas doses de 5 ou 10 frascos-ampola, nos casos moderados e graves, respectivamente. $\mathrm{Em} \mathrm{APH}$, recomenda-se ${ }^{1320}$ lavar a região com água fria; realizar compressas frias; elevar o membro acometido; e, pela possibilidade de se tratar de acidente por Lonomiasp, todo paciente que não trouxer a lagarta para identificação deve ser orientado a retornar ao serviço de emergência, no caso de apresentar sangramentos. ${ }^{1320}$

\subsubsection{Acidente por Himenópteros ${ }^{1320}$}

Na ordem Himenóptera, estão incluídas abelhas, vespas e formigas, que têm no ferrão o aparelho inoculador de veneno.

Pode causar quadro alérgico, decorrente de poucas picadas, em pessoa previamente sensibilizada, com manifestações locais ou sistêmicas, ou quadro tóxico, devido à ataque por múltiplas abelhas ou vespas.

A reação tóxica sistêmica causada por múltiplas picadas de abelhas ou vespas inicia-se com uma intoxicação histamínica (sensação de prurido, rubor e calor generalizados, podendo surgir pápulas e placas urticariformes disseminadas), hipotensão, taquicardia, cefaleia, náuseas e/ou vômitos, cólicas abdominais e broncoespasmo. Convulsões e arritmias cardíacas são menos frequentes. Complicações como insuficiência respiratória aguda, insuficiência renal aguda, coagulação intravascular disseminada podem ocorrer.

O cuidado inicial consiste na retirada do ferrão imediatamente após o acidente e de forma cuidadosa, para não comprimir a glândula presente no aguilhão, além de realização de compressas frias locais. ${ }^{1320}$

Se a vítima tiver reação alérgica grave à reação tóxica ao veneno e estiver em posse de uma caneta injetora de epinefrina, o socorrista deve acionar o serviço médico de emergência e auxiliá-lo no manuseio deste dispositivo (Quadro 19.20). ${ }^{1321,1322}$

\section{Princípios Éticos e Legais da Ressuscitação Cardiopulmonar}

\subsection{A Ética da Ressuscitação e Decisões de Fim de Vida}

Uma avaliação sobre ética em conduta médica exige uma análise de seu significado. A palavra "ética" vem do grego ethos e significa aquilo que pertence ao "bom costume", ao "costume superior". Pressupõe, para isso, a consideração e o entendimento dos valores do local e tempo onde determinada conduta está sendo analisada. Está em curso uma mudança do enfoque da prática médica.

Quadro 19.20 - Recomendações para atendimento de primeiros socorros em acidentes por animais peçonhentos ${ }^{1321,1322}$

\begin{tabular}{|c|c|c|}
\hline Recomendações & Classe de Recomendação & Nível de Evidência \\
\hline Acionar o serviço médico de emergência em caso de acidentes por animais peçonhentos & I & A \\
\hline Em acidentes por picadas de abelhas, deve-se retirar o ferrão & I & A \\
\hline Se possível, levar o animal para identificação & I & A \\
\hline Acionar o serviço médico de emergência em caso de acidentes por animais peçonhentos & I & A \\
\hline Em acidentes por picadas de abelhas, deve-se retirar o ferrão & 1 & A \\
\hline Se possível, levar o animal para identificação & I & A \\
\hline
\end{tabular}


Diferentemente do modelo centrado no médico, dá-se preferência, atualmente, a um modelo centrado no paciente, trazendo-o para a discussão e tomada de decisões em saúde. Isso nos obriga a reavaliar nossos preceitos éticos e alterar ou reafirmar linhas de conduta. Esta diretriz irá abordar os princípios básicos e as perspectivas, bem como atualização de suas bases legais.

\subsection{Princípios Éticos}

Os pilares da ética médica constituem a base para fundamentar decisões de fim de vida e ressuscitação, são esses: a autonomia, beneficência, não maleficência e justiça. ${ }^{1323-1325}$

\subsubsection{Autonomia}

Representa a capacidade do indivíduo de governar a si próprio e fazer parte dos processos de decisões inerentes à sua saúde. Ganha importância em um cenário de condutas centradas no paciente. É um princípio universal na prática médica e que exige que o paciente esteja informado e apto a tomar decisões consistentes, baseado em suas crenças e valores. Para isso, é indispensável que o paciente seja munido de informações precisas e completas, sendo capaz de interpretar de forma realista seu cenário médico e as opções terapêuticas. ${ }^{1326,1327}$

\subsubsection{Não Maleficência}

Consiste na obrigação do médico de não causar dano ao paciente, em respeito ao axioma primum non nocere. O cenário da RCP exige do médico discernimento na aplicação de condutas salvadoras. Isso pode ser extremamente difícil no contexto da emergência, em que encontra-se geralmente munido de poucas informações.

\subsubsection{Beneficência}

Fundamentado nas ações que forneçam benefícios ao paciente após ponderar riscos. Sua aplicabilidade encontra-se na realização de RCP em situações em que se preveja melhora do prognóstico e da qualidade de vida. ${ }^{1328}$

\subsubsection{Justiça}

Implica em distribuir recursos limitados de uma sociedade igualmente entre os seus membros. No contexto da ressuscitação, significa realizar RCP em todos aqueles que possam se beneficiar dela, considerando os recursos disponíveis. A interrupção das medidas de RCP por limitação financeira não é razoável, mas é ponderado que se considere o custo total de determina medida, principalmente quando o benefício é duvidoso, há relevante chance de não maleficência ou dano. ${ }^{1326,1327}$

\subsection{Futilidade Médica}

É fundamental na tomada de decisão médica a ponderação do real benefício ou futilidade de uma ação. Entender seu conceito, então, é de crucial importância. Schneiderman et al. ${ }^{1329}$ definem uma ação fútil como aquela que não pode atingir os objetivos, não importando a frequência com que é repetida. A World Medical Association considera um tratamento fútil quando não oferece esperança razoável de cura ou melhora, ou ainda quando o paciente não é capaz de obter benefício, dada sua condição clínica. ${ }^{1327}$ Medidas de RCP podem ser consideradas fúteis, quando a chance de sobrevivência com boa qualidade de vida é mínima. ${ }^{1330}$

No entanto, algumas considerações são necessárias para sua compreensão. A definição de futilidade pode variar conforme os objetivos; por exemplo, uma ação pode ser fútil para a cura de uma doença, mas eficaz para realizar cuidados paliativos. Além disso, é necessário diferenciar futilidade de dano, que é uma ação cujas desvantagens superam os benefícios.

Alguns autores classificam a futilidade em fisiológica e normativa. Na futilidade fisiológica, o tratamento tem pouca chance de atingir um determinado objetivo, e seu estabelecimento envolve um julgamento médico que leva em conta o objetivo terapêutico proposto e a probabilidade de sucesso. Alguns sistemas de pontuação de risco, como o Pre-Arrest Morbidity e o Prognosis After Resuscitation, podem auxiliar nesta definição, mas seus limites mostram-se muitas vezes arbitrários para determinar com exatidão a linha que divide o sucesso improvável da futilidade. ${ }^{1331}$

$\mathrm{Na}$ futilidade normativa, as decisões levam em conta a qualidade de vida que o paciente teria se sobrevivesse a uma PCR. Assim, alguns fatores, por vezes subjetivos, tornam-se relevantes, de acordo com as preferências e crenças individuais. Dessa forma, uma ordem de não ressuscitar baseada na futilidade normativa não é uma decisão puramente médica. O entendimento de futilidade deve ser compartilhado com a equipe e amplamente esclarecido aos envolvidos, já que uma decisão de não iniciar ou de parar medidas de ressuscitação com base em futilidade não significa abandono. ${ }^{1332,1333}$

\subsection{Os Desfechos da Ressuscitação Cardiopulmonar}

A padronização de condutas e a educação em RCP são fundamentais para a otimização dos resultados, em termos de mortalidade e qualidade de vida. Evidências apontam que medidas de RCP implantadas efetivamente e precocemente podem aumentar a chance de sucesso em 50\%. Para isso, é preciso o interesse das instituições de saúde e de gestão pública na implementação de políticas nesse âmbito. ${ }^{1334,1335}$

A análise da efetividade torna-se mais complexa ao observarmos que uma pequena parte dos pacientes que retornam para circulação espontânea consegue chegar às unidades de terapia intensiva, sendo ainda menor o número dos que conseguem vir a ter alta hospitalar. ${ }^{1336,1337}$

\subsection{Aspectos Jurídicos}

Nas últimas décadas, tem-se observado enorme avanço da medicina e da biotecnologia e, como consequência, o homem tem sido visto mais como um objeto do que propriamente um ser. Hoje, é extremamente comum que pessoas com doenças em fase terminal e incuráveis sejam mantidas vivas graças a um enorme arsenal terapêutico e tecnológico, que apenas 
prolonga o processo de morte e deixa em segundo plano a dignidade do paciente.

Segundo a constituição de 1988, no Art. 1o, inciso III, a dignidade da pessoa humana é um dos fundamentos no nosso Estado. Assim, para os pacientes com doenças incuráveis, deve ser dado o direito de morrer com dignidade, evitandose as intervenções terapêuticas que lhes tragam mais dor e sofrimento, e que só prolonguem a morte. ${ }^{1338}$

É por meio da prática da ortotanásia, que significa morte correta, que o direito de morrer com dignidade fica salvaguardado. A fim de regulamentar a prática da ortotanásia no âmbito das atividades desenvolvidas pelos médicos, o Conselho Federal de Medicina (CFM) brasileiro editou a resolução 1.805/2006, a qual dispõe sobre o conceito que o CRM tem de ortotanásia e estabelece os procedimentos para que ela seja aplicada. Na referida resolução, lê-se: "na fase terminal de enfermidades graves e incuráveis é permitido ao médico limitar ou suspender procedimentos e tratamentos que prolonguem a vida do doente, garantindo-lhe os cuidados necessários para aliviar os sintomas que levam ao sofrimento, na perspectiva de uma assistência integral, respeitada a vontade do paciente ou de seu representante legal."

O médico tem a obrigação de esclarecer ao paciente ou a seu representante legal as modalidades terapêuticas adequadas para cada situação. A decisão referida deve ser fundamentada e registrada em prontuário. É assegurado, ao doente ou a seu representante legal, o direito de solicitar uma segunda opinião médica.

No Brasil, não há legislação específica acerca do direito à morte digna, a não ser a já referida resolução 1.805/2006 do CFM. Em outubro de 2007, a Justiça Federal suspendeu liminarmente os efeitos da resolução do CFM, sob a alegação de que a resolução não versa sobre o direito penal, mas sobre a ética médica e suas consequências. Após 3 anos, a Justiça Federal julgou improcedente a ação civil pública, e a resolução entrou novamente em vigor em dezembro de 2010.

$\mathrm{Na}$ medicina atual, tem-se valorizado cada vez mais o fortalecimento da relação médico-paciente e a participação ativa do doente, seus familiares e de toda a equipe multidisciplinar de saúde na tomada de decisões transparentes, inclusive aquelas relacionadas aos cuidados e à assistência ao paciente terminal.

\subsection{Diretrizes Avançadas}

Diretrizes avançadas são decisões previamente estabelecidas pelo paciente e a equipe, para nortear condutas a serem tomadas, caso ele esteja incapaz de opinar. A autonomia do paciente é respeitada, reduzindo as probabilidades de incorrer em dano ou futilidade. Ressalta-se que são condutas estabelecidas dentro de preceitos morais e legais, não podendo estar acima da constituição no país. Nos Estados Unidos, a constituição federal assegura aos cidadãos o direito de recusar um tratamento médico, incluindo a RCP. ${ }^{1339}$ No Brasil atualmente não dispomos de recurso legal desta plenitude.

\subsection{Situações Especiais}

\subsubsection{Suicídio}

Nesse contexto, vale a regra geral de iniciar prontamente as manobras de RCP e, em um segundo momento, fazer a avaliação completa, e o plano terapêutico clínico e psiquiátrico. $\mathrm{O}$ atendimento de uma PCR no contexto de uma tentativa de suicídio é passível de um dilema ético. Por um lado, valendo-se do princípio da autonomia, pode ser argumentado que uma tentativa de suicídio, por si só, é uma expressão de escolhas pessoais. Isso leva em conta que nem todo doente mental é incapaz de tomar decisões. Por outro lado, é claro que a saúde mental desses pacientes, bem como sua capacidade de escolha, dificilmente poderá ser avaliada com clareza em uma situação de emergência. ${ }^{1340,1341}$

\subsubsection{Ressuscitação Simbólica}

Por vezes, são iniciadas medidas de RCP de forma «simbólica», sem pressa e/ou omitindo condutas mais agressivas, dando à equipe médica e aos familiares a ideia de ter "feito algo", e evitando potencial conflito. Isto é especialmente comum quando não há forte relação médicopaciente, e quando há uma clara falta de informação. Esta "ressuscitação simbólica" é igualmente enganosa e paternalista, e prejudica tanto a relação médico-paciente quanto a formação e a educação das equipes. ${ }^{1342}$

Uma alternativa valiosa pode ser um "código sob medida", onde RCP de alta qualidade pode ser realizada, mas com limites claros e pré-definidos. Neste cenário de transparência, o paciente, os familiares e a equipe estabelecem os benefícios de condutas futuras. ${ }^{1343,1344}$ 


\section{Referências}

1. Gonzalez MM, Timerman S, Gianotto-Oliveira R, Polastri TF, Canesin MF, Schimidt A, et al. Sociedade Brasileira de Cardiologia. I Diretriz de Ressuscitacão Cardiopulmonar e Cuidados Cardiovasculares de Emergência da Sociedade Brasileira de Cardiologia. Arq Bras Cardiol. 2013;101(2 Supl 3):1-221.

2. Monsieurs KG, Nolan JP, Bossaert LL, Greif R, Maconochie IK, Nikolaou NI, et al. European Resuscitation Council Guidelines for Resuscitation 2015: Section 1. Executive summary. Resuscitation. 2015 Oct; 95:1-80.

3. Neumar RW, Shuster M, Callaway CW, Gent LM, Atkins DL, Bhanji F, et al. Part 1: executive summary: 2015 American Heart Association Guidelines Update for Cardiopulmonary Resuscitation and Emergency Cardiovascular Care. Circulation. 2015;132(18 Suppl 2):S315-367.

4. Zipes DP, Libby P, Bonow OR, Mann DL, Tomaselli GF. Braunwald's heart disease: a textbook of cardiovascular medicine. 9th ed. Rio de Janeiro: Saunders/ Elsevier;2011.

5. World Health Organization.(WHO). The top 10 causes of death: The 10 leading causes of death in the world, 2000 and 2012. [Cited in 2016 June 10].Available from: http://www.who.int/mediacentre/factsheets/fs310/ enAvailable

6. Brasil. Ministério da Saude. Departamento de Informática do SUS Datasus. [on-line]. Brasília (DF). Disponível em: [Citado em 2016 jun 10] Disponível em : http://www2.datasus.gov.br

7. Chan PS, McNally B, Tang F, Kellermann A. CARES Surveillance Group. Recent trends in survival from out-of-hospital cardiac arrest in the United States. Circulation. 2014; 130(21):1876-82.

8. Lai H, Choong CV, Fook-Chong S, Ng YY, Finkelstein EA, Haaland B, et al. PAROS study group. Interventional strategies associated with improvements in survival for out-of-hospital cardiac arrests in Singapore over 10 years. Resuscitation. 2015 Apr;89:155-61.

9. Cobb LA, Fahrenbruch CE, Olsufka M, Copass MK. Changing incidence of out-of-hospital ventricular fibrillation, 1980-2000. JAMA. 2002 288(23):3008-13.

10. Agarwal DA, Hess EP, Atkinson EJ, White RD. Ventricular fibrillation in Rochester, Minnesota: experience over 18 years. Resuscitation. 2009;80(11):1253-8.

11. Rea TD, Olsufka M, Bemis B, White L, Yin L, Becker L, et al. A populationbased investigation of public access defibrillation: role of emergency medical services care. Resuscitation. 2010;81(2):163-7.

12. Gianotto-Oliveira R, Gonzalez MM, Vianna CB, Monteiro Alves M, Timerman S, Kalil Filho R, et al. Survival after ventricular fibrillation cardiac arrest in the Sao Paulo metropolitan subway system: first successfu targeted automated external defibrillator (AED) program in Latin America. J Am Heart Assoc. 2015;4(10):e002185.

13. Gianotto-Oliveira R, Gonzalez MM, Vianna CB, Monteiro Alves M, Timerman S, Kalil Filho R, et al. Part 5: adult basic life support and cardiopulmonary resuscitation quality: 2015 American Heart Association Guidelines Update for Cardiopulmonary Resuscitation and Emergency Cardiovascular Care. Circulation. 2015;132(18 Suppl 2):S414-35.

14. Meaney PA, Bobrow BJ, Mancini ME, Christenson J, de Caen AR, Bhanji F, et al. CPR Quality Summit Investigators. the American Heart Association Emergency Cardiovascular Care Committee. and the Council on Cardiopulmonary. Critical Care. Perioperative and Resuscitation. Cardiopulmonary resuscitation quality: [corrected] improving cardiac resuscitation outcomes both inside and outside the hospital: a consensus statement from the American Heart Association. Circulation.2013;128(4):417-35.

15. Idris AH, Guffey D, Pepe PE, Brown SP, Brooks SC, Callaway CW, et al. Resuscitation Outcomes Consortium Investigators. Chest compression rates and survival following out-of-hospital cardiac arrest. Crit Care Med. 2015;43(4):840-8.
16. Idris AH, Guffey D, Aufderheide TP, Brown S, Morrison LJ, Nichols P, et al. Resuscitation Outcomes Consortium (ROC) Investigators. Relationship between chest compression rates and outcomes from cardiac arrest. Circulation. 2012;125(24):3004-12

17. Vadeboncoeur T, Stolz U, Panchal A, Silver A, Venuti M, Tobin J, et al. Resuscitation. 2014;85(2):182-8.

18. Bohn A, Weber TP, Wecker S, Harding U, Osada N, Van Aken H, et al. The addition of voice prompts to audiovisual feedback and debriefing does not modify CPR quality or outcomes in out of hospital cardiac arrest-a prospective, randomized trial. Resuscitation. 2011;82(3):257-62.

19. Zuercher M, Hilwig RW, Ranger-Moore J, Nysaether J, Nadkarni VM, Berg $M D$, et al. Leaning during chest compressions impairs cardiac output and left ventricular myocardial blood flow in piglet cardiac arrest. Crit Care Med. 2010;38(4):1141-6.

20. Glatz AC, Nishisaki A, Niles DE, Hanna BD, Eilevstjonn J, Diaz LK, et al. Sternal wall pressure comparable to leaning during CPR impacts intrathoracic pressure and haemodynamics in anaesthetized children during cardiac catheterization. Resuscitation. 2013;84(12):1674-9.

21. Cheskes S, Schmicker RH, Christenson J, Salcido DD, Rea T, Powell J, et al. Resuscitation Outcomes Consortium (ROC) Investigators. Perishock pause: an independent predictor of survival from out-of-hospital shockable cardiac arrest. Circulation. 2011;124(1):58-66.

22. Beesems SG, Wijmans L, Tijssen JG, Koster RW. Duration of ventilations during cardiopulmonary resuscitation by lay rescuers and first responders: relationship between delivering chest compressions and outcomes. Circulation. 2013;127(15):1585-90.

23. Sugerman NT, Edelson DP, Leary M, Weidman EK, Herzberg DL, Vanden Hoek TL, et al. Rescuer fatigue during actual in-hospital cardiopulmonary resuscitation with audiovisual feedback: a prospective multicenter study. Resuscitation. 2009;80(9):981-4.

24. Manders S, Geijsel FE. Alternating providers during continuous chest compressions for cardiac arrest: every minute or every two minutes? Resuscitation. 2009;80(9):1015-8.

25. Bohm K, Rosenqvist M, Herlitz J, Hollenberg J, Svensson L. Survival is similar after standard treatment and chest compression only in outof-hospital bystander cardiopulmonary resuscitation. Circulation. 2007;116(25):2908-12.

26. Sayre MR, Berg RA, Cave DM, Page RL, Potts J, White RD. American Heart Association Emergency Cardiovascular Care Committee. Handsonly (compression-only) cardiopulmonary resuscitation: a call to action for bystander response to adults who experience out-of-hospital sudden cardiac arrest: a science advisory for the public from the American Heart Association Emergency Cardiovascular Care Committee. Circulation. 2008;117(16):2162-7.

27. Hupfl M, Selig HF, Nagele P. Chest-compression-only versus standard cardiopulmonary resuscitation: a meta-analysis. Lancet. 2010;376(9752):1552-7.

28. da Fonseca AH, da Fonseca FI, Oliveira RG, Barral TN, Gonzalez MM, Timerman S. Avaliação da frequência e profundidade das compressões torácicas realizadas com o uso de metrônomo. Rev Bras Clin Med. 2012;10(3):175-8.

29. Niles D, Nysaether J, Sutton R, Nishisaki A, Abella BS, Arbogast K, et al. Leaning is commonduring in-hospital pediatric CPR, and decreased with automated corrective feedback. Resuscitation. 2009;80(5):553-7.

30. Semeraro F, Taggi F, Tammaro G, Imbriaco G, Marchetti L, Cerchiari EL. ICPR: a new application of high-quality cardiopulmonary resuscitation training. Resuscitation 2011;82(4):436-41.

31. Gianotto-Oliveira R, Andrade FP, Toledo AP, Gonzales MM, Timerman S. Continuous cardiopulmonary resuscitation training compared to single training by laypersons. Signa Vitae.2015; 10(2):149-62 . 
32. Bobrow BJ, Vadeboncoeur TF, Spaite DW, Potts J, Denninghoff K, Chikani V, et al The effectiveness of ultrabrief and brief educational videos for training lay responders in hands-only cardiopulmonary resuscitation: implications for the future of citizen cardiopulmonary resuscitation training. Circ Cardiovasc Qual Outcomes 2011;4(2):220-6.

33. Deakin CD, O'Neill JF, Tabor T. Does compression-only cardiopulmonary resuscitation generate adequate passive ventilationduring cardiac arrest? Resuscitation. 2007;75(1):53-9.

34. Rhee P, Kuncir EJ, Johnson L, Brown C, Velmahos G, Martin M, et al. Cervical spine injury is highly dependent on the mechanism of injury following blunt and penetrating assault. J Trauma. 2006;61(5):1166-70.

35. Holly LT, Kelly DF, Counelis GJ, Blinman T, McArthur DL, Cryer HG. Cervical spine trauma associated with moderate and severe head injury: incidence, risk factors, and injury characteristics. J Neurosurg. 2002;96(3 Suppl):285-91 .

36. Berg RA, Hemphill R, Abella BS, Aufderheide TP, Cave DM, Hazinski MF, et al. Part 5: Adult basic life support: 2010 American Heart Association Guidelines for Cardiopulmonary Resuscitation and Emergency Cardiovascular Care. Circulation. 2010;122(18 Suppl 3):S685-705.

37. Hastings $\mathrm{RH}$, Wood PR. Head extension and laryngeal view during laryngoscopy with cervical spine stabilization maneuvers. Anesthesiology. 1994;80(4):825-31.

38. Gerling MC, Davis DP, Hamilton RS, Morris GF, Vilke GM, Garfin SR, et al. Effects of cervical spine immobilization technique and laryngoscope blade selection on an unstable cervical spine in a cadáver model of intubation. Ann Emerg Med. 2000;36(4):293-300.

39. Baskett P, Nolan J, Parr M. Tidal volumes which are perceived to be adequate for resuscitation. Resuscitation. 1996;31(3):231-4.

40. Heidenreich JW, Higdon TA, Kern KB, Sanders AB, Berg RA, Niebler R, et al.Single-rescuer cardiopulmonary resuscitation: 'two quick breaths'--an oxymoron. Resuscitation. 2004;62(3):283-9.

41. Kobayashi M, Fujiwara A, Morita H, Nishimoto Y, Mishima T, Nitta M, et al. A manikin-based observational study on cardiopulmonary resuscitation skills at the Osaka Senri medical rally. Resuscitation. 2008;78(3):333-9.

42. Berg MD, Idris AH, Berg RA. Severe ventilatory compromise due to gastric distention during pediatric cardiopulmonary resuscitation. Resuscitation. 1998;36(1):71-3.

43. Aufderheide TP, Sigurdsson G, Pirrallo RG, Yannopoulos D, McKnite S, von Briesen C, et al. Hyperventilation-induced hypotension during cardiopulmonary resuscitation. Circulation. 2004;109(16):1960-5.

44. Kitamura T, Iwami T, Kawamura T, Nagao K, Tanaka H, Hiraide A Implementation Working Group for All-Japan Utstein Registry of the Fire and Disaster Management Agency. Bystander-initiated rescue breathing for out-of-hospital cardiac arrests of noncardiac origin. Circulation. 2010;122(3):293-9.

45. Kitamura T, Iwami T, Kawamura T, Nagao K, Tanaka H, Berg RA, et al . Implementation Working Group for All-Japan Utstein Registry of the Fire and Disaster Management Agency. Time-dependent effectiveness of chest compression-only and conventional cardiopulmonary resuscitation for out-of-hospital cardiac arrest of cardiac origin. Resuscitation. 2011;82(1):3-9

46. Ornato JP, Hallagan LF, McMahan SB, Peeples EH, Rostafinski AG. Attitudes of BCLS instructors about mouth-to-mouth resuscitation during the AIDS epidemic. Ann Emerg Med. 1990(2);19:151-6.

47. Hew P, Brenner B, Kaufman J. Reluctance of paramedics and emergency medical technicians to perform mouth-to-mouth resuscitation. J Emerg Med. 1997;15(3):279-84.

48. Larsen MP, Eisenberg MS, Cummins RO, Hallstrom AP. Predicting survival from out-of-hospital cardiac arrest: a graphic model. Ann Emerg Med. 1993;22(11):1652-8.
49. Valenzuela TD, Roe DJ, Cretin S, Spaite DW, Larsen MP. Estimating effectiveness of cardiac arrest interventions: a logistic regression survival model. Circulation. 1997;96(10):3308-13.

50. Iwami T, Kawamura T, Hiraide A, Berg RA, Hayashi Y,Nishiuchi T, et al Effectiveness of bystander-initiated cardiac-only resuscitation for patients with out-of-hospital cardiac arrest. Circulation. 2007;116(25):2900-7.

51. Estner HL, Günzel C, Ndrepepa G, William F, Blaumeiser D, Rupprecht B, et al. Outcome after out-of-hospital cardiac arrest in a physician-staffed emergency medical system according to the Utstein style. Am Heart J. 2007;153(5):792-9.

52. Berger RD, Palazzolo J, Halperin H. Rhythm discrimination during uninterrupted CPR using motion artifact reduction system. Resuscitation 2007;75(1):145-52.

53. Neumar RW, Shuster M, Callaway CW, Gent LM, Atkins DL, Bhanji F, et al Part 1: Executive Summary: 2015 American Heart Association Guidelines Update for Cardiopulmonary Resuscitation and Emergency Cardiovascular Care. Circulation. 2015; 132(18 Suppl 2):S315-67.

54. White RD, Vukov LF, Bugliosi TF. Early defibrillation by police: initia experience with measurement of critical time intervals and patient outcome. Ann Emerg Med. 1994;23(5):1009-13.

55. Davis EA, Jr Mosesso VN. Performance of police first responders in utilizing automated external defibrillation on victims of sudden cardiac arrest. Prehosp Emerg Care. 1998;2(2):101-7.

56. Bissing JW, Kerber RE. Effect of shaving the chest of hirsute subjects on transthoracic impedance to self-adhesive defibrillation electrode pads. Am J Cardiol. 2000;86(5):587-9.

57. Sado DM, Deakin CD, Petley GW, Clewlow F. Comparison of the effects of removal of chest hair with not doing so before external defibrillation on transthoracic impedance. Am J Cardiol. 2004;93(1):98-100.

58. Timerman S. Suporte basico de vida e desfibrilação externa. Barueri: Manole; 2007.

59. Monsieurs KG, Conraads VM, Goethals MP, Snoeck JP, Bossaert LL. Semiautomatic external defibrillation and implanted cardiac pacemakers: understanding the interactions during resuscitation. Resuscitation. 1995;30(2):127-31

60. Alferness CA. Pacemaker damage due to external counter shock in patients with implanted cardiac pacemakers. Pacing Clin Electrophysiol. 1982;5(3):457-8

61. Panacek EA, Munger MA, Rutherford WF, Gardner SF. Report of nitropatch explosions complicating defibrillation. Am J Emerg Med. 1992;10(2):128-9.

62. Atkins DL, Jorgenson DB. Attenuated pediatric electrode pads for automated external defibrillator use in children. Resuscitation. 2005;66(1):31-7.

63. Jorgenson D, Morgan C, Snyder D, Griesser H, Solosko T, Chan K, et al. Energy attenuator for pediatric application of an automated external defibrillator. Crit Care Med. 2002;30(4 Suppl):S145-7.

64. Bar-Cohen Y, Walsh EP, Love BA, Cecchin F. First appropriate use of automated external defibrillator in an infant. Resuscitation. 2005;67(1):135-7.

65. Konig B, Benger J, Goldsworthy L. Automatic external defibrillation in a 6 year old. Arch Dis Child. 2005;90(3):310-1.

66. Travers AH, Rea TD, Bobrow BJ, Edelson DP, Berg RA, Sayre MR, et al Part 4: CPR overview: 2010 American Heart Association Guidelines for Cardiopulmonary Resuscitation and Emergency Cardiovascular Care. Circulation. 2010;122(18 Suppl 3):S676-84.

67. Marsch S, Tschan F, Semmer NK, Zobrist R, Hunziker PR, Hunziker S. ABC versus $C A B$ for cardiopulmonary resuscitation: a prospective, randomized simulator- based trial. Swiss Med Wkly. 2013 Sep;143:w13856. 
68. Lubrano R, Cecchetti C, Bellelli E, Gentile I, Loayza Levano H, Orsini F, et al. Comparison of times of intervention during pediatric CPR maneuvers using $\mathrm{ABC}$ and $\mathrm{CAB}$ sequences: a randomized trial. Resuscitation 2012;83(12):1473-7.

69. Kleinman ME, Brennan EE, Goldberger ZD, Swor RA, Terry M, Bobrow BJ, et al. Part 5: adult basic life support and cardiopulmonary resuscitation quality: 2015 American Heart Association Guidelines Update for Cardiopulmonary Resuscitation and Emergency Cardiovascular Care. Circulation. 2015;132(18 Suppl 2):S414-35.

70. Perkins GD, Handley AJ, Koster RW, Castrén M, Smyth MA, Olasveengen T, et al. European Resuscitation Council Guidelines for Resuscitation 2015: Section 2. Adult basic life support and automated external de?brillation. Resuscitation. 2015 Oct;95:81-99.

71. Clawson J, Olola C, Scott G, Heward A, Patterson B. Effect of a Medical Priority Dispatch System key question addition in the seizure/convulsion/ fitting protocol to improve recognition of ineffective (agonal) breathing. Resuscitation. 2008;79(2):257-64

72. Bahr J, Klingler H, Panzer W, Rode H, Kettler D. Skills of lay people in checking the carotid pulse. Resuscitation. 1997;35(1):23-6.

73. Tibballs J, Russell P. Reliability of pulse palpation by healthcare personnel to diagnose paediatric cardiac arrest. Resuscitation. 2009;80(1):61-4.

74. Mather C, O'Kelly S. The palpation of pulses. Anaesthesia. 1996;51(2):189-91.

75. Ochoa FJ, Ramalle-Gomara E, Carpintero JM, Garcia A, Saralegui I. Competence of health professionals to check the carotid pulse. Resuscitation. 1998;37(3):173-5.

76. Chamberlain D, Smith A, Colquhoun M, Handley AJ, Kern KB, Woollard M, et al. Randomised controlled trials of staged teaching for basic life support: 2. Comparison of CPRperformance and skill retention using either staged instruction or conventional training. Resuscitation. 2001;50(1):27-37.

77. Hostler D, Guimond G, Callaway C. A comparison of CPR delivery with various compression-to-ventilation ratios during two-rescuer CPR. Resuscitation. 2005;65(3):325-8.

78. Mosier J, Itty A, Sanders A, Mohler J, Wendel C, Poulsen J, et al.Cardiocerebral resuscitation is associated with improved survival and neurologic outcome from out-of-hospital cardiac arrest in elders. Acad Emerg Med. 2010;17(3):269-75.

79. Kellum MJ, Kennedy KW, Ewy GA. Cardiocerebral resuscitation improves survival of patients with out-of-hospital cardiac arrest. Am J Med. 2006;119(4):335-40.

80. Akahane M, Ogawa T, Tanabe S, Koike S, Horiguchi H, Yasunaga $\mathrm{H}$, et al. Impact of telephone dispatcher assistance on the outcomes of pediatric out-of-hospital cardiac arrest. Crit Care Med. 2012;40(5):1410-6.

81. Vaillancourt C, Charette M, Kasaboski A, Hoad M, Larocque V, Crête D, et al. Cardiac arrest diagnostic accuracy of 9-1-1 dispatchers: a prospective multi-center study. Resuscitation 2015 May;90:116-20.

82. Plodr M, Truhlar A, Krencikova J, Praunova M, Svaba V, Masek J, et al. Effect of introduction of a standardized protocol in dispatcher-assisted cardiopulmonary resuscitation. Resuscitation. 2016 Sep;106:18-23.

83. Sayre MR, Berg RA, Cave DM, Page RL, Potts J, White RD. American Heart Association Emergency Cardiovascular Care Committee. Handsonly (compression-only) cardiopulmonary resuscitation: a call to action for bystander response to adults who experience out-of-hospital sudden cardiac arrest: a science advisory for the public from the American Heart Association Emergency Cardiovascular Care Committee. Circulation. 2008;117(16):2162-7.

84. White L, Rogers J, Bloomingdale M, Fahrenbruch C, Culley L, Subido C, et al. Dispatcher-assisted cardiopulmonary resuscitation: risks for patients not in cardiac arrest. Circulation. 2010;121(1):91-7.

85. Kitamura T, Iwami T, Kawamura T, Nagao K, Tanaka H, Berg RA, et al. Implementation Working Group for All-Japan Utstein Registry of the Fire and Disaster Management Agency. Time-dependent effectiveness of chest compression-only and conventional cardiopulmonary resuscitation for out-of-hospital cardiac arrest of cardiac origin. Resuscitation. 2011;82(1):3-9.

86. Neumar RW, Shuster M, Callaway CW, Gent LM, Atkins DL, Bhanji F, et al. Part 1: executive summary: 2015 american heart association guidelines update for cardiopulmonary resuscitation and emergency cardiovascular care. Circulation 2015;132(18 Suppl 2): S315-67.

87. Forcina MS, Farhat AY, O'Neil WW, Haines DE. Cardiac arrest survival after implementation of automated external defibrillator technology in the in-hospital setting. Critical care medicine 2009;37(4):1229-36.

88. Stults KR, Brown DD, Kerber RE. Efficacy of an automated external defibrillator in the management of out-of-hospital cardiac arrest: validation of the diagnostic algorithm and initial clinical experience in a rural environment. Circulation 1986;73(4):701-9.

89. Jost D, Degrange H, Verret C, Hersan O, Banville IL, Chapman FW, et al. DEFI 2005 Work Group. DEFI 2005: a randomized controlled trial of the effect of automated external defibrillator cardiopulmonary resuscitation protocol on outcome from out-of-hospital cardiac arrest. Circulation 2010;121(14):1614-22.

90. CarpenterJ, Rea TD, MurrayJA, Kudenchuk PJ, Eisenberg MS. Defibrillation waveform and post-shock rhythm in out-of-hospital ventricular fibrillation cardiac arrest. Resuscitation 2003;59(2): 189-96.

91. Freeman K, Hendey GW, Shalit M, Stroh G. Biphasic defibrillation does not improve outcomes compared to monophasic defibrillation in out-ofhospital cardiac arrest. Prehosp Emergency Care 2008;12(2):152-6

92. Hess EP, Atkinson EJ, White RD. Increased prevalence of sustained return of spontaneous circulation following transition to biphasic waveform defibrillation. Resuscitation 2008;77(1):39-45.

93. Glover BM, Walsh SJ, McCann CJ, Moore MJ, Manoharan G, Dalzell GW, et al. Biphasic energy selection for transthoracic cardioversion of atrial fibrillation. The BEST AF Trial. Heart. 2008;94(7):884-7.

94. Page RL, Kerber RE, Russell JK, Trouton T, Waktare J, Gallik D, et al. BiCard Investigators. Biphasic versus monophasic shock waveform for conversion of atrial fibrillation: the results of an international randomized, doubleblind multicenter trial. J Am Coll Cardiol 2002;39(12):1956-63.

95. Reisinger J, Gstrein C, Winter T, Zeindlhofer E, Höllinger K, Mori M, et al. Optimization of initial energy for cardioversion of atrial tachyarrhythmias with biphasic shocks. Am J Emerg Med .2010;28(2):159-65.

96. Hess EP, Agarwal D, Myers LA, Atkinson EJ, White RD. Performance of a rectilinear biphasic waveform in defibrillation of presenting and recurrent ventricular fibrillation: a prospective multicenter study. Resuscitation . 2011;82(6):685-9.

97. Faddy SC, Jennings PA. Biphasic versus monophasic waveforms for transthoracic defibrillation in out-of-hospital cardiac arrest. The Cochrane Database of Syst Rev. 2016 Feb;2:Cd006762.

98. Deakin CD, McLaren RM, Petley GW, Clewlow F, Dalrymple-Hay MJ. A comparison of transthoracic impedance using standard defibrillation paddles and self-adhesive defibrillation pads. Resuscitation. 1998;39(12):43-6.

99. Dodd TE, Deakin CD, Petley GW, Clewlow F. External defibrillation in the left lateral position--a comparison of manual paddles with self-adhesive pads. Resuscitation. 2004;63(3):283-6.

100. Wilson RF, Sirna S, White CW, Kerber RE. Defibrillation of high-risk patients during coronary angiography using self-adhesive, preapplied electrode pads. J Am Coll Cardiol. 1987;60(4):380-2.

101. Vogiatzis IA, Sachpekidis V, Vogiatzis IM, Kambitsi E, Karamitsos T, Samanidis D, et al. External cardioversion of atrial fibrillation: the role of electrode position on cardioversion success. Int J Cardiol. 2009;137(1):e8-10.

102. Caterine MR, Yoerger DM, Spencer KT, Miller SG, Kerber RE. Effect of electrode position and gel-application technique on predicted 
transcardiac current during transthoracic defibrillation. Ann Emerg Med $.1997 ; 29(5): 588-95$

103. Kirchhof P, Eckardt L, Loh P, Weber K, Fischer RJ, Seidl KH, et al. Anterior-posterior versus anterior-lateral electrode positions for external cardioversion of atrial fibrillation: a randomised trial. Lancet. 2002;360(9342):1275-9.

104. Krasteva V, Matveev M, Mudrov N, Prokopova R. Transthoracic impedance study with large self-adhesive electrodes in two conventional positions for defibrillation. Physiol Meas .2006;27(10):1009-22

105. Link MS, Berkow LC, Kudenchuk PJ, Halperin HR, Hess EP, Moitra VK, et al. Part 7: adult advanced cardiovascular life support: 2015 american heart association guidelines update for cardiopulmonary resuscitation and emergency cardiovascular care. Circulation .2015;132(18 Suppl 2):S444-64.

106. Kudenchuk PJ, Cobb LA, Copass MK, Olsufka M, Maynard C, Nichol G. Transthoracic incremental monophasic versus biphasic defibrillation by emergency responders (TIMBER): a randomized comparison of monophasic with biphasic waveform ascending energy defibrillation for the resuscitation of out-of-hospital cardiac arrest due to ventricular fibrillation. Circulation .2006;114(19):2010-8.

107. Schneider T, Martens PR, Paschen H, Kuisma M, Wolcke B, Gliner BE, et al. Multicenter, randomized, controlled trial of 150-J biphasic shocks compared with 200- to 360-J monophasic shocks in the resuscitation of out-of-hospital cardiac arrest victims. optimized response to cardiac arrest (ORCA) investigators. Circulation .2000;102(15):1780-7.

108. Walsh SJ, McClelland AJ, Owens CG, Allen J, Anderson JM, Turner C, et al. Efficacy of distinct energy delivery protocols comparing two biphasic defibrillators for cardiac arrest. Am J Cardiol .2004;94(3):378-80.

109. Bobrow BJ, Clark LL, Ewy GA, Chikani V, Sanders AB, Berg RA, et al. Minimally interrupted cardiac resuscitation by emergency medical services for out-of-hospital cardiac arrest. JAMA.2008;299(10):1158-65

110. Conover Z, Kern KB, Silver AE, Bobrow BJ, Spaite DW, Indik JH. Resumption of chest compressions after successful defibrillation and risk for recurrence of ventricular fibrillation in out-of-hospital cardiac arrest. Circ Arrhythm Electrophysiol .2014;7(4):633-9.

111. Morrison LJ, Henry RM, Ku V, Nolan JP, Morley P, Deakin CD. Singleshock defibrillation success in adult cardiac arrest: a systematic review. Resuscitation. 2013;84(11):1480-6.

112. Morrison LJ, Long J, Vermeulen M, Schwartz B, Sawadsky B, Frank J, et al. A randomized controlled feasibility trial comparing safety and effectiveness of prehospital pacing versus conventional treatment: 'PrePACE'. Resuscitation. 2008;76(3):341-9

113. Delguercio LR, Feins NR, Cohn JD, Coomaraswamy RP, Wollman SB, State D. Comparison of blood flow during external and internal cardiac massage in man. Circulation. 1965;31(3 Suppl 1):171-80.

114. Wik L, Kramer-Johansen J, Myklebust H, Sørebø H, Svensson L, Fellows $\mathrm{B}$, et al. Quality of cardiopulmonary resuscitation during out-of-hospital cardiac arrest. JAMA. 2005;293(3):299-304.

115. Ornato JP, Gonzalez ER, Garnett AR, Levine RL, McClung BK. Effect of cardiopulmonary resuscitation compression rate on end-tidal carbon dioxide concentration and arterial pressure in man. Crit Care Med. $1988 ; 16(3): 241-5$.

116. Swenson RD, Weaver WD, Niskanen RA, Martin J, Dahlberg S Hemodynamics in humans during conventional and experimental methods of cardiopulmonary resuscitation. Circulation. 1988;78(3):630-9.

117. Kern KB, Sanders AB, Raife J, Milander MM, Otto CW, Ewy GA. A study of chest compression rates during cardiopulmonary resuscitation in humans: the importance of rate-directed chest compressions. Arch Intern Med. 1992:152(1):145-9.

118. Boczar ME, Howard MA, Rivers EP, Martin GB, Horst HM, Lewandowski $\mathrm{C}$, et al. A technique revisited: hemodynamic comparison of closed-and open-chest cardiac massage during human cardiopulmonary resuscitation. Crit Care Med. 1995;23(3):498-503.

119. Raman J, Saldanha RF, Branch JM, Esmore DS, Spratt PM, Farnsworth AE, et al. Open cardiac compression in the postoperative cardiac intensive care unit. Anaesth Intensive Care. 1989;17(2):129 -35.

120. Anthi A, Tzelepis GE, Alivizatos P, Michalis A, Palatianos GM, Geroulanos S. Unexpected cardiac arrest after cardiac surgery: incidence, predisposing causes, and outcome of open chest cardiopulmonary resuscitation. Chest. 1998;113(1):15-9.

121. Pottle A, Bullock I, Thomas J, Scott L. Survival to discharge following Open Chest Cardiac Compression (OCCC): a 4-year retrospective audit in a cardiothoracic specialist centre-Royal Brompton and Harefield NHS Trust, United Kingdom. Resuscitation. 2002;52(3):269 -72.

122. Calinas-Correia J, Phair I. Physiological variables during open chest cardiopulmonary resuscitation: results from a small series. J Accid Emerg Med. 2000;17(3):201-4

123. Fialka C, Sebök C, Kemetzhofer P, Kwasny O, Sterz F, Vécsei V. Openchest cardiopulmonary resuscitation after cardiac arrest in cases of blunt chest or abdominal trauma: a consecutive series of 38 cases. J Trauma. 2004;57(4):809-14

124. Powell DW, Moore EE, Cothren CC, Ciesla DJ, Burch JM, Moore JB, et al. Is emergency department resuscitative thoracotomy futile care for the critically injured patient requiring prehospital cardiopulmonary resuscitation? J Am Coll Surg. 2004;199(2):211-5.

125. Sheppard FR, Cothren CC, Moore EE, Orfanakis A, Ciesla DJ, Johnson JL, et al. Emergency department resuscitative thoracotomy for nontorso injuries. Surgery. 2006;139(4):574-6

126. Seamon MJ, Fisher CA, Gaughan JP, Kulp H, Dempsey DT, Goldberg AJ. Emergency department thoracotomy: survival of the least expected. World J Surg. 2008;32(4):604-12.

127. Powell RW, Gill EA, Jurkovich GJ, Ramenofsky ML. Resuscitative thoracotomy in children and adolescents. Am Surg. 1988;54(4):188-91.

128. Rothenberg SS, Moore EE, Moore FA, Baxter BT, Moore JB, Cleveland HC. Emergency Department thoracotomy in children-a critical analysis. J Trauma. 1989;29(10):1322-5

129. SackJB, Kesselbrenner MB, Jarrad A. Interposed abdominal compressioncardiopulmonary resuscitation and resuscitation outcome during asystole and electromechanical dissociation. Circulation. 1992;86(6):1692-700.

130. Sack JB, Kesselbrenner MB, Bregman D. Survival from in-hospital cardiac arrest with interposed abdominal counterpulsation during cardiopulmonary resuscitation. JAMA. 1992;267(3):379-85.

131. Mateer JR, Stueven HA, Thompson BM, Aprahamian C, Darin JC. Prehospital IAC-CPR versus standard CPR: paramedic resuscitation of cardiac arrests. Am J Emerg Med. 1985;3(2):143-6.

132. Miller B, Cohen A, Serio A, Bettock D. Hemodynamics of cough cardiopulmonary resuscitation in a patient with sustained torsades de pointes/ventricular flutter. J Emerg Med. 1994;12(5):627-32.

133. Keeble W, Tymchak WJ. Triggering of the Bezold Jarisch Reflex by reperfusion during primary $\mathrm{PCl}$ with maintenance of consciousness by cough CPR: a case report and review of pathophysiology. J Invasive Cardiol. 2008;20(8):E239-42.

134. Niemann JT, Rosborough J, Hausknecht M, Brown D, Criley JM. CoughCPR: documentation of systemic perfusion in man and in an experimenta model: a "window" to the mechanism of blood flow in external CPR. Crit Care Med. 1980;8(3):141-6

135. Saba SE, David SW. Sustained consciousness during ventricular fibrillation: case report of cough cardiopulmonary resuscitation. Cathet Cardiovasc Diagn. 1996;37(1):47-8.

136. Pellis T, Kette F, Lovisa D, Franceschino E, Magagnin L, Mercante WP, et al. Utility of pre-precordial thump for treatment of out of hospital cardiac arrest: a prospective study. Resuscitation. 2009;80(1):17-23. 
137. Kohl P, King AM, Boulin C. Antiarrhythmic effects of acute mechanical stiumulation. In: Kohl P, Sachs F, Franz MR, editors. Cardiac mechanoelectric feedbackand arrhythmias: form pipette to patient. Philadelphia: Elsevier/Saunders;2005. p. 304-14.

138. Nehme Z, Andrew E, Bernard SA, Smith K. Treatment of monitored outof-hospital ventricular fibrillation and pulseless ventricular tachycardia utilising the precordial thump. Resuscitation. 2013;84(12):1691-6.

139. Bornemann C, Scherf D. Electrocardiogram of the month. Paroxysmal ventricular tachycardia abolished by a blow to the precordium. Dis Chest. 1969;56(1):83-4.

140. Dale KM, Lertsburapa K, Kluger J, White CM. Moxifloxacin and torsade de pointes. Ann Pharmacother. 2007;41(2):336-40.

141. De Maio VJ, Stiell IG, Spaite DW, Ward RE, Lyver MB, Field BJ 3rd, et al. Ontario Prehospital Advanced Life Support (OPALS) Study Group. CPRonly survivors of out-of-hospital cardiac arrest: implications for out-ofhospital care and cardiac arrest research methodology. Ann Emerg Med. 2001;37(6):602-8.

142. Pennington JE, Taylor J, Lown B. Chest thump for reverting ventricular tachycardia. N Engl J Med. 1970;283(22):1192-5.

143. Rahner E, Zeh E. Die Regularisierung von Kammertachykardien durch pra"kordialen Faustschlag. ("The Regularization of Ventricular Tachycardias by Precordial Thumping.") Med Welt. 1978;29: 1659-1663.

144. Caldwell G, Millar G, Quinn E, Vincent R, Chamberlain DA. Simple mechanical methods for cardioversion: defence of the precordial thump and cough version.Br Med J. (Clin Res Ed). 1985;291(6496):627-30.

145. Krijne R. Rate acceleration of ventricular tachycardia after a precordial chest hump. Am J Cardiol. 1984;53(7):964-5.

146. Debaty G, Shin SD, Metzger A, Kim T, Ryu HH, Rees J, et al. Tilting for perfusion: Head-up position during cardiopulmonary resuscitation improves brain flow in a porcine model of cardiac arrest. Resuscitation .2015 Feb;87:38-43.

147. Moore JC, Holley JE Jr, Frascone RJ, Segall N, Lick C, Klein L, et al. Headup position lowers intracranial pressure in a human cadaver model of cardiopulmonary resuscitation. Circulation. 2018 Mar;134:A18260.

148. Mazer SP, Weisfeldt M, Bai D, Cardinale C, Arora R, Ma C, et al. Reverse, CPR: a pilot study of CPR in the prone position. Resuscitation. 2003;57(3):279-85.

149. Sun WZ, Huang FY, Kung KL, Fan SZ, Chen TL. Successful cardiopulmonary resuscitation of two patients in the prone position using reversed precordial compression. Anesthesiology. 1992;77(1):202-4.

150. Tobias JD, Mencio GA, Atwood R, Gurwitz GS. Intraoperative cardiopulmonary resuscitation in the prone position. J Pediatr Surg. 1994;29(12):1537-8.

151. Brown J, Rogers J, Soar J. Cardiac arrest during surgery and ventilation in the prone position: a case report and systematic review. Resuscitation. 2001;50(2):233-8.

152. Wik L, Olsen JA, Persse D, Sterz F, Lozano M Jr, Brouwer MA, et al. Manual vs. integrated automatic load-distributing band CPR with equal survival after out of hospital cardiac arrest. The randomized CIRC trial. Resuscitation. 2014;85(6):741-8.

153. Rubertsson S, Lindgren E, Smekal D, Östlund O, Silfverstolpe J, Lichtveld RA, et al. Mechanical chest compressions and simultaneous defibrillation vs conventional cardiopulmonary resusci-tation in out-of-hospital cardiac arrest: the LINC randomized trial. JAMA. 2014;311(1):53-61.

154. Perkins GD, Lall R, Quinn T, Deakin CD, Cooke MW, Horton J, et al. Mechanical versus manual chest com-pression for out-of-hospital cardiac arrest (PARAMEDIC): a pragmatic, cluster randomised controlled trial. Lancet. 2015;385(9972):947-55.

155. Spiro JR, White S, Quinn N, Gubran CJ, Ludman PF, Townend JN, et al. Automated cardiopulmonary resuscitation using a load-distributing band external cardiac support device for in-hospital cardiac arrest: a single centre experience of AutoPulse-CPR. Int J Cardiol. 2015 Feb;180:7-14.

156. Ong ME, Quah JL, Annathurai A, Noor NM, Koh ZX, Tan KB, et al. Improving the quality of cardiopul-monary resuscitation by training dedicated cardiac arrest teams incorporating a mechanical loaddistributing device at the emergency department. Resuscitation. 2013;84(4):508-14.

157. Lerner EB, Persse D, Souders CM, Sterz F, Malzer R, Lozano M Jr, et al. Design of the Circulation Improving Resuscitation Care (CIRC) Trial: a new state of the art design for out-of-hospitalc ardiac arrest research. Resuscitation. 2011;82(3):294-9.

158. Lindner KH, Pfenninger EG, Lurie KG, Schürmann W, Lindner IM, Ahnefeld FW. Effects of active compression-decompression resuscitation on myocardial and cerebral blood flow in pigs. Circulation. 1993;88(3):1254-63.

159. Shultz JJ, Coffeen P, Sweeney M, Detloff B, Kehler C, Pineda E, et al. Evaluation of standard and active compression-decompression CPR in an acute human model of ventricular fibrillation. Circulation. 1994;89(2):684-93.

160. Chang MW, Coffeen P, Lurie KG, Shultz J, Bache RJ, White CW. Active compression-decompression CPR improves vital organ perfusion in a dog model of ventricular fibrillation. Chest. 1994;106(4):1250-9.

161. Orliaguet GA, Carli PA, Rozenberg A, Janniere D, Sauval P, Delpech P. Endtidal carbon dioxide during out-of-hospital cardiac arrest resuscitation: comparison of active compression-decompression and standard CPR. Ann Emerg Med. 1995;25(1):48-51.

162. Guly UM, Mitchell RG, Cook R, Steedman DJ, Robertson CE. Paramedics and technicians are equally successful at managing cardiac arrest outside hospital. BMJ. 1995;310(6987):1091-4.

163. Tucker KJ, Galli F, Savitt MA, Kahsai D, Bresnahan L, Redberg RF. Active compression-decompression resuscitation: effect on resuscitation success after in-hospital cardiac arrest. J Am Coll Cardiol. 1994;24(1):201-9.

164. Malzer R, Zeiner A, Binder M, Domanovits H, Knappitsch G, Sterz F, et al. Hemodynamic effects of active compression-decompression after prolonged CPR. Resuscitation. 1996;31(3):243-53.

165. Mauer D, Schneider T, Dick W, Withelm A, Elich D, Mauer M. Active compression-decompression resuscitation: a prospective, randomized study in a two-tiered EMS system with physicians in the field. Resuscitation. 1996;33(2):125-34.

166. Nolan J, Smith G, Evans R, McCusker K, Lubas P, Parr M, et al. The United Kingdom pre-hospital study of active compressiondecompression resuscitation. Resuscitation. 1998;37:119-25.

167. Cohen TJ, Goldner BG, Maccaro PC, Ardito AP, Trazzera S, Cohen MB, et al. A comparison of active compression-decompression cardiopulmonary resuscitation with standard cardiopulmonary resuscitation for cardiac arrests occurring in the hospital.N Engl J Med. 1993;329(26):1918-21.

168. Lafuente-Lafuente C, Melero-Bascones M. Active chest compressiondecompression for cardiopulmonary resuscitation. Cochrane Database Syst Rev. 2013 Sep;(9):CD002751.

169. Plaisance $P$, Lurie KG, Payen D. Inspiratory impedance during active compression-decompression cardiopulmonary resuscitation: a randomized evaluation in patients in cardiac arrest. Circulation. 2000;101(9):989-94.

170. Plaisance P, Lurie KG, Vicaut E, Martin D, Gueugniaud PY, Petit JL, et al. Evaluation of an impedance threshold device in patients receiving active compression-decompression cardiopulmonary resuscitation for out of hospital cardiac arrest. Resuscitation. 2004;61(3):265-71.

171. Wolcke BB, Mauer DK, Schoefmann MF, Teichmann H, Provo TA, Lindner $\mathrm{KH}$, et al. Comparison of standard cardiopulmonary resuscitation versus the combination of active compression-decompression cardiopulmonary resuscitation and an inspiratory impedance threshold device for out-ofhospital cardiac arrest. Circulation. 2003;108(18):2201-5. 
172. Aufderheide TP, Pirrallo RG, Provo TA, Lurie KG. Clinical evaluation of aninspiratory impedance threshold device during standard cardiopulmonary resuscitation in patients with out-of-hospital cardiac arrest. Crit Care Med. 2005;33(4):734-40.

173. Thayne RC, Thomas DC, Neville JD, Van Dellen A. Use of an impedance threshold device improves short-term outcomes following out-of-hospital cardiac arrest. Resuscitation. 2005;67(1):103-8.

174. Cabrini L, Beccaria P, Landoni G, Biondi-Zoccai GG, Sheiban I, Cristofolini $\mathrm{M}$, et al A. Impact of impedance threshold devices on cardiopulmonary resuscitation: a systematic review and meta-analysis of randomized controlled studies. Crit Care Med. 2008;36(5):1625-32.

175. Aufderheide TP, Nichol G, Rea TD, Brown SP, Leroux BG, Pepe PE, et al Resuscitation Outcomes Consortium (ROC) Investigators. A trial of an impedance threshold device in out-of-hospital cardiac arrest. N Engl J Med. 2011:365(9):798-806.

176. Aufderheide TP, Frascone RJ, Wayne MA, Mahoney BD, Swor RA, Domeier RM, et al. Standard cardiopulmonary resuscitation versus active compression-decompression cardiopulmonary resuscitation with augmentation of negative intrathoracic pressure for out-of-hospital cardiac arrest: a randomised trial. Lancet. 2011;377(9762):301-11

177. Frascone RI, Wayne MA, Swor RA, Mahoney BD, Domeier RM, Olinger $M L$, et al. Treatment of non-traumatic out-of-hospital cardiac arrest with active compression decompression car-diopulmonary resuscitation plus an impedance threshold device. Resuscitation. 2013;84(9):1214-22

178. McDonald JL. Systolic and mean arterial pressures during manual and mechanical CPR in humans. Ann Emerg Med. 1982;11(6):292-5.

179. Ward KR, Menegazzi JJ, Zelenak RR, Sullivan RJ, McSwain NE Jr. A comparison of chest compressions between mechanical and manual CPR by monitoring end-tidal PCO2 during human cardiac arrest. Ann EmergMed. 1993;22(4):669-74.

180. Taylor GJ, Rubin R, Tucker M, Greene HL, Rudikoff MT, Weisfeldt ML. External cardiac compression: a randomized comparison of mechanical and manual techniques. JAMA. 1978;240(7):644-6.

181. Lu XG, Kang X, Gong DB. The clinical efficacy of thumper modal 1007 cardiopulmonary resuscitation: A prospective randomized control trial. Zhongguo Weizhong Bing Ji Jiu Yi Xue. 2010;22(8):496-7.

182. Smekal D, Lindgren E, Sandler H, Johansson J, Rubertsson S. CPR-related injuries after manual or mechanical chest compressions with the LUCAS device: a multicentre study of victims after unsuccessful resuscitation. Resuscitation. 2014;85(12):1708-12.

183. Timerman S, Cardoso LF, Ramires JA, Halperin H. Improved hemodynamic performance with a novel chest compression device during treatment of in-hospital cardiac arrest. Resuscitation. 2004;61(3):273-80.

184. Casner M, Andersen D, Isaacs SM. The impact of a new CPR assist device on rate of return of spontaneous circulation in out-of-hospital cardiac arrest. Prehosp Emerg Care. 2005;9(1):61-7.

185. Ong ME, Ornato JP, Edwards DP, Dhindsa HS, Best AM, Ines CS, et al. Use of an automated, load-distributing band chest compression device for outof-hospital cardiac arrest resuscitation. JAMA. 2006;295(22):2629-37.

186. Hallstrom A, Rea TD, Sayre MR, Christenson J, Anton AR, Mosesso VN Jr, et al. Manual chest compression vs use of an automated chest compression device during resuscitation following outof- hospital cardiac arrest: a randomized trial. JAMA. 2006;295(22):2620-8.

187. Wallmüller C, Sterz F, Testori C, Schober A, Stratil P, Hörburger D, et al. Emergency cardio-pulmonary bypassin cardiac arrest: seventeen years of experience. Resuscitation. 2013;84(3):326-30.

188. Kagawa E, Dote K, Kato M, Sasaki S, Nakano Y, Kajikawa M, et al. Should we emergently revascularize occluded coronaries for cardiac arrest? rapid-response extracorporeal membrane oxygenation and intra-arrest percutaneous coronary intervention. Circulation. 2012;126(13):1605-13.
189. Chen YS, Yu HY, Huang SC, Lin JW, Chi NH, Wang CH, et al Extracorporeal membrane oxygenation support can extend the duration of cardiopulmonary resuscitation. Crit Care Med. 2008;36(9):2529 -35.

190. Stub D, Bernard S, Pellegrino V, Smith K, Walker T, Sheldrake J, et al. Refractory cardiac arrest treated with mechanical CPR, hypothermia, ECMO and early reperfusion (the CHEER trial). Resuscitation. 2015 Jan;86:88-94.

191. Maekawa K, Tanno K, Hase M, Mori K, Asai Y. Extracorporeal cardiopulmonary resuscitation for patients with out-of-hospital cardiac arrest of cardiacorigin: a propensity-matched study and predictor analysis. Crit Care Med. 2013:41(5):1186-96

192. Sakamoto T, Morimura N, Nagao K, Asai Y, Yokota H, Nara S, et al Extracorporeal cardiopulmonary resuscitation versus conventional cardiopulmonary resuscitation in adults with out-of-hospital cardiac arrest: a prospective observational study. Resuscitation. 2014;85(6):762-8.

193. Haneya A, Philipp A, Diez C, Schopka S, Bein T, Zimmermann M, et al. A 5-year experience with cardiopulmonary resuscitation using extracorporeal life support in non-postcardiotomy patients with cardiac arrest. Resuscitation. 2012;83(11):1331-7.

194. Wang CH, Chou NK, Becker LB, Lin JW, Yu HY, Chi NH, et al. Improved outcome of extracorporeal cardiopulmonary resuscitation for out-ofhospital cardiac arrest - a comparison with that for extracorporeal rescue for in-hospital cardiac arrest. Resuscitation. 2014;85(9):1219-24.

195. Meaney PA, Nadkarni VM, Kern KB, Indik JH, Halperin HR, Berg RA. Rhythms and outcomes of adult in-hospital cardiac arrest. Crit Care Med. 2010;38(1):101-8.

196. Nadkarni VM, Larkin GL, Peberdy MA, Carey SM, Kaye W, Mancini ME, et al. First documented rhythm and clinical outcome from in-hospital cardiac arrest among children and adults. JAMA. 2006;295(1):50-7.

197. Brady WJ, Gurka KK, Mehring B, Peberdy MA, O'Connor RE; American Heart Association's Get with the Guidelines (formerly, NRCPR) Investigators. In-hospital cardiac arrest: impact of monitoring and witnessed event on patient survival and neurologic status at hospital discharge. Resuscitation. 2011;82(7):845-52.

198. Peberdy MA, Ornato JP, Larkin GL, Braithwaite RS, Kashner TM, Carey SM et al. Survival from in-hospital cardiac arrest during nights and weekends. JAMA. 2008;299(7):785-92

199. Gonzalez MM, Berg RA, Nadkarni VM, Vianna CB, Kern KB, Timerman S, etal. Left ventricular systolic function and outcome after in-hospital cardiac arrest. Circulation. 2008;117(14):1864-72.

200. Link MS, Berkow LC, Kudenchuk PJ, , Halperin HR, Hess EP, Moitra VK, et al. Part 7: Adult Advanced cardiovascular life support: 2015 American Heart Association Guidelines Update for cardiopulmonary resuscitation and emergency cardiovascular care. Circulation. 2015;132(18 Supp 2):S444-64

201. Hasegawa K, Hiraide A, Chang Y, Brown DF. Association of prehospital advanced airway management with neurologic outcome and survival in patients with out-of-hospital cardiac arrest. JAMA. 2013;309(3):257-66

202. Kurz MC, Prince DK, Christenson J, Carlson J, Stub D, Cheskes S, et al. Association of advanced airway device with chest compression fraction during out-of-hospital cardiopulmonary arrest. Resuscitation. 2016 Jan;98:35-40.

203. Kang K, Kim T, Ro YS, Kim YJ, Song KJ, Shin SD. Prehospital endotracheal intubation and survival after out-of-hospital cardiac arrest: results from the Korean nationwide registry. Am J Emerg Med. 2016;34(2):128-32.

204. Benoit JL, Gerecht RB, Steuerwald MT, McMullan JT. Endotracheal intubation versus supraglottic airway placement in out-of-hospital cardiac arrest: a meta-analysis. Resuscitation. 2015 Aug;93:20-6.

205. Holmberg M, Holmberg S, Herlitz J. Low chance of survival among patients requiring adrenaline (epinephrine) or intubation after out-of-hospital cardiac arrest in Sweden. Resuscitation. 2002;54(1):37-45. 
206. Hiltunen P, Jäntti H, Silfvast T, Kuisma M, Kurola J; FINNRESUSCI Prehospital study group. Airway management in out-of-hospital cardiac arrest in Finland: current practices and outcomes. Scand J Trauma Resusc Emerg Med. 2016 Apr 12;24:49.

207. Zwemer CF, Whitesall SE, D'Alecy LG. Cardiopulmonary-cerebral resuscitation with $100 \%$ oxygen exacerbates neurological dysfunction following nine minutes of normothermic cardiac arrest in dogs. Resuscitation. 1994;27(2):159-70.

208. Lipinski CA, Hicks SD, Callaway CW. Normoxic ventilation during resuscitation and outcome from asphyxial cardiac arrest in rats. Resuscitation. 1999;42(3):221-9.

209. Kleinman ME, Brennan EE, Goldberger ZD, Swor RA, Terry M, Bobrow BJ, et al. Part 5: Adult basic life support and cardiopulmonary resuscitation quality: 2015 American Heart Association guidelines update for cardiopulmonary resuscitation and emergency cardiovascular care. Circulation. 2015;132(18 Suppl2):S414-35.

210. Dorges V, Wenzel V, Knacke P, Gerlach K. Comparison of different airway management strategies to ventilate apneic, nonpreoxygenated patients. Crit Care Med. 2003;31(3):800-4.

211. Alexander R, Hodgson P, Lomax D, Bullen C. A comparison of the laryngeal mask airway and Guedel airway, bag and facemask ventilation following formal training. Anaesthesia. 1993;48(3):231-4.

212. Nagao T, Kinoshita K, Sakurai A, Yamaguchi J, Furukawa M, Utagawa A, et al. Effects of bag-mask versus advanced airway ventilation for patients undergoing prolonged cardiopulmonary resuscitation in pre-hospital setting. J Emerg Med. 2012;42(2):162-70.

213. Weiler N, Heinrichs W, Dick W. Assessment of pulmonary mechanics and gastric inflation pressure during mask ventilation. Prehosp Disaster Med. 1995;10(2):101-5.

214. Doerges V, Sauer C, Ocker H, Wenzel V, Schmucker P. Airway management during cardiopulmonary resuscitation- a comparative study of bagvalve-mask, laryngeal mask airway and combitube in a bench model. Resuscitation. 1999;41(1):63-9.

215. Palmer JH, Rall DR. The effect of cricoid pressure on the cricoid cartilage and vocal cords: an endoscopic study in anaesthetized patients. Anaesthesia. 2000;55(3):263-8.

216. Wang $\mathrm{CH}$, Chen WJ, Chang WT, Tsai MS, Yu PH, Wu YW, et al. The association between timing of tracheal intubation and outcomes of adult in-hospital cardiac arrest: a retrospective cohort study. Resuscitation. 2016 Aug;105:59-65.

217. Katz SH, Falk JL. Misplaced endotracheal tubes by paramedics in an urban emergency medical services system. Ann Emerg Med. 2001;37(1):32-7.

218. Lyon RM, Ferris JD, Young DM, McKeown DW, Oglesby AJ, Robertson C. Field intubation of cardiac arrest patients: a dying art?. Emerg Med J. 2010;27(4):321-3.

219. Mulcaster JT, Mills J, Hung OR, MacQuarrie K, Law JA, Pytka S, et al. Laryngoscopic intubation: learning and performance. Anesthesiology. 2003;98(1):23-7.

220. O'Neill JF, Deakin CD. Do we hyperventilate cardiac arrest patients? Resuscitation. 2007;73(1):82-5.

221. Ornato JP, Shipley JB, Racht EM, Slovis CM, Wrenn KD, Pepe PE, et al. Multicenter study of a portable, hand- size, colorimetric end-tidal carbon dioxide detection device. Ann Emerg Med. 1992;21(5):518-23.

222. Grmec S. Comparison of three different methods to confirm tracheal tube placement in emergency intubation. Intensive Care Med. 2002;28(6):701-4

223. Chou HC, Tseng WP, Wang CH, Ma MH, Wang HP, Huang PC, et al. Tracheal rapid ultrasound exam (T.R.U.E.) for confirming endotracheal tube placement during emergency intubation. Resuscitation. 2011;82(10):1279-84.
224. Zadel S, Strnad M, Prosen G, Mekiš D. Point of care ultrasound for orotracheal tube placement assessment in out-of hospital setting. Resuscitation. 2015 Feb;87:1-6.

225. Chou HC, Chong KM, Sim SS, Ma MH, Liu SH, Chen NC, et al. Realtime tracheal ultrasonography for confirmation of endotracheal tube placement during cardiopulmonary resuscitation. Resuscitation. 2013;84(12):1708-12.

226. McMullan J, Gerecht R, Bonomo J, Robb R, McNally B, Donnelly J, et al, Airway management and out-of-hospital cardiac arrest outcome in the CARES registry. Resuscitation. 2014;85(5):617-22.

227. Hanif MA, Kaji AH, Niemann JT. Advanced airway management does not improve outcome of out-of-hospital cardiac arrest. Acad Emerg Med. 2010;17(9):926-31.

228. Rabitsch W, Schellogowski P, Staudinger T, Hofbauer R, Dufek V, Eder B, et al. Comparison of a conventional tracheal airway with the Combitube in an urban emergency medical service system run by physicians. Resuscitation. 2003;57(1):27-32.

229. Rumball C, Macdonald D, Barber P, Wong H, Smecher C. Endotracheal intubation and esophageal tracheal Combitube insertion by regular ambulance attendants: a comparative trial. Prehosp Emerg Care. 2004;8(1):15-22.

230. Samarkandi AH, Seraj MA, el Dawlatly A, Mastan M, Bakhamees HB. The role of laryngeal mask airway in cardiopulmonary resuscitation. Resuscitation. 1994;28(2):103-6.

231. Deakin CD, Peters R, Tomlinson P, Cassidy M. Securing the prehospital airway: a comparison of laryngeal mask insertion and endotracheal intubation by UK paramedics. Emerg Med J. 2005;22(1):64-7.

232. Wiese CH, Semmel T, Muller JU, Bahr J, Ocker H, Graf BM. The use of the laryngeal tube disposable (LT-D) by paramedics during out-of-hospital resuscitation- an observational study concerning ERC guidelines 2005. Resuscitation. 2009;80(2):194-8.

233. Kette F, Reffo I, Giordani G, Buzzi F, Borean V, Cimarosti R, et al. The use of laryngeal tube by nurses in out-of-hospital emergencies: preliminary experience. Resuscitation. 2005;66(1):21-5.

234. Meyer O, Bucher M, Schröder J. Effect of using a laryngeal tube on the no-flow time in a simulated, single-rescuer, basic life support setting with inexperienced users. Anaesthesist. 2016;65(3):183-9.

235. Ono Y, Hayakawa M, Maekawa K, Mizugaki A, Katabami K, Wada T, et al. Should laryngeal tubes or masks be used for out-of-hospital cardiac arrest patients? Am J Emerg Med. 2015;33(10):1360-3.

236. Paal P, Pircher I, Baur T, Gruber E, Strasak AM, Herff H, etal. Mobile phoneassisted basic life support augmented with a metronome. J Emerg Med. 2012;43(3):472-7.

237. Hafner JW, Sturgell JL, Matlock DL, Bockewitz EG, Barker LT. "Stayin alive": a novel mental metronome to maintain compression rates in simulated cardiac arrests. J Emerg Med. 2012;43(5):e373-7.

238. Halperin HR, TsitlikJE, Gelfand M, Weisfeldt ML, Gruben KG, Levin HR, et al. A preliminary study of cardiopulmonary resuscitation by circumferential compression of the chest with use of a pneumatic vest. N Engl J Med. 1993;329(11):762-8.

239. Kern KB, Hilwig RW, Berg RA, Ewy GA. Efficacy of chest compressiononly BLS CPR in the presence of an occluded airway. Resuscitation. 1998;39(3):179-88.

240. Levine RL, Wayne MA, Miller CC. End-tidal carbon dioxide and outcome of out-of-hospital cardiac arrest. N Engl J Med. 1997;337(5):301-6.

241. Grmec S, Kupnik D. Does the Mainz Emergency Evaluation Scoring (MEES) in combination with capnometry (MEESc) help in the prognosis of outcome from cardiopulmonary resuscitation in a prehospital setting? Resuscitation. 2003;58(1):89-96. 
242. Kolar M, Krizmaric M, Klemen P, Grmec S. Partial pressure of end-tidal carbon dioxide successful predicts cardiopulmonary resuscitation in the field: a prospective observational study. Crit Care. 2008;12(5):R115.

243. van der Wouw PA, Koster RW, Delemarre BJ, de Vos R, LampeSchoenmaeckers AJ, Lie KI. Diagnostic accuracy of transesophageal echocardiography during cardiopulmonary resuscitation. J Am Coll Cardiol. 1997;30(3):780-3.

244. Wayne MA, Levine RL, Miller CC. Use of end-tidal carbon dioxide to predict outcome in prehospital cardiac arrest. Ann Emerg Med. $1995 ; 25(6): 762-7$

245. Cantineau JP, Lambert Y, Merckx P, Reynaud P, Porte F, Bertrand C, et al. End-tidal carbon dioxide during cardiopulmonary resuscitation in humans presenting mostly with asystole: a predictor of outcome. Crit Care Med. 1996;24(5):791-6

246. Bhende MS, Karasic DG, Karasic RB. End-tidal carbon dioxide changes during cardiopulmonary resuscitation after experimental asphyxial cardiac arrest. Am J Emerg Med. 1996;14(4):349-50.

247. Ornato JP, Peberdy MA, Reid RD, Feeser VR, Dhindsa HS; NRCPR Investigators. Impact of resuscitation system errors on survival from inhospital cardiac arrest. Resuscitation. 2012;83(1):63-9.

248. Castrejon S, Cortes M, Salto ML, Benittez LC, Rubio R, Juárez M, et al. Improved prognosis after using mild hypothermia to treat cardiorespiratory arrest due to a cardiac cause: comparison with a control group. Rev Esp Cardiol. 2009;62(7):733-41.

249. Wallmuller C, Meron G, Kurkciyan I, Schober A, Stratil P, Sterz F. Causes of in-hospital cardiac arrest and influence on outcome. Resuscitation. 2012;83(10):1206-11.

250. Field JM, Hazinski MF, Sayre MR, Chameides L, Schexnayder SM, Hemphill R, et al. Part 1: executive summary: 2010 American Heart Association Guidelines for Cardiopulmonary Resuscitation and Emergency Cardiovascular Care. Circulation. 2010;122(18 Suppl 3):S640-56.

251. Pokorna N, Necas E, Skripsky R, Kratochvil J, Andrlik M, Franek O. How accurately can the aetiology of cardiac arrest be established in na out-ofhospital setting? Analysis by "concordance in diagnosis crosscheck tables". Ressuscitation. 2011;82(4): 391-7.

252. Price S, Uddin S, Quinn T. Echocardiography in cardiac arrest. Cur Opin Crit Care. 2010;16(3):211-5

253. Testa A, Cibinel GA, Portale G, Forte P, Giannuzzi R, Pignataro G, et al. The proposal of an integrated ultrasonographic approach into the ALS algorithm for cardiac arrest: the PEA protocol. Eur Rev Med Pharmacol Sci. 2010;14(2):77-88

254. Siassakos D, Bristowe K, Draycott TJ, Angouri J, Hambly H, Winter C, et al. Clinical efficiency in a simulated emergency and relationship to team behaviours: a multisite cross-sectional study. BJOG. 2011;118(5):596-607.

255. Brindley PG, Reynolds SF. Improving medical communication in critical care medicine. J Crit Care. 2011; 26(2):155-9.

256. Dine CJ, Gersh RE, Leary M, Riegel BJ, Bellini LM, Abella BS. Improving cardiopulmonary resuscitation quality and resuscitation training by combining audiovisual feedback and debriefing. Crit Care Med. 2008;36(10):2817-22

257. Dalzell GW, Adgey AA. Determinants of successful transthoracic defibrillation and outcome in ventricular fibrillation. Br Heart J. 1991;65(6):311-6

258. Theodorou AA, Gutierrez JA, Berg RA. Fire attributable to a defibrillation attempt in a neonate. Pediatrics. 2003;112(3 Pt 1):677-9.

259. Kerber RE, Jensen SR, Grayzel J, Kennedy J, Hoyt R. Elective cardioversion: influence of paddle-electrode location and size on success rates and energy requirements. N Engl J Med. 1981;305(12):658-62.

260. Dahl CF, Ewy GA, Warner ED, Thomas ED. Myocardial necrosis from direct current countershock. Effect of paddle electrode size and time interval between discharges. Circulation. 1974;50(5):956-61.
261. Higgins SL, Herre JM, Epstein AE, Greer GS, Friedman PL, Gleva ML, et al. A comparison of biphasic and monophasic shocks for external defibrillation. Physio-Control Biphasic Investigators. Prehosp Emerg Care. 2000;4(4):305-13.

262. Schwarz B, Bowdle TA, Jett GK, Mair P, Lindner KH, Aldea GS, et al. Biphasic shocks compared with monophasic damped sine wave shocks for direct ventricular defibrillation during open heart surgery. Anesthesiology. 2003;98(5):1063-9.

263. Martens PR, Russell JK, Wolcke B, Paschen H, Kuisma M, Gliner BE, et al Optimal Response to Cardiac Arrest study: defibrillation waveform effects. Resuscitation. 2001;49(3):233-43.

264. Walsh SJ, McClelland AJ, Owens CG, Allen J, Anderson JM, Turner C, et al. Efficacy of distinct energy delivery protocols comparing two biphasic defibrillators for cardiac arrest. Am J Cardiol. 2004;94(3):378-80.

265. Eftestol T, Sunde K, Steen PA. Effects of interrupting precordial compressions on the calculated probability of defibrillation success during out-of-hospital cardiac arrest. Circulation. 2002;105(19):2270-3.

266. Wik L, Hansen TB, Fylling F, Steen T, Vaagenes P, Auestad BH, et al Delaying defibrillation to give basic cardiopulmonary resuscitation to patients with out-of-hospital ventricular fibrillation: a randomized trial. JAMA. 2003;289(11):1389-95.

267. Baker PW, Conway J, Cotton C, Ashby DT, Smyth J, Woodman RJ, et al. Defibrillation or cardiopulmonary resuscitation first for patients with out-ofhospital cardiac arrests found by paramedics to be in ventricular fibrillation? A randomised control trial. Resuscitation. 2008;79(3):424-31.

268. Jacobs IG, Finn JC, Oxer HF, Jelinek GA. CPR before defibrillation in out-of-hospital cardiac arrest: a randomized trial. Emerg Med Australas. 2005; 17(1):39-45.

269. Gonzalez ER, Ornato JP. The dose of epinephrine during cardiopulmonary ressuscitation in humans: what should it be? DICP. 1991;25(7-8):773-7.

270. Gueugniaud PY, David JS, Chanzy E, Hubert H, Dubien PY, Mauriaucourt $P$, et al. Vasopressin and epinephrine vs. epinephrine alone in cardiopulmonary resuscitation. N Engl J Med. 2008;359(1):21-30.

271. Kudenchuk PJ, Cobb LA, Copass MK, Cummins RO, Doherty AM, Fahrenbruch CE, et al. Amiodarone for resuscitation after outofhospital cardiac arrest due to ventricular fibrillation. N Engl J Med. 1999;341(12):871-8

272. Kudenchuk PJ, Brown SP, Daya M. et al. For the Resuscitation Outcomes Consortium Investigators. Amiodarone, Lidocaine, or Placebo in out-ofhospital cardiac arrest. N Engl J Med. 2016; 374: 1711-1722.

273. Scheinman MM, Levine JH, Cannom DS, Friehling T, Kopelman HA Chilson DA, et al. Dose-ranging study of intravenous amiodarone in patients with life-threatening ventricular tachyarrhythmias. The Intravenous Amiodarone Multicenter Investigators Group. Circulation. 1995;92(11):3264-72.

274. Kowey PR, Levine JH, Herre JM, Pacifico A, Lindsay BD, Plumb $\mathrm{VJ}$, et al. Randomized, double-blind comparison of intravenous amiodarone and bretylium in the treatment of patients with recurrent, hemodynamically destabilizing ventricular tachycardia or fibrillation. The Intravenous Amiodarone Multicenter Investigators Group. Circulation. 1995;92(11):3255-63.

275. Tzivoni D, Banai S, Schuger C, Benhorin J, Keren A, Gottlieb S, et al. Treatment of torsade de pointes with magnesium sulfate. Circulation. 1988;77(2):392-7.

276. Böttiger BW, Arntz HR, Chamberlain DA, Bluhmki E, Belmans A, Danays T, et al. Thrombolysis during resuscitation for out-of-hospital cardiac arrest. N Engl J Med. 2008;359(25):2651-62.

277. Maca J, Kula R, Jahoda J, Chylek V, Gumulec J. Thrombolysis and cardiac arrest. Bratisl Lek Listy. 2010;111(11):619-24.

278. Nordseth T, Olasveengen TM, Kvaløy JT, Wik L, Steen PA, Skogvoll E. Dynamic effects of adrenaline (epinephrine) in out-of-hospital cardiac 
arrest with initial pulseless electrical activity (PEA). Resuscitation. 2012;83(8):946-52.

279. Donnino MW, Salciccioll JD, Howell MD, Cocchi MN, Giberson B, Berg K, et al. Time to administration of epinephrine and outcome after in-hospital cardiac arrest with non-shockable rhythms: retrospective analysis of large in-hospital data registry. BMJ. 2014 May 20;348:G3028.

280. Wetsch WA, Spöhr F, Teschendorf P, Böttiger BW, Padosh SA. Thrombolysis during cardio-pulmonary resuscitation. Dtsch Med Wochenschr. 2010;135(40):1983-8.

281. de Vos R, Oosterom L, Koster RW, de Haan RJ. Decisions to terminate resuscitation. Resuscitation Committee. Resuscitation. 1998;39(1-2):7-13.

282. Kern KB, Ewy GA, Voohees WD, Babbs CF, Tacker WA. Myocardial perfusion pressure: a predictor of 24-hour survival during prolonged cardiac arrest in dogs. Resuscitation. 1988;16(4):241-50.

283. Michael JR, Guerci AD, Koehler RC, Shi AY, Tsitlik J, Chandra N, al. Mechanisms by which epinephrine augments cerebral and myocardial perfusion during cardiopulmonary resuscitation in dogs. Circulation. 1984;69(4):822-35.

284. Lee SW. Drugs in resuscitation: an update. Singapore Med J. 2011;52(8):596-602.

285. Jacobs IG, Finn JC, Jelinek GA, Oxer HF, Thompson PL. Effect of adrenaline on survival in out-of-hospital cardiac arrest: A randomized double-blind placebo-controlled trial. Resuscitation. 2011;82(9):1138-43.

286. Hagihara A, Hasegawa M, Abe T, Nagata T, Wakata Y, Miyazaki S. Prehospital epinephrine use and survival among patients with outofhospital cardiac arrest. JAMA. 2012;307(11):1161-8.

287. Machida M, Miura S, Matsuo K, Ishikura H, Saku K. Effect of intravenous adrenaline before arrival at the hospital in out-of-hospital cardiac arrest. J Cardiol. 2012;60(6):503-7.

288. Callaham M, Madsen CD, Barton CW, Saunders CE, Pointer J. A randomized clinical trial of high-dose epinephrine and norepinephrine vs standard-dose epinephrine in prehospital cardiac arrest. JAMA.1992;268(19):2667-72.

289. Brown CG, Martin DR, Pepe PE, Stueven H, Cummins RO, Gonzalez E, et al. A comparison of standard-dose and high-dose epinephrine in cardiac arrest outside the hospital. The Multicenter High-Dose Epinephrine Study Group. N Engl J Med. 1992;327(15):1051-5.

290. Sherman BW, Munger MA, Foulke GE, Rutherford WF, Panacek EA. Highdose versus standard-dose epinephrine treatment of cardiac arrest after failure of standard therapy. Pharmacotherapy. 1997;17(2):242-7.

291. Stiell IG, Hebert PC, Weitzman BN, Wells GA, Raman S, Stark RM, et al. High-dose epinephrine in adult cardiac arrest. N Engl J Med. 1992;327(15):1045-50.

292. Goto Y, Maeda T, Goto Y. Effects of prehospital epinephrine during outofhospital cardiac arrest with initial non-shockable rhythm: an observational cohort study. Crit Care. 2013;17(5):R188.

293. Nakahara S, Tomio J, Nishida M, Morimura N, Ichikawa M, Sakamoto T. Association between timing of epinephrine administration and intact neurologic survival following out-of-hospital cardiac arrest in Japan: a population-based prospective observational study. Acad Emerg Med. 2012;19(7):782-92.

294. Koscik C, Pinawin A, McGovern H, Allen D, Media DE, Ferguson T, et al. Rapid epinephrine administration improves early outcomes in out-ofhospital cardiac arrest. Resuscitation. 2013;84(7):915-20.

295. Aung K, Htay T. Vasopressin for cardiac arrest: a systematic review and metaanalysis. Arch Intern Med. 2005;165(1):17-24.

296. Kudenchuk PJ, Cobb LA, Copass MK, Cummins RO, Doherty AM, Fahrenbruch CE, et al. Amiodarone for resuscitation after out-ofhospital cardiac arrest due to ventricular fibrillation. N Engl J Med. 1999;341(12):871-8.
297. Jemmett ME, Kendal KM, Fourre MW, Burton JH. Unrecognized misplacement of endotracheal tubes in a mixed urban to rural emergency medical services setting. Acad Emerg Med. 2003;10(9):961-5.

298. Weaver WD, Fahrenbruch CE, Johnson DD, Hallstrom AP, Cobb LA, Copass MK. Effect of epinephrine and lidocaine therapy on outcome after cardiac arrest due to ventricular fibrillation. Circulation. 1990;82(6):2027-34.

299. Herlitz J, Ekström L, Wennerblom B, Axelsson A, Bang A, Lindkyist J, et al. Lidocaine in out-of-hospital ventricular fibrillation. Does it improve survival? Resuscitation. 1997; 33(3):199-205.

300. Teo KK, Yusuf S, Furberg CD. Effects of prophylactic antiarrhythmic drug therapy in acute myocardial infarction. An overview of results from randomized controlled trials. JAMA. 1993;270(13):1589-95.

301. Kudenchuk PJ, Newell C, White L, Fahrenbruch C, Rea T, Eisenberg M. Prophylactic lidocaine for post resuscitation care of patients with out-of-hospital ventricular fibrillation cardiac arrest. Resuscitation. 2013;84(11):1512-8.

302. Hassan TB, Jagger $C$, Barnett DB. A randomized trial to investigate the efficacy of magnesium sulphate for refractory ventricular fibrillation. Emerg Med J. 2002;19(1):57-62.

303. Manz M, Jung W, Lueritz B. Effect of magnesium on sustained ventricular tachycardia. Herz. 1997; Jun;22( Suppl 1):51-5.

304. Markel DT, Gold LS, Allen J, Fahrenbruch CE, Rea TD, Eisenberg MS, et al. Procainamide and survival in ventricular fibrillation out-of-hospital cardiac arrest. Acad Emerg Med. 2010;17(6):617-23.

305. Skrifvars MB, Pettilä V, Rosenberg PH, Castrén M. A multiple logistic regression analysis of in-hospital factors related to survival at six months in patients resuscitated from out-of-hospital ventricular fibrillation. Resuscitation. 2003;59(3):319-28.

306. Longstreth WT Jr, Copass MK, Dennis LK, Rauch-Matthews ME, Stark MS, Cobb LA. Intravenous glucose after out-of-hospital cardiopulmonary arrest: a community-based randomized trial. Neurology. 1993;43(12):2534-41.

307. Engdahl J, Bang A, Lindqvist J, Herlitz J. Factors affecting short- and longterm prognosis among 1069 patients with out-of-hospital cardiac arrest and pulseless electrical activity. Resuscitation. 2001;51(1):17-25.

308. Weil MH, Rackow EC, Trevino R, Grundler W, Falk JL, Griffel MI. Difference in acid-base state between venous and arterial blood during cardiopulmonary resuscitation. N Engl J Med. 1986;315(3):153-6.

309. Stueven HA, Thompson BN, Aprahamian C, Tonsfeldt DJ. Calcium chloride: reassessment of use in asystole. Ann Emerg Med. 1984;13(9 Pt 2):820-2.

310. Stueven HA, Thompson B, Aprahamian C, Tonsfeldt DJ, Kastenson EH. The effectiveness of calcium chloride in refractory electromechanical dissociation. Ann Emerg Med. 1985;14(7):626-9.

311. Mentzelopoulos SD, Malachias S, Chamos C, Konstantopoulos D, Ntaidou T, Papastylianou A, et al. Vasopressin, steroids, and epinephrine and neurologically favorable survival after in-hospital cardiac arrest: a randomized clinical trial. JAMA. 2013;310(3):270-9.

312. Spöhr F, Arntz HR, Bluhmki E, Bode C, Carli P, Chamberlain D, et al. International multicentre trial protocol to assess the efficacy and safety of tenecteplase during cardiopulmonary resuscitation in patients with outof-hospital cardiac arrest: the Thrombolysis in Cardiac Arrest (TROICA) Study. Eur J Clin Invest. 2005;35(5):315-23.

313. Keuper W, Dieker HJ, Brouwer MA, Verheugt FW. Reperfusion therapy in out-of-hospital cardiac arrest: current insights. Resuscitation. 2007;73(2):189-201.

314. Hedges JR, Syverud SA, Dalsey WC, Feero S, Easter R, Shultz B. Prehospital trial of emergency transcutaneous cardiac pacing. Circulation. 1987;76(6):1337-43.

315. Cummins RO, Graves JR, Larsen MP, Hallstrom AP, Hearne TR, Ciliberti $\mathrm{J}$, et al. Out-of-hospital transcutaneous pacing by emergency medical 
technicians in patients with asystolic cardiac arrest. N Engl J Med. 1993;328(19):1377-82.

316. Madias C, Maron BJ, Alsheikh-Ali AA, Rajab M, Estes NA 3rd, Link MS. Precordial thump for cardiac arrest is effective for asystole but not for ventricular fibrillation. Heart Rhythm. 2009;6(10):1495-500.

317. Miller J, Tresch D, Horwitz L, Thompson BM, Aprahamian C, Darin JC. The precordial thump. Ann Emerg Med. 1984;13(9 Pt 2):791-4.

318. Haman L, Parizek P, Vojacek J. Precordial thump efficacy in termination of induced ventricular arrhythmias. Resuscitation. 2009;80(1):14-6.

319. Deakin CD, Nolanb JP, Soarc J, Sunded K, Kostere RW, Smith GB, et al. European Resuscitation Council Guidelines for Resuscitation 2010 Section 4. Adult advanced life support. Resuscitation. 2010;81(10):1305-52.

320. Mangrum JM, DiMarco JP. The evaluation and management of bradycardia. N Engl J Med. 2000;342(10):703-9.

321. Mancini ME, Soar J, Bhanji F, Billi JE, Dennett J, Finn J, et al. Part 12: Education, Implementation, and Teams: 2010 International Consensus on Cardiopulmonary Resuscitation and Emergency Cardiovascular Care Science With Treatment Recommendations. Circulation. 2010;122(16 Suppl 2):S539-81.

322. Nolan J, Smith G, Evans R, McCusker K, Lubas P, Parr M, et al. The United Kingdom pre-hospital study of active compression decompression resuscitation. Resuscitation. 1998;37(2):119-25.

323. Mandal A. Que é bradicardia? [Internet] [Citado 2010 fev 22] Disponível em http://www. news-medical.net/health/Bradycardia-Causes(Portuguese).aspx.

324. Thomsen JH, Nielsen N, Hassager C, Wanscher M, Pehrson S, Køber L, et al. Bradycardia during targeted temperature management: an early marker of lower mortality and favorable neurologic outcome in comatose out-ofhospital cardiac arrest patients. Crit Care Med. 2016;44(2):308-18.

325. Staer-Jensen H, Sunde K, Olasveengen TM, Jacobsen D, Drægni T, Nakstad $\mathrm{ER}$, et al. Bradycardia during therapeutic hypothermia is associated with good neurologic outcome in comatose survicors of out-of-hospital cardiac arrest. Crit Care Med. 2014;42(11):2401-8.

326. Furman S, Hayers D, Holmes D. A practice of cardiac pacing. New York: Futura Publishing; 1986.

327. Smith I, Monk TG, White PF. Comparison of transesophageal atrial pacing with anticholinergic drugs for the treatment of intraoperative bradycardia. Anesth Analg. 1994;78(2):245-52.

328. Brady WJ, Swart G, DeBehnke DJ, Ma OJ, Aufderheide TP. The efficacy of atropine in the treatment of hemodynamically unstable bradycardia and atrioventricular block: prehospital and emergency department considerations. Resuscitation. 1999;41(1):74-55.

329. Dauchot P, Gravenstein JS. Effects of atropine on the eletrocardiogram in different age groups. Clin Pharmacol Ther. 1971;12(2):274-80.

330. Bektas F, Soyuncu S. The efficacy of transcutaneous cardiac pacing in ED. Am J Emerg Med. 2016;34(11):2090-3.

331. Mehta D, Wafa S, Ward DE, Camm AJ. Relative efficacy of various physical manoeuvres in the termination of junctional tachycardia. Lancet. 1988;1(8596):1181-5

332. Engelstein ED, Lippman N, Stein KM, Lerman BB. Mechanismspecific effects of adenosine on atrial tachycardia. Circulation. 1994;89(6):2645-54

333. Markowitz SM, Stein KM, Mittal S, Slotwiner DJ, Lerman BB. Differential effects of adenosine on focal and macroreentrant atrial tachycardia. J Cardiovasc Electrophysiol. 1999;10(4):489-502.

334. Stock JP. Beta adrenergic blocking drugs in the clinical management of cardiac arrhythmias. Am J Cardiol. 1966;18(3):444-9.

335. Steinbeck G, Hoffmann E. 'True' atrial tachycardia. Eur Heart J. 1998;19 (Suppl E):E10-2, E48-9.
336. Lim SH, Anantharaman V, Teo WS, Goh PP, Tan AT. Comparison of treatment of supraventricular tachycardia by Valsalva maneuver and carotid sinus massage. Ann Emerg Med. 1998;31(1):30-5.

337. Wen ZC, Chen SA, Tai CT, Chiang CE, Chiou CW, Chang MS, et al. Electrophysiological mechanisms and determinants of vagal maneuvers for termination of paroxysmal supraventricular tachycardia. Circulation. 1998;98(24):2716-23.

338. Derbes VJ, Kerr A. Valsalva's maneuver and Weber's experiment. N Engl J Med. 1955;253(19):822-3.

339. Smith GD, Fry MM, Morgans A, Cantwell K. Effectiveness of the Valsalva manoeuvre for reversion of supraventricular tachycardia. Cochrane Database Syst Rev. 2015 Feb 18;(2):CD009502.

340. Davies AJ, Kenny RA. Frequency of neurologic complications following carotid sinus massage. Am J Cardiol. 1998;81(10):1256-7.

341. Cheng KA.; Intravenous Adenosine versus Verapamil in Terminating Episodes of Paroxysmal Supraventricular Tachycardia Study Group. A randomized, multicenter trial to compare the safety and efficacy of adenosine versus verapamil for termination of paroxysmal supraventricular tachycardia. Zhonghua Nei Ke Za Zhi. 2003;42(11):773-6.

342. Hood MA, Smith WM. Adenosine versus verapamil in the treatment of supraventricular tachycardia: a randomized double-crossover trial. Am Heart J. 1992;123(6):1543-9.

343. Rankin AC, Oldroyd KG, Chong E, Dow JW, Rae AP, Cobbe SM. Adenosine or adenosine triphosphate for supraventricular tachycardias? Comparative double-blind randomized study in patients with spontaneous or inducible arrhythmias. Am Heart). 1990;119(2 Part 1):316-23.

344. Biaggioni I, Olafsson B, Robertson RM, Hollister AS, Robertson D. Cardiovascular and respiratory effects of adenosine in conscious man evidence for chemoreceptor activation. Circ Res. 1987;61(6):779-86.

345. Kaplan IV, Kaplan AV, Fisher JD. Adenosine induced atrial fibrillation precipitating polymorphic ventricular tachycardia. Pacing Clin Electrophysiol. 2000;23(1):140-1.

346. Gupta AK, Shah CP, Maheshwari A, Thakur RK, Hayes OW, Lokhandwala YY. Adenosine induced ventricular fibrillation in Wolff-Parkinson-White syndrome. Pacing Clin Electrophysiol. 2002;25(4 Pt 1):477-80.

347. Ross DL, Uther JB. Diagnosis of concealed accessory pathways in supraventricular tachycardia. Pacing Clin Electrophysiol. 1984;7(6 Pt 1):1069-85.

348. Poutiainen AM, Koistinen MI, Airaksinen KE, Hartikainen EK, Kettunen RV, Karjalainen JE, et al. Prevalence and natural course of ectopic atrial tachycardia. Eur Heart J. 1999;20(9):694-700.

349. Olshansky B, Rosenfeld LE, Warner AL, et al. The Atrial Fibrillation Followup Investigation of Rhythm Management (AFFIRM) study: approaches to control rate in atrial fibrillation. J Am Coll Cardiol. 2004;43(7):1201-8.

350. Gupta A, Naik A, Vora A, Lokhandwala Y. Comparison of efficacy of intravenous diltiazem and esmolol in terminating supraventricular tachycardia. J Assoc Physicians India. 1999;47(10):969-72.

351. Olukotun AY, Klein GJ. Efficacy and safety of intravenous nadolol for supraventricular tachycardia. Am J Cardiol. 1987;60(6):59D-62D.

352. Anderson S, Blanski L, Byrd RC, Das G, Engler R, Laddu A, etal. Comparison of the efficacy and safety of esmolol, a short-acting beta blocker, with placebo in the treatment of supraventricular tachyarrhythmias. Am Heart . 1986;111(1):42-8

353. Wesley RC Jr, Haines DE, Lerman BB, DiMarco JP, Crampton RS. Effect of intravenous magnesium sulfate on supraventricular tachycardia. Am . Cardiol. 1989;63(15):1129-31.

354. Joshi PP, Deshmukh PK, Salkar RG. Efficacy of intravenous magnesium sulphate in supraventricular tachyarrhythmias. J Assoc Physicians India. 1995:43(8):529-31. 
355. Stiles MK, Sanders P, Disney P, Brooks A, John B, Lau DH, et al. Differential effects of intravenous magnesium on atrioventricular node conduction in supraventricular tachycardia. Am J Cardiol. 2007;100(8):1249-53.

356. Weigner MJ, Caulfield TA, Danias PG, Silverman DI, Manning WJ. Risk for clinical thromboembolism associated with conversion to sinus rhythm in patients with atrial fibrillation lasting less than 48 hours. Ann Intern Med. 1997;126(8):615-20.

357. Galve E, Rius T, Ballester R, Artaza MA, Arnau JM, García-Dorado $\mathrm{D}$, et al. Intravenous amiodarone in treatment of recent-onset atrial fibrillation: results of a randomized, controlled study. J Am Coll Cardiol. 1996;27(5):1079-82.

358. Stambler BS, Wood MA, Ellenbogen KA. Comparative efficacy of intravenous ibutilide versus procainamide for enhancing termination of atrial flutter by atrial overdrive pacing. Am J Cardiol. 1996;77(11):960-6.

359. Donovan KD, Power BM, Hockings BE, Dobb GJ, Lee KY. Intravenous flecainide versus amiodarone for recent-onset atrial fibrillation. Am J Cardiol. 1995;75(10):693-7.

360. Kochiadakis GE, Igoumenidis NE, Simantirakis EN, Marketou ME, Parthenakis FI, Mezilis NE, et al. Intravenous propafenone versus intravenous amiodarone in the management of atrial fibrillation of recent onset: a placebo-controlled study. Pacing Clin Electrophysiol. 1998;21(11 Pt 2):2475-9.

361. Ellenbogen KA, Stambler BS, Wood MA, Sager PT, Wesley RC Jr, Meissner $M C$, et al. Efficacy of intravenous ibutilide for rapid termination of atrial fibrillation and atrial flutter: a dose-response study. J Am Coll Cardiol. 1996;28(1):130-6.

362. Alboni P, Botto GL, Baldi N, Luzi M, Russo V, Gianfranchi L, etal. Outpatient treatment of recent-onset atrial fibrillation with the "pill-in-the-pocket" approach. N Engl J Med. 2004;351(23):2384-91.

363. Alp NJ, Bell JA, Shahi M. Randomised double blind trial of oral versus intravenous flecainide for the cardioversion of acute atrial fibrillation. Heart. 2000;84(1):37-40.

364. Botto GL, Bonini W, Broffoni T, Molteni S, Lombardi R, Alfieri G, et al. Conversion of recent onset atrial fibrillation with single loading oral dose of propafenone: is in-hospital admission absolutely necessary? Pacing Clin Electrophysiol. 1996;19(11 Pt 2):1939-43.

365. Abi-Mansour P, Carberry PA, McCowan RJ, Henthorn RW, Dunn GW, Perry KT. Conversion efficacy and safety of repeated doses of ibutilide in patients with atrial flutter and atrial fibrillation. Study Investigators. Am Heart J. 1998;136(4 Pt 1):632-42.

366. Martínez-Marcos FJ, García-Garmendia JL, Ortega-Carpio A, FernándezGómez JM, Santos JM, Camacho C. Comparison of intravenous flecainide, propafenone, and amiodarone for conversion of acute atrial fibrillation to sinus rhythm. Am J Cardiol. 2000;86(9):950-3.

367. Clemo HF, Wood MA, Gilligan DM, Ellenbogen KA. Intravenous amiodarone for acute heart rate control in the critically ill patient with atrial tachyarrhythmias. Am J Cardiol 1998;81(5):594-8.

368. Camm AJ, Capucci A, Hohnloser SH, Torp-Pedersen C, Van Gelder IC, Mangal B, et al. A randomized active-controlled study comparing the efficacy and safety of vernakalant to amiodarone in recent-onset atrial fibrillation. J Am Coll Cardiol. 2011;57(3):313-21.

369. Roy D, Pratt CM, Torp-Pedersen C, Wyse DG, Toft E, Juul-Moller $S$, et al. Vernakalant hydrochloride for rapid conversion of atrial fibrillation: a phase 3, randomized, placebo-controlled trial. Circulation. 2008;117(12):1518-25

370. Reisinger J, Gatterer E, Heinze G, Wiesinger K, Zeindlhofer E, Gattermeier $\mathrm{M}$, et al. Prospective comparison of flecainide versus sotalol for immediate cardioversion of atrial fibrillation. Am J Cardiol. 1998;81(12):1450-4.

371. Platia EV, Michelson EL, Porterfield JK, Das G. Esmolol versus verapamil in the acute treatment of atrial fibrillation or atrial flutter. Am J Cardiol. 1989;63(13):925-9.
372. Ellenbogen KA, Dias VC, Cardello FP, Strauss WE, Simonton CA, Pollak SJ, et al. Safety and efficacy of intravenous diltiazem in atrial fibrillation or atrial flutter. Am J Cardiol. 1995;75(1):45-9.

373. Fromm C, Suau SJ, Cohen V, Likouzeros A, Jellinek-Cohen S, Rose J, et al. Diltiazem vs metoprolol in the management of atrial fibrillation or flutter with rapid ventricular rate in the emergency department. J Emerg Med. 2015;49(2):175-82.

374. Sellers TD Jr, Bashore TM, Gallagher JJ. Digitalis in the preexcitation syndrome. Analysis during atrial fibrillation. Circulation. 1977;56(2):260-7.

375. Akhtar M, Shenasa M, Jazayeri M, Caceres J, Tchou PJ. Wide QRS complex tachycardia. Reappraisal of a common clinical problem. Ann Intern Med. 1988;109(11):905-12.

376. Brugada P, Brugada J, Mont L, Smeets J, Andries EW. A new approach to the differential diagnosis of a regular tachycardia with a wide QRS complex. Circulation. 1991;83(5):1649-59.

377. Vereckei A, Duray G, Szénási G, Altemose GT, Miller JM. Application of a new algorithm in the differential diagnosis of wide QRS complex tachycardia. Eur Heart J. 2007;28(5):589-600.

378. Stewart RB, Bardy GH, Greene HL. Wide complex tachycardia: misdiagnosis and outcome after emergent therapy. Ann Intern Med. 1986;104(6):766-71.

379. Wellens HJ, Conover M. The EGC in emergency decision marking.Wide QRS Tachycardia. Philadelphia: WB Saunders; 2006. p. 129-157.

380. Gupta AK, Thakur RK. Wide QRS complex tachycardias. Med Clin North Am. 2001;85(2):245-66.

381. Somberg JC, Bailin SJ, Haffajee Cl, Paladino WP, Kerin NZ, Bridges D, et al. Intravenous lidocaine versus intravenous amiodarone (in a new aqueous formulation) for incessant ventricular tachycardia. Am J Cardiol. 2002;90(8):853-9

382. Marill KA, deSouza IS, Nishijima DK, Stair TO, Setnik GS, Ruskinn IN. Amiodarone is poorly effective for the acute termination of ventricular tachycardia. Ann Emerg Med. 2006;47(3):217-24.

383. Schutzenberger W, Leisch F, Kerschner K, Harringer W, Herbinger W. Clinical efficacy of intravenous amiodarone in the short term treatment of recurrent sustained ventricular tachycardia and ventricular fibrillation. Br Heart J. 1989;62(5):367-71.

384. Tomlinson DR, Cherian P, Betts TR, Bashir Y. Intravenous amiodarone for the pharmacological termination of haemodynamically tolerated sustained ventricular tachycardia: is bolus dose amiodarone an appropriate first-line treatment? Emerg Med J. 2008;25(1):15-8.

385. Marill KA, deSouza IS, Nishijima DK, Senecal EL, Setnik GS, Stair TO, et al. Amiodarone or procainamide for the termination of sustained stable ventricular tachycardia: an historical multicenter comparison. Acad Emerg Med. 2010;17(3):297-306.

386. Gorgels AP, van den Dool A, Hofs A, Mulleneers R, Smeets IL, Vos MA, et al. Comparison of procainamide and lidocaine in terminating sustained monomorphic ventricular tachycardia. Am J Cardiol. 1996;78(1):43-6.

387. Ho DS, Zecchin RP, Richards DA, Uther JB, Ross DL. Double-blind trial of lignocaine versus sotalol for acute termination of spontaneous sustained ventricular tachycardia. Lancet. 1994;344(8914):18-23.

388. Taylor SE. Amiodarone: an emergency medicine perspective. Emerg Med (Fremantle). 2002;14(4):422-9.

389. Ortiz M, Martin A, Arribas F, Coll-Vinent B, Del Arco C, Peinado R, et al. Randomized comparison of intravenous procainamide vs. intravenous amiodarone for the acute treatment of tolerated wide QRS tachycardia: the PROCAMIO study. Eur Heart J. 2017;38(17):1329-35.

390. Passman R, Kadish A. Polymorphic ventricular tachycardia, long Q-T syndrome, and torsades de pointes. Med Clin North Am. 2001;85(2):321-41 
391. Khan IA. Long QT syndrome: diagnosis and management. Am Heart J. 2002;143(1):7-14

392. Eryol NK, Colak R, OzdogruR I, Tanriverdi F, Unal S, Topsakal R, etal. Effects of calcium treatment on QT interval and QT dispersion in hypocalcemia. Am J Cardiol. 2003;91(6):750-2.

393. Benoit SR, Mendelsohn AB, Nourjah P, Staffa JA, Graham DJ. Risk factors for prolonged QTc among US adults: Third National Health and Nutrition Examination Survey. Eur J Cardiovasc Prev Rehabil. 2005;12(4):363-8.

394. Halkin A, Roth A, Lurie I, Fish R, Belhassen B, Viskin S. Pause-dependent torsade de pointes following acute myocardial infarction: a variant of the acquired long QT syndrome. J Am Coll Cardiol. 2001;38(4):1168-74.

395. Kurita T, Ohe T, Marui N, Aihara N, Takaki H, Kamamura S, et al. Bradycardia-induced abnormal QT prolongation in patients with complete atrioventricular block with torsades de pointes. Am J Cardiol. 1992;69(6):628-33

396. Tötterman KJ, Turto H, Pellinen T. Overdrive pacing as treatment of sotalolinduced ventricular tachyarrhythmias (torsade de pointes). Acta Med Scand Suppl. 1982;668:28-33.

397. Assimes TL, Malcolm I. Torsade de pointes with sotalol overdose treated successfully with lidocaine. Can J Cardiol. 1998;14(5):753-6.

398. Vukmir RB, Stein KL. Torsades de pointes therapy with phenytoin. Ann Emerg Med. 1991;20(2):198-200.

399. Hypothermia after Cardiac Arrest Study Group. Mild therapeutic hypothermia to improve the neurologic outcome after cardiac arrest. N Engl J Med. 2002;346(8):549-56.

400. Bernard SA, Gray TW, Buist MD, Jones BM, Silvester W, Gutteridge G, et al. Treatment of comatose survivors of out-of-hospital cardiac arrest with induced hypothermia. N Engl J Med. 2002;346(8):557-63.

401. Peberdy MA, Callaway CW, Neumar RW, Geocadin RG, Zimmerman JL, Donnino M, et al. Part 9: Post-Cardiac arrest care in: 2010 international consensus on cardiopulmonary resuscitation and emergency cardiovascular care science with treatment and recommendations. Circulation 2010;122(18 Suppl 3):S738-86.

402. Laver S, Farrow C, Turner D, Nolan J. Mode of death after admission to an intensive care unit following cardiac arrest. Intensive Care Med. 2004;30(11):2126-8.

403. Belliard G, Catez E, Charron C, Caille V, Aegerter P, Dubourg O, et al. Efficacy of therapeutic hypothermia after out-of-hospital cardiac arrest due to ventricular fibrillation. Resuscitation. 2007;75(2):252-9.

404. Castrejón S, Cortés M, Salto ML, Benittez LC, Rubio R, Juárez M, et al. Improved prognosis after using mild hypothermia to treat cardiorespiratory arrest due to a cardiac cause: comparison with a control group. Rev Esp Cardiol. 2009;62(7):733-41.

405. Kilgannon JH, Jones AE, Shapiro NI, Angelos MG, Milcarek B, Hunter K, et al. Association between arterial hyperoxia following resuscitation from cardiac arrest and in-hospital mortality. JAMA. 2010;303(21):2165-71.

406. Menon DK, Coles JP, Gupta AK, Fryer TD, Smielewski P, Chatfield DA, et al. Diffusion limited oxygen delivery following head injury. Crit Care Med. 2004;32(6):1384-90.

407. Alhazzani W, Alshahrani M, Jaeschke R, Forel JM, Papazian L, Sevransky $J$, et al. Neuromuscular blocking agents in acute respiratory distress syndrome: a systematic review and meta-analysis of randomized controlled trials. Crit Care. 2013;17(2):R43.

408. Salciccioli JD, Cocchi MN, Rittenberger JC, Peberdy MA, Ornato JP, Abella BS, et al. Continuous neuromuscular blockade is associated with decreased mortality in post-cardiac arrest patients. Resuscitation. 2013;84(12):1728-33.

409. Noc M, Fajadet J, Lassen JF, Kala P, MacCarthy P, Olivecrona GK, et al. Invasive coronary treatment strategies for out-of-hospital cardiac arrest: a consensus statement from the European association for percutaneous cardiovascular interventions (EAPCI)/stent for life (SFL) groups. Euro Intervention. 2014;10(1):31-7.

410. Nolan JP, Soar J, Cariou A, Cronberg T, Moulaert VR, Deakin CD, Bottiger BW, et al. European Resuscitation Council and European Society of Intensive Care Medicine Guidelines for Post-resuscitation Care 2015 - Section 5 of the European Resuscitation Council Guidelines for Resuscitation 2015. Resuscitation. 2015 Oct;95:202-22.

411. Nolan JP, Hazinski MF, Billi JE, Boettiger BW, Bossaert L, de Caen AR, et al. Part 1: Executive summary: 2010 International Consensus on Cardiopulmonary Resuscitation and Emergency Cardiovascular Care Science with Treatment recommendations. Resuscitation. 2010 Oct;81(Suppl 1): e1-25.

412. ILCOR update: Target temperature management. Target temperature management following cardiac arrest: An update. ILCOR 2013. [Cited in 2015 Dec 10]. Available from: http://www.ilcor.org/data/TTM-ILCORupdate-Dec-2013.pdf

413. Nielsen N, Wetterslev J, Cronberg T, Erlinge D, Gasche Y, Hassager C, et al. Target temperature management at $33 \mathrm{C}$ versus $36 \mathrm{C}$ after cardiac arrest. N Engl J Med. 2013;369(23):2197-206

414. Bro-Jeppesen J, Kjaergaard J, Horsted TI, Wanscher MC, Nielsen SL, Rasmussen LS, et al. The impact of therapeutic hypothermia on neurological function and quality of life after cardiac arrest. Resuscitation. 2009;80(2):171-6.

415. Arrich J. Clinical application of mild therapeutic hypothermia after cardiac arrest. Crit Care Med. 2007;35(4):1041-7.

416. Sunde K, Pytte M, Jacobsen D, Mangschau A, Jensen LP, Smedsrud C, et al. Implementation of a standardised treatment protocol for post resuscitation care after out-of-hospital cardiac arrest. Resuscitation. 2007;73(1):29-39.

417. Bernard SA, Jones BM, Horne MK. Clinical trial of induced hypothermia in comatose survivors of out-of-hospital cardiac arrest. Ann Emerg Med. 1997;30(2):146-53

418. Holzer M, Müllner M, Sterz F, Robak O, Kliegel A, Losert H, et al. Efficacy and safety of endovascular cooling after cardiac arrest: cohort study and Bayesian approach. Stroke. 2006;37(7):1792-7.

419. Kim F, Olsufka M, Carlbom D, Deem S, Longstreth WT Jr, Hanrahan M et al. Pilot study of rapid infusion of $2 \mathrm{~L}$ of 4 degrees $\mathrm{C}$ normal saline for induction of mild hypothermia in hospitalized, comatose survivors of out-of-hospital cardiac arrest. Circulation. 2005;112(5):715-9.

420. Nielsen N, Friberg H. Temperature management after cardiac arrest. Curr Opin Crit Care. 2015;21(3):202-8.

421. Yokoyama H, Nagao K, Hase M, Tahara Y, Hazui H, Arimoto H, et al Impact of therapeutic hypothermia in the treatment of patients with outof-hospital cardiac arrest from the J-PULSEHYPO study registry. Circ J. 2011;75(5):1063-70.

422. Lee BK, Lee SJ, Jeung KW, Lee HY, Heo T, Min Y. Outcome and adverse events with 72-hour cooling at 32 degrees $C$ as compared to 24-hour cooling at 33 degrees $\mathrm{C}$ in comatose asphyxial arrest survivors. Am J Emerg Med. 2014;32(4):297-301.

423. Imamura M, Matsukawa T, Ozaki M, Sessler DI, Nishiyama T, Kumazawa T. The accuracy and precision of four infrared aural canal thermometers during cardiac surgery. Acta Anaesthesiol Scand. 1998;42(2):1222-6.

424. Pujol A, Fusciardi J, Ingrand P, Baudouin D, Le Guen AF, Menu P. After drop after hypothermic cardiopulmonary bypass: the value of tympanic membrane temperature monitoring. J Cardiothorac Vasc Anesth. 1996;10(3):336-41.

425. Kliegel A, Losert H, Sterz F, Kliegel M, Holzer M, Uray T, et al. Cold simple intravenous infusions preceding special endovascular cooling for faster induction of mild hypothermia after cardiac arrest-a feasibility study. Resuscitation. 2005:64(3):347-51.

426. Kim F, Olsufka M, Carlbom D, Deem S, Longstreth WT Jr, Hanrahan M, et al. Pilot study of rapid infusion of $2 \mathrm{~L}$ of 4 degrees $\mathrm{C}$ normal saline for 
induction of mild hypothermia in hospitalized, comatose survivors of out-of-hospital cardiac arrest. Circulation. 2005;112(5):715-9.

427. Rocha TH, Vieira SR. Hiportermia terapêutica em pacientes pós-parada cardiorrespiratória: mecanismos de ação e desenvolvimento de protocolo assistencial. Rev Bras Ter Intensiva. 2010;22(2):196-205.

428. Zeiner A, Holzer M, Sterz F, Schörkhuber W, Eisenburger P, Havel C, et al. Hyperthermia after cardiac arrest is associated with an unfavorable neurologic outcome. Arch Intern Med. 2001;161(16):2007-12.

429. Mahmood MA, Zweifler RM. Progress in shivering control. J Neurol Sci 2007;261(1-2):47-54.

430. Polderman KH, Herold I. Therapeutic hypothermia and controlled normothermia in the intensive care unit: practical considerations, side effects, and cooling methods. Crit Care Med. 2009;37(3):1101-20.

431. Wadhwa A, Sengupta P, Durrani J, Akça O, Lenhardt R, Sessler DI, et al. Magnesium sulphate only slightly reduces the shivering threshold in humans. Br J Anaesth. 2005;94(6):756-62.

432. Neumar RW, Nolan JP, Adrie C, Aibiki M, Berg RA, Böttiger BW, et al. Post cardiac arrest syndrome: epidemiology, pathophysiology, treatment, and prognostication. A consensus statement from the international liaison committee on resuscitation; the american heart association emergency cardiovascular care committee; the council on cardiovascular surgery and anesthesia; the council on cardiopulmonary, perioperative, and critical care; the council on clinical cardiology; and the stroke council. Circulation. 2008;118(23):2452-83.

433. Gonzalez MM, Timerman S, Gianotto-Oliveira R, Polastri TF, Canesin MF, Schimidt A, et al. Sociedade Brasileira de Cardiologia. I Diretriz de ressuscitação cardiopulmonar e cuidados cardiovasculares de emergência da Sociedade Brasileira de Cardiologia. Arq Bras Cardiol. 2013;101(2 Suppl 3):1-221.

434. Neumar RW, Otto CW, Link MS, Kronick SL, Shuster M, Callaway CW, et al. Part 8: adult advanced cardiac life support. 2010 americas heart association guidelines for cardiopulmonay resuscitation and emergency cardiovascular care. Circulation. 2010;122(18 Suppl 3):S729-67.

435. Peberdy MA, Callaway CW, Neumar RW, Geocadin RG, Zimmerman IL, Donnino M, et al. Part 9: Post-Cardiac arrest care in: 2010 international consensus on cardiopulmonary resuscitation and emergency cardiovascular care science with treatment and recommendations. Circulation. 2010;122(18 Suppl 3):S738-86.

436. Polderman KH. Application of therapeutic hypothermia in the intensive care unit: opportunities and pitfalls of a promising treatment modality, part 2: practical aspects and side effects. Intensive Care Med. 2004;30(5):757-69.

437. Polderman KH, Peerdeman SM, Girbes AR. Hypophosphatemia and hypomagnesemia induced by cooling in patients with severe head injury. J Neurosurg. 2001;94(5):697-705.

438. Tortorici MA, Kochanek PM, Poloyac SM. Effects of hypothermia on drug disposition, metabolism, and response: a focus of hypothermiamediated alterations on the cytochrome P450 enzyme system. Crit Care Med. 2007;35(9):2196-204.

439. Hovdenes J, Laake JH, Aaberge L, Haugaa H, Bugge JF. Therapeutic hypothermia after out-of-hospital cardiac arrest: experiences with patients treated with percutaneous coronary intervention and cardiogênico shock. Acta Anaesthesiol Scand. 2007;51(2):137-42.

440. Gillies MA, Pratt R, Whiteley C, Borg J, Beale RJ, Tibby SM. Therapeutic hypothermia after cardiac arrest: a retrospective comparison of surface and endovascular cooling techniques. Resuscitation. 2010;81(9)1117-22.

441. Polderman KH, Herold I. Therapeutic hypothermia and controlled normothermia in the intensive care unit: practical considerations, side effects, and cooling methods. Crit Care Med. 2009;37(3):1101-20

442. Winters SA, Wolf KH, Kettinger SA, Seif EK, Jones JS, Bacon-Baguley T. Assessment of risk factors for post-rewarming "rebound hyperthermia" in cardiac arrest patients undergoing therapeutic hypothermia. Resuscitation. 2013;84(9):1245-9.
443. Bro-Jeppesen J, Hassager C, Wanscher M, Søholm H, Thomsen JH, Lippert FK, et al. Post-hypothermia fever is associated with increased mortality after out-of-hospital cardiac arrest. Resuscitation. 2013;84(12):1734-40.

444. Nielsen N, Hovdenes J, Nilsson F, Rubertsson S, Stammet P, Sunde K, et al. Outcome, timing and adverse events in therapeutic hypothermia after outof-hospital cardiac arrest. Acta Anaesthesiol Scand. 2009;53(7):926-34 .

445. Schmidt-Schweda S, OhlerA, PostH, PieskeB. Moderate hypothermia for severe cardiogenic shock (COOL Shock Study I \& II). Resuscitation. 2013;84(3):319-25.

446. Nolan JP, Morley PT, Hoek TL, Hickey RW; Advancement Life support Task Force of the International Liaison committee on Resuscitation. Therapeutic hypothermia after cardiac arrest. An advisory statement by the Advancement Life support Task Force of the International Liaison committee on Resuscitation. Resuscitation. 2003;57(3):231-5.

447. Thygesen K, Alpert JS, Jaffe AS, Simoons ML, Chaitman BR, White HD, et al. Third universal definition of myocardial infarction. Circulation. 2012;126(16):2020-35.

448. Sabatine MS, Cannon CP. Approach to the patient with chest pain. In: Bonow Ro, Mann D, Zipes D, Libby P. Braunwald's heart disease: a textbook of cardiovascular medicine. 9th ed. Philadelphia: Elsevier; 2012. Chap35; p. 1076-86.

449. Thom T, Kannel W, Silbershatz H. Cardiovascular diseases in the United States and prevention approaches. In: Fuster V, Alexander R, Schlant R, O' Rourke R, Roberts R, Sonnenblick E (editors). Hurst's the Heart. 10th ed. New York: McGraw-Hill; 2001. p. 3-7.

450. Lopez AD, Mathers CD, Ezzati M, Jamison DT, Murray CJ. Global and regional burden of disease and risk factors, 2001: systematic analysis of population health data. Lancet. 2006;367(9524):1747-57.

451. Peterson ED, Roe MT, Mulgund J, DeLong ER, Lytle BL, Brindis RG, et al. Association between hospital process performance and outcomes among patients with acute coronary syndromes. JAMA. 2006;295(16):1912-20.

452. Go AS, Mozaffarian D, Roger VL, Benjamin EJ, Berry JD, Borden WB, et al. Heart disease and stroke statistics--2013 update: a report from the American Heart Association. Circulation. 2013;127(1):e6-e245.

453. Roger VL, Go AS, Lloyd-Jones DM, Benjamin EJ, Berry JD, Borden WB, et al. Heart disease and stroke statistics--2012 update: a report from the American Heart Association. Circulation. 2012;125(1):e2-220.

454. Bradley EH, Curry LA, Spatz ES, Herrin J, Cherlin EJ, Curtis JP, et al. Hospital strategies for reducing risk-standardized mortality rates in acute myocardial infarction. Ann Intern Med. 2012;156(9):618-26

455. Gharacholou SM, Alexander KP, Chen AY, Wang TY, Melloni C, Gibler WB, et al. Implications and reasons for the lack of use of reperfusion therapy in patients with ST-segment elevation myocardial infarction: findings from the CRUSADE initiative. Am Heart J. 2010;159(5):757-63.

456. Subherwal S, Bach RG, Chen AY, Gage BF, Rao SV, Newby LK, et al. Baseline risk of major bleeding in non-ST-segment-elevation myocardial infarction: the CRUSADE (Can Rapid risk stratification of Unstable angina patients Suppress ADverse outcomes with Early implementation of the ACC/AHA Guidelines) Bleeding Score. Circulation. 2009;119(14):1873-82.

457. Yusuf S, Reddy S, Ounpuu S, Anand S. Global burden of cardiovascular diseases: part I: general considerations, the epidemiologic transition, risk factors, and impact of urbanization. Circulation. 2001;104(22):2746-53.

458. Critchley J, Liu J, Zhao D, Wei W, Capewell S. Explaining the increase in coronary heart disease mortality in Beijing between 1984 and 1999. Circulation. 2004;110(10):1236-44.

459. Yusuf S, Hawken S, Ounpuu S, Dans T, Avezum A, Lanas F, et al. Effect of potentially modifiable risk factors associated with myocardial infarction in 52 countries (the INTERHEART study): case-control study. Lancet. 2004;364(9438):937-52.

460. Anderson JL, Adams CD, Antman EM, Bridges CR, Califf RM, Casey DE $\mathrm{Jr}$, et al. ACC/AHA 2007 guidelines for the management of patients with 
unstable angina/non-ST-Elevation myocardial infarction: a report of the American College of Cardiology/American Heart Association Task Force on Practice Guidelines (Writing Committee to Revise the 2002 Guidelines for the Management of Patients With Unstable Angina/NonST-Elevation Myocardial Infarction) developed in collaboration with the American College of Emergency Physicians, the Society for Cardiovascular Angiography and Interventions, and the Society of Thoracic Surgeons endorsed by the American Association of Cardiovascular and Pulmonary Rehabilitation and the Society for Academic Emergency Medicine. J Am Coll Cardiol. 2007; 50(7):e1-157.

461. Canto JG, Shlipak MG, Rogers WJ, Malmgren JA, Frederick PD, Lambrew $\mathrm{CT}$, et al. Prevalence, clinical characteristics, and mortality among patients with myocardial infarction presenting without chest pain. JAMA. 2000;283(24):3223-9.

462. Culic V, Eterovic D, Miric D, Silic N. Symptom presentation of acute myocardial infarction: influence of sex, age, and risk factors. Am Heart J. 2002;144(6):1012-7.

463. Brieger D, Eagle KA, Goodman SG, Steg PG, Budaj A, White K, et al. Acute coronary syndromes without chest pain, an underdiagnosed and undertreated high-risk group: insights from the Global Registry of Acute Coronary Events. Chest. 2004;126(2):461-9.

464. Canto JG, Fincher C, Kiefe Cl, Allison JJ, Li Q, Funkhouser E, et al. Atypical presentations among Medicare beneficiaries with unstable angina pectoris. Am J Cardiol. 2002;90(3):248-53.

465. Cambou JP, Simon T, Mulak G, Bataille V, Danchin N. The French registry of Acute ST elevation or non-ST-elevation Myocardial Infarction (FAST$\mathrm{MI})$ : study design and baseline characteristics. Arch Mal Coeur Vaiss. 2007;100(6-7):524-34.

466. Thygesen K, Alpert JS, Jaffe AS, Simoons ML, Chaitman BR, White HD, et al. Third universal definition of myocardial infarction. J Am Coll Cardiol. 2012;60(16):1581-98.

467. Amsterdam EA, Wenger NK, Brindis RG, CaseyJr DE, Ganiats TG, Holmes Jr DR, et al. 2014 AHA/ACC guideline for the management of patients with non-ST-elevation acute coronary syndromes: a report of the American College of Cardiology/American Heart Association Task Force on Practice Guidelines. Circulation. 2014;130(25):e344-426.

468. Januzzi JL Jr, Bamberg F, Lee H, Truong QA, Nichols JH, Karakas M, et al. High-sensitivity troponin T concentrations in acute chest pain patients evaluated with cardiac computed tomography. Circulation. $2010 \cdot 121(10): 1227-34$

469. Tomonaga Y, Gutzwiller F, Luscher TF, Riesen WF, Hug M, Diemand A, et al. Diagnostic accuracy of point-of-care testing for acute coronary syndromes, heart failure and thromboembolic events in primary care: a cluster-randomised controlled trial. BMC Fam Pract. 2011 Mar 24;12:12.

470. Armstrong PW, Fu Y, Chang WC, Topol EJ, Granger CB, Betriu A, et al. Acute coronary syndromes in the GUSTO-IIb trial: prognostic insights and impact of recurrent ischemia. The GUSTO-IIb Investigators. Circulation. 1998;98(18):1860-8.

471. Furman MI, Dauerman HL, Goldberg RJ, Yarzebski J, Lessard D, Gore JM. Twenty-two year (1975 to 1997) trends in the incidence, in-hospital and long-term case fatality rates from initial Q-wave and non-Q-wave myocardial infarction: a multi-hospital, community-wide perspective. J Am Coll Cardiol. 2001;37(6):1571-80.

472. Nicolau JC, Timerman A, Marin-Neto JA, Piegas LS, Barbosa CJDG, Franci A, et al. Diretrizes da Sociedade Brasileira de Cardiologia sobre angina instável e infarto agudo do miocárdio sem supradesnível do segmento ST. Arq Bras Cardiol. 2014;102(3Supl.1):1-61.

473. Mehran R, Pocock SJ, Nikolsky E, Clayton T, Dangas GD, Kirtane AJ, et al. A risk score to predict bleeding in patients with acute coronary syndromes. J Am Coll Cardiol. 2010;55(23):2556-66.

474. Antman EM, Cohen M, Bernink PJ, McCabe CH, Horacek T, Papuchis $\mathrm{G}$, et al. The TIMI risk score for unstable angina/non-ST elevation MI: a method for prognostication and therapeutic decision making. JAMA. 2000;284(7):835-42

475. Sabatine MS, McCabe CH, Morrow DA, Giugliano RP, de Lemos JA, Cohen $\mathrm{M}$, et al. Identification of patients at high risk for death and cardiac ischemic events after hospital discharge. Am Heart J. 2002;143(6):966-70.

476. Morrow DA, Antman EM, Snapinn SM, McCabe CH, Theroux P, Braunwald E. An integrated clinical approach to predicting the benefit of tirofiban in non-ST elevation acute coronary syndromes. Application of the TIMI Risk Score for UA/NSTEMI in PRISM-PLUS. Eur Heart J. 2002;23(3):223-9.

477. Granger CB, Goldberg RJ, Dabbous O, Pieper KS, Eagle KA, Cannon CP, et al. Predictors of hospital mortality in the global registry of acute coronary events. Arch Intern Med. 2003;163(19):2345-53.

478. Maroko PR, Radvany P, Braunwald E, Hale SL. Reduction of infarct size by oxygen inhalation following acute coronary occlusion. Circulation. 1975;52(3):360-8.

479. Kelly RF, Hursey TL, Parrillo JE, Schaer GL. Effect of $100 \%$ oxygen administration on infarct size and left ventricular function in a canine model of myocardial infarction and reperfusion. Am Heart J. 1995;130(5):957-65.

480. Stub D, Smith K, Bernard S, Nehme Z, Stephenson M, Bray JE, et al. Air versus oxygen in ST-Segment-Elevation Myocardial Infarction. Circulation. 2015;131(24):2143-50.

481. Borzak S, Cannon CP, Kraft PL, Douthat L, Becker RC, Palmeri ST, et al. Effects of prior aspirin and anti-ischemic therapy on outcome of patients with unstable angina. TIMI 7 Investigators. Thrombin Inhibition in Myocardial Ischemia. Am J Cardiol. 1998;81(6):678-81.

482. Ray WA, Varas-Lorenzo C, Chung CP, Castellsague J, Murray KT, Stein $\mathrm{CM}$, et al. Cardiovascular risks of nonsteroidal antiinflammatory drugs in patients after hospitalization for serious coronary heart disease. Circ Cardiovasc Qual Outcomes. 2009;2(3):155-63.

483. Ibanez B, James S, Agewall S, Antunes MJ, Bucciarelli-Ducci C, Bueno $\mathrm{H}$,et al. 2017 ESC Guidelines for the management of acute myocardial infarction in patients presenting with ST-segment elevation: The Task Force for the management of acute myocardial infarction in patients presenting with ST-segment elevation of the European Society of Cardiology (ESC). Eur Heart J. 2018;39(2):119-77.

484. Hofmann R, James SK, Jernberg T, Lindahl B, Erlinge D, Witt N, et al Oxygen therapy in suspected acute myocardial infarction. N Engl J Med. 2017;377(13):1240-9.

485. ISIS-2 (Second International Study of Infarct Survival) Collaborative Group. Randomised trial of intravenous streptokinase, oral aspirin, both, or neither among 17,187 cases of suspected acute myocardial infarction: ISIS-2. Lancet. 1988 Aug 13;2(8607):349-60.

486. Freimark D, Matetzky S, Leor J, Boyko V, Barbash IM, Behar S, et al Timing of aspirin administration as a determinant of survival of patients with acute myocardial infarction treated with thrombolysis. Am J Cardiol 2002;89(4):381-5.

487. CURRENT-OASIS 7 Investigators, Mehta SR, Bassand JP, Chrolavicius S, Diaz R, Eikelboom JW, et al. Dose comparisons of clopidogrel and aspirin in acute coronary syndromes. N Engl J Med. 2010;363(10):930-42.

488. Yusuf S, Zhao F, Mehta SR, Chrolavicius S, Tognoni G, Fox KK, et al. Effects of clopidogrel in addition to aspirin in patients with acute coronary syndromes without ST-segment elevation. N Engl J Med. 2001;345(7):494-502.

489. Wiviott SD, Braunwald E, McCabe CH, Montalescot G, Ruzyllo W, Gottlieb $\mathrm{S}$, et al. Prasugrel versus clopidogrel in patients with acute coronary syndromes. N Engl J Med. 2007;357(20):2001-15

490. Ruff CT, Giugliano RP, Antman EM, Murphy SA, Lotan C, Heuer H, et al Safety and efficacy of prasugrel compared with clopidogrel in different regions of the world. Int J Cardiol. 2012;155(3):424-9. 
491. Montalescot G, Bolognese L, Dudek D, Goldstein P, Hamm C, Tanguay $\mathrm{JF}$, et al. Pretreatment with prasugrel in non-ST-segment elevation acute coronary syndromes. N Engl J Med. 2013;369(11):999-1010.

492. Roffi M, Chew DP, Mukherjee D, Bhatt DL, White JA, Moliterno DJ, et al. Platelet glycoprotein Ilb/Illa inhibition in acute coronary syndromes. Gradient of benefit related to the revascularization strategy. Eur Heart J. 2002;23(18):1441-8.

493. Theroux P, Ouimet H, McCans J, Latour JG, Joly P, Levy G, et al. Aspirin, heparin, or both to treat acute unstable angina. N Engl J Med. 1988;319(17):1105-11

494. Theroux P, Waters D, Qiu S, McCans J, de Guise P, Juneau M. Aspirin versus heparin to prevent myocardial infarction during the acute phase of unstable angina. Circulation. 1993;88(5 Pt 1):2045-8.

495. Oler A, Whooley MA, Oler J, Grady D. Adding heparin to aspirin reduces the incidence of myocardial infarction and death in patients with unstable angina. A meta-analysis. JAMA. 1996;276(10):811-5.

496. Gruppo Italiano per lo Studio della Sopravvivenza nell'Infarto Miocardico. GISSI-2: a factorial randomised trial of alteplase versus streptokinase and heparin versus no heparin among 12,490 patients with acute myocardial infarction. Lancet. 1990;336(8707):65-71.

497. Tavazzi L. Heparin in acute myocardial infarction. Haemostasis. 1990;20 (Suppl 1):122-8.

498. Hsia J, Hamilton WP, Kleiman N, Roberts R, Chaitman BR, Ross AM. A comparison between heparin and low-dose aspirin as adjunctive therapy with tissue plasminogen activator for acute myocardial infarction. Heparin-Aspirin Reperfusion Trial (HART) Investigators. N Engl J Med. 1990;323(21):1433-7.

499. Bleich SD, Nichols TC, Schumacher RR, Cooke DH, Tate DA, Teichman SL. Effect of heparin on coronary arterial patency after thrombolysis with tissue plasminogen activator in acute myocardial infarction. Am J Cardiol. 1990;66(20):1412-7.

500. Prins $\mathrm{MH}$, Hirsh J. Heparin as an adjunctive treatment after thrombolytic therapy for acute myocardial infarction. Am J Cardiol. 1991;67(3):3A-11A.

501. Yamamoto N, Ogawa H, Oshima S, Soejima H, Fujii H, Misumi K, et al. The effect of heparin on tissue factor and tissue factor pathway inhibitor in patients with acute myocardial infarction. Int J Cardiol. 2000;75(2-3):267-74.

502. Verheugt FW, Liem A, Zijlstra F, Marsh RC, Veen G, Bronzwaer JG. High dose bolus heparin as initial therapy before primary angioplasty for acute myocardial infarction: results of the Heparin in Early Patency (HEAP) pilot study. J Am Coll Cardiol. 1998;31(2):289-93.

503. Murphy SA, Gibson CM, Morrow DA, Van de Werf F, Menown IB, Goodman SG, et al. Efficacy and safety of the low-molecular weight heparin enoxaparin compared with unfractionated heparin across the acute coronary syndrome spectrum: a meta-analysis. Eur Heart J. 2007;28(17):2077-86.

504. White HD, Braunwald E, Murphy SA, Jacob AJ, Gotcheva N, Polonetsky $\mathrm{L}$, et al. Enoxaparin vs. unfractionated heparin with fibrinolysis for STelevation myocardial infarction in elderly and younger patients: results from ExTRACT-TIMI 25. Eur Heart J. 2007;28(9):1066-71.

505. Giraldez RR, Nicolau JC, Corbalan R, Gurfinkel EP, Juarez U, LopezSendon J, et al. Enoxaparin is superior to unfractionated heparin in patients with ST elevation myocardial infarction undergoing fibrinolysis regardless of the choice of lytic: an ExTRACT-TIMI 25 analysis. Eur Heart J. 2007;28(13):1566-73.

506. Morrow DA, Antman EM, Murphy SA, Qin J, Ruda M, Guneri S, et al. Effect of enoxaparin versus unfractionated heparin in diabetic patients with ST-elevation myocardial infarction in the Enoxaparin and Thrombolysis Reperfusion for Acute Myocardial Infarction Treatment-Thrombolysis In Myocardial Infarction study 25 (ExTRACT-TIMI 25) trial. Am Heart ). 2007;154(6):1078-84.

507. Lavi S, Cantor WJ, Casanova A, Tan MK, Yan AT, Dzavik V, et al. Efficacy and safety of enoxaparin compared with unfractionated heparin in the pharmacoinvasive management of acute ST-segment elevation myocardial infarction: Insights from the TRANSFER-AMI trial. Am Heart]. 2012;163(2):176-81.e2.

508. Ferguson JJ, Califf RM, Antman EM, Cohen M, Grines CL, Goodman S, et al. Enoxaparin vs unfractionated heparin in high-risk patients with non-STsegment elevation acute coronary syndromes managed with an intended early invasive strategy: primary results of the SYNERGY randomized trial. JAMA. 2004;292(1):45-54.

509. Jolly SS, Faxon DP, Fox KA, Afzal R, Boden WE, Widimsky P, et al. Efficacy and safety of fondaparinux versus enoxaparin in patients with acute coronary syndromes treated with glycoprotein Ilb/llla inhibitors or thienopyridines: results from the OASIS 5 (Fifth Organization to Assess Strategies in Ischemic Syndromes) trial. J Am Coll Cardiol. 2009;54(5):468-76

510. Fifth Organization to Assess Strategies in Acute Ischemic Syndromes Investigators, Yusuf S, Mehta SR, Chrolavicius S, Afzal R, Pogue J, et al. Comparison of fondaparinux and enoxaparin in acute coronary syndromes. N Engl J Med. 2006;354(14):1464-76.

511. Steg PG, Mehta S, Jolly S, Xavier D, Rupprecht HJ, Lopez-Sendon JL, et al. Fondaparinux with UnfracTionated heparin during revascularization in acute coronary syndromes (FUTURA/OASIS 8): a randomized trial of intravenous unfractionated heparin during percutaneous coronary intervention in patients with non-ST-segment elevation acute coronary syndromes initially treated with fondaparinux. Am Heart J. 2010;160(6):1029-34.

512. Mega JL, Braunwald E, Mohanavelu S, Burton P, Poulter R, Misselwitz F, et al. Rivaroxaban versus placebo in patients with acute coronary syndromes (ATLAS ACS-TIMI 46): a randomised, double-blind, phase II trial. Lancet. 2009;374(9683):29-38.

513. Alexander JH, Lopes RD, James S, Kilaru R, He Y, Mohan P, et al. Apixaban with antiplatelet therapy after acute coronary syndrome. N Engl J Med. 2011;365(8):699-708.

514. Hoshi T, Sato A, Nogami A, Gosho M, Aonuma K, SAFE-A Investigators. Rationale and design of the SAFE-A study: SAFety and Effectiveness trial of Apixaban use in association with dual antiplatelet therapy in patients with atrial fibrillation undergoing percutaneous coronary intervention. J Cardiol. 2017;69(4):648-51.

515. Povsic TJ, Roe MT, Ohman EM, Steg PG, James S, Plotnikov A, et al. A randomized trial to compare the safety of rivaroxaban vs aspirin in addition to either clopidogrel or ticagrelor in acute coronary syndrome: The design of the GEMINI-ACS-1 phase II study. Am Heart J. 2016 Apr;174:120-8.

516. de Kam PJ, Voors AA, van den Berg MP, van Veldhuisen DJ, Brouwer J, Crijns $\mathrm{HJ}$, et al. Effect of very early angiotensin-converting enzyme inhibition on left ventricular dilation after myocardial infarction in patients receiving thrombolysis: results of a meta-analysis of 845 patients. FAMIS, CAPTIN and CATS Investigators. J Am Coll Cardiol. 2000;36(7):2047-53.

517. O'Connor RE, Bossaert L, Arntz HR, Brooks SC, Diercks D, Feitosa-Filho G, et al. Part 9: Acute coronary syndromes: 2010 International Consensus on Cardiopulmonary Resuscitation and Emergency Cardiovascular Care Science With Treatment Recommendations. Circulation. 2010;122(16 Suppl 2):S422-65.

518. Pitt B, White H, Nicolau J, Martinez F, Gheorghiade M, Aschermann M, et al. Eplerenone reduces mortality 30 days after randomization following acute myocardial infarction in patients with left ventricular systolic dysfunction and heart failure. J Am Coll Cardiol. 2005;46(3):425-31.

519. Montalescot G, Pitt B, Lopez de Sa E, Hamm CW, Flather M, Verheugt $\mathrm{F}$, et al. Early eplerenone treatment in patients with acute ST-elevation myocardial infarction without heart failure: the Randomized Double-Blind Reminder Study. Eur Heart J. 2014;35(34):2295-302.

520. Adamopoulos C, Ahmed A, Fay R, Angioi M, Filippatos G, Vincent J, et al. Timing of eplerenone initiation and outcomes in patients with heart failure after acute myocardial infarction complicated by left ventricular systolic dysfunction: insights from the EPHESUS trial. Eur J Heart Fail. 2009;11(11):1099-105. 
521. First International Study of Infarct Survival Collaborative Group. Randomised trial of intravenous atenolol among 16027 cases of suspected acute myocardial infarction: ISIS-1. Lancet. 1986;;2(8498):57-66

522. International Collaborative Study Group. Reduction of infarct size with the early use of timolol in acute myocardial infarction. N Engl J Med. 1984;310(1):9-15

523. Al-Reesi A, Al-Zadjali N, Perry J, Fergusson D, Al-Shamsi M, Al-Thagafi $M$, et al. Do beta-blockers reduce short-term mortality following acute myocardial infarction? A systematic review and meta-analysis. CJEM. 2008;10(3):215-23

524. Horiuchi Y, Tanimoto S, Aoki J, Nakajima H, Hara K, Tanabe K. Effects of beta-blockers on left ventricular remodeling in patients with preserved ejection fraction after acute myocardial infarction. Int J Cardiol. 2016 Oct $15 ; 221: 765-9$

525. Hulten E, Jackson JL, Douglas K, George S, Villines TC. The effect of early, intensive statin therapy on acute coronary syndrome: a meta-analysis of randomized controlled trials. Arch Intern Med. 2006;166(17):1814-21.

526. Teshima Y, Yufu K, Akioka H, Iwao T, Anan F, Nakagawa M, et al. Early atorvastatin therapy improves cardiac function in patients with acute myocardial infarction. J Cardiol. 2009;53(1):58-64.

527. Lenderink T, Boersma E, Gitt AK, Zeymer U, Wallentin L, Van de Werf F, et al. Patients using statin treatment within $24 \mathrm{~h}$ after admission for STelevation acute coronary syndromes had lower mortality than non-users: a report from the first Euro Heart Survey on acute coronary syndromes. Eur Heart J. 2006;27(15):1799-804

528. Spencer FA, Fonarow GC, Frederick PD, Wright RS, Every N, Goldberg RJ, et al. Early withdrawal of statin therapy in patients with non-ST-segment elevation myocardial infarction: national registry of myocardial infarction. Arch Intern Med. 2004;164(19):2162-8.

529. Heeschen C, Hamm CW, Laufs U, Snapinn S, Bohm M, White HD, et al. Withdrawal of statins increases event rates in patients with acute coronary syndromes. Circulation. 2002;105(12):1446-52.

530. Pourafkari L, Visnjevac O, Ghaffari S, Nader ND. Statin drugs mitigate cellular inflammatory response after ST elevation myocardial infarction, but do not affect in-hospital mortality. J Cardiovasc Thorac Res. 2016;8(1):34-9.

531. Marenzi G, Cosentino N, Cortinovis S, Milazzo V, Rubino M, Cabiati A, et al. Myocardial Infarct Size in Patients on Long-Term Statin Therapy Undergoing Primary Percutaneous Coronary Intervention for ST-Elevation Myocardial Infarction. Am J Cardiol. 2015;116(12):1791-7.

532. Briguori C, Colombo A, Airoldi F, Violante A, Focaccio A, Balestrieri P, et al. Statin administration before percutaneous coronary intervention: impact on periprocedural myocardial infarction. Eur Heart J. 2004;25(20):1822-8.

533. Patti G, Pasceri V, Colonna G, Miglionico M, Fischetti D, Sardella G, et al. Atorvastatin pretreatment improves outcomes in patients with acute coronary syndromes undergoing early percutaneous coronary intervention: results of the ARMYDA-ACS randomized trial. J Am Coll Cardiol. 2007;49(12):1272-8.

534. Cannon CP, Blazing MA, Giugliano RP, McCagg A, White JA, Theroux P, et al. Ezetimibe Added to Statin Therapy after Acute Coronary Syndromes. N Engl J Med. 2015;372(25):2387-97

535. Nabel EG, Braunwald E. A tale of coronary artery disease and myocardial infarction. N Engl J Med. 2012;366(1):54-63.

536. Fibrinolytic Therapy Trialists' (FTT) Collaborative Group. Indications for fibrinolytic therapy in suspected acute myocardial infarction: collaborative overview of early mortality and major morbidity results from all randomised trials of more than 1000 patients. Lancet. 1994;343(8893):311-22.

537. Gruppo Italiano per lo Studio della Streptochinasi nell'Infarto Miocardico (GISSI). Effectiveness of intravenous thrombolytic treatment in acute myocardial infarction. Lancet. 1986;1(8478):397-402.
538. SIS-3 (Third International Study of Infarct Survival) Collaborative Group. ISIS-3: a randomised comparison of streptokinase vs tissue plasminogen activator vs anistreplase and of aspirin plus heparin vs aspirin alone among 41,299 cases of suspected acute myocardial infarction. Lancet. 1992;339(8796):753-70.

539. GUSTO investigators. An international randomized trial comparing four thrombolytic strategies for acute myocardial infarction. N Engl J Med. 1993;329(10):673-82.

540. Assessment of the Safety and Efficacy of a New Thrombolytic (ASSENT-2) Investigators, Van De Werf F, AdgeyJ, Ardissino D, Armstrong PW, Aylward $\mathrm{P}$, et al. Single-bolus tenecteplase compared with front-loaded alteplase in acute myocardial infarction: the ASSENT-2 double-blind randomised trial. Lancet. 1999;354(9180):716-22.

541. Avezum Jr A, Feldman A, Carvalho AC, Sousa AC, Mansur Ade P, Bozza $A E$, et al. $V$ Guideline of the Brazilian Society of Cardiology on Acute Myocardial Infarction Treatment with ST Segment Elevation. Arq Bras Cardiol. 2015;105(2 Suppl 1):1-105

542. Pastore CA, Pinho JA, Pinho C, Samesima N, Pereira Filho HG, Kruse J, et al. III Diretrizes da Sociedade Brasileira de Cardiologia sobre analise e emissao de laudos eletrocardiograficos. Arq Bras Cardiol. 2016;106(4 Suppl 1):1-23.

543. Squire IB, Lawley W, Fletcher S, Holme E, Hillis WS, Hewitt C, et al. Humoral and cellular immune responses up to 7.5 years after administration of streptokinase for acute myocardial infarction. Eur Heart J. 1999;20(17):1245-52.

544. GUSTO Angiographic Investigators. The effects of tissue plasminogen activator, streptokinase, or both on coronary-artery patency, ventricular function, and survival after acute myocardial infarction. N Engl J Med. 1993;329(22):1615-22.

545. Ross AM, Coyne KS, Moreyra E, Reiner JS, Greenhouse SW, Walker PL, et al. Extended mortality benefit of early postinfarction reperfusion. Global Utilization of Streptokinase and Tissue Plasminogen Activator for Occluded Coronary Arteries Trial. Circulation. 1998;97(16):1549-56.

546. Boersma E, Maas AC, Deckers JW, Simoons ML. Early thrombolytic treatment in acute myocardial infarction: reappraisal of the golden hour. Lancet. 1996;348(9030):771-5.

547. Weaver WD, Simes RJ, Betriu A, Grines CL, Zijlstra F, Garcia E, et al Comparison of primary coronary angioplasty and intravenous thrombolytic therapy for acute myocardial infarction: a quantitative review. JAMA 1997:278(23):2093-8.

548. Grines CL, Browne KF, Marco J, Rothbaum D, Stone GW, O'Keefe J, et al. A comparison of immediate angioplasty with thrombolytic therapy for acute myocardial infarction. The Primary Angioplasty in Myocardial Infarction Study Group. N Engl J Med. 1993;328(10):673-9.

549. Widimsky P, Budesinsky T, Vorac D, Groch L, Zelizko M, Aschermann $M$, et al. Long distance transport for primary angioplasty vs immediate thrombolysis in acute myocardial infarction. Final results of the randomized national multicentre trial--PRAGUE-2. Eur Heart J. 2003;24(1):94-104

550. Andersen HR, Nielsen TT, Rasmussen K, Thuesen L, Kelbaek H, Thayssen P, et al. A comparison of coronary angioplasty with fibrinolytic therapy in acute myocardial infarction. N Engl J Med. 2003;349(8):733-42.

551. Grines CL, Cox DA, Stone GW, Garcia E, Mattos LA, Giambartolomei A et al. Coronary angioplasty with or without stent implantation for acute myocardial infarction. Stent Primary Angioplasty in Myocardial Infarction Study Group. N Engl J Med. 1999;341(26):1949-56.

552. Stone GW, Grines CL, Cox DA, Garcia E, Tcheng JE, Griffin JJ, et al. Comparison of angioplasty with stenting, with or without abciximab, in acute myocardial infarction. N Engl J Med. 2002;346(13):957-66

553. Palmerini T, Biondi-Zoccai G, Della Riva D, Mariani A, Sabate M, Valgimigl $\mathrm{M}$, et al. Clinical outcomes with drug-eluting and bare-metal stents in patients with ST-segment elevation myocardial infarction: evidence 
from a comprehensive network meta-analysis. J Am Coll Cardiol. 2013;62(6):496-504.

554. Sabate M, Cequier A, Iniguez A, Serra A, Hernandez-Antolin R, Mainar $\mathrm{V}$, et al. Everolimus-eluting stent versus bare-metal stent in ST-segment elevation myocardial infarction (EXAMINATION): 1 year results of a randomised controlled trial. Lancet. 2012;380(9852):1482-90.

555. Sabate M, Brugaletta S, Cequier A, Iniguez A, Serra A, Jimenez-Quevedo P, et al. Clinical outcomes in patients with ST-segment elevation myocardial infarction treated with everolimus-eluting stents versus bare-metal stents (EXAMINATION): 5-year results of a randomised trial. Lancet. 2016;387(10016):357-66.

556. Brodie BR, Gersh BJ, Stuckey T, Witzenbichler B, Guagliumi G, Peruga JZ, et al. When is door-to-balloon time critical? Analysis from the HORIZONSAMI (Harmonizing Outcomes with Revascularization and Stents in Acute Myocardial Infarction) and CADILLAC (Controlled Abciximab and Device Investigation to Lower Late Angioplasty Complications) trials. J Am Coll Cardiol. 2010;56(5):407-13.

557. Gershlick AH, Stephens-Lloyd A, Hughes S, Abrams KR, Stevens SE, Uren $\mathrm{NG}$, et al. Rescue angioplasty after failed thrombolytic therapy for acute myocardial infarction. N Engl J Med. 2005;353(26):2758-68.

558. Assessment of the Safety and Efficacy of a New Treatment Strategy with Percutaneous Coronary Intervention (ASSENT-4 PCI) investigators. Primary versus tenecteplase-facilitated percutaneous coronary intervention in patients with ST-segment elevation acute myocardial infarction (ASSENT-4 PCI): randomised trial. Lancet. 2006;367(9510):569-78.

559. Keeley EC, Boura JA, Grines CL. Comparison of primary and facilitated percutaneous coronary interventions for ST-elevation myocardial infarction: quantitative review of randomised trials. Lancet. 2006;367(9510):579-88.

560. Cantor WJ, Fitchett D, Borgundvaag B, Ducas J, Heffernan M, Cohen EA, et al. Routine early angioplasty after fibrinolysis for acute myocardial infarction. N Engl J Med. 2009;360(26):2705-18.

561. Fernandez-Aviles F, Alonso JJ, Castro-Beiras A, Vazquez N, Blanco J, AlonsoBriales J, et al. Routine invasive strategy within 24 hours of thrombolysis versus ischaemia-guided conservative approach for acute myocardial infarction with ST-segment elevation (GRACIA-1): a randomised controlled trial. Lancet. 2004;364(9439):1045-53.

562. Awad HH, Anderson FA Jr, Gore JM, Goodman SG, Goldberg RJ. Cardiogenic shock complicating acute coronary syndromes: insights from the Global Registry of Acute Coronary Events. Am Heart J. 2012;163(6):963-71.

563. Zion MM, Balkin J, Rosenmann D, Goldbourt U, Reicher-Reiss H, Kaplinsky E, et al. Use of pulmonary artery catheters in patients with acute myocardial infarction. Analysis of experience in 5,841 patients in the SPRINT Registry. SPRINT Study Group. Chest. 1990;98(6):1331-5.

564. Hochman JS, Sleeper LA, Webb JG, Sanborn TA, White HD, Talley JD, et al. Early revascularization in acute myocardial infarction complicated by cardiogenic shock. SHOCK Investigators. Should We Emergently Revascularize Occluded Coronaries for Cardiogenic Shock. N Engl J Med. 1999;341(9):625-34.

565. Thiele H, Zeymer U, Neumann FJ, Ferenc M, Olbrich HG, Hausleiter J, et al. Intraaortic balloon support for myocardial infarction with cardiogenic shock. N Engl J Med. 2012;367(14):1287-96.

566. Andersen HR, Falk E, Nielsen D. Right ventricular infarction: frequency, size and topography in coronary heart disease: a prospective study comprising 107 consecutive autopsies from a coronary care unit. J Am Coll Cardiol. 1987;10(6):1223-32.

567. Mehta SR, Eikelboom JW, Natarajan MK, Diaz R, Yi C, Gibbons RJ, et al. Impact of right ventricular involvement on mortality and morbidity in patients with inferior myocardial infarction. J Am Coll Cardiol. 2001;37(1):37-43.
568. Zehender M, Kasper W, Kauder E, Schonthaler M, Geibel A, Olschewski $M$, et al. Right ventricular infarction as an independent predictor of prognosis after acute inferior myocardial infarction. $N$ Engl J Med. 1993;328(14):981-8.

569. Lopez-Sendon J, Coma-Canella I, Alcasena S, Seoane J, Gamallo C. Electrocardiographic findings in acute right ventricular infarction: sensitivity and specificity of electrocardiographic alterations in right precordial leads V4R, V3R, V1, V2, and V3. J Am Coll Cardiol. 1985;6(6):1273-9.

570. Wellens HJ. The value of the right precordial leads of the electrocardiogram. N Engl J Med. 1999;340(5):381-3.

571. Zimetbaum PJ, Josephson ME. Use of the electrocardiogram in acute myocardial infarction. N Engl J Med. 2003;348(10):933-40.

572. Goldstein JA. Pathophysiology and management of right heart ischemia. J Am Coll Cardiol. 2002;40(5):841-53.

573. Love JC, Haffajee Cl, Gore JM, Alpert JS. Reversibility of hypotension and shock by atrial or atrioventricular sequential pacing in patients with right ventricular infarction. Am Heart J. 1984;108(1):5-13.

574. Topol EJ, Goldschlager N, Ports TA, Dicarlo LA, Jr., Schiller NB, Botvinick $\mathrm{EH}$, et al. Hemodynamic benefit of atrial pacing in right ventricular myocardial infarction. Ann Intern Med. 1982;96(5):594-7.

575. Zehender M, Kasper W, Kauder E, Geibel A, Schonthaler M, Olschewski $\mathrm{M}$, et al. Eligibility for and benefit of thrombolytic therapy in inferior myocardial infarction: focus on the prognostic importance of right ventricular infarction. J Am Coll Cardiol. 1994;24(2):362-9.

576. Bowers TR, O'Neill WW, Grines C, Pica MC, Safian RD, Goldstein JA. Effect of reperfusion on biventricular function and survival after right ventricular infarction. N Engl J Med. 1998;338(14):933-40.

577. Lim ST, Marcovitz P, Pica M, O'Neill W, Goldstein J. Right ventricular performance at rest and during stress with chronic proximal occlusion of the right coronary artery. Am J Cardiol. 2003;92(10):1203-6.

578. Yasuda T, Okada RD, Leinbach RC, Gold HK, Phillips H, McKusick KA, et al. Serial evaluation of right ventricular dysfunction associated with acute inferior myocardial infarction. Am Heart J. 1990;119(4):816-22.

579. Larose E, Ganz P, Reynolds HG, Dorbala S, Di Carli MF, Brown KA, et al. Right ventricular dysfunction assessed by cardiovascular magnetic resonance imaging predicts poor prognosis late after myocardial infarction. J Am Coll Cardiol. 2007;49(8):855-62.

580. Hochman JS, Buller CE, Sleeper LA, Boland J, Dzavik V, Sanborn TA, et al. Cardiogenic shock complicating acute myocardial infarction--etiologies, management and outcome: a report from the SHOCK Trial Registry. SHould we emergently revascularize Occluded Coronaries for cardiogenic shock? J Am Coll Cardiol. 2000;36(3 Suppl A):1063-70.

581. Pohjola-Sintonen S, Muller JE, Stone PH, Willich SN, Antman EM, Davis VG, et al. Ventricular septal and free wall rupture complicating acute myocardial infarction: experience in the Multicenter Investigation of Limitation of Infarct Size. Am Heart J. 1989;117(4):809-18.

582. Moreno R, Lopez-Sendon J, Garcia E, Perez de Isla L, Lopez de Sa E, Ortega A, et al. Primary angioplasty reduces the risk of left ventricular free wall rupture compared with thrombolysis in patients with acute myocardial infarction. J Am Coll Cardiol. 2002;39(4):598-603.

583. Skehan JD, Carey C, Norrell MS, de Belder M, Balcon R, Mills PG. Patterns of coronary artery disease in post-infarction ventricular septal rupture. $\mathrm{Br}$ Heart J. 1989;62(4):268-72.

584. Crenshaw BS, Granger CB, Birnbaum Y, Pieper KS, Morris DC, Kleiman NS, et al. Risk factors, angiographic patterns, and outcomes in patients with ventricular septal defect complicating acute myocardial infarction. GUSTO-I (Global Utilization of Streptokinase and TPA for Occluded Coronary Arteries) Trial Investigators. Circulation. 2000;101(1):27-32.

585. Bursi F, Enriquez-Sarano M, Jacobsen SJ, Roger VL. Mitral regurgitation after myocardial infarction: a review. Am J Med. 2006;119(2):103-12. 
586. Birnbaum Y, Fishbein MC, Blanche C, Siegel RJ. Ventricular septal rupture after acute myocardial infarction. N Engl J Med. 2002;347(18):1426-32.

587. Stout KK, Verrier ED. Acute valvular regurgitation. Circulation. 2009;119(25):3232-41.

588. Smyllie JH, Sutherland GR, Geuskens R, Dawkins K, Conway N, Roelandt JRTC. Doppler color flow mapping in the diagnosis of ventricular septal rupture and acute mitral regurgitation after myocardial infarction. JACC. 1990;15(6):1449-55.

589. Poulsen SH, Praestholm M, Munk K, Wierup P, Egeblad H, Nielsen-Kudsk JE. Ventricular septal rupture complicating acute myocardial infarction: clinical characteristics and contemporary outcome. Ann Thorac Surg. 2008;85(5):1591-6.

590. Figueras J, Cortadellas J, Soler-Soler J. Left ventricular free wall rupture: clinical presentation and management. Heart. 2000;83(5):499-504.

591. Thiele H, Kaulfersch C, Daehnert I, Schoenauer M, Eitel I, Borger M, et al. Immediate primary transcatheter closure of postinfarction ventricular septal defects. Eur Heart J. 2009;30(1):81-8.

592. Oliveira-Filho I, Martins SC, Pontes-Neto OM, Longo A, Evaristo EF, Carvalho JJ, et al. Guidelines for acute ischemic stroke treatment: part I. Arq Neuropsiquiatr. 2012;70(8):621-9.

593. Martins SC, Freitas GR, Pontes-Neto OM, Pieri A, Moro CH, Jesus PA, et al. Guidelines for acute ischemic stroke treatment: part II. Arq Neuropsiquiatr, et al. Guidelines for acute ischemic stroke treatment: part II. Arq Neuropsiquiatr. 2012;70(11):885-93

594. World Health Organization (WHO). The Global Burden of Diseases. 2010 [Internet]. [Cited in 2018 Nov 5]. Available from:http://www.who.int/ healthinfo/global_burden_disease/en/

595. Saposnik G, Del Brutto OH; Iberoamerican Society of Cerebrovascular Diseases. Stroke in South America: a systematic review of incidence, prevalence, and stroke subtypes. Stroke. 2003;34(9):2103-7.

596. Mansur AP, Favarato D. Trends in mortality rate from cardiovascular disease in Brazil, 1980-2012. Arq Bras Cardiol. 2016;107(1): 20-5.

597. Lotufo PA. Stroke is still a neglected disease in Brazil. Sao Paulo Med J. 2015;133(6):457-9.

598. Pontes-Neto OM, Silva GS, Feitosa MR, de Figueiredo NL, Fiorot JA $\mathrm{Jr}$, Rocha TN, et al. Stroke awareness in Brazil: alarming results in a community-based study. Stroke. 2008;39(2):292-6.

599. Panício MI, Mateus L, Ricarte IR, Figueiredo MM, Fukuda TG, Seixas JC, et al. The Influence of Patient's Knowledge about Stroke in Brazil: a cross sectional study. Arq Neuropsiquiatr. 2014;72(12):938-41.

600. Wojner-Alexandrov AW, Alexandrov AV, Rodriguez D, Persse D, Grotta JC. Houston paramedic and emergency stroke treatment and outcomes study (HoPSTO). Stroke. 2005;36(7):1512-8.

601. Mosley I, Nicol M, Donnan G, Patrick I, Dewey H. Stroke symptoms and the decision to call for an ambulance. Stroke. 2007:38(2):361-6.

602. Novak EM, Zetola VH, Muzzio JA, Puppi M, Carraro Jr H, Werneck LC. Lay knowledge about stroke. Arq Neuropsiquiatr. 2003;61(3B):772-6.

603. Schroeder EB, Rosamond WD, Morris DL, Evenson KR, Hinn AR. Determinants of use of emergency medical services in a population with stroke symptoms: the Second Delay in Accessing Stroke Healthcare (DASH II) Study. Stroke. 2000;31(11):2591-6

604. Morris DL, Rosamond WD, Hinn AR, Gorton RA. Time delays in accessing stroke care in the emergency department. Acad Emerg Med. 1999;6(3):218-23.

605. Morris DL, Rosamond W, Madden K, Schultz C, Hamilton S. Prehospital and emergency department delays after acute stroke: the Genentech Stroke Presentation Survey. Stroke. 2000;31(11):2585-90.

606. Ebinger M, Kunz A, Wendt M, Rozanski M, Winter B, Waldschmidt C, et al. Effects of golden hour thrombolysis: a Prehospital Acute Neurological
Treatment and Optimization of Medical Care in Stroke (PHANTOM-S) substudy. JAMA Neurol. 2015;72(1):25-30.

607. Carvalho JJ, Alves MB, Viana GA, Machado CB, dos Santos BF, Kanamura $\mathrm{AH}$, et al. Stroke epidemiology, patterns of management, and outcomes in Fortaleza, Brazil: a hospital-based multicenter prospective study. Stroke. 2011;42(12):3341-6

608. Jauch EC, Saver JL, Adams HP Jr, Bruno A, Connors JJ, Demaerschalk BM, et al. Guidelines for the early management of patients with acute ischemic stroke: a guideline for healthcare professionals from the American Heart Association/American Stroke Association. Stroke. 2013;44(3):870-947.

609. Silver FL, Rubini F, Black D, Hodgson CS. Advertising strategies to increase public knowledge of the warning signs of stroke. Stroke. 2003;34(8):1965-8

610. Suyama J, Crocco T. Prehospital care of the stroke patient. Emerg Med Clin North Am. 2002;20(3):537-52

611. Jacobs L, Kinkel WR, Heffner Jr RR. Autopsy correlations of computerized tomography: experience with 6,000 CT scans. Neurology. 1976;26(12):1111-8.

612. Wardlaw IM, Keir SL, Dennis MS. The impact of delays in computed tomography of the brain on the accuracy of diagnosis and subsequent management in patients with minor stroke. J Neurol Neurosurg Psychiatry. 2003;74(1):77-81.

613. Saur D, Kucinski T, Grzyska U, Eckert B, Eggers C, Niesen W, etal. Sensitivity and interrater agreement of $\mathrm{CT}$ and diffusion-weighted $\mathrm{MR}$ imaging in hyperacute stroke. AJNR Am J Neuroradiol. 2003;24(5):878-85.

614. Barber PA, Demchuk AM, Zhang J, Buchan AM. Validity and reliability of a quantitative computed tomography score in predicting outcome of hyperacute stroke before thrombolytic therapy. ASPECTS Study Group. Alberta Stroke Programme Early CT Score. Lancet. 2000;355(9216):1670-4

615. Demchuk AM, Hill MD, Barber PA, Silver B, Patel SC, Levine SR, et al Importance of early ischemic computed tomography changes using ASPECTS in NINDS rtPA Stroke Study. Stroke. 2005;36(10):2110-5.

616. Wardlaw JM, Keir SL, Seymour J, Lewis S, Sandercock PA, Dennis MS, etal. What is the best imaging strategy for acute stroke? Health Technol Assess. 2004;8(1):iii, ix-x, 1-180.

617. Chalela JA, Kidwell CS, Nentwich LM, Luby M, Butman JA, Demchuk AM, et al. Magnetic resonance imaging and computed tomography in emergency assessment of patients with suspected acute stroke: a prospective comparison. Lancet. 2007;369(9558):293-8.

618. Fiebach JB, Schellinger PD, Gass A, Kucinski T, Siebler M, Villringer A, et al. Stroke magnetic resonance imaging is accurate in hyperacute intracerebra hemorrhage: a multicenter study on the validity of stroke imaging. Stroke. 2004;35(2):502-6.

619. Coutts SB, Simon JE, Tomanek Al, Barber PA, Chan J, Hudon ME, et al. Reliability of assessing percentage of diffusion-perfusion mismatch. Stroke. 2003;34(7):1681-3.

620. Schramm P, Schellinger PD, Klotz E, Kallenberg K, Fiebach JB, Külkens S, et al. Comparison of perfusion computed tomography and computed tomography angiography source images with perfusion-weighted imaging and diffusion-weighted imaging in patients with acute stroke of less than 6 hours' duration. Stroke. 2004;35(7):1652-8.

621. Lev MH, Farkas J, Rodriguez VR, Schwamm LH, Hunter GJ, Putman CM et al. CT angiography in the rapid triage of patients with hyperacute stroke to intraarterial thrombolysis: accuracy in the detection of large vesse thrombus. J Comput Assist Tomogr. 2001;25(4):520-8.

622. Demchuk AM, Burgin WS, Christou I, Felberg RA, Barber PA, Hill MD, et al. Thrombolysis in brain ischemia (TIBI) transcranial Doppler flow grades predict clinical severity, early recovery, and mortality in patients treated with intravenous tissue plasminogen activator. Stroke. 2001;32(1):89-93 
623. Marler J, National Institute of Neurological Disorders and Stroke. Rapid identification and treatment of acute stroke. Proceedings of a National Symposium on Rapid Identification and Treatment of Acute Stroke. Bethesda: National Institute of Neurological Disorders and Stroke; 1997.

624. Mitchell JB, Ballard DJ, Whisnant JP, Ammering CJ, Samsa GP, Matchar DB. What role do neurologists play in determining the costs and outcomes of stroke patients? Stroke. 1996;27(11):1937-43.

625. Ronning OM, Guldvog B. Should stroke victims routinely receive supplemental oxygen? A quasi-randomized controlled trial. Stroke. 1999;30(10):2033-7.

626. Bhalla A, Sankaralingam S, Dundas R, Swaminathan R, Wolfe CD, Rudd AG. Influence of raised plasma osmolality on clinical outcome after acute stroke. Stroke. 2000;31(9):2043-8.

627. Bruno A, Kent TA, Coull BM, Shankar RR, Saha C, Becker KJ, et al. Treatment of hyperglycemia in ischemic stroke (THIS): a randomized pilot trial. Stroke. 2008;39(2):384-9.

628. Huang Y, Sharma VK, Robinson T, Lindley RI, Chen X, Kim JS, et al. Rationale, design, and progress of the ENhanced Control of Hypertension ANd Thrombolysis strokE stuDy (ENCHANTED) trial: An international multicenter 2 ? $\times$ ? 2 quasi-factorial randomized controlled trial of low vs. standard-dose rt-PA and early intensive vs. guideline recommended blood pressure lowering in patients with acute ischaemic stroke eligible for thrombolysis treatment. Int J Stroke. 2015;10(5):778-8.

629. Sprigg N, Gray LJ, Bath PM, Boysen G, De Deyn PP, Friis P, etal. Relationship between outcome and baseline blood pressure and other haemodynamic measures in acute ischaemic stroke: data from the TAIST trial. J Hypertens. 2006;24(7):1413-7.

630. Aslanyan S, Fazekas F, Weir CJ, Horner S, Lees KR; GAIN International Steering Committee and Investigators. Effect of blood pressure during the acute period of ischemic stroke on stroke outcome: a tertiary analysis of the GAIN International Trial. Stroke. 2003;34(10):2420-5.

631. Leonardi-Bee J, Bath PM, Phillips SJ, , Sandercock PA; IST Collaborative Group. Blood pressure and clinical outcomes in the International Stroke Trial. Stroke. 2002;33(5):1315-20.

632. Azzimondi G, Bassein L, Nonino F, Fiorani L, Vignatelli L, Re G, et al. Fever in acute stroke worsens prognosis: a prospective study. Stroke. 1995;26(11):2040-3.

633. Sandercock PAG, Counsell C, Kane EJ. Anticoagulants for acute ischaemic stroke. Cochrane Database of Syst Rev. 2015 Mar 12;(3):CD000024.

634. Wong KS, Chen C, Ng PW, Tsoi TH, Li HL, Fong WC, et al. Low-molecularweight heparin compared with aspirin for the treatment of acute ischaemic stroke in Asian patients with large artery occlusive disease: a randomised study. Lancet Neurol. 2007;6(5):407-13.

635. CAST (Chinese Acute Stroke Trial) Collaborative Group. CAST: randomised placebo-controlled trial of early aspirin use in 20.000 patients with acute ischaemic stroke. Lancet. 1997;349(9066):1641-9.

636. International Stroke Trial Collaborative Group. The International Stroke Trial (IST): a randomised trial of aspirin, subcutaneous heparin, both, or neither among 19435 patients with acute ischaemic stroke. Lancet. 1997;349(9065):1569-81.

637. Johnston SC, Amarenco P, Albers GW, Denison H, Easton D, Evans SR, et al. Ticagrelor versus Aspirin in Acute Stroke or Transient Ischemic Attack. N Engl J Med. 2016;375(1):35-43.

638. Zhang Q, Wang C, Zheng M, Li Y, Li J, Zhang L, et al. Aspirin plus clopidogrel as secondary prevention after stroke or transient ischemic attack: a systematic review and meta-analysis. Cerebrovasc Dis. 2015;39(1):13-22.

639. Amarenco P, Bogousslavsky J, Callahan A 3rd, Goldstein LB, Hennerici M, Rudolph AE, et al. High-dose atorvastatin after stroke or transient ischemic attack. N Engl J Med. 2006;355(6):549-59.
640. KennedyJ, Hill MD, Ryckborst KJ, Eliasziw M, Demchuk AM, Buchan AM, et al. Fast assessment of stroke and transient ischaemic attack to prevent early recurrence (FASTER): a randomised controlled pilot trial. Lancet Neurol. 2007;6(11):961-9.

641. Hacke W, Donnan G, Fieschi C, Kaste M, von Kummer R, Broderick JP, et al. Association of outcome with early stroke treatment: Pooled analysis of ATLANTIS, ECASS, and NINDS rt-PA stroke trials. Lancet. 2004;363(9411):768-74.

642. Multicenter Acute Stroke Trial--Europe Study Group, Hommel M, Cornu C, Boutitie F, Boissel JP. Thrombolytic therapy with streptokinase in acute ischemic stroke. N Engl J Med. 1996;335(3):145-50.

643. Brasil. Ministério da Saúde. Portaria 664 de 12 de abril de 2012. Diario Oficial da União 13 abr 2012;72:33-5.

644. Demaerschalk BM, Kleindorfer DO, Adeoye OM, Demchuk AM, Fugate JE, Grotta JC, et al. Scientific Rationale for the Inclusion and Exclusion Criteria for Intravenous Alteplase in Acute Ischemic Stroke: A Statement for Healthcare Professionals From the American Heart Association/American Stroke Association. Stroke. 2016;47(2):581-641.

645. Pincus MM. Consent issues in the management of cerebrovascular diseases: a position paper of the American Academy of Neurology Ethics and Humanities Subcommittee. Neurology. 1999;53(1)1:9-11.

646. Meyer BC, Raman R, Hemmen T, Obler R, Zivin JA, Rao R, et al. Efficacy of site-independent telemedicine in the STRokE DOC trial: a randomised, blinded, prospective study. Lancet Neurol. 2008;7(9):787-95.

647. Hill MD, Lye T, Moss H, Barber PA, Demchuk AM, Newcommon NJ, et al. Hemio-rolingual angioedema and ace inhibition after alteplase treatment of stroke. Neurology. 2003;60(9):1525-7.

648. Furlan A, Higashida R, Wechsler L, , Gent M, Rowley H, Kase C,et al. Intraarterial prourokinase for acute ischemic stroke: The PROACT II Study: a randomized controlled trial. JAMA. 1999;282(21):2003-11.

649. Mattle HP, Arnold M, Georgiadis D, Baumann C, Nedeltchev K, Benninger $\mathrm{D}$, et al. Comparison of intraarterial and intravenous thrombolysis for ischemic stroke with hyperdense middle cerebral artery sign. Stroke. 2008;39(2):379-83.

650. Nedeltchev K, Fischer U, Arnold M. Ballinari P, Haefeli T, Kappeler L, et al. Long-term effect of intra-arterial thrombolysis in stroke. Stroke. 2006;37(12):3002-7.

651. Macleod MR, Davis SM, Mitchell PJ, Gerraty RP, Fitt G, Hankey GJ, et al. Results of a multicentre, randomised controlled trial of intra-arterial urokinase in the treatment of acute posterior circulation ischaemic stroke. Cerebrovasc Dis. 2005;20(1):12-17.

652. Broderick JP, Palesch YY, Demchuk AM, Yeatts SD, Khatri P, Hill MD, et al. Endovascular therapy after intravenous t-PA versus t-PA alone for stroke. N Engl J Med. 2013;368(10):893-903.

653. Smith WS, Sung G, Saver J, Budzik R, Duckwiler G, Liebeskind DS, et al. Mechanical thrombectomy for acute ischemic stroke: final results of the Multi MERCI trial. Stroke. 2008;39(4):1205-12.

654. Berkhemer OA, Fransen PS, Beumer D, van den Berg LA, Lingsma HF, Yoo AJ, et al. A randomized trial of intraarterial treatment for acute ischemic stroke. N Engl J Med. 2015;372(1):11-20.

655. Campbell BC, Mitchell PJ, Kleinig TJ, Dewey HM, Churilov L, Yassi N, etal. Endovascular therapy for ischemic stroke with perfusion-imaging selection. N Engl J Med. 2015;372(11):1009-18.

656. Goyal M, Demchuk AM, Menon BK, Eesa M, Rempel JL, Thornton J, et al. Randomized assessment of rapid endovascular treatment of ischemic stroke. N Engl J Med. 2015;372(11):1019-30.

657. Saver JL, Goyal M, Bonafe A, Diener HC, Levy El, Pereira VM, et al. Stentretriever thrombectomy after intravenous t-PA vs. t-PA alone in stroke. $\mathrm{N}$ Engl J Med. 2015;372(24):2285-95. 
658. Raffin CN, Fernandes JG, Evaristo EF, Siqueira Neto JI, Friedrich M, Puglia $\mathrm{P}$, et al. Clinical and interventional revascularization in the acute ischemic stroke: national opinion. Arq Neuropsiquiatr. 2006;64(2A):342-8.

659. Brasil. Ministério da Saúde. Portaria 665/GM/MS de 12 de abril de 2012 Homologa a adesão dos municípios e das respectivas equipes de atenção básica ao Program Nacional de Melhoria do Acesso e da qualidade da Atenção Básica (PMAQ-AB) Diário Oficial da União 13 abr 2012; 72:35-9.

660. Brasil. Ministério da Saúde. Portaria 800/GM/MS de 17 de junho de 2015. Dispõe sobre os critérios de habilitação dos estabelecimentos hospitalares como Centro de Atendimento de Urgência aos Pacientes com Acidente Vascular Cerebral. AVC. No âmbito do SUS, institui o respectivo incentivo financeiro e aprova a linha de cuidados em AVC. Diário Oficial da União 19 jun $2015 ;$ n. 115 , p.34.

661. Dennis MS, Burn JP, Sandercock PA, Bamford JM, Wade DT, Warlow CP. Long-term survival after first-ever stroke: the Oxfordshire Community Stroke Project. Stroke. 1993;24(6):796-800.

662. Flaherty ML, Haverbusch M, Sekar P, Kissela B, Kleindorfer D, Moomaw CJ, et al. Long-term mortality after intracerebral hemorrhage. Neurology. 2006;66(8):1182-6.

663. Gebel JM, Broderick JP. Intracerebral hemorrhage. Neurol Clin. 2000;18(2):419-38

664. Qureshi Al, Tuhrim S, Broderick JP, Batjer HH, Hondo H, Hanley DF. Spontaneous intracerebral hemorrhage. N Engl J Med. 2001;344(19):1450-60.

665. Sacco RL, Boden-Albala B, Gan R, Chen X, Kargman DE, Shea S, et al. Stroke incidence among white, black, and Hispanic residents of an urban community: the Northern Manhattan Stroke Study. Am J Epidemiol. 1998;147(3):259-68.

666. O'Donnell MJ, Chin SL, Rangarajan S, Xavier D, Liu L, Zhang H, et al. Global and regional effects of potentially modifiable risk factors associated with acute stroke in 32 countries (INTERSTROKE): a case-control study. Lancet. 2016;388(10046):761-75

667. Law MR, Morris JK, Wald NJ. Use of blood pressure lowering drugs in the prevention of cardiovascular disease: meta-analysis of 147 randomised trials in the context of expectations from prospective epidemiological studies. BMJ. 2009 May 19;338:b1665.

668. Jellinger KA. Alzheimer disease and cerebrovascular pathology: an update. J Neural Transm (Vienna). 2002;109(5-6):813-36.

669. Kurth T, Kase CS, Berger K, Gaziano JM, Cook NR, Buring JE. Smoking and risk of hemorrhagic stroke in women. Stroke. 2003;34(12):2792-5.

670. Hillbom M, Haapaniemi H, Juvela S, Palomäki H, Numminen H, Kaste M. Recent alcohol consumption, cigarette smoking, and cerebral infarction in young adults. Stroke. 1995;26(1):40-5.

671. Rosand J, Hylek EM, O'Donnell HC, Greenberg SM. Warfarin-associated hemorrhage and cerebral amyloid angiopathy: a genetic and pathologic study. Neurology. 2000;55(7):947-51.

672. Toyoda K, Okada Y, Minematsu K, Kamouchi M, Fujimoto S, Ibayashi S, et al. Antiplatelet therapy contributes to acute deterioration of intracerebral hemorrhage. Neurology. 2005;65(7):1000-4.

673. GUSTO Angiographic Investigators. The effects of tissue plasminogen activator, streptokinase, or both on coronary artery patency, ventricular function, and survival after acute myocardial infarction. N Engl J Med. 1993;329(22):1615-22.

674. Kernan WN, Viscoli CM, Brass LM, Broderick JP, Brott T, Feldmann E, et al. Phenylpropanolamine and the risk of hemorrhagic stroke. N Engl J Med. 2000;343(25):1826-32.

675. Catto AJ, Kohler HP, Bannan S, Stickland M, Carter A, Grant PJ. Factor XIII Val 34 Leu: a novel association with primary intracerebral hemorrhage. Stroke. 1998;29(4):813-6.
676. Goldstein LB, Amarenco P, Szarek M, Callahan A 3rd, Hennerici M, Sillesen $\mathrm{H}$, et al. Hemorrhagic stroke in the Stroke Prevention by Aggressive Reduction in Cholesterol Levels study. Neurology. 2008;70(24 Pt2):2364-70.

677. Greenberg SM, Briggs ME, Hyman BT, Kokoris GJ, Takis C, Kanter DS et al. Apolipoprotein E epsilon 4 is associated with the presence and earlier onset of hemorrhage in cerebral amyloid angiopathy. Stroke. $1996 ; 27(8): 1333-7$.

678. Weir C], Murray GD, Adams FG, Muir KW, GrossetDG, Lees KR. Poor accuracy of stroke scoring systems for differential clinical diagnosis of intracranial haemorrhage and infarction. Lancet. 1994;344(8928):999-1002.

679. Brott T, Adams HP Jr., Olinger CP, Marler JR, Barsan WG, Biller J, et al Measurements of acute cerebral infarction: a clinical examination scale. Stroke. 1989;20(7):864-70.

680. Meretoja A, Strbian D, Putaala J, Curtze S, Haapaniemi E, Mustanoja S et al. SMASH-U: a proposal for etiologic classification of intracerebral hemorrhage. Stroke. 2012;43(10):2592-7.

681. Laissy JP, Normand G, Monroc M, Duchateau C, Alibert F, Thiebot J. Spontaneous intracerebral hematomas from vascular causes. Predictive value of CT compared with angiography. Neuroradiology. 1991;33(4):291-5

682. Kothari RU, Brott T, Broderick JP, Barsan WG, Sauerbeck LR, Zuccarello M, et al. The ABCs of measuring intracerebral hemorrhage volumes. Stroke. 1996;27(8):1304-5.

683. Hemphill III JC, Bonovich DC, Besmertis L, Manley GT, Johnston SC. The $\mathrm{ICH}$ score: a simple, reliable grading scale for intracerebral hemorrhage. Stroke. 2001;32(4):891-7.

684. Rost NS, Smith EE, Chang Y, Snider RW, Chanderraj R, Schwab K, et al Prediction of functional outcome in patients with primary intracerebral hemorrhage: the FUNC score. Stroke. 2008;39(8):2304-9.

685. Brott T, Broderick J, Kothari R, Barsan W, Tomsick T, Sauerbeck L, et al. Early hemorrhage growth in patients with intracerebral hemorrhage. Stroke. 1997;28(1):1-5

686. Wada R, Aviv RI, Fox AJ, Sahlas DJ, Gladstone DJ, Tomlinson G, et al. CT angiography "spot sign" predicts hematoma expansion in acute intracerebral hemorrhage. Stroke. 2007;38(4):1257-62.

687. Demchuk AM, Dowlatshahi D, Rodriguez-Luna D, Molina CA, Blas YS, Dzialowski I, et al. Prediction of haematoma growth and outcome in patients with intracerebral haemorrhage using the $\mathrm{CT}$ angiography spot sign (PREDICT): a prospective observational study. Lancet Neurol. 2012;11(4):307-14

688. Linfante I, Llinas RH, Caplan LR, Warach S. MRI features of intracerebral hemorrhage within 2 hours from symptom onset. Stroke. 1999;30(11):2263-7.

689. Singer OC, Sitzer M, du Mesnil de Rochemont R, Neumann-Haefelin T. Practical limitations of acute stroke MRI due to patient-related problems. Neurology. 2004;62(10):1848-9.

690. Zhu XL, Chan MS, Poon WS. Spontaneous intracranial hemorrhage: which patients need diagnostic cerebral angiography? A prospective study of 206 cases and review of the literature. Stroke. 1997;28(7):1406-9.

691. Dammert S, Krings T, Moller-Hartmann W, Ueffing E, Hans FJ, Willmes K, et al. Detection of intracranial aneurysms with multislice CT: comparison with conventional angiography. Neuroradiology. 2004;46(6):427-34.

692. Hino A, Fujimoto M, Yamaki T, Iwamoto Y, Katsumori T. Value of repeat angiography in patients with spontaneous subcortical hemorrhage. Stroke. 1998;29(12):2517-21.

693. Davis SM, Broderick J, Hennerici M, Brun NC, Diringer MN, Mayer SA et al. Hematoma growth is a determinant of mortality and poor outcome after intracerebral hemorrhage. Neurology. 2006;66(8):1175-81. 
694. Hwang DY, Dell CA, Sparks MJ, Watson TD, Langefeld CD, Comeau ME, et al. Clinician judgment vs formal scales for predicting intracerebral hemorrhage outcomes. Neurology. 2016;86(2):126-33.

695. Hansen BM, Nilsson OG, Anderson H, Norrving B, Säveland H, Lindgren A. Long term (13 years) prognosis after primary intracerebral haemorrhage: a prospective population based study of long term mortality, prognostic factors and causes of death. J Neurol Neurosurg Psychiatry. 2013;84(10):1150-5

696. van Asch CJ, Luitse MJ, Rinkel GJ, van der Tweel I, Algra A, Klijn CJ. Incidence, case fatality, and functional outcome of intracerebral haemorrhage over time, according to age, sex, and ethnic origin: a systematic review and meta-analysis. Lancet Neurol. 2010;9(2):167-76.

697. Steiner T, Kaste M, Forsting M, Mendelow D, Kwiecinski H, Szikora I, et al. Recommendations for the management of intracranial haemorrhage - part I: spontaneous intracerebral haemorrhage. The European Stroke Initiative Writing Committee and the Writing Committee for the EUSI Executive Committee. Cerebrovasc Dis. 2006;22(4):294-316.

698. Willmot M, Leonardi-Bee J, Bath PM. High blood pressure in acute stroke and subsequent outcome: a systematic review. Hypertension. 2004;43(1):18-24.

699. Butcher KS, Jeerakathil T, Hill M, Demchuk AM, Dowlatshahi D, Coutts SB, et al. The intracerebral hemorrhage acutely decreasing arterial pressure trial. Stroke. 2013;44(3):620-6.

700. Anderson CS, Huang Y, Wang JG, Arima H, Neal B, Peng B, et al. Intensive blood pressure reduction in acute cerebral haemorrhage trial (INTERACT): a randomised pilot trial. Lancet Neurol. 2008;7(5):391-9.

701. Anderson CS, Huang Y, Arima H, Heeley E, Skulina C, Parsons MW, et al. Effects of early intensive blood pressure-lowering treatment on the growth of hematoma and perihematomal edema in acute intracerebral hemorrhage: the Intensive Blood Pressure Reduction in Acute Cerebral Haemorrhage Trial (INTERACT). Stroke. 2010;41(2):307-12.

702. Antihypertensive Treatment of Acute Cerebral Hemorrhage (ATACH) Investigators. Antihypertensive treatment of acute cerebral hemorrhage. Crit Care Med. 2010;38(2):637-48.

703. Anderson CS, Heeley E, Huang Y, Wang J, Stapf C, Delcourt C, et al. Rapid blood-pressure lowering in patients with acute intracerebral hemorrhage. N Engl J Med. 2013;368(25):2355-65.

704. Qureshi Al, Palesch YY, Barsan WG, Hanley DF, Hsu CY, Martin RL, et al. Intensive blood-pressure lowering in patients with acute cerebral hemorrhage: N Engl J Med. 2016:375(11):1033-43.

705. Wolfe TJ, Torbey MT. Management of intracranial pressure. Curr Neurol Neurosci Rep. 2009;9(6):477-85.

706. Poungvarin N, Bhoopat W, Viriyavejakul A, Rodprasert P, Buranasiri P, Sukondhabhant $\mathrm{S}$, et al. Effects of dexamethasone in primary supratentorial intracerebral hemorrhage. N Engl J Med. 1987;316(20):1229-33.

707. Wintzen AR, de Jonge $H$, Loeliger EA, Bots GT. The risk of intracerebral hemorrhage during oral anticoagulant treatment: a population study. Ann Neurol. 1984;16(5):553-8.

708. Kuramatsu JB, Gerner ST, Schellinger PD, Glahn J, Endres M, Sobesky J, et al. Anticoagulant reversal, blood pressure levels, and anticoagulant resumption in patients with anticoagulation-related intracerebral hemorrhage. JAMA. 2015;313(8):824-36.

709. Lin J, Hanigan WC, Tarantino M, Wang J. The use of recombinant activated factor VII to reverse warfarin induced anticoagulation in patients with hemorrhages in the central nervous system: preliminary findings. J Neurosurg. 2003;98(4):737-40.

710. Ilyas C, Beyer GM, Dutton RP, Scalea TM, Hess JR. Recombinant factor VIla for warfarin associated intracranial bleeding. J Clin Anesth. 2008;20(4):276-9.

711. Tanaka KA, Szlam F, Dickneite G, LevyJH. Effects of prothrombin complex concentrate and recombinant activated factor VII on vitamin Kantagonist induced anticoagulation. Thromb Res. 2008;122(1):117-23.
712. Vespa PM, O'Phelan K, Shah M, Mirabelli J, Starkman S, Kidwell C, et al. Acute seizures after intracerebral hemorrhage: a factor in progressive midline shift and outcome. Neurology. 2003;60(9):1441-6.

713. Naidech AM, Garg RK, Liebling S, Levasseur K, Macken MP, Schuele SU, et al. Anticonvulsant use and outcomes after intracerebral hemorrhage. Stroke. 2009;40(12):3810-5.

714. Schwarz S, Hafner K, Aschoff A, Schwab S. Incidence and prognostic significance of fever following intracerebral hemorrhage. Neurology. 2000;54(2):354-61.

715. Paciaroni M, Agnelli G, Venti M, Alberti A, Acciarresi M, Caso V. Eficacy and safety of anticoagulants in the prevention of venous thromboembolism in patients with acute cerebral hemorrhage: a meta-analysis of controlled studies. J Thromb Haemost. 2011;9(5):893-8.

716. Mendelow AD, Gregson BA, Fernandes HM, Murray GD, Teasdale GM, Hope DT, et al. Early surgery versus initial conservative treatment in patients with spontaneous supratentorial intracerebral haematomas in the International Surgical Trial in Intracerebral Haemorrhage (STICH): a randomised trial. Lancet. 2005;365(9457):387-97.

717. Mendelow AD, Gregson BA, Rowan EN, Murray GD, Gholkar A, Mitchell $\mathrm{PM}$, et al. Early surgery versus initial conservative treatment in patients with spontaneous supratentorial lobar intracerebral haematomas (STICH II): a randomised trial. Lancet. 2013;382(9890):397-408.

718. Kirollos RW, Tyagi AK, Ross SA, van Hille PT, Marks PV. Management of spontaneous cerebellar hematomas: a prospective treatment protocol. Neurosurgery. 2001;49(6):1378-86.

719. Mould WA, Carhuapoma JR, Muschelli J, Lane K, Morgan TC, McBee NA, et al. Minimally invasive surgery plus recombinant tissue-type plasminogen activator for intracerebral hemorrhage evacuation decreases perihematomal edema. Stroke. 2013;44(3):627-34.

720. Naff N, Williams MA, Keyl PM, Tuhrim S, Bullock MR, Mayer SA, et al. Low-dose recombinant tissue-type plasminogen activator enhances clot resolution in brain hemorrhage: the intraventricular hemorrhage thrombolysis trial. Stroke. 2011;42(11):3009-16.

721. Basaldella L, Marton E, Fiorindi A, Scarpa B, Badreddine H, Longatti P. External ventricular drainage alone versus endoscopic surgery for severe intraventricular hemorrhage: a comparative retrospective analysis on outcome and shunt dependency. Neurosurg Focus. 2012;32(4):E4.

722. Gonzalez MM, Timerman S, Gianotto-Oliveira R, Sociedade Brasileira de Cardiologia. I Diretriz de ressuscitação cardiopulmonar e cuidados cardiovasculares de emergência da Sociedade Brasileira de Cardiologia. Arq Bras Cardiol. 2013; 101(2Supl 3): 1-221

723. Truhlár A, Deakin CD, Soar J, Khalifa GE, Alfonzo A, Bierens JJ.et al. European Resuscitation Cuncil Guidelines for Resuscitation 2015. Section 4. Cardiac arrest in special circumstances. Resuscitation.2015 Oct 95:148-201.

724. Lavonas EJ, Drennan IR, Gabrielli A, Heffner AC, Hoyte CC, Orkin AM, et al. Part 10: special circumstances of resuscitation: 2015 American Heart Association Guidelines Update for Cardiopulmonary Resuscitation and Emergency Cardiovascular Care. Circulation. 2015;132(Suppl 2):S501-S518.

725. Safar P, Paradis NA, Weil MH. Asphyxial cardiac arrest. In: Paradis NA, HalperinHR, Kern KB, Wenzel V, Chamberlain DA, editors. Cardiac arrest - the science and practice of resuscitation medicine. 2nd ed. Cambridge: Cambridge University Press; 2007. p. 969-93.

726. Deasy C, Bray J, Smith K, Bernard S, Cameron P, VACAR Steering Committee, et al. Hanging-associated out-of-hospital cardiac arrests in Melbourne, Australia. Emerg Med J. 2013;30(1):38-42.

727. Ogawa T, Akahane M, Koike S, Tanabe S, Mezoguchi T, Imamura T. Outcomes of chest compression only CPR versus conventional CPR conducted by lay people in patients with out of hospital cardiopulmonary arrest witnessed by bystanders: nationwide population based observational study. BMJ. 2011 Jan 27;342: c7106. 
728. Georgescu V, Tudorache O, Nicolau M,Strambu V. Study regarding the survival of patients suffering a traumatic cardiac arrest. J Med Life. 2015;8 (Spec Issue):103-9

729. Kutcher ME, Forsythe RM, Tisherman SA. Emergency preservation and resuscitation for cardiac arrest from trauma. Int J Surg. 2015 Oct 20. pii: S1743-9191(15)01279-0.

730. Zengin S, YavuzE, Al B, Cindoruk S, Altunbas G, Gunusboga H, etal. Benefits of cardiac sonography performed by a non-expert sonographer in patients with non-traumatic cardiopulmonary arrest. Resuscitation. 2016 May;102:105-9.

731. Testa A, Cibinel GA, Portale G, Forte P, Pignataro G, Silveri NG, et al. The proposal of an integrated ultrasonographic approach into the ALS algorithm for cardiac arrest: the PEA protocol. Eur Rev Med Pharmacol Sci. 2010;14(2):77-88

732. Chan SS. Emergency ultrasound detection of hypovolaemia as a cause of cardiac arrest. Resuscitation. 2008;79(2):340-1

733. Hernandez C1, Shuler K, Hannan H, Sonyika C, Likourezos A, Marshall J. CAUSE: Cardiac arrest ultra-sound exam--a better approach to managing patients in primary non-arrhythmogenic cardiac arrest. Resuscitation. 2008;76(2):198-206.

734. Castro FFM. Manual de suporte avançado de vida em anafilaxia e asma. Sao Paulo; Editora Atheneu: 2014.

735. Neugut Al, Ghatak AT, Miller RL. Anaphylaxis in the United States: an investigation into its epidemiology. Arch Intern Med. 2001;161(1):15-21.

736. Banerji A, Clark S, Blanda M, LoVecchio F, Snyder B, Camargo CA Jr. Multicenter study of patients with angiotensin-converting enzyme inhibitor-induced angioedema who present to the emergency department. Ann Allergy Asthma Immunol. 2008;100(4):327-32.

737. Agah R, Bandi V, Guntupalli KK. Angioedema: the role of ACE inhibitors and factors associated with poor clinical outcome. Intensive Care Med. 1997;23(7):793-6

738. Bork K, Hardt J, Schicketanz KH, Ressel N. Clinical studies of sudden upper airway obstruction in patients with hereditary angioedema due to C1 esterase inhibitor deficiency. Arch Intern Med. 2003;163(10):1229-35.

739. Fisher M. Blood volume replacement in acute anaphylactic cardiovascular collapse related to anaesthesia. Br J Anaesth. 1977;49(10):1023-6.

740. Nicolas F, Villers D, Blanloeil Y. Hemodynamic pattern in anaphylactic shock with cardiac arrest. Crit Care Med. 1984;12(2):144-5.

741. Jaff MR, McMurtry MS, Archer SL,Cushman M, Goldenberg SZ, Goldhaber SZ, et al.; American Heart Association Council on Cardiopulmonary, Critical Care, Perioperative and Resuscitation; American Heart Association Council on Peripheral Vascular Disease; American Heart Association Council on Arteriosclerosis, Thrombosis and Vascular Biology. Management of massive and submassive pulmonary embolism, iliofemoral deep vein thrombosis, and chronic thromboem- bolic pulmonary hypertension: a scientific statement from the American Heart Association. Circulation. 2011;123(16):1788-830

742. Schmid C, Zietlow S, Wagner TO, Laas J, Borst HG. Fulminant pulmo- nary embolism: symptoms, diagnostics, operative technique, and results. Ann Thorac Surg. 1991;52:1102-5; discussion 1105.

743. Kürkciyan I, Meron G, Sterz F, Janata K, Domanovts H, Holzer M, et al. Pulmonary embolism as a cause of cardiac arrest: presentation and outcome. Arch Intern Med. 2000;160(10):1529-35.

744. Courtney DM, Kline JA. Identification of prearrest clinical factors associated with outpatient fatal pulmonary embolism. Acad Emerg Med. 2001;8:1136-42.

745. Courtney DM, Kline JA. Prospective use of a clinical decision rule to identify pulmonary embolism as likely cause of outpa- tient cardiac arrest. Resuscitation. 2005;65:57-64

746. Comess KA, DeRook FA, Russell ML, Tognazzi-Evans TA, Beach KW. The incidence of pulmonary embolism in unexplained sudden cardiac arrest with pulseless electrical activity. Am J Med. 2000;109(5):351-6.
747. Wood KE. Major pulmonary embolism: review of a pathophysiologic approach to the golden hour of hemodynamically significant pulmonary embolism. Chest. 2002;121(3):877-905.

748. Bottiger BW, Arntz HR, Chamberlain DA, Blumke E, Belmans A, DaNcys T, et al. Thrombolysis during resuscitation for out-of-hospital cardiac arrest. N Engl J Med. 2008;359(25):2651-62.

749. Abu-Laban RB, Christenson JM, Innes GD, van Beek CA Wanger KP, McKnighy RD, et al. Tissue plasminogen activator in cardiac arrest with pulseless electrical activity. N Engl J Med. 2002;346(20):1522-8.

750. Li X, Fu QL, Jing XL, Li YJ, Zhan H, Ma ZF, et al. A meta-analysis of cardiopulmonary resuscitation with and without the administration of thrombolytic agents. Resuscitation. 2006;70(1):31-6.

751. Min KW, Kim WS, Jang SJ, Choi YD, Chang S, Jung SH, et al. Comparison between systemic and catheter thrombolysis in patients with pulmonary embolism. Am J Emerg Med. 2016;34(6):985-8

752. Shannon MW. A general approach to poisoning. In: Shannon: Haddad and Winchester's clinical management of poisoning and drug overdose. 4th ed. Philadelphia: Saunders/Elsevier; 2007. p. 13-30.

753. Chyka PA, Seger D, Krenzelok EP, American Academy of Clinical Toxicology; European Association of Poisons Centres and Clinical Toxicologists. Position paper: single-dose activated charcoal. Clin Toxicol (Phila). 2005;43(2):61-87.

754. Robertson TM, Hendey GW, Stroh G, Shalit M. Intranasal naloxone is a viable alternative to intravenous naloxone for prehospital narcotic overdose. Prehosp Emerg Care. 2009;13(4):512-5.

755. Borras MC, Becerra L, Ploghaus A, Gostic JM, DaSilva A, Gonzalez $\mathrm{RG}$, et al.MRI measurement of CNS responses to naloxone infusion and subsequent mild noxious thermal stimuli in healthy volunteers. J Neurophysiol. 2004;91(6):2723-33.

756. Clarke SF, Dargan PI, Jones AL. Naloxone in opioid poisoning: walking the tightrope. Emerg Med J. 2005;22:612-6.

757. Lheureux P, Vranckx M, Leduc D, Askenasi R. Flumazenil in mixed benzodiazepine/tricyclic antidepressant overdose: a placebo-controlled study in the dog. Am J Emerg Med. 1992;10(3):184-8.

758. McCord J, Jneid H, Hollander JE, de Lemos JA, Corcek B, Hsue P, et al. Management of cocaine-associated chest pain and myocardial infarction: a scientific statement from the American Heart Association Acute Cardiac Care Committee of the Council on Clinical Cardiology. Circulation. 2008;117(14):1897-907.

759. Wood DM, Dargan PI, Hoffman RS. Management of cocaine-induced cardiac arrhythmias due to cardiac ion channel dysfunction. Clin Toxico (Phila). 2009;47(1):14-23.

760. Weinberg G, Ripper R, Feinstein DL, Hoffman W. Lipid emulsion infu-sion rescues dogs from bupivacaine-induced cardiac toxicity. Reg Anesth Pain Med. 2003;28(3):198-202.

761. Cao D, Heard K, Foran M, Koyfman A. Intravenous lipid emulsion in the emergency department: a systematic review of the literature.J Emerg Med. 2015;48:387-97.

762. Koppel C, Wiegreffe A, Tenczer J. Clinical course, therapy, outcome and analytical data in amitriptyline and combined amitriptyline/ chlordiazepoxide overdose. Hum Exp Toxicol. 1992;11(6):458-65.

763. Tran TP, Panacek EA, Rhee KJ, Foulke GE. Response to dopamine vs norepinephrine in tricyclic antidepressant-induced hypotension. Acad Emerg Med. 1997;4(9):864-8.

764. Charalambous CP, Zipitis CS, Keenan DJ. Chest reexploration in the intensivecare unit after cardiac surgery: a safe alternative to returning to the operatingtheater. Ann Thorac Surg 2006;81:191-4.4

765. Kempen PM, Allgood R. Right ventricular rupture during closed-chest cardiopulmonary resuscitation after pneumonectomy with pericardiotomy: acase report. Crit Care Med. 1999;27:1378-9.458. 
766. Bohrer H, Gust R, Bottiger BW. Cardiopulmonary resuscitation after cardiacsurgery. J Cardiothorac Vasc Anesth 1995;9:352.459.

767. Overlie PA. Emergency use of cardiopulmonary bypass. J Interv Cardiol. 1995;8:239-47

768. Sprung J, Ritter MJ, Rihal CS, Warner ME Wilson BA, Williams BA, et al. Outcomes of cardiopulmonary resuscitation and predictors of survival in patients undergoing coro- nary angiography including percutaneous coronary interventions. Anesth ?Analg. 2006;102(1):217-24 .

769. Harmon KG, Asif IM, Klossner D, Drezner JA. Incidence of sudden cardiac death in National Collegiate Athletic Association athletes. Circulation .2011;123(15):1594-600

770. Chandra N, Papadakis M, Sharma S. Preparticipation screening of young competitive athletes for cardiovascular disorders. Phys Sportsmed 2010;38(1):54-63.

771. Angelini P. Coronary artery anomalies: an entity in search of an identity. Circulation 2007;115(10):1296-305.

772. Maron BJ, Doerer JJ, Haas TS, Tierney DM, Mueller FO, et al. Sudden deaths in young ?competitive athletes: analysis of 1866 deaths in the United States, 1980-2006. Circulation. 2009;119(8):1085-92.

773. Maron BJ, Gohman TE, Kyle SB, Estes III NA, Link MS. Clinical profile and spectrum of commotio cordis. JAMA 2002;287(9):1142-6.

774. Ghorayeb N, Costa RVC, Daher DJ, Oliveira Filho JA, Oliveira MA, et al.Guideline in Cardiology of Sport and Exercise of the Brazilian Society of Cardiology and the Brazilian Society of Sports Medicine. Arq Bras Cardiol. 2013;100(1Supl.2):1-41.

775. Budnick LD. Bathtub-related electrocutions in the United States, 1979 to 1982. JAMA. 1984;252(7):918-20.

776. Magarão RVQ, Guimarães HP, Lopes RD. Lesões por choque elétrico e por raios. Rev Bras Clin Med. São Paulo, 2011; 9(4):288-93.

777. Zafren K, Durrer B, Herry JP, Brugger H. Lightning injuries: prevention and on-site treatment in mountains and remote areas. Official guidelines of the International Commission for Mountain Emergency Medicine and the Medical Commission of the International Mountaineering and Climbing Federation (ICAR and UIAA MEDCOM). Resuscitation 2005;65:369-72.

778. Brasil. Ministério da Saúde. Informação em saúde (TABNET). [Citado em 2018 jan 10]. Disponível em: < http://www2.datasus.gov.br/DATASUS >

779. Zwingmann J, Mehlhorn AT, Hammer T, Bayer J, Sudkamp NP, Strohm PC, et al. Survival and neurologic outcome after traumatic out-of-hospital cardiopulmonary arrest in a pediatric and adult population: a systematic review. Crit Care . 2012;16(4):R117.

780. Millin MG, Galvagno SM, Khandker SR, Malki A, Bulger EM, Standards and Clinical Committee of the NAEMSP, ASCOT. Withholding and termination of resuscitation of adult cardiopulmonary arrest secondary to trauma: resource document to the joint NAEMSP-ACSCOT position statements. J Trauma Acute Care Surg 2013;75(3):459-67.

781. Beuran M, Paum S, Gaspar B, Vartic N, Hostiuc S, Chiotoroiu A, et al. Prehospital Trauma Care: a Clinical Review. Chirurgia (Bucur). 2012; 107(5):564-70

782. Smith RM, Conn AK. Prehospital care - scoop and run or stay and play? Injury. 2009;40 (Suppl 4):S23-6.

783. Luna GK, Pavlin EG, Kirkman T, Copass MK, Rice CL. Hemodynamic effects of external cardiac massage in trauma shock. J Trauma. 1989;29(10):1430-3.

784. Willis CD, Cameron PA, Bernard SA, Fitzgerald M. Cardiopulmonary resuscitation after traumatic cardiac arrest is not always futile. Injury. 2006;37(5):448-54.

785. Edelmuth RC, Buscariolli YD, Ribeiro Jr MA. Cirurgia para controle de danos: Estado atual. Rev Col Bras Cir. 2013;40(2):142-51.
786. Bickell WH, Wall Jr MJ, Pepe PE, Martin RR, Ginger VF, Allen MK,et al. Immediate versus delayed fluid resuscitation for hypotensive patients with penetrating torso injuries. N Engl J Med. 1994;331(17):1105-9.

787. Rhee PM, Acosta J, Bridgeman A, Wang D, Jordan M, Rich N. Survival after emergency department thoracotomy: review of published data from the past 25 years. J Am Coll Surg. 2000;190(3):288-98.

788. Manz E, Nofz L, Norman A, Davies GE. Incidence of clotted heamopericardium in traumatic cardiac arrest in 152 thoracotomy patients. Scand J Trauma Resusc Emerg Med .2013;22:P20.

789. Brasil. Ministério da Sáude. Boletim epidemiológico no Brasil. Ano 2015 (ano base de dados 2013). [Citado em 2015 jan 19]. Disponível em :http:// www.sobrasa.org/? $p=23335$

790. Szpilman D, Bierens JJ, Handley AJ, Orlowski JP. Drowning: Current Concepts. N Engl J Med. 2012 Oct;366:2102-10.

791. van Beck EF, Branche CM, Szpilman D, Modell JH, Bierens JJ. A New Definition of Drowning: Towards documentation and Prevention of a Global Health Problem. Bulletin of World Health Organization. 2005;83(11):853-6.

792. Szpilman D, Tipton M, Sempsrott J, Webber J, Bierens J, Dawes P, et al. Drowning timeline: a new systematic model of the drowning process, $\mathrm{Am}$ J Emerg Med. 2016;34(11):2224-6.

793. Szpilman D, Elmann J \& Cruz-Filho FES; Drowning Classification: A Revalidation Study Based On The Analysis Of 930 Cases Over 10 Years; World Congress on Drowning, Netherlands 2002, Book of Abstracts, ISBN:90-6788-280-01, pg 66.

794. Kleinman ME, Brennan EE, Goldberger ZD, Swor RA, Terry M, Bobrow BJ, et al.2015 American Heart Association Guidelines Update for Cardiopulmonary Resuscitation and Emergency Cardiovascular Care. Part 5: Adult Basic Life Support and Cardiopulmonary Resuscitation Quality. Circulation. 2015;132(18 Suppl 2):S414-35.

795. Brasil. Ministério da Saúde. VIGITEL: Vigilância de fatores de risco e proteção para doenças crônicas por inquérito telefônico,. Brasilia;2012.

796. Ogunnaike BO, Whitten CW, Minhajuddin A, Melikman E, Joshi GP, Moon TS, et al; American Heart Association's Get With The Guidelines(®)Resuscitation Investigators. Body mass index and outcomes of in-hospital ventricular tachycardia and ventricular fibrillation arrest. Resuscitation. 2016 Aug;105:156-60.

797. Testori C, Sterz F, Losert H, Krizanac D, Haugk M, Uray T, et al. Cardiac arrest survivors with moderate elevated body mass index may have a better neurological outcome: a cohort study. Resuscitation. 2011;82(7):869-73.

798. Chalkias A, Xanthos $T$. The obesity paradox in cardiac arrest patients. Int J Cardiol.2014 (171); 101-2.

799. Brasil. Ministério da Saúde. Pesquisa Nacional de Saúde (PNS). Brasilia, 2015.

800. Brasil. Ministério da Saúde. Sistema de Informações Hospitalares (SIH). Brasilia; 2015.

801. Global Initiative for Asthma. Global Strategy for Asthma Management and Prevention, 2016. [Cited in 2017 jan 12].Available from: www. ginasthma.org

802. Bowman FP, Menegazzi JJ, Check BD, Duckett TM. Lower esophageal sphincter pressure during prolonged cardiac arrest and resuscitation. Ann Emerg Med.1995;26(2):216-9.

803. Leatherman JW, McArthur C, Shapiro RS. Effect of prolongation of expiratory time on dynamic hyperinflation in mechanically ventilated patients with severe asthma. Crit Care Med 2004;32(7):1542-5.

804. European Society of Gynecology (ESG); Association for European Paediatric Cardiology (AEPC); German Society for Gender Medicine (DGesGM), Regitz-Zagrosek V, Blomstrom CL, Borghi C, Cifkova R, Ferreira R, Foidart JM, et al; ESC Committee for Practice Guidelines. ESC Guidelines on the management of cardiovascular diseases during pregnancy: the Task Force on the Management of Cardiovascular Diseases 
during Pregnancy of the European Society of Cardiology (ESC). Eur Heart J. 2011;32(24):3147-97.

805. Martins LC, Freire CMV, Capuruçu CAB, Nunes MCP, Rezende CAL. Risk prediction of cardiovascular complications in pregnant women with heart disease. Arq Bras Cardiol. 2016;106(4):289-96.

806. McGregor AJ, Barron R, Rosene-Montella K. The pregnant heart: cardiac emergencies during pregnancy. Am J Emerg Med. 2015;33(4):573-9.

807. Avila WS, Rossi EG, Ramires JA, Grinberg M, Bortolotto MR, Zugaib M, et al. Pregnancy in patients with heart disease: experience with 1,000 cases. Clin Cardiol. 2003;26(3):135-42.

808. Campanharo FF, Cecatti JG, Haddad SM, Parpinelli MA, Born D, Costa ML, et al; Brazilian Network for Surveillance of Severe Maternal Morbidity Study Group. The Impact of Cardiac Diseases during Pregnancy on Severe Maternal Morbidity and Mortality in Brazil. PLoS One. 2015;10(12):e0144385.

809. Tarasoutchi F, Montera MW, Grinberg M, Barbosa MR, Piñeiro DJ, Sánchez CR, et al, sociedade Brasileira de Cardiologia. Diretriz Brasileira de Valvopatias -2011 / I Diretriz Interamericana de Valvopatias - SIAC 2011. Arq Bras Cardiol. 2011;97(5 Suppl. 1): 1-67.

810. Tedoldi CL, Freire CMV, Bub TF,et al.Sociedade Brasileira de Cardiologia. Diretriz da Sociedade Brasileira de Cardiologia para gravidez na mulher portadora de cardiopatia. Arq Bras Cardiol.2009;93(6 Suppl 1):e110-78.

811. Sliwa K, Johnson MR, Zilla P, Roos-Hesselink JW. Management of valvular disease in pregnancy: a global perspective. Eur Heart J. 2015;36(18):1078-89.

812. Nishimura RA, Otto CM, Bonow RO, Carabello BA, Erwin JP 3rd, Guyton RA, et al; ACC/AHA Task Force Members. 2014 AHA/ACC Guideline for the Management of Patients With Valvular Heart Disease: executive summary: a report of the American College of Cardiology/American Heart Association Task Force on Practice Guidelines. Circulation. .2014;129(23):2440-92.

813. Basu S, Aggarwal P, Kakani N, Kumar A. Low-dose maternal warfarin intake resulting in fetal warfarin syndrome: In search for a safe anticoagulant regimen during pregnancy. Birth Defects Res A Clin Mol Teratol. 2016;106(2):142-7.

814. Friedrich E, Hameed AB. Fluctuations in anti-factor Xa levels with therapeutic enoxaparin anticoagulation in pregnancy. J Perinatol. 2010;30(4):253-7.

815. van Hagen IM, Roos-Hesselink JW, Ruys TP, Merz WM, Goland S, Gabriel $\mathrm{H}$,et al; ROPAC Investigators and the EURObservationalResearch Programme (EORP) Team. Pregnancy in Women With a Mechanical Heart Valve: Data of the European Society of Cardiology Registry of Pregnancy and Cardiac Disease (ROPAC). Circulation. 2015;132(2):132-42.

816. Montorsi P, De Bernardi F, Muratori M, Cavoretto D, Pepi M. Role of cinefluoroscopy, transthoracic, and transesophageal echocardiography in patients with suspected prosthetic heart valve thrombosis. Am J Cardiol. 2000;85(1):58-64.

817. Özkan M, Çakal B, Karakoyun S, Gürsoy OM, Çevik C, Kalçik M, et al. Thrombolytic therapy for the treatment of prosthetic heart valve thrombosis in pregnancy with low-dose, slow infusion of tissue-type plasminogen activator. Circulation. 2013;128(5):532-40.

818. Campuzano K, Roqué H, Bolnick A, Leo MV, Campbell WA. Bacterial endocarditis complicating pregnancy: case report and systematic review of the literature. Arch Gynecol Obstet. 2003;268(4):251-5.

819. Baddour LM, Wilson WR, Bayer AS, Fowler VG Jr, Tleyjeh IM, Rybak M]. et al; American Heart Association Committee on Rheumatic Fever, Endocarditis, and Kawasaki Disease of the Council on Cardiovascular Disease in the Young, Council on Clinical Cardiology, Council on Cardiovascular Surgery and Anesthesia, and Stroke Council. Infective Endocarditis in Adults: Diagnosis, Antimicrobial Therapy, and Management of Complications: A scientific statement for healthcare professionals from the American Heart Association. Circulation. 2015;132(15):1435-86.
820. Habib G, Lancellotti P, Antunes MJ, Bongiorni MG, Casalta JP, Del Zotti F,etal; Document Reviewers. 2015 ESC Guidelines for the management of infective endocarditis: The Task Force for the Management of Infective Endocarditis of the European Society of Cardiology (ESC). Endorsed by: European Association for Cardio-Thoracic Surgery (EACTS), the European Association of Nuclear Medicine (EANM). Eur HeartJ. 2015;36(44):3075-128.

821. Ruys TP, Roos-HesselinkJW, Hall R, Subirana-Domènech MT, Grando-Ting J, Estensen M, et al. Heart failure in pregnant women with cardiac disease: data from the ROPAC. Heart. 2014;100(3):231-8.

822. Sliwa K, Hilfiker-Kleiner D, Petrie MC, Mebazaa A, Pieske B, Buchmann E, et al; Heart Failure Association of the European Society of Cardiology Working Group on Peripartum Cardiomyopathy. Current state of knowledge on aetiology, diagnosis, management, and therapy of peripartum cardiomyopathy: a position statement from the Heart Failure Association of the European Society of Cardiology Working Group on peripartum cardiomyopathy. Eur J Heart Fail. 2010;12(8):767-78.

823. De Cara JM, Lang RM, Foley MR. Management of heart failure during pregnancy (Internet). UpToDate. 2018 Dec 5(Cited in 2016 Jun 01 ) Available from: https://www.uptodate.com/contents/management-ofheart-failure-during-pregnancy\#H20.

824. Hilfiker-Kleiner D, Haghikia A, Nonhoff J, Bauersachs J. Peripartum cardiomyopathy: current management and future perspectives. Eur Heart J. 2015;36(18):1090-7

825. Bocchi EA, Marcondes-Braga FG, Bacal F, Ferraz AS, Albuquerque D, Rodrigues D, et al., Sociedade Brasileira de Cardiologia. Atualização da Diretriz Brasileira de Insuficiência Cardíaca Crônica - 2012. Arq Bras Cardiol 2012;98(1 Suppl 1): 1-33.

826. Haghikia A, Podewski E, Berliner D, Sonnenschein K, Fischer D, Angermann $\mathrm{CE}$, et al. Rationale and design of a randomized, controlled multicentre clinical trial to evaluate the effect of bromocriptine on left ventricular function in women with peripartum cardiomyopathy. Clin Res Cardiol. 2015;104(11):911-7.

827. Melo MA, Carvalho JS, Feitosa FE, Araujo Júnior E, Peixoto AB, Costa Carvalho FH, Carvalho RC. Peripartum cardiomyopathy treatment with dopamine agonist and subsequent pregnancy with a satisfactory outcome. Rev Bras Ginecol Obstet. 2016;38(6):308-13.

828. Bauersachs J, Arrigo M, Hilfiker-Kleiner D, Veltmann C, Coats AJ, CrespoLeiro MG, et al. Current management of patients with severe acute peripartum cardiomyopathy: practical guidance from the Heart Failure Association of the European Society of Cardiology Study Group on peripartum cardiomyopathy. Eur J Heart Fail. 2016;18(9):1096-105

829. Avila WS, de Carvalho ME, Tschaen CK, Rossi EG, Grinberg M, Mady C, et al. Pregnancy and peripartum cardiomyopathy. A comparative and prospective study. Arq Bras Cardiol. 2002;79(5):484-93.

830. Dennis AT, Solnordal CB. Acute pulmonary oedema in pregnant women. Anaesthesia. 2012;67(6):646-59.

831. Sciscione AC, Ivester T, Largoza M, Manley J, Shlossman P, Colmorgen $\mathrm{GH}$. Acute pulmonary edema in pregnancy. Obstet Gynecol. 2003;101(3):511-5

832. Knotts RJ, Garan H. Cardiac arrhythmias in pregnancy. Semin Perinatol. 2014;38(5):285-8.

833. Enriquez AD, Economy KE, Tedrow UB. Contemporary management of arrhythmias during pregnancy. Circ Arrhythm Electrophysiol. 2014;7(5):961-7.

834. Page RL, Joglar JA, Caldwell MA, Calkins H, Conti JB, etal. 2015 ACC/AHA HRS Guideline for the Management of Adult Patients With Supraventricular Tachycardia: A Report of the American College of Cardiology/American Heart Association Task Force on Clinical Practice Guidelines and the Heart Rhythm Society. J Am Coll Cardiol. 2016;67(13):e27-115.

835. Driver K, Chisholm CA, Darby AE, Malhotra R, Dimarco JP, Ferguson JD. Catheter Ablation of Arrhythmia During Pregnancy. J Cardiovasc Electrophysiol. 2015;26(6):698-702. 
836. Tromp CH, Nanne AC, PernetPJ, Tukkie R, Bolte AC. Electrical cardioversion during pregnancy: safe or not? Neth Heart J. 2011;19(3):134-6.

837. Nakagawa M, Katou S, Ichinose M, Nobe S, Yonemochi H, Miyakawa I, Saikawa T. Characteristics of new-onset ventricular arrhythmias in pregnancy. J Electrocardiol 2004;37:47-53.

838. Natale A, Davidson T, Geiger MJ, Newby K. Implantable cardioverterdefibrillators and pregnancy: a safe combination? Circulation. 1997;96(9):2808-12.

839. Suri V, Keepanasseril A, Aggarwal N, Vijayvergiya R, Chopra S, Rohilla M. Maternal complete heart block in pregnancy: analysis of four cases and review of management. J Obstet Gynaecol Res. 2009;35(3):434-7.

840. Cox JL, Gardner MJ. Treatment of cardiac arrhythmias during pregnancy. Prog Cardiovasc Dis. 1993;36(2):137-78.

841. Greer IA. Clinical Practice. Pregnancy Complicated by Venous Thrombosis. NEngl J Med. 2015;373(6):540-7.

842. Bates SM, Greer IA, Middeldorp S, Veenstra DL, Prabulos AM, Vandvik PO; American College of Chest Physicians. VTE, thrombophilia, antithrombotic therapy, and pregnancy: Antithrombotic Therapy and Prevention of Thrombosis, 9th ed: American College of Chest Physicians Evidence-Based Clinical Practice Guidelines. Chest. 2012;141(2 Suppl):e691S-736S.

843. RCOG Green-top Guideline No. 37b - thromboembolic disease in pregnancy and the puerperium: acute management. London: Royal College of Obstetricians and Gynaecologists, $>$ \{Cied in 2015 Apr 12). Available from: (https://www.rcog.org.uk/globalassets/documents/ guidelines/gtg-37b .pdf).

844. Greer IA, Nelson-Piercy C. Low-molecular-weight heparins for thromboprophylaxis and treatment of venous thromboembolism in pregnancy: a systematic review of safety and efficacy. Blood. 2005;106(2):401-7.

845. Romualdi E, Dentali F, Rancan E, Squizzato A, Steidl L, Middeldorp S, et al. Anticoagulant therapy for venous thromboembolism during pregnancy: a systematic review and a meta-analysis of the literature. J Thromb Haemost. 2013;11(2):270-81.

846. te Raa GD, Ribbert LS, Snijder RJ, Biesma DH. Treatment options in massive pulmonary embolism during pregnancy; a case-report and review of literature. Thromb Res. 2009;124(1):1-5.

847. Baumgartner H, Bonhoeffer P, De Groot NM, de Haan F, Deanfield JE, Galie N,et al; TaskForce on the Management of Grown-up Congenital Heart Disease of the European Society of Cardiology (ESC); Association for European Paediatric Cardiology (AEPC); ESC Committee for Practice Guidelines (CPG). ESC Guidelines for the management of grownup congenital heart disease (new version 2010). Eur Heart J. 2010; 31(23):2915-57.

848. Drenthen W, Pieper PG, Roos-Hesselink JW, van Lottum WA, Voors AA, Mulder BJ, et al. Outcome of pregnancy in women with congenital heart disease: a literature review. J Am Coll Cardiol. 2007;49(24):2303-11.

849. Diller GP, Uebing A. Predicting the risks of pregnancy in congenital heart disease: the importance of external validation. Heart. 2014;100(17):1311-2.

850. Bedard E, Dimopoulos K, Gatzoulis MA. Has there been any progress made on pregnancy outcomes among women with pulmonary arterial hypertension? Eur Heart J. 2009;30(3):256-65.

851. Weiss BM, Zemp L, Seifert B, Hess OM. Outcome of pulmonary vascular disease in pregnancy: a systematic overview from 1978 through 1996. J Am Coll Cardiol. 1998;31(7):1650-7

852. Galiè N, Humbert M, Vachiery JL, Gibbs S, Lang I, Torbicki A, et al. 2015 ESC/ERS Guidelines for the diagnosis and treatment of pulmonary hypertension: The Joint Task Force for the Diagnosis and Treatment of Pulmonary Hypertension of the European Society of Cardiology (ESC) and the European Respiratory Society (ERS): Endorsed by: Association for European Paediatric and Congenital Cardiology (AEPC), International
Society for Heart and Lung Transplantation (ISHLT). Eur Heart J. 2016;37(1):67-119.

853. Presbitero P, Somerville J, Stone S, Aruta E, Spiegelhalter D, Rabajoli F. Pregnancy in cyanotic congenital heart disease. Outcome of mother and fetus. Circulation. 1994;89(6):2673-6.

854. Brickner ME. Cardiovascular management in pregnancy: congenital heart disease. Circulation. 2014;130(3):273-82.

855. Greutmann M, Pieper PG. Pregnancy in women with congenital heart disease. Eur Heart J. 2015;36(37):2491-9.

856. Zugaib M, Francisco R, eds. Zugaib Obstetricia. 3ạ ed. São Paulo; Manole; 2016.

857. Zugaib M, Bittar R, Francisco R, eds. Protocolos assistenciais da Clínica Obstétrica FMUSP. 5ำ ed. São Paulo: Atheneu; 2015.

858. Sass N, Silveira MR, Oliveira LG, Facca T, Sato JL, Korkes HA, et al. Maternal mortality in Brazil and proportion to hypertensive disorders: a trend of stagnation. Pregnancy Hypertens. 2015;5(1):78.

859. Abalos E, Cuesta C, Grosso A, Chou D, Say L. Global and regional estimates of preeclampsia and eclampsia: a systematic review. Eur J Obstet Gynecol Reprod Biol. 2013;170(1):1-7

860. von Dadelszen P, Payne B, Li J, Ansermino JM, Broughton Pipkin F, Côté AM,et al; PIERS Study Group. Prediction of adverse maternal outcomes in pre-eclampsia: development and validation of the fullPIERS model. Lancet. 2011;377(9761):219-27.

861. Gruslin A,Leymare B. Pre-eclampsia: fetal assessment and neonatal outcomes. Best Pract Res Clin Obstet Gynaecol. 2011;25(4):491-507.

862. Abalos E, Duley L, Steyn DW. Antihypertensive drug therapy for mild to moderate hypertension during pregnancy. Cochrane database Syst Rev. 2014;(2):CD002252.

863. Malachias MV, Souza WK, Plavnik FL, Rodrigues CIS, Brandão AA, Neves MFT, et al. 7 a Diretriz Brasileira de Hipertensão Arterial. Arq Bras Cardiol. 2016;107(3 Suppl 3):1-83.

864. Magee LA, Pels A, Helewa M, Rey E, von Dadelszen P; Canadian Hypertensive Disorders of Pregnancy (HDP) Working Group. Diagnosis, evaluation, and management of the hypertensive disorders of pregnancy. Pregnancy Hypertension. 2014;4(2):105-45.

865. World Health Organization. WHO Recommendations for Prevention and Treatment of Pre-Eclampsia and Eclampsia. Geneva;2011.

866. American College of Obstetricians and Gynecologists; Task Force on Hypertension in Pregnancy. Hypertension in pregnancy. report of the American College of obstetricians and gynecologists' task force on hypertension in pregnancy. Obstet Gynecol. 2013;122(5):1122-31.

867. Magee LA, Singer J, von Dadelszen P; CHIPS Study Group. Less-tight versus tight control of hypertension in pregnancy. $N$ Engl J Med. 2015;372(5):407-17.

868. Magee LA, von Dadelszen P, Rey E, Ross S, Asztalos E, Murphy K, et al The Control of Hypertension In Pregnancy Study (CHIPS) randomised controlled trial. Archives of disease in childhood. Fetal and neonatal.2014 Jun;99:A5-6.

869. Rodrigues FS, Tavares JG, Bergantin LB, de Oliveira Jr IS, Wanderley AG, Ferraz RR, et al. Utilização do verapamil em pacientes gestantes hipertensas. Rev Pesq Inov Farm. 2012;4(1):1-7.

870. Tranquilli AL, Dekker G, Magee L, Roberts J, Sibai BM, Steyn W, et al. The classification, diagnosis and management of the hypertensive disorders of pregnancy: A revised statement from the ISSHP. Pregnancy Hypertens.2014;4(2):97-104.

871. Polewczyk A. Coronary disease in pregnancy. Heart. 2015;101(7):502-3

872. Wright D, Kenny-Scherber C, Montgomery A, Salehian O. Acute coronary syndrome in pregnancy. Clin Med Cardiol. 2009;3:125-31. 
873. Elkayam U, Jalnapurkar S, Barakkat MN, Khatri N, Kealey AJ, Mehra A, et al. Pregnancy-associated acute myocardial infarction: a review of contemporary experience in 150 cases between 2006 and 2011. Circulation. 2014;129(16):1695-702.

874. Roth A, Elkayam U. Acute myocardial infarction associated with pregnancy. J Am Coll Cardiol. 2008;52(3):171-80.

875. Jeejeebhoy FM, Zelop CM, Lipman S, Carvalho B, Joglar J, Mhyre JM, et al. Cardiac Arrest in Pregnancy: A Scientific Statement From the American Heart Association. Circulation. 2015;132(18):1747-73.

876. Mather PJ, Hansen CL, Goldman B, Inniss S, Piña I, Norris R, et al. Postpartum multivessel coronary dissection. J Heart Lung Transplant. 1994;13(3):533-7.

877. Shade GH Jr, Ross G, Bever FN, Uddin Z, Devireddy L, Gardin JM. Troponin I in the diagnosis of acute myocardial infarction in pregnancy, labor, and post partum. Am J Obstet Gynecol. 2002;187(6):1719-20

878. Saw J, Ricci D, Starovoytov A, Fox R, Buller CE. Spontaneous coronary artery dissection: prevalence of predisposing conditions including fibromuscular dysplasia in a tertiary center cohort. JACC Cardiovasc Interv. 2013;6(1):44-52.

879. James AH, Jamison MG, Biswas MS, Brancazio LR, Swamy GK, Myers ER. Acute myocardial infarction in pregnancy: a United States populationbased study.Circulation. 2006;113(12):1564-71

880. Roth A, Elkayam U. Acute myocardial infarction associated with pregnancy. Ann Intern Med. 1996;125(9):751-62.

881. Ladner HE, Danielsen B, Gilbert WM. Acute myocardial infarction in pregnancy and the puerperium: a population-based study. Obstet Gynecol. 2005;105(3):480-4.

882. Beirer M, Banke IJ, Münzel D, Wendorff H, Khaladj N, Kirchhoff C, et al. Emergency cesarean section due to acute aortic dissection type A (Debakey I) without Marfan syndrome: a case report and review of the literature.J Emerg Med. 2014;46(1):e13-7.

883. Rajagopalan S, Nwazota N, Chandrasekhar S. Outcomes in pregnant women with acute aortic dissections: a review of the literature from 2003 to 2013. Int J Obstet Anesth. 2014;23(4):348-56

884. Avila WS, Dias R, Yamada RT, Armelin A. Disseção aguda de aorta durante a gravidez. Arq Bras Cardiol. 2006;87(4):e112-5

885. Cox DA, Ginde S, Kuhlmann RS, Earing MG. Management of the pregnant woman with Marfan syndrome complicated by ascending aorta dilation. Arch Gynecol Obstet. 2014;290(4):797-802

886. Yuan SM. Bicuspid aortic valve in pregnancy. Taiwan J Obstet Gynecol. 2014:53(4):476-80.

887. Suresh MS, LaToya CM, Munnur U. Cardiopulmonary resuscitation and the parturient. Best Pract Res Clin Obstet Gynaecol. 2010;24(3):383-400.

888. Brent RL. Saving lives and changing family histories: appropriate counseling of pregnant women and men and women of reproductive age, concerning the risk of diagnostic radiation exposures during and before pregnancy. Am J Obstet Gynecol. 2009;200(1):4-24.

889. Brent RL. The effect of embryonic and fetal exposure to $x$-ray, microwaves, and ultrasound: counseling the pregnant and nonpregnant patient about these risks. Semin Oncol. 1989;16(5):347-68.

890. De Santis M, Cesari E, Nobili E, Straface G, Cavaliere AF, Caruso A. Radiation effects on development. Birth Defects Res C Embryo Today. 2007;81(3):177-82

891. Kruskal JB. Diagnostic imaging procedures during pregnancy(Internet). UpToDate. 2018 May 14.(Acesso em 02 de Junho de 2016.).Availabel from: https://www.uptodate.com/contents/diagnostic-imaging-inpregnant-and-nursing-women

892. ARSAC Notes for Guidance on the Clinical Administration of Radiopharmaceuticals and use of sealed Radioactive Sources. Last updated: 15 January 2016. [Cited in 2017 Feb 24] Available from: https:/ www.gov.uk/government/uploads/system/uploads/attachment_data/ file/492127/ARSAC_NfG_2016.pdf.

893. Committee Opinion No. 656: Guidelines for Diagnostic Imaging During Pregnancy and Lactation. Obstet Gynecol. 2016;127(2):e75-80.

894. de Souza JA, Martinez EE Jr, Ambrose JA, Alves CM, Born D, Buffolo E, et al. Percutaneous balloon mitral valvuloplasty in comparison with open mitral valve commissurotomy for mitral stenosis during pregnancy. J Am Coll Cardiol. 2001;37(3):900-3.

895. Avila WS, Hajjar LA, Souza T R, Gomes MP Jr, Grinberg M, Zugaib M. Aortic valvuloplasty with balloon catheter in maternal-fetal emergency in adolescence. Arq Bras Cardiol. 2009;93(6):e76-9, e89-92.

896. Elassy SM, Elmidany AA, Elbawab HY. Urgent cardiac surgery during pregnancy: a continuous challenge. Ann Thorac Surg. 2014;97(5):1624-9.

897. Avila WS, Gouveia AM, Pomerantzeff P, Bortolotto MR, Grinberg M, Stolf $\mathrm{N}$, et al. Maternal-fetal outcome and prognosis of cardiac surgery during pregnancy. Arq Bras Cardiol. 2009;93(1):9-14

898. Martinelli Filho M, Zimerman LI, Lorga AM, Vasconcelos JT, Rassi A Jr. Guidelines for implantable electronic cardiac devices of the Brazilian Society of Cardiology. Arq Bras Cardiol. 2007;89(6):e210-38.

899. Esper RB, Furtado RH, Tarasoutchi F, Spina GS, Grinberg M, Avila WS Permanent pacemaker implantation in a pregnant woman with rheumatic mitral valve disease. Arq Bras Cardiol. 2009;92(5):e32-5,e59-62.

900. Micromedex ${ }^{\circledR}$ 2.0, (electronic version). Truven Health Analytics, Greenwood Village, Colorado, USA. [Cited in 2016 June 23]. Available from: http://www.micromedexsolutions.com/UpToDate

901. Drugs and Lactation Database (LactMed) (base de dados online). Bethesda (MD): U.S. National Library of Medicine. [Cited 2016 Apr 23].available from: https://toxnet.nlm.nih.gov/newtoxnet/lactmed.htm.

902. E-lactancia (versão eletrônica). Base de dados da APILAM (Association for Promotion and Cultural and Scientific Research of Brestfeeding). [Cited in 2016 Apr 12]. Available from: www.e-lactancia.org

903. FDA website: [Cited in 2016 May 20]. Available from:http://www.fda. gov/drugs/developmentapprovalprocess/developmentresources/labeling ucm093307.htm

904. Pieper PG. Use of medication for cardiovascular disease during pregnancy. Nat Rev Cardiol. 2015;12(12):718-29.

905. Appleton GO, Cummins RO, Larson MP, Graves JR. CPR and the single rescuer: at what age should you "call first" rather than "call fast"? Ann Emerg Med. 1995;25(4):492-4.

906. Mogayzel C, Quan L, Graves IR, Tiedeman D, Fahrenbruch C, Herndon P. Out-of-hospital ventricular fibrillation in children and adolescents: causes and outcomes. Ann Emerg Med. 1995;25(4):484-91.

907. Perondi MB, Reis AG, Paiva EF, Nadkarni VM, Berg RA. A comparison of high-dose and standard-dose epinephrine in children with cardiac arrest. N Engl J Med. 2004;350(17):1722-30.

908. Peberdy MA, Kaye W, Ornato JP, Larkin GL, Nadkarni V, Mancini ME, et al. Cardiopulmonary resuscitation of adults in the hospital: a report of 14720 cardiac arrests from the National Registry of Cardiopulmonary Resuscitation. Resuscitation. 2003;58(3):297-308.

909. de Caen AR, Maconochie IK, Aickin R, Atkins DL, Biarent D, Guerguerian AM, et al; Pediatric Basic Life Support and Pediatric Advanced Life Support Chapter Collaborators. Part 6: Pediatric Basic Life Support and Pediatric Advanced Life Support. 2015 International Consensus on Cardiopulmonary Resuscitation and Cardiovascular Care Science with Treatment Recommendations. Circulation. 2015;132(16 Suppl 1):S177-S203. Erratum in: Circulation. 2016;134(9):e121.

910. Guimarães HP; Projeto de Destaques das Diretrizes da AHA. Destaques da American Heart Association 2015. Atualização das Diretrizes de RCP e ACE 2015. \{Citado agosto 15]. Disponível em: https://eccguidelines.heart. org/wp-content/uploads/2015/10/2015-AHA-Guidelines-HighlightsPortuguese.pdf 
911. Girotra S, Spertus JA, Li Y, Berg RA, Nadkarni VM, Chan PS; American Heart Association Get With the Guidelines-Resuscitation Investigators. Survival trends in pediatric in-hospital cardiac arrests: an analysis from Get With The Guidelines-Resuscitation. Circ Cardiovasc Qual Outcomes. 2013;6(1):42-9.

912. Maconochie IK, Bingham R, Eich C, López-Herce J, Rodríguez-Núñez A, Rajka T, et al; Paediatric life support section Collaborators. European Resuscitation Council Guidelines for Resuscitation 2015. Section 6. Paediatric life support. Resuscitation. 2015 Oct;95:223-48.

913. Gonzalez MM, Timerman S, Oliveira RG, Polastri TF, Dallan LAP, Araújo S, et al; Sociedade Brasileira de Cardiologia. I Guideline for cardiopulmonary resuscitation and emergency cardiovascular care - Brazilian Society of Cardiology: Executive Summary. Arq Bras Cardiol. 2013;100(2):105-13.

914. Marsch S, Tschan F, Semmer NK, Zobrist R, Hunziker PR, Hunziker S. ABC versus $C A B$ for cardiopulmonary resuscitation: a prospective, randomized simulator-based trial. Swiss Med Wkly. 2013 Sep 6;143:w13856.

915. Sekiguchi $\mathrm{H}$, Kondo $\mathrm{Y}$, Kukita I. Verification of changes in the time taken to initiate chest compressions according to modified basic life support guidelines. Am J Emerg Med. 2013;31(8):1248-50.

916. Lubrano R, Cecchetti C, Bellelli E, Gentile I, Loayza, Levano H, et al. Comparison of times of intervention during pediatric CPR maneuvers using $\mathrm{ABC}$ and $\mathrm{CAB}$ sequences: a randomized trial. Resuscitation. 2012;83(12):1473-7.

917. Peddy SB, HazinskiMF, Laussen PC, Thiagarajan RR, Hoffman GM, Nadkarni $\mathrm{V}$, et al. Cardiopulmonary resuscitation: special considerations for infants and children with cardiac disease. Cardiol Young. 2007;17(Suppl 2):116-26.

918. Sutton RM, French B, Niles DE, Donoghue A, Topjian AA, Nishisaki A, et al. 2010 American Heart Association recommended compression depths during pediatric in-hospital resuscitations are associated with survival. Resuscitation. 2014;85(9):1179-84.

919. Idris AH, Guffey D, Pepe PE, Brown SP, Brooks SC, Callaway CW, et al; Resuscitation Outcomes Consortium Investigators. Chest compression rates and survival following out-of-hospital cardiac arrest. Crit Care Med. 2015;43(4):840-8.

920. Kitamura T, Iwami T, Kawamura T, Nagao K, Tanaka H, Nadkarni VM, et al; Implementation working group for All-Japan Utstein Registry of the Fire and Disaster Management Agency. Conventional and chest-compressiononly cardiopulmonary resuscitation by bystanders for children who have out-of-hospital cardiac arrests: a prospective, nationwide, populationbased cohort study. Lancet. 2010;375(9723):1347-54.

921. Goto Y, Maeda T, Goto Y. Impact of dispatcher-assisted bystander cardiopulmonary resuscitation on neurological outcomes in children with out-of-hospital cardiac arrests: a prospective, nationwide, population based cohort study. J Am Heart Assoc. 2014;3(3):e000499.

922. Valenzuela TD, Kern KB, Clark LL, Berg RA, Berg MD, Berg DD, et al. Interruptions of chest compressions during emergency medical systems resuscitation. Circulation. 2005;112(9):1259-65.

923. Peska E, Kelly AM, Kerr D, Green D. One-handed versus two-handed chest compressions in paediatric cardio-pulmonary resuscitation. Resuscitation. 2006;71(1):65-9

924. Atkins DL, Berger S, DuffJP, Gonzales JC, Hunt EA, Joyner BL, et al. Part 11: Pediatric Basic Life Support and Cardiopulmonary Resuscitation Quality: 2015 American Heart Association Guidelines for Cardiopulmonary Resuscitation and Emergency Cardiovascular Care. Circulation. 2015;132(18 Suppl 2):S519-25.

925. de Caen AR, Berg MD, Chameides L, Gooden CK, Hickey RW, Scott HF, et al. Part 12: Pediatric Advanced Life Support: 2015 American Heart Association Guidelines for Cardiopulmonary Resuscitation and Emergency Cardiovascular Care. Circulation. 2015;132(18 Suppl 2):S526-42.

926. Maconochie IK, Bingham R, Eich C, López-Herce J, Rodríguez-Núñes A, Rajka T, et al. European Resuscitation Council Guidelines for Resuscitation 2015: Section 6. Paediatric life support. Resuscitation. 2015;95:223-48.
927. Girotra S, Spertus JA, Li Y, Berg RA, Nadkarni VM, Chan PS; American Heart Association Get With The Guidelines-Resuscitation Investigators. Survival trends in pediatric in-hospital cardiac arrests: an analysis from Get With The Guidelines-Resuscitation. Circ Cardiovasc Qual Outcomes. 2013;6(1):42-9.

928. Tibballs J, Carter B, Kiraly NJ, Ragg P, Clifford M. External and internal biphasic direct current shock doses for pediatric ventricular fibrillation and pulseless ventricular tachycardia. Pediatr Crit Care Med. 2011;12(1):1420.

929. Berg MD, Samson RA, Meyer RJ, Clark LL, Valenzuela TD, Berg RA. Pediatric defibrillation doses often fail to terminate prolonged out-ofhospital ventricular fibrillation in children. Resuscitation. 2005;67(1):63-7.

930. Rodríguez-Núñez A, Lopez-Herce J, Garcia C, Dominguez P, Carrillo A, Bellon JM; Spanish Study Group of Cardiopulmonary Arrest in Children. Pediatric defibrillation after cardiac arrest: initial response and outcome. Crit Care. 2006;10(4):R113.

931. Rossano JW, Quan L, Kenney MA, Rea TD, Atkins DL. Energy doses for treatment of out-of-hospital pediatric ventricular fibrillation. Resuscitation. 2006; 70(1):80-9.

932. Berg RA, Chapman FW, Berg MD, Hilwig RW, Banville I, Walker RG, et al. Attenuated adult biphasic shocks compared with weight-based monophasic shocks in a swine model of prolonged pediatric ventricular fibrillation. Resuscitation. 2004;61(2):189-97.

933. Berg MD, Banville IL, Chapman FW, Walker RG, Gaballa MA, Hilwig RW, et al. Attenuating the defibrillation dosage decreases postresuscitation myocardial dysfunction in a swine model of pediatric ventricular fibrillation. Pediatr Crit Care Med. 2008;9(4):429-34.

934. Berg RA, Samson RA, Berg MD, Chapman FW, Hilwig RW, Banville I, et al. Better outcome after pediatric defibrillation dosage than adult dosage in a swine model of pediatric ventricular fibrillation. J Am Coll Cardiol. 2005;45(5):786-9.

935. Tang W, Weil MH, Jorgenson D, Klouche K, Morgan C, Yu T, et al. Fixedenergy biphasic waveform defibrillation in a pediatric model of cardiac arrest and resuscitation. Crit Care Med. 2002;30(12):2736-41.

936. Walcott GP, Melnick SB, Killingsworth CR, Ideker RE. Comparison of low-energy versus high-energy biphasic defibrillation shocks following prolonged ventricular fibrillation. Prehosp Emerg Care. 2010;14(1):62-70.

937. Eftestol T, Sunde K, Steen PA. Effects of interrupting precordial compressions on the calculated probability of defibrillation success during ou-of-hospital cardiac arrest. Circulation. 2002;105(19):2270-3 .

938. Mittal S, Ayati S, Stein KM, Knight BP, Morady F, Schwartzman D, et al. Comparison of a novel rectilinear biphasic waveform with a damped sine wave monophasic waveform for transthoracic ventricular defibrillation. ZOLL inverstigators. J Am Coll Cardil. 1999;34(5):1595-601.

939. Van Alem AP, Chapman FW, Lank P, Hart AA, Koster RW. A prospective, randomized and blinded comparison of first shock success ofmonophasic and biphasic waveforms in out-of-hospital cardiac arrest. Resuscitation. 2003;58(1):17-24.

940. Rea TD, Helbock M, Perry S, Garcia M, Cloyd D, Becher L, et al. Increasing use of cardiopulmonary resuscitation during out-of-hospital ventricular fibrillation arrest: survival implication of guideline changes. Circulation. 2006;114(25):2760-5.

941. Menegazzi JJ, Hsieh M, Niemann JT, Swor RA. Derivation of clinical predictor of failed rescue shock during out-of-hospital ventricular defibrillation. Prehosp Emerg Care. 2008;12(3):347-51.

942. Rea TD, Shah S, Kidenchuk PJ, Copass MK, Cobb LA. Automated external defibrillator: to what extent does the algorithm delay CPR? Ann Emerg Med. 2005;46(2):132-41.

943. Becker L, Gold LS, Eisenberg M, White L, Hearne T, Rea T. Ventricular fibrillation in King County, Washington: a 30-year perspective. Resuscitation. 2008;79(1):22-7. 
944. Atkins DL, Sirna S, Kieso R, Charbonnier F, Kerber RE. Pediatric defibrillation: importance of paddle size in determining transthoracic impedance. Pediatrics. 1988;82(6):914-8.

945. Atkins DL, Kerber RE. Pediatric defibrillation: current flow is improved by using "adult" electrode paddles. Pediatrics. 1994;94(1):90-3.

946. Samson RA, Atkins DL, Kerber RE. Optimal size of self-adhesive preapplied electrode pads in pediatric defibrillation. Am J Cardiol. 1995;75(7):544-5.

947. Atkins DL, Everson-Stewart S, Sears GK, Daya M, Osmond MH, Warden $\mathrm{CR}$, et al; Resuscitation Outcomes Consortium Investigators. Epidemiology and outcomes from out-of-hospital cardiac arrest in children: the Resuscitation Outcomes Consortium Epistry-cardiac arrest. Circulation. 2009;119(11):1484-91.

948. International Liaison Committee on Resuscitation. 2005 International Consensus on Cardiopulmonary Resuscitation and Emergency Cardiovascular Care Science With Treatment Recommendations. Part 6: Pediatric Basic and Advanced Life Support. Resuscitation. 2005;67(23):271-91.

949. Babbs CF, Tacker WA, Van Vleet JF, Bourland JD, Geddes LA. Therapeutic indices for transchest defibrillator shocks: effective, damaging, and lethal electrical doses. Am Heart J. 1980;99(6):734-8.

950. Gaba DM, Talner NS. Myocardial damage following trnsthoracic direct current countershock in newborn piglets. Pediatr Cardiol. $1982 ; 2(4): 281-8$

951. Berg RA. Attenuated adult biphasic shocks for prolonged pediatric ventricular fibrillation: support for pediatric automated defibrillators. Crit Care Med. 2004;32(9 Suppl):S352-5.

952. American Heart Association. Pediatric basic and advanced life support. Circulation. 2005;112(Suppl. II):II73-II90.

953. American Heart Association. Pediatric basic life support. Circulation. 2005;112(Suppl. IV):IV156-IV166.

954. American Heart Association. Pediatric advanced life support. Circulation. 2005; (Suppl IV):IV167-IV187.

955. Kleinman ME, Chameides L, Schexnayder SM, Samson RA, Hazinski MF, Atkins DL, et al. Part 14: pediatric advanced life support: 2010 American Heart Association Guidelines for Cardiopulmonary Resuscitation and Emergency Cardiovascular Care. Circulation. 2010;122(18 Suppl 3):S876-908

956. Voeckel WG, Lurie KG, McKnite S, Zielinski T, Lindstrom P, Peterson C, et al. Effects of epinephrine and vasopressine in a piglet model of prolonged ventricular fibrillation and cardiopulmonary resuscitation. Crit Care Med. 2002; 30 (5): 957-62.

957. Gausche M, Lewis RJ, Stratton SJ, Haynes BE, Gunter CS, Goodrich $\mathrm{SM}$, et al. Effects of out-of-hospital pediatric endotracheal intubation on survival and neurological outcome: a controlled clinical trial. JAMA .2000;283(6):783-90. Erratum in: JAMA. 2000;283(24):3204.

958. Nichols DG, Ungerleir RM, Spevak PJ, Greelay WJ, Cameron DE, Lappe DG, et al. Critical heart disease in infants and children. 2nd ed. Philadelphia: Mosby Elsevier; 2006. p. 333-65.

959. Hazinsky MF. Terapia volêmica e medicamentos para o choque e parada cardíaca. In: SAVP. Manual de provedores. Rio de Janeiro; Ed. Adindes; 2004. p. $127-57$

960. Kleinman ME, de Caen AR, Chameides L, Atkins DL, Berg RA, Berg MD, et al; Pediatric Basic and Advanced Life Support Chapter Collaborators. Pediatric Basic and Advanced Life Support: 2010 International Consensus on Cardiopulmonary Resuscitation and Emergency Care Science With Treatment Recommendations. Pediatrics. 2010;126(5):e1261-318.

961. Kleinman ME, Chameides L, Schexnayder SM, Samson RA, Hazinski MF Atkins DL, et al. Part 14: Pediatric Advanced Life Suport: 2010 American Heart Association Guidelines for Cardiopulmonary Resuscitation and Emergency Cardiovascular Care. Circulation. 2010;122(18 Suppl 3):S876-908.
962. Biarent D, Bingham R, Eich C, López-Herce J, Maconochie I, RodríguezNúñez A, et al. European Resuscitation Council Guidelines for Resuscitation 2010. Section 6. Paediatric Life Support. Resuscitation. 2010;81(10):1364-88

963. American Academy of Pediatrics; American Heart Association. Pediatric Advanced Life Support - Provider Manual: Part 4: recognition and management of cardiac arrest in pediatric. Dallas (TX); 2016.

964. Papastylianou A, Mentzelopoulos S. Current pharmacological advances in the treatment of cardiac arrest. Emerg Med Int. 2012;2012:815857.

965. Nichols DG, Ungerleir RM, Spevak PJ, Greelay WJ, Cameron DE, Lappe DG, et al. Critical heart disease in infants and children. 2nd ed. Philadelphia: Mosby Elsevier; 2006. p. 173-203.

966. Tanaka AC. Alterações do ritmo cardíaco em situações de emergência. In Lopes AA, Tanaka AC. Emergências em cardiologia pediátrica. São Paulo Atheneu; 2007. p. 51-96.

967. Moffa PJ, Sanches PC. Eletrocardiograma normal e patológico. São Paulo: Rocca; 2001.

968. Magalhães LP, Guimarães LC, Melo SL, Mateo El, Andalaft RB, Xavier LF, et al; Sociedade Brasileira de Cardiologia. Diretriz de Arritmias cardíacas em crianças e cardiopatias congênitas. Arq Bras Cardiol. 20(1 supl 1):1-58.

969. Wills BA, Nguyen MD, Ha TL, Dong TH, Tran TN, Le TT, et al. Comparison of three fluid solutions for resuscitation in dengue shock syndrome. N Eng J Med. 2005;353(9):877-89.

970. Booy R, Habibi P, Nadel S, de Munter C, Britto J, Morrison A, et al Meningococcal Research Group. Reduction in case fatality rate from meningococcal disease associated with improved health care delivery. Arch Dis Child 2001;85(5):386-90

971. Schierhout G, Roberts I. Fluid resuscitation with colloid or crystalloid solutions in critically ill patients: a systematic review of randomized trials. BMJ. 1998;316(7136):961-4.

972. Finfer S, Bellomo R, Boyce N, French J, Myburgh J, Norton R; SAFE Study Investigators. A comparison of albumin and saline for fluid resuscitation in the intensive care unit. N Engl J Med. 2004;350(22):2247-56.

973. Maitland K, Kiguli S, Opoka RO, Engoru C, Olupot-Olupot P, Akech SO et al; FEAST Trial Group. Mortality after fluid bolus in African children with severe infection. N Engl J Med. 2011;364(26):2483-95.

974. Dykes EH, Spence LJ, Young JG, Bohn DJ, Filler RM, Wesson DE. Preventable pediatric trauma deaths in a metropolitan region. J Pediatr Surg. 1989;24(1):107-10.

975. Muizelaar JP, Marmarou A, Ward JD, Kontos HA, Choi SC, Becker DP, et al. Adverse effects of prolonged hyperventilation in patients with severe head injury; a randomized clinical trial. J Neurosurg. 1991;75(5):731-9.

976. Bascaya MK. Inadvertent intracranial placement of a nasogastric tube in patients with head injuries. Surg Neurol.1999;52(4):426-7.

977. World Health Organization. (WHO). Global Report on drowing: preventing a leading. [Cited in 2016 Jun 10]. Available from: http://www. who.int/violence injury_prevention/global_report_drowning/en/

978. Lin CY, Wang YF, Lu TH, Kawach I. Unintentional drowning mortality, by age and body of water: an analysis of 60 countries. Inj Prev. 2015;21(e1):e43-50.

979. Idris AH, Berg RA, Bierens J, Bossaert L, Branche CM, Gabrielli A, et al American Heart Association; Maatschappij tot Redding van Drenkelingen European Resuscitation Council; US Centers for Disease Control and Prevention; University of Florida; University of North Carolina; Australia and New Zealand Resuscitation Council; InterAmerican Heart Foundation; Heart and Stroke Foundation of Canada; Resuscitation Council of Southern Africa Recommended guidelines for uniform reporting of data from drowning: the "Ustein style". Resuscitation. 2003;59(1):45-57.

980. Waksman RD, Gikas RM, Maciel W. Guia para Prevenção de Acidentes e Violências da Sociedade Brasileira de Pediatria. São Paulo: Editora Publifolha; 2005. 
981. Papa L, Hoelle R, Idris A. Systematic review of definitions for drowning incidents. Resuscitation. 2005;65(3):255-64.

982. Layon AJ, Modell JH. Drowning: update 2009. Anesthesiology. 2009;110(6):1390-401

983. Watson RS, Cummings P, Quan L, Bratton S, Weiss NS. Cervical spine injuries among submersion victims. J Trauma. 2001;51(4):658-62.

984. Dodd FM, Simon E, McKeown D, Patrick MR. The effect of a cervical collar on the tidal volume of anaesthetised adult patients. Anaesthesia. 1995;50(11):961-3.

985. Waksman RD, Gikas RM, Maciel W. Guia para Prevenção de Acidentes e Violências da Sociedade Brasileira de Pediatria. São Paulo; Editora Publifolha, 2005.

986. American Heart Association. American Stroke Association. Suporte Avançado de vida - American Heart Association. Dallas (TX); 2008.

987. Venema AM, Groothoff JW, Bierens JJ. The role of bystanders during rescue and resuscitation of drowning victims. Resuscitation. 2010;81(4):434-9.

988. Quan L, Wentz KR, Gore EJ, Copass MK. Outcome and predictors of outcome in pediatric submersion victims receiving prehospital care in King County, Washington. Pediatrics. 1990;86(4):586-93.

989. Manolios N, Mackie I. Drowning and near-drowning on Australian beaches patrolled by life-savers: a 10-year study, 1973-1983. Med J Aust. 1988;148(4):165-7, 70-1.

990. Rosen P, Stoto M, Harley J. The use of the Heimlich maneuver in neardrowning: institute of Medicine report. J Emerg Med. 1995;13(3):397-405.

991. O'Driscoll BR, Howard LS, Davison AG; British Thoracic Society. BTS guideline for emergency oxygen use in adult patients. Thorax. 2008; 63 Suppl 6:vi1-68. Erratum in: Thorax. 2009;64(1):91.

992. Modell JH, Calderwood HW, Ruiz BC, Downs JB, Chapman R Jr. Effects of ventilatory patterns on arterial oxygenation after near-drowning in sea water. Anesthesiology. 1974;40(4):376-84.

993. Golden FS, Tipton MJ, Scott RC. Immersion, near-drowning and drowning. BrJ Anaesth. 1997;79(2):214-25.

994. Moran I, Zavala E, Fernandez R, Blanch L, Mancebo J. Recruitment manoeuvres in acute lung injury/acute respiratory distress syndrome. Eur Respir J Suppl. 2003 Aug;42:37s-42s.

995. Koster RW, Sayre MR, Botha M, Cave DM, Cudnik MT, Handley AJ, et al. 2010 International Consensus on Cardiopulmonary Resuscitation and Emergency Cardiovascular Care Science with Treatment Recommendations. Part 5. Adult Basic Life Support. Resuscitation. 2010;81 Suppl 1:e48-70.

996. Wyatt JP, Tomlinson GS, Busuttil A. Resuscitation of drowning victims in south- east Scotland. Resuscitation. 1999;41(2):101-4.

997. Schmidt U, Fritz KW, KasperczykW, Tscherne H. Successful resuscitation of a child with severe hypothermia after cardiac arrest of 88 minutes. Prehosp Disaster Med. 1995;10(1):60-2.

998. Bolte RG, Black PG, Bowers RS, Thorne JK, Corneli HM. The use of extracorporeal rewarming in a child submerged for 66 minutes. JAMA. 1988;260(3):377-9.

999. Gregorakos L, Markou N, Psalida V, Kanakaki M, Alexopoulou A, Sotiriou $\mathrm{E}$, et al. Near-drowning: clinical course of lung injury in adults. Lung. 2009;187(2):93-7.

1000. Eich C, Brauer A, Timmermann A, Schwarz SK, Russo SG, Neubert K, et al. Outcome of 12 drowned children with attempted resuscitation on cardiopulmonary bypass: an analysis of variables based on the "Utstein Style for Drowning". Resuscitation. 2007;75(1):42-52.

1001. Guenther U, Varelmann D, Putensen C, Wrigge H. Extended therapeutic hypothermia for several days during extracorporeal membraneoxygenation after drowning and cardiac arrest two cases of survival with no neurological sequelae. Resuscitation. 2005;67(2-3):157-341.
1002. Proceedings of the 2005 International Consensus on Cardiopulmonary Resuscitation and Emergency Cardiovascular Care Science with Treatment Recommendations;2005. V.67, p.157-341.

1003. Nolan JP, Morley PT, Vanden Hoek TL, Hickey RW; Advancement Life support Task Force of the International Liaison committee on Resuscitation. Therapeutic hypothermia after cardiac arrest. An advisory statement by the Advancement Life support Task Force of the International Liaison committee on Resuscitation. Resuscitation. 2003;57(3):231-5.

1004. Nolan JP, Neumar RW, Adrie C, Aibiki M, Berg RA, Böttiger BW, et al. Post-cardiac arrest syndrome: epidemiol- ogy, pathophysiology, treatment, and prognostication. A Scientific Statement from the International Liaison Committee on Resuscitation; the American Heart Association Emergency Cardiovascular Care Committee; the Council on Cardiovascular Surgery and Anesthesia; the Council on Cardiopulmonary, Peri-operative, and Critical Care; the Council on Clinical Cardiology; the Council on Stroke. Resuscitation. 2008;79(3):350-79.

1005. Lopes AA,Tanaka ACS. Emergências em cardiologia pediátrica. São Paulo: Atheneu; 2007.

1006. Lee YS, Baek JS, Kwon BS, Kim GB, Bae EJ, Noh CL, et al. Pediatric emergency room presentation of congenital heart disease . Korean Circ J. 2010;40(1):36-41.

1007. Bajaj L, Turner CG, Bothner J. Therapy from emergency department for acute bronchiolitis. Pediatrics. 2006;117(3):633-40.

1008. Sociedade Brasileira de Pneumologia. IV Diretrizes Brasileiras para o manejo da asma. J Bras Pneumol. 2006;32(supl 7):S447-S474.

1009. Alpern ER, Stanley RM, Gorelick MH, Donaldson A, Knight S, Teach SJ, et al; Pediatric Emergency Care Applied Research Network. Epidemiology of pediatric emergency medicine research network: the PECARN Core Data Profect. Pediatr Emerg Care. 2006;22(10):689-99.

1010. Ebaid M. Cardiologia em pediatria: temas fundamentais. São Paulo: Roca; 2000.

1011. Croti UA, Mattos SS, Pinto Jr VC, Aiello VD. Cardiologia e cirurgia cardiovascular pediátrica. São Paulo: Roca; 2008.

1012. Matthews IL, Bjornstad PG, Kaldestad RH, Heiberg L, Thaulow E, Gronn $M$. The impact of shunt size on lung function in infants with univentricular heart physiology. Pediatr Crit Care Med. 2009;10(1):60-5.

1013. De Oliveira NC, Van Arsdell GS. Practical use of alplha blockade strategy in the management of hypoplastic left heart syndrome following stage one palliation with a Blalock-Taussig shunt. Semin Thorac Cardiovasc Surg Pediatric Card Surg Annu. 2004;7:11-5.

1014. Motta P, Mossad E, Toscana D, Zestos M, Mee R. Comparison of phenoxybenzamine to sodium nitroprusside in infants undergoing surgery. J Cardiothorac Vasc Anesth. 2005; 19(1):54-9.

1015. Raymond TT, Cunnyngham CB, Thompson MT, Thomas JA, Dalton HJ, Nadkarni VM; American Heart Association National Registry of CPR Investigators. Outcomes among neonates, infants, and children after extracorporeal cardiopulmonary resuscitation for refractory in hospital pediatric cardiac arrest: A report from the National Registry of Cardiopulmonary Resuscitation. Pediatr Crit Care Med. 2010;11(3):362-71.

1016. Shekerdemian LS, Bush A, Shore DF, Lincoln C, Redington AN. Cardiopulmonary interactions after Fontan operations: augmentation of cardiac output using negative pressure ventilation. Circulation. 1997;96(11):3934-42.

1017. Booth KL, Roth SJ, Thiagarajan RR, Almodovar MC, del Nido PJ, Laussen PC. Extracorporeal membrane oxygenation support of the Fontan and bidirectional Glenn circulations. Ann Thorac Surg. 2004;77(4):1341-8.

1018. Polderman FN, Cohen J, Blom NA, Delhaas T, Helbing WA, Lam J, et al. Sudden unexpected death in children with a previously diagnosed cardiovascular disorder. Int J Cardiol. 2004;95(2-3):171-6.

1019. Sanatani S, Wilson G, Smith CR, Hamilton RM, Williams WG, Adatia I. Sudden unexpected death in children with heart disease. Congenit Heart Dis. 2006;1(3):89-97. 
1020. Hoeper MM, Galie N, Murali S, Olschewski H, Rubenfire M, Robbins $\mathrm{IM}$, et al. Outcome after cardiopulmonary resuscitation in patients with pulmonary arterial hypertension. Am J Respir Crit Care Med. 2002;165(3):341-4.

1021. Rimensberger PC, Spahr-Schopfer I, Berner M, Jaeggi E, Kalangos A, Friedli B, et al. Inhaled nitric oxide versus aerosolized iloprost in secondary pulmonary hypertension in children with congenital heart disease: vasodilator capacity and cellular mechanisms. Circulation. 2001;103(4):544-8

1022. Limsuwan A, Wanitkul S, Khosithset A, Attanavanich S, Samankatiwat P. Aerosolized iloprost for postoperative pulmonary hypertensive crisis in children with congenital heart disease. Int J Cardiol. 2008;129(3):333-8.

1023. Morris K, Beghetti M, Petros A, Adatia I, Bohn D. Comparison of hyperventilation and inhaled nitric oxide for pulmonary hypertension after repair of congenital heart disease. Crit Care Med. 2000;28(8):2974-8.

1024. Strueber M, Hoeper MM, Fischer S, Cypel M, Warnecke G, Gottlieb J, et al. Bridge to thoracic organ transplantation in patients with pulmonary arterial hypertension using a pumpless lung assist device. Am J Transplant. 2009;9(4):853-7.

1025. Liu KS, Tsai FC, Huang YK, Wu MY, Chang YS, Chu JJ, Lin PJ. Extracorporeal life support: a simple and effective weapon for postcardiotomy right ventricular failure. Artif Organs. 2009;33(7):504-8.

1026. Dhillon R, Pearson GA, Firmin RK, Chan KC, Leanage R. Extracorporeal membrane oxygenation and the treatment of critical pulmonary hypertension in congenital heart disease. Eur J Cardiothorac Surg. 1995;9(10):553-6.

1027. Azeka E, Auler Júnior JO, Fernandes PM, Nahas WC, Fiorelli Al, Tannuri $U$, et al. Registry of Hospital das Clínicas of the University of São Paulo Medical School: first official solid organ and tissue transplantation report - 2008. Clinics (Sao Paulo). 2009;64(2):127-34.

1028. Bacal F, Neto JD, Fiorelli Al, Mejia J, Marcondes-Braga FG, Mangini S, et al; Sociedade Brasileira de Cardiologia. [ll Brazilian Guidelines for Cardiac Transplantation]. Arq Bras Cardiol. 2010;94(1 Suppl):e16-76.

1029. Extracorporeal Life Support Organization. General Guidelines for all ECLS Cases. Version 1.1. Ann Arbor, MI. 2009.

1030. Lequier L. Extracorporeal Life Support in pediatric and neonatal critical care: a review. J Intensive Care Med. 2004;19(5):243-58.

1031. Dalton HJ. Extracorporeal life support: moving at the speed of light. Respir Care. 2011;56(9):1445-56.

1032. Bragan TV, Lequier L, Lorusso R, MacLauren G, Peek G. Extracorporeal Life Support: the ECLS Red Book. 5th ed. Stollery Children's Hospital. Edmonton, Alberta(Canada); 2012.

1033. Extracorporeal Life Support: the ECLS Registry Report. Extracorporeal Life Support Organization. Ann Arbor: University of Michigan; 2004.

1034. Short BL, Walker LK. ECLS and the brain. In: Zwischenbreger JB, Steinhorn $\mathrm{RH}$, Bartlett RH, eds. ECMO: Extracorporeal cardiopulmonary support in critical care. 2nd.ed. Ann Arbor: ELSO; 2000. p. 133-44.

1035. Topjian AA, French B, Sutton RM, ConlonT, Nadkarni VM, Moler FW, et al. Early postresuscitation hypotension is associates with increased mortality following pediatric cardiac arrest. Critic Care Med. 2014;42(6):1518-23.

1036. Tobjan AA, Clark AE, Casper TC, Berger JT, Schlein CL, Dean JM, et al; Pediatric Emergency Care Applied Research Network. Early lactate elevations following resuscitation from pediatric cardiac arrest are associated with increased mortality. Pediatr Crit Care Med. 2013;14(8):e380-7.

1037. Van den Berghe G, Wouters P, Weekers F, Verwaest C, Bruyninckx F, Schetz $M$, et al. Intensive insulin therapy in the critically ill patient. N Engl J Med. 2001;345(19):1359-67.

1038. Losert H, Sterz F, Roine RO, Holzer M, Martens P, Cerchiari E, et al. Strict normoglycaemic blood glucose levels in the therapeutic management of patients within 12 hs after cardiac arrest might not be necessary. Ressuscitation. 2008;76(2):214-20.

1039. Oksanen t, Skrifvars MB, Varpula T, Kuitunen A, Pettilä V, Nurmi J, et al. Strict versus moderate glucose control after resuscitation ventricular fibrillation. Intensive Care Med. 2007;33(12):2093-100.

1040. Davis PG, Tan A, ODonnell CP, Schulze A. Resuscitation of newborn infants with $100 \%$ oxygen or air: a systematic review and meta-analysis. Lancet. 2004;364(9442):1329-33.

1041. Rabi Y, Rabi D, Yee W. Room air resuscitation of the depressed newborn: a systematic review and meta-analysis. Resuscitation. 2007;72(3):353-63.

1042. Balan IS, Fiskum G, Hazelton J, Cotto-Cumba C, Rosenthal RE. Oximetryguided reoxygenation improves neurological outcome after experimental cardiac arrest. Stroke. 2006;37(12):3008-13.

1043. Liu Y, Rosenthal RE, Haywood Y, Miljkovic-Lolic M, Vanderhoek JY, Fiskum G. Normoxic ventilation after cardiac arrest reduces oxidation of brain lipids and improves neurological outcome. Stroke. 1998;29(8):1679-86.

1044. Marsala J, Marsala M, Vanick I, Galik J, Orendacova J. Post cardiac arrest hyperoxic resuscitation enhances neuronal vulnerability of the respiratory rhythm generator and some brainstem and spinal cord neuronal pools in the dog. Neurosci Lett. 1992;146(2):121-4.

1045. Richards EM, Rosenthal RE, Kristian T, Fiskum G. Postischemic hyperoxia reduces hippocampal pyruvate dehydrogenase activity. Free Radic Biol Med. 2006;40(11):1960-70.

1046. Richards EM, Fiskum G, Rosenthal RE, Hopkins I, McKenna MC. Hyperoxic reperfusion after global ischemia decreases hippocampal energy metabolism. Stroke. 2007;38(5):1578-84

1047. Vereczki V, Martin E, Rosenthal RE, Hof PR, Hoffman GE, Fiskum G. Normoxic resuscitation after cardiac arrest protects against hippocampal oxidative stress, metabolic dysfunction and neuronal death.J Cereb Blood Flow Metab. 2006;26(6):821-35.

1048. Zwemer CF, Whitesall SE, D'Alecy LG. Cardiopulmonary-cerebral resuscitation with $100 \%$ oxygen exacerbates neurological dysfunction following nine minutes of normothermic cardiac arrest in dogs. Resuscitation. 1994;27(2):159-70. Erratum in: Resuscitation. 1994;27(3):267.

1049. de Caen AR, Kleinman ME, Chameides L, Atkins DL, Berg RA, Berg MD, et al; Paediatric Basic and Advanced Life Support Chapter Collaborators. Part 10: Pediatric basic and advanced life support 2010 International Consensus on Cardiopulmonary Resuscitation and Emergency Cardiovascular Care Science with Treatment Recommendations. Resuscitation. 2010;81 (Suppl 1):e213-59.

1050. Kleinman ME, de Caen AR, Chameides L, Atkins DL, Berg R, Berg MD, et al; Pediatric Basic and Advanced Life Support Chapter Collaborators. Part 10: Pediatric basic e advanced life support: 2010 Internacional Consensus on Cardiopulmonary Resuscitation and Emergency Cardiovascular Care Science With Treatment Recommendations. Circulation. 2010;122(16 Suppl 2):S466-515.

1051. Maconochie I, de Caen A, Aickin R, Atkins DL, Biarent D, Guerguerian AM, et al; Pediatric Basic Life Support and Pediatric Advanced Life Support Chapter Collaborators. Part 6: Pediatric basic life support and pediatric advanced life support 2015 International Consensus on Cardiopulmonary Resuscitation and Emergency Cardiovascular Care Science with Treatment Recommendations. Resuscitation. 2015 Oct:95:e147-68.

1052. Del Castillo J, Lopez-Herce J, Matamoros M, Cañadas S, Rodriguez-Calvo A, Cechetti C, et al; Iberoamerican Pediatric Cardiac Arrest Study Network RIBEPCI. Hyperoxia, hypocapnia and hypercapnia as outcome factors after cardiac arrest in children. Resuscitation. 2012;83(12):1456-61.

1053. Lopez-Herce J, del Castillo J, Matamoros M, Canadas S, Rodriguez-Calvo A Cecchetti C, et al; Iberoamerican Pediatric Cardiac Arrest Study Network RIBEPCI. Post return of spontaneous circulation factors associated with mortality in pediatric in-hospital cardiac arrest: a prospective multicenter multicenter multinational observational study. Crit Care. 2014:18(6):607. 
1054. Roberts BW, Kilgannon JH, Chansky ME, Mittal N, Wooden J, Trzciak S. Association between postresuscitation partial pressure of arterial carbon dioxide and neurological outcome in patients with post-cardiac arrest syndrome. Circulation. 2013;127(21):2107-13.

1055. Brasil. Ministério da Saúde. Portal da Saúde. Datasus: Estatísticas Vitais. [Internet]. [Citado em 2016 jul 7]. Disponível em: http://www2.datasus. gov.br/DATASUS/index.php?area $=0205$

1056. Almeida, MF, Guinsburg, R, Martinez, FE, Procianoy, RS, Leone, CR, Marba ST, et al. Perinatal factors associated with early deaths of preterm infants born in Brazilian Network on Neonatal Research centers. J Pediatr (Rio J). 2008;84(4):300-7.

1057. de Almeida MF, Guinsburg R, da Costa JO, Anchieta LM, Freire LM, Junior DC. Resuscitative procedures at birth in late preterm infants. J Perinatol. 2007;27(12):761-5.

1058. Almeida MF, Kawakami LM, Santos RM, Anchieta LM, Guinsburg R. Ashyscia in infants > 2500 g in Brazil. J Pediatr (Rio J). 2017;93(6):576-84

1059. FIOCRUZ. Rede Brasileira de Pesquisas Neonatais. [Internet]. Dados [Citado em 2016 jul 7]. Disponível em: http://www.redeneonatal.fiocruz.br/

1060. Perlman JM, Risser R. Cardiopulmonary resuscitation in the delivery room. Associated clinical events. Arch Pediatr Adolesc Med. 1995;149(1):20-5

1061. Almeida MF, Guinsburg R; Sociedade Brasileira de Pediatria. Reanimação do recém-nascido ? 34 semanas em sala de parto: diretrizes. [Citado em 2016 Jul 7]. Disponível em: http:// www.sbp.com.br/reanimacao/wp-content/uploads/2016/01/ DiretrizesSBPReanimacaoRNMaior34semanas26jan2016.pdf

1062. Guinsburg R, de Almeida MF; Sociedade Brasileira de Pediatria Reanimação do Prematuro < 34 semanas em sala de parto: J Pediatr (Rio J). 2005;(1 supl):53-515.

1063. Almeida MF, Guinsburg R. Reanimação neonatal em sala de parto: documento científico do programa de reanimação da Sociedade Brasileira de Pediatria. [Citado em 2016 maio 15]. Disponível em: http://www.sbp. com.br/pdfs/PRN-SBP.

1064. Perlman JM, Wyllie J, Kattwinkel J, Wyckoff MH, Aziz K, Guinsburg R, et al; Neonatal Resuscitation Chapter Collaborators. Part 7: Neonatal resuscitation: 2015 international consensus on cardiopulmonary resuscitation and emergency cardiovascular care science with treatment recommendations. Circulation. 2015;132(16 Suppl 1):S204-41.

1065. Wyckoff MH, Aziz K, Escobedo MB, Kapadia VS, Kattwinkel J, Perlman JM, et al. Part 13: Neonatal Resuscitation: 2015 American Heart Association guidelines update for cardiopulmonary resuscitation and emergency cardiovascular care. Circulation. 2015;132(18 Suppl 2):S543-560.

1066. Wyllie J, Bruinenberg J, Roehr CC, Rüdiger M, Trevisanuto D, Urlesberger B. European Resuscitation Council Guidelines for Resuscitation 2015: Section 7. Resuscitation and support of transition of babies at birth. Resuscitation. 2015;95 Oct:249-63.

1067. Brasil. Ministério da Saúde. Agência Nacional de Vigilância Sanitária. (ANVISA). Pediatria: prevenção e controle de infecção hospitalar. Brasília; 2006.

1068. O'Donnell CP, Kamlin CO, Davis PG, Carlin JB, Morley CJ. Clinical assessment of infant colour at delivery. Arch Dis Child Fetal Neonatal Ed. 2007;92(6):F465-7.

1069. McDonald SJ, Middleton P, Dowswel IT, Morris PS. Effect of timing of umbilical cord clamping of term infants on maternal and neonatal outcomes. Evid Based Child Health. 2014;9(2):303-97.

1070. Rabe H, Diaz-Rossello JL, Duley L, Dowswell T. Effect of timing of umbilical cord clamping and other strategies to influence placental transfusion at preterm birth on maternal and infant outcomes. Cochrane Database Syst Rev. 2012 Aug 15;(8):CD003248.

1071. World Health Organization. (WHO). Thermal protection of the newborn: a practical guide Geneve; 1997. [Cited 2015 Jul 7]. Available from: http:// www.who.int/reproductivehealth/publications/maternal_perinatal_ health/MSM_97_2/en/

1072. Laptook AR, Salhab W, Bhaskar B; Neonatal Research Network. Admission temperature of low birth weight infants: predictors and associated morbidities. Pediatrics. 2007;119(3):e643-9.

1073. de Almeida MF, Guinsburg R, Sancho GA, Rosa IR, Lamy ZC, Martinez FE, et al; Brazilian Network on Neonatal Research. Hypothermia and early neonatal mortality in preterm infants. J Pediatr. 2014;164(2):271-5.

1074. Russo A, McCready M, Torres L, Theuriere C, Venturini S, Spaight M, et al. Reducing hypothermia in preterm infants following delivery. Pediatrics. 2014;133(4):e1055-62.

1075. Gandhi B, Rich W, Finer N. Time to achieve stable pulse oximetry values in VLBW infants in the delivery room. Resuscitation. 2013;84(7):970-3.

1076. Wiswell TE, Gannon CM, Jacob J, Goldsmith L, Szyld E, Weiss K, et al. Delivery room management of the apparently vigorous meconiumstained neonate: results of the multicenter, international collaborative trial. Pediatrics. 2000;105(1 Pt 1):1-7.

1077. Follett G, Cheung PY, Pichler G, Aziz K, Schmölzer GM. Time needed to achieve changes in oxygen concentration at the T-Piece resuscitator during respiratory support in preterm infants in the delivery room. Paediatr Child Health. 2015;20(2):e10-2.

1078. Goldsmith JP, Kattwinkel J. The role of oxygen in the delivery room. Clin Perinatol. 2012;39(4):803-15.

1079. Kamlin CO, O'Connell LA, Morley CJ, Dawson JA, Donath SM, O'Donnell $\mathrm{CP}$, et al. A randomized trial of stylets for intubating newborn infants. Pediatrics. 2013;131(1):e198-205.

1080. Schmölzer GM, Agarwal M, Kamlin CO, Davis PG. Supraglottic airway devices during neonatal resuscitation: an historical perspective, systematic review and meta-analysis of available clinical trials. Resuscitation. 2013;84(6):722-30.

1081. Kempley ST, Moreiras JW, Petrone FL. Endotracheal tube length for neonatal intubation. Resuscitation. 2008;77(3):369-73.

1082. Tochen ML. Orotracheal intubation in the newborn infant: a method for determining depth of tube insertion. J Pediatr. 1979;95(6):1050-1 .

1083. Kapadia V, Wyckoff MH. Chest compressions for bradycardia or asystole in neonates. Clin Perinatol. 2012;39(4):833-42.

1084. Kapadia, VS, Wyckoff, MH. Drugs during delivery room resuscitation-what, when and why? Semin Fetal Neonatal Med. 2013;18(6):357-61.

1085. Morley PT, Atkins DL, Billi JE, Bossaert L, Callaway CW, de Caen AR, et al. Part 3: Evidence evaluation process: 2010 international consensus on cardiopulmonary resuscitation and emergency cardiovascular care science with treatment recommendations. Circulation. 2010;122(16 Suppl 2):S283-90.

1086. Ersdal HL, Mduma E, Svensen E, Perlman JM. Early initiation of basic resuscitation interventions including face mask ventilation may reduce birth asphyxia related mortality in low-income countries: a prospective descriptive observational study. Resuscitation. 2012;83(7):869-73.

1087. Darmstadt GL, Bhutta ZA, Cousens S, Adam T, Walker N, de Bernis L; Lancet Neonatal Survival Steering Team. Evidence-based, costeffective interventions: how many newborn babies can we save? Lancet. 2005;365(9463):977-88.

1088. Montera MW, Almeida RA, Tinoco EM, Rocha RM, Moura LZ, Réa-Neto A, et al.; Sociedade Brasileira de Cardiologia. II Diretriz brasileira de insuficiência cardíaca aguda. Arq Bras Cardiol. 2009;93(3 Suppl 3):1-65.

1089. Montera MW, Pereira SB, Colafranceschi AS, Almeida DR, Tinoco EM, Rocha RM, et al; Summary of the II Brazilian Guideline update on acute Heart Failure 2009/2011. Arq Bras Cardiol. 2012;98(5):375-83.

1090. Mangini S, Pires PV, Braga FG, Bacal F. Decompensated heart failure. Einstein Sao Paulo). 2013;11(3):383-91. 
1091. Albuquerque DC, Neto JD, Bacal F, Rohde LE, Bernardez-Pereira S, Berwanger O, et al; Investigadores Estudo BREATHE. I Brazilian Registry of heart failure - clinical aspects, care quality and hospitalization outcomes. Arq Bras Cardiol. 2015;104(6):433-42.

1092. Stevenson LW, Massie BM, Francis GS. Optimizing therapy for complex or refractory heart failure: a management algorithm. Am Heart J. 1998;135(6Pt 2 Su):S293-309.

1093. Canesin MF, Oliveira Jr MT, Pereira-Barretto AC. (editores). SAVIC - Suporte avançado de vida em insuficiência cardíaca. Rio de Janeiro: Med Line Editora Ltda; 2011

1094. Chen Y, Chen P, Hanaoka M, Huang X, Droma Y, Kubo K. Mechanical ventilation in patients with hypoxemia due to refractory heart failure. Intern Med. 2008;47(5):367-73.

1095. Faris R, Flather MD, Purcell H, Poole-Wilson PA, Coats AJ. Diuretics for heart failure. Cochrane Database Syst Rev. 2006 Jan 25;(1):CD003838.

1096. Granada J, Uribe W, Chyou PH, Maassen K, Vierkant R, Smith PN, et al Incidence and predictors of atrial flutter in the general population. J Am Coll Cardiol. 2000;36(7):2242-6.

1097. Adams KF Jr, Fonarow GC, Emerman CL, Lejemtel TH, Costanzo MR, Abraham WT, et al; ADHERE Scientific Advisory Committee and Investigators. Characteristics and outcomes of patients hospitalized for heart failure in the United States: rationale, design, and preliminary observations from the first 100.000 cases in the Acute Decompensated Heart Failure National Registry (ADHERE). Am Heart J. 2005;149(2):209-16.

1098. Benza RL, Tallaj JA, Felker GM, Zabel KM, Kao W, Bourge RC, et al; OPTIME-CHF Investigators. The impact of arrhythmias in acute heart failure. J Card Fail. 2004;10(4):279-84.

1099. Bocchi EA, Braga FG, Ayub-Ferreira SM, Rohde LE, Oliveira WA, Almeida DR, et al.; Sociedade Brasileira de Cardiologia. III Brazilian Guidelines on Chronic Heart Failure. Arq Bras Cardiol. 2009;93(1 Suppl 1):3-70.

1100. Bocchi EA, Marcondes-Braga FG, Bacal F, Ferraz AS, Albuquerque D, Rodrigues $\mathrm{D}$, et al. Updating of the Brazilian guideline for chronic heart failure - 2012. Arq Bras Cardiol. 2012:98(1 Suppl 1):1-33.

1101. Beemath A, Stein PD, Skaf E, Al Sibae MR, Alesh I. Risk of venous thromboembolism in patients hospitalized with heart failure. Am J Cardiol. 2006;98(6):793-5.

1102. Turpie AG. Thrombosis prophylaxis in the acutely ill medical patient: insights from the prophylaxis in MEDical patients with ENOXaparin (MEDENOX) trial. Am J Cardiol. 2000;86(12B):48M-52M.

1103. Jain P, Massie BM, Gattis WA, Klein L, Gheorghiade M. Current medical treatment for the exacerbation of chronic heart failure resulting in hospitalization. Am Heart J. 2003;145(2 Suppl):S3-17.

1104. Thackray S, Eastaugh J, Freemantle N, Cleland JG. The effectiveness and relative effectiveness of intravenous inotropic drugs acting through the adrenergic pathway in patients with heart failure: a meta-regression analysis. Eur J Heart Fail. 2002;4(4):515-29.

1105. Felker GM, Benza RL, Chandler AB, Leimberger JD, Cuffe MS, Califf RM, et al; OPTIME-CHF Investigators. Heart failure etiology and response to milrinone in decompensated heart failure: results from the OPTIME-CHF study. J Am Coll Cardiol. 2003:41(6):997-1003.

1106. Follath F, Cleland JG, Just H, Papp JG, Scholz H, Peuhkurinen K, et al; Steering Committee and Investigators of the Levosimendan Infusion versus Dobutamine (LIDO) Study. Efficacy and safety of intravenous levosimendan compared with dobutamine in severe low-output heart failure (the LIDO study): a randomized double-blind trial. Lancet. 2002;360(9328):196-202.

1107. Stevenson LW, Pagani FD, Young JB, Jessup M, Miller L, Kormos RL, et al INTERMACS profiles of advanced heart failure: the current picture. J Heart Lung Transplant. 2009;28(6):535-41.

1108. Rihal CS, Naidu SS, Givertz MM, Szeto WY, Burke JA, Kapur NK, etal. 2015 SCAI/ACC/HFSA/STS Clinical Expert Consensus Statement on the use of percutaneous mechanical circulatory support devices in cardiovascular care endorsed by the AHA, the Cardiological Society of India and Sociedad Latino Americana de Cardiologia - Intervention; Affirmation of value by the Canadian Association of Interventional Cardiology Association Canadienne de Cardiologie d'intervention. J Am Coll Cardiol. 2015;65(19):e7-e26.

1109. Levy B, Bastien O, Karim B, Cariou A, Chouihed T, Combes A, et al. Experts recomendations for the management of adult patients with cardiogenic shock. Ann Intensive Care. 2015;5(1):52.

1110. Bernoche C, Kopel L, Lopes L, Geisler D, Macatrão-Costa MF, Lage SG. Atualização no manejo clínico do choque cardiogênico. Rev Soc Cardiol Estado Sao Paulo. 2015;26(1):14-20.

1111. Thiele H, Zeymer U, Neumann FJ, Ferenc M, Olbrich HG, Hausleiter J, et al; IABP-SHOCK II Trial Investigators. Intraaortic balloon support for myocardial infarction with cardiogenic shock. N Engl J Med. 2012;367(14):1287-96

1112. Thiele H, Zeymer U, Neumann FJ, Ferenc M, Olbrich HG, Hausleiter J, et al; Intraaortic Balloon Pump in cardiogenic shock II (IABP-SHOCK II) trial investigators. Intraaortic balloon counterpulsations in acute myocardial infarction complicated by cardiogenic shock (IABP-SHOCK II): final 12 months results of a randomized open-label trial. Lancet. 2013;382(9905):1638-45

1113. Bezerra CG, Adam EL, Baptista ML, Ciambelli GS, Kopel L, Bernoche C, et al. Aortic counterpulsation therapy in patients with advanced heart failure: analysis of the TBRIDGE Registry. Arq Bras Cardiol. 2016;106(1):26-32.

1114. Extracorporeal Life Support Organization (ECLS) Registry Report. [Cited in 2017 Dec 10. Available from: https://www.elso.org/Registry/Statistics/ InternationalSummary.aspx

1115. Stevenson LW, Pagani FD, Young JB, Jessup M, Miller L, Kormos RL, et al. INTERMACS profiles of advanced heart failure: the current picture. J Heart Lung Transplant. 2009;28(6):535-41.

1116. Kirklin JK, Naftel DC, Stevenson LW, Kormos RL, Pagani FD, Miller MA, et al. INTERMACS database for durable devices for circulatory support: first annual report. J Heart Lung Transplant. 2008;27(10):1065-72.

1117. Nomenclature and criteria for diagnosis of diseases of the heart and blood vessels. The Criteria Committee of the New York Heart Association. Boston: New York Association; 1992.

1118. Hunt SA, Abraham WT, Chin MH, Feldman AM, Francis GS, Ganiats TG, et al; American College of Cardiology; American Heart Association Task Force on Practice Guidelines; American College of Chest Physicians; International Society for Heart and Lung Transplantation; Heart Rhythm Society. ACC/AHA 2005 Guideline Update for the Diagnosis and Management of Chronic Heart Failure in the Adult: a report of the American College of Cardiology/American Heart Association Task Force on Practice Guidelines (Writing Committee to Update the 2001 Guidelines for the Evaluation and Management of Heart Failure): developed in collaboration with the American College of Chest Physicians and the International Society for Heart and Lung Transplantation: endorsed by the Heart Rhythm Society. Circulation. 2005;112(12):e154-235.

1119. Schmidt M, Burrell A, Roberts L, Bailey M, Sheldrake J, Rycus PT, et al. Predicting survival after ECMO for refractory cardiogenic shock: the survival after veno? arterial?ECMO (SAVE)?score. Eur Heart J. 2015;36(33):2246-56.

1120. Muller G, Flecher E, Lebreton G, Luyt CE, Trouillet JL, Bréchot N, et al The ENCOURAGE mortality risk score and analysis of long-term outcomes after VA-ECMO for acute myocardial infarction with cardiogenic shock. Intensive Care Med. 2016;42(3):370-8.

1121. Seldinger SI. Catheter replacement of the needle in percutaneous arteriography: A new technique. Acta Radiologica. 1953;39(5):368-76.

1122. Abrams D, Combes A, Brodie D. Extracorporeal Membrane Oxygenation in Cardiopulmonary Disease in Adults. J Am Coll Cardiol. 2014;63(25 Pt A):2769-78. 
1123. Huang SC, Yu HY, Ko WJ, Chen YS. Pressure criterion for placement of distal perfusion catheter to prevent limb ischemia during adult extracorporeal life support. J Thorac Cardiovasc Surg. 128(5):776-7.

1124. Combes A, Bacchetta M, Brodie D, Müller T, Pellegrino V. Extracorporeal membrane oxygenation for Respiratory failure in adults. Curr Opin Crit Care. 2012;18(1):99-104.

1125. Ghodsizad A, Koerner MM, Brehm CE, El-Banayosy A. The role of extracorporeal membrane oxygenation circulatory support in the crash and burn patient: from implantation to weaning. Curr Opin Cardiol. 2014; 29(3):275-80.

1126. Aissaoui N, Luyt CE, Leprince P, Trouillet JL, Léger P, Pavie A, et al. Predictors of successful extracorporeal membrane oxygenation (ECMO) weaning after assistance for refractory cardiogenic shock. Intensive Care Med. 2011;37(11):1738-45.

1127. Khani-Hanjani A, Loor G, Chamogeorgakis T, Shafii A, Mountis M, Hanna M, el al. Case series using the ROTAFLOW system as a temporary right ventricular assist device after HeartMate II implantation.. ASAIO J. 2013;59(4):456-60.

1128. Sayer GT, Baker JN, Parks KA. Heart rescue: the role of mechanical circulatory support in the management of severe refractory cardiogenic shock. Currr Opin Crit Care. 2012;18(5):409-16.

1129. Ranieri VM, Rubenfeld GD, Thompson BT, Ferguson ND, Caldwell E, Fan E, et al; ARDS Definition Task Force. Acute respiratory distress syndrome: the Berlin Definition. JAMA. 2012;307(23):2526-33.

1130. MacLaren G, Combes A, Bartlett RH. Contemporary extracorporeal membrane oxygenation for adult respiratory failure: life support in the new era. Intensive Care Med. 2011;38(2):210-20.

1131. Fan E, Gattinoni L, Combes A, Schmidt M, Peek G, Brodie D, Muller T, et al. Venovenous extracorporeal membrane oxygenation for acute respiratory failure: A clinical review from an international group of experts. Intensive Care Med. 2016;42(5):712-24.

1132. Peek GJ, Mugford M, Tiruvoipati R, Wilson A, Allen E, Thalanany MM, et al; CESAR trial collaboration. Efficacy and economic assessment of conventional ventilatory support versus extracorporeal membrane oxygenation for severe adult respiratory failure (CESAR): a multicentre randomised controlled trial. Lancet. 2009;374(9698):1351-63. Erratum in: Lancet. 2009;374(9698):1330.

1133. Murray JF, Matthay MA, Luce JM, Flick MR. An expanded definition of the adult respiratory distress syndrome. Am Rev Respir Dis. 1988;138(3):7203. Erratum in: Am Rev Respir Dis 1989;139(4):1065.

1134. Diaz-Guzman E, Zwischenberger JB, Thannickal VJ, Hoopes CW. Extracorporeal membrane oxygenation for acute respiratory failure in adults: the need for pulmonary INTERMACS. Am J Respir Crit Care Med. 2014;190(11):1321-2.

1135. Mikkelsen ME, Woo YJ, Sager JS, Fuchs BD, Christie JD. Outcomes using extracorporeal life support for adult respiratory failure due to status asthmaticus. ASAIO J. 2009;55(1):47-52.

1136. Rich PB, Awad SS, Crotti S, Hirschl RB, Bartlett RH, Schreiner RJ. A prospective comparison of atriofemoral and femoro-atrial flow in adult venovenous extracorporeal life support. J Thorac Cardiovasc Surg. 1998;116(4):628-32.

1137. Walczak R, Lawson DS, Kaemmer D, McRobb C, McDermott P, Smigla $\mathrm{G}$, et al. Evaluation of a pre-primed microporous hollow-fiber membrane for rapid response neonatal extracorporeal membrane oxygenation. Perfusion. 2005;20(5):269-75.

1138. Schmidt M, Zogheib E, Rozé H, Repesse X, Lebreton G, Luyt CE, etal. The PRESERVE mortality risk score and analysis of long-term outcomes after extracorporeal membrane oxygenation for severe acute respiratory distress syndrome. Intensive Care Med. 2013;39(10):1704-13.

1139. Slutsky AS, Ranieri VM. Ventilator-induced lung injury. N Engl J Med. 2013;369(22):2126-36. Erratum in: N Engl J Med. 2014;370(17):1668-9.
1140. Fanelli V, Ranieri M, Mancebo J, Moerer O, Quintel M, Morley S, et al. Feasibility and safety of low-flow extracorporeal carbon dioxide removal to facilitate ultra-protective ventilation in patients with moderate acute respiratory distress syndrome. Crit Care. 2016 Feb 10;20:36.

1141. Blume ED, Rosenthal DN, Rossano JW, Baldwin JT, Eghtesady P, Morales DL, et al; PediMACS Investigators. Outcomes of children implanted with ventricular assist devices in the United States - First analysis of the Pediatric Interagency Registry for Mechanical Circulatory Support (PediMACS). J Heart Lung Transplant. 2016;35(5):578-84.

1142. Almond CS, Morales DL, Blackstone EH, Turrentine MW, Imamura M, Massicotte MP, et al. Berlin Heart EXCOR pediatric ventricular assist device for bridge to heart transplantation in US children. Circulation. 2013;127(16):1702-11.

1143. Canêo LF, Neirotti RA. ECMO: Improving our results by chasing the rabbits. Braz J Cardiovasc Surg. 2015;30(6):657-9.

1144. Miana LA, Caneo LF, Tanamati C, Penha JG, Guimarães VA, Miura N, et al. Post-cardiotomy ECMO in pediatric and congenital heart surgery: impact of team training and equipment in the results. Rev Bras Cir Cardiovasc. 2015;30(4):409-16.

1145. Flórez CX, Bermon A, Castillo VR, Salazar R. Setting Up an ECMO Program in a South American Country: outcomes of the first 104 pediatric patients. World J Pediatr Congenit Heart Surg. 2015;6(3):374-81.

1146. Moreno GE, Magliola R, Pilán ML, Althabe M, Balestrini M, Lenz AM, et al. [Mechanical circulatory support in pediatrics. Experience at the Dr. Juan P. Garrahan Pediatric Hospital. Argentina]. Arch Cardiol Mex. 2014;84(4):256-61.

1147. Park M, Mendes PV, Zampieri FG, Azevedo LC, Costa EL, Antoniali F, et al; ERICC research group; ECMO group Hospital Sírio Libanês and Hospital das Clínicas de São Paulo. The economic effect of extracorporeal membrane oxygenation to support adults with severe respiratory failure in Brazil: a hypothetical analysis. Rev Bras Ter Intensiva. 2014;26(3):253-62.

1148. Caneo LF, Miana LA, Tanamati C, Penha JG, Shimoda MS, Azeka E, et al. Use of short-term circulatory support as a bridge in pediatric heart transplantation. Arq Bras Cardiol. 2015;104(1):78-84.

1149. Dallan LAP, Quilici AP, Gonzalez MM, Ramires JA, Timerman S. Simulação clínica em cardiologia. Rev Soc Cardiol Estado de São Paulo. 2013;23(3):55-60.

1150. Gaba DM. Do as we say, not as you do: using simulation to investigate clinical behavior in action. Simul Healthc. 2009;4(2):67-9.

1151. Gaba DM. The future vision of simulation in healthcare. Simul Health. 2007;2(2):126-35

1152. Ypinazar VA, Margolis SA. Clinical simulators: applications and implications for rural medical education. Rural Remote Health. 2006;6(2):527.

1153. Kirschner P, van Merrienboer JG. Ten steps to complex learning: a systematic approach to four component instructional design. Mahwah (NJ): Lawrence Erlbaum Associates; 2007.

1154. Brandão CF, Collares CF, Marin HF. A simulação realística como ferramenta educacional para estudantes de medicina. Scientia Medica. 2014;24(2):187-92.

1155. Quilici AP, Abrão K, Timerman S. Ensino e simulação. Rev Soc Cardiol Estado de São Paulo. 2013;20(2):282-4.

1156. Cheng A, Eppich W, Grant V, Sherbino J, Zendejas B, Cook DA. Debriefing for technology-enhanced simulation: a systematic review andmetaanalysis. Med Educ. 2014;48(7):657-66.

1157. Kolb DA. Experiential learning: experience as the source of learning development. Englewood Cliffs, NJ: Prentice-Hall Inc; 1984.

1158. Guimarães HP, Lane JC, Flato UA, Timerman A, Lopes RD. A história da ressuscitação cardiopulmonar no Brasil. Rev Bras Clin Med. 2009;7:238-44. 
1159. Schartel SA, Metro DG. Evaluation: measuring performance, ensuring competence, achieving long-term excellence. Anesthesiology. 2010;112(3):519-20.

1160. Hamilton R. Nurses' knowledge and skill retention following cardiopulmonary resuscitation training: a review of the literature. J Adv Nurs. 2005;51(3):288-97.

1161. Oermann MH, Kardong-Edgren SE, McColgan JK, Hurd DA, Haus C, Snelson C, et al. Advantages and barriers to use of HeartCodeTM BLS with voice advisory manikin for teaching nursing students. Int J Nurs Educ Scholarsh. 2010; 7: 26

1162. Nishiyama C, Iwami T, Murakami Y, Kitamura T, Okamoto Y, Marukawa $\mathrm{S}$, et al. Effectiveness of simplified 15-min refresher BLS training program: a randomized controlled trial. Resuscitation. 2015 May;90:56-60.

1163. Perkins GD, Travers AH, Berg RA, Castren M, Considine J, Escalante R, et al; Basic Life Support Chapter Collaborators. Part 3: Adult basic life support and automated external defibrillation2015 International Consensus on Cardiopulmonary Resuscitation andEmergency Cardiovascular Care Science with Treatment Recommendations. Resuscitation. 2015 Oct;95:e43-69.

1164. Abella BS, Edelson DP, Kim S, Retzer E, Myklebust H, Barry AM, et al. CPR quality improvement during in-hospital cardiac arrest using a real-time audiovisual feedback system. Resuscitation. 2007;73(1):54-61.

1165. Meaney PA, Bobrow BJ, Mancini ME, Christenson J, de Caen AR, Bhanji $\mathrm{F}$, et al; on CPR Quality Summit Investigators, the American Heart Association Emergency Cardiovascular Care Committee, and the Council on Cardiopulmonary, Critical Care, Perioperative and Resuscitation. CPR quality: improving cardiac resuscitation outcomes both inside and outside the hospital: a Consensus Statement from the American Heart Association. Circulation. 2013;128(4):417-35.

1166. Zoll. [Internet]. [Cited in 2017 Dec 15]. Available from: http://www.zoll. com/medical-technology/real-cpr-help.

1167. Zoll. [Internet]. [Cited in 2017 Dec 15]. Available from: file:///C:/Users/ user/Desktop/Q_CPR_EMS_Product_Overview_FINAL.pdf

1168. Yeung J, Davies R, Gao F, Perkins GD. A randomised control trial of prompt and feedback devices and their impact on quality of chest compressions- a simulation study.Resuscitation. 2014;85(4):553-9.

1169. Woollard M, Poposki J, McWhinnie B, Rawlins L, Munro G, O'Meara P. Achy breaky makey wakey heart? A randomised crossover trialof musical prompts.Emerg Med J. 2012;29(4):290-4.

1170. Buist MD, Moore GE, Bernard SA, Waxman BP, Anderson JN, Nguyen TV. Effects of a medical emergency team on reduction of incidence of and mortality from unexpected cardiac arrests in hospital: preliminary study. BMJ. 2002;324(7334):387-90.

1171. Bellomo R, Goldsmith D, Uchino S, Buckmaster J, Hart G, Opdam $\mathrm{H}$, et al. Prospective controlled trial of effect of medical emergency team on postoperative morbidity and mortality rates. Crit Care Med. 2004;32(4):916-21.

1172. DeVita MA, Bellomo R, Hillman K, Kellum J, Rotondi A, Teres D, et al. Findings of the first consensus conference on medical emergency teams. Crit Care Med. 2006;34(9):2463-78.

1173. Cretikos MA, Chen J, Hillman KM, Bellomo R, Finfer SR, Flabouris A; MERIT Study Investigators. The effectiveness of implementation of the medical emergency team (MET) system and factors associated with use during the MERIT study. Crit Care Resusc. 2007;9(2):205-12.

1174. Buist MD, Jarmolowski E, Burton PR, Bernard SA, Waxman BP, Anderson J. Recognising clinical instability in hospital patients before cardiac arrest or unplanned admission to intensive care: a pilot study in a tertiary-care hospital. Med J Aust. 1999;171(1):22-5.

1175. Hillman KM, Bristow PJ, Chey T, Daffurn K, Jacques T, Norman SL. Antecedents to hospital deaths. Intern Med J. 2001;31(6):343-8.
1176. Berwick DM, Calkins DR, McCannon CJ, Hackbarth AD. The 100000 lives campaign: setting a goal and a deadline for improving health care quality. JAMA. 2006;295(3):324-7.

1177. Hillman K, Chen J, Cretikos M, Bellomo R, Brown D, Doig G, et al; MERIT study investigators. Introduction of the medical emergency team (MET) system: a cluster-randomised controlled trial. Lancet. 2005;365 (9477):2091-7. Erratum in: Lancet. 20051;366(9492):1164.

1178. Guimarães JI, Souza GE, Quilici AP, Gonzales MM, Gomes AG, Garcia AM, et al. Diretriz de apoio ao suporte avançado de vida em cardiologia - código azul - registro de ressuscitação - normatização do carro de emergência. Arq Bras Cardiol. 2003;81(supl IV):1-14.

1179. Salamonson Y, Kariyawasam A, van Heere B, O'Connor C. The evolutionary process of Medical Emergency Team (MET) implementation: reduction in unanticipated ICU transfers. Resuscitation 2001;49(2):135-41.

1180. Gerdik C, Vallish RO, Miles K, Godwin SA, Wludyka PS, Panni MK. Successful implementation of a family and patient activated rapid response team in an adult level 1 trauma center. Resuscitation. 2010;81(12):1676-81.

1181. Hodgetts TJ, Kenward G, Vlachonikolis IG, Payne S, Castle N. The identification of risk factors for cardiac arrest and formulation of activation criteria to alert a medical emergency team. Resuscitation. 2002;54(2):125-31

1182. Parr MJ, Hadfield JH, Flabouris A, Bishop G, Hillman K. The Medical Emergency Team: 12 month analysis of reasons for activation, immediate outcome and not-for-resuscitation orders. Resuscitation. 2001;50(1):39-44

1183. Lee A, Bishop G, Hillman KM, Daffurn K. The medical emergency team. Anaesth Intensive Care 1995; 23(2):183-6.

1184. Brilli RJ, Gibson R, Luria JW, Wheeler TA, Shaw J, Linam M, et al. Implementation of a medical emergency team in a large pediatric teaching hospital prevents respiratory and cardiopulmonary arrests outside the intensive care unit. Pediatr Crit Care Med. 2007;8(3):236-46.

1185. Sharek PJ, Parast LM, Leong K, Coombs J, Earnest K, Sullivan J, et al. Effect of a rapid response team on hospital-wide mortality and code rates outside the ICU in a Children's Hospital. JAMA. 2007;298(19):2267-74.

1186. Mistry KP, Turi J, Hueckel R, Mericle JM, Meliones JN. Pediatric Rapid Response Teams in the Academic Medical Centre. Clin Ped Emerg Med. 2006;7(4):241-7.

1187. Massey D, Aitken LM, Chaboyer W. Literature review: do rapid response systems reduce the incidence of major adverse events in the deteriorating ward patient? J Clin Nurs. 2010;19(23-24):3260-73.

1188. Santamaria J, Tobin A, Holmes J. Changing cardiac arrest and hospita mortality rates through a medical emergency team takes time and constant review. Crit Care Med. 2010;38(2):445-50.

1189. Duckitt RW, Buxton-Thomas R, Walker J, Cheek E, Bewick V, Venn R, et al. Worthing physiological scoring system: derivation and validation of a hysiological early-warning system for medical admissions. An observational, population-based single centre study. Br J Anaesth. 2007:98(6):769-74

1190. Hodgetts TJ, Kenward G, Vlachonikolis IG, Payne S, Castle N. The identification of risk factors for cardiac arrest and formulation of activation criteria to alert a medical emergency team. Resuscitation 2002;54(2):125-31.

1191. Chan PS, Nichol G, Krumholz HM, Spertus JA, Nallamothu BK; American Heart Association National Registry of Cardiopulmonary Resuscitation. American Heart Association National Registry of Cardiopulmonary Resuscitation (NRCPR) Investigators. Hospital variation in time to defibrillation after in-hospital cardiac arrest. Arch Intern Med. 2009;169(14):1265-73.

1192. Dacey MJ, Mirza ER, Wilcox V, Doherty M, Mello J, Boyer A, et al. The effect of a rapid response team on major clinical outcome measures in a community hospital. Crit Care Med. 2007;35(9):2076-82. 
1193. Baxter AD, Cardinal P, Hooper J, Patel R. Medical emergency teams at The Ottawa Hospital: the first two years. Can J Anaesth. 2008;55(4):223-31.

1194. Tibballs J, Kinney S, Duke T, OakleyE, Hennessy M. Reduction of paediatric in-patient cardiac arrest and death with a medical emergency team: preliminary results. Arch Dis Child. 2005;90(11):1148-52.

1195. Calzavacca P, Licari E, Tee A, Egi M, Downey A, Quach J, et al. The impact of rapid response system on delayed emergency team activation patient characteristics and outcomes. A follow-up stydy. Resuscitation. 2010;81(1):31-5

1196. Chen J, Bellomo R, Flabouris A, Hillman K, Finfer S; MERIT Study Investigators for the Simpson Centre; ANZICS Clinical Trials Group. The relationship between early emergency team calls and serious adverse events. Crit Care Med. 2009;37(1):148-53.

1197. King E, Horvath R, Shulkin DJ. Establishing a rapid response team (RRT) in an academic hospital: one year's experience. J Hosp Med. 2006;1(5):296-305.

1198. McFarlan SJ, Hensley S. Implementation and outcomes of a rapid response team. J Nurs Care Qual. 2007;22(4):307-13.

1199. Rothschild JM, Woolf S, Finn KM, Friedberg MW, Lemay C, Furbush KA, et al. A controlled trial of a rapid response system in an academic medical center. Jt Comm J Qual Patient Saf. 2008;34(7):417-25, 365.

1200. Souza GE, Quilici AP, Gonzalez MM. Apoio ao Suporte Avançado em Cardiologia: Código Azul. In: Timernan S, Gonzalez MM, Ramires JA. Ressuscitação em emergências cardiovasculares: do básico ao avançado. Barueri-SP: Manole; 2007. p. 380-5.

1201. Peberdy MA, Cretikos M, Abella BS, DeVita M, Goldhill D, Kloeck W, et al; International Liaison Committee on Resuscitation; American Heart Association; Australian Resuscitation Council; European Resuscitation Council; Heart and Stroke Foundation of Canada; InterAmerican Heart Foundation; Resuscitation Council of Southern Africa; New Zealand Resuscitation Council; American Heart Association Emergency Cardiovascular Care Committee; American Heart Association Council on Cardiopulmonary, Perioperative, and Critical Care; Interdisciplinary Working Group on Quality of Care and Outcomes Research. Recommended guidelines for monitoring, reporting, and conducting research on medical emergency team, outreach, and rapid response systems: an Utstein-style scientific statement: a scientific statement from the International Liaison Committee on Resuscitation (American Heart Association, Australian Resuscitation Council, European Resuscitation Council, Heart and Stroke Foundation of Canada, Inter American Heart Foundation, Resuscitation Council of Southern Africa, and the New Zealand Resuscitation Council); the American Heart Association Emergency Cardiovascular Care Committee; the Council on Cardiopulmonary, Perioperative, and Critical Care; and the Interdisciplinary Working Group on Quality of Care and Outcomes Research. Circulation. 2007;116(21):2481-500.

1202. Fernandes AP, Vancini CR, Cohrs F, Moreira RS. Qualidade das anotações de enfermagem relacionadas à ressuscitação cardiopulmonar comparadas ao modelo Utstein. Acta Paul Enferm. 2010;23(6):757-63.

1203. Cavalcante TM, Lopes RS. O atendimento à parada cardiorrespiratória em unidade coronariana segundo o protocolo Utstein. Acta Paul Enferm. 2006;19(1):7-15

1204. Cummins RO, Chamberlain DA, Abramson NS, Allen M, Baskett PJ, Becker $\mathrm{L}$, et al. Recommended guidelines for uniform reporting of data from out-of-hospital cardiac arrest: the Utstein Style. A statement for health professionals from a task force of the American Heart Association, the European Resuscitation Council, the Heart and Stroke Foundation of Canada, and the Australian Resuscitation Council. Circulation 1991; 84(2):960-75.

1205. Boaventura AP, Araújo IE. Registro do atendimento da parada cardiorrespiratória no ambiente intrahospitalar: aplicabilidade de um instrumento. Rev Gaúcha Enferm. 2006;27(3):434-42.

1206. Silva KR, Granitoff N. Registro de ressuscitação cardiopulmonar intrahospitalar: comparação com o Estilo Utstein. Rev Soc Cardiol Estado de São Paulo. 2003;13(2 Supl. B):90.
1207. Torreão LA, Reis AG, Troster E, Oselka G. [Cardiopulmonary resuscitation: discrepancy between the actual cardiopulmonary resuscitation and the documentation in the medical record]. J. Pediatr (Rio J). 2000;76(6):429-33.

1208. House E, BaileyJ. Resistance documentation: a nursing research issue. Int J Nurs Stud. 1992;29(4):371-80.

1209. Lin S, Morrison LJ, Brooks SC. Development of a data dictionary for the Strategies for Post Arrest Resuscitation Care (SPARC) network for post cardiac arrest research. Resuscitation. 2011;82(4):419-22.

1210. Guimarães JI, Souza GE, Quilici AP, Gonzales MM, Gomes AG, Garcia AM, et al. ,Sociedade Brasileira de Cardiologia. Diretriz de apoio ao suporte avançado de vida em cardiologia - código azul - registro de ressuscitação - normatização do carro de emergência. Arq Bras Cardiol. 2003;81(supl IV): $1-14$

1211. Cone DC, Jaslow DS, Brabson TA. Now that we have the Utstein style, are we using it? Acad Emerg Med. 1999;6(9):923-8.

1212. Lopes JL, Gengo e Silva RC, Palomo JS, Gonzalez MM, Pires FA, Gutierrez $M A$, et al. Sistematização do registro eletrônico de atendimento da parada cardiorrespiratória. J Health Inform. 2012;4(1):17-22.

1213. Brasil. Ministério da Saúde. Portaria no 3432, de 12 de agosto de 1998. Estabelece critérios de classificação para as unidades de tratamento intensivo - UTI. [Acesso em 2012 jun 5]. Disponível em: http://www. assobrafir.com.br/userfiles/file/PTGM-MS3432-98UTI.pdf

1214. Brasil. Ministério da Saúde. Portaria no 123, de 28 de fevereiro de 2005. Política nacional de atenção cardiovascular de alta complexidade. [Acesso em 2012 jun 5]. Disponível em: http://www.saude.mg.gov. br/atos_normativos/legislacao-sanitaria/estabelecimentos-de-saude/ cardiologia/portaria_0123.pdf

1215. Brasil. Ministério da Saúde. Portaria no 2048, de 5 de novembro de 2002. Aprova o Regulamento Técnico dos Sistemas Estaduais de Urgência e Emergência. [Citado em 2010 Maio 20]. Disponível em: http://www. bvsms.saude.gov.br/saudelegis/gm/2002/prt2048_05_11_2002.html

1216. Lopez SLB, Fernandes RJ. Uma breve revisão do atendimento préhospitalar. Medicina (Ribeirão Preto). 1999;32:381-7.

1217. Conselho Regional de Medicina. São Paulo. Parecer Número 14402/2004/.

1218. Eisenberg MJ, Topol EJ. Prehospital administration of aspirin in patients with unstable angina and acute myocardial infarction. Arch Intern Med. 1996;156(14):1506-10.

1219. Braunwald E, Antman EM, BeasleyJW, Califf RM, Cheitlin MD, Hochman JS, et al. ACC/AHA guidelines for the management of patients with unstable angina and non-ST-segment elevation myocardial infarction. A report of the American College of Cardiology/American Heart Association Task Force on Practice Guidelines (Committee on the Management of Patients With Unstable Angina). J Am Coll Cardiol. 2000;36(3):970-1062. Erratum in: J Am Coll Cardiol 2001;38(1):294-5.

1220. Neumar RW, Shuster M, Callaway CW, Gent LM, Atkins DL, Bhanji F, et al. Part 1: Executive Summary: 2015 American Heart Association Guidelines Update for Cardiopulmonary Resuscitation and Emergency Cardiovascular Care. Circulation. 2015;132(18 Suppl 2):S315-67.

1221. Kleinman ME, Brennan EE, Goldberger ZD, Swor RA, Terry M, Bobrow BJ, et al. Part 5: Adult Basic Life Support and Cardiopulmonary Resuscitation Quality: 2015 American Heart Association Guidelines Update for Cardiopulmonary Resuscitation and Emergency Cardiovascular Care. Circulation. 2015;132(18 Suppl 2):S414-35

1222. Atendimento pré-hospitalar ao traumatizado básico e avançado. PHTLS Pré-Hospital Trauma Life Support. Comitê do PHTLS da National Association of Emergency Medical Technicians (NAEMT) em cooperação com o Comitê de Trauma do Colégio Americano de Cirurgiões. $7^{\mathfrak{a}}$ ed. Rio de Janeiro: Elsevier; 2012.

1223. Link MS, Berkow LC, Kudenchuk PJ, Halperin HR, Hess EP, Moitra VK, et al. Part 7: Adult Advanced Cardiovascular Life Support: 2015 American Heart Association Guidelines Update for Cardiopulmonary Resuscitation 
and Emergency Cardiovascular Care. Circulation. 2015;132(18 Suppl 2):S444-64.

1224. Callaway CW, Donnino MW, Fink EL, Geocadin RG, Golan E, Kern KB, et al. Part 8: Post-Cardiac Arrest Care: 2015 American Heart Association Guidelines Update for Cardiopulmonary Resuscitation and Emergency Cardiovascular Care. Circulation. 2015;132(18 Suppl 2):S465-82.

1225. Mancini ME, Diekema DS, Hoodley TA, Kadlec K, Levelle MH, McGrowan JE. 2015 AHA Guidelines Update for Cardiolpulmonary Ressuscitation and Emergency Cardiovascular Care: Part 3: ethical issues. Circulation. 2015;132(18 Suppl 2):S383-S396.

1226. Hopson LR, Hirsh E, Delgado J, Domeier RM, Krohmer J, McSwain NE Jr, et al. National Association of EMS Physicians Standards and Clinical Practice Committee; American College of Surgeons Committee on Trauma. Guidelines for withholding or termination of resuscitation in prehospital traumatic cardiopulmonary arrest. J Am Coll Surg. 2003;196(3):475-81.

1227. Mollberg NM, Wise SR, Berman K, Chowdhry S, Holevar M, Sullivan R, et al. The consequences of noncompliance with guidelines for whitholding or terminating resuscitation in traumatic cardiac arrest patients. J Trauma. 2011;71(4):997-1002

1228. Markenson D, Ferguson JD, Chameides L, Cassan P, Chung KL, Epstein J, et al. Part 17: first aid: 2010 American Heart Association and American Red Cross Guidelines for First Aid. Circulation. 2010;122(18 Suppl 3):S934-46. Erratum in: Circulation. 2012;125(13):e540.

1229. Singletary EM, Charlton NP, Epstein JL, Ferguson JD, Jensen JL, MacPherson Al, et al. Part 15: first aid: 2015 American Heart Association and American Red Cross Guidelines Update for First Aid. Circulation. 2015;132(18 Suppl 2):S574-89.

1230. Singletary EM, Zideman DA, Buck ED, Chang WT, Jensen JL, Swain JM, et al. Part 9: first aid: 2015 International Consensus on First Aid Science With Treatment Recommendations. Circulation. 2015;132(16Suppl 1):S269-311.

1231. Prehospital Trauma Life Support. (PHTLS). National Association of Emergency Medical Technicians. (NAEMT). 6th ed. Rio de Janeiro: Elsevier; 2007.

1232. Eftestol T, Wik L, Sunde K, Steen PA. Effects of cardiopulmonary resuscitation on predictors of ventricular fibrillation defibrillation success during out-of-hospital cardiac arrest. Circulation. 2004;110(1):10-5

1233. Kothari RU, Pancioli A, Liu T, Brott T, Broderick J. Cincinnati Pre hospital Stroke Scale: reproducibility and validity. Ann Emerg Med. 1999;33(4):373-8.

1234. Rosanio S, Schwarz ER, Ware DL, Vitarelli A. Syncope in adults: systematic review and proposal of a diagnostic and therapeutic algorithm. Int J Cardiol. 2013 Jan 20;162(3):149-57.

1235. American Heart Association. Suporte básico de vida. (SBV). SBV para profissionais de saúde. São Paulo: Prous Science; 2006

1236. Berg RA, Hemphill R, Abella BS, Aufderheide TP, Cave DM, Hazinski MF, et al. Part 5: adult basic life support: 2010 American Heart Association Guidelines for Cardiopulmonary Resuscitation and Emergency Cardiovascular Care. Circulation. 2010;122(18 Suppl 3):S685-705. Erratum in: Circulation. 2011;124(15):e402.

1237. Heimlich HJ. A life-saving maneuver to prevent food-choking. JAMA 1975;234(4):398-401

1238. Lih-Brody L,Singer M, Brody Jr. E. Lifevac: a Novel Device for the Resuscitation Adolescent Choking Victim. Annals of Emergency Medicine. 2017; 70(4):S149-S150.

1239. Bintz M, Cogbill TH. Gastric rupture after the Heimlich maneuver. J Trauma. 1996;40(1):159-60.

1240. Steg PG, Bonnefoy E, Chabaud S, Lapostolle F, Dubien PY, Cristofini P, et al; Comparison of Angioplasty and Prehospital Thrombolysis In acute Myocardial infarction (CAPTIM) Investigators. Impact of time to treatment on mortality after prehospital fibrinolysis or primary angioplasty: data from the CAPTIM randomized clinical trial. Circulation. 2003;108(23):2851-6.
1241. Piegas LS, Timerman A, Feitosa GS, Nicolau JC, Mattos LA, Andrade MD, et al. V Diretriz da Sociedade Brasileira de Cardiologia sobre Tratamento do Infarto Agudo do Miocárdio com Supradesnível do Segmento ST. Arq Bras Cardiol. 2015;105(2):1-105

1242. Everts B, Karlson BW, Wahrborg P, Hedner T, Herlitz J. Localization of pain in suspected acute myocardial infarction in relation to final diagnosis, age and sex, and site and type of infarction. Heart Lung. 1996;25(6):430-7. Erratum in: Heart Lung 1997;26(3):176.

1243. Braga JR, Santos IS, Flato UP, Guimaraes HP, Avezum A. [The impact of diabetes mellitus on the mortality of acute coronary syndromes]. Arq Bras Endocrinol Metabol. 2007;51(2):275-80.

1244. Solomon CG, Lee TH, Cook EF, Weisberg MC, Brand DA, Rouan GW, et al. Comparison of clinical presentation of acute myocardial infarction in patient older than 65 years of age to younger patients: the Multicenter Chest Pain Study experience. Am J Cardiol. 1989;63(12):772-6.

1245. Douglas PS, Ginsburg GS. The evaluation of chest pain in women. N Eng J Med. 1996;334(20):1311-5.

1246. Braunwald E, Antman EM, Beasley JW, Califf RM, Cheitlin MD, Hochman JS, et al; American College of Cardiology; American Heart Association. Committee on the Management of Patients With Unstable Angina. ACC/ AHA 2002 guideline update for the management of patients with unstable angina and non-ST-segment elevation myocardial infarction- -summary article: a report of the American College of Cardiology/ American Heart Association task force on practice guidelines (Committee on the Management of Patients With Unstable Angina). J Am Coll Cardiol. 2002;40(7):1366-74.

1247. Piegas LS, Feitosa G, Mattos LA, Nicolau JC, Rossi Neto JM, Timerman A, et al; Sociedade Brasileira de Cardiologia. IV Diretriz da Sociedade Brasileira de Cardiologia sobre tratamento do infarto agudo do miocárdio com supradesnível do segmento ST. Arq Bras Cardiol. 2009;93(6 supl.2):e179-264.

1248. Dracup K, Alonzo AA, Atkins JM, Bennett NM, Braslow A, Clark LT, et al. The physician's role in minimizing prehospital delay in patients at high risk for acute myocardial infarction: recommendations from the National Heart Attack Alert Program. Working Group on Educational Strategies To Prevent Prehospital Delay in Patients at High Risk for Acute Myocardial Infarction. Ann Intern Med. 1997;126(8):645-51.

1249. Luepker RV, Raczynski JM, Osganian S, Goldberg RJ, Finnegan JR Jr, Hedges $\mathrm{JR}$, et al. Effect of community intervention on patient delay and emergency medical service use in acute coronary heart disease: The Rapid Early Action for Coronary Treatment (REACT) Trial. JAMA. 2000;284(1):60-7.

1250. Pinto DS, Kirtane AJ, Nallamothu BK, Murphy SA, Cohen DJ, Laham RJ, et al. Hospital delays in reperfusion for ST-elevation myocardial infarction: implications when selecting a reperfusion strategy. Circulation. 2006;114(19):2019-25

1251. Finnegan JR Jr, Meischke H, Zapka JG, Leviton L, Meshack A, BenjaminGarner R, et al. Patient delay in seeking care for heart attack symptoms: findings from focus groups conducted in five U.S. regions. Prev Med. 2000;31(3):205-13

1252. Diercks DB, Kontos MC, Chen AY, Pollack CV Jr, Wiviott SD, Rumsfeld JS, et al. Utilization and impact of pre-hospital electrocardiograms for patients with acute ST-segment elevation myocardial infarction: data from the NCDR (National Cardiovascular Data Registry) ACTION (Acute CoronaryTreatment and Intervention Outcomes Network) Registry. J Am CollCardiol. 2009;53(2):161-6

1253. Brown JP, Mahmud E, Dunford JV, Ben-Yehuda O. Effect of prehospital 12-lead electrocardiogram on activation of the cardiac catheterization laboratory and door-to-balloon time in ST-segment elevation acute myocardial infarction. Am J Cardiol. 2008;101(2):158-61.

1254. Del Zoppo GJ, Saver JL, Jauch EC, Adams HPJr; American Heart Association Stroke Council. Expansion of the time window for treatment of acute ischemic stroke with intravenous tissue plasminogen activator: a science advisory from the American Heart Association/American Stroke Association. Stroke. 2009;40(8):2945-8. Erratum in: Stroke. 2010;41(9):e562. 
1255. National Institute of Neurological Disorders and Stroke rt-PA Stroke Study Group. Tissue plasminogen activator for acute ischemic stroke. N Engl J Med. 1995;333(24):1581-7.

1256. Hacke W, Kaste M, Bluhmki E, Brozman M, Davalos A, Guidetti D, et al; ECASS Investigators. Thrombolysis with alteplase 3 to 4.5 hours after acute ischemic stroke. N Engl J Med. 2008;359(13):1317-29.

1257. Barsan WG, Brott TG, Broderick JP, Haley EC, Levy DE, Marler JR. Time of hospital presentation in patients with acute stroke. Arch Intern Med. 1993;153(22):2558-61.

1258. Mosley I, Nicol M, Donnan G, Patrick I, Dewey H. Stroke symptoms and the decision to call for an ambulance. Stroke. 2007;38(2):361-3.

1259. Morgenstern LB, Bartholomew LK, Grotta JC, Staub L, King M, Chan W. Sustained benefit of a community and professional intervention to increase acute stroke therapy. Arch Intern Med. 2003;163(18):2198-202.

1260. Rossnagel K, Jungehülsing GJ, Nolte $\mathrm{CH}$, Müller-Nordhorn J, Roll S, Wegscheider K, et al. Out-of-hospital delays in patients with acute stroke. Ann Emerg Med. 2004;44(5):476-83.

1261. Adams HP Jr, del Zoppo G, Alberts MJ, Bhatt DL, Brass L, Furlan A, et al; American Heart Association; American Stroke Association Stroke Council; Clinical Cardiology Council; Cardiovascular Radiology and Intervention Council; Atherosclerotic Peripheral Vascular Disease and Quality of Care Outcomes in Research Interdisciplinary Working Groups. Guidelines for the early management of adults with ischemic stroke: a guideline from the American Heart Association/American Stroke Association Stroke Council, Clinical Cardiology Council, Cardiovascular Radiology and Intervention Council, and the Atherosclerotic Peripheral Vascular Disease and Quality of Care Outcomes in Research Interdisciplinary Working Groups: the American Academy of Neurology affirms the value of this guideline as an educational tool for neurologists. Stroke. 2007;38(5):1655-711. Erratum in: Stroke. 2007;38(6):e38. Stroke. 2007;38(9):e96.

1262. Kothari RU, Pancioli A, Liu T, Brott T, Broderick J. Cincinnati Prehospital Stroke Scale: reproducibility and validity. Ann Emerg Med. 1999;33(4):373-8

1263. Kidwell CS, Starkman S, Eckstein M, Weems K, Saver JL. Identifying stroke in the field. Prospective validation of the Los Angeles prehospital stroke screen (LAPSS). Stroke. 2000;31(1):71-76.

1264. Barsan WG, Brott TG, Olinger CP, Adams HP Jr, Haley EC Jr, Levy DE. Identification and entry of the patient with acute cerebral infarction. Ann Emerg Med. 1988;17(11):1192-5.

1265. Godoy DA, Pinero GR, Svampa S, Papa F, Di Napoli M. Hyperglycemia and short-term outcome in patients with spontaneous intracerebral hemorrhage. Neurocrit Care. 2008;9(2):217-29.

1266. Busse WW, Lemanske RF Jr. Asthma. N Engl J Med. 2001;344(5):350-62.

1267. Cookson W. The alliance of genes and environment in asthma and allergy. Nature. 1999;402(6760 Suppl):B5-11.

1268. Sociedade Brasileira de Pneumologia e Tisiologia. IV Diretrizes brasileiras para o manejo da asma. J Bras Pneumol. 2006;32(Supl 7):S447-74.

1269. Hamid S, Kumaradevan J, Cochrane GM. Single centre open study to compare patient recording of PRN salbutamol use on a daily diary card with actual use as recorded by the MDI compliance monitor. Respir Med. 1998;92(10):1188-90.

1270. Simon HK. Caregiver knowledge and delivery of a commonly prescribed medication (albuterol) for children. Arch Pediatr Adolesc Med. 1999;153(6):615-8.

1271. Joint Task Force on Practice Parameters; American Academy of Allergy, Asthma and Immunology; American College of Allergy, Asthma and Immunology; Joint Council of Allergy, Asthma and Immunology. The diagnosis and management of anaphylaxis: an updated practice parameter. J Allergy Clin Immunol. 2005;115(3 Suppl 2):S483-523. Erratum in: J Allergy Clin Immunol. 2008;122(1):68.
1272. Bernd LA, Solé D, Pastorino AC, Prado EA, Castro FF, Rizzo MC, et al. Anafilaxia: guia prático para o manejo. Rev Bras Alerg Imunopatol. 2006;29(6):283-91.

1273. Bernd LA, Fleig F, Alves MB, Bertozzo R, Coelho M, Correia J, et al. Anafilaxia no Brasil - Levantamento da ASBAI. Rev Bras Alerg Imunopatol. 2010;33(5):190-8

1274. Sampson HA, Muñoz-Furlong A, Campbell RL, Adkinson NF Jr, Bock SA, Branum A, et al. Second symposium on the definition and management of anaphylaxis: summary report-Second National Institute of Allergy and Infectious Disease/Food Allergy and Anaphylaxis Network symposium. J Allergy Clinl mmunol. 2006;117(2):391-7.

1275. Moneret-Vautrin DA, Morisset M, Flabbee J, Beaudouin E, Kanny G. Epidemiology of life-threatening and lethal anaphylaxis: a review. Allergy. 2005;60(4):443-51.

1276. Grabenhenrich L, Hompes S, Gough H, Ruëff F, Scherer K, Pföhler C, et al. Implementation of anaphylaxis management guidelines: a register-based study. PLoS One. 2012;7(5):e35778.

1277. Sicherer SH, Forman JA, Noone SA. Use assessment of self-administered epinephrine among food-allergic children and pediatricians. Pediatrics. 2000;105(2):359-62.

1278. Sheikh A, Simons FER, Barbour V, Worth A. Adrenaline autoinjectors for the treatment of anaphylaxis with and without cardiovascular collapse in the community. Cochrane Database Syst Rev. 2012 Aug 15;(8):CD008935.

1279. Clegg SK, Ritchie JM. "Epipen" training: a survey of the provision for parents and teachers in West Lothian. Ambul Child Health. 2001;7(3-4):169-75.

1280. Sociedade Brasileira de Pediatria - Departamento de Alergia. Anafilaxia: guia prático de atualização. Rio de Janeiro; 2016.

1281. Lockey RF, Kemp SF, Lieberman PL, Sheikh A. Anaphylaxis. In: Pawankar R, Canonica GW, Holgate S, Lockey R, Blaiss M (eds). World Allergy Organization (WAO). White Book on Allergy. Update 2013. WAO; 2013:48-53.

1282. Dhami S, Panesar SS, Roberts G, Muraro A, Worm M, Bilò MB, et al; EAACI Food Allergy and Anaphylaxis Guidelines Group. Management of anaphylaxis: a systematic review. Allergy. 2014;69(2):168-75.

1283. Fisher RS, van Emde Boas W, Blume W, Elger C, Genton P, Lee P, et al. Epileptic Seizures and Epilepsy: Definitions Proposed by the International League Against Epilepsy (ILAE) and the International Bureau for Epilepsy (IBE). Epilepsia. 2005;46(4):470-2.

1284. Guilhoto LM, Nobre C, Silva AR, Tavares C. Ação educativa de professores de ensino fundamental sobre epilepsia na periferia do Município de São Paulo. J Epilepsy Clin Neurophysiol. 2007;13(3):143-7.

1285. O'Hara KA. First aid for seizures: the importance of education and appropriate response. J Child Neurol. 2007;22(5 Suppl):30S-7S.

1286. Epilepsy Foundation. [Internet]. [Cited in 2018 Jan 20]. Available from: [http://www.epilepsy.com/learn/treating-seizures-and-epilepsy/seizurefirst-aid] Acessado em 20/1/2016.

1287. Markenson D, Ferguson JD, Chameides L, Cassan P, Chung KL, Epstein J, et al. Part 17: first aid: 2010 American Heart Association and American Red Cross Guidelines for First Aid. Circulation. 2010;122(18 Suppl 3):S934-46. Erratum in: Circulation. 2012;125(13):e540.

1288. Silbergleit R, Durkalski V, Lowenstein D, Conwit R, Pancioli A, Palesch $Y$, et al; NETT Investigators. Intramuscular versus intravenous therapy for prehospital status epilepticus. N Engl J Med. 2012;366(7):591-600.

1289. Portela JL, Garcia PC, Piva JP, Barcelos A, Bruno F, Branco R, et al. Intramuscular midazolam versus intravenous diazepam for treatment of seizures in the pediatric emergency department: a randomized clinical trial. Med Intensiva. 2014;39(3):160-6.

1290. Glauser T, Shinnar S, Gloss D, Alldredge B, Arya R, Bainbridge J, et al. Evidence-Based Guideline: treatment of convulsive status epilepticus in 
children and adults: report of the Guideline Committee of the American Epilepsy Society. Epilepsy Curr. 2016;16(1):48-61.

1291. Wild D, von Maltzahn R, Brohan E, Christensen T, Clauson P, GonderFrederick L. A critical review of the literature on fear of hypoglycemia in diabetes: implications for diabetes management and patient education. Patient Educ Couns. 2007;68(1):10-5

1292. Brodows RG, Williams C, Amatruda JM. Treatment of insulin reactions in dia-betics. JAMA. 1984;252(24):3378-81.

1293. Slama G, Traynard PY, Desplanque N, Pudar H, Dhunputh I, Letanoux $M$, et al. The search for an optimized treatment of hypoglycemia. Carbohydrates in tablets, solution, or gel for the correction of insulin reactions. Arch Intern Med. 1990;150(3):589-93.

1294. Bronstein AC, Spyker DA, Cantilena LR Jr, Green JL, Rumack BH, Dart RC. 2010 Annual Report of the American Association of Poison Control Centers' National Poison Data System (NPDS): 28th Annual Report. ClinToxicol (Phila). 2011;49(10):910-41. Erratum in: Clin Toxicol (Phila). 2014;52(10):1285.

1295. Sistema Nacional de Informações toxico-farmacológicas. (Sinitox). [Citado em 2017 fev 27]. Disponível em: http://sinitox.icict.fiocruz.br/sites/sinitox. icict.fiocruz.br/files//Tabela7_2013.pdf.

1296. International Federation of Red Cross and Red Crescent Societies. International first aid and resuscitation guidelines 2016 for National Society First Aid Programme Managers, Scientific Advisory Groups, first aid instructors and first responders. Geneva; 2016.

1297. Homan CS, Maitra SR, Lane BP, Thode HC Jr, Davidson L. Histopathologic evaluation of the therapeutic efficacy of water and milk dilution for esophageal acid injury. Acad Emerg Med. 1995;2(7):587-91.

1298. Prehospital Trauma Life Support. (PHTLS). National Association of Emergency Medical Technicians. (NAEMT). 8th ed. Rio de Janeiro: Elsevier; 2016

1299. Spiller HA, Rodgers GC Jr. Evaluation of administration of activated charcoal in the home. Pediatrics. 2001;108(6):E100.

1300. Lamminpää A, Vilska J, Hoppu K. Medical charcoal for a child's poisoning at home: availability and success of administration in Finland. Hum ExpToxicol. 1993;12(1):29-32.

1301. Balla JI, Elstein AS. Skull x-ray assessment of head injuries: a decision analytic approach. Methods Inf Med. 1984;23(3):135-8.

1302. Bijur PE, Haslum M, Golding J. Cognitive and behavioral sequelae of mild head injury in children. Pediatrics. 1990;86(3):337-44.

1303. Geeraedts LM Jr, Kaasjager HA, van Vugt AB, Frölke JP. Exsanguination in trauma: a review of diagnostics and treatment options. Injury. 2009;40(1):11-20.

1304. King NA, Philpott SJ, Leary A. A randomized controlled trial assessing the use of compression versus vasoconstriction in the treatment of femoral hematoma occurring after percutaneous coronary intervention. Heart Lung. 2008;37(3):205-10.

1305. Levy AS, Marmar E. The role of cold compression dressings in the postoperative treatment of total knee arthroplasty. Clin Orthop Relat Res. 1993 Dec;(297):174-8.

1306. Beekley AC, Sebesta JA, Blackbourne LH, Herbert GS, Kauvar DS, Baer DG, et al; 31st Combat Support Hospital Research Group. Prehospital tourniquet use in Operation Iraqi Freedom: effect on hemorrhage control and outcomes. J Trauma. 2008;64(2 Suppl):S28-37.

1307. King DR, van der Wilden G, Kragh JF Jr, Blackbourne LH. Forward assessment of 79 prehospital battlefield tourniquets used in the current war. J Spec Oper Med. 2012;12(4):33-8.

1308. Kue RC, Temin ES, Weiner SG, Gates J, Coleman MH, Fisher J, et al. Tourniquet use in a civilian emergency medical services setting: a descriptive analysis of the Boston EMS Experience. Prehosp Emerg Care. 2015;19(3):399-404.
1309. Passos E, Dingley B, Smith A, Engels PT, Ball CG, Faidi S, et al; Canadian Trauma Trials Collaborative. Tourniquet use for peripheral vascular injuries in the civilian setting. Injury. 2014;45(3):573-7.

1310. Cox ED, Schreiber MA, McManus J, Wade CE, Holcomb JB. New hemostatic agents in the combat setting. Transfusion. 2009;49 Suppl 5:248S-55S.

1311. Wedmore I, McManus JG, Pusateri AE, Holcomb JB. A special report on the chitosan-based hemostatic dressing: experience in current combat operations. J Trauma. 2006;60(3):655-8.

1312. Brasil. Ministério da Saude. Secretaria de Atenção à Saúde. Cartilha para tratamento de emergência das queimaduras. Departamento de Atenção Especializada. Brasília; 2012.

1313. Purdue GF, Layton TR, Copeland CE. Cold injury complicating burn therapy. J Trauma. 1985;25(2):167-8

1314. Yava A, Koyuncu A, Tosun N, Kiliç S. Effectiveness of local cold application on skin burns and pain after transthoracic cardioversion. Emerg Med J. 2012;29(7):544-9.

1315. Nguyen NL, Gun RT, Sparnon AL, Ryan P. The importance of immediate cooling-a case series of childhood burns in Vietnam. Burns. 2002;28(2):173-6.

1316. Swain AH, Azadian BS, Wakeley CJ, Shakespeare PG. Management of blisters in minor burns. BMJ (Clin Res Ed). 1987;295(6591):181.

1317. Maenthaisong R, Chaiyakunapruk N, Niruntraporn S, Kongkaew C. The efficacy of aloe vera used for burn wound healing: a systematic review. Burns. 2007;33(6):713-8.

1318. Jull AB, Rodgers A, Walker N. Honey as a topical treatment for wounds. Cochrane Database Syst Rev. 2008 Oct;4:CD005083.

1319. Brasil. Ministério da Saúde. Manual de Diagnóstico e Tratamento dos Acidentes por Animais Peçonhentos. Brasília: Fundação Nacional de Saúde, 1998

1320. Cardoso JLC, França FOS, Fan HW, Malaque CM, Jr Haddad V. - Animais Peçonhentos no Brasil: Biologia, Clínica e Terapêutica dos Acidentes. São Paulo. Savier/Fapesp. 2003.

1321. Brasil. Ministério da Saúde. Guia de Vigilância em Saúde. $1 \underline{\text { a }}$ ed. - Brasília: Secretaria de Vigilância em Saúde. Guia de Vigilância em Saúde. 2014, capítulo 11: 719-740.

1322. Wedmore I, McManus JG, Pusateri AE, Holcomb JB. A special report on the chitosan-based hemostatic dressing: experience in current combat operations. J Trauma. 2006;60(3):655-658.

1323. Beauchamp TL, Childress JF. Principles of biomedical ethics. 6th ed. New York: Oxford University Press; 2009.

1324. British Medical Association. Medical ethics today: the BMA's handbook of ethics and law. 3rd ed. London (UK): Blackwell; 2002.

1325. Marco CA, Marco CA. Ethical issues of resuscitation: an American perspective. Postgrad Med J. 2005;81(959):608-12.

1326. O'Neill O. Autonomy and trust in bioethics. Cambridge (NY): Cambridge University Press; 2002

1327. World Medical Association. Medical ethics manual. 3rd ed. Ferney-Voltaire Cedex. London: World Health Communication Associates; 2015.

1328. Lippert FK, Raffay V, Georgiou M, Steen PA, Bossaert L. European Resuscitation Council guidelines for resuscitation 2010 Section 10 The ethics of resuscitation and end-of-life decisions. Resuscitation. 2010;81(10):1445-51.

1329. Schneiderman LJ, Jecker NS, Jonsen AR. Medical futility: its meaning and ethical implications. Ann Intern Med. 1990:112(12):949-54

1330. Waisel DB, Truog RD. The cardiopulmonary resuscitation-not-indicated order: futility revisited. Ann Intern Med. 1995;122(4):304-8. 
1331. Kite S, Wilkinson S. Beyond futility: to what extent is the concept of futility useful in clinical decision-making about CPR? Lancet Oncol. 2002;3(10):638-42.

1332. Committee on Bioethics (DH-BIO) of the Council of and Europe. Guide on the decision-making process regarding medical treatment in end-of-life situations. Strasbourg; 2014.

1333. Blinderman CD, Krakauer EL, Solomon MZ. Time to revise the approach to determining cardiopulmonary resuscitation status. JAMA. 2012;307(9):917-8.

1334. Nakamura F, Hayashino Y, Nishiuchi T, Kakudate N, Takegami M, Yamamoto $Y$, et al. Contribution of out-of-hospital factors to a reduction in cardiac arrest mortality after witnessed ventricular fibrillation or tachycardia. Resuscitation. 2013;84(6):747-51.

1335. Soreide E, Morrison L, Hillman K, Monsieurs K, Sunde K, Zideman D, et al; Utstein Formula for Survival Collaborators. The formula for survival in resuscitation. Resuscitation. 2013;84(11):1487-93.

1336. Wissenberg M, Lippert FK, Folke F, Weeke P, Hansen CM, Christensen EF, et al. Association of national initiatives to improve cardiac arrest management with rates of bystander intervention and patient survival after out-ofhospital cardiac arrest. JAMA. 2013;310(13):1377-84

1337. Haywood KL, Whitehead L, Perkins GD. The psychosocial outcomes of cardiac arrest: relevant and robust patient-centred assessment is essential. Resuscitation. 2014;85(6):718-9.
1338. Bomtempo TV. Análise constitucional da ortotanásia: O direito de morrer com dignidade. [Internet]. [Citado 2018 abr 20]. Disponível em: http:// www.ambito-juridico.com.br/site/index.php?

1339. O'Keeffe S, Redahan C, Keane P, Daly K. Age and other determinants of survival after in-hospital cardiopulmonary resuscitation. Q J Med. 1991;81(296):1005-10.

1340. David AS, Hotopf M, Moran P, Owen G, Szmukler G, Richardson G. Mentally disordered or lacking capacity? Lessons for management of serious deliberate self harm. BMJ. 2010 Sep 7;341:c4489.

1341. Sontheimer D. Suicide by advance directive? J Med Ethics. 2008;34(9):e4.

1342. Fallat M; American College of Surgeons Committee on Trauma; American College of Emergency Physicians Pediatric Emergency Medicine Committee; National Association of Ems Physicians; American Academy of Pediatrics Committee on Pediatric Emergency Medicine. Withholding or termination of resuscitation in pediatric out-of-hospital traumatic cardiopulmonary arrest. Pediatrics. 2014;133(4):e1104-16.

1343. Sanders A, Schepp M, Baird M. Partial do-not-resuscitate orders: a hazard to patient safety and clinical outcomes? Crit Care Med. 2011;39(1):14-8.

1344. Forman EN, Ladd RE. Why not a slow code? Virtual Mentor. 2012;14(10):759-62. 